\title{
Processo, administração, acesso e jurisdição da justiça e formas consensuais de solução de conflitos
}

Adriana Goulart de Sena Orsini, José Querino Tavares Neto, Regina Garcimartín Montero,

Sérgio Henriques Zandona Freitas (coords.) 



\section{COMITÉ CIENTÍFICO}

\section{SERIE LEFIS}

\section{Coordinación}

Prof. Fernando Galindo Ayuda. Universidad de Zaragoza

Profa. María Pilar Lasala Calleja. Universidad de Zaragoza

Consejo asesor

Prof. Javier García Marco. Universidad de Zaragoza

Prof. Alejando González-Varas Ibáñez. Universidad de Zaragoza

Prof. Philip Leith. Universidad Queen's de Belfast

Prof. Emérito Abdul Paliwala. Universidad de Warwick

Prof. Aires Rover. Universidad Federal de Santa Catarina

Prof. Erich Schweighofer. Universidad de Viena

Prof. Ahti Saarenpää. Universidad de Rovaniemi 
PROCESSO, ADMINISTRAÇÃO, ACESSO E JURISDIÇÃO DA JUSTIÇA

E FORMAS CONSENSUAIS DE SOLUÇÃO DE CONFLITOS 



\title{
PROCESSO, ADMINISTRAÇÃO, ACESSO E JURISDIÇÃO DA JUSTIÇA \\ E FORMAS CONSENSUAIS DE SOLUÇÃO DE CONFLITOS
}

\author{
Adriana Goulart de Sena Orsini, \\ José Querino Tavares Neto, \\ Regina Garcimartín Montero, \\ Sérgio Henriques Zandona Freitas \\ (coords.)
}


PROCESSO, administração e jurisdição da justiça e Formas consensuais de solução de conflitos [Recurso electrónico] / Adriana Goulart de Sena Orsini... [et al.] (coords.). — Zaragoza : Prensas de la Universidad de Zaragoza, 2019

403 p. ; $22 \mathrm{~cm}$. - (LEFIS series ; 28)

ISBN 978-84-17633-62-2

1. Informática-Derecho-Brasil. 2. Internet en la administración pública. 3. Derecho procesalBrasil. 4. Mediación-Brasil. 5. Transacciones extrajudiciales-Brasil

ORSINI, Adriana Goulart de Sena

34(81):004

004.738.5:35

$004.738: 347.469(81)$

004.738:347.918(81)

004.738:347.925(81)

Cualquier forma de reproducción, distribución, comunicación pública o transformación de esta obra solo puede ser realizada con la autorización de sus titulares, salvo excepción prevista por la ley. Diríjase a CEDRO (Centro Español de Derechos Reprográficos, www.cedro.org) si necesita fotocopiar o escanear algún fragmento de esta obra.

(C) LEFIS

(C) CONPEDI, Conselho Nacional de Pesquisa e Pós-Graduação em Direito Brasil.

(C) De la presente edición, Prensas de la Universidad de Zaragoza (Vicerrectorado de Cultura y Proyección Social)

$1 .^{a}$ edición, 2019

El Centro Universitário de João Pessoa - PB - UNIPÊ ha subvencionado parcialmente la edición de este libro.

Prensas de la Universidad de Zaragoza. Edificio de Ciencias Geológicas, c/ Pedro Cerbuna, 12. 50009 Zaragoza, España. Tel.: 976761 330. Fax: 976761063

puz@unizar.es http://puz.unizar.es

https://www.conpedi.org.br/

Esta editorial es miembro de la UNE, lo que garantiza la difusión y comercialización de sus publicaciones a nivel nacional e internacional. 


\section{SUMÁRIO}

\section{PROCESSO, ADMINISTRAÇÃO, ACESSO E JURISDIÇÃO DA JUSTIÇA}

APRESENTAÇÃO

Regina Garcimartín Montero, José Querino Tavares Neto.

A COMPLEXIDADE DA MOROSIDADE DO PODER JUDICIÁRIO BRASILEIRO E A

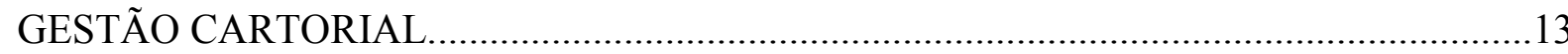

Josélia da Silveira Nogueira, Orides Mezzaroba.

A EXTRAJUDICIALIZAÇÃO E O REGISTRO CIVIL DAS PESSOAS NATURAIS COMO FORMA DE ACESSO À JUSTIÇA.

Priscila Alves Patah.

CARGA ECONÔMICA DO PROCESSO COMO ÓBICE À CONSECUÇÃO DO PRINCÍPIO DO ACESSO À JUSTIÇA E OS MEIOS ALTERNATIVOS DE SOLUÇÃO DE LITIGIOS.

Maria José Carvalho de Sousa Milhomem.

COMO SE JOGA O PROCESSO?: O USO DA TEORIA DOS JOGOS COMO INSTRUMENTO DE APOIO PARA A REESTRUTURAÇÃO DO PROCESSO PENAL BRASILEIRO PÓS-CONSTITUIÇÃO FEDERAL DE 1988

Fernando Laércio Alves da Silva.

COMPETÊNCIA ABSOLUTA DO JUÍZO ARBITRAL NO CPC FERE O ACESSO À JUSTIÇA?

Maria Cristina Zainaghi, Luis Guilherme Krenek Zainaghi.

CRISE DO PROCESSO OU CRISE DA JURISDIÇÃO? O ACESSO À JUSTIÇA PELA VERTENTE DO DIREITO MATERIAL

Benedito Cerezzo Pereira Filho, Daniela Marques De Moraes.

ESTUDO EXPLORATÓRIO SOBRE APLICAÇÃO DE TÉCNICA DE ANÁLISE SEMÂNTICA LATENTE, PARA VINCULAÇÃO DE PROCESSOS JUDICIAIS A TEMAS DE REPERCUSSÃO GERAL E INCIDENTE DE RESOLUÇÃO DE DEMANDA REPETITIVA

Tiago Melo, Richerland Pinto Medeiros.

FREIOS E CONTRAPESOS NA CONCESSÃO DE MEDICAMENTOS DE ALTO CUSTO. POLITIZAÇÃO DA JUSTIÇA OU JUDICIALIZAÇÃO DA POLÍTICAS PÚBLICAS DE SAÚDE?

Adriana Freitas Antunes Camatta, Lívia Maria Cruz Gonçalves de Souza.

INTELIGÊNCIA ARTIFICIAL E JUIZ NATURAL - QUANDO A PREVISIBILIDADE E A PADRONIZAÇÃO PODEM TOMAR O ASSENTO DO JUIZ ORDINÁRIO. 162

Conceição de Maria de Abreu Ferreira Machado, Clara Angélica Gonçalves Cavalcanti Dias. 
O MAGISTRADO GESTOR ESTRATÉGICO DE UNIDADES JUDICIÁRIAS. 179 Adriano da Silva Ribeiro.

O MINIMALISMO JUDICIAL DE CASS SUNSTEIN COMO ALTERNATIVA HERMENÊUTICA AO SISTEMA DE PRECEDENTES DO CÓDIGO DE PROCESSO CIVIL DE 2015.

Bruno Paiva Bernardes, Sérgio Henriques Zandona Freitas.

O MODELO DE ADMINISTRAÇÃO DE CONFLITOS NO CONTEXTO DO SISTEMA DE JUSTIÇA BRASILEIRO E AS CONSEQUÊNCIAS DE SUA ADOÇÃO COMO PARTIDA PARA A NECESSÁRIA AMPLIAÇÃO DE FOCO E DE PARADIGMAS......222 Magda Fiegenbaum, Grazielly Alessandra Baggenstoss.

O OFICIAL DE JUSTIÇA COMO CONCILIADOR EXTERNO: O PERFIL ADEQUADO À ATENDER A PERSPECTIVA AUTOCOMPOSITIVA DO NOVO CÓDIGO DE PROCESSO CIVIL E AS POLÍTICAS JURIIDICO-LEGISLATIVAS DE TRATAMENTO ADEQUADOS CONFLITOS

Ricardo Tadeu Estanislau Prado, Pedro Manoel Abreu.

PERSPECTIVAS DO ACESSO À JUSTIÇA NA GARANTIA DO DIREITO À ÁGUA POTÁVEL E AO SANEAMENTO BÁSICO EM DUQUE DE CAXIAS. 265 Alessandra Bentes Teixeira Vivas, Mônica Micaela de Paula.

SISTEMA PROCESSUAL E ACESSO À JUSTIÇA. A EFETIVIDADE JURISDICIONAL NA PERSPECTIVA SISTÊMICA FUNCIONAL-INSTRUMENTALISTA E JURISPRUDENCIALISTA 282

Sílzia Alves Carvalho.

\section{FORMAS CONSENSUAIS DE SOLUÇÃO DE CONFLITOS}

APRESENTAÇÃO.... .301

Adriana Goulart de Sena Orsini, Sérgio Henriques Zandona Freitas.

A CONCILIAÇÃO JUDICIAL COMO FORMA ADEQUADA DE TRATAMENTO DE CONFLITOS FACE AO PRINCÍPIO DA INDISPONIBILIDADE DE DIREITOS LABORAIS.

Adriana Goulart de Sena Orsini.

A LEGITIMIDADE DO CONSENSO NA MEDIAÇÃO DE CONFLITOS: ANÁLISE REFLEXIVA NO CONTEXTO JURÍDICO BRASILEIRO.

Carla Maria Franco Lameira Vitale, Luciana Aboim Machado Gonçalves da Silva.

A SOLUÇÃO EXTRAJUDICIAL DE CONFLITOS: UM OLHAR PARA ALÉM DA MEDIAÇÃO E DA CONCILIAÇÃO.

Ana Paula Parra Leite, Zilda Mara Consalter.

NOVOS CAMINHOS PARA A SOLUÇÃO DE CONFLITOS JUDICIAIS A PARTIR DA EXPERIÊNCIA BRASILEIRA COM O DIREITO SISTÊMICO: POSSIBILIDADES DE

APLICAÇÃO NA ESPANHA... 364

Tatiane Silva Ferreira, Márcio Eduardo Senra Nogueira Pedrosa Morais. 
REFLEXÕES SOBRE A TRADIÇÃO HISTÓRICO-JURÍDICA DE PROTEÇÃO AO MENOR NO BRASIL E A JUSTIÇA RESTAURATIVA......................................................38

Conceição Aparecida Barbosa. 


\section{PROCESSO, ADMINISTRAÇÃO, ACESSO E JURISDIÇÃO DA JUSTIÇA ${ }^{1}$}

\section{APRESENTAÇÃO}

El bienestar y el grado de desarrollo de los derechos de los ciudadanos depende en buena medida del buen funcionamiento de dos poderes estatales: el Ejecutivo y el Judicial. Aunque tengan un alcance, legislación y principios muy diversos, Administración y Justicia deben articular los medios para lograr la efectiva implementación de las garantías y derechos de los particulares en un Estado moderno. De poco servirían declaraciones o cuerpos legislativos con ambiciosas intenciones si fueran imposibles de implementar o si se tolerase de forma reiterada su incumplimiento. De ahí que el correcto funcionamiento de los medios de garantizar la efectividad de los derechos atraigan con frecuencia la atención de los estudiosos del Derecho.

La lejanía geográfica entre Brasil y España, países de origen de la mayoría de los autores de este libro, no se corresponde con su indudable cercanía cultural y jurídica que avala un estudio que aúne el análisis de distintas instituciones en estos países de forma que sirve de mutuo enriquecimiento.

Tanto Brasil como España cuentan con Constituciones aprobadas en las últimas décadas del S. $\mathrm{XX}$. Aunque no sea una larga trayectoria, permite afrontar con la debida madurez el correcto funcionamiento de las instituciones jurídicas a la luz de los principios constitucionales y afrontar los retos de la época actual. Cercana ya la conclusión de la segunda década del S. XXI se pueden determinar con precisión los aspectos que de forma más sobresaliente invitan al jurista a la reflexión en los tiempos actuales.

Uno de las principales novedades en el mundo jurídico en los primeros años del nuevo siglo ha sido la irrupción de las nuevas tecnologías en el mundo del Derecho. El uso de la informática y de los recursos que proporcionan las nuevas tecnologías se están implantando de forma desigual no sólo en los distintos ámbitos del ordenamiento jurídico sino también en la geografía de nuestros países. A pesar de que el avance es desigual, es imparable y se va asumiendo de forma cada vez más cotidiana por parte de los ciudadanos y de los profesionales del Derecho. Este nuevo horizonte plantea nuevos desafíos al estudioso del Derecho: desde la solución de los

\footnotetext{
${ }^{1}$ Nota Técnica: Os artigos que não constam neste livro foram selecionados para publicação na Plataforma Index Law Journals, - http://indexlaw.org/index.php/conpedireview/index.
} 
inconvenientes técnicos que pudieran darse para incorporar los medios tecnológicos a la Administración y a la Justicia, como la inserción de los principios informadores del Derecho ante el uso de estos nuevos instrumentos (audiencia, igualdad, etc.).

No es ajena tampoco a la inquietud de los autores de este libro la optimización del uso de los recursos del Estado en un contexto de crisis económica que en la actualidad forma parte de la realidad tanto brasileña como española aunque con distintos matices. El aumento de las necesidades de los ciudadanos frente a las instituciones en épocas de recesión (mayor litigiosidad, aumento del gasto en políticas sociales, etc.) ha ido acompañada de un recorte en los medios económicos. Esta situación requiere establecer prioridades ante la escasez de recursos y optimizar los ya disponibles procurando el menor impacto en los derechos del ciudadano.

Junto con una atinada visión de los nuevos retos que supone para el jurista la aparición de factores novedosos en el mundo jurídico, no faltan en esta obra estudios en torno a problemas jurídicos clásicos: lucha contra las desigualdades, accesibilidad de la Justicia a los ciudadanos, etc.

Dentro de las cuestiones que tradicionalmente han preocupado a los estudiosos del Derecho ocupa un lugar preferente el elemento humano en la administración de la justicia. Esta especial preocupación se materializa de forma evidente en los análisis que se llevan a cabo en estas páginas; ni los medios tecnológicos ni la oportuna dotación de medios económicos son de utilidad sin la adecuada formación y la profesionalidad de los operarios jurídicos. La necesaria formación de los jueces, la creación de la voluntad colegiada, las posibilidades del arbitraje como medio de solución de los conflictos entre otras cuestiones encuentran también su lugar en esta obra.

Los autores de los estudios que componen esta obra son prestigiosos juristas de Brasil y España; a sus años de experiencia se ha de añadir en muchos casos un buen conocimiento de la praxis en sus respectivos paises. Invitamos al lector a adentrarse en estas páginas con la confianza de que encontrará respuesta y sugerentes reflexiones a las cuestiones más acuciantes sobre la eficacia de la Administración y la Justicia.

Zaragoza, Septiembre de 2018. 
Coordenadores do GT:

Prof. Dra. Regina Garcimartín Montero. Universidad de Zaragoza.

Prof. Dr. José Querino Tavares Neto. Universidade Federal de Goiás. 


\title{
A COMPLEXIDADE DA MOROSIDADE \\ DO PODER JUDICIÁRIO BRASILEIRO E A GESTÃO CARTORIAL
}

\author{
Josélia da Silveira Nogueira \\ Universidade Federal de Santa Catarina - UFSC \\ Orides Mezzaroba \\ Universidade Federal de Santa Catarina - UFSC
}

\begin{abstract}
Resumo
O estudo mostra resultados do Conselho Nacional de Justiça relativo às causas que levam à morosidade do Judiciário brasileiro. Contou-se com a pesquisa empírica junto ao cartório judicial da Vara Criminal de Araranguá, em Santa Catarina, bem como com a análise de indicadores do Relatório Justiça em Números 2017. É uma pesquisa descritiva com abordagem qualitativa, onde se analisa a morosidade dentro de um conjunto de fatores, e não a partir de uma única causa. Para se ter um Judiciário célere, é preciso que ocorra uma mudança cultural, onde o foco seja administrar melhor os cartórios judiciais.
\end{abstract}

Palavras-chave: acesso à justiça, morosidade, Conselho Nacional de Justiça, gerenciamento de processos judiciais

\begin{abstract}
Resumen/Résumé
The study shows the National Council of Justice's results about the reasons for the Brazilian Judiciary's slowly. It was used an empirical research in Araranguá's Criminal Registry, Santa Catarina,as well as an a review of Justice in Numbers Report 2017. It is a descriptive research with qualitative approach, where it is analised the slowly inside a group of conditions, and not from a single cause. For a speedy Judiciary, it is necessary to happens a cultural change, where the attention can be to improve the manegement of judicial registries.
\end{abstract}

Keywords/Palabras-claves/Mots-clés: acess to justice, slowly, National Council of Justice, management of legal proceedings. 


\section{Introdução}

A morosidade na tramitação dos processos, dentro do Poder Judiciário, tem sido tema de debate fervoroso em todo o país. Seja em congressos importantes, seja na mesa de bar, o assunto se repete: o que está acontecendo com a justiça no Brasil? Vale a pena ajuizar uma demanda ou é melhor não questionar um direito, considerando o tempo até a decisão definitiva e os gastos com custas e advogado?

Sensíveis à insatisfação dos jurisdicionados, e estando mais do que visível a necessidade de controlar essa situação, criou-se o Conselho Nacional de Justiça (CNJ) para analisar números e apresentar o Judiciário por dentro. E a partir das informações obtidas, não há outro caminho possível a seguir senão tratar da gestão institucional responsável. Um olhar organizador de todas as conclusões obtidas com o Relatório Justiça em Números nos leva necessariamente a ver premente a necessidade de reavaliar o modelo da justiça brasileira, quase artesanal, utilizado desde o século XIX.

Assim, os números trazidos pelo CNJ não serviram só para identificar onde estão os entraves que geram a inaceitável tardia prestação jurisdicional. As informações obtidas servem também para desmistificar algumas opiniões tendenciosas, principalmente quanto à necessidade de redução do acesso à justiça.

É importante tratar da crise do Poder Judiciário, pois tendo clareza dos dados numéricos essenciais, se torna possível resolver o problema da prestação da jurisdição em tempo razoável, atacando o que realmente gera morosidade, e, principalmente, mantendo incólumes as garantias constitucionais advindas com a Emenda Constitucional no 19 (Reforma Administrativa do Estado) e a Emenda Constitucional n ${ }^{\circ} 45$ (Reforma do Poder Judiciário).

Muitos defendem que o aumento do volume e da complexidade das demandas judiciais não condizem com a estrutura disponibilizada pelo Poder Judiciário. E continuam, afirmando que nunca será possível suprir essa demanda que só faz crescer, o que torna necessária a restrição do acesso à justiça sob pena de torná-lo inautêntico. Contudo, não é isso que os números do CNJ indicam no Relatório Justiça em Números 2017 - Ano-base 2016 (CNJ, 2017, p. 88): de 2015 para 2016 houve redução do número de casos novos por magistrado e servidor, percebida especialmente no primeiro grau de jurisdição! E logo em seguida, como que tomado de uma surpresa desconcertante, ressalta o relatório que apesar do ingresso de menos ações, a carga de trabalho continua crescendo, donde conclui que isso pode decorrer do constante aumento do acervo processual. Esse paradoxo reforça o equívoco de culpar pelas mazelas do Judiciário o acesso amplo. 
Há, também, quem culpe a crise do Poder Judiciário em função do excesso de burocracia, decorrente de legislação obsoleta. Outros colocam na falta de informatização a razão da ausência de agilidade dos processos. Salários ou número de servidores e magistrados, como também a falta estrutura e quantidade de fóruns pelo Brasil são motivos alegados para justificar o insucesso atual.

Contudo, a morosidade processual não tem uma relação convergente com uma única causa. O que existem são problemas que se intercalam e terminam por desaguar na questão relacionada à gestão dos cartórios judiciais, onde os processos permanecem a maior parte do tempo de tramitação. A falta de razoabilidade no tempo de tramitação dos processos não se relaciona com o contingente de processos recém ajuizados, mas sim com o que está sendo feito com os que já estão em tramitação. Informações do Relatório Justiça em Números 2017 - Anobase 2016 (CNJ, 2017, p. 136) dão conta de que os casos não solucionados pelo Judiciário ainda correspondem a 2,7 vezes a demanda. Em outras palavras, em 2016 houve redução no quantitativo de processos de conhecimento nas varas criminais em relação ao ano de 2015 e mesmo assim o acervo de processos aumentou!

Não se defende aqui a ideia de que se deve aceitar todo tipo de pedido quando do ajuizamento de uma ação, pois para isso já existem regras e o juiz, com o poder do jurisdicere, tem em suas mãos a chance de evitar ações frívolas. Quanto aos litigantes habituais, resolveria a questão um controle automatizado e relativamente simples aplicado a todos que demandam buscando uma resposta a sua questão. Isso também é gestão. Enquanto não se pensa em formas de impedir o acesso inidôneo, não se deve atrelar a demanda dos jurisdicionados ao assoberbamento do Poder Judiciário.

Nesse sentido, questiona-se até que ponto a morosidade processual decorre somente de uma série de problemas complexos e concatenados entre si, como o aumento no número de ajuizamentos decorrente do amplo acesso, ou é alvo da falta de gestão dos processos que já estão em tramitação dentro dos cartórios brasileiros.

Para responder esse questionamento, o presente estudo tem como objetivo apresentar conclusões do órgão oficial de informação, $\mathrm{CNJ}$, a respeito da efetividade da prestação dos serviços judiciais no ano de 2016, bem como exemplos bem sucedidos de soluções para o combate à morosidade, obtidos dentro do próprio Judiciário brasileiro, através da gestão dos cartórios.

Objetivando apresentar causas da morosidade do Poder Judiciário em face do gerenciamento dos cartórios judiciais, utilizou-se pesquisa bibliográfica, importante nesse caso, pois segundo Lakatos (2010, p. 166) este tipo de trabalho de pesquisa "não é mera repetição do 
que já foi dito ou escrito sobre certo assunto, mas propicia o exame de um tema sob novo enfoque ou abordagem, chegando a conclusões inovadoras". Com os números que o CNJ apresenta em seu Relatório de 2016 é possível chegar a várias conclusões. A partir delas, tornase imprescindível apreender que o problema da morosidade é complexo e deve ser analisado dentro de um conjunto de fatores, e não a partir de uma única causa. Agregado a isso, os exemplos de casos exitosos no combate à morosidade ressaltam aspectos que, aliados aos números reais, incrementam o presente estudo.

Foi utilizada a pesquisa empírica junto ao cartório judicial da $1^{\mathrm{a}}$ Vara Criminal de Araranguá, estado de Santa Catarina, Brasil, e tomou-se conhecimento de como eram conduzidos os processos dentro do Judiciário. Verificou-se, também, outros dois casos de sucesso liderados por Jorge Antonio Maurique e Marcos Alaor Diniz Grangeia, ambos desembargadores do Poder Judiciário e preocupados com o problema da falta de celeridade. Por isso, o método de abordagem escolhido foi o indutivo, pois parte-se de casos particulares identificados no Brasil, observa-se os fatos e seus desdobramentos, aproximando-se deles para tentar descobrir a relação entre eles e se faz uma generalização da relação encontrada.

Lançou-se mão do método descritivo, observando fatos e levantamentos estatísticos para chegar a conclusões sobre as melhores práticas em prol da celeridade. Além disso, foram expostas "características de determinada população ou fenômeno, estabelecendo correlações entre as variáveis estudadas". (VERGARA, 2005).

Ademais, a pesquisa elaborada é qualitativa e foi feita uma análise de conteúdo. A coleta de dados partiu de uma pesquisa documental ao Relatório do Justiça em Números 2017, do CNJ, que serviu para nortear os passos para uma análise descritiva de observação ou documental e oferece suporte para levantar os aspectos seguintes:

-Que números apresentam fatores ligados à morosidade do Judiciário?

-Alterar a legislação processual, aumentar o número de servidores/magistrados, limitar o acesso ao judiciário, incrementar o orçamento ou aumentar o número de fóruns nos estados brasileiros servirão como medida para reduzir a morosidade?

A Resolução CNJ no 76/2009 fundamenta indicadores e variáveis mencionadas no Relatório Justiça em Números, e em seus anexos consta o detalhamento das fórmulas que norteiam o Sistema de Estatísticas do Poder Judiciário (SIESPJ).

A experiência no âmbito do cartório judicial aliada à ciência dos dados apurados e apresentados no Relatório do CNJ foram importantes e fundamentais na busca pelo tema envolvendo a problemática sobre a morosidade processual.

Esse estudo será apresentado em quatro partes, iniciando com a introdução onde ficará 
clara a temática, importância desse estudo bem como a metodologia adotada. O referencial teórico será tratado no momento seguinte, onde serão apresentados números do CNJ e algumas conclusões importantes envolvendo aspectos diversos, bem como práticas de sucesso já aplicadas em cartórios do Estado de Santa Catarina, Rondônia e Rio Grande do Sul, e que levam em conta o planejamento estratégico dos cartórios e a importância de sua administração. $\mathrm{Na}$ terceira etapa é apresentada a análise e discussão dos resultados. E na última fase caberá a apresentação das considerações finais relacionadas ao tema estudado.

\section{Referencial teórico}

\subsection{Os números do CNJ}

Avaliar quais os fatores que afetam os serviços judiciais no país e entender se há somente um motivador da falta de celeridade nos processos que tramitam nos cartórios brasileiros são propostas imprescindíveis para se verificar o porquê de considerar o Poder Judiciário ineficiente e injusto. Contudo, não se pretende convencer que os números trazidos pelo CNJ são uma lógica absoluta e irrefutável. Eles demonstram consequências importantes, e que nos levam a fazer um caminho de volta às causas do problema, momento em que será possível identificar o melhor remédio para a crise da instituição judiciária.

De qualquer forma, cabe começarmos por dados eloquentes, como o trazido pelo gráfico apresentado na figura 110 do Relatório Justiça em Números 2017- Ano Base 2016 (CNJ, 2017, p. 136). Apresenta-se uma série histórica dos casos novos e das pendências, especificamente no âmbito criminal (excluídas as execuções penais):

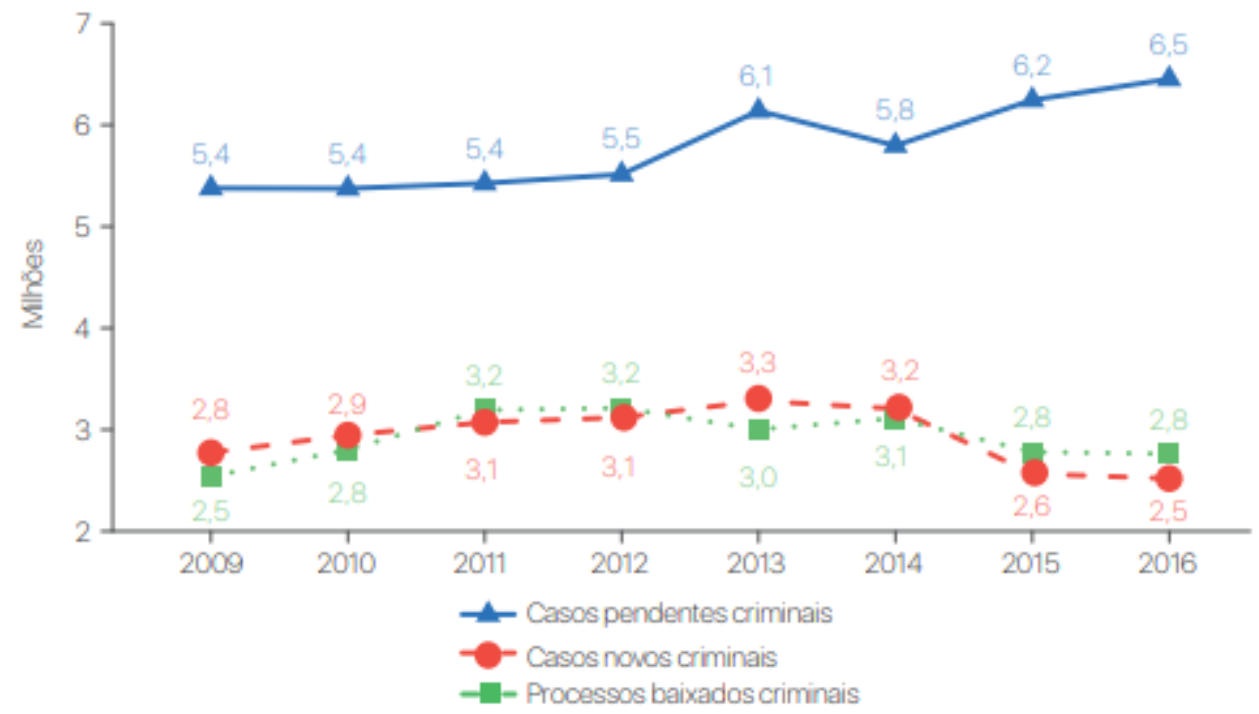

Fonte: Brasil, 2016. 
Analisando o gráfico, verifica-se que os números relativos aos casos pendentes aumentam, ao passo que os novos casos vêm diminuindo. Disso se conclui que no âmbito analisado não há que se culpar o excesso de ajuizamento pelos entraves do Judiciário. Mas se obtém dado valioso a partir dessa informação: o que fica pendente de solução dentro dos cartórios é que vem emperrando a máquina pública judiciária.

Exemplo cristalino dessa situação é mencionada pelo CNJ (2017, p. 146) quando apresenta o Tribunal de Justiça do Rio de Janeiro, relativo aos números do ano de 2016. Apesar de se destacar com o maior índice de produtividade dos magistrados brasileiros e segundo maior índice de produtividade dos servidores de todo Poder Judiciário, fica em terceiro lugar no ranking de maior taxa de congestionamento. Portanto, mesmo com alta produtividade, o Tribunal do Rio de Janeiro não consegue baixar o resíduo processual acumulado de anos anteriores.

O CNJ identificou também que até o ano de 2016 apenas 49,2\% dos municípios brasileiros são sede do Judiciário (2017, p. 28). Mas isso não parece ser de grande influência no cômputo geral de tramitação dos processos, já que estados como Maranhão, Pará e Amazonas possuem apenas $7 \%$ das unidades judiciárias, mas representam somente $9 \%$ da população brasileira (2017, p. 29). Entretanto, torna-se um problema quando se verifica que o primeiro grau de jurisdição foi o responsável, em 2016, por 86\% dos processos ingressados e $94 \%$ do acervo processual de todo Poder Judiciário brasileiro (CNJ, 2017, p. 87). Se é assim, poucos municípios acabam acumulando ajuizamentos de diversas cidades contíguas, atrapalhando o andamento geral dos processos.

Outra conclusão desconcertante: foi identificado pelo CNJ (2017, p. 87) que todos os ramos de justiça no Brasil possuem demanda processual superior ao número de servidores, cargos e funções alocadas no primeiro grau de jurisdição. E como se não bastasse, o CNJ (2017, p. 88) concluiu também que houve redução no número de casos novos por magistrado e servidor, mas a carga de trabalho permaneceu crescendo em 2016. Então, é possível verificar que o acervo existente vem sendo o grande turbador da tranquilidade dos cidadãos quando o assunto é falta de celeridade processual. O estoque não está sendo processado a contento e cada vez aumenta mais o número de processos num limbo que fica entre processos ajuizados e processos encerrados.

\subsection{A complexidade do processo judicial e a necessidade de uma visão sistêmica do problema}

Após a verificação de algumas conclusões pontuais do CNJ é possível afirmar que o processo judicial tramita dentro de uma estrutura complexa. Por isso, a solução para a 
morosidade do judiciário deve ser atacada por diversas frentes, sempre respeitando o princípio constitucional do amplo acesso à justiça.

A respeito da ideia de tratar determinados problemas evitando o pensamento mecanicista o Professor Aurelio L. Andrade menciona que "os problemas mais importantes que enfrentamos no mundo globalizado, nas organizações e em nossas cidades e comunidades estão intimamente interconectados. Não podemos tentar resolvê-los de maneira fragmentada - isto só irá gerar mais problemas" $(2014$, p. 5).

Dentro dessa perspectiva sistêmica, identifica-se a existência de diversos fatores coligados que atacam a celeridade. O Poder Judiciário tornou-se uma organização complexa, e diante da falta de modernização, informatização e racionalização da gestão administrativa está sendo posta em cheque a sua legitimidade. Assim, a gestão ineficiente de recursos e meios para a solução dos conflitos proporciona atrasos inaceitáveis na prestação jurisdicional. A seleção inadequada e a falta de treinamento específico tornam o ambiente de trabalho ineficaz. A má distribuição e utilização de recursos materiais, rotinas obsoletas, colegas desmotivados e técnicas arcaicas na realização de tarefas diárias colocam à prova uma instituição que tem o condão de atender à importante demanda social relacionada à justiça.

Quando tratou de O poder invisível - a burocracia judicial brasileira, no $32^{\circ}$ Encontro Anual da Associação Nacional de Pós-graduação e Pesquisa em Ciências Sociais, Paulo Eduardo Alves da Silva ressaltou que "algumas rotinas burocráticas simples têm um efeito enorme sobre o tempo total do processo. Como exemplo, a publicação de uma decisão (no Cartório A, chegou-se a uma soma equivalente a $63.6 \%$ do total) e a juntada de algum documento." (2008, p. 15)

Cumulado a isso, há que se entender que do magistrado e do servidor que são aprovados em concurso público não são exigidos conhecimentos para o serviço administrativo de gerência e apoio à prestação jurisdicional. Contudo, especificamente falando dos juízes de direito, o CNJ envia metas de trabalho direcionadas não mais ao magistrado, mas ao gestor, mudança não aleatória na forma de tratamento, mas indicativa de algo que se espera do destinatário. Ora, faltando treinamento específico, pouco se consegue alcançar em nível de magistratura. Com relação aos demais servidores, falta habilidades no atendimento ao público, com simplificação dos serviços prestados, principalmente no que concerne ao atendimento direto no balcão. Falta perceber o cidadão como alguém que demanda explicações de fácil compreensão, já que não têm preparação técnica e, por vezes, intelectual para entender os trâmites e as nomenclaturas jurídicas. 
A nação brasileira despertou para seus direitos reprimidos por décadas de autoritarismo. Ao lado disso, foi promulgada uma Constituição Federal garantidora de direitos e, por fim, mas não menos importante, houve uma consolidação de visões consumeristas, ambientalistas, entre outras, e a falta de estrutura do servidor e do magistrado para lidar com essas questões que envolvem gestão refletiram diretamente no cartório, na forma de acúmulo de serviço.

A parte de tudo isso, a sociedade, partes e procuradores, também mudaram, ficaram mais exigentes e querem respostas mais rápidas. O timing do mundo mudou nas últimas décadas, e isso fez com que também houvesse a exigência de uma postura diferente no funcionamento do Poder Judiciário.

Porém, com a falta de legitimidade e o descrédito com que está fulminado o Judiciário, interessante analisar o problema de uma forma que integre todas as variáveis que levaram à situação em que se encontra. Além disso, é importante abordar experiências de quem pensou em soluções, colocou-as em prática e obteve resultados satisfatórios. Trata-se de quem teve a ideia de impulsionar a tramitação dos processos repensando e usando técnicas de planejamento, talvez a saída mais promissora para os problemas por que passa o Judiciário brasileiro.

\subsection{Casos de sucesso na administração dos cartórios judiciais}

A Vara Criminal de Araranguá, estado de Santa Catarina, no Brasil, no ano de 2010 era a pior vara do Fórum. $\mathrm{O}$ ambiente era fisicamente desmotivador: mesas abarrotadas de processo, ambiente sujo e desconfortável. E quanto às formas de tratar as questões que surgiam, era possível perceber uma falta de padronização nas respostas às perguntas diárias que eu tinha sobre os procedimentos. Até que um novo chefe de cartório assumiu a Vara Criminal e iniciou a aplicação de técnicas de gestão básicas. Primeiramente, iniciou determinando o cumprimento dos processos em ordem cronológica, lição de justiça que deveria ser norma dentro do judiciário. Após, organizou os escaninhos em ordem numérica, o que parece pueril a menos quando existam oito escaninhos com processos localizados numericamente pelo nome do servidor (exemplo: João 1 , João 2 , João $3, \ldots$ ), o qual estava em licença para tratamento de saúde, ou seja, aqueles processos todos aguardavam seu retorno! Os autos não tinham início, meio e fim, porque eram amontoados de atos desordenados e de difícil entendimento. Para tanto, o chefe sugeriu que fossem utilizados separadores de páginas com o nome dos atos, o que facilitou até mesmo o manusear e a busca por peças específicas. Os documentos que deviam 
ser juntados nos processos ficavam espalhados em cima de uma mesa, com menção da data num bilhetinho. Criaram-se pastas próprias para juntada.

Mas o mais interessante foi o uso de checklist para determinados procedimentos. Essa foi uma dica importante que poupou muitos casos da prescrição. Quando era interposto recurso num processo, ele tinha que ser encaminhado para o segundo grau de jurisdição, na capital do estado, mas se faltasse a intimação de um acusado, ou as contrarrazões da defesa, voltava para cumprimento pelo cartório, em Araranguá. E esse tempo entre ida, verificação do erro, conserto e nova remessa à capital prejudicava muito o andamento do processo. Passamos a utilizar o checklist $\mathrm{e}$ não tivemos mais esse problema.

Verificou-se a necessidade de utilizá-lo inclusive em processos que necessitavam ser arquivados, já que foram identificados arquivamentos indevidos, com bens apreendidos sem destinação pelo magistrado ou até com valores a serem devolvidos às partes. Em procedimentos eivados de detalhes, como a formação de processos de execução criminal, facilitou muito o procedimento de conferência dos requisitos, o que se transforma em segurança para o servidor que sabe que está tratando de tudo que é necessário sem esquecer de nenhum detalhe, mas também para as partes envolvidas é muito relevante.

Após um período de adaptações, houve a divisão da Vara Criminal, de modo que a relatada acima é a $1^{\text {a }}$ Vara Criminal, e vem apresentando resultados bastante satisfatórios a cada inspeção feita pela Corregedoria Geral da Justiça de Santa Catarina, significando com isso que a incidência de uma nova gestão cartorial transformou o pior cartório no melhor de toda a Comarca. Outro exemplo de caso bem sucedido ocorreu no Tribunal de Justiça de Rondônia, através das ideias do Desembargador Marcos Alaor Diniz Grangeia. Em sua opinião, o Poder Judiciário passa por uma séria crise de gestão e é necessário adotar gerência estratégica, cooperativa, democrática, participativa e solidária. Em sua obra, observa que:

\footnotetext{
Aos olhos de muitos que se dedicam à análise dos problemas da Justiça, está patente que a crise instalada no Poder Judiciário deriva da falta de agilidade e possui um viés gerencial com consequências na economia do país, no desprestígio social do Poder e na segurança pública. O sistema judiciário de solução de conflitos necessita ser equacionado para contribuir para a melhoria da velocidade confiabilidade do Poder Judiciário. Nessa perspectiva, a atividade desenvolvida por magistrados e servidores de cartório, na administração da serventia, ganha relevo e transcende a própria sentença, pois esta passou a ser apenas um capítulo da jornada jurisdicional. (GRANGEIA, 2011, p. 28)
}

O Desembargador buscou em quatro autores as abordagens teóricas necessárias sobre modelagem organizacional. São eles: Jay Galbraith, Djalma de Oliveira, Karl Weick e Bianor Cavalcanti. A partir daí, criou um Manual de Implementação de Planejamento Estratégico para 
Cartórios repleto de ferramentas. O trabalho dele é voltado ao fazer, simples mas não simplório. Pragmático ao extremo, lança exemplos de planos de ação como os abaixo elencados:

FATOR: Fluxo de processos

\begin{tabular}{|c|c|c|c|c|}
\hline ler & & & & \\
\hline Responsáve1: Jui & z Titular & & & \\
\hline $\begin{array}{c}\text { Descrição da } \\
\text { Atividade } \\
\text { (O quê?) }\end{array}$ & $\begin{array}{c}\text { Responsáve1 } \\
\text { pela } \\
\text { Atividade } \\
\text { (Quem?) }\end{array}$ & $\begin{array}{c}\text { Cronograma } \\
\text { / Meta } \\
\text { (Quando / } \\
\text { Quanto?) }\end{array}$ & $\begin{array}{c}\text { Metodologia de Trabalho } \\
\text { (Como?) }\end{array}$ & $\begin{array}{c}\text { Local de } \\
\text { Desenvolvimento } \\
\text { (Onde?) }\end{array}$ \\
\hline $\begin{array}{l}\text { E } 1 \text { a b o r a r } \\
\text { relatório de } \\
\text { análise crítica, } \\
\text { a pon t a n d o } \\
\text { soluções } \quad \text { e } \\
\text { meios de sua } \\
\text { implementação. }\end{array}$ & $\begin{array}{c}\text { Juiz } \\
\text { Diretor da } \\
\text { Secretaria } \\
\text { e } \\
\text { Servidores. }\end{array}$ & 6 meses & 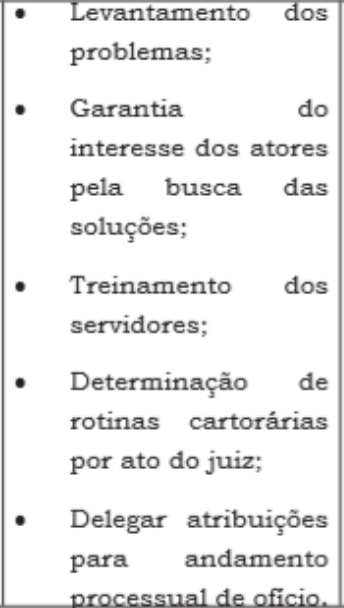 & $\begin{array}{l}\text { Dependências } \\
\text { do Fórum. }\end{array}$ \\
\hline
\end{tabular}

Fonte: GRANGEIA, Marcos Alaor Diniz. Administração judiciária

- gestão cartorária. $1^{\text {a }}$ Edição. Brasília, ENFAM. 2011. p. 148

Temos, ainda, o desembargador gaúcho, Jorge Antônio Maurique, juiz do Tribunal Regional Federal da $4^{\mathrm{a}}$ Região, o primeiro a obter para o gabinete o certificado internacional de gestão ISO 9001. Buscando uma forma de dar clareza e celeridade aos processos, e decidido a combater a morosidade, ele criou metas, estabeleceu prazos para os julgamentos e padronizou os procedimentos. "Hoje, $90 \%$ dos processos recebidos no gabinete são julgados em no máximo quatro meses", disse ele à Revista VEJA, em fevereiro de 2017.

Em seu entendimento, a garantia constitucional da duração razoável do processo só vai alcançar os jurisdicionados se forem utilizados métodos. E depois de obtido um nível inicial de excelência, uma opção é buscar a certificação do ISO 9001, para que esse trabalho tenha continuidade e uma avaliação periódica. Dessa forma, a qualidade sempre vai ser encarada como algo a ser buscado.

É necessário entender que depois de um longo período de tempo qualquer sentença deixa de prover à parte uma resposta à expectativa de que veria seu problema resolvido, porque com transcurso dos prazos fica a impressão de que, ao fim e ao cabo, ninguém foi vencedor, todos perderam, seja porque as circunstâncias já não são mais as mesmas, seja porque as 
necessidades se alteraram e esse novo momento não comporta receber essa resposta tardia sem um olhar de reprovação.

\section{Resultados e discussões}

Em termos de solução para a morosidade, constou-se que o Desembargado Marcos Alaor Diniz Grangeia foi o que conseguiu completar todo o processo de busca por uma maneira nova de gerenciar o Judiciário. Ele procurou técnicas específicas, elaborou um Manual e aplicou em sua unidade de trabalho com êxito. Entre suas motivações, esclareceu (p.29):

A partir do aperfeiçoamento e racionalização das atividades desenvolvidas, é preciso identificar, definir e implantar instrumentos eficazes de planejamento e gerenciamento, que possam colaborar efetivamente para a melhoria de desempenho das unidades organizacionais que compõem o Poder Judiciário. Às atividades voltadas para a desburocratização e simplificação, devem-se somar ações objetivas, que estabeleçam parâmetros mais flexíveis para a modelagem dos processos decisórios.

Entretanto, quando o assunto envolve acesso à justiça e morosidade, a discussão mais fervorosa envolve aspectos econômicos e orçamentários. O Banco Mundial alerta que o Judiciário aumenta o Risco-Brasil e afasta investidores. Com isso, a Análise Econômica do Direito passa a fazer parte da discussão. Um modelo imposto por poderosas entidades de governança global (FMI - Fundo Monetário Nacional, OMC - Organização Mundial do Comércio, Banco Mundial), exercem o controle sobre as instituições, buscando beneficiar um determinado segmento da sociedade, que é o setor econômico.

Ocorre que a concepção econômica não pode servir de base para tornar o Judiciário eficiente e a maximização da riqueza não pode alterar o valor dos direitos fundamentais. Cada vez mais comum é verificar juízes sendo chamados de insensíveis ao contexto econômico. É aí que a discussão tem início.

Muitos entendem que o que for numericamente exprimível será observado pelo Judiciário para que se chegue a um resultado eficiente aos olhos do poderio econômico, ou seja, aquele que detém poder econômico determina como o CNJ vai mandar o judiciário funcionar no Brasil, de forma a não causar prejuízo às influentes e grandes corporações. É onde surge a Análise Econômica do Direito (AED) e a questão sobre as infinitas demandas da sociedade frente à um orçamento público finito.

O significante da vez é o dinheiro e o progresso econômico o único valor social a ser buscado. A discussão sobre a justiça das decisões, que pautava o direito, se perdeu na poeira de uma estrada que parece não levar mais a lugar nenhum. 
Não existe mal nenhum em o cidadão avaliar o custo/benefício de ajuizar uma ação. Porque isso é uma prática usual e natural. Se para "vender" um acesso irrestrito ao Judiciário foi aprovada uma lei que proporciona o abarrotamento do judiciário e a limitação de seus recursos financeiros e humanos, não é o cidadão contribuinte quem deve (de novo) pagar. Antes de causar o problema, era necessário verificar as consequências de uma mudança legislativa. $\mathrm{E}$ isso não foi feito por incompetência, por exibicionismo, por marketing político, etc. Se foi aprovada uma lei que retira os custos de tramitação da demanda e os honorários sucumbenciais, porque não se pensou antes a respeito do amplo acesso ao judiciário e o que dele resultaria. Quem trouxe aos brasileiros a possibilidade do custo/benefício atrativo foi a lei, feita por representantes eleitos, e as regras do jogo possibilitaram ao cidadão que não quer riscos ajuizar ações quando evidenciar equilíbrio na relação custo/benefício.

Como ressalta Paulo Cezar Alves Sodré (2014, p.13), "não se ignora que a celeridade processual é um instrumento importantíssimo para a consolidação do acesso à justiça, não sendo, portanto, a celeridade processual e o acesso à justiça objetivos excludentes. Muito ao contrário, eles se complementam".

Todavia, a premissa da AED é de que o que importa é gastar a menor quantidade de recursos possível. Ao invés disso, é necessário focar os esforços na elaboração de um filtro anterior ao ajuizamento de uma lide, e não gastar pautas de validação de teorias que tão somente mascaram a intervenção do poderio econômico estrangeiro no Judiciário. Procura-se encontrar um critério que filtre o ingresso de ações no sistema, contendo excessos e abusos? Parece haver uma grande dificuldade em se (re)pensar os procedimentos, em todos os níveis, em todas as esferas, inclusive dentro dos cartórios judiciais.

Fala-se muito em interesses individuais em contraponto à exploração de bens comuns ou públicos. Mas não se vê publicações questionando o porquê de as pessoas ajuizarem "demandas impróprias", com baixa probabilidade de êxito. Nem se identifica celeumas envolvendo o porquê da existência de demandas repetitivas. O que se ouve à exaustão é que esses dois itens acarretam um volume de processos que não pode ser assimilado pela estrutura do judiciário, gerando inefetividade e lentidão. A primeira assertiva está muito relacionada ao despreparo educacional que é peculiar do nosso povo. As escolas e seus professores apresentam déficits decorrentes de um descaso público (proposital) com a principal arma de uma nação decente: a educação. Um povo bem instruído tem mais condições de discernir e escolher suas lides e sobre assuntos que devam ser levados a juízo. Entretanto, quando a educação do cidadão passa pelo que ele vê e ouve na hora da novela, muitos equívocos se comete. 
É usual assistir programas da maior emissora de TV do Brasil onde o Judiciário é o salvador e remediador de todas as injustiças. Considerando a imensa população que assiste novelas e o poder das informações ali veiculadas, não deve parecer estranho o comportamento daquele que, frente a pequenas mazelas descabidas, busca no judiciário a cura para suas desditas.

Ainda sobre expurgar do mundo jurídico as demandas repetitivas, verifica-se que ninguém se questiona acerca disso. Mas se verifica a todo o momento que elas são um grande mal para o judiciário, abarrotam os cartórios e assoberbam os magistrados. Por que existem demandas repetitivas? Várias são as respostas. Entre elas, porque a atuação dos brasileiros em associações ainda é muito fraca. Ademais, quem poderia representar em nome de muitas pessoas ainda não o faz. Ou seja, não se sabe litigar interesses em conjunto, como um ente só, e não se tem instituições interessadas em fazer isso. Identificadas, essas duas questões podem acarretar prejuízo ao interesse coletivo porque acabam por levar para o judiciário casos indevidos, em grande quantidade e para análise individual. É o chamado "trabalho de formiguinha".

Então, na opinião de alguns, a saída é limitar o acesso. E isso é prejudicial ao cidadão que tem em seu ordenamento maior a garantia do acesso à justiça como um dos direitos fundamentais. Caso essa limitação não seja bem trabalhada, quem perderá será o homem comum, de pouco saber, imbuído dos valores que a novela atesta a ele diuturnamente como verdadeiros. E mais uma vez o poder econômico estrangeiro submeterá a população brasileira aos ditames e opressões típicas de quem busca acumular dinheiro, sem questionar valores diversos do progresso econômico.

A força do mercado é muito grande hoje, e os poderosos atores da economia global querem controlar até mesmo o sistema jurídico. O certo era serem controlados por ele, mas o próprio Estado perdeu a força depois que a globalização e a atividade do mercado proporcionaram um deslocamento de poder, e isso fulminou o Judiciário brasileiro.

Assim, uma corrente de pensamentos exporta ideias do constitucionalismo estadunidense e faz crer que o que importa não são questões como justiça, mas sim garantir acesso geral ao mercado capitalista mundial.

Dessa forma, gráficos e números descrevem o direito. Então, percebe-se que regras legais estão à venda e o direito também. Tendências políticas e interesses comerciais mandam e desmandam. Ao aplicar a teoria da AED, teriam sido levadas em consideração as complexidades e diversidades locais, brasileiras? Não é aceitável como corretos os aspectos ideológicos da análise econômica. Esse modelo tem sido expandido pelo mundo, vendido como 
verdade, porque assim interessa ao poder econômico: obter lucro se tornou mais importante que existir justiça entre os homens.

\section{Considerações finais}

Este trabalho teve como objetivo demonstrar que a celeridade do Poder Judiciário está atrelada a diversos fatores inter-relacionados, e que eles todos convergem para uma só direção: adoção de estratégias de resultado na prestação de serviços para uma melhor gestão dos cartórios judiciais.

O presente estudo apresentou conclusões do órgão oficial de informação, $\mathrm{CNJ}$, a respeito da efetividade da prestação dos serviços judiciais no ano de 2016, confrontando números de novos casos criminais com aqueles pendentes de solução; da abrangência do Judiciário nos municípios brasileiros, menor que 50\%; do percentual do acervo processual de todo Poder Judiciário; do número aquém de servidores frente à demanda no primeiro grau de jurisdição; da redução de casos novos por magistrado e servidor, bem como do estoque que cada vez aumenta mais sem sofrer solução de continuidade. Ainda como objetivo, procurou-se trazer três casos de sucesso, relacionados a projetos de planejamento estratégico e que ilustram bem a aplicação de técnicas junto a cartórios judiciais.

A partir das inúmeras informações obtidas no Relatório Justiça em Números 2017 Ano-base 2016, abre-se espaço para novas pesquisas, principalmente no que concerne a incongruências que possam advir caso determinados índices do CNJ deixem de ser analisados em conjunto com outros, provocando interpretações equivocadas.

Assim, alcançou-se os objetivos propostos, senão vejamos: ainda que se alegue que o excesso de recursos processuais possibilitado pela lei vigente seja responsável por um acesso insatisfatório à justiça considerando o deslinde demorado, é possível, mediante a padronização de procedimentos tornar menor o tempo de tramitação do processo. Ou seja, não é a possibilidade diversificada de recursos que torna o processo demorado, mas sim a falta de gestão procedimental da engrenagem judiciária. A maior parte das pessoas acha que falta pessoal para dar conta do serviço, mas o que é necessário é capacitar as pessoas para trabalhar com controle de qualidade de processos e procedimentos. Muitos pensam que faltam recursos financeiros para atender bem a demanda, mas o que não se sabe é trabalhar organizadamente com os recursos disponíveis. Há os que entendem que os processos têm tramitação lenta porque se ampliou demais o acesso ao Judiciário, possibilitando o ingresso de ações frívolas, quando o problema está em não saber trabalhar com quantidade volumosa de processos. Limitar o 
ingresso no Judiciário do cidadão que tem uma pretensão também não é o caminho para dar celeridade e um melhor acesso. Se existem ações frívolas, que a elas seja dado tratamento punitivo. O que não se concebe é misturar um problema com outro, até porque quando o acesso ao Judiciário não tinha a amplitude de hoje já existia o problema da morosidade.

Decorrente do trabalho elaborado, é possível sugerir a existência de um departamento em cada instituição judiciária voltado ao controle da qualidade dos processos e procedimentos, que promova treinamentos periódicos e mudanças na cultura das pessoas que prestam serviço público.

\section{Referências bibliográficas}

$32^{\circ}$ Encontro Anual da ANPOCS - Associação Nacional de Pós-graduação e Pesquisa em Ciências Sociais, 2008, Caxambu/MG. GT 5 - Conflitualidade social, administração da justiça e segurança pública. O poder invisível - a burocracia judicial brasileira. 27 a 31 Out. 2008. Disponível em: <http://anpocs.org/index.php/papers-32-encontro/gt-27/gt0525/2313-paulosilva-o-poder/file>. Acesso em: 06 abr. 2018.

ANDRADE, Aurélio L. O curso do pensamento sistêmico. Print Editora. São Paulo. 2014.

BRASIL, Conselho Nacional de Justiça. A justiça em números - indicadores estatísticos do Poder Judiciário, ano 2016, in http://www.cnj.jus.br. Acesso em 14 out. 2017.

GRANGEIA, Marcos Alaor Diniz. Administração judiciária - gestão cartorária. $1^{\text {a }}$ Edição. Brasília, ENFAM. 2011. 156p.

LAKATOS, E. M. Fundamentos de metodologia científica. 7. ed. São Paulo:Atlas, 2010.

RABIN, Claudio Goldberg. O Judiciário se acostumou a não ser cobrado. Revista Veja, fev. 2017. Disponível em: < http://veja.abril.com.br/brasil/o-judiciario-se-acostumou-a-naoser-cobrado/> Acesso em: 03 fev. 2017.

SILVA, Paulo Eduardo Alves da Silva. Gerenciamento de processos judiciais. Saraiva, 2010 . 
SILVA, Paulo Eduardo Alves da; NOGUEIA, Mauro Oddo. In: OLIVEIRA, Saulo Barbará de. (Org. e Coautor). Instrumentos de gestão pública. São Paulo: Saraiva, 2015. p. 187-216. SODRÉ, Paulo Cezar Alves.

A administração do poder judiciário e o acesso à justiça no Brasil: as alterações introduzidas pela emenda constitucional $n^{\mathbf{0}} \mathbf{4 5}$ /2004. Florianópolis. 2014. Curso de Mestrado em Direito, Estado e Sociedade. Dissertação apresentada ao Curso de Pósgraduação Strictu Sensu em Direito, Programa de Mestrado, da Universidade Federal de Santa Catarina. Disponível em < https://repositorio.ufsc.br/xmlui/bitstream/handle/123456789/ 103243/274165.pdf?sequence=1\&isAllowed=y>. Acesso em: 06 abr. 2018.

VERGARA, Sylvia Constant. Projetos e relatórios de pesquisa em administração. 3. Ed. São Paulo: Atlas, 2000. 


\title{
A EXTRAJUDICIALIZAÇÃO E O REGISTRO CIVIL DAS PESSOAS NATURAIS COMO FORMA DE ACESSO À JUSTIÇA
}

\author{
Priscila Alves Patah \\ Universidad de Salamanca e FADISP
}

\begin{abstract}
Resumo
O artigo estuda a extrajudicialização e serventias extrajudiciais, quanto aos atos praticados no Registro Civil das Pessoas Naturais. O acesso à justiça deve estar inserido não somente no Poder Judiciário. Com excesso de processos, há uma tendência a que questões jurídicas possam e devam ser resolvidas por outros entes. Aqui, inserem-se os cartórios extrajudiciais, especificamente o Registro Civil das Pessoas Naturais, deixando que o Judiciário resolva somente os litígios que não podem ser resolvidos senão por este Poder. Selecionamos os atos de reconhecimento de filho, registro de nascimento em caso de reprodução assistida e retificação de registro de forma administrativa.
\end{abstract}

Palavras-chave: Extrajudicialização, Poder Judiciário, Serventias Extrajudiciais, Registro Civil das Pessoas Naturais, Segurança Jurídica.

\begin{abstract}
Resumen/Résumé
The article studies extrajudicialization and extrajudicial services, regarding the acts practiced in the Civil Registry of Natural Persons. Access to justice must be included not only in the judiciary. With excess of processes, there is a tendency that legal issues can and should be resolved by other entities. Here, extrajudicial registries are inserted, specifically the Civil Registry of Natural Persons, allowing the Judiciary to resolve only those disputes that can not be solved except by this Power. We select the acts of child recognition, birth registration in case of assisted reproduction and rectification of registration in an administrative way.
\end{abstract}

Keywords/Palabras-claves/Mots-clés: Extrajudicialization, Judicial power, Extrajudicial Services, Civil registry of individuals, Legal Security. 


\section{Considerações Iniciais}

É crescente o número de processos no Poder Judiciário, conforme a análise do Conselho Nacional da Justiça - CNJ, na Justiça em Números ${ }^{1}$, cujo foco é analisar os números da justiça a fim de imprimir celeridade no julgamento de números.

Ressalta-se que o excesso de trabalho pode ser prejudicial à análise dos casos que realmente demandam uma intervenção do magistrado. Dentre os diversos processos que chegam ao Judiciário, muitos não demandam uma atuação jurisdicional e, por isso, não precisariam estar sob sua análise.

Estes são, por exemplo, os casos de jurisdição voluntária, de acordos que são homologados por juízes e de alguns atos de execução. Tais atos poderiam ser desjudicializados ou extrajudicializados e as serventias extrajudiciais utilizadas para atendimento à população de forma célere e eficaz, como já o fazem em outras oportunidades, trazendo efetividade ao acesso à justiça, como veremos a seguir.

\section{A extrajudicialização como forma de acesso à Justiça}

Em todo o mundo, encontramos certa preocupação com o "acesso à justiça" (CAPPELLETTI; GARTH, 1988, p. 161). No tocante ao acesso à justiça, poder-se-ia pensar que talvez o melhor seria mencionar o acesso ao direito ${ }^{2}$. Haveria, assim, um legítimo direito de acesso ao direito à uma população tão carente de informações jurídicas como a brasileira.

No Brasil, com o advento da Constituição Federal de 1988, o amplo acesso à justiça foi disseminado (MOTA, 2010, p. 43), no artigo 5, XXXV, que prevê que "a lei não excluirá da apreciação do Poder Judiciário lesão ou ameaça a direito". Dessa forma, a população brasileira, com o passar dos anos, se vale do Poder Judiciário para pleitear quaisquer tipos de direitos e resolução de problemas.

O não fomento do diálogo em questões muitas vezes simples, como direitos de vizinhança, indenizações decorrentes de acidentes de trânsito, questões de direitos de família, problemas com concessionárias de serviços públicos, entre outros, geram o crescente número de processos.

\footnotetext{
${ }^{1} \mathrm{http} / /$ www.cnj.jus.br/files/conteudo/arquivo/2017/09/904f097f215cf19a2838166729516b79.pdf. Acesso em 04/11/2017, às 15:54.

${ }^{2}$ Em Portugal, Paula Costa e Silva bem definiu a situação, dispondo que naquele país melhor seria o acesso ao direito sem que, preferencialmente se passasse pelos tribunais. (COSTA E SILVA, 2009, p. 19)
} 
Observa-se que o acesso à justiça de fato era necessário a uma população carente de recursos materiais e intelectuais ${ }^{3}$. A importância do acesso ao Poder Judiciário através da assistência judiciária para os pobres, a fim de facilitar o princípio da isonomia, conforme as Primeira e Segunda Ondas de Acesso à Justiça, de Cappelletti e Garth (1988), parece, em princípio, ter sido cumprida constitucionalmente e efetivamente, de alguma forma, com a criação das Defensorias Públicas e Ministério Público, cada vez mais fortes e atuantes, embora ainda seja esperado um aumento no número de profissionais de tais áreas.

A população brasileira, em geral pouco instruída, não conhece seus direitos (e nem tanto seus deveres). Assim, era mesmo necessário, em um primeiro momento, que ela pudesse ter um aliado a quem se socorrer para se amparar juridicamente, tal como previram Cappelletti e Garth (1988).

Ocorre que temos na atualidade, um Estado que não está adotando meios eficazes à prestação do serviço jurisdicional (BONICIO, 2006, p. 68), resultando num Judiciário atolado em processos (COSTA E SILVA, 2009, p. 21), que demoram anos, e repleta de demandas que pouco têm a ver com a garantia de direitos ${ }^{4}$, e em desprestígio à celeridade (DUARTE, 2007, p. 208). Saliente-se que o decurso do tempo pode ser nocivo (DINAMARCO, 2013, p. 66), e nem sempre traz a esperada Justiça ${ }^{5}$. Desta feita, está na hora de rever o acesso à justiça ${ }^{6}$, para melhorá-lo, a fim de garantir o direito primário de todo o povo: a cidadania.

Não é possível continuarmos com o quadro atual de justiça, pois a garantia da inafastabilidade permanece no sistema brasileiro, ao menos para boa parcela da população, absolutamente inócua (BONICIO, 2006, p. 68). O conceito de Justiça merece uma ampliação (BARROSO, 2015, p. 73/74), de forma que seja alcançada além do Poder Judiciário. Assim, a Terceira Onda de Acesso à Justiça, de Cappelletti e Garth ${ }^{7}$, com juízos especializados e

\footnotetext{
3 "Ocorre que, no Brasil, assim como em tantos outros países do mundo, há vários obstáculos que impedem as pessoas de ter acesso à justiça, tais como a pobreza e a falta de cultura e informações, e a inexistência de programas e posturas oficiais a este respeito." (BONICIO, 2006, p. 68)

4 "Deve-se concluir, portanto, que a excessiva facilidade de acesso a certo tipo de litigante e o estímulo à litigiosidade podem tornar a justiça não só seletiva, mas principalmente "inchada", estando repleta de demandas que pouco têm que ver com a garantia de direitos." (TARTUCE, 2015, p. 139).

5 "O "acesso à justiça" não é mais tido apenas como o mero direito do cidadão de acesso ao judiciário, pois de nada adianta permitir o seu acesso e não dar condições para que se obtenha uma sentença justa e um processo imparcial.” (MOTA, 2010, p. 19)

6 "Em resumo, é possível afirmar que o sistema não se preocupa com o acesso à justiça e esta falta de preocupação provoca enormes conseqüências na vida das pessoas que necessitam de tutela jurisdicional." (BONICIO, 2006, p. 69)

${ }^{7}$ A Justiça multi-portas falada por Frank Sander e mencionada por Rodolfo de Camargo Mancuso é desejada e deve ser colocada em prática, a fim de garantir uma justiça efetiva, não só com o amplo acesso, mas com a ampla resolução de conflitos e pendências jurídicas não conflituosas.
} 
amparados na arbitragem, conciliação e incentivos econômicos faz-se necessária, mas ainda deve-se ir mais longe.

Ao nosso sentir, somente deveriam ser levados ao Judiciário as situações excepcionais, sem o qual não poderiam ser resolvidas, reservando-se ao juiz os casos de maior gravidade (BARROSO, 2015, p. 73/74).

Essas questões são trazidas por Cândido Rangel Dinamarco, na obra "Nova Era do Processo Civil", apontando a pretensão bifronte, ou seja, quando se fala na pretensão deduzida pelo autor como objeto do processo, uma que diz respeito ao mérito e a outra que diz respeito a aspiração a um provimento jurisdicional em relação àquela primeira, que seriam os pedidos mediato e imediato, respectivamente (DINAMARCO, 2013, p. 49/50). Em algumas ações, nota-se que a segunda pretensão é muito mais relevante do que a primeira, já que a primeira pretensão, mérito, muitas vezes, prescindiria do Judiciário, como nos casos de jurisdição voluntária, por ausência, inclusive, de lide.

Assim, Santos previu "uma revolução mais ampla que inclua a democratização do Estado e da sociedade" $(2017$, p. 8), com o acesso efetivo e célere, tal qual dispõe a Constituição Federal brasileira.

Já não são suficiente reformas processuais (DINAMARCO, 2013, p. 13/14), sendo necessário, nos dizeres de Boaventura de Souza Santos, uma "revolução democrática da justiça", com “uma nova concepção do acesso ao direito e à justiça" (SANTOS, 2017, p. 24/25).

É preciso que a população possa resolver suas questões jurídicas em outros locais. Aqui, lembramos que o papel das agências reguladoras pode ir além de regulamentação. Os juizados especiais podem ir além de ingresso de ações e também servir como órgão de consulta. Os advogados, defensores públicos e profissionais do Ministério Público podem e devem tender ao diálogo, não se valendo somente do combate. A arbitragem, que confere prestígio à autonomia da vontade dos litigantes, manifestada quando optam por esse meio alternativo (DINAMARCO, 2013, p. 43), deve ser incentivada. Cabe aqui pensar em soluções que envolvam o diálogo, a retórica e a justiça formal e material, de forma que seja o Direito parte integrante da realidade social(MACHADO, 2016, p. 11).

Por isso, Marco Antonio Greco Bortz sugere como solução "educação, concurso público, divisão do trabalho e concentração dos casos mais graves no órgão principal" (BORTZ, 2009, p. 77). Por sua vez, Henrique Ferraz Corrêa de Mello não descarta a instituição de um tribunal administrativo vocacionado para as causas de interesse dos poderes públicos, como ocorre na França, Portugal e Espanha (MELLO, 2016, p. 46). 
A Justiça multi-portas de por Frank Sander e mencionada, na esfera nacional, por Rodolfo de Camargo Mancuso (2011), onde o acesso à Justiça não teria apenas a porta de entrada do Poder Judiciário, deve ser colocada em prática, a fim de garantir uma justiça efetiva, não só com o amplo acesso formal, mas com a ampla resolução de conflitos e demais questões jurídicas.

Aqui, cogitamos a Quarta Onda de Acesso à Justiça, condizente com o estágio atual de evolução da Justiça, que seriam os cartórios extrajudiciais, que são uma excelente opção para a resolução de questões jurídicas e, muitas vezes, pacificadoras de conflitos, além de significar ganhos ao Estado, usuário, sociedade, Poder Público e Judiciário (BORTZ, 2009, p. 108/109).

Isto porque notários e registradores são profissionais do direito, dotados de fé pública, imparciais e conhecedores a fundo das disciplinas em que atuam, com dever de informação jurídica ${ }^{8}$.

\section{A extrajudicialização nas serventias extrajudiciais ${ }^{9}$}

O problema do acesso à justiça no Brasil não é simples e demanda uma mudança no ensino universitário nos cursos de Direito (SANTOS, 2017, p. 24/25) ${ }^{10}$, reforma constitucional com possível criação de um Tribunal Constitucional (PATAH, 2016) e a simplificação do Direito, como querem Cappelletti e Garth, "pois se a lei é mais compreensível, ela se torna mais acessível às pessoas comuns" (CAPPELLETTI; GARTH, 1988, p. 156/157). Tais propostas se encaixam num cenário a longo prazo. Porém, de forma a atender expectativas mais atuais e urgentes, o legislador tem se preocupado com a extrajudicialização e a desjudicialização.

Assim, tem demonstrado estar mais satisfeito com os resultados de leis que apresentaram um resultado positivo tanto com a diminuição de número de processos no Poder Judiciário, como melhor satisfação para as partes, devido à celeridade com a necessária

\footnotetext{
${ }^{8}$ Acreditamos que os atuais registradores e notários tem deveres anexos como o da informação (verificação, comunicação e participação), conforme dito por PACHECO, 2009, p. 97.

${ }^{9}$ Esclarecendo o adjetivo extrajudicial, os autores portugueses Rui Pinto e Helena Tomaz assim explanam: "O adjetivo "extrajudicial" é importante: não estamos perante o exercício do direito de ação, não estamos na função jurisdicional, seja no plano orgânico (não há tribunal), no plano procedimental (não se pede sentença), ou no plano do objeto (não se dirime um litígio, declarando o direito). Nenhum despacho nele proferido certifica um direito ou facto com valor de caso julgado.”(PINTO; TOMAZ, 2015, p. 5)

${ }^{10}$ Em Portugal, Paula Costa e Silva propôs "a criação de uma disciplina sobre meios extrajudiciais de resolução de conflitos, a integrar no curriculum do mestrado em ciências jurídico-forenses, na Faculdade de Direito da Universidade de Lisboa" (COSTA E SILVA, 2009, p.13).
} 
segurança jurídica, temos um legislador cuja tendência é aumentar a busca pelo acesso à justiça em outras esferas (COSTA E SILVA, 2009, p. 36).

Dessa forma, surgiram as leis de inventário e partilha, divórcio e inventário extrajudiciais, mediação e conciliação ${ }^{11}$, retificação administrativa, usucapião extrajudicial, alienação fiduciária em garantia com o procedimento sendo feito pelos registradores de imóveis.

No passado, atos que hoje são praticados por notários e registradores, o eram por juízes, como atos de jurisdição voluntária, como a atribuição destinada a conferir fé pública judicial ao contrato de alienação de imóveis, cujos efeitos dependiam da intervenção do juiz, com força de coisa julgada (BORTZ, 2009, p. 79).

Essa tendência à extrajudicialização em prol das serventias extrajudiciais deve ser ampliada $^{12}$, pois já mostrou ser acertada. Caberia, nesse contexto, a retificação administrativa de nome de transexual diretamente nos cartórios de registro civil, com fundamento no art. 110, Lei de Registros Públicos, a exemplo do que já ocorre em outros países, como Espanha e Portugal (GONÇALVES, 2014, p. 245), tal qual decidido recentemente pelo E. Supremo Tribunal Federal. No entanto, tendemos a entender pela apresentação de laudo médico indicando o transexualismo, além da manifestação de vontade do interessado. Ainda, podemos cogitar de alteração de regime de bens diretamente nas serventias extrajudiciais.

Com isso, teríamos, no Brasil, um Poder Judiciário cada vez mais especializado em lides, deixando que demais questões sejam resolvidas por outras entidades.

A seguir, veremos quem são os conhecidos cartórios e alguns atos que já são praticados nas serventias extrajudiciais.

\section{Alguns procedimentos de extrajudicialização no Registro Civil das Pessoas Naturais}

Os registros públicos têm por fim conferir autenticidade, segurança e eficácia aos atos jurídicos, conforme estabelece o art. $1^{\circ}$ da Lei $n^{\circ}$ 6.015/73, sendo o Registro de Imóveis uma de suas especialidades, que tem por fim atribuir certeza jurídica aos direitos inscritos, e, do

\footnotetext{
${ }^{11}$ Os métodos alternativos tem sido utilizados em diversos países, para decidir causas judiciais. (CAPPELLETTI; GARTH, 1988, p. 81)

${ }^{12}$ Henrique Ferraz Corrêa de Mello questiona, inclusive, por que a citação deve ser feita por um funcionário do fórum, se, um oficial do registro de títulos e documentos poderia fazê-lo mais rapidamente e com menor custo ${ }^{12}$.
} 
ângulo do pensamento complexo, o Registro de Imóveis é uma instituição de publicização de direitos, certificadora de segurança jurídica(RICHTER, 2005, p. 136).

Buscamos apresentar três institutos jurídicos objetos de extrajudicialização: reconhecimento de filho, registro de nascimento nos casos de técnicas de reprodução assistida e retificação de assento, todos na via administrativa. O intuito é apenas introduzir o leitor às novas formas de acesso à justiça pelas serventias extrajudiciais no registro civil das pessoas naturais.

Ainda na esfera das serventias extrajudiciais, porém em outras áreas específicas, encontramos o inventário e partilha de bens, divórcio e separação nos tabelionatos de notas, a prática cada vez maior de protestos de títulos e outros documentos ${ }^{13}$, a retificação de área, alienação fiduciária em garantia e usucapião extrajudicial, nos registros de imóveis.

\subsection{Reconhecimento de filhos}

O reconhecimento de filhos, de forma espontânea, pode se dar no próprio termo de nascimento, por escritura pública, por testamento e por documento público ou documento escrito particular, com o reconhecimento da firma do signatário. Cabe, ainda, o reconhecimento judicial de filiação. Independe, também, de estado civil dos genitores ou de eventual parentesco entre eles, na atual legislação.

Importante ressaltar que, em sendo o pai menor de idade, há que se distinguir duas situações: se ele for menor absolutamente incapaz, o reconhecimento dar-se-á somente por decisão judicial. Já no caso de ele ser relativamente incapaz, poderá reconhecer o filho, inclusive sem assistência de seus pais, tutor, curador ou apoiador, uma vez que o reconhecimento de filho pode ocorrer em testamento.

No caso da genitora ser menor, seja absolutamente ou relativamente incapaz, havendo Declaração de Nascido Vivo - DNV, tal informação poderá ingressar no assento de nascimento, independentemente de decisão judicial, por ser fato natural.

A Lei $n^{\circ} 8.560 / 92$ já previa o procedimento para indicação do suposto pai quando do registro de nascimento de criança sem participação ou anuência do pai. Assim, o procedimento tem início quando a mãe comparece sozinha e sem certidão de casamento (indicativo da presunção legal de paternidade) ou termo a parte com reconhecimento paterno.

\footnotetext{
${ }^{13}$ Recentemente, foi autorizado o protesto de contrato de honorários advocatícios pelos tabeliães de notas do Estado de São Paulo (Processo CG no 2017/171359).
} 
O Oficial, por sua vez, indaga-a sobre a indicação do suposto pai da criança. Concordando, ela indica o pai, com dados de qualificação e localização, a fim de que o juiz corregedor localize o indicado e o chame para uma audiência.

Reconhecendo a criança como sua filha, o processo, que corre na via administrativa, irá retornar à serventia extrajudicial e será averbado o nome do pai, com possibilidade de alteração do sobrenome para acrescentar o patronímico paterno. Caso contrário, o juiz irá encaminhar o caso ao Ministério Público, a fim de ingressar com ação de investigação de paternidade.

Com o Provimento $n^{0}$ 16/2012, o Conselho Nacional de Justiça - CNJ estendeu a possibilidade do procedimento acima ao período posterior ao registro, ampliando a possibilidade de indicação do suposto pai pela mãe para além do ato de registro de nascimento.

Ainda, possibilitou o reconhecimento paterno ou materno (hipótese não tão comum, mas existente) diretamente nos cartórios de registro civil das pessoas naturais. Assim, comparecendo o genitor que deseja reconhecer seu(sua) filho(a) e preenchendo um termo, juntamente com o filho(a) reconhecido(a), se maior ou com o outro genitor que consta no assento, se menor, na presença do Oficial, este dará seguimento à averbação de reconhecimento paterno/materno, se o registro for de sua serventia. Em não sendo, os interessados encaminharão o termo e os documentos ao cartório onde lavrado o assento em questão. Trata-se de medida extremamente eficiente e segura, que colaborou para a extrajudicialização e celeridade, baseada no consenso.

Nessa esteira, o Provimento $n^{0} 63 / 2017$ do CNJ procurou abranger outra hipótese de reconhecimento de filho, qual seja a socioafetiva. Assim, previu o reconhecimento por termo cujo modelo segue anexo ao provimento, de forma similar ao Provimento $n^{\circ} 16$, CNJ.

Da mesma forma, prevê que o reconhecimento de paternidade ou de maternidade socioafetiva poderá ser processado perante oficial diferente ao que lavrado o assento, mediante a exibição de documento oficial de identificação com foto do requerente e da certidão de nascimento do filho, ambos no original e cópia.

Prevê, ainda, que se o filho for maior de doze anos, o reconhecimento da paternidade ou maternidade socioafetiva exigirá seu consentimento e que na falta da mãe ou do pai do menor, na impossibilidade de manifestação válida destes ou do filho, quando exigido, o caso será apresentado ao juiz competente, nos termos da legislação local,

Por fim, prevê que o reconhecimento espontâneo da paternidade ou maternidade socioafetiva não obstaculizará a discussão judicial sobre a verdade biológica. 
Em que pese a boa intenção do $\mathrm{CNJ}$ em facilitar os procedimentos de reconhecimento de filiação socioafetiva, deixamos a reflexão se este órgão não estaria ingressando nas atribuições do Poder Legislativo. Ainda, há preocupação com a questão de adoção disfarçada de reconhecimento socioafetivo, pois a atribuição do registrador não engloba a produção de provas tal qual na esfera jurisdicional.

Quanto ao artigo 14 do Provimento $n^{\circ} 63, \mathrm{CNJ}$, previu-se que poderá constar, no máximo, dois pais e duas mães. Não se sabe qual foi a finalidade desses números, porém havendo uma criança filha de dois pais homoafetivos que já figuram no assento e venha a ser reconhecida por um pai socioafetivo, não haveria possibilidade de averbação segundo esse provimento.

\subsection{Registro de nascimento nos casos de técnicas de reprodução assistida}

O legislador do atual Código Civil procurou inserir situação comum no início de sua vigência - a inseminação artificial heteróloga - prevista no inciso V, artigo 1597 do Código Civil. Porém, a cada dia surgem novas situações que têm sido resolvidas por decisões das Varas de Registros Públicos e Conselho Superior da Magistratura, no Estado de São Paulo, e pelo Superior Tribunal de Justiça e Supremo Tribunal Federal. Essas inovações mudaram a atividade do registrador civil, a respeito dos registros de nascimento.

Até passado recente, regia os assentos e nascimento a maternidade sempre certa, afinal, mãe era quem dava à luz a criança. Hoje, o conceito de maternidade e paternidade é muito mais amplo, incluindo a socioafetividade, a adoção a possibilidade de figurar no assento de nascimento duas mães e nenhum pai, a irrelevância do estado civil dos genitores, entre outras inovações.

Como mencionado em decisões da $2^{\mathrm{a}}$ Vara de Registros Públicos da Comarca de São Paulo, "na pós-modernidade, o tempo passa a ser auto-referencial (o presente influenciado pelo próprio presente ante a inexistência de passado sobre o tema)". Dessa feita, interessa a análise de algumas decisões, que têm sempre como fundamento a prevalência do melhor interesse da criança, e foram proferidas no âmbito administrativo.

Em 2010, a Corregedoria Geral da Justiça do Estado de São Paulo, julgou improcedente recurso do Ministério Público, que requereu o reconhecimento da maternidade presumida pela gestação. O caso foi de fertilização "in vitro" e posterior inseminação artificial, com implantação em mulher distinta da que forneceu o material genético, sem intenção de 
assumir a maternidade, com a presença dos requisitos previstos na Resolução 1358/1992 do Conselho Federal de Medicina.

Já no ano seguinte, houve a proposta de criação de formulário sobre as circunstâncias históricas do parto, a ser arquivado pelo oficial em classificador próprio. O parecer foi contrário à medida, por ser disciplina inoportuna no âmbito administrativo-correcional.

Em 2013, foi discutida a reprodução assistida heteróloga parcial (com doação de oócito) e maternidade de substituição, onde a gestante era a irmã da doadora. O recurso de relatoria do então Desembargador José Renato Nalini, foi provido, com base na prevalência da verdade contida no procedimento de reprodução assistida consoante pedido de todos os participantes do protocolo médico.

Entre os anos 2015 e 2016, quatro relevantes decisões administrativas foram proferidas pela $2^{\text {a }}$ Varra de Registros Públicos da Capital do Estado de São Paulo. Em todas, a Resolução 2013/2013, que posteriormente foi revogada pelo Conselho Federal de medicina, não foi usada como fundamento, visto que há ausência de legitimidade para vinculação social, o que somente poderia ocorrer pelo processo legislativo previsto na Constituição Federal.

As quatro decisões foram julgadas procedentes e tratam, cada uma delas, de casos específicos. São elas: fecundação "in vitro" e gestação por substituição; inseminação artificial em uma das companheiras, com doador de sêmen anônimo, onde a intenção das requerentes era figurar no assento os nomes das duas mães, óvulo de uma companheira fertilizado "in vitro" com sêmen de doador anônimo, posteriormente implantado no ventre da outra; requerimento para constar nome dos pais biológicos no assento, tendo em vista fertilização "in vitro" e gestação por substituição.

Conforme se percebe, a evolução das técnicas de reprodução assistida exigem do direito uma atualização. Dessa forma, o Conselho Nacional de Justiça publicou o Provimento $\mathrm{n}^{\mathrm{o}}$ 52, de 14 de março de 2016, que dispôs sobre o registro de nascimento e emissão da respectiva certidão dos filhos havidos por reprodução assistida.

Referido Provimento previu que o assento de nascimento de filhos havidos por técnicas de reprodução assistida será inscrito no Livro A, independentemente de prévia autorização judicial, desde que cumpra alguns requisitos, como por exemplo: apresentar termo de consentimento, certidão de casamento ou escritura de união estável. Tratou, ainda, da hipótese de gestação por substituição, em que não constaria do registro o nome da parturiente informada na declaração de nascido vivo - DNV, e das hipóteses de reprodução assistida "post-mortem".

Em novembro de 2017, o CNJ editou o Provimento $n^{\circ}$ 63/2017, revogando o Provimento $\mathrm{n}^{\mathrm{o}}$ 52. Referido provimento prevê o assento de nascimento de filho havido por 
técnicas de reprodução assistida no Livro A, independentemente de prévia autorização judicial, a partir do cumprimento de alguns requisitos.

Assim, deverá ser apresentada ao registrador civil das pessoas naturais: a declaração de nascido vivo - DNV, a declaração, com firma reconhecida, do diretor técnico da clínica, centro ou serviço de reprodução humana em que foi realizada a reprodução assistida, indicando que a criança foi gerada por reprodução assistida heteróloga, assim como o nome dos beneficiários,certidão de casamento, certidão de conversão de união estável em casamento, escritura pública de união estável ou sentença em que foi reconhecida a união estável do casal.

Como se denota, o provimento contempla o registro de nascimento diretamente nas serventias extrajudiciais apenas para casais que comprovem casamento ou união estável. E, ainda, apenas para casos de reprodução assistida em clínicas médicas especializadas. Assim, os casos que não se enquadrem nessas situações continuarão a exigir a intervenção da autoridade judiciária. Isto porque, permite o registro a situações que tragam comprovação para contemplar a segurança jurídica inerente aos registros públicos.

Dito provimento traz também a previsão de que na hipótese de gestação por substituição, que são os casos de cessão temporária de útero, vulgarmente conhecida como "barriga de aluguel”, não constará do registro o nome da parturiente, informado na declaração de nascido vivo - DNV.

Situações como a de pessoas que não estão em relacionamento conjugal ou com companheiros formais ou, ainda, os casos de reprodução assistida feita fora de clínicas, em casa e informalmente, como as "caseirinhas", não poderão ser registradas nos termos do Provimento $\mathrm{n}^{\mathrm{o}} 63$.

No caso de inseminação artificial “pos mortem” é indispensável, para fins de registro, a apresentação do termo de autorização prévia específica do falecido ou falecida para uso do material biológico preservado, lavrado por instrumento público ou particular, com firma reconhecida.

Outra situação polêmica é a do artigo $17, \S 3^{\circ}$ do Provimento n 63 , que revê que o conhecimento da ascendência biológica não implica no reconhecimento do vínculo de parentesco e dos respectivos efeitos jurídicos entre doador ou doadora e o fillho gerado por meio de reprodução assistida.

Uma inovação acertada é a das hipóteses de filhos de casais homoafetivos, em que respectivo assento de nascimento deverá ser adequado para constar os nomes dos ascendentes, sem haver qualquer distinção à ascendência paterna ou materna, visando minimizar eventuais discriminações. 
A normativa estadual de São Paulo traz, no item 42-B.1, Capítulo XVII a previsão de que no caso de doação voluntária de gametas ou embriões, deverá constar na declaração que a clínica médica se compromete a manter, de forma permanente, registro com dados clínicos, características fenotípicas e uma amostra de material celular dos doadores. Tal conduta poderia evitar situações como casamento entre irmãos e auxiliaria no conhecimento da ascendência biológica.

Contudo, questiona-se qual seria a sanção para aquelas que não mantiverem o arquivo e, ainda, para aquelas que fecharem. Sugerimos, aqui, a criação por meio de lei de um banco nacional para tais cadastros, controlado pelo Conselho Federal de Medicina que teria o controle do acervo de forma perene, ainda que a clínica chegasse ao fim.

Observa-se a preocupação do CNJ em uniformizar e regulamentar situações de fato, não pensadas pelo legislador do Código Civil de 2002. Os fatos da vida não esperam pela previsão legislativa. No entanto, não pode o direito negar sua existência, tampouco tratá-los como institutos distantes - tal como a adoção unilateral.

\subsection{Retificação de assento}

Retificar significa corrigir. Os artigos 109 e 110 da Lei nº 6015/73 tratam da retificação no Registro Civil das Pessoas Naturais, sendo que o artigo 109 trata da retificação na esfera jurisdicional. Já, o artigo 110 traz a possibilidade de retificação administrativa, ou seja, diretamente nas serventias extrajudiciais, para os erros que não exijam qualquer indagação para a constatação imediata de necessidade de sua correção.

Para tanto, necessária a provocação do registrador civil das pessoas naturais, tendo em vista o princípio do rogatório atinente aos registros públicos. Assim, o requerente apresentará ao protocolo do cartório extrajudicial uma petição assinada por ele, seu representante legal ou procurador, juntando as provas do alegado e inserindo o que pretende corrigir.

Ocorre que até a égide da Lei $\mathrm{n}^{0} 13.484$, de 2017, era necessária a manifestação conclusiva do Ministério Público. Atualmente, no entanto, independe de prévia autorização judicial ou manifestação do Ministério Público, nos seguintes casos: erros que não exijam qualquer indagação para a constatação imediata de necessidade de sua correção; erro na transposição de elementos constantes em ordens e mandados judiciais, termos ou requerimentos, bem como outros títulos a serem registrados, averbados ou anotados, e o documento utilizado para referida averbação e/ou retificação; inexatidão da ordem cronológica e sucessiva referente à numeração do livro, da folha, da página, do termo e data do registro e, 
ausência de indicação do Município relativo ao nascimento ou naturalidade do registrado, nas hipóteses em que existir descrição precisa do endereço do local de nascimento e elevação de indicação do Município relativo ao nascimento ou naturalidade do registrado.

Todos os atos previstos em lei trazem sólida segurança em sua realização na esfera administrativa. E a alteração da Lei de Registros Públicos com a exclusão da manifestação conclusiva do Ministério Público corroborou ainda mais para celeridade do procedimento, enaltecendo a função extrajudicial e jurídica que exercem os delegados das serventias extrajudiciais. Nos demais casos não previstos em lei, há de se observar o trâmite legal, com envio ao Ministério Público e/ou juiz corregedor, ou orientar o usuário do serviço público a ingressar com o pedido de retificação por meio de ação, conforme artigo 109, Lei no 6.015/73.

No Estado de São Paulo, cabe retificação para alterações necessárias do patronímico familiar por subseqüente matrimônio, divórcio ou separação dos pais, a serem processadas a requerimento do interessado, independentemente de procedimento de retificação e serão averbadas nos assentos de nascimento dos filhos. Em tais casos, apresenta-se requerimento e certidão comprovando a alteração do nome decorrente de alteração do estado civil dos pais. Quando se tratar de registrado menor de idade, não vislumbra-se empecilho ao deferimento e alteração. Já, em se tratando de registrado maior de idade, sua anuência ao pedido do pai ou da mãe é essencial.

\section{Considerações finais}

Nota-se que, em razão da experiência no aconselhamento das partes, do dever de imparcialidade e dos conhecimentos jurídicos de direito privado, notários e registradores estão particularmente aptos para atuarem na extrajudicialização.

Dessa forma, além dos procedimentos de reconhecimento de filhos, inclusive por socioafetividade, registros de nascimentos diretamente nas serventias extrajudiciais, mesmo nos casos de reprodução assistida, e retificação de assentos,é possível que sejam atribuídasoutras funções aos registradores brasileiros, de forma a contribuir para a extrajudicialização.

Assim, diante dos novos Provimentos e alterações legislativas e tendo em vista o princípio da dignidade da pessoa humana e o exercício da cidadania pelos registros públicos, cabe ao registrador civil das pessoas naturais a orientação aos usuários quanto as novas formas de extrajudicialização. Trata-se de importante medida de isonomia e desburocratização, sendo de suma importância o papel do registrador nesse momento em que a pós-modernidade traz 
novas questões jurídicas. Exige-se do registrador agir com eticidade, a fim de garantir a segurança jurídica inerente a estes serviços.

Conclui-se que a prática de cada vez mais atos judiciais pelas serventias extrajudiciais será uma medida de acesso à Justiça à população, com características de celeridade, fé pública e segurança jurídica.

\section{Referências bibliográficas}

BARROSO, Luís Roberto. Curso de Direito Constitucional Contemporâneo: os conceitos fundamentais e a construção do novo modelo. São Paulo: Saraiva, 2015, 5. ed.

BONICIO, Marcelo José Magalhães. Proporcionalidade e Processo: a garantia constitucional da proporcionalidade, a legitimação do processo civil e o controle das decisões judiciais. São Paulo: Atlas, 2006.

BORTZ, Marco Antonio Greco. A desjudicialização - um fenômeno histórico e global. RDNotarial, CNB/SP, v.1, n.1, p.75/110, 2009.

BRANDELLI, Leonardo. Nome civil da pessoa natural. São Paulo: Saraiva, 2012.

Registro de Imóveis: Eficácia material. Rio de Janeiro: Forense, 2016.

. Usucapião administrativa de acordo com o novo Código de Processo Civil. São

Paulo: Saraiva, 2016.

CAPPELLETTI, Mauro. GARTH, Bryant. Acesso à Justiça. Tradução de Ellen Gracie Northfleet. Porto Alegre: Sergio Antonio Fabris Editor, 1988, reimpressão 2015.

CHALHUB, MelhimNamem. Alienação fiduciária: negócio fiduciário. Rio de Janeiro: Forense, 2017, 5. ed.

COSTA E SILVA, Paula. A nova face da Justiça: os meios extrajudiciais de resolução de controvérsias. Coimbra: Coimbra Editora, 2009. 
DINAMARCO, Cândido Rangel. Nova era do processo civil. São Paulo: Malheiros, 2013, 4. ed.

DIP, Ricardo (Coord.). Direito Registral e o Novo Código de Processo Civil. Rio de Janeiro: Forense, 2016.

DUARTE, RonniePreuss. Garantia de acesso à justiça: os direitos processuais fundamentais. Coimbra: Coimbra Editora, 2007.

GONÇALVES, Camila. Transexualidade e Direitos Humanos: o reconhecimento da identidade de gênero entre os direitos da personalidade. Curitiba: Juruá Editora, 2014.

JUNQUEIRA, José de Mello. Alienação fiduciária de coisa imóvel: Lei nº 9.514, de 20.11.97. São Paulo: ARISP, 1998.

MANCUSO, Rodolfo de Camargo. Acesso à Justiça: condicionantes legítimas e ilegítimas. São Paulo: Revista dos Tribunais, 2011.

MELLO, Henrique Ferraz Corrêa de. Usucapião extrajudicial. São Paulo: YK, 2016, 1. ed.

MOTA, Júlia Cláudia Rodrigues da Cunha. As serventias extrajudiciais e as novas formas de acesso à justiça. Porto Alegre: Sergio Antonio Fabris Editor, 2010.

PACHECO, José. Autenticidade e forma legal dos actos jurídicos extrajudiciais: novos rumos. Coimbra: Coimbra, 2009.

PATAH, Priscila Alves. Separação e divórcio - uma visão atual. Desjudicialização e as serventias extrajudiciais - as escrituras públicas de separação e divórcio. http://www.cidp.pt/publicacoes/revistas/rjlb/2016/6/2016_06_1217_1241.pdf, Acesso em: $20 / 10 / 2017$, às $17: 05$

- Ativismo judicial e outras formas de desnaturação de decisões judiciais. http://www.cidp.pt/publicacoes/revistas/rjlb/2016/5/2016_05_1279_1298.pdf. Acesso em: $28 / 11 / 2017$, às $17: 49$ 
RESTIFFE, Paulo Neto. RESTIFFE, Paulo Sérgio. Propriedade fiduciária imóvel. São Paulo: Malheiros.

RICHTER, Luiz Egon. Do procedimento de retificação administrativa no registro de imóveis. Revista dos Tribunais, Instituto de Registro Imobiliário do Brasil. Revista de Direito Imobiliário v.28, n.59, p.134-152, jul/dez. 2005.

SAMPAIO, Lia Regina Castaldi. BRAGA, Adolfo Neto. O que é mediação de conflitos. São Paulo: Brasiliense, 2007.

SANTOS, Boaventura de Sousa. Para uma revolução democrática da justiça. 3.ed. http://sociologial.dominiotemporario.com/doc/REVOLUCAO_DEMOCRATICA_JUSTICA. pdf Acesso em: 02/10/2017, às 17:30.

TARTUCE, Fernanda. Mediação nos conflitos civis. São Paulo: Método, 2015, 2. ed. rev., atual. e ampl. 


\title{
CARGA ECONÔMICA DO PROCESSO COMO ÓBICE À CONSECUÇÃO DO PRINCÍPIO DO ACESSO À JUSTIÇA E OS MEIOS ALTERNATIVOS DE SOLUÇÃO DE LITIGIOS
}

\author{
Maria José Carvalho de Sousa Milhomem \\ Universidade Ceuma - Unicema
}

\begin{abstract}
Resumo
Objetivou-se com a presente pesquisa analisar o acesso à justiça como princípio fundamental de exercício de cidadania e de garantia do cidadão ao Poder Judiciário, mesmo quando incapaz de suportar os ônus das despesas processuais, nos termos da legislação brasileira vigente, analisando os institutos da justiça gratuita e a assistência judiciária gratuita. Demonstra-se ainda como os custos do processo podem representar óbice ao acesso à justiça, e paralelamente como os meios alternativos de solução de controvérsias, os chamados Tribunais Multiportas podem ser utilizados como ferramentas de efetivação do acesso à justiça.
\end{abstract}

Palavras chave: Acesso à Justiça, Custas Processuais, Justiça Gratuita, Assistência Judiciária Gratuita, Tribunal Multiportas.

\begin{abstract}
Resumen/Résumé
The objective of this research was to analyze access to justice as a fundamental principle of exercising citizenship and guaranteeing the citizen to the Judiciary, even when unable to bear the burden of procedural expenses, under the terms of current Brazilian legislation, analyzing the institutes of the free legal aid and free legal aid. It also demonstrates how the costs of the process can represent an obstacle to access to justice, and in parallel with alternative means of dispute settlement, the so-called Multiport Courts can be used as tools for effective access to justice
\end{abstract}

Keywords/Palabras-claves/Mots-clés: Access to justice, Related searches Free Justice, Free Legal Assistance, Multiportas Court. 


\section{Introdução}

O homem, através de lutas políticas e sociais, conquistou aos poucos seus direitos, em especial nos séculos XVIII, XIX e XX. Esses direitos foram positivados com representação de um consenso ético mundial na Declaração Universal de Direitos Humanos (BOBBIO, 2010).

Nesse contexto de conquista de direitos fundamentais, a primeira geração de direitos fundamentais tem sua origem teórica no movimento iluminista e jusnaturalista dos séculos XVII e XVIII, com filósofos como Hobbes, Locke, Rousseau e Kant. Esses filósofos defendiam um Estado protetor das liberdades individuais, desta forma construíram os subsídios de fundamento das revoluções do século XVIII. As revoluções burguesas iniciaram o processo de positivação dos direitos humanos nas Constituições escritas do mundo ocidental.

A segunda geração de direitos fundamentais surgiu entre o final do século XIX e o início do século passado, em decorrência de acentuadas diferenças entre classes sociais, resultado da exploração da força de trabalho do proletariado pelos industriais, dos graves problemas econômicos e sociais decorrentes da Revolução Industrial.

Os teóricos do socialismo concluíram que o reconhecimento formal de direitos não era suficiente para garantir sua fruição e seu gozo, e diante dessa constatação, passaram a exigir do Estado participação ativa na realização desses direitos. Em 1917 a Constituição Mexicana e, em 1919, a Constituição de Weimar, consagram em seus textos os direitos humanos de segunda geração que passaram a representar uma exigência prestacional do Estado como instrumento de realização da Justiça Social. Assim, os direitos sociais, culturais e econômicos começam a integrar uma obrigação a ser prestada pelo próprio Estado, nessa condição, o Poder Público passa a ter papel fundamental na realização da justiça social.

Já os direitos fundamentais de terceira geração, surgiram após a Segunda Grande Guerra, emergindo como elementos para a garantia dos direitos difusos e coletivos, em especial, a proteção do meio ambiente, que já reclamava novas técnicas de garantia e proteção. Assim, com o surgimento dos direitos fundamentais de terceira geração, o direito deixa de ser o direito individual e passa a ser direito das coletividades.

Deve-se ressaltar nesse contexto, a importância da construção do estado de bem-estar social, como condição para a consolidação dos estados nacionais e da própria ideia de proteção social. Na medida em que o Wefare State despertou nos indivíduos uma busca por novos direitos substantivos, as sociedades modernas começaram a valorizar o caráter coletivo ao individual. Com as reformas trazidas por esse movimento, o acesso à justiça ganhou importância (CAPPELLETTI; GARTH, 1988, p.11). 
No Brasil, a Constituição Federal de 1988, em seu artigo 5², inciso XXXV, concede o acesso à justiça como um princípio fundamental da República ao dispor que "a lei não excluirá da apreciação do judiciário lesão ou ameaça a direito". Assim, o acesso à justiça é um direito fundamental, que visa assegurar a inafastabilidade da tutela jurisdicional do Estado (BARROSO; ROSIO, 2012, p.26).

Tendo-se como base em Cappelletti; Garth (1988, p. 31), para os quais há três elementares modelos de acesso à justiça, que em seus estudos utilizaram a terminologia "ondas" para explicar o processo de conquista e expansão do direito de acesso à justiça, sendo a Assistência Judiciária voltada aos pobres, os modelos da Justiça Gratuita e dos Advogados Públicos ou Dativos, a tutela dos interesses difusos e, o chamado "enfoque de acesso à justiça", a exemplo da Justiça Eleitoral, que se apresenta totalmente isenta de custas, independentemente da capacidade econômica de seu jurisdicionado.

A partir dessa visão tridimensional do acesso à justiça, torna-se possível observar os reais obstáculos do acesso à justiça, a exemplo do pagamento de custas judiciais como requisito de acesso, o que na maioria das vezes, tem elevado o valor econômico do processo, gerando óbice impeditivo de acesso efetivo ao judiciário.

O Brasil é um país marcado pelas desigualdades sociais e, consequentemente, possui verdadeiros abismos que separam as pessoas carentes dos mais básicos dos direitos, como saúde educação e, in casu, o acesso à justiça.

Apesar de previsto como garantia fundamental na Carta Política de 1988, tem-se que o acesso à justiça ainda carece de mecanismos que o dotem de efetividade, sendo esta questão, atualmente, um dos grandes desafios a serem solucionados pelo legislador pátrio.

Nota-se que os instrumentos atualmente disponíveis de acesso à justiça não são suficientes para atendimentos de todas as demandas, diante da grande litigiosidade da população e dos procedimentos processuais, a par disso surge os meios alternativos de resolução de conflitos, os chamados Tribunais Multiportas, ferramenta mais simples e com menor custo, ou às vezes nenhum, e que oferta acesso à justiça, tal como a forma tradicional.

Objetivou-se, portanto, no presente artigo, sem, contudo, pretender esgotar o assunto, fazer uma abordagem inicial do acesso à justiça como direito constitucional, da gratuidade desse acesso que não consegue contemplar todos os cidadãos dela que necessitam, assim como o custo do processo como óbice de acesso à justiça, e ao mesmo tempo demonstrar que há outras formas de acesso à justiça, não apenas pela forma tradicional, como a implantação do Tribunal Multiportas, com a abertura de outros meios extrajudiciais de solução de conflitos. 
O método de procedimento utilizado na presente pesquisa foi o dedutivo, com pesquisa bibliográfica e documental, de forma descritiva e exploratória, a partir da leitura de CAPPELLETTI; GARTH, assim com uma análise sobre a legislação brasileira, doutrina, especialmente no tocante ao acesso à justiça e os meios alternativos de solução de conflitos.

\section{Direito constitucional do acesso à justiça}

A Carta Constitucional brasileira assegura que, dentre os direitos fundamentais previstos, firma-se o acesso à justiça como uma das tônicas da promoção da justiça social, melhorando a qualidade de vida dos cidadãos, na medida em que amplia a oferta aos mecanismos oferecidos pela Constituição para fazerem valer seus direitos.

A Constituição de 1988 alargou os direitos fundamentais e consagrou neste rol, o direito ao acesso à justiça ao estabelecer no artigo $5^{\circ}$, inciso XXXV que "a lei não excluirá da apreciação do judiciário lesão ou ameaça a direito", evitando-se, portanto, a inafastabilidade da tutela do Estado.

Nessa ótica, é intuitivo que o livre acesso à justiça e todos os direitos e garantias a ela vinculados estão articulados à seara dos direitos humanos e fundamentais de qualquer povo e que restrições nesse âmbito implicam, sem esforço, um ambiente de injustiças e expressiva desigualdade social.

Incrementado pela Constituição Federal de 1988, o acesso à justiça é para Cappelletti, Garth (1988, p.23) "direito outorgado ao cidadão de resolver seus litígios ou de reivindicar seus direitos sob os auspícios do Estado" sob argumento que direito de acesso precisa ter uma igualdade na sua acessibilidade e seus resultados precisam ser individual e socialmente justos.

Não obstante a consagração do acesso à justiça como direito fundamental, tem-se que a sua concretização esbarra em diversos óbices, tais como o acúmulo extremo de demandas, defasagem do aparato judiciário, número insuficiente de juízes e servidores, modelo processual que desfavorece a celeridade, haja vista a previsão de grande número de recursos, entre outros - circunstâncias que reduzem ou até mesmo impedem a efetividade do referido direito.

Nesse cenário, sobreleve-se que dentre as restrições que mais afetam o acesso à justiça, destacam-se aquelas atinentes à situação econômica das pessoas que pretendem ingressar no judiciário, bem como as implicações lesivas que a ausência de poder aquisitivo é capaz de gerar ao direito ao acesso à justiça. Aspectos como os elevados gastos com as custas judiciais, honorários advocatícios, peritos e afins constituem situações que dificultam sobremaneira a 
fruição do supracitado direito fundamental pela parcela economicamente hipossuficiente dos cidadãos.

Assim, o fator econômico compromete a consecução do princípio do acesso à justiça, insculpido na Carta Magna de 1988, à medida que os elevados custos impostos ao processo judicial não podem ser suportados por aqueles que se encontram na camada social com menor poder aquisitivo.

Enquanto nos países desenvolvidos o problema a ser solucionado é possibilitar que as minorias segregadas (gênero, etnia, religião) possuam pleno acesso à justiça, o Brasil possui como máximo desafio propiciar o mesmo direito à maior parte de sua população: os menos abastados.

Nesse sentido leciona Joaquim Falcão (1996, P.273-274):

\begin{abstract}
Na maioria dos países desenvolvidos, a questão do acesso à Justiça é focalizada como desafio de implementar, através da prestação jurisdicional, os direitos das minorias. Um desafio democrático, também fundamental para o Brasil. Mas, data vênia, não acredito ser o principal, se é que podemos falar em hierarquia de direitos. Explico melhor. Quem não tem acesso à Justiça no Brasil não são apenas minorias étnicas, religiosas ou sexuais, entre outras. Quem não tem acesso é a maioria do povo brasileiro. O Judiciário, por seus custos financeiros, processos jurídico-formais e conformação cultural é privilégio das elites, concedido, comedidamente, a alguns setores das classes médias urbanas. A maioria da nossa população, as classes populares, quando tem acesso, o tem como vítima ou como réu. Não é deles, um ativo. É um passivo. Não é deles um direito, mas um dever.
\end{abstract}

Observa-se, dessa forma, que a pobreza além de mazela social, que atinge considerável camada da população, levando à marginalização e preconceito, é também obstáculo que desestimula o acesso à justiça, porquanto a carga econômica do processo, geralmente elevada, não pode ser suportada pelos cidadãos pobres, sem prejuízo de sua própria subsistência.

Acerca das desigualdades sociais como fator impeditivo do acesso à justiça pelas pessoas social e economicamente hipossuficientes, leciona Carvalho (2005, p. 286) que a justiça entre nós, no sentido de garantia de direitos, existe apenas para a pequena minoria de doutores, pois segundo esse Autor "Ela é inacessível à multidão dos crentes e macumbeiros, isto é, à grande maioria dos brasileiros. Para eles, existe o Código Penal, não o Código Civil, assim como para os doutores existe apenas o Código Civil”.

É cediço que, para contemplar o direito fundamental de acesso à justiça existe no ordenamento pátrio dois institutos jurídicos: a assistência judiciária gratuita e a justiça gratuita.

A assistência judiciária gratuita no Brasil possui fundamento constitucional próprio, tal como assegura o artigo $5^{\circ}$, inciso LXXIV, da Constituição Republicana de 1988, ao 
estabelecer que o Estado a prestará "aos que comprovarem insuficiência de recursos" (BRASIL, 1988). Os artigos 134 e 135, também Constitucionais, estabelecem os fundamentos das chamadas Defensorias Públicas, como órgãos vinculados ao Poder Executivo, através do qual são fornecidos advogados para aqueles que, por insuficiência de recursos financeiros, estão a princípio alijados do direito de buscar a Justiça para solução de litígios.

Do mesmo modo, o Código de Processo Civil contempla a justiça gratuita para aqueles que mesmo não sendo pobres e possuindo advogado particular, não têm condições de arcar com o valor das custas processuais.

Apesar da existência tais previsões legais em prol da efetivação do acesso à justiça, constata-se que ainda remanescem problemas que se impõem contra a concretização do mencionado direito fundamental, porquanto o Estado não consegue absorver a enorme demanda de processos judiciais que abarrotam o sistema judiciário, mormente quando vigora fortemente no seio da nossa sociedade a cultura do "litiganismo", sendo certo que a adoção de procedimentos informais de resolução dos conflitos geraria mais celeridade e menores custos tanto para o Estado como para os indivíduos que desejam ver satisfeitos seus direitos.

Parece contraditório afirmar que a maioria da população brasileira não possui recursos suficientes para arcar com os gastos de um processo e ao mesmo tempo apontar que o nosso judiciário está abarrotado de lides. Nesse sentido, Sadek (2014, p.60), explica que a "porta de entrada" do judiciário atrai um tipo específico de litigante, a saber, pessoas com maior nível de escolaridade e de renda, enquanto se fecha ou descorçoa a grande massa populacional, que não possui conhecimento ou poder econômico suficiente para fazer uso dos instrumentos indispensáveis à consecução dos seus direitos.

Diante desse contrassenso, necessário que o Estado rompa as barreiras que atravancam o acesso ao judiciário pelos menos favorecidos, mediante a facilitação do ingresso em juízo, com fornecimento aos indivíduos dos instrumentos processuais, financeiros e materiais necessários ao regular andamento das demandas, restando claro que o acesso da população pobre à justiça implica não apenas em concessão de benefícios de justiça e assistência judiciária gratuitas, mas também compreende o oferecimento de um processo mais efetivo, célere, aperfeiçoamento do sistema recursal e, principalmente, disponibilização aos cidadãos de meios alternativos de resolução de conflitos que realmente obtenham resultados positivos, a exemplo do fortalecimento dos Tribunais Multiportas, também objeto do presente trabalho.

Antes de iniciarmos as ponderações sobre custos do processo, além dos meios alternativos de conflitos já existentes no ordenamento pátrio, bem como as sugestões acerca 
dos Tribunais Multiportas, necessário fazer uma reflexão sobre a gratuidade do acesso à justiça no Brasil.

\section{A gratuidade do acesso à justiça no Brasil}

No Brasil há dois institutos que, muito embora distintos, acabam por se confundirem na prática forense, que é a Justiça Gratuita, que possui dogmática processual, compreendida pela isenção total sobre as custas judiciárias e, ao lado dela, a Assistência Judiciária Gratuita, que consiste num serviço organizado prestado pelo Estado para fornecer acesso à justiça através de órgãos vinculados ao Poder Executivo, como, por exemplo, as Defensorias Públicas.

Importante observar que a assistência judiciária gratuita é aquela prestada pelo Estado de forma integral e plena, que engloba tanto a assistência jurídica quanto a assistência judiciária, ou seja, além de orientação e patrocínio em juízo, de forma gratuita através da Defensoria Pública e órgãos conveniados, promove campanhas educativas e de conscientização de direitos à população carente, a exemplo das campanhas de direitos do consumidor, entre outros.

Ao passo que a justiça gratuita é a dispensa de pagamento de custas processuais e emolumentos, pode alcançar ainda outras despesas do processo, sendo ofertada para aquelas pessoas que não são pobres e que tem patrocínio particular, mas não conseguem suportar as custas do processo sem prejuízo de seu sustento e/ou de sua família.

Quer dizer, a assistência jurídica engloba a assistência judiciária, com patrocínio gratuito da causa por advogado fornecido pelo Estado, seja pelas Defensorias Públicas (criadas pela Lei Complementar $n^{\circ} 80$ de 1994) ${ }^{1}$ seja pelas entidades paraestatais conveniadas ou não ao Poder Público, como os Núcleos de Prática das Universidades Públicas e Privadas, ao passo que a justiça gratuita engloba somente a gratuidade processual, ou seja, a isenção e pagamento de custas, emolumentos e despesas processuais, podendo ou não incluir tanto as que são devidas ao Estado, como créditos de terceiros, a exemplo dos honorários de perito (MINOTTO, 2014, p. 03).

Portanto, fácil perceber, que garantir o acesso à justiça não significa necessariamente estabelecer uma Justiça totalmente financiada pelo Estado, em comparativo com os serviços públicos de saúde e educação.

Para Cappelletti; Garth (2002, p.8) o acesso à justiça não é simplesmente franquear o ingresso do indivíduo na justiça, mas acima de tudo, conceder-lhe a consciência de seus direitos,

\footnotetext{
${ }^{1}$ Artigo 185 do NCPC trata da Defensoria Pública, e ainda regulada nos artigos 186 e 187.
} 
com orientação jurídica devida, de modo a possibilitar a utilização dos instrumentos processuais que a lei dispõe, buscando resultados justos. $\mathrm{O}$ acesso à justiça é um direito fundamental dos mais relevantes, em vista que tutela os demais direitos.

A par dessa importância, o Supremo Tribunal Federal chancelou a vigência tanto do instituto da justiça gratuita, quanto da assistência judiciária gratuita, como elementos válidos ao aprimoramento do acesso à justiça no sistema constitucional brasileiro, ao firmar que a garantia da assistência jurídica integral do artigo $5^{\circ}$, LXXIV, aos que comprovarem insuficiência de recursos não revogou a assistência judiciária gratuita da Lei 1.060/50, aos necessitados, bastando para obtenção desta, declaração feita pelo próprio interessado, de que a sua situação econômica não permite ingressar em Juízo sem prejuízo da sua manutenção ou de sua família, ressaltando que a norma infraconstitucional (Lei 1.060/50) põe-se, ademais, dentro do espírito da Constituição, a qual deseja que seja facilitado o acesso de todos à Justiça (BRASIL, RE 205746).

O Superior Tribunal de Justiça também resguarda o direito ao acesso à justiça confrontando-o com os institutos de garantias já previstos e usuais, tentando desenhar critérios mais objetivos para se aplicar os institutos vigentes, rectius, justiça gratuita e assistência judiciária gratuita, tentando mitigar os elementos de subjetividade excessivamente considerados, tendo decidido em diversos julgados que a concessão de assistência judiciária às pessoas cuja "renda mensal seja superior a 10 salários mínimos poderá ser deferida, caso existentes elementos que indiquem que o pagamento das custas prejudicará "o sustento próprio ou da família" do requerente" (REsp 1317175/SC, BRASIL).

A assistência jurídica integral e a justiça gratuita estão previstas na Constituição Federal, artigo 5. ${ }^{\circ}$ inciso LXXIV, bem como no novo Código de Processo Civil, artigos 98 a 102 e 185 a 187 como dever do Estado aos que comprovarem insuficiência de recursos. Tratase de um direito público subjetivo consagrado a todo aquele que comprovar que sua situação econômica não lhe permite pagar honorários advocatícios e despesas processuais, sem prejuízo de seu próprio sustento ou de sua família (MINOTTO, 2014, p. 03).

De só mais importância, o acesso à justiça, amplo, garantido como direito fundamental, republicano e democrático, não necessariamente confronta com a definição e aplicação das custas processuais, não podendo ser apontada como única responsável pela dificuldade encontrada pelo cidadão ordinário em tentar alcançar a solução de um conflito, pois, além de significar elemento indispensável à captação de recursos para o custeio dos processos, se cobrada de maneira isonômica acaba por criar elementos de aperfeiçoamento das relações socioeconômicas, amplamente consideradas. 
A exegese jurisprudencial, além de revelar como a Justiça brasileira vem se comportando acerca do tema aqui proposto, traz o primado de que o respeito ao acesso à justiça se equipara a outros direitos e garantias fundamentais que não podem ser mitigados dentro de um Estado Democrático e de Direito, sob pena de comprometer a própria realização da cidadania e o respeito à vida humana. Reconhecido em diversos tratados internacionais, o acesso à justiça é um direito fundamental, estando previsto na Declaração Americana dos Direitos do Homem de 1948.

Do mesmo modo que as Defensorias, os Núcleos de Prática Jurídica das Universidades, conveniadas com as Defensorias Públicas, também prestam serviço gratuito, e assim como as Defensorias Públicas, gozam de algumas prerrogativas, dentre as quais se destacam o fato de não se submeterem ao crivo subjetivo do julgador ao deferimento da assistência judiciária gratuita. Isso porque, o critério e os pressupostos ${ }^{2}$ de análise do assistido são realizados pela própria Defensoria Pública ou pelos órgãos conveniados que prestam esse serviço.

Dizendo de outro modo, via de regra, o juiz não indefere os pedidos de assistência judiciária gratuita dos assistidos pelas Defensorias Públicas e suas conveniadas, nesses casos o deferimento é automático. Entretanto, o mesmo não ocorre em relação ao requerimento de justiça gratuita, em que o critério subjetivo é fator hegemônico na análise do pedido.

Diante disso, a análise a seguir, ainda neste capítulo se resume à justiça gratuita patrocinada por advogado particular, a qual está estabelecida nos artigos 98 a 102 do novo Código de Processo Civil.

\subsection{O critério subjetivo do deferimento da gratuidade}

A Lei 1060/50 que trata da assistência judiciária gratuita e do benefício da gratuidade da justiça carece de critérios objetivos ao seu deferimento. O novo Código de Processo Civil, que passou a regular a matéria, permaneceu com essa omissão, deixando ao critério subjetivo do julgador a análise quanto ao deferimento ou não da gratuidade da justiça. No entanto, a jurisprudência consolidada orienta que a simples afirmação do estado de hipossuficiência é capaz de suprir a lacuna, sendo suficiente ao deferimento da gratuidade da justiça.

\footnotetext{
${ }^{2}$ A Defensoria Pública do Estado atende pessoas com renda de até 03 salários mínimos, equivalente a R \$ 2.640,00, conforme Resolução no 006-CSDPEMA e LC 19/1994, ao passo que a Defensoria Pública da União, tem como parâmetro, o valor de receita familiar menor que o limite de isenção do Imposto de Renda, atualmente de R\$1.637,11.
} 
Contudo, na prática, por ser subjetivo o critério, fica a cargo do julgador a análise caso a caso, não sendo unânime o deferimento pela orientação do Superior Tribunal de Justiça, de que a simples afirmação é suficiente para lograr o requerente o benefício da gratuidade da justiça.

Nesse sentir, o sistema apresenta distorções, na medida em que não preenche as definições de isonomia ou igualdade processuais, sob cuja percepção de que cobrar custas daqueles que possuam capacidade para fazê-lo ajusta-se à isenção para aqueles abaixo de um determinado padrão de renda, objetivamente considerado, pois, conforme Capelletti; Garth (2002, p. 21):

Pessoas ou organizações que possuam recursos financeiros consideráveis a serem utilizados têm vantagens óbvias ao propor ou defender demandas. Em primeiro lugar, elas podem pagar para litigar. Podem, além disso, suportar as delongas do litígio. Cada uma dessas capacidades, em mãos de uma única das partes, pode ser uma arma poderosa; a ameaça de litígio torna-se tanto plausível quanto efetiva.

É justo, portanto, dentro desse contexto, sustentar que as custas processuais, além de instrumento de autofinanciamento e capacitação técnica do sistema judiciário, servem como instrumento de equilíbrio entre aqueles que não possuam capacidade econômica para suportar os ônus das demandas judiciais, além da necessária despesa com advogados e documentações e aqueles que tenham abastada condição financeira, sendo-lhe defeso valer-se da isenção, objetivamente regulamentada.

Desta senda, tem-se que a concessão da gratuidade da justiça está atrelada a certa discricionariedade do julgador, vez que prepondera o critério subjetivo para sua concessão. Assim, ausentes critérios mais pragmáticos que possam orientar os Juízes para apreciação dos pedidos de justiça gratuita, são comuns situações em que pessoas que realmente necessitam da mencionada benesse acabam não a obtendo, enquanto litigantes que não fazem jus ao benefício são agraciados com o mesmo.

No que tange à Defensoria Pública, consoante anteriormente explanado, os limites legais de rendimentos abarcados para atendimento pela Instituição, quais sejam, renda de até 03 (três) salários mínimos, enquanto a Defensoria Pública da União tem como parâmetro, o valor da receita familiar menor que o limite de isenção do Imposto de Renda, atualmente de R\$ 1.637,11 (mil seiscentos e trinta e sete reais e onze centavos) - verifica-se que tais referências acabam por excluir do amparo pelas Defensorias Públicas, os indivíduos que percebem renda 
maior que os supracitados valores, mas que ainda assim não conseguem subsidiar os gastos de um processo, sem colocar em risco seu próprio sustento.

Nesse sentido, torna-se ainda mais pertinente a discussão sobre a carga econômica do processo e a necessidade de nos debruçarmos sobre alternativas tangíveis à solução eficaz dos conflitos de forma a onerar menos não apenas as pessoas que necessitam ser socorridas pela justiça, mas também o próprio poder judiciário.

\section{A carga econômica do processo como óbice ao acesso à justiça}

A exigência de custas judiciais, que em sua maioria são de elevado valor, e o empenho para um efetivo acesso à justiça são duas posturas estatais que se contrapõem. Assim, os serviços judiciais, que são fornecidos pelo Estado, revertem-se em um óbice ao acesso ao judiciário, haja vista que a maioria da população não possui condição de financiar o processo, ocasionando, por vezes, desistência da busca à adequada solução do litígio, através da prestação jurisdicional (LONGO, 2010).

Conforme destaca Saiach $(2015$, p.64) é certo que todo processo tem uma finalidade essencialmente econômica, muito embora esta não seja sua única finalidade, mas a maioria dos pleitos termina com ressarcimento de danos e prejuízos que importa em valor econômico. Um desses custos é justamente a taxa de justiça.

O custo do processo, em especial, o pagamento de custas iniciais para ingressar com ação, bem como despesas com advogado e os gastos para produção de provas, representam obstáculo efetivo ao acesso à justiça.

Conforme salienta Marinoni (2010, p.189), é evidente que o custo do processo representa grave empecilho para garantia e efetividade de direitos, podendo impedir o cidadão de propor ação, quer dizer, por razões financeiras, expressiva parte dos cidadãos pode ser obrigada a abrir mão de seus direitos.

Cappelletti (1988, p.32) analisou o custo do processo em diversos países, constando no relatório conhecido como Projeto Florença. Evidente que essa realidade afeta o jurisdicionado brasileiro, sendo um obstáculo sério ao acesso à justiça, como destaca Didier (2016, p.20) "na medida em que segrega aqueles que não têm recursos financeiros suficientes para arcar com os custos de um processo judicial", nem têm como contratar profissional habilitado a postular em juízo, em seu nome, o direito violado.

A Constituição Federal consagra no artigo $5^{\circ}$, inciso XXXV, o acesso à justiça como direito fundamental, no qual deve ser fornecido ao cidadão, meios que possibilitem seu acesso 
e a razoável duração do processo. Esse direito fundamental, como já ressaltado, tem grande ênfase nas palavras de Greco (2003, p.56):

No Estado Democrático Contemporâneo, a eficácia concreta dos direitos constitucional e legalmente assegurados depende de garantia da tutela jurisdicional efetiva, porque sem ela o titular do direito não dispõe da proteção necessária do Estado ao seu pleno gozo. A tutela jurisdicional efetiva é, portanto, não apenas uma garantia, mas, ela própria, também um direito fundamental, cuja eficácia irrestrita é preciso assegurar, em respeito à própria dignidade humana.

Destaque-se que a justiça gratuita deve ser deferida sempre que o requerente preencher os requisitos ao seu deferimento. Araken de Assis (1998, P.21), ao analisar o tema, ressalta:

(...) O direito mencionado recebe inúmeras designações. Elas carecem de importância. Sua tônica avulta no caráter universal. "Iniciando pelas pessoas naturais, da sua concepção à morte, e abrangendo as pessoas jurídicas; os nacionais e os estrangeiros; e até entes despersonalizados (art. 12, III, IV, V, VII e IX), todos podem invocá-lo sem exceções."

(...) Ora, o art. $5^{\circ}$, LXXIV, da $\mathrm{CF} / 88$, não distingue entre pessoas físicas e jurídicas, no âmbito da assistência jurídica, que é mais abrangente do que gratuidade. E a circunstância de o dispositivo se situar dentre os direitos e garantias individuais nada significa, porque o art. $5^{\circ}$ se aplica a ambas, indiferentemente, inclusive protegendo as pessoas jurídicas da interferência estatal (inc. XVIII) e da dissolução compulsória (inc. XIX).

É certo que subsiste o dever de pagamento das custas judiciais em virtude da movimentação do aparelho jurisdicional, cabendo aos necessitados, declarados pela lei como tal, a isenção do dever legal de suportar os encargos financeiros de um processo judicial, ou seja, as custas judiciais, as despesas processuais e os honorários advocatícios (SARAIVA, 2014).

Dentro dessa análise, permeia-se que os processos de relevante aspecto econômico, envolvendo grandes cifras, deveriam suportar boa parcela da incidência de cobrança das custas judiciais, permitindo o mais irrestrito ambiente de isenção sobre as causas economicamente modestas.

Para Saraiva (2014), é empregado pelo ordenamento jurídico brasileiro, o chamado princípio da sucumbência, que estabelece o dever de pagamento, pela parte vencida (autor ou réu) das custas processuais e honorários advocatícios em favor da parte vencedora. Assim, as custas processuais, os honorários advocatícios, os honorários periciais e ônus da sucumbência são custos que, não raro, desmotivam a propositura de ações judiciais e, por vezes, até mesmo a apresentação de defesas processuais. 
Desse modo, as custas judicias podem gerar um óbice ao acesso à justiça, contrariando a garantia do artigo $5^{\circ}$, LXXIX da Carta Política.

Não bastasse, o deferimento da gratuidade da justiça ficar ao critério subjetivo do julgador, é ato discricionário do magistrado diante da falta de critérios objetivos estabelecidos tanto na Lei 1060/50 quanto no novo Código de Processo Civil, o que por vezes, obstaculiza ao cidadão o ingresso em juízo para ver protegido seu direito violado.

Por isso, no objetivo de viabilizar o acesso à justiça, cuja extensão não é possível prever abstratamente, foram adotados no novo Código de Processo Civil, algumas possíveis soluções como, por exemplo, a possibilidade de concessão parcial da gratuidade processual, o parcelamento das $\operatorname{custas}^{3}$ ou ainda que seja deferido o pagamento ao final do processo. Outra possibilidade é a adoção dos parâmetros fixados pela Lei 9.289/1996, que fixa o valor das custas judiciais da Justiça Federal, que são bem inferiores às da Justiça Estadual. Outra alternativa é a uniformização das custas judiciais cobradas pelos Estados, o que tem sido cogitada pelo Conselho Nacional de Justiça (LONGO, 2010).

$\mathrm{O}$ direito de acesso à justiça, independente do óbice econômico, como o pagamento de custas judicias, é direito fundamental garantido pela Carta Magna. Portanto, todo indivíduo tem garantido formalmente o acesso à tutela estatal e esse acesso à jurisdição é mais que um direito, é uma conquista. Entretanto, no Brasil, o elevado valor das custas e a sua disparidade entre os Estados da Federal, constitui um dos fatores inibidores do acesso à justiça em sua plenitude.

De fato, todos os direitos demandam custos, como alerta Sunstein; Holmes (2012, p.34-38) para quem "o cálculo dos custos dos direitos pode ameaçar a realização dos direitos cujos custos são calculados".

Essa realidade, do alto valor cobrado pelas custas judicias, tem sido alvo de preocupação pelo Conselho Nacional de Justiça, que criou um grupo de trabalho encarregado de propor parâmetros para a fixação de custas processuais, procurando buscar uma solução que atenda aos jurisdicionados sem perder de vista que os tribunais precisam dessa fonte de recursos (BRASIL).

Nessa esteira, é possível constatar que a questão dos custos do processo como óbice à efetivação do direito ao acesso à justiça subsiste, não obstante os instrumentos lançados pelo legislador pátrio para facilitar o ingresso das pessoas desprovidas de recursos financeiros ao judiciário.

\footnotetext{
${ }^{3}$ Art. $98, \S 5^{\circ} \mathrm{e} 6^{\circ}$ do novo Código de Processo Civil.
} 
Assim, faz-se mister que os aplicadores do direito busquem outras alternativas para promoção da pacificação social, mormente soluções que se deem sem a judicialização do conflito, via disponibilização de novas portas aos indivíduos para acesso à justiça, com a resolução de lides via método célere, seguro, de baixo custo e eficaz

Propõe-se, no presente estudo, a implementação dos Tribunais Multiportas (Multidoor Courthouses), de origem americana, como novas opções de solução de conflitos, que podem ser concretizadas sem necessidade de ingresso no convencional sistema judicial.

\title{
5. Tribunais multiportas (multi-door courthouses) como instrumento de efetivação do acesso à justiça
}

A busca por métodos alternativos de solução de conflitos tem sido tema recorrente no mundo jurídico, principalmente em decorrência da chamada crise do judiciário, motivada, entre outros fatores, pela morosidade dos processos judiciais, os altos custos atrelados à sua utilização, deficiência e sucateamento do aparato estatal.

Nesse cenário, ganha importância o estudo da Justiça Multiportas, sistema de origem norte americana, criado no início século passado, cujo fortalecimento se deu a partir de uma conferência ministrada em 1976 pelo Professor da Universidade de Harvard Frank E. A. Sanders, possuindo como ideia central o oferecimento de múltiplas portas àqueles que precisam da justiça, cada porta a ser usada para um caso diferenciado.

Os Tribunais Multiportas são conceituados por GONÇALVES (2014; p. 189) como:

\begin{abstract}
Um centro de resolução de conflitos multifacetário, que se baseia na noção de que o sistema judicial moderno não deveria possuir apenas uma porta que levasse todos os litígios ao processo judicial, mas várias portas que conduzissem a variados meios de resolução de controvérsias. Basicamente, o Tribunal Multiportas consiste num sistema judiciário que acolhe, num mesmo local, diversas modalidades de solução de litígios (hererocompositivias, autocompositivas e híbridas; judiciais e não judiciais), a fim de que seja possível direcionar o conflito ao melhor método para sua resolução.
\end{abstract}

A tônica da atuação dos Tribunais Multiportas é, portanto, identificar quais os métodos de resolução de conflitos mais adequados para solucionar os casos que lhes são direcionados, remetendo-os, então, à "porta" mais propícia ao apaziguamento da controvérsia.

Nessa esteira, explica Luchiari (2011, p. 308-309): 
O Fórum de Múltiplas Portas ou Tribunal Multiportas constitui uma forma de organização judiciária na qual o Poder Judiciário funciona como um centro de resolução de disputas, com vários e diversos procedimentos, cada qual com suas vantagens e desvantagens, que devem ser levadas em consideração, no momento da escolha, em função das características específicas de cada conflito e das pessoas nele envolvidas. Em outras palavras, o sistema de uma única 'porta', que é a do processo judicial, é substituído por um sistema composto de vários tipos de procedimento, que integram um 'centro de resolução de disputas', organizado pelo Estado, comporto de pessoas treinadas para receber as partes e direcioná-las ao procedimento mais adequado para o seu tipo de conflito. Nesse sentido, considerando que a orientação ao público é feita por um funcionário do Judiciário, ao magistrado cabe, além da função jurisdicional, que lhe é inerente, a fiscalização e o acompanhamento desse trabalho (função gerencial), a fim de assegurar a efetiva realização dos escopos do ordenamento jurídico e a correta atuação dos terceiros facilitadores, com a observância dos princípios constitucionais".

Os Tribunais Multiportas propiciam, assim, múltiplas opções à disposição dos indivíduos para solução extraprocessual de conflitos, implicando em uma justiça mais próxima da sociedade, mormente os menos favorecidos financeiramente.

Destarte, a proposta de aplicação do sistema multiportas no Brasil possibilita considerável ampliação do acesso à justiça, com maior flexibilidade e viabilidade de participação da sociedade, inclusive da parcela menos abastada, que não possui condição de arcar com os gastos de um processo judicial.

Sobre as vantagens da implementação do mencionado sistema pondera GONÇALVES (2014; 185):

A revolução proposta encontra seu fundamento na necessidade de se promover a democratização do acesso à justiça, habilitando o cidadão a tutelar seus interesses e possibilitando ao corpo social a composição pacífica de seus conflitos. A proposta, ainda, encontra-se alinhada à terceira onda renovatória cappellettiana, uma vez que "esse enfoque de correlacionar e adaptar o processo civil ao tipo de litígio", de acordo com as características de cada um (complexidade, valor envolvido, natureza da controvérsia, relação entre as partes, suas características pessoais, dentre outros).

O Brasil, de forma tímida, registre-se, tem dado atenção às soluções alternativas de conflitos, consoante nota-se no atual Código de Processo Civil, que prevê a mediação e conciliação como instrumentos de solução de controvérsias.

O Conselho Nacional de Justiça, outrossim, elaborou a Resolução 125/2010, que instituiu a Política Nacional de tratamento adequado dos conflitos de interesse no âmbito do Poder Judiciário, a qual incorporou os meios alternativos de conflitos no ordenamento pátrio, via criação do Núcleo Permanente de Métodos Consensuais de Solução de Conflitos dos Tribunais de Justiça, com escopo de assegurar que todos os cidadãos tenham acesso à orientação 
adequada para seus problemas, com oferecimento de instrumentos para resolução de contendas, em especial a mediação e a conciliação

Ademais, verifica-se no Brasil o crescimento do incentivo à conciliação e mediação de forma extrajudicial, sem que haja qualquer processo judicial instaurado.

Não obstante tais avanços, a atuação dos processualistas pátrios no que diz respeito à criação e fomento de soluções alternativas de resolução de conflitos ainda é muito incipiente, ao contrário dos países de primeiro mundo, que já adotam tal prática desde meados do século passado.

Sobreleve-se a forte influência do litiganismo na mentalidade brasileira, circunstância que enquanto não contornada, tornará infrutífera as tentativas do poder público de promover a conciliação judicial ou extrajudicial entre as partes. Por óbvio que, essa cultura do litiganismo ocorre em sua grande maioria pelo desrespeito das empresas em relação aos consumidores.

Assim, necessário que o Judiciário, além da disponibilização das alternativas já mencionadas - conciliação, mediação e arbitragem - também promova políticas públicas capazes de modificar a cultura do litígio tão arraigada em nosso sistema jurídico, pois inegável que as partes, ao buscarem o judiciário para deslinde de controvérsias, já chegam tomadas pelo espírito de confronto, indispostas a ceder, a dialogar e a chegar a um consenso.

Outrossim, necessário que o poder público não apenas incorpore meios alternativos de resolução de conflitos característicos dos Tribunais Multiportas, mas que também evite a "calcificação" de tais opções, de modo a impedir que as mesmas acabem se tornando caras, morosas e ineficazes, a exemplo do processo judicial.

É o que pondera CABRAL $(2013$, p.146)

Um novo modelo de sistema de justiça deve resultar, de um lado, de uma correta perspectivação dos movimentos ligados à resolução alternativa de litígios e aos mecanismos da justiça informal ou alternativa e por outro decorre da consagração de novas formas de procedimentos dentro dos modelos tradicionais, muito em especial quando não há, ou é baixa a intensidade do litígio, incentivando uma multiplicidade de instâncias de justiça, traduzida na coexistência de diversos modelos de pacificação social, mas reservando imperiosamente aos tribunais a litigância nuclear.

O referido Autor sugere, inclusive, adoção de meio alternativo de resolução de conflito utilizado na Costa Rica, que pode ser manejado pelos particulares (2013, pg. 148):

A exemplo do que ocorre em Costa Rica, os meios alternativos de resolução de conflitos poderiam ser desenvolvidos pelo Estado e/ou por particulares, individualmente ou reunidos em entidades especializadas, operando a título gratuito ou oneroso, sendo que todas as atividades privadas poderiam ser controladas pelo Ministério da Justiça e as públicas não judiciais por ele geridas 
Assim, de acordo com o modelo acima, na mesma esteira dos utilizados pelos Estados Unidos da América, Inglaterra, Alemanha e Portugal, a função jurisdicional passaria a ter caráter subsidiário, apenas sendo acionada quando frustrada as tentativas de solução pelos meios alternativos (GONÇALVES; 2014, p. 229).

O protagonismo dos próprios particulares na pacificação de seus conflitos também é defendido por Tartuce, citada por GONÇALVES (2014; 228):

\begin{abstract}
A atuação dos próprios grupos e dos cidadãos como protagonistas na composição de seus conflitos é conduta a ser estimulada pelo Estado. Nesse sentido, merece destaque a realização da justiça coexistencial, enquanto protagonizada pelos próprios envolvidos na controvérsia. Entender o acesso à justiça como sinônimo de acesso à jurisdição é uma posição que precisa ser revista. Considerar o poder judiciário como a primeira e prioritária oferta para o encaminhamento e a composição de conflitos traduz uma visão exacerbada de garantia de acesso ao Poder Judiciário que em nada contribui para a efetiva distribuição de justiça em um regime democrático, pluralista e participativo. [...] Percebe-se, assim, que não há pretensão em substituir a via judiciária por outras instâncias de composição de conflitos; busca-se, em realidade, disponibilizar mais mecanismos a permitir a adoção de vias diferenciadas mais adequadas ao tratamento das controvérsias em relação de complementaridade com o mecanismo jurisdicional clássico.
\end{abstract}

A adoção de sistemática parecida no Brasil, deixando a atuação do Poder Judiciário apenas no âmbito suplementar, mediante incentivo de solução alternativas de contendas a cargo de particulares, ampliaria o leque de opções de solução consensual de conflitos extrajudicial já existentes, facilitando o alcance dos mais necessitados à justiça e reduziria os custos tanto para o poder Judiciário como para os cidadãos que desejam ter seus problemas solucionados.

\title{
6. Conclusão
}

A Constituição de 1988 surge como instrumento de afirmação e realização dos direitos humanos, e espelhou-se na Declaração Universal dos Direitos Humanos para elaborar as Garantias Fundamentais agrupadas no corpo da norma constitucional, dentre elas o acesso à justiça.

Grinover; Cintra (2004, p.86) destacam que o acesso à justiça, identificado como acesso à ordem jurídica justa não corresponde a mera admissão ao processo, ou possibilidade de ingresso em juízo. Além disso, para os autores, faz-se necessário que se viabilize o devido processo legal, que seja assegurado o contraditório efetivo, com vistas à produção de uma solução justa, capaz de satisfazer o bem da vida em disputa para quem o merece. Garantir o 
acesso à justiça significa ter resultados, eliminando efetivamente os conflitos e promovendo a pacificação social.

A propósito, destaca Sierra (2012, p.47) que o acesso à justiça é um dos mais importantes direitos humanos, relevante canal de efetivação dos demais direitos. É, portanto, um direito instrumental utilizado para fazer valer os demais direitos, e sob essa ótica, não pode ser pensado como simples acesso ao judiciário ou exercício do direito de peticionar, mas um direito que requer seja atendido de forma efetiva, de modo célere e com todas as garantias constitucionais.

Cappelletti; Garth (2002, p.67) se preocuparam com o estudo do acesso à justiça e elaboraram um relatório chamado de Projeto Florença em que classificaram o acesso à justiça em três ondas. A primeira onda voltada a assistência aos pobres, a segunda onda uma preocupação em alargar os direitos difusos e coletivos e a terceira onda, uma preocupação com o estudo do próprio acesso à justiça.

Para Cappelletti; Garth (2002, p.68), na terceira onda "um novo enfoque de acesso à justiça", foram três os obstáculos a serem superados para o efetivo acesso à justiça, sendo: a) as custas judiciais; b) possiblidade das partes, pois alguns litigantes gozam de vantagens estratégicas, especialmente pessoas e organizações que possuem recursos financeiros consideráveis e podem suportar a demora do litígio, e os litigantes habituais, que por conhecerem o direito podem planejar melhor as estratégias e prevenir expectativa mais propícia a casos futuros; c) Problemas especiais dos interesses difusos, como tutela adequada ao direito ao meio ambiente salutar e igualado, à proteção do consumidor, dentre outros (ZANFERDINI; MAZZO, 2015, p.81-83).

Essa terceira onda do movimento pelo acesso trouxe importantes preocupações tendentes a tornar mais acessível a justiça, onde há uma preocupação com a implicação dos procedimentos, a criação de outros meios alternativos de justiça, uma preocupação com as novas demandas sociais, com a efetivação da tutela requerida.

A presente pesquisa analisou dois dos obstáculos citados por Cappelletti; Garth (2002), quais sejam: as custas judiciais e a possiblidade das partes, contudo, com ênfase ao obstáculo das custas judicias.

Nesse sentido, fez-se abordagem dos Meios de Solução Alternativa de Conflitos (MARC's) à luz do sistema Multiportas como opção a ser trabalhada pelo ordenamento pátrio, porquanto, não obstante os avanços verificados no ordenamento pátrio, no que diz respeito à implementação dos instrumentos de mediação e conciliação como alternativas de resolução de conflitos, tem-se que ainda falta uma política pública mais contundente no sentido de realmente 
modificar a cultura da litigância que está impregnada em nossa sociedade, não só em relação às partes, mas também entre os advogados, empresas e até mesmo os próprios julgadores.

Outrossim, foi aventada a possibilidade de incorporação de Meios Alternativos de Solução de Conflitos a serem manejados pelos próprios particulares, por meio de entidades personalizadas ou congêneres, com a atuação subsidiária do Poder Judiciário, o que reduziria os custos do processo suportados pelas partes e pelo próprio Poder Público.

Ademais, não se vislumbra, de forma alguma, com tais medidas, o aniquilamento do Poder Judiciário enquanto pacificador social, mas apenas a disponibilização de mais vias a serem acessadas pelos cidadãos, de modo que se consiga efetivamente a concretização do acesso à justiça a todos que dela precisam, diminuindo assim, a barreira do acesso à justiça pelo óbice econômico.

\section{Referências bibliográficas}

ASSIS, Araken. Execução civil nos juizados especiais. São Paulo: Revista dos Tribunais, 1998.

BARROSO, Darlan; ROSIO, Roberto. Processo Civil. $2^{\circ}$ ed., $2^{\circ}$ tiragem. São Paulo: Revista dos Tribunais, 2012.

BOBBIO, Norberto. As Ideologias e o poder em crise. Brasília: Universidade de Brasília: 2010, p. $97-98$

BRASIL. Conselho Nacional de Justiça. Resolução no 125 , de 29 de novembro de 2010. Disponível em: $<$ http://www.cnj.jus.br/busca-atos-adm?documento=2579 $>$ Acesso Em 02 mai. 2018.

BRASIL. Lei n⿳ 1.060/50, de 05 de fevereiro de 1950. Diário Oficial da União da República Federativa do Brasil. Disponível em:

$<$ http://www.planalto.gov.br/ccivil_03/leis/11060compilada.htm> acesso em: 04 mai. 2018.

BRASIL. Lei n 13.105 de 16 de março de 2015. Diário Oficial da União da República Federativa do Brasil. Disponível em: <http://www.planalto.gov.br/ccivil_03/_ato20152018/2015/lei/113105.htm> Acesso em 04 mai 2019. 
BRASIL. Superior Tribunal de Justiça. Disponível em: < http://www.stj.jus.br/SCON/ jurisprudencia/toc.jsp> Acesso em: 23 abril. 2018.

BRASIL. Supremo Tribunal Federal. Disponível em:http://www.stf.jus.br/portal/cms/ verNoticiaDetalhe.asp?idConteudo=320293 $>$ acesso em 06 mai. 2018.

CARVALHO, José Murilo de. Cidadania no Brasil: o Longo Caminho. $7^{\mathrm{a}}$ ed. Rio de Janeiro, Civilização Brasileira, 2005.

CABRAL, Marcelo Malizia. In Revista do Ministério Público do RS. Porto Alegre, n. 73, p. 125-155, jan. 2013 - abr. 2013.

CAPPELLETTI, Mauro; GARTH, Bryant. Acesso à justiça. Tradução Ellen Gracie Northfleet. Porto Alegre: Fabris, 1988.

CAPPELLETTI, Mauro; GARTH, Bryant. Acesso à justiça. Tradução Ellen Gracie Northfleet. Porto Alegre: Fabris, 2002.

GRECO, Leonardo. O processo de execução. Rio de Janeiro: Renovar, 2003.

CINTRA, Antônio Carlos de Araújo; GRINOVER, Ada Pellegrini; DINAMARCO, Cândido Rangel. Teoria geral do processo. 19a . ed. São Paulo: Malheiros, 2003.

FALCÃO, Joaquim de Arruda. Acesso à justiça: diagnóstico e tratamento. In Justiça: promessa e realidade. $\mathrm{O}$ acesso à justiça em países ibero-americanos. Organização: Associação dos Magistrados Brasileiros, AMB. Rio de Janeiro: Nova Fronteira, 1996 p. 273 274.)

GONÇALVES, Vinícius José Corrêa. Tribunais multiportas: pela efetivação dos direitos fundamentais de acesso a justiça e a razoável duração dos processos. Curitiba: Juruá, 2014.

LONGO, Caricielli Maisa; acesso à justiça e custas judiciais: uma dicotomia. Disponível em:<http://revistas.unoeste.br/revistas/ojs/index.php/ch/article/viewFile/542/758>.Acesso em: 18 mar 2018. 
LUCHIARI, Valeria Feriolo Lagrasta. Histórico dos métodos alternativos de solução de conflitos. In: GROSMAN, Claudia Frankel; MANDELBAUM, Helena Gurfinkel (Org.). Mediação no judiciário: teoria na prática. São Paulo: Primavera Editorial, 2011, 283-320.

MARINONI, Luiz Guilherme. Curso de processo civil. Teoria Geral do Processo. V.1 4 ed. revista e atualizada. São Paulo: Editora Revista dos Tribunais, 2010.

MINOTTO, Arthur Monteiro. Justiça gratuita e a assistência judiciária. Disponível em $<$ https://www.portaleducacao.com.br/direito/artigos/56961/justica-gratuita-e-a-assistenciajudiciaria.> Acesso em 04 mai. 2018.

SADEK; Maria Tereza Aina. REVISTA USP. São Paulo, no 101, p 55-66, março/abril/maio 2014.

SAIACH, Luis A. Rodríguez. Manual del alumno universitário en Derecho Procesal Civil. Buenos Aires: Gowa Ediciones Profesionales, 2015.

SARAIVA, Izabela Novaes. $O$ acesso às pretensões de justiça e os seus complicadores. Diponível em: <http://www.conteudojuridico.com.br/artigo,o-acesso-as-pretensoes-de-justicae-os-seus-complicadores,48181.html>. Acesso em: 18 dez 2015.

SIERRA, Amanda Queiroz. Unissal e acesso à justiça. Sistemas de solução de controvérsias: contribuições e perspectivas. Curitiba: Juruá Editora, 2012.

TARTUCE, Fernanda. Dellore, Luiz. Gratuidade da justiça no Novo CPC.In:Didier Jr, Fredie (Org.) Coleção NOVO CPC, doutrina selecionada. Parte Geral. $2^{\text {a }}$ edição revista e atualizada. Salvador: Jus Podivm, 2016.

ZANFERDINI, Flávia de Almeida Montingelli; MAZZO, Fernando Henrique Machado. Do movimento de acesso à justiça às preocupações sobre o aumento da litigiosidade de massa. Meritum - Belo Horizonte - v. 10 - n. 1 - p. 77-100 - jan./jun. 2015. 


\title{
COMO SE JOGA O PROCESSO?: O USO DA TEORIA DOS JOGOS COMO INSTRUMENTO DE APOIO PARA A REESTRUTURAÇÃO DO PROCESSO PENAL BRASILEIRO PÓS-CONSTITUIÇÃO FEDERAL DE 1988
}

\author{
Fernando Laércio Alves da Silva \\ Universidade Federal de Viçosa \\ PUC-Minas \\ Faculdade de Direito de Campos
}

\section{Resumo}

A teoria dos jogos é comumente utilizada em outras áreas das Ciências Sociais, como a Administração, a Economia e a Política. Mas o presente trabalho busca verificar sua aplicabilidade no Direito, como mecanismo de monitoramento da adequação da estrutura processual brasileira, mais especificamente o processo penal, ao modelo de processo de garantias imposto pela Constituição Federal de 1988. Assim, por meio de pesquisa documental consistente em revisão bibliográfica sobre as obras que tratam da teoria dos jogos e sobre o modelo constitucional de processo, procuramos verificar a compatibilidade e a utilidade da teoria, ainda de uso pouco comum no Direito.

Palavras-chave: Direito processual, modelo constitucional de processo, processo penal, teoria dos jogos, reforma processual.

\section{Abstract/Resumen/Résumé}

Game theory is commonly used in other areas of the Social Sciences, such as Administration, Economics and Politics. But the present work seeks to verify its applicability as a mechanism to monitor the adequacy of the Brazilian procedural structure, more specifically the criminal procedure, to the model of the process of guarantees imposed by the Federal Constitution of 1988. Thus, through documentary research consisting of a bibliographical review about the game theory and the constitutional model of the process, we try to verify the compatibility and usefulness of that theory, which is still not widely used in law.

Keywords/Palabras-claves/Mots-clés: Procedural law, constitutional process model, criminal procedure, game theory, procedure reformation 


\section{Introdução}

O presente trabalho destina-se à apresentação dos elementos básicos da teoria dos jogos e à interrogação sobre a possibilidade e a pertinência de sua utilização como instrumento técnico de monitoramento do grau de adequação do processo penal brasileiro no estágio de sua reestruturação a partir dos marcos teóricos determinados para todos os campos do direito processual - civil, penal e trabalhista - pela Constituição Federal de 1988, quais sejam, o marcos teóricos do Estado Democrático de Direito e do modelo constitucional de processo. Antes, porém, de passarmos a tal empreitada, necessário se fazem alguns breves esclarecimentos a fim de que o leitor não se veja conduzido em falsa expectativa e, menos ainda, em falsa pista.

Em primeiro lugar é preciso que reste desde já claro que nossa análise em nada se aproxima do ensaio de Piero Calamandrei intitulado $\mathrm{Il}$ processo come giuoco (CALAMANDREI, 1950), publicado no já distante ano de 1950. Sem entrar no mérito da relevância de seu ensaio para a ciência processual, o fato é que em momento algum Calamandrei, ao menos não no referido trabalho, procedeu a uma análise da estrutura processual à luz da teoria dos jogos ${ }^{1}$. Longe disso, Piero Calamandrei, no referido trabalho, usa a ideia do jogo tão somente como alegoria para proceder a uma análise do processo de base dispositiva em uma quadra histórica na qual a comunidade jurídico-processual italiana debatia os rumos para a reforma processual no pós-guerra.

Não que o ensaio de Calamandrei seja inservível a nossa análise. Mesmo porque, quando ele reconhece que o processo "[...]nasce e si crea volta per volta, mossa per mossa, cosi come lo modellano in maneira imprevista e imprevedibile le combinazione spesso bizzarre delle

\footnotetext{
${ }^{1}$ Uma rápida verificação das referências bibliográficas nas quais se apoiou Calamandrei para a redação de seu ensaio já permite concluir que em nenhum momento tenha ele tido contato com a teoria dos jogos, cujo conteúdo, inclusive, à época ainda se encontrava em processo de maturação e contido no campo da matemática e da economia. Mesmo porque, como bem esclarece José Augusto Moreira de Carvalho, embora os primeiros conceitos que dariam embasamento ao que posteriormente foi chamado de teoria dos jogos tenham sido publicados pelo matemático Félix Edouard Justin Emile Borel entre os anos de 1921 e 1927, a referida teoria somente foi desenvolvida em 1944 pelo esforço conjunto do matemático John von Neumann e do economista Oskar Morgenstern que publicaram nesse ano a obra The Theory of Games and Economic Behavior. Ainda assim, nesse momento a teoria dos jogos ainda se encontrava em processo de desenvolvimento, tanto que em sua obra Neumann e Morgenstern apresentaram estudos acerca da aplicabilidade da teoria dos jogos em relação aos chamados jogos de soma zero com dois jogadores. Somente seis anos depois, em 1950, a partir das pesquisas de John Forbes Nash Jr, John C. Harsanyi e Reinhard Selten, foi que os postulados da teoria dos jogos alcançaram maior abrangência, passando a abarcar também outras modalidades de jogos estratégicos, entre os quais os jogos de soma não-zero, os jogos cooperativos e não cooperativos e os jogos de informação imperfeita (MOREIRA DE CARVALHO, 2007, p. 216-217).
} 
forze contrpposte che vi si scontrano. [...].” (CALAMANDREI, 1950, p. 9) ${ }^{2}$, estabelece possivelmente sem tal pretensão - as bases que demonstram ser possível o estudo das técnicas para tomada de decisão racional em cada uma dessas rodadas e movimentos. Queremos dizer apenas que a presente pesquisa passa ao largo das críticas de Calamandrei.

Em segundo lugar, necessário se faz esclarecer que nossa análise igualmente se afasta daquela empreendida por Alexandre Morais da Rosa (ROSA, 2016). É fato que suas pesquisas serviram de ponto de partida e, principalmente, de fonte de inspiração e curiosidade acadêmico-científica em relação ao conteúdo da teoria dos jogos

Parece-nos, contudo, que o citado autor procedeu apenas uma releitura do sistema e, principalmente, do ordenamento processual penal brasileiro valendo-se, para tanto, da teoria dos jogos como um de seus pontos de apoio. Diverso e mais delimitado é o recorte do presente trabalho, voltando-se especificamente à indagação sobre a real aplicabilidade da teoria dos jogos ao processo de tomada de decisão pelos sujeitos processuais e, consequentemente, ao monitoramento dos caminhos da reforma do processo penal conduzidas no intuito de adequar tecnicamente (GONÇALVES, 2012, p. 16; LALANDE, 1999, p. 1109) o processo penal aos ditames constitucionalmente estabelecidos na Constituição Federal Brasileira de 1988.

Por fim, em terceiro lugar, é preciso deixar claro ao leitor que não trata o trabalho do desenvolvimento das bases matemáticas e, menos ainda, do estabelecimento de um algoritmo destinado ao monitoramento da racionalidade das decisões dos sujeitos processuais. Ao contrário, limita-se à verificação da aplicabilidade dos conceitos e elementos da teoria dos jogos como instrumentos ou ferramentas técnicas para avaliação dos processos de tomada de decisão pelos sujeitos processuais ao longo do desenvolvimento da estrutura processual penal, tudo com fincas a desaguar em uma reestruturação do processo penal brasileiro de acordo com o que lhe determina a Constituição Federal de 1988, da perspectiva acusatória e da identificação do Estado Democrático de Direito e do modelo constitucional de processo como marcos de delimitação do processo e da atuação de cada um dos sujeitos processuais.

\section{Noções elementares sobre a teoria dos jogos}

É de José Augusto Moreira de Carvalho, em nossa opinião, a conceituação mais clara da teoria dos jogos que, segundo ele, nada mais é que "[...] um método utilizado para representar e compreender as decisões tomadas por agentes que interagem entre si." (MOREIRA DE

${ }^{2} \mathrm{O}$ trecho em questão integra outro trecho maior que foi objeto de transcrição tanto de sua versão traduzida para o português como de seu teor original na nota de rodapé anterior. 
CARVALHO, 2007, p. 215). Definição essa que se alinha perfeitamente ao esclarecimento apresentado por Ronaldo Fiani, segundo o qual "situações que envolvam interações entre agentes racionais que se comportam estrategicamente podem ser analisadas formalmente como um jogo". De modo tal que "um jogo nada mais seria do que uma representação formal que permitiria a análise de situações em que agentes interagem entre si, agindo racionalmente." (FIANI, 2004, p. 2) ${ }^{3}$.

O objeto de análise da teoria dos jogos contempla, portanto, aquilo que se pode definir como jogos estratégicos. Ou seja, aquelas situações nas quais o alcance de um determinado resultado pretendido pelo jogador depende não de sua sorte ou de seu conhecimento em probabilidade, mas de sua capacidade de adotar posturas e tomar decisões estratégicas racionalmente construídas tendo por um dos elementos de reflexão o fato dessas decisões serem tomadas em ambiente de interação com outro ou outros jogadores igualmente capacitados a adotar posturas e tomar decisões racionalmente estratégicas ${ }^{4}$.

Em síntese, como afirmam Douglas G. Baird, Robert H. Gertner e Randal C. Picker,

Game theory, like all economic modeling, works by simplifying a given social situation and stepping back from the many details that are irrelevant to the problem at hand. The test of a model is whether it can hone our intuition by illuminating the basic forces that are at work but not plainly visible when we look at an actual case in all its detail. The spirit of the enterprise is to write down the game with the fewest elements that captures the essence of the problem. The use of the word "game" is appropriate because one can reduce the basic elements of complicated social and economic interactions to forms that resemble parlor games. (BAIRD; GERTNER; PICKER, 1994, p. 7).

Perceba o leitor- que mesmo limitando-se a teoria dos jogos aos chamados jogos de interação - excluídos, portanto, os jogos de azar -, ainda assim tal campo se mostra extremante amplo. Isso porque, conforme a estrutura do processo de interação entre os agentes e o grau de informações de que cada um deles dispõe para a tomada de sua decisão ou, conforme o caso,

\footnotetext{
${ }^{3}$ Muito semelhante ao que ensinam H. Scott Bierman e Luis Fernandes, para quem A teoria dos jogos preocupase com o modo como indivíduos tomam decisões quando estão cientes de que suas ações afetam uns aos outros e quando cada indivíduo leva isso em conta. É a interação entre os tomadores de decisões individuais, todos eles com um propósito em vista, cujas decisões têm implicações para outras pessoas, o que torna as decisões estratégicas diferentes de outras decisões. (BIERMAN; FERNANDES, 2011, p. 4).

${ }^{4}$ Nesse sentido, Ronaldo Fiani explica que "A teoria dos jogos procura entender como os jogadores, sejam eles indivíduos, empresas, organizações, países, etc., tomam suas decisões em situações de interação estratégica. Em outras palavras, a teoria dos jogos visa a explicar como esses jogadores fazem as suas escolhas em situações de interação estratégica.

Para estudarmos como os jogadores tomam suas decisões, temos de considerar as preferências desses jogadores, pois essas preferências é que irão nortear as escolhas dos jogadores. Utilizaremos aqui a teoria da escolha racional, ou seja, a teoria que parte das preferências dos jogadores para entender suas escolhas, assumindo como um princípio básico a ideia de que os jogadores são racionais.” (FIANI, 2009, p. 23).
} 
de suas diversas decisões, diversas serão as modalidades de jogo e, consequentemente, o método de construção racional dessas decisões.

Sem estender demais nesta questão, sob pena de apresentarmos mais elementos do que realmente necessário para o desenvolvimento do trabalho, nos limitaremos, neste ponto, a informar ao leitor que os jogos estratégicos podem ser organizados sob seis parâmetros distintos: quanto aos resultados, parâmetro que diferencia os jogos em jogos de soma zero ou de soma não-zero; quanto ao modo de interação entre os jogadores, segundo o que se classificam em jogos cooperativos ou jogos não cooperativos; quanto ao número de interações entre os jogadores, falando-se em jogos estáticos e jogos dinâmicos; quanto à forma de movimentação, dividindo-se em jogos simultâneos ou jogos sequenciais; quanto ao conteúdo de sua estrutura, classificando-se em jogos de informação completa e jogos de informação incompleta; e, por quanto à extensão da informação, ocasião em que falamos em jogos de informação perfeita e jogos de informação imperfeita. (MOREIRA DE CARVALHO, 2007, p. 221-223; BÊRNI, 2004, p. 17-22).

Em todos esses casos a teoria dos jogos atua verificando e estabelecendo métodos de validação das estratégias empregadas pelos jogadores em interação, compreendendo-se, neste sentido por estratégia ou regra de decisão a " [...] norma que especifica o caminho a ser seguido em qualquer situação possível." (BÊRNI, 2004, p. 10). Desta feita, a teoria dos jogos, para qualquer das classificações acima mencionadas, se estrutura a partir de cinco elementos: jogo, interações, agentes, racionalidade e comportamento estratégico.

Por jogo, segundo esclarecimento de Ronaldo Fiani, deve se compreender um modelo formal. Significa isso dizer, nas palavras do próprio autor, que "[...] a teoria dos jogos envolve técnicas de descrição e análise, ou, em outras palavras, que existem regras preestabelecidas para apresentar e estudar um jogo. Portanto, o estudo dessas técnicas é um elemento fundamental para compreensão da teoria.” (FIANI, 2009, p. 12).

Em outras palavras, só há que se falar em um jogo - no qual os jogadores interajam de maneira racional e estratégica - se, em primeiro plano, tal jogo se estrutura sobre regras de funcionamento preestabelecidas. $\mathrm{O}$ que nos parece perfeitamente lógico já que, não havendo regras preestabelecidas ou, ainda que previamente estabelecidas, podendo tais regras sofrer alterações ao longo do jogo ao bel prazer de qualquer dos jogadores, restará impossível aos demais construir qualquer decisão minimamente racional que não seja a decisão de não jogar ${ }^{5}$.

\footnotetext{
${ }^{5}$ Basta recordarmos as diversas situações de jogo estratégico desenvolvidas entre crianças nas quais uma delas, insatisfeita com seu desempenho - geralmente a dona do jogo - altera unilateral e indevidamente as regras durante a partida de modo tal que ela consiga reverter o sentido de seu desempenho e sagrar-se vencedora, ainda que isso
} 
Em segundo plano significa isso também ser necessário que essas regras preestabelecidas se mostrem claras e do pleno conhecimento de todos os jogadores.

Por interações se compreende a verificabilidade ou não de impacto ou afetabilidade da ação de qualquer dos jogadores sobre os demais ou sobre o resultado final do jogo (FIANI, 2009, p. 12).

Por agentes deve se compreender os indivíduos (seja um indivíduo único, um grupo de indivíduos organizado ou mesmo uma pessoa jurídica) com capacidade decisória suficiente para afetar os demais e, a partir do momento que ingressam na estrutura do jogo e se tornam sujeitos decisores que realmente influenciam os demais agentes, passam a ser chamados de jogadores. Já neste ponto, inclusive, aproveitamos o ensejo para esclarecer ao leitor que todos os agentes decisores que integram o modelo formal do jogo são chamados jogadores. O que, em hipótese alguma pode ser confundido com a separação dos sujeitos processuais em partes (órgão público ou privado de acusação e acusado) e julgador. De acordo com a teoria dos jogos, todos esses são considerados jogadores uma vez que inseridos em uma estrutura de interação na qual são chamados à tomada de decisões racionais que influenciam os demais sujeitos e o próprio resultado final do jogo.

Como quarto elemento da teoria dos jogos se estabelece a racionalidade, o que, de maneira simplificada significa dizer que os jogadores devem conduzir seu processo de tomada de decisão ao longo do jogo a partir de parâmetros racionais, ou seja, “[...] que empregam os meios mais adequados aos objetivos que almejam [...]." (FIANI, 2009, p. 13). Ao aprofundarmos a temática - ainda dentro do significado de racionalidade para a teoria dos jogos - percebemos que se trata de questão um pouco mais complexa. Afinal, dizer simplesmente que o agir racionalmente significa empregar os meios mais adequados ao alcance dos objetivos almejados se mostra sobremaneira superficial, e de fato o é.

Em verdade, a adequada compreensão do significado de racionalidade - a partir do qual se constrói o conceito de tomada de decisão racional dentro da teoria dos jogos - não pode se afastar da compreensão de que tal decisão, ou conjunto de decisões, deverá ser tomada no contexto de um jogo de interação entre diversos agentes, os quais atuam - ou, ao menos, é isso que deve pressupor o jogador - igualmente de maneira racional, tentando antever a jogada de seu opositor e, assim, racionalmente antecipar-se a tal jogada, seja para impedi-la, seja para darlhe direcionamento distinto. Tal decisão somente pode ser alcançada, de acordo com a teoria dos jogos, quando tomada racionalmente, isto é, conscientemente afastada de preconcepções 
ou tradições irracionais que acabariam por viciar a decisão e, consequentemente, comprometeriam o alcance do resultado almejado.

É o que esclarece Duilio de Avila Bêrni:

Devemos tentar compreender o ponto de vista do oponente, não subestimar seu grau de racionalidade e, supondo-o racional, tentar antever sua reação a nossa reação. Trata-se de situações de interação entre dois indivíduos (ou grupos de indivíduos, ou mesmo três ou mais indivíduos), com interesses divergentes, mas não necessariamente opostos [...]. O destino de um agente depende tanto de sua própria ação quanto da ação do outro agente. (BÊRNI, 2004, p. 13.).

O sexto e último elemento da teoria dos jogos é o chamado comportamento estratégico, cujo significado é também apresentado por Ronaldo Fiani:

\footnotetext{
Por comportamento estratégico entende-se que cada jogador, ao tomar a sua própria decisão, leva em consideração o fato de que os jogadores interagem entre si, e que, portanto, sua decisão terá conseqüências (sic) sobre os demais jogadores, assim como as decisões dos outros jogadores terão conseqüências (sic) sobre ele. Obviamente, isso envolve raciocínios complexos, em que aquilo que um dos jogadores farão em resposta às suas ações, o que, por sua vez, depende do que os demais jogadores acham que ele fará, e assim por diante.

[...] os jogadores tomam decisões estratégicas, no sentido preciso de que suas decisões não contemplam apenas os seus objetivos e suas possibilidades de escolha, mas também os objetivos e as possibilidades de escolha dos demais jogadores. (FIANI, 2004, p. 4).
}

A adoção de um comportamento estratégico, isto é, a capacidade do jogador em desenvolver raciocínios complexos a partir do prévio conhecimento das regras do jogo e da antecipação das decisões e movimentos passiveis de ser adotados pelos demais jogadores em resposta a qualquer de suas próprias decisões se estabelece como o elemento crucial da teoria dos jogos.

Perceba, porém, o leitor que a adoção desse comportamento racionalmente estratégico, no plano concreto do jogo depende não apenas do conhecimento das regras de funcionamento do jogo, embora tal conhecimento configure um pré-requisito. Isso porque passa também pela auto checagem de seu grau de racionalidade no processo de tomada de decisão e pelo grau de interesse em efetivamente agir estrategicamente, o que das recompensas do resultado do jogo se mostrarem sedutoras a ponto de convencê-lo a adotar uma postura de racionalidade ótima, ao invés de uma postura de irracionalidade ou mesmo de racionalidade limitada, de que fala Alexandre Morais da Rosa: 
Por ela [racionalidade limitada] os sujeitos devem separar os assuntos que exigem os estabelecimento de metas, projetar as táticas que podem ser exitosas e após avaliação, decidir entre alternativas. A atitude do jogador será fundamental. Caso não saiba como apresentar as informações pode sofrer os efeitos de táticas diversas. [...] Aliás, no discurso em que recebeu o prêmio Nobel de 1978, Simon afirmou que as conclusões sobre a prevalência da racionalidade perfeita são contrárias aos processos reais de tomada de decisão e, assim, é preciso entender como funciona a complexidade humana par além da percepção - que pode ser distorcida - já que diante da capacidade de assimilação e processamento do mesmo material de informações, as decisões podem ser conflitantes, submetidas ao fator satisfatoriedade. (ROSA, 2016, p. 88).

Havendo ainda um outro fator impactante no processo de tomada de decisão a ponto de impedir que o jogador se comporte estrategicamente no sentido da busca de um resultado ótimo, contentando-se apenas com um resultado satisfatório. Trata-se do chamado mecanismo de satisfatoriedade, de que fala Alexandre Morais da Rosa:

Vinculada à racionalidade limitada, o mecanismo da satisfatoriedade (satisficing), apresenta-se como o modelo de tomada de decisão em que ao invés de apurar todas as opções e caminhos probatórios, ou seja, de ampliar o rol de informações, estabelece-se padrão mínimo de aceitabilidade. (ROSA, 2016, p. 117).

E que tem seu pleno esclarecimento apresentado por Robert Stenberg:

[...] consideramos as opções individualmente e, então, selecionamos uma opção logo que encontramos aquela que é satisfatória ou suficientemente boa para atender ao nosso nível mínimo de aceitabilidade. Não levamos em consideração todas as possíveis opções e, então, julgamos cuidadosamente quais entre todo o universo de opções maximizará nossos ganhos e minimizará nossas perdas. Desse modo, examinaremos o menor número possível de opções necessário para chegar a uma decisão que, acreditamos, satisfará nossas exigências mínimas. Algumas provas indicam que, quando existem disponíveis recursos limitados de memória de trabalho, pode haver aumento do uso da satisfatoriedade para tomar decisões. Evidentemente, a satisfatoriedade é apenas uma entre diversas estratégias não tão boas que as pessoas podem usar. (STENBER, 2012, p. 432).

Não se trata diretamente de uma crítica nem à racionalidade limitada e, menos ainda, ao mecanismo de satisfatoriedade. Mesmo porque a verificação de sua ocorrência no caso concreto é resultado direto da aplicação técnica da teoria dos jogos. Em outras palavras: somente dentro do contexto do próprio jogo é possível verificar se uma dada decisão estratégica adotada pelo(s) jogador(es) é racional ou não e, sendo racional, se busca um resultado ótimo ou apenas satisfatório. Além disso, tais situações, caso concretamente verificadas embora possam decorrer, por óbvio, de um erro estratégico do jogador, podem também resultar de uma falha do mecanismo de funcionamento do jogo ou mesmo do baixo grau de atratividade da recompensa que deveria motivar o jogador. 
Daí a utilidade da teoria dos jogos para além de uma técnica de auxílio à construção da decisão racional estratégica de um jogador. Ela se presta também como técnica de detecção de imperfeições e de melhoramento do modelo do jogo de modo a corrigir as suas distorções impeditivas tanto do agir estratégico do jogador como do incremento do grau de atratividade da recompensa, de modo tal que os jogadores se sintam motivados a racionalmente traçar estratégias de jogo voltadas ao seu alcance e não ao simples contentamento com um resultado satisfatório.

Perceba o leitor, no entanto, uma questão crucial referente ao de grau de atratividade da recompensa e daquilo que se deve tomar por resultado ótimo ou satisfatório. Como comentamos rapidamente no início do presente tópico, conforme as características em destaque os jogos de estratégica podem adotar conformações absolutamente variadas, de modo tal que aquilo que se compreenderia como grau de atratividade da recompensa e como resultado meramente satisfatório em um determinado contexto de jogo pode não ser equivalente em outro contexto.

Se no plano ideal, a resposta ao questionamento sobre o que viria a ser um resultado ótimo pode se orientar no sentido de que seria aquele resultado no qual o agente alcança o grau máximo de satisfação ou um ganho pleno, no plano concreto tal resposta não se mostra tão simples. Isso porque, além de depender do grau de interação e do caminho estratégico adotado pelos demais jogadores, a ideia do que venha a ser um resultado ótimo pode, dependendo da modalidade de jogo, sofrer mutação ao longo de seu desenvolvimento.

De modo tal que, aquilo que à primeira vista se mostrava como um resultado ótimo para o jogador, pode alterar-se após a jogada de seu oponente já que esta cria um novo horizonte, ora mais, ora menos amplo, de oportunidades ao primeiro jogador.

Além disso, é preciso ter em mente que, ao menos para um dos jogadores, aquela partida $(P)$ que ele trava com o(s) outro(s) pode estar inserida em um contexto mais amplo que configure uma outra categoria de jogo $(J)$. Nesse caso, a decisão por ele tomada em $P$ que, a primeira vista poderia ser tachada como uma decisão que busca apenas um resultado satisfatório ao invés de um resultado ótimo, quando visualizada dentro do contexto mais amplo de $J$ se mostra, em verdade, a decisão racional acertada apta a permitir que o jogador, em $J$ alcance a recompensa pretendida.

Por outro lado, há que se verificar - e, como já mencionado, para isso também se presta a teoria dos jogos - a existência ou não de elementos impeditivos ou dificultadores do pleno desenvolvimento do jogo ou mesmo não motivadores à adoção, pelo(s) jogador(es) de um comportamento estratégico racional, seja, por exemplo, em $P$, seja em $J$. Elementos impeditivos 
ou dificultadores esses que, segundo Ronaldo Fiani, podem ser de três categorias: padrões inconscientes de comportamento, padrões de comportamento norteados pela tradição e padrões de comportamento norteados por imperativo ético, religioso ou político.

Quanto ao primeiro desses casos, explica Fiani, se verifica no caso concreto porque “[...] nossas emoções impedem que avaliemos as conseqüências (sic) de um ato em relação aos nossos objetivos [...]” e, assim, “[...] padrões inconscientes de comportamento se impõem sobre a nossa capacidade de escolha deliberada, resultando naquilo que, em linguagem corrente, definimos como agir 'sem pensar'." (FIANI, 2004, p. 10). No campo processual, principalmente no civil e no trabalhista, diuturnamente é possível se deparar com casos desse tipo, nos quais uma das partes, por exemplo, instada pela outra ou mesmo pelo magistrado ou pelo conciliador a firmar acordo com a parte adversa para pôr fim à contenda - acordo esse que, analisado racionalmente, se encaixa perfeitamente no conceito de uma decisão ótima -, não o aceita simplesmente porque a mágoa ou o sentimento de injustiça o impede de enxergar o caso de maneira mais clara e o leva a preferir a continuidade da contenda à qualquer transação com seu adversário, mesmo se grande for o risco de derrota.

O segundo desses casos, chamado de padrão de comportamento norteado pela tradição se verifica quando "[...] agimos de uma dada maneira apenas porque essa é a forma que todos sempre agiram." (FIANI, 2004, p. 10). Perceba o leitor que, diferente do caso anterior, aqui o jogador deixa de adotar um comportamento estratégico racional não em razão de qualquer contaminação de seu inconsciente ou de seu espectro emocional, mas simplesmente porque seu comportamento se mostra adequado a um padrão anteriormente construído e enraizado como o padrão devido (tradição). De tal modo que muitas vezes se mantém preso à tradição, ainda que isso resulte na adoção de um comportamento racionalmente distorcido, porque o preço de romper com a tradição a ele se mostra mais caro que o resultado do jogo (FIANI, 2004, p. 10).

Por fim, fala Ronaldo Fiani no caso do padrão de comportamento norteado por imperativo ético, religioso ou político, que se verifica quando "[...] conhecemos as alternativas possíveis e as conseqüências (sic) de nossas escolhas (ao contrário de quando agimos emocionalmente), mas deliberadamente deixamos de levar isso em consideração para fazermos 'o que tem de ser feito'.” (FIANI, 2004, p. 10). Talvez esse, inclusive, o caso mais facilmente verificável no campo do direito processual penal, no qual os sujeitos processuais, principalmente os sujeitos estatais, até conhecem a correta dinâmica de tomada de decisão racional. Contudo, convencidos de que exercem sua atividade em função de um objetivo maior - um verdadeiro múnus público de realizar a justiça e proteger a sociedade contra o problema da criminalidade crescente - persistem na adoção de comportamentos estrategicamente não 
racionais que inevitável e curiosamente acabam por entregar-lhes resultados contrários ao objetivo pretendido.

Diante dessas situações, a teoria dos jogos se lança como um instrumental de apoio técnico tanto ao monitoramento e detecção das situações que levam o jogador a adoção de comportamentos estratégicos não racionais ou, ainda que racionais, inadequados como à indicação de soluções que desestimulem tal modelo comportamental e, por outro lado, estimulem a atuação estratégica racional dos jogadores (FIANI, 2004, p. 12).

O modo como a teoria dos jogos cumprirá tal papel varia conforme o grau de comprometimento da capacidade de tomada de decisão estratégica racional pelos jogadores. Mas também varia conforme a modalidade concreta do jogo. Desta feita, considerando que o nosso objeto de análise é especificamente o padrão comportamental dos sujeitos processuais no processo penal, antes de nos dedicarmos a tal análise - que, inclusive, configura o último ponto de investigação do trabalho - necessário se faz esclarecermos, de acordo com os critérios classificatórios já informados, como se classifica o processo penal dentro da teoria dos jogos.

\section{Compreendendo e classificando o processo penal a partir da teoria dos jogos}

É preciso deixar claro ao leitor que, diverso do que possa parecer em uma análise ancorada no senso comum e, principalmente, na ideia de processo como instrumento da jurisdição para o exercício de uma justiça pacificadora da sociedade ${ }^{6}$, não há qualquer inconveniente em se proceder a leitura do processo penal pelas lentes da teoria dos jogos.

Falar em processo como uma espécie de jogo não é menosprezar a importância de seu desenvolvimento, seus institutos e, menos ainda, de seu objeto concreto e seus resultados. Afinal, como bem esclarece Alexandre Morais da Rosa, "não se 'brinca' com a liberdade e a culpa das pessoas." (ROSA, 2016, p. 45). Fosse assim, a teoria dos jogos não teria alcançado a relevância que alcançou no campo das ciências econômicas e das ciências sociais (BÊRNI, 2004; FIANI, 2004). Mesmo porque, tal como no direito, nada há de brincadeira ou menosprezo com o resultado pretendido pelos sujeitos em nenhum desses campos das ciências sociais aplicadas.

Em verdade, quando falamos em possibilidade e pertinência da utilização da teoria dos jogos como instrumental técnico de apoio para compreensão do desenvolvimento da atividade

\footnotetext{
${ }^{6}$ Que é a ideia motriz do pensamento da Escola Instrumentalista do Processo, ostensivamente exposta nas obras de Cândido Rangel Dinamarco (DINAMARCO, 2013) e Antonio Scarance Fernandes (FERNANDES, 2005), entre outros.
} 
processual e, principalmente, para a transformação comportamental dos sujeitos processuais, o fazemos no sentido de "[...] demonstrar como a matriz de tomada de decisão pode ser delineada. [...] O destaque será na lógica das posições antagônicas (condenar/absolver) e do julgador (terceiro que não deveria ser comprometido).” (ROSA, 2016, p. 45).

O que tem se mostrado cada vez mais necessário no Brasil desde o advento da Constituição Federal de 1988, que impôs a vinculação de todas as estruturas processuais, inclusive a estrutura processual penal, ao marco do Estado Democrático de Direito, o que, consequentemente, implica na reconstrução dessas estruturas dentro dos limites das garantias constitucionais do processo e do devido processo legal tal qual concebidos na teoria do processo constitucional (BARACHO, 1984; BRÊTAS, BARROS, 2006).

Feitos esses esclarecimentos, podemos passar à classificação do processo penal de acordo com a teoria dos jogos, já adiantando que, de acordo com os critérios classificatórios dos tipos ou modalidades de jogos anteriormente mencionados podemos afirmar que o processo penal se classifica como um jogo de soma não-zero, sequencial, dinâmico, não cooperativo e de informação incompleta e imperfeita.

Trata-se de um jogo de soma não-zero porque, diverso do que se verifica nos chamados jogos de soma zero, nos quais o ganho de um dos jogadores corresponde exatamente à perda do outro, nos jogos de soma não-zero tanto é possível que dois ou mais jogadores simultaneamente ganhem ou percam, como também é possível que o ganho de um não corresponda exatamente à perda do outro (BÊRNI, 2004, p. 16).

Embora uma leitura apressada possa conduzir o leitor em falsa pista e fazê-lo crer que o processo penal se classifica como um jogo de soma zero - afinal, em tese e à primeira vista, o ganho do jogador-acusador é a derrota do jogador-acusado e vice versa - quando analisado o jogo no plano concreto e a partir das estratégias racionais possíveis de adoção pelos jogadores, dúvida não resta de que se trata de um jogo de soma não-zero.

De fato, o jogador-acusador pode ser considerado vencedor se seu pedido condenatório é julgado procedente pelo jogador-julgador. Contudo, igualmente poderá ser considerado vencedor o jogador-acusado se, nesse mesmo caso, a estratégia racional adotada não for a de pleitear sua absolvição - ou, pelo menos, não como única tese de defesa - e, na mesma decisão proferida pelo jogador-julgador, embora julgando procedente o pedido condenatório, acolheu em sua plenitude os argumentos do acusado referentes, por exemplo, à desclassificação do crime, à rejeição de qualificadoras, causas de aumento de pena e circunstâncias agravantes, o que resultaria na aplicação de uma pena concreta em seu mínimo legal - ou até mesmo abaixo dele - resultado esse considerado ótimo ou mesmo satisfatório pelo jogador-acusado. 
E quando se lembra que o processo judicial tem ainda um terceiro sujeito, o juiz ou, para valermo-nos da expressão adequada à teoria dos jogos, o jogador-julgador - imparcial em relação aos resultados pretendidos pelos outros jogadores e para os quais desenvolvem suas estratégias racionais -, mais clara fica a natureza de jogo de soma não-zero do processo penal tal qual determinado pelo texto constitucional de 1988.

É que no modelo constitucional de processo penal, esse terceiro sujeito processual não é mais, como na inquisitoriedade e na própria neoinquisitoriedade, um agente de segurança pública, responsável pelo combate à criminalidade (MARQUES, 2016, p. 50). Ao contrário, ele exerce uma função pública - a serviço do cidadão - de responder adequadamente às demandas que lhe são apresentadas. No caso específico, as demandas de natureza penal. Diante disso, o resultado ótimo almejado por ele almejado enquanto jogador não coincide, e nem pode coincidir, com o resultado ótimo pretendido pelos jogadores parciais. Não pode ele entrar no jogo querendo condenar ou mesmo absolver o acusado.

Seus objetivos são dois: garantir que a estrutura processual se desenvolva concretamente conforme as regras do jogo e construir sua decisão final a partir dos argumentos e provas produzidos pelas partes. Logo, como jogador, sua estratégia racional deve desenvolver-se no sentido de garantir a efetivação daqueles dois objetivos, sendo seu resultado ótimo o alcance desses objetivos, independente de qual seja o resultado para os outros jogadores.

É ainda o processo penal uma modalidade de jogo sequencial ${ }^{7}$, já que “[...] o movimento dos jogadores é realizado numa ordem preestabelecida, ou seja, os agentes possuem conhecimento do que ocorreu no jogo no momento anterior à sua escolha." (MOREIRA DE CARVALHO, 2007, p. 222). Aliás, a realização de qualquer movimento por um dos jogadores de maneira diversa à ordem preestabelecida pode resultar na nulidade do jogo e determinar a sua retomada a partir da jogada imediatamente anterior em razão da expressão exigência da garantia do devido processo legal.

Além disso, o processo penal deve ser classificado como uma espécie de jogo dinâmico uma vez que existe mais de um momento de interação estratégica entre os jogadores. Em outras palavras, cada um deles realiza mais de uma jogada dentro da estrutura do jogo, podendo-se, inclusive, na esteira de Alexandre Morais da Rosa, chamar cada um desses momentos de subjogo. Nas palavras do próprio autor, “[...] ao contrário de uma jogada, a sucessão de estágios faz que a etapa - subjogo - exija constante avaliação das possibilidades e antecipações de

\footnotetext{
${ }^{7} \mathrm{O}$ que, obviamente afasta a possibilidade de ser um jogo simultâneo.
} 
sentidos [...].” (ROSA, 2016, p. 47). Etapas ou subjogos esses delimitados em seus aspectos macro e micro pelo próprio ordenamento ${ }^{8}$.

Tendo por critério o grau de conhecimento da informação pelos jogadores no momento de suas jogadas, o processo ainda pode ser considerado como um jogo de informação incompleta e de informação imperfeita. Classifica-se como jogo de informação incompleta porque, diverso dos jogos de informação completa, nos quais "[...] cada jogador detém toda a informação relevante para escolher sua jogada, que será feita simultaneamente ao outro jogador." (BÊRNI, 2004, p. 19), no processo penal - como um típico jogo de informação incompleta - "[...] não é possível conhecer previamente as características do outro jogador, tampouco dos resultados (pay-offs) possíveis.” (MOREIRA DE CARVALHO, 2007, p. 222).

É fato que, quando da propositura da ação penal, o jogador-acusador possui em mãos uma série de elementos a partir dos quais constrói a hipótese acusatória e lhe permitem, de antemão, prever racionalmente uma maior ou menor capacidade persuasiva de seu argumento. Contudo, ainda não sabe quais elementos o jogador-acusado dispõe em mãos e tampouco de que maneira igualmente racional pretende utiliza-los para desconstruir sua tese. Este, por sua vez, embora, já disponha no momento de seu primeiro movimento tanto das informações obrigatoriamente apresentadas pelo jogador-acusador e de outras que tenha coletado diretamente, ainda não sabe de maneira absoluta como o jogador-acusador manipulará o conjunto de informações ao longo do jogo. Todos eles elementos da estrutura do jogo somente serão conhecidas à medida de seu desenvolvimento, daí porque a classificação do processo penal como uma espécie de jogo de informação incompleta.

Dentro desse contexto, é que o processo também deve ser classificado como um jogo de informação imperfeita. Isso porque, como os jogadores, no momento de realizarem suas tomadas de decisão não tem conhecimento completo sobre o comportamento dos demais, igualmente lhes escapa o conhecimento pleno sobre a evolução do jogo (BÊRNI, 2004, p. 18).

Por fim, quanto ao modo de interação entre os jogadores, o processo penal é classificado como um jogo não cooperativo. Isso porque, enquanto num jogo cooperativo, o resultado favorável somente se alcança se os jogadores atuarem de maneira colaborativa entre si (MOREIRA DE CARVALHO, 2007, p. 222), nos jogos não cooperativos, o advento de

\footnotetext{
${ }^{8}$ Por delimitação macro podemos caracterizar, por exemplo, as três grandes fases do processo de conhecimento: propositura e recebimento da acusação, na qual se inclui, por óbvio, a fase de apresentação de defesa prévia do acusado, com base na qual o juiz pode desde já julgar improcedente o pedido ou dar prosseguimento à demanda, instrução e julgamento. Já por delimitação micro podemos caracterizar as etapas ou subjogos que se estabelecem dentro dessas grandes fases como, por exemplo, o subjogo que se estabelece na produção da prova testemunhal e o subsubjogo que se estabelece na oitiva de cada uma das testemunhas arroladas pela acusação e pela defesa.
} 
resultados favoráveis não depende de compromisso entre os jogadores que, na maioria das vezes, inclusive, atuam como verdadeiros opositores, não se vinculando o resultado mais ou menos favorável ao grau de colaboração com os demais jogadores, mas a sua própria capacidade de se comportar de modo racionalmente estratégico.

É claro que, como bem alerta Alexandre Morais da Rosa, a classificação do processo penal a partir dos critérios definidos pela teoria dos jogos é uma classificação por esse motivo, a nosso ver, que serve mais para que o analista tenha uma visão geral sobre qual o perfil de jogo no processo penal. Concretamente, a atuação dos sujeitos processuais pode alterar parcialmente aquela classificação geral do processo. Assim, por exemplo, se o acusado, a despeito do direito de não produzir prova contra si e de manter-se em silêncio, decide celebrar acordo de colaboração premiada ${ }^{9}$ em busca de um resultado mais favorável que aquele que racionalmente previu que alcançaria se adotasse estratégia diversa. Nesse caso, o processo penal casuisticamente se converte de um jogo não cooperativo em um jogo cooperativo.

Enfim, se de maneira geral o processo penal é classificado como um jogo de soma nãozero, sequencial, dinâmico, não cooperativo e de informação incompleta e imperfeita, casualmente uma ou outra dessas características pode restar afastada como consequência da própria estratégia comportamental racionalmente trilhada pelos jogadores.

Diante de todos esses esclarecimentos realizados acerca da teoria dos jogos, seus elementos principais - e como, a partir dela, o processo penal pode ser classificado -, o leitor pode estar se perguntando como ela pode servir de base de apoio para a reestruturação do processo penal brasileira, há trinta anos pendente de realização. Questionamento esse de absoluta pertinência, mesmo porque de nada adiantaria o exercício de classificação do processo penal se a partir dele não resultasse qualquer utilidade concreta.

Por obvio, a utilização da teoria dos jogos não implica - como de fato nem o poderia - no afastamento da teoria do direito como base para a construção normativa e prática do processo penal. Tanto é assim que passamos ao largo de qualquer conjecturação nesse sentido. Ao contrário, a teoria dos jogos se oferta como instrumento técnico de apoio destinado exatamente a detectar o grau de aderência da estrutura normativo-legal vigente ${ }^{10}$ ao modelo constitucionalmente estabelecido e, com isso, verificar os entraves ao adequado funcionamento do processo - ou adequado funcionamento do jogo processual (SILVA, 2014).

\footnotetext{
${ }^{9}$ Colaboração premiada essa de que trata os artigos $3^{\circ}$ a $7^{\circ}$ da Lei n. 12.850, de 2 de agosto de 2013.

${ }^{10}$ Por estrutura normativo-legal vigente deve se compreender exatamente a legislação processual penal infraconstitucional vigente, com especial foco no Código de Processo Penal.
} 


\section{A confirmação da incompatibilidade entre o CPP de 1941 e a disciplina constitucional do processo penal brasileiro pela teoria dos jogos: para bem jogar são necessárias as regras adequadas}

Para além de uma questão acadêmico-teórica, no plano concreto-pragmático a leitura do cenário atual do processo penal brasileiro a partir das lentes da teoria dos jogos leva à inevitável constatação de uma absoluta incompatibilidade entre o que se quer que o processo penal brasileiro seja e o que o processo penal brasileiro ainda é. Incompatibilidade essa que provoca não apenas insegurança acerca da amplitude conteudística de suas regras de funcionamento (enquanto jogo) como ainda impede ou pelo menos dificulta que os sujeitos processuais enxerguem os pay-offs do jogo e passem a conduzir suas atividades de maneira racionalmente estratégica para o alcance das recompensas pretendidas.

Enquanto as regras de funcionamento do processo penal - compreendido como jogo se mostrarem pouco claras não apenas no que se refere à adequada fixação da estrutura procedimental (BORGES, 2012, p. 243), como também às consequências processuais para o sujeito que se comporta de maneira contrária a elas, a formação dos sujeitos no sentido de buscarem o comportamento racionalmente estratégico persiste mais dificultosa. Isso porque o que se verifica no plano concreto é uma espécie de função imunizante da estrutura procedimental prevista no CPP de base neoinquisitorial em relação à metodologia fundamental do processo prevista constitucionalmente. Função imunizante essa que conduz os sujeitos processuais a persistir na adoção de comportamentos inconscientes, norteados pela tradição ou norteados por imperativo ético, religioso ou político.

A título de exemplo, a garantia do benefício da dúvida razoável em favor do acusado encontra obstáculos se o julgador, preso a uma visão instrumentalista e neoinquisitorial, ainda encontra reforço à manutenção de um comportamento ativo na gestão das provas na regra do art. 156 do CPP de 1941. Da mesma forma, de nada adianta pleitear-se uma postura estratégica do membro do ministério público se a legislação lhe estabelece a obrigatoriedade de propositura da ação penal pública sempre que presentes minimamente os seus elementos de sustentação, pouco importando se já naquele momento o sujeito acusador sabe - racionalmente - da fragilidade de seus argumentos por conta de uma limitada base probatória.

Ante o grau de incompatibilidade entre o Código de Processo Penal brasileiro vigente e a Constituição Federal de 1988, o recurso à teoria dos jogos não seria, à primeira vista, imprescindível para detectá-lo. Bastaria para tanto o estoque teórico próprio da teoria do direito. Não se trata, contudo, simplesmente de um exercício de verificação de compatibilidade ou 
incompatibilidade entre um e outro. Este é apenas o primeiro passo da empreitada de reconstrução do processo no campo normativo-procedimental de modo a torna-lo compatível com a base aglutinante de garantias estabelecida no texto constitucional.

É nesse segundo momento da empreitada - o da reconstrução da estrutura normativoprocedimental ou, para fazermos uso da linguagem da teoria dos jogos, das regras de funcionamento e desenvolvimento do jogo - que a teoria dos jogos se mostra útil. Isso porque, como conjunto de técnicas de medição do grau de racionalidade na atuação dos indivíduos em situações de interação, mostra-se ferramenta útil para a aferição da qualidade dos dispositivos normativos - tanto os ainda projetados como os em vigor - para fazer o jogo processual funcionar de maneira mais clara. E, não apenas isso, como também para motivar os sujeitos processuais a atuar no processo como verdadeiros jogadores racionais, buscando em cada subjogo ou momento processual realinhar estrategicamente seu comportamento em busca do resultado mais favorável.

Perceba o leitor que, ao menos assim nos parece, a comissão de juristas constituída para a redação da mais recente tentativa de reforma ampla da legislação processual penal brasileira por meio da elaboração de um novo Código de Processo Penal, materializada no PLS n. 156/2009 - em especial em seus arts. $1^{\circ}$ a $5^{\circ}$, que tratam dos princípios do processo penal -, teve por motivação exatamente essa proposta de profunda reformulação da estrutura processual penal brasileira de modo a que ele efetivamente espelhe o modelo de processo penal pretendido no texto constitucional (COUTINHO, 2010, p. 14).

O risco, contudo, é que a mesma motivação não se faça presente ao longo do processo legislativo e, consequentemente, resulte em mais uma tentativa frustrada de reforma global da legislação processual penal ou, o que seria igualmente desastroso, a aprovação de um texto legislativo de tal forma desnaturalizado em seus pontos essenciais que não se mostre suficiente para a solução das incompatibilidades verificadas no código atualmente vigente.

Situações essas que nos parecem absolutamente possíveis e de concretização mais provável que a aprovação de um texto legal que mantenha intactos os dispositivos legais minimamente necessários a que o jogo processual penal possa ser disputado por sujeitos racionais em comportamento estratégico.

É o que nos parece a partir de um simples processo de tentativa de espelhamento entre o caminho trilhado no direito comparado, tomando por exemplo específico o caso chileno, e o que vem sendo seguido no processo legislativo de análise do PLS n. 156/2009.

O problema é que, tão logo iniciada sua tramitação nas Casas Legislativas Federais brasileiras, o caminho seguido pelos legisladores acerca de seu conteúdo propositivo não tem 
se afastado substancialmente das orientações propostas pela comissão de juristas que elaborou o anteprojeto. Basta proceder à comparação entre a versão original do projeto e aquela aprovada no Senado Federal e que atualmente tramita na Câmara dos Deputados para se perceber os retrocessos destinados a tentar conservar a mentalidade inquisitória no processo penal brasileiro. Mentalidade essa que se manifesta às claras nas diversas manifestações e audiências públicas que têm sido realizadas em ambas as Casas Legislativas.

Enfim, para que o processo penal brasileiro se livre da herança inquisitorial e se estruture como o texto constitucional exige, não basta qualquer lei, qualquer reforma do CPP. Necessário se faz uma reforma profunda que impacte de maneira ampla nas regras do jogo.

De toda sorte, mesmo que confirmada no futuro próximo a projeção aqui lançada e o Novo Código de Processo Penal Brasileiro, caso aprovado, conserve institutos de base neoinquisitorial que tornam mais dificultosa, em maior ou menor amplitude, a atuação estratégica racional dos sujeitos processuais, isso não implica na inutilidade do recurso à teoria dos jogos como técnica de apoio no intento de estabelecer um novo standard comportamental para os sujeitos no processo penal.

Ao contrário disso, parece-nos que ela se torna ainda mais interessante. Isso porque serviria como instrumento técnico relevante para apontar os pontos falhos da reforma. Apontamentos esses demonstrados a partir de bases empíricas que se somariam aos fundamentos jurídico-científicos para alimentar a continuidade do ciclo de adequação das regras do jogo e, além disso, como instrumento técnico de fomento à remodelação da mentalidade dos sujeitos processuais em conformidade com as exigências de uma visão racionalmente estratégica de suas ações e comportamentos no processo penal.

Além disso, mesmo nesse cenário de falha - total ou parcial - do intento de reforma global do Código de Processo Penal, a teoria dos jogos pode ainda servir como instrumento de formação racional dos sujeitos processuais, permitindo-lhes enxergar que os pay-offs da substituição do standard comportamental conforme o delineamento neoinquisitorial do processo penal pelo delineamento do mesmo processo a partir das bases constitucionais lhes é estrategicamente mais vantajosa que a permanência no status quo.

É fato que a existência de um Código de Processo Penal livre de brechas e incompatibilidades sistêmicas com as garantias constitucionais do processo tornaria menos árdua a tarefa de remodelamento do standard comportamental dos sujeitos processuais.

A ausência de tal qualidade no texto legal vigente - seja o atual, seja o potencialmente vindouro - no entanto, por si só não impede o recurso à teoria dos jogos como técnica de esclarecimento dos jogadores acerca da importância de tal mudança comportamental e da sua 
atuação de maneira racionalmente estratégica para a maximização de resultados positivos em sua atividade. Mesmo porque, a partir do momento em que o regramento constitucional passou a ser visto como isso, um regramento real, e não apenas como meros compromissos ideológicopolíticos, ele adquiriu consistência suficiente para ser concretamente aplicado de modo a sobrepor-se à estrutura normativa infraconstitucional que lhe esteja contrária, seja de modo a afastá-la ou limitá-la, seja de modo a ressemantizá-la.

\section{Considerações finais}

Como esclarecido desde as primeiras linhas introdutórias, a pesquisa resultante no presente trabalho teve por objetivo verificar a possibilidade e a pertinência de utilização da teoria dos jogos como instrumento técnico para monitoramento do grau de adequação do processo penal brasileiro e de fomento à reestruturação normativa e prática determinados pelo marco do modelo constitucional do processo implantado com o advento da Constituição Federal de 1988. Ou seja, em momento algum se teve a pretensão - e nem se poderia ter - de apresentar a teoria dos jogos como uma teoria processual capaz de substituir as teorias jurídicas até hoje lançadas. Daí o fato de a apresentarmos como instrumento de apoio, com o específico fim de servir ao monitoramento e fomento à adequação constitucional do processo penal brasileiro.

Para tanto, em um primeiro momento, tratamos de apresentar ao leitor os elementos básicos da teoria dos jogos - até mesmo por estar ela inserida em um campo do saber pouco familiar os profissionais do Direito. Em um segundo momento, demonstramos como o processo penal pode ser compreendido à luz da teoria dos jogos. E em um terceiro e derradeiro momento, buscamos verificar se tal teoria realmente se mostra hábil a servir como técnica de detecção de imperfeições e de melhoramento do modelo do jogo estabelecido para o processo penal brasileiro, de modo a corrigir as suas distorções impeditivas tanto do agir estratégico do jogador como do incremento do grau de atratividade da recompensa, de modo tal que os jogadores se sintam motivados a racionalmente traçar estratégias de jogo voltadas ao seu alcance e não ao simples contentamento com um resultado satisfatório.

Nesse aspecto, ao final da análise - ao menos assim nos pareceu - restou verificado que a teoria dos jogos, quando bem compreendida em seus elementos característicos, pode, de fato, ser utilizada para os fins propostos de monitoramento e fomento à reforma do processo penal. Isso porque, de um lado, ela se mostra extremamente eficiente para verificar as imperfeições da estrutura normativa do jogo processual face àquilo que dele se espera - afinal de contas, para que o jogo possa ser bem jogado, a estrutura, as regras e o campo de jogo devem 
estar estabelecidos de tal modo que permitam a fluidez do jogo e a plena e adequada visão por todos os jogadores envolvidos.

E enquanto as regras de funcionamento do processo penal, convenhamos, se mostrarem pouco claras não apenas no que se refere à adequada fixação da estrutura procedimental, dificilmente se poderá exigir dos sujeitos a busca de um comportamento racional estratégico. Longe disso, a estrutura de jogo presente no Código de Processo Penal, como já dito, acaba por exercer uma função imunizante da em relação à metodologia fundamental do processo prevista constitucionalmente, levando os sujeitos processuais a persistir na adoção de comportamentos inconscientes, norteados pela tradição ou norteados por imperativo ético, religioso ou político.

Nesse contexto, a teoria dos jogos, mostra-se ferramenta útil para a aferição da qualidade dos dispositivos normativos - tanto os ainda projetados como os em vigor - para fazer o jogo processual funcionar de maneira mais clara. E, não apenas isso, como também para motivar os sujeitos processuais a atuar no processo como verdadeiros jogadores racionais, buscando em cada subjogo ou momento processual realinhar estrategicamente seu comportamento em busca do resultado mais favorável.

\section{Referências}

BAIRD, Douglas G.; GERTNER, Robert H.; PICKER, Randal C. Game theory and the law. Cambridge Massachusetts: Harvard University Press, 1994.

BARROS, Flaviane de Magalhães. Ensaio de uma teoria geral do processo de bases principiológica: sua aplicação no processo legislativo administrativo e jurisdicional. In:

GALUPPO, Marcelo Campos (org.). O Brasil que queremos: reflexões sobre o Estado democrático de direito. Belo Horizonte: PUC Minas, 2006, p. 227-238.

BÊRNI, Duilio de Avila. Teoria dos jogos: jogos de estratégia, estratégia decisória, teoria da decisão. Rio de Janeiro: Reichmann \& Affonso, 2004.

BIERMAN, H. Scott; FERNANDEZ, Luis. Teoria dos jogos. Tradução de Arlete Simille Marques. 2. ed. São Paulo: Pearson Prentice Hall, 2011. 
BORGES, Fábio Leonel. Procedimentalidade democrática e princípio do discurso como garantias constitucionais. Revista da Faculdade de Direito (UFU), Uberlândia, v. 40, p. 239$265,2012$.

CALAMANDREI, Piero. Il processo come giuoco. Rivista di diritto processuale, Padova, ano V, n. 1, p. 3-31, 1950.

COUTINHO, Jacinto Nelson de Miranda. Sistema acusatório: cada parte no lugar constitucionalmente demarcado. In: COUTINHO, Jacinto Nelson de Miranda; CASTANHO

DE CARVALHO, Luis Gustavo Grandinetti (org.). O novo processo penal à luz da Constituição: análise crítica do projeto de lei n. 156/2009, do Senado Federal. Rio de Janeiro: Lumen Juris, 2010, p. 01-17.

DINAMARCO, Cândido Rangel. A instrumentalidade do processo. 15. ed. São Paulo: Malheiros, 2013

FERNANDES, Antonio B. Teoria geral do procedimento e o procedimento no processo penal. São Paulo: RT, 2005

FIANI, Ronaldo. Teoria dos jogos: para cursos de administração e economia. 1. ed. 3. reimp. Rio de Janeiro: Elsevier, 2004.

FIANI, Ronaldo. Teoria dos jogos: com aplicações em economia, administração e ciências sociais. 3. ed. Rio de Janeiro: Elsevier, 2009.

GONÇALVES, Aroldo Plinio. Técnica processual e teoria do processo. 2. ed. Belo Horizonte, Del Rey, 2012.

LALANDE, André. Vocabulário técnico e crítico da filosofia. Tradução de Fátima Sá Correia et al. 3. ed. São Paulo: Martins Fontes, 1999. 
MARQUES, Leonardo Augusto Marinho. O modelo constitucional de processo e o eixo estrutural da processualidade democrática. Revista Brasileira de Direito Processual Penal, Porto Alegra, v.2, n. 1, p. 43-55, 2016.

MOREIRA DE CARVALHO, José Augusto. Introdução à teoria dos jogos no direito. Revista de Direito Constitucional e Internacional, São Paulo, v. 15, n. 59, p. 213-234, abr-jun. 2007.

ROSA, Alexandre Morais da. Guia compacto do processo penal conforme a teoria dos jogos. 3. ed. Florianópolis: Empório do Direito, 2016.

SILVA, Fernando Laércio Alves da. O decidir de ofício como desvirtuamento do jogo processual penal constitucionalizado. In: XXIII Congresso Nacional do CONPEDI. Florianópolis: Conpedi, 2014. p. 368-383. Disponível em $<$ http://www.publicadireito.com.br/artigos/?cod=398e24b46129ded4>. Acesso em 10.fev.2018.

STENBERG, Robert J. Psicologia cognitiva. Tradução de Anna Maria Luche. São Paulo: Cengage Learning, 2012. 


\title{
COMPETÊNCIA ABSOLUTA DO JUÍZO ARBITRAL NO CPC FERE O ACESSO À JUSTIÇA?
}

\author{
Maria Cristina Zainaghi \\ Uninove-Unip
}

Luís Guilherme Krenek Zainaghi

PUC-SP

\begin{abstract}
Resumo
O Código de Processo Civil estabeleceu em seu artigo 485, inciso VII, estabeleceu que o juiz extinguirá o processo sem resolução de mérito quando o mesmo acolher a alegação de existência de convenção de arbitragem ou quando o juízo arbitral reconhecer sua competência, assim concluímos que hoje a competência arbitral seria absoluta. Porém assim estaremos diante de uma inconstitucionalidade posto que, estamos tolhendo o direito da parte ao acesso à justiça? Para desenvolvimento do tema e resposta ao questionamento apresentado utilizaremos do método hipotético-dedutivo.
\end{abstract}

Palavras-chave: Competência absoluta, juízo arbitral, acesso à justiça.

\begin{abstract}
Resumen/Résumé
The Code of Civil Procedure established in its article 485, item VII, established that the judge would extinguish the case without merit resolution when the same accept the allegation of the existence of an arbitration agreement or when the arbitration authority recognizes its, so we conclude that today's arbitration would be absolute. But so, we are facing an unconstitutionality that we are crippling the right of the party to access to justice? For the development of the theme and response to the question presented we use the hypothetical-deductive method.
\end{abstract}

Keywords/Palabras-claves/Mots-clés: absolute competence, arbitration, access to justice.

\section{Introdução}

No presente trabalho buscaremos esclarecer a constitucionalidade do disposto no inciso VIII do artigo 485 do Código de Processo Civil que estabeleceu que o juiz deverá 
extinguir o processo na esfera do judiciário, pelo fato de as partes, terem estabelecido a eleição do juízo arbitral que, na hipótese, por conta da competência funcional, é absoluta.

Assim visando estabelecer o cabimento desse descarte do Poder Judiciário e, portanto, responder a problematização apresentada, teremos que estudar primeiramente o instituto da competência, para posteriormente lembrarmos o princípio do acesso à justiça, previsto no artigo $5^{\circ}$, XXXV da Constituição Federal e, posteriormente, estudaremos o instituto da arbitragem, bem como a inserção no contrato da cláusula arbitral.

Finalizando buscaremos a relação da jurisdição estatal e a arbitragem, com a busca de entendimento jurisprudencial.

Para que possamos responder ao questionamento da própria constitucionalidade dessa competência utilizaremos o método hipotético-dedutivo.

\section{Competência}

Ao pensarmos no conceito de competência temos que estabelecer regramentos básicos de jurisdição. Essa entendida como sendo a atividade atribuída ao Estado para que o mesmo solucione os conflitos que lhe são apresentados.

"Jurisdiccion es el derecho y el deber al ejercicio de la función de justicia, y jurisdicción civil significa en consecuencia, el derecho y el deber de juzgar en assuntos civiles.” (Schönke: 1950; p.49).

A jurisdição é o conceito amplo do dever que se atribuí ao Estado para que solucione os conflitos, sendo que, na atualidade essa função, pode-se dizer que, deixou de ser uma atividade exclusivamente estatal. Neste sentido Wambier e Talamini asseveram que "a jurisdição é a função de resolver conflitos em lugar dos litigantes, por meio de aplicação de uma solução prevista pelo sistema jurídico” (Wambier/Talamini: 2016; p. 108)

“A expressão ‘jurisdição', no sentido de todo o poder público, seja legislativa, seja
judiciária, seja executiva, revela o conteúdo medieval. O sentido exato é o de poder
dizer o direito (dicere ius), razão por que se há de exigir pressuposto conceptual de
julgamento. De 'dizer' (dictio) qual a regra jurídica, o ius, que incidiu.” (Pontes de
Miranda: 1973; p. 99).

Derivando do entendimento de jurisdição, onde a legislação atribuí a solução, por terceiro, do conflito, dela se estabelecerá os critérios de divisão que na responsabilidade Estatal se atribuí para resolverem as demandas apresentadas demonstram a competência.

Como nos ensina Theodoro "a competência é justamente o critério de distribuir entre os vários órgãos judiciários as atribuições relativas ao desempenho da jurisdição" (Theodoro: 2017; p.109) 
Note-se que por vezes se confundiu os conceitos de jurisdição e competência, sendo certo, hoje, claramente sua distinção.

"La competência, que es el limite dentro do qual el juez puede ejercer aquella facultad." (Bacre: 1986; p. 177).

"A competência delimita-se, por uma parte, atendendo à condição objetiva dos assuntos cíveis que sejam debatidos. A delimitação desta competência objetiva resulta da atribuição das distintas classes de processos a Tribunais de diferentes classes e hierarquias. A competência objetiva traduz-se, pois num problema de separação de atribuições entre Tribunais hierarquicamente organizados e de categoria distinta" (Goldschmidt: 2003; p. 202-203).

Segundo Chiovenda (1943; p. 214) a competência obedece três critérios, quais sejam:
a) Critério objetivo ${ }^{1}$;
b) Critério funcional ${ }^{2}$;
c) Critério da territorialidade ${ }^{3}$.

Nesta linha de classificação o Código de Processo Civil estabeleceu a divisão entre a competência absoluta e a relativa, sendo que em seu artigo $54^{4}$ estabelece que somente a competência relativa poderá ser alterada.

Assim a competência em razão do valor e do território são espécies de competência relativa, pois são as que podem ser alteradas, como previsto no artigo $63^{5}$ do Código de Processo Civil.

Sendo que as competências em razão da matéria; funcional e situação do imóvel, são exemplos de competência absoluta, ou seja, tais competências não poderão sofrer alteração.

Neste sentido, a competência atribuída ao juízo arbitral está caracterizada como absoluta, posto que, em se estabelecendo cláusula compromissória arbitral a mesma se sobreporá a Justiça Estatal, devendo, pois, o juiz abdicar de sua competência e prol do árbitro.

Isto se dá por se considerar o juízo arbitral uma espécie de competência jurisdicional, ou seja, de órgão específico.

\footnotetext{
${ }^{1}$ A competência objetiva se extrai a competência em razão do valor e a competência em razão da matéria, que por si só são autoexplicativas.

${ }^{2}$ A competência funcional está relacionada aos órgãos dos Tribunais.

${ }^{3}$ A competência territorial está relacionada ao local onde se deverá ajuizar a demanda.

${ }^{4}$ Art. 54. A competência relativa poderá modificar-se pela conexão ou pela continência, observado o disposto nesta Seção.

${ }^{5}$ Art. 63. As partes podem modificar a competência em razão do valor e do território, elegendo foro onde será proposta ação oriunda de direitos e obrigações.
} 


\section{Acesso à justiça}

$\mathrm{O}$ artigo $5^{\circ}$, inciso $\mathrm{XXXV}^{6}$ da Constituição Federal, estabelece o direito das partes em requerer o provimento jurisdicional, ou seja, o direito de ação, também chamado de inafastabilidade do provimento jurisdicional.

Assim o acesso à justiça é garantia constitucional que tem sofrido transformações.

O conceito de acesso à justiça tem sofrido uma transformação importante, correspondente a uma mudança equivalente no estudo e ensino do processo civil. Nos estados liberais "burgueses" dos séculos dezoito e dezenove, os procedimentos adotados para solução dos litígios civil refletiam a filosofia essencialmente individualista dos direitos, então vigorante. (Cappelletti:1988, p.9)

Canotilho ao tratar do direito ao provimento jurisdicional, assevera que:

Quando os textos constitucionais, internacionais e legislativos, reconhecem, hoje, um direito de acesso aos tribunais este direito concebe-se como uma dupla dimensão: (1) um direito de defesa ante os tribunais e contra actos dos poderes públicos; (2) um direito de proteção do particular através de tribunais do Estado no sentido de este o proteger perante a violação dos seus direitos por terceiros (dever de proteção do Estado e direito do particular a exigir essa proteção)." (Canotilho:2000, p.483).

Já Watanabe, ensina:

O princípio da inafastabilidade do controle jurisdicional, inscrito no inc. XXXV do art. $5^{\circ}$ da $\mathrm{CF}$, não assegura apenas o acesso formal aos órgãos judiciários, mas sim o acesso à Justiça que propicie a efetiva e tempestiva proteção contra qualquer forma de denegação da justiça e também o acesso à ordem jurídica justa. Cuida-se de um ideal que, certamente, está ainda muito distante de ser concretizado, e, pela falibilidade do ser humano, seguramente jamais o atingiremos na sua inteireza. Mas a permanente manutenção desse ideal na mente e no coração dos operadores do direito é uma necessidade para que o ordenamento jurídico esteja em contínua evolução. (Watanabe: 1996, p.21).

Claro que esse acesso à justiça está condicionado a requisitos como custas processuais e as formalidades como os pressupostos como a capacidade civil, processual e postulatória e ainda, as condições como a legitimidade das partes e o interesse.

Notemos que o acesso à justiça deve ser garantido com o cumprimento de pressupostos e condições da ação. Portanto o direito de ação está atrelado a parte ter que ter seus direitos à personalidade, ou seja, ter os direitos assegurados no artigo $2^{07}$ do Código Civil, ou seja, somente aquele que é ser vivo pode demandar.

\footnotetext{
${ }^{6}$ Art. $5^{\circ}$ Todos são iguais perante a lei, sem distinção de qualquer natureza, garantindo-se aos brasileiros e aos estrangeiros residentes no País a inviolabilidade do direito à vida, à liberdade, à igualdade, à segurança e à propriedade, nos termos seguintes:

XXXV - a lei não excluirá da apreciação do Poder Judiciário lesão ou ameaça a direito;

${ }^{7}$ Art. $2^{\circ}$. A personalidade civil da pessoa começa do nascimento com vida; mas a lei põe a salvo, desde a concepção, os direitos do nascituro.
} 
A capacidade processual, está ligada ao exercício do direito de ação, ou seja, ao exercício dos direitos civil, de forma que se excluem em demandar pessoalmente aqueles que estão inseridos nos artigos, $3^{\circ}$ e $4^{\mathrm{o}}{ }^{8}$ do Código Civil, ou seja, a exceção dos menores que deverão estar representados pelos detentores do poder familiar e, dos maiores de 16 e menores de 18 anos; os ébrios habituais e os viciados em tóxico; aqueles que, por causa transitória ou permanente, não puderem exprimir sua vontade; os pródigos todos esses para demandarem deverão estar assistidos por quem os represente.

A capacidade postulatória essa será assegurada ao advogado, devidamente inscrito no quadro da Ordem Dos Advogados do Brasil.

Quanto as condições da ação, temos que para que se postule em juízo deve a parte ter legitimidade, ou seja, estar relacionada a relação jurídica que se vai demandar. Assim o artigo $17^{9}$ do Código de Processo Civil exige a legitimidade e o interesse como condições para a interposição da demanda.

Além dessas condições, a princípio, qualquer pessoa natural ou jurídica, poderia requerer a intervenção do Estado, para que o Judiciário solucione o conflito apresentado.

\section{Arbitragem}

\subsection{Histórico}

Para entendermos a intenção do legislador processual que passou a atribuir ao Tribunal arbitral competência absoluta, temos que entender o próprio juízo arbitral.

Em que pese muitos apontarem o Juízo Arbitral a partir da criação da Lei $n^{0}$ 9.307, datada de 23 de setembro de 1996, o Código de Processo Civil de 1973, em seus artigos 1072 até o 1102 tratava da matéria, como procedimento especial, lá apresentado como: Juízo Arbitral.

Neste momento a arbitragem era voltada aos processos civis. Neste sentido nos ensinava Pontes de Miranda:

\footnotetext{
${ }^{8}$ Art. $3^{\circ}$. São absolutamente incapazes de exercer pessoalmente os atos da vida civil os menores de 16 (dezesseis) anos.

Art. $4^{\circ}$. São incapazes, relativamente a certos atos ou à maneira de os exercer:

I - os maiores de dezesseis e menores de dezoito anos;

II - os ébrios habituais e os viciados em tóxico;

III - aqueles que, por causa transitória ou permanente, não puderem exprimir sua vontade;

IV - os pródigos.

Parágrafo único. A capacidade dos indígenas será regulada por legislação especial.

${ }^{9}$ Art. 17. Para postular em juízo é necessário ter interesse e legitimidade.
} 
“o juízo arbitral, de que aqui se cogita, é juízo arbitral para processos civil. Nem compreende os juízos arbitrais de direito público, nem, a fortiori, os de direito interestatal ou supra-estatal, sem se afastar que os arts. 1072-1102 possam ser, ou vir a ser conteúdo de alguma lei, que a eles, ou a algum deles se refira." (Pontes de Miranda: 1977; p. 223).

Note-se que, Pontes de Miranda em 1977 já previa que se teria uma Lei Arbitral, como realmente tivemos em 1996, que foi alterada pela Lei ${ }^{\circ} 13.129$, datada de 26 de maio de 2015.

\subsection{Conceito}

A arbitragem é segundo Carmona:

"meio alternativo de solução de controvérsias através da intervenção de uma ou mais pessoas que recebem seus poderes de uma convenção privada, decidindo com base nela, sem intervenção estatal, sendo a decisão destinada a assumir a mesma eficácia da sentença judicial - é colocada à disposição de quem quer que seja, para solução de conflitos relativos a direitos patrimoniais acerca dos quais os litigantes possam dispor" (Carmona: 2009; p.31).

\section{Na visão de Francisco Cahali}

"A arbitragem, ao lado da jurisdição estatal, representa uma forma heterocompositiva de solução de conflitos. As partes capazes, de comum acordo, diante de um litígio, ou por meio de uma cláusula contratual, estabelecem que um terceiro, ou colegiado, terá poderes para solucionar a controvérsia, sem a intervenção estatal, sendo que a decisão terá a mesma eficácia que uma sentença judicial.” (Cahali: 2011; p. 75).

Note-se que Pontes de Miranda (1977; p. 344) em crítica ao juízo arbitral, asseverava que "o juízo arbitral é primitivo, regressivo mesmo, a que se pretende volver, por atração psíquica a momento pré-estatais, os "anarquistas" de esquerda e os de alta capitalismo.

\subsection{Convenção de arbitragem}

Como veremos no item jurisdição e arbitragem, o juízo arbitral tem competência funcional em relação ao juízo estatal, sempre que o contrato estabelecer que a demanda havida daquela relação contratual deva ser decidida em juízo privado.

A convenção de arbitragem é a matriz deste método de solução de conflito. Ou seja, é forma pela qual as partes exercem a sua opção pela jurisdição arbitral. E representa o espaço da liberdade, o lugar para as partes contratarem livremente (nos limites da lei) a arbitragem e seus detalhes. (Cahali: 2011; p. 107).

Na Lei de Arbitragem a convenção se divide em cláusula compromissória e o compromisso arbitral. 
"A cláusula compromissória é a previsão em contrato de que eventuais conflitos dele emergente serão resolvidos pela arbitragem" (Cahali: 2011; p. 107).

Vê-se pelo simples conceito da cláusula compromissória que ela estabelece, contratualmente, a competência do Juízo Arbitral.

O compromisso arbitral a previsão do juízo arbitral se dá após o conflito instaurado, ou seja, o conflito leva as partes a firmarem o compromisso arbitral, abrindo mão do acesso ao Juízo Estatal.

No artigo $9^{\circ}{ }^{10}$ da Lei de Arbitragem estabelece que o compromisso arbitral pode ser estabelecido de maneira judicial ou extrajudicial.

Assim caso a parte não compareça, haverá o acionamento do judiciário para que estabeleça as regras do compromisso arbitral.

Diante da ausência poderá a parte optar pela intervenção do juízo estatal que, deverá estabelecer as regras que serão obedecidas pelo juiz arbitral.

Assim se buscará a substituição da vontade das partes, quanto as regras da clausula compromissória através de uma sentença que conterá as regras que serão estabelecidas no juízo arbitral, ou seja, nesta sentença o juiz cuidará apenas do estabelecimento das regras do compromisso arbitral, que valerá para as partes.

\subsubsection{Procedimento da cláusula compromissória judicial}

Diante da resistência o autor requererá a citação da outra parte para que compareça em juízo para que se especifique as regras que serão cumpridas na arbitragem.

É certo que havendo resistência da parte o juiz decidira os termos.

\subsubsection{Sentença e seus efeitos na cláusula compromissória judicial.}

A sentença nessa hipótese se limitara a estabelecer o regramento que regerá a arbitragem.

\footnotetext{
${ }^{10} \mathrm{Art.} 9^{\circ} \mathrm{O}$ compromisso arbitral é a convenção através da qual as partes submetem um litígio à arbitragem de uma ou mais pessoas, podendo ser judicial ou extrajudicial.

$\S 1^{\circ} \mathrm{O}$ compromisso arbitral judicial celebrar-se-á por termo nos autos, perante o juízo ou tribunal, onde tem curso a demanda.

$\S 2^{\circ} \mathrm{O}$ compromisso arbitral extrajudicial será celebrado por escrito particular, assinado por duas testemunhas, ou por instrumento público.
} 
Assim ela assumira o valor do compromisso arbitral previsto no artigo $7^{\circ 11}$ da Lei de arbitragem.

\subsection{As medidas de urgência na arbitragem}

Há ainda a possibilidade da intervenção judicial quando, antes de se instaurar o processo arbitral, houver necessidade de se buscar uma medida urgência.

O judiciário poderá conceder medida de urgência antes de instituído o juízo arbitral, sendo que nesta hipótese é necessário o ajuizamento do processo arbitral no prazo de 30 dias contados da efetivação da medida.

As medidas de urgência contribuem para entendermos a cooperação que se estabelece entre o juiz estatal e o juiz arbitral, que será chamado após a obtenção da tutela provisória concedida.

Poderá o juiz arbitral manter, revogar ou modificar a medida concedida, quando essa é concedida em caráter antecedente ao procedimento arbitral.

Caso requerida após o ajuizamento do procedimento arbitral, a mesma se fará por determinação do arbitro e, portanto, por carta arbitral.

\section{Arbitragem e jurisdição}

...ramo do direito destinado precisamente à tarefa de garantir a eficácia prática do ordenamento jurídico, instituindo órgãos públicos com a incumbência de atuar essa garantia e disciplinando as modalidades e formas de sua atividade. Esses são órgãos judiciários, e a sua atividade chama-se, desde tempos imemoriais, jurisdição (iurisdictio); as pessoas que exercem a jurisdição chamam-se juízes e formam, em seu conjunto, a Magistratura (Liebman: 2005; p.19-20).

\footnotetext{
${ }^{11}$ Art. $7^{\circ}$ Existindo cláusula compromissória e havendo resistência quanto à instituição da arbitragem, poderá a parte interessada requerer a citação da outra parte para comparecer em juízo a fim de lavrar-se o compromisso, designando o juiz audiência especial para tal fim.

$\S 1^{\circ} \mathrm{O}$ autor indicará, com precisão, o objeto da arbitragem, instruindo o pedido com o documento que contiver a cláusula compromissória.

$\S 2^{\circ}$ Comparecendo as partes à audiência, o juiz tentará, previamente, a conciliação acerca do litígio. Não obtendo sucesso, tentará o juiz conduzir as partes à celebração, de comum acordo, do compromisso arbitral.

$\S 3^{\circ}$ Não concordando as partes sobre os termos do compromisso, decidirá o juiz, após ouvir o réu, sobre seu conteúdo, na própria audiência ou no prazo de dez dias, respeitadas as disposições da cláusula compromissória e atendendo ao disposto nos arts. 10 e $21, \S 2^{\circ}$, desta Lei.

$\S 4^{\circ}$ Se a cláusula compromissória nada dispuser sobre a nomeação de árbitros, caberá ao juiz, ouvidas as partes, estatuir a respeito, podendo nomear árbitro único para a solução do litígio.

$\S 5^{\circ} \mathrm{A}$ ausência do autor, sem justo motivo, à audiência designada para a lavratura do compromisso arbitral, importará a extinção do processo sem julgamento de mérito.

$\S 6^{\circ}$ Não comparecendo o réu à audiência, caberá ao juiz, ouvido o autor, estatuir a respeito do conteúdo do compromisso, nomeando árbitro único.

$\S 7^{\circ}$ A sentença que julgar procedente o pedido valerá como compromisso arbitral.
} 
"Jurisdição é atuação de lei, não pode haver sujeição a jurisdição senão onde pode haver sujeição á lei; e vice-versa, em regra, onde há sujeição á lei, aí há sujeição á jurisdição.” (Chiovenda: 1943; p. 55)

Com o passar do tempo temos verificado que o conceito jurisdicional deve ser entendido de forma mais ampla, com a inclusão do juízo arbitral como meio de heterocomposição.

Neste sentido, inclusive, o judiciário tem entendido que, nas hipóteses em que o contrato prevê a mediação ou arbitragem para solucionar os conflitos havidos em virtude do contrato, o judiciário deverá extinguir o processo sem resolução do mérito, nos termos do disposto no artigo $485, \mathrm{VII}^{12}$ do CPC.

Note-se que o juiz estatal deve se declarar incompetente, sempre que as partes houverem optado pelo juiz arbitral, neste sentido o Conflito de Competência $\mathrm{n}^{\mathrm{o}}$ 146.939/PA, que teve como Relator o Ministro MARCO AURÉLIO BELLIZZE, SEGUNDA SEÇÃO, julgado em 23/11/2016, DJe 30/11/2016 ${ }^{13}$

\footnotetext{
${ }^{12}$ Art. 485. O juiz não resolverá o mérito quando:

I - indeferir a petição inicial;

II - o processo ficar parado durante mais de 1 (um) ano por negligência das partes;

III - por não promover os atos e as diligências que lhe incumbir, o autor abandonar a causa por mais de 30 (trinta) dias;

IV - verificar a ausência de pressupostos de constituição e de desenvolvimento válido e regular do processo; V - reconhecer a existência de perempção, de litispendência ou de coisa julgada;

VI - verificar ausência de legitimidade ou de interesse processual;

VII - acolher a alegação de existência de convenção de arbitragem ou quando o juízo arbitral reconhecer sua competência;

VIII - homologar a desistência da ação;

IX - em caso de morte da parte, a ação for considerada intransmissível por disposição legal; e

$\mathrm{X}$ - nos demais casos prescritos neste Código.

13 CONFLITO DE COMPETÊNCIA POSITIVO. JUÍZO ARBITRAL E JUÍZO ESTATAL. POSSIBILIDADE, EM TESE, DE CONFIGURAÇÃO DE CONFLITO DE COMPETÊNCIA.

ENTENDIMENTO SUFRAGADO PELA SEGUNDA SEÇÃO DO STJ. CONTRATO DE FRANQUIA, COM CLÁUSULA COMPROMISSÓRIA ARBITRAL. JUÍZO ESTATAL QUE DETERMINA, NO BOJO DE AÇÃO JUDICIAL, A EXCLUSÃO/EXTINÇÃO DE PROCEDIMENTO ARBITRAL ANTERIORMENTE INSTAURADO PARA O DESLINDE DE CONTROVÉRSIA ADVINDA DO MESMO CONTRATO (ENVOLVENDO AS MESMAS PARTES SIGNATÁRIAS, COM DISCUSSÃO SE HOUVE OU NÃO CESSÃO DE POSIÇÃO CONTRATUAL DE TERCEIRO FRANQUEADO). CONFLITO CONHECIDO PARA RECONHECER A COMPETÊNCIA DO JUÍZO ARBITRAL.

1. De acordo com o atual posicionamento sufragado pela Segunda Seção desta Corte de Justiça, compete ao Superior Tribunal de Justiça dirimir conflito de competência entre Juízo arbitral e órgão jurisdicional estatal, partindo-se, naturalmente, do pressuposto de que a atividade desenvolvida no âmbito da arbitragem possui natureza jurisdicional.

$1.1 \mathrm{O}$ conflito positivo de competência afigura-se caracterizado, não apenas quando dois ou mais Juízos, de esferas diversas, declaram-se simultaneamente competentes para julgar a mesma causa, mas também quando, sobre o mesmo objeto, duas ou mais autoridades judiciárias tecem deliberações excludentes entre si.

2. O Juízo da $2^{\text {a }}$ Vara Cível e Empresarial de Belém/PA, a despeito da existência de cláusula compromissória arbitral inserta no contrato de franquia estabelecido entre Partout Administração e To Be kids, a vincular, no mínimo, as partes signatárias (pairando, é certo, controvérsia sobre a ocorrência de
} 
Neste sentido julgado proferido em Recurso Especial n ${ }^{o}$ REsp 1597658/SP ${ }^{14}$, o Relator Ministro RICARDO VILLAS BÔAS CUEVA do Superior Tribunal de Justiça asseverou:

Consigne-se, além disso, que vige na jurisdição privada, o princípio basilar do Kompetenz-Kompetenz , consagrado nos arts. $8^{\circ}$ e 20 da Lei de Arbitragem, que estabelece ser o próprio árbitro quem decide, em prioridade com relação ao juiz togado, a respeito de sua competência para avaliar a existência, validade ou eficácia do contrato que contém a cláusula compromissória.

Essa competência poderá contar sempre com a colaboração do juízo estatal, inclusive quando for necessária a intervenção judicial para o estabelecimento do regramento da cláusula arbitral, mas sem especificação e, a parte deixar de comparecer no juízo arbitral.

\section{Conclusões}

Como vimos neste trabalho é incontroverso o posicionamento legal e jurisprudência no sentido de que a competência do juízo arbitral, quando escolhido, é funcional, e por consequência absoluta.

Nesse entendimento, vemos que o acesso à justiça não é tolhido pela opção do juízo arbitral, mas trata-se de uma opção das partes que, livremente, escolhem abrir mão do Judiciário e optam por uma solução privada de seu conflito.

cessão de posição contratual por parte de Toys), entendeu, diversamente do Juízo arbitral, pela não instauração da competência do Juízo arbitral, inclusive com a determinação de extinção do feito ali iniciado. 3. Tem-se por configurado o conflito positivo de competência, na medida em que, sobre o mesmo objeto (no caso, a definição acerca da instauração da competência do Juízo arbitral), dois ou mais Juízos, de esferas distintas, tecem deliberações excludentes entre si, a considerar que, por lei, a questão deve ser precedentemente decidida por um deles (no caso, o Juízo arbitral).

4. É de se reconhecer a inobservância do art. $8^{\circ}$ da Lei n.

9.307/1996, que confere ao Juízo arbitral a medida de competência mínima, veiculada no Princípio da Komptenz Komptenz, cabendo-lhe, assim, deliberar sobre a sua competência, precedentemente a qualquer outro órgão julgador, imiscuindo-se, para tal propósito, sobre as questões relativas à existência, à validade e à eficácia da convenção de arbitragem e do contrato que contenha a cláusula compromissória.

5. Conflito conhecido para declarar competente o Juízo arbitral.

(CC 146.939/PA, Rel. Ministro MARCO AURÉLIO BELLIZZE, SEGUNDA SEÇÃO, julgado em 23/11/2016, DJe 30/11/2016)

14 RECURSO ESPECIAL. PROCESSO CIVIL. CONTRATO DE FRANQUIA. EMBARGOS DE DECLARAÇÃO. OMISSÃO, CONTRADIÇÃO OU OBSCURIDADE. NÃO OCORRÊNCIA. CLÁUSULA COMPROMISSÓRIA. INCOMPETÊNCIA DO JUÍZO ESTATAL. KOMPETENZKOMPETENZ.

1- Ação ajuizada em 14/12/2010. Recurso especial interposto em 16/7/2012.

2- O propósito recursal é definir se o Juízo da $8^{\mathrm{a}}$ Vara Cível Central da Comarca de São Paulo - SP é competente para processar e julgar a presente ação, em razão da existência de cláusula arbitral no contrato de franquia que constitui o objeto da lide.

3- Ausentes os vícios do art. 535 do CPC, rejeitam-se os embargos de declaração.

4- A convenção de arbitragem prevista contratualmente afasta a jurisdição estatal, impondo ao árbitro o poder-dever de decidir as questões decorrentes do contrato, além da própria existência, validade e eficácia da cláusula compromissória.

5- Recurso especial provido.

(REsp 1597658/SP, Rel. Ministro RICARDO VILLAS BÔAS CUEVA, Rel. p/ Acórdão Ministra NANCY

ANDRIGHI, TERCEIRA TURMA, julgado em 18/05/2017, DJe 10/08/2017) 
Assim o juízo arbitral funciona como uma escolha e, mera liberalidade das partes que, o elegem como o instrumento de solução do conflito.

A arbitragem pode ser prevista no contrato firmado, como uma espécie de eleição de juízo ou ainda, posteriormente após o conflito instaurado, mas também por escolha das partes.

Portanto, é cediço que a arbitragem como meio de solução de conflitos está presente como uma opção para que o jurisdicionado tenha uma solução mais célere de seu conflito.

Desta feita, por ser um ato de escolha da parte, não se pode falar que estamos coibindo o direito da parte de acessar à justiça por via processual tradicional.

Também verificamos que, hoje, podemos encontrar um conceito diferente para jurisdição, que ao contrario do que se conceituava, hoje não mais representa uma exclusividade estatal, pois o juízo arbitral provoca os mesmos efeitos do juízo estatal.

A semelhança no resultado é estabelecida, inclusive, pelo fato de que a decisão proferida pelo arbitro, ou seja, a sentença arbitral, consta no rol de sentenças cujo cumprimento é dado como título executivo judicial.

Diante desse entendimento, vê-se claramente que o resultado e efeito do juízo arbitral se assemelha com a sentença proferida pelo juiz estatal e, admite o regramento de seu cumprimento semelhante.

Assim, podemos concluir com o próprio conceito de poder jurisdicional proferido por Canotilho, onde assevera que "é o conjunto de magistrados (ordinários, administrativos, fiscais, constitucionais) a quem é confiada a função jurisdicional.” (Canotilho:2000, p.644), logo, o juízo arbitral é também JURISDIÇÃO.

\section{Referências bibliográficas}

ALCALÁ-ZAMORA Y CASTILLO. Niceto. Estudios diversos de derecho procesal. Librería Bosch: Barcelona/Espanha: 1985.

ARENHART, Sérgio Cruz. A Intervenção Judicial e o Cumprimento da Tutela Específica. Revista Páginas de Direito, Porto Alegre, ano 10, nº 965, 01 de abril de 2010. Disponível em: http://www.tex.pro.br/home/artigos/36-artigos-abr-2010/5973-a-intervencao-judicial-e-ocumprimento-da-tutela-especifica. Acessado em 04/11/17 às 20 hs.

BACRE. Aldo. Teoria General del Processo. Tomo I. Abeledo-Perrot: Buenos Aires. 1986. 
BARBOSA. Rui. Oração dos estudantes. Martin Claret: São Paulo: 2003.

BARCELLAR, R. P. Mediação e arbitragem - Col. Saberes do Direito 53. 2. ed. São Paulo: Editora Saraiva, 2016.

BUENO, C. S. Manual de Direito Processual Civil. 3. ed. São Paulo: Editora Saraiva, 2017.

BÜLOW. Oscar Von. Teoria das exceções e dos pressupostos processuais. LZN Editora: Campinas: 2003.

CAHALI. Francisco José. Curso de arbitragem. Editora Revista dos Tribunais: São Paulo. 2011 .

CAHALI, F.; RODOVALHO, T.; FREIRE, A. Arbitragem. São Paulo: Editora Saraiva, 2016.

CARMONA. Carlos Alberto. Arbitragem e Processo - um comentário à Lei $n^{\circ}$ 9.307/96. $3^{\text {a }}$ edição. Editora Atlas: São Paulo. 2009

CANOTILHO. J.J. Gomes. Direito constitucional e teoria da constituição. $4^{\mathrm{a}}$ edição. Almedina: Coimbra. 2000

CAPELLETI. Mauro. Tutela dos interesses difusos. In Ajuris 33/169: 1984

---. Acesso à justiça. Fabris Editora: Porto Alegre: 2002.

CHIOVENDA. Giuseppe. Instituições de direito processual civil. Volume II. Saraiva: São Paulo. 1943.

GOLDSCHMIDT. James. Direito Processual Civil. Tomo I. $1^{\text {a }}$ edição. Bookseller Editora e Distribuidora: Campinas. 2003.

GONCALVES, M. V. R. Direito Processual Civil Esquematizado. 8. ed. São Paulo: Editora Saraiva, 2017. 
GONCALVES, M. V. R. Novo curso de Direito Processual Civil 1. 14. ed. São Paulo: Editora Saraiva, 2017.

LIEBMAN, Enrico Tullio. Estudos sobre o processo civil brasileiro. Editora Saraiva: São Paulo. 1947

LIEBMAN, Enrico Tullio. Manual de Direito Processual Civil. Volume I. $3^{\text {a }}$ edição. Malheiros Editora: São Paulo. 2005.

MIRANDA. Pontes de. Comentários ao Código de Processo Civil. Tomo XV. Editora Forense: Rio de Janeiro. 1977.

MIRANDA. Pontes de . Comentários ao Código de Processo Civil. Tomo I. Forense: Rio de Janeiro. 1973

NERY JR. Nelson. Princípios do processo na Constituição Federal. $12^{\mathrm{a}}$ edição. Editora Revista dos Tribunais: São Paulo. 2015.

SCHÖNKE. Adolfo. Derecho procesal civil. Bosch, Casa Editorial: Barceona. 1950.

THEODORO JR. Humberto. Curso de direito processual civil, volume I, 58 a edição. Editora Forense: Rio de Janeiro. 2017.

TUCCI. José Rogério Cruz e. Tempo e processo. Editora Revista dos Tribunais: São Paulo. 1997.

---. José Rogerio e Rogerio Lauria. Devido processo legal e tutela jurisdicional. Editora Revista dos Tribunais: São Paulo. 1993.

WAMBIER, Luiz Rodrigues e TALAMINI, Eduardo. Curso avançado de processo civil -

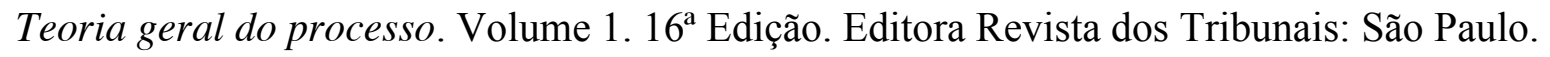
2016. 
WATANABE, Kazuo. Tutela antecipada e tutela específica das obrigações de fazer e não fazer. In: Teixeira, Sálvio de Figueiredo. Reforma do Código de Processo Civil. São Paulo: Saraiva, 1996. 


\title{
CRISE DO PROCESSO OU CRISE DA JURISDIÇÃO? O ACESSO À JUSTIÇA PELA VERTENTE DO DIREITO MATERIAL
}

\author{
Benedito Cerezzo Pereira Filho \\ Universidade de Brasília - UnB
}

Daniela Marques de Moraes

Universidade de Brasília - UnB

\begin{abstract}
Resumo
O processo civil foi pensado pela lógica da segurança do e no procedimento. Desenvolveu-se sob a égide da segurança jurídica, que comprometeu a duração razoável do processo. Seu tempo desencadeou a denominada 'crise do processo', inviabilizando a jurisdição enquanto dever do Estado e direito do cidadão, descurando que sua relevância está na satisfação do direito. Os objetivos deste estudo são identificar a existência da crise, sua origem, o conceito de jurisdição e a análise do acesso à justiça pelo direito material. Será utilizado o método de pesquisa bibliográfico para a compreensão da jurisdição e de sua funcionalidade no sistema constitucional-processual.
\end{abstract}

Palavras-chave: crise, jurisdição, acesso à justiça, processo, efetividade.

\section{Abstract/Resumen/Résumé}

The processual law was conceived according the safety provided by and at the procedure. It was developed under the aegis of legal certainty, what had direct impact on reasonable length of process. This "procedure crisis" impaired the jurisdiction that should be given by the state for the people as well overlooked that its relevance resides on Judicial Accountability. This study aims to identify if that crisis exists, what is the jurisdiction concept, as well how to access Justice access through material law. The bibliographic research method will be used to understand the jurisdiction and its functionality in the constitutional-procedural system. 
Keywords/Palabras-claves/Mots-clés: crisis, jurisdiction, justice access, process, effectiveness.

\section{Introdução}

Virou lugar comum afirmar que o processo civil está em crise. Aliás, esse inexato entendimento foi utilizado para fundamentar a viabilidade do atual Código de Processo Civil e, por via oblíqua, para justificar a ab-rogação do Código Buzaid de 1973.

Essa decantada crise se justificaria pela demora demasiada na prestação da tutela jurisdicional. Incapaz de enxergar o meandro da questão, a maioria dos doutrinadores simplifica o complexo ${ }^{1}$ e busca resposta a partir de um problema falso: o processo civil está em crise porque é moroso, letárgico. Seguida dessa conclusão, vem a derradeira: o princípio constitucional do acesso universal à justiça fica prejudicado ante a crise do processo.

O presente estudo, no entanto, tem por objetivo demonstrar que se há crise, ela não pode ser atribuída ao processo civil em si e, muito menos, tendo como motivo a sua duração. Ao contrário do que muitos pensam, nunca foi meta do legislador elaborar um processo civil calcado pela rapidez na solução dos litígios.

Pelo contrário, como se observará no decorrer deste ensaio, o processo civil sempre foi pensado pela lógica da segurança do e no procedimento. Ou seja, sempre se prestigiou o valor segurança em detrimento da rapidez.

O legislador só primou por um procedimento célere nas denominadas tutelas diferenciadas, ${ }^{2}$ no mais, esmerou-se por se proteger sob um procedimento que não permite decisões liminares vocacionadas à satisfação integral do direito reclamado em juízo.

Não se percebeu, por muitos anos, que a crise está na própria jurisdição. Não se deu conta, também, que acesso ao judiciário não é sinônimo de acesso à justiça e que a relevância da jurisdição está na satisfação e não na cognição pura e simplesmente.

É objetivo, portanto, estudar o acesso à justiça pelo ângulo do direito material, ou seja, verificar em que medida e a que custo a jurisdição está vocacionada - ou não - a cumprir com a promessa constitucional insculpida no artigo $5^{\circ}$, inciso XXXV da Constituição Federal de não furtar da apreciação do poder judiciário lesão ou ameaça a direito.

\footnotetext{
${ }^{1}$ Sobre essa questão de simplificar o complexo, ler MORIN (2011).

${ }^{2}$ Entende-se por tutela diferenciada toda decisão proferida sem a obediência estrita à ordinariedade do processo civil comum, calcada em decisão proferida após cognição ampla, exauriente, pautada, pelo menos, em dois juízos de mérito, primeira e segunda instâncias e dependente de tutela executiva.
} 
Valendo-se do método de pesquisa bibliográfica e comparativa, refletir-se-á sobre os conceitos de acesso à justiça, ação de direito processual e ação de direito material, tutela cognitiva e executiva, tudo a partir da constatação e da amplitude do entendimento sobre jurisdição e sua funcionalidade no sistema constitucional-processual.

Por ser consenso no meio jurídico de que a principal fonte da tal morosidade processual cível está(ria) na tutela executiva por pagamento de quantia, ante a ausência de efetividade das decisões condenatórias, elegeu-se essa modalidade de tutela para servir de hipótese no trabalho proposto.

Alerta-se, desde já, que apesar do atual Código de Processo Civil ter se orientado pela busca da diminuição do tempo do processo, infelizmente, o discurso foi mais eficaz do que a prática e a mazela da jurisdição continua intacta.

Justifica-se, pois, o estudo proposto ante a necessidade de se compreender adequadamente o problema para, somente depois, se averiguar a possibilidade de apresentar respostas.

\section{A importância do "olhar" crítico}

O alerta do processualista MOREIRA (2001, p. 228) de que seu "primeiro dever é exortar os ouvintes a que não alimentam a expectativa de revelações sensacionais sobre o porvir da justiça, neste último ano de século e do milênio, ou no próximo, a começar em 2001, diga o que disser a propaganda desavergonhadamente enganosa com que tentaram embriagar-nos", serve, também, como indicativo para os pretensos leitores desse trabalho.

Não há soluções mágicas. É necessário, antes de tudo, compreender e admitir a complexidade da questão para, então, buscar avanços que sejam possíveis de se realizar no mundo dos fatos.

O estudo do direito tem ensinado que é mais eficaz desmistificar mitos do que propriamente "enxergar" soluções milagrosas levantadas às pressas e sem o devido esmero. Não obstante, o Projeto de Lei $n^{\circ} 8.046$, elaborado no Senado Federal num breve tempo de seis meses e que deu origem ao presente Código de Processo Civil, foi construído sob a bandeira propagandista de que seria capaz de "reduzir a duração do processo em até 70\%"3.

\footnotetext{
${ }^{3}$ Novo CPC irá reduzir em até 70\% a duração do processo, prevê ministro Luiz Fux. Publicado pelo Superior Tribunal de Justiça. Disponível em: https://stj.jusbrasil.com.br/noticias/2480361/novo-cpc-ira-reduzir-em-ate-70a-duracao-do-processo-preve-ministro-luiz-fux
} 
Em razão dessas idiossincrasias é oportuno recordar a advertência de LYRA FILHO (1999, p. 3), segundo a qual “A maior dificuldade, numa apresentação do Direito, não será mostrar o que ele é, mas dissolver as imagens falsas ou distorcidas que muita gente aceita como retrato fiel."

A problemática se angulariza, na exata medida em que a propagação dessas imagens é popularizada numa prática jurídica na qual se ‘ensina o direito errado' que, no dizer, também, de LYRA FILHO (1980, p. 5), se bifurca em dois sentidos: "como o ensino do direito em forma errada e como errada concepção do direito que se ensina. O primeiro se refere a um vício de metodologia; o segundo, à visão incorreta dos conteúdos que se pretende ministrar."

Ser caçador de novidades, que desculpem os “modistas” é fácil. Fazer a crítica é difícil. E assim o é porque ao crítico "Não lhe é dado defender nem os seus interesses pessoais, nem os alheios, mas somente a sua convicção, e a sua convicção, deve fomar-se tão pura e tão alta, que não sofra a ação das circunstâncias externas. Pouco lhe deve importar as simpatias ou antipatias dos outros; um sorriso complacente, se pode ser recebido e retribuído com outro, não deve determinar, como a espada de Breno, o pêso da balança; acima de tudo, dos sorrisos e das desatenções, está o dever de dizer a verdade, e em caso de dúvida, antes calá-la, que negá-la” (ASSIS, 2011, p. 9). Por isso, é de se pensar que, para advogar em prol de um acesso universal à justiça é imprescindível compreender criticamente a funcionalidade do sistema, analisar o contexto em que foram pensados os regimes político, econômico e social, a que serviram ou servem.

É ter em mente, antes de tudo, que é preciso, como Mahatma Gandhi, falar, pensar e fazer a mesma coisa (GOSWAMI, 2010, p. 21). Assim, por exemplo, não se tem como advogar em prol de um acesso universal à justiça e, ao mesmo tempo, defender o entendimento de que a tutela executiva por soma deva ser prestada somente sob a tipicidade do meio executivo ordinário, calcado na expropriação de bens do devedor pela medida executiva da penhora.

Igualmente, é extremamente contraditório doutrinar em prol da duração razoável do processo, levantando bandeira para o artigo $4^{\circ}$ do CPC, segundo o qual as partes têm o direito de obter em prazo razoável a solução integral do mérito, incluída a atividade satisfativa, se, ao mesmo tempo, festeja-se a dicção do seu artigo 1.012 o qual prescreve que a apelação terá o efeito suspensivo. ${ }^{4}$

A crítica que se pretende, portanto, é sobre o entendimento do sistema, na busca por logicidade e coerência com a aplicabilidade dos direitos fundamentais dos jurisdicionados.

\footnotetext{
${ }^{4}$ A esse respeito, ler PEREIRA FILHO (2017).
} 


\section{O tempo da justiça cível}

Sobre o tempo da justiça cível muito se poderia e se deve dizer. ${ }^{5}$ No entanto, nesse momento, cabe analisar, criticamente, se as festejadas reformas processuais foram capazes de atingi-lo ao ponto de satisfazer o jurisdicionado no seu direito fundamental ao processo justo, entendido como aquele vocacionado a proporcionar uma tutela adequada, tempestiva e efetiva.

As reformas processuais foram sempre pautadas pelo discurso de se diminuir o tempo do processo e desafogar o judiciário. A começar pela Emenda Constitucional no 45 de 2004 que "teve como mote central o combate à crise do Judiciário" (GABBAY, 2018), introduzindo o direito à razoável duração do processo, ${ }^{6}$ à súmula vinculante e ao instituto da repercussão geral.

Anote-se, contudo, que ela contemplou os interesses da Defensoria Pública. Instituição de extraordinária importância para o tema acesso à justiça, em vista da assistência judicial/extrajudicial integral e gratuita que presta à população que não reúne condições de arcar com as custas e com as despesas processuais, teve asseguradas a autonomia funcional e administrativa.

Ainda visando a duração do processo, contemporaneamente à Emenda Constitucional $\mathrm{n}^{\mathrm{o}} 45$, os chefes dos três Poderes subscreveram um pacto de Estado, o I Pacto pelo Judiciário Pacto de Estado em favor de um Judiciário mais Rápido e Republicano -, no qual foram apontados 11 compromissos para o desenvolvimento da prestação da Justiça:

\footnotetext{
1. Implementação da Reforma Constitucional do Judiciário;

2. Reforma do sistema recursal e dos procedimentos;

3. Defensoria Pública e Acesso às Justiça;

4. Juizados Especiais e Justiça Itinerante;

5. Execução Fiscal;

6. Precatórios;

7. Graves violações contra os Direitos Humanos;

8. Informatização;

9. Produção de dados e indicadores estatísticos;

10. Coerência entre a atuação administrativa e as orientações jurisprudenciais já pacificadas;

11. Incentivo à aplicação das penas alternativas.
}

No ano de 2009, ainda sob os propósitos de proteção dos direitos humanos, de efetividade da prestação da tutela jurisdicional e de acesso universal à justiça, reafirmando-se

\footnotetext{
${ }^{5}$ Como uma das referências, NUNES (2010).

${ }^{6}$ Neste texto, utilizando da hermenêutica, a compreensão é que o termo ideal deve ser "duração suportável" do processo. Nesse sentido, ver: PEREIRA FILHO (2015).
} 
os compromissos acima transcritos e ampliando-se os objetivos inaugurais, fora firmado o II

Pacto Republicano - o Pacto Republicano de Estado por um Sistema de Justiça mais Acessível, Ágil e Efetivo, cujos objetivos e compromissos são:

I - acesso universal à Justiça, especialmente dos mais necessitados;

II - aprimoramento da prestação jurisdicional, mormente pela efetividade do princípio constitucional da razoável duração do processo e pela prevenção de conflitos;

III - aperfeiçoamento e fortalecimento das instituições de Estado para uma maior efetividade do sistema penal no combate à violência e criminalidade, por meio de políticas de segurança pública combinadas com ações sociais e proteção à dignidade da pessoa humana.

Para a consecução dos objetivos estabelecidos neste Pacto, assumem os seguintes compromissos, sem prejuízo das respectivas competências constitucionais relativamente à iniciativa e à tramitação das proposições legislativas:

a) criar um Comitê Interinstitucional de Gestão do presente Pacto Republicano de Estado por um Sistema de Justiça mais Acessível, Ágil e Efetivo, com representantes indicados por cada signatário, tendo como objetivo desenvolver e acompanhar as ações pactuadas;

b) conferir prioridade às proposições legislativas relacionadas aos temas indicados no Anexo deste Pacto, dentre as quais destacam-se a continuidade da Reforma Constitucional do Poder Judiciário e os temas relacionados à concretização dos direitos fundamentais, à democratização do acesso à Justiça, inclusive mediante o fortalecimento das Defensorias Públicas, à efetividade da prestação jurisdicional e ao aperfeiçoamento dos serviços públicos prestados à sociedade;

c) incrementar medidas tendentes a assegurar maior efetividade ao reconhecimento dos direitos, em especial a concessão e revisão de benefícios previdenciários e assistenciais;

d) fortalecer a mediação e a conciliação, estimulando a resolução de conflitos por meios autocompositivos, voltados à maior pacificação social e menor judicialização; e) ampliar a edição de súmulas administrativas e a constituição de Câmaras de Conciliação;

f) celebrar termos de cooperação entre os Poderes com o objetivo de intensificar ações de mutirão para monitoramento da execução penal e das prisões provisórias, fortalecendo a assistência jurídica aos presos e familiares e promovendo ações de capacitação e reinserção social;

g) incentivar a aplicação de penas alternativas;

h) integrar ações de proteção às crianças e adolescentes vítimas ou em situação de risco e promover medidas de aprimoramento do Sistema de Justiça em que se insere o menor em conflito com a lei;

i) aperfeiçoar a assistência e o Programa de Proteção à Vítima e à Testemunha;

j) estruturar e apoiar as ações dos órgãos de controle interno e ouvidorias, no âmbito das instituições do Sistema de Justiça, com o objetivo de promover maior transparência e estimular a participação social;

k) melhorar a qualidade dos serviços prestados à sociedade, possibilitando maior acesso e agilidade, mediante a informatização e desenvolvimento de programas de qualificação dos agentes e servidores do Sistema de Justiça;

1) fortalecer o exercício do direito fundamental à ampla defesa e da advocacia;

m) viabilizar os recursos orçamentários necessários à implantação dos programas e ações previstos neste Pacto.

Mas, juristas sensíveis as reais condições da justiça brasileira, não se empolgaram com as reformas. Apontada como tímida e de superfície, foi severamente reprochada pelo processualista PASSOS (2012, p. 204) que afirmou: "Nada de diferente poderia acontecer com a Emenda da reforma do Poder Judiciário. Um faz de conta que favorece alguns setores do 


\section{Judiciário e seus vizinhos e nada soma em favor do cidadão e da democracia brasileira."}

\section{E acrescentou:}

Os motivos 'conhecidos' e que foram apontados como determinantes da Emenda 45: Crise do Poder Judiciário. Crise de legitimação? Crise de organização? Crise de desempenho? Não. Crise centrada na 'excessiva duração' do processo. Reformou-se para obter uma prestação jurisdicional mais célere e mais efetiva: Celeridade, efetividade, deformalização. Uma reforma dita como sendo feita em favor do cidadão, do jurisdicionado. Ou um falso diagnóstico da crise ou o propósito de encobrimento ou despistamento da atenção dos jurisdicionados para os reais problemas do Poder Judiciário, que se identificam com os problemas de nosso país e de sua feição econômica, política e social. (2012, pp. 204-205)

\section{O processualista, ao fazer uso da crítica, percebeu nas reformas "um falso diagnóstico}

da crise". Para aclarar, mais uma vez se pronuncia PASSOS (2012, pp. 136-137):

Dessa constatação, recolho o que tenho reiteradamente afirmado. Somos um país permissivo, mas não somos um país democrático. Há uma tolerância aparente das elites, alicerçada na consciência da fraqueza dos dominados; e há uma mansa aceitação dos dominados, por falta de consciência quanto aos caminhos de sua libertação. O grande drama do Brasil é que os senhores, donos de engenhos e beneficiários de sesmarias e hoje titulares de autonomias indevassáveis e privilégios intocáveis, só aceitam uma democracia formal, de faz de conta, em que o máximo admitido é um poder de controle intraestamentário, que se dá em termos de compadrio no seio das muitas capitanias hereditárias de nossas autonomias constitucionalizadas, sempre excluído o povo enquanto titular de soberania. Daí o espetáculo dilacerante de sermos democracia formal sem nenhuma democracia real. Muitos falaram nas promessas não cumpridas da democracia, por deficiência de sua teorização e institucionalização. No Brasil, será correto falar-se em promessas dolosamente não cumpridas, por se ter até hoje, conscientemente, prometido o que jamais se desejou cumprir. A maturidade e a consciência política só se alcançam com a práxis, na escola da atividade política concreta, no embate das lutas e resistências cotidianas, não por meio de compêndios, ordens do dia e plataformas de governo ou estatutos de partidos políticos. E só na medida em que se oferece para nós o espaço que possibilita essa luta e essa presença é que se inicia o nosso aprendizado e se efetiva nossa participação. $\mathrm{O}$ Poder não concede, não transige, não liberaliza. O Poder, por essência e vocação, oprime, exclui, expropria. Só o Poder participado é Poder-Serviço, e a participação nunca é obtida como dádiva, mas é sempre conseguida como fruto da resistência indormida dos que adquiriram consciência de sua cidadania. Como, portanto, dizermos: 'Vamos reformar o Judiciário', quando na verdade o que urge, como tarefa inadiável, é repensarmos as instituições políticas do nosso país e do mundo contemporâneo!

Em complementação ao que afirmou Passos, não se pode deixar de enxergar, conforme asseverou MARONA (2013, p. 546), que:

A toda evidência, a reforma do Judiciário, no Brasil, nos moldes como se operou, serviu à centralização e à verticalização do poder no âmbito do próprio Judiciário, mas não assegurou (e tenha talvez até retardado) a possibilidade de controle público sobre sua atuação, o que teria demandado um fortalecimento da Justiça local, além de mecanismos que favorecessem a participação da sociedade civil no governo e na gestão dos tribunais. 
O Código de Processo Civil de 2015, igualmente, também não foi feliz na busca pela diminuição do tempo da justiça. Faltou-lhe percepção do problema e coragem para reformas de cunhos estruturais, ao ponto de afirmarem MARINONI, ARENHART e MITIDIERO (2017, p. 11):

\begin{abstract}
O presente Código de Processo Civil poderia ser muito mais adequado. Ele não foi capaz nem mesmo de corrigir a principal disfunção do Código de 1973, quando, é preciso lembrar, essa foi a principal razão eleita para desculpar a sua criação. Recordese que todos viam como grave e imperdoável contradição, diante do instituto da tutela antecipada surgido em 1994, a falta de executividade imediata da sentença na pendência da apelação. Ocorre que o legislador, pressionado por setores ignorantes e reacionários, manteve a sentença na mesma condição de inefetividade em que estava o Código de 1973. Pior do que isso só pode ser a proclamação demagógica de que o novo Código tornará realidade a promessa constitucional de duração razoável do processo.
\end{abstract}

O tempo da justiça, então, permanece como está(va). Alterou-se a funcionalidade, mas, manteve-se intacta a estrutura.

\title{
4. "Crise" da jurisdição: o processo civil como vilão
}

Acentuada a "crise", o processo civil foi acusado de ser o responsável pela letargia da justiça cível. As reformas legislativas foram e são todas embasadas nessa pauta: o processo civil é moroso.

Essa conclusão é um equivoco e uma traição interpretativa àqueles que pensaram e elaboraram toda a sistemática do processo civil brasileiro. Quem estuda minimamente suas raízes, sabe muito bem que ele foi concebido para dar uma "garantia" à defesa num procedimento ordinário cuja a exigência pela busca da "verdade" absoluta é corroborada por uma tutela executiva, no caso da obrigação de pagar quantia, igualmente protetora do patrimônio daquele que foi reconhecido como devedor. ${ }^{7}$

A maioria da doutrina não percebe o óbvio: se o processo civil foi pensado para ser moroso, não pode ser acusado de não prestar justamente por cumprir a missão para qual foi elaborado.

Sempre atento e ávido na crítica, SILVA (2008), nesse ponto, esclarece: "No que respeita ao direito processual, direi que o dogmatismo fez com que perdêssemos a visão do bosque. Vemos apenas as árvores e estamos ofuscados pela sua grandiosidade." E arremata com

\footnotetext{
${ }^{7}$ Recomenda-se, neste ponto, a leitura dos seguintes textos: SILVA (1993) e PEREIRA FILHO (2006).
} 
sapiência e conhecimento de causa:

\begin{abstract}
Ao contrário da opinião dominante, porém, penso que o Poder Judiciário funciona bem, tendo em vista o condicionalismo teórico e político dentro do qual ele sobrevive. Ele funciona segundo os princípios e pressupostos imaginados por aqueles que os conceberam. Um ponto que não preocupa aqueles que se angustiam com os atuais problemas da administração da justiça é saber se a celeridade processual fora, realmente, concebida como um objetivo desejado pelo sistema. Ou seja, ainda não se demonstrou que nosso sistema processual fora programado para andar rápido. Ao contrário, ao priorizar o valor segurança, inspirada em juízos de certeza, como uma imposição das filosofias liberais do Iluminismo, o sistema renunciou à busca de efetividiade - que nossas circunstâncias identificam com celeridade, capaz de atender às solicitação de nossa apressada civilização pós-moderna. O Poder Judiciário funciona satisfatoriamente bem, em nosso país. Os problemas da Justiça são estruturais. Não funcionais. Ele atende rigorosamente bem ao modelo que o concebeu." (SILVA, 2008)
\end{abstract}

Em outro texto de igual porte, o processualista gaúcho volta a afirmar: "Venho sustentando que a jurisdição brasileira - dentro do marco institucional que a concebeu e dos pressupostos que lhe imprimem o sistema - funciona bem. Diria funciona além do que se poderia esperar de uma estrutura anacrônica, ainda dependente dos ideias do iluminismo europeu." (SILVA, 2009)

Acusar o processo civil de não prestar por ser moroso é uma contradição. MOREIRA (2001, p. 02) afirma ser um mito "a crença de que cabe aos defeitos da legislação processual a maior responsabilidade pela duração excessiva dos pleitos" e esclarece que tais "percepções" só podem ser "redigidos por pessoas que nunca sequer passaram pela porta do Fortim."

A crise, então, não é do processo civil, mas, da jurisdição e a forma pela qual foi concebida. Essa "falha" estrutural não foi sentida nem pelo legislador do atual Código de Processo Civil. Apesar de tão recente, recepcionou essa velha "crise" da jurisdição. Fato que não passou despercebido pelos processualistas MARINONI, ARENHART e MITIDIERO (2017, p. 11):

Um Código de Processo Civil é sempre algo inacabado. Não pelo fato de o legislador desconhecer o Direito e a função que a legislação processual deve desempenhar na sociedade - embora isso não raramente aconteça. Mas sim porque o texto legal é, em si, insuficiente para regular a vida em sociedade. São os doutrinadores que, em vista da sua missão específica de mergulhar sobre a teoria para iluminar a legislação, tem a tarefa de elaborar construções dogmáticas para que o produto do legislador possa corresponder às necessidades sociais. É claro que essa tarefa pode ter como matéria prima uma legislação mais ou menos adequada. O presente Código de Processo Civil poderia ser muito mais adequado. Ele não foi capaz nem mesmo de corrigir a principal disfunção do Código de 1973, quando, é preciso lembrar, essa foi a principal razão eleita para desculpar a sua criação. Recorde-se que todos viam como grave e imperdoável contradição, diante do instituto da tutela antecipada surgido em 1994, a falta de executividade imediata da sentença na pendência da apelação. Ocorre que o legislador, pressionado por setores ignorantes e reacionários, manteve a sentença na 
mesma condição de inefetividade em que estava o Código de 1973. Pior do que isso só pode ser a proclamação demagógica de que o novo Código tornará realidade a promessa constitucional de duração razoável do processo. Note-se que, também nessa linha, é lamentável que o legislador tenha se dobrado ao argumento fácil e equivocado de que não é possível limitar o duplo juízo sobre mérito, dogma tupiniquim que retira valor à figura do juiz de primeiro grau e impede que os tribunais de apelação trabalhem com racionalidade. Também é simplesmente triste o modo como o Código trata da eficácia das decisões das Cortes Supremas, lembrando, numa bizarra e inusitada norma (caput do art. 927, salvo pelos seus adequados parágrafos), quais são as decisões que devem ser observadas pelos tribunais inferiores.

A complexidade está na estrutura, na base do nosso sistema. A jurisdição presta seu papel de acordo com o propósito para o qual foi pensada, não podendo, como está, ser deslocada para atender o reclamo do artigo $5^{\circ}$, inciso LXXVIII, da CF e nem do art. $4^{\circ}$ do CPC que, simplesmente, proclamam que o processo tem de atender à duração razoável.

\section{Acesso à justiça}

Não é difícil concluir que se a jurisdição, responsável pela realização da justiça, está eivada desse vício de origem, seu correspondente acesso à justiça, por via obliqua, também carregará o mesmo equívoco.

Ainda mais porque, por acesso à justiça deve-se entender a plena realização do direito afirmado e reconhecido em juízo.

O direito de ação por ser um direito fundamental, não pode ser vilipendiado, negligenciado. No entanto, apensar da estrutura a que está sustentado o sistema processual, é preciso reconhecer e vislumbrar caminhos que possam conduzir o direito do cidadão à plena efetivação, na exata medida que lhe foi prometido pelo legislador constitucional, precisamente no artigo $5^{\circ}$, incisos XXXV e LXXVIII, da CF.

\subsection{Ação de direito processual e ação de direito material}

Talvez não seja demais relembrar que a ida ao judiciário não é uma opção para aquele que necessita realizar um direito, antes, é uma obrigação.

O direito de crédito, por exemplo, enquanto mera previsão legislativa, não pode ser realizado no mundo dos fatos até que, realmente, um determinado cidadão se veja na condição de exigir de outro a concretização desse direito. 
Somente após consumada a condição ou o termo, o, agora credor, poderá exigir do devedor o pagamento do valor entre eles ajustado. A esse poder, dá-se o nome de ação de direito material.

Adimplido pelo devedor o pacto, tem-se que a pretensão de direito material foi realizada por aquele que se encontrava na situação de submissão em relação a outra parte. É o que se denomina de fisiologia do direito, seu potencial de se realizar independentemente do uso e da força da jurisdição.

A esse fenômeno, dá-se o nome de ação de direito material.

No entanto, se por qualquer razão o "devedor" resistir a ação do "credor", instaura-se a lide: pretensão qualificada pela resistência. Nesse exato momento, a ação material, consubstanciada no direito do particular de exigir a sua pretensão, é obstada pelo Estado-juiz, que o proíbe o uso da própria força para exigir o cumprimento da obrigação em seu favor, sob pena de ser responsabilizado criminalmente, ante a previsão do art. 345 do Código Penal, segundo o qual: "Fazer justiça pelas próprias mãos, para satisfazer pretensão, embora legítima, salvo quando a lei o permite."

Sua 'opção' é ir ao poder judiciário, que lhe promete, pelo exercício da jurisdição e em plena realização do acesso à justiça, efetivar a sua a ação de direito material, já que ele Estado-juiz - não o deixa concretizar pelas próprias forças.

Surge para o particular a necessidade do uso da ação de direito processual, cuja vocação está justamente na possibilidade de o cidadão invocar o poder e o direito para fazer valer a sua pretensão de direito material. Assim o é porque "Se a convivência humana fosse incapaz de gerar conflitos, duas coisas inexistiriam: o poder e o direito, quando nada." (PASSOS, 1993)

Assim, aquele que tem uma pretensão resistida está obrigado a ir ao judiciário caso tenha interesse em realizá-la no mundo fático.

\section{Jurisdição como dever}

O importante é perceber que a ação de direito processual serve para fazer valer a ação de direito material.

Em outras palavras, o cidadão quando vai ao judiciário não almeja uma ação de direito processual, ou seja, uma sentença de mera procedência do seu pedido. Aliás, no caso da tutela de crédito, ele já sabe que é credor. Assim, em verdade, ele quer a realização da sua pretensão 
de direito material de recebimento do que lhe é devido e que foi impedido de concretizar ante a resistência da outra parte.

Bem vistas as coisas, a ação de direito processual é o procedimento legal que o cidadão precisa se submeter para receber do Estado-juiz a sua pretensão, ou seja, ação de direito material.

Essa é a promessa do Estado constitucional e processual a todos que se encontrarem numa situação carente de proteção jurídica.

A jurisdição, portanto, antes de ser poder é, em última análise, um dever. É o Estado que promete, mediante provocação pela ação de direito processual, realizar a ação de direito material a todo cidadão cuja pretensão tenha sido resistida pela parte contrária.

A jurisdição, então, é um dever do Estado e um direito fundamental do cidadão. A partir do momento, por exemplo, que na ação de direito processual se reconhece a existência de um crédito, a efetivação desse direito - ação de direito material - passa a ser um dever do Estado-juiz.

No caso, se ratificará em juízo, o que o credor, privadamente, já havia exigido no mundo dos fatos. Ele necessita arcar com o ônus de demonstrar no poder judiciário, sob as regras do procedimento - ação de direito processual - que tem o direito ao crédito afirmado como existente em relação ao devedor.

A partir desse momento, ao nosso ver, nasce para o Estado, o dever de concretizar o direito por ele declarado como sendo devido. O exercício da jurisdição, nessa ordem de ideia, pressupõe o dever de realizar, de forma adequada, tempestiva e efetiva, a pretensão de crédito reconhecida de forma definitiva pelo Estado-juiz.

A esse dever, contudo, alia-se a força do direito, ou seja, o Poder. De nada adiantaria uma decisão carente de cumprimento, ou que ficasse a mercê da outra parte para ser respeitada ou não.

O uso desse poder é racionalmente exercido por meio da ação de direito processual, justamente para permitir que a força do direito seja utilizada para a concretização da decisão proferida, ou seja, no cumprimento da pretensão ao crédito -ação de direito material.

Em resumo, jurisdição não se encerra na declaração de um direito. A técnica processual utilizada para o reconhecimento de um direito, seja ela sentença meramente declaratória ou acoplada de condenação, constituição e, até mesmo executiva e mandamental, que não satisfaz o interessado, nega o seu verdadeiro sentido e objetivo. 
A decisão judicial, seja de procedência ou de improcedência, só terá conotação de jurisdição constitucional, se for capaz de cumprir satisfatoriamente com o seu comando normativo num tempo que seja suportável.

É essa vocação de realizar direito no mundo dos fatos que se deve entender por dever jurisdicional plenamente capaz de cumprir com a promessa constitucional de acesso universal à jurisdição.

\section{Tutela executiva: objetivo do jurisdicionado}

Não se pode perder de vista que o autor ao utilizar da ação de direito processual o faz visando, por óbvio, a ação de direito material. É ela que lhe interessa.

No caso da tutela de crédito, o que se visa é o seu recebimento. O adimplemento da obrigação assumida pelo réu devedor.

O acesso à justiça para o autor credor é o resultado esperado da sua ação. Ou seja, a partir do momento em que ele não puder agir mais privadamente, pois, a recusa do devedor ao adimplemento o impede de continuar a exigir à força o seu direito, ele utilizará a ação de direito processual par alcançar esse desiderato pelo exercício regular da jurisdição.

Quem vai a juízo reclamar uma proteção jurídica para recebimento de um crédito, não espera obter, pura e simplesmente, uma sentença de procedência. Pelo contrário, o que se espera é que o Estado-juiz cumpra o prometido e realize a pretensão deduzida em juízo nos exatos termos previstos na constituição e no processo civil.

É esse dever do Estado-juiz que o autor-credor almeja. Bem por isso, tecnicamente, ação de direito processual é ajuizada contra o juiz (Estado) e em face do réu devedor.

Se fosse possível sentir o diálogo extraído de uma relação jurídica processual, seria perceptível ouvir o juiz indagar: autor/credor você quer que eu realize sua pretensão ao crédito - ação de direito material - em face de quem? Com quais fundamentos jurídicos?

Concretizada em juízo essa pretensão, nasce para o Estado-juiz o dever de cumpri-la e para o autor-credor o direito de recebê-la integralmente.

\subsection{Medidas executivas - poder geral do juiz}

Afirma, com propriedade, PASSOS (1993) que: "a rigor, só tem direito quem invoca uma sentença transitada em julgado da qual deriva determinada pretensão. Aqui, a pretensão se faz 'direito"'. 
A bem da verdade, muito embora o autor/credor saiba mais do que ninguém da existência do seu crédito, portanto, do seu direito, ele só o terá se houver o reconhecimento judicial pela sentença proferida na ação de direito processual.

Esse é um desconforto que ele terá que passar. É, por assim dizer, a regra do jogo.

Contudo, pelo que foi visto até aqui, depois de reconhecido, ratificado em juízo, o credor tem direito ao cumprimento da obrigação e essa incumbência passa a ser um dever do Estado-juiz.

Como bem afirma PASSOS (1993): “O conhecer deriva da circunstância de ser o juiz um terceiro desinformado dobre os fatos da causa; o julgar, porque lhe incumbe, com base nos fatos, dizer o direito; o efetivar, porque ele não diz o direito aconselhando, sim disciplinando impositivamente."

Bem por isso, pode-se concluir, mais uma vez apoiado no mestre baiano, que "se é assim, a efetividade do julgado não é algo que se coloca fora da esfera do poder do Magistrado.” (PASSOS, 1993) Pelo contrário, é seu dever realizar no mundo dos fatos o que reconheceu em juízo mediante procedimento legal - ação de direito processual - sob pena de faltar com sua missão constitucional de fazer justiça àquele que precisar e que foi proibido de realizá-la pelas próprias forças.

Em contrapartida, para desempenhar seu dever, o juiz não pode ficar submetido a um procedimento obsoleto e que o restrinja a um mero expectador das atividades, que podem ser até legais, do devedor.

O que se está pretendendo dizer é que sendo dever do juiz concretizar sua decisão, não se pode, em contrapartida, limitar sua atuação ao meio executivo típico do procedimento expropriatório da penhora.

Ele precisa ter um poder geral que lhe permita influenciar na vontade do devedor para que esse se convença a cumprir a decisão judicial imposta. Isso só poderá ocorrer se houver uma compreensão adequada do real conceito de jurisdição e de acesso à justiça.

\section{A previsão legislativa do artigo 139, IV do CPC: uma esperança}

A previsão legislativa do artigo 139, IV do CPC/2015 está causando uma preocupação, talvez, exagerada, na doutrina e no judiciário, porque passou-se a ver nesse dispositivo a possibilidade do juiz aplicar medidas executivas atípicas na tutela executiva por soma.

O supracitado artigo tem a seguinte redação: Art. 139. O juiz dirigirá o processo conforme as disposições deste Código, incumbindo-lhe: IV - determinar todas as medidas 
indutivas, coercitivas, mandamentais ou sub-rogatórias necessárias para assegurar o cumprimento de ordem judicial, inclusive nas ações que tenham por objeto prestação pecuniária.

Todo o alarme surgiu porque algumas decisões reconheceram nesse artigo uma forma do juiz forçar o devedor a cumprir com a obrigação sem que seja pela medida típica do procedimento expropriatório, ou seja, a penhora.

São medidas que procuram agir de forma indireta na vontade do devedor, forçando-o a cumprir com o julgado materializado no título executivo judicial. Assim, por exemplo, diante da recusa do devedor em efetivar o pagamento e ausente indicação de bens passíveis de penhora, o juiz estaria autorizado a determinar medidas capazes de convencer o devedor a satisfazer a execução, tais como: cassação da $\mathrm{CNH}$, do passaporte, do talão de cheques, do cartão de crédito etc.

A ideia, em última análise, é dar ao devedor um tratamento de devedor. Se ele afirma que não tem como pagar uma dívida de dez mil Reais, por exemplo, não se afigura razoável que possa ostentar, no seu cotidiano, uma vida incompatível com quem se autodeclara incapaz de solver suas dívidas, por mínimas que sejam.

É evidente que a aplicabilidade deste dispositivo requer prudência e fundamentação adequada. Assim, por exemplo, cassar a CNH de um taxista ou de um motorista profissional, ao argumento de que se trata de uma medida indutiva para o cumprimento da obrigação, não se coaduna com as garantias processuais que todos merecem, independente se autor/credor ou réu/devedor.

Por outro lado, será uma medida eficaz àquele que, sob o pretexto de não possuir bens passíveis de penhora, desfila na sociedade dirigindo carros de alto valor, ostentando uma vida nas redes sociais incompatível com a alegada condição de incapacidade de cumprir com suas obrigações.

O que se pretende, ao aplicar essas medidas, é, tão somente, imbuir o devedor de um pouco de responsabilidade pelos seus atos. Aliás, a responsabilidade é dever de todos os sujeitos que participam do processo, inclusive o juiz. Mais uma vez, com total acerto, esclarece PASSOS (1993): "Estivéssemos num pais em que a ordem jurídica valesse e em que todo exercício de poder envolvesse responsabilidade, muitos acertos de contas teríamos. Mas, como assim não é, apenas temos muitas dores de cabeça."

Quem afirma que o uso dessas medidas, quando devidamente fundamentadas e depois de esgotadas as outras vias menos gravosas, fere o direito constitucional do devedor, não compreende o conceito de jurisdição e o alcance do princípio universal de acesso à justiça. 
Sempre com PASSOS (1993): "O direito existe com inextirpável vocação de efetividade. Ele é posto para 'ordenar' efetivamente a correlação dos interesses que disciplina. Impensável na esfera do mero aconselhamento ou recomendação. Ele ordena, impõe, submete, sujeita. Melhor dizendo. Os que em seu nome decidem e operam é que submetem." Para não continuar a incorrer na velha máxima ganhou, mas não levou, é que a tutela executiva não pode ficar a depender da boa vontade do devedor.

\section{Conclusão}

$\mathrm{O}$ acesso à justiça é um direito fundamental consagrado a todos. E nem poderia ser diferente porque é o meio legítimo que o cidadão tem para participar do poder que, nunca é demais lembrar, a ele pertence por força do artigo $1^{\circ}$, parágrafo único da Constituição Federal.

Ao contrário dos poderes legislativo e executivo, cuja legitimidade pode ser facilmente verificada pelo exercício do direito ao voto e, em alguns casos de participação direta do povo, no Judiciário, essa legitimidade só pode ser medida pela sua atuação.

É pela capacidade de exercer a jurisdição, que se verifica a legitimidade do poder judiciário. Uma atuação em contraditório efetivo, substancial, com condições de igualdade das partes em procedimento colaborativo, pautadas por decisões adequadamente fundamentada, constitui condição sine qua non para se justificar a essência do poder judiciário.

No caso da tutela pecuniária, compreendida a jurisdição como dever e o acesso à justiça como o recebimento do crédito pleiteado, justifica-se plenamente o uso das medidas previstas no artigo 139, inciso IV do Código de Processo Civil.

Só quem não tem o devido entendimento da função que incumbe ao poder judiciário é que defenderá a não aplicabilidade do dispositivo em comento. Nesse ponto, inclusive, é bom que se diga que não se inventou a roda. O código revogado, CPC Buzaid de 1973, no seu artigo 14 , inciso $\mathrm{V}$, tinha previsão similar e que, se bem compreendida, poderia produzir os mesmos efeitos que o decantado artigo 139, IV está acarretando.

Mesmo antes da reforma legislativa que introduziu esse artigo 14, $\mathrm{V}$, no código revogado, tese de doutorado defendida na Universidade Federal do Paraná (PEREIRA FILHO, 2002) advogava em prol da necessidade de se reconhecer um poder geral ao juiz para que lhe fosse viável desincumbir o seu dever de efetivar a tutela pecuniária a quem demonstrasse ser titular do crédito. 
Naquela oportunidade, todas essas medidas suscitadas pela análise do artigo 139, inciso IV do CPC de 2015, foram contempladas como sendo viáveis e imprescindíveis à concretização do direito de crédito.

É necessário compreender que, sendo dever do Juiz, enquanto Membro do Estado, realizar no mundo dos fatos o que proibiu o particular de fazer pelas próprias forças (ação de direito material), não se pode furtar dele meios processuais adequados para o desenvolvimento dessa sua incumbência.

Igualmente, imprescindível para o cidadão ter um procedimento judicial que the garanta o acesso à justiça material e não meramente processual. Explicando melhor, quem vai a juízo reclamar um direito, quer o bem da vida alvo do conflito e não uma resposta judicial pautada numa sentença de procedência.

O impacto de uma medida coercitiva, indutiva ou mandamental, sobre direitos do devedor é maior e, às vezes até insuportável, àqueles que não compreendem a ação como direito fundamental, a jurisdição como dever e o acesso à justiça como satisfação integral do direito de crédito.

Bem vistas as coisas, a aplicabilidade dessas medidas executivas, longe de ferir direitos e garantias do devedor, é um meio legal e legítimo de se garantir efetivo acesso à justiça a quem necessitar.

\section{Referências bibliográficas}

ASSIS, Machado de. O jornal e o livro. São Paulo: Companhia das Letras, 2011.

GABBAY, Daniela Monteiro. Acesso ao Judiciário nem sempre é sinônimo de acesso à Justiça. Valor Econômico. Disponível em: http://www.valor.com.br/politica/5494921/acessoao-judiciario-nem-sempre-e-sinonimo-de-acesso-justica

GOSWAMI, Amit. O ativista quântico: princípios da física quântica para mudar o mundo e a nós mesmos. trad. por Marcello Borges. São Paulo: Aleph, 2010.

LYRA FILHO, Roberto. O direito que se ensina errado. Brasília: Centro Acadêmico da UnB, 1980.

O que é Direito. 11. ed., São Paulo: Editora Brasiliense, 1999. 
MARINONI, Luiz Guilherme; ARENHART, Sérgio Cruz; MITIDIERO, Daniel. Novo código de processo civil comentado. 3. ed. rev., atual. e ampl. São Paulo: Revista dos Tribunais, 2017.

Novo curso de processo civil: teoria do processo civil. v. 1, 2. ed., São Paulo: Revista dos Tribunais, 2017.

MARONA, Marjori Corrêa. Reforma do judiciário no Brasil. In: AVRITZER, Leonardo et al (orgs.). Dimensões políticas da justiça. Rio de Janeiro: Civilização Brasileira, 2013. pp. 535547.

MORAES, Daniela Marques de. A importância do olhar do outro para a democratização do acesso à justiça. Rio de Janeiro: Lumen Juris, 2015.

MOREIRA, José Carlos Barbosa. O futuro da justiça: alguns mitos. Revista de Processo. vol. 102, abr. 2001.

MORIN, Edgar. Introdução ao pensamento complexo. Porto Alegre: Sulina, 2011.

Novo CPC irá reduzir em até 70\% a duração do processo, prevê ministro Luiz Fux.

Publicado pelo Superior Tribunal de Justiça. Disponível em: https://stj.jusbrasil.com.br/ noticias/2480361/novo-cpc-ira-reduzir-em-ate-70-a-duracao-do-processo-preve-ministro-luizfux

NUNES, Dierle José Coelho. Processo jurisdicional democrático: uma análise crítica das reformas processuais. Curitiba: Juruá, 2008.

NUNES, Gustavo Henrique Schneider. Tempo do processo civil e direitos fundamentais. São Paulo: Letras Jurídicas, 2010.

PASSOS, José Joaquim Calmon de. Até quando abusarás, Ó Catilina? Cautelares e liminares Catástrofe Nacional. Revista do Advogado. São Paulo: Imprenta - AASP, 1993. 
Revisitando o direito, o poder, a justiça e o processo: reflexões de um jurista que trafega na contramão. Salvador: JusPodivm, 2012.

PEREIRA FILHO, Benedito Cerezzo. A duração razoável do processo na perspectiva do novo código de processo civil - lei $\mathrm{n}^{\mathrm{o}}$ 13.105, de 16 de março de 2015. In: GRINOVER, Ada Pellegrini et al. O novo código de processo civil: questões controvertidas. São Paulo: Atlas, 2015.

. O novo código de processo civil e a velha opção pelo efeito "suspensivo" no recurso de apelação. In: LIMA, Cíntia Rosa Pereira; DINIZ, Eduardo Saad; MARRARA, Thiago (Coords.). O Direito Brasileiro em Evolução: Estudos em homenagem à Faculdade de Direito de Ribeirão Preto. São Paulo: Almedina, 2017.

. O poder do juiz: ontem e hoje. Revista da Ajuris. v. 104, 2006. pp. 19-33.

. Repensando o processo de execução para uma maior efetividade da tutela do crédito pecuniário. Tese de doutorado. Universidade Federal do Paraná. Curitiba, 2002.

SILVA, Ovídio Araújo Baptista da. A 'plenitude de defesa' no processo civil. In: TEIXEIRA, Sálvio de Figueiredo (org.). As garantias do cidadão na justiça. São Paulo, Saraiva, 1993.

Advocacia em tempos de crise. Revista Magister de Direito Civil e Processual Civil. v. 5, n. 28, Porto Alegre: Magister, jan./fev. 2009. pp. 95-106.

. Da função à estrutura. Revista de Processo. v. 33, n. 158, abr. 2008. pp. 9-19.

. Jurisdição, direito material e processo. Rio de Janeiro: Forense, 2008. 


\title{
ESTUDO EXPLORATÓRIO SOBRE APLICAÇÃO DE TÉCNICA DE ANÁLISE SEMÂNTICA LATENTE, PARA VINCULAÇÃO DE PROCESSOS JUDICIAIS A TEMAS DE REPERCUSSÃO GERAL E INCIDENTE DE RESOLUÇÃO DE DEMANDA REPETITIVA
}

\author{
Tiago Melo \\ Universidad de Salamanca \\ Richerland Medeiros \\ Universidade Estadual Paulista Júlio de Mesquita Filho
}

\begin{abstract}
Resumo
Este artigo apresenta estudo baseado em técnicas de processamento de linguagem natural para vinculação de processos judiciais a temas repetitivos. O estudo utiliza a análise semântica latente, a partir da aplicação da matriz termo-documento em seis temas candidatos a se tornarem incidentes de resolução de demanda repetitiva. Em um conjunto de 225.080 petições iniciais digitais, foram encontrados 8.706 processos com score significativo de similaridade a um dos thesaurus criados para cada tema. O resultado do estudo indica que essa técnica pode ser aplicada com sucesso em processos judiciais eletrônicos e tem o potencial de melhorar significativamente a produtividade do judiciário.
\end{abstract}

Palavras-chave: Repercussão geral, demanda repetitiva, análise semântica latente, processamento de linguagem natural, inteligência artificial.

\section{Abstract/Resumen/Résumé}

This article presents a study based on natural language processing techniques for linking judicial processes to repetitive themes. The study uses latent semantic analysis, from the application of the thermo-document matrix in six themes that are candidates to become repetitive demand resolution incidents. In a set of 225,080 digital initial petitions, we found 8,706 processes with significant similarity score to one of the thesaurus created for each theme. The result of the study indicates that this technique can be applied successfully in electronic court cases and has the potential to significantly improve the productivity of the judiciary.

Keywords/Palabras-claves/Mots-clés: General repercussion; repetitive law suits; latente semantic analysis; natural language processing; artificial intelligence. 


\section{Introdução}

Processos físicos, em papel, estão se tornando uma exceção na Justiça Brasileira. Em 2016, 70\% dos novos casos que entraram em Tribunais no Brasil o fizeram em sua forma digital (Justiça em Números, 2017, p.78). Em 2009, esse índice foi de 12\%. De 2009 a 2016, 67,7 milhões de processos eletrônicos e consequentemente seus autos digitais, adentraram à realidade de tribunais de justiça, fazendo parte do dia-a-dia de serventuários, advogados, partes e magistrados.

Ao contrário do que se poderia supor, o crescimento vertiginoso do processo eletrônico, por si só, não foi acompanhado por uma melhoria significativa em índices de produtividade e celeridade. Acompanhando a série histórica do relatório Justiça em Números, de 2009 a 2016, o estoque de processos pendentes no judiciário cresceu 31,2\%, de 60,7 para 79,7 milhões de processos (Justiça em Números, 2017, p. 67). A taxa de congestionamento na Justiça Estadual, em 2016 foi de 70\%, frente a 69\% em 2019. Ou seja, não houve melhora.

Este artigo relativiza o insucesso do processo eletrônico na resolução do centenário problema da produtividade na justiça brasileira. Na verdade, o processo judicial em forma digital, em bits e não mais em papel, solucionou uma série de problemas intrínsecos à sua característica "não física". Inúmeras tarefas intensivas em mão de obra e de cunho repetitivo foram eliminadas, simplificadas ou automatizadas por sistemas de informação (Madalena, 2012). O novo formato de processos, em bits, apresenta uma série de oportunidades e novos desafios para gestão do processo judicial. O emprego da tecnologia tradicional, por mais avançada que seja, não substitui, nem apoia de forma incisiva as tarefas intensivas em conhecimento, em particular aquelas relacionadas ao ato de julgar, decidir, típico de magistrados. De acordo com Ruschel (2012), esse trabalho é o mesmo, independentemente do formato do processo.

Pode-se argumentar, inclusive que, ao alterar o tipo de mídia, e uma vez tendo o suporte de sistemas de gestão informatizadas com a automatização de tarefas, o gargalo na tramitação de processos judiciais passou das atividades intensivas em mão de obra (de cartório), para as de cunho mais intelectual (de gabinete).

O fenômeno observado na justiça brasileira, de substituição de processos físicos por processos eletrônicos, reflete o que vem acontecendo no mundo nos últimos 10 anos. A conjunção de duas importantes leis da informática explica esse fenômeno, as Leis de Moore e a de Kryder (Katz, 2013). A primeira preconiza, de forma acertada nos últimos 20 anos, que o 
poder de processamento dos computadores dobra a cada 18 meses; enquanto que a segunda estabeleceu - também de forma acertada nas duas últimas décadas - a mesma relação, sendo que para o custo decrescente de armazenamento de dados. Ou seja, ambas as leis aprovisionaram as condições estruturais para o processamento e armazenamento de um volume praticamente ilimitado de dados.

Isso já foi observado por Atheniense (2017), apontando o mundo jurídico brasileiro como "fonte geradora de um grande volume de dados, constituindo um verdadeiro big data". Os 13,5 milhões de novos processos eletrônicos que entraram em 2016 certamente corroboram com essa afirmação.

A disciplina acadêmica que congrega as técnicas, ferramentas e preceitos da aplicação de tecnologia em uma quantidade massiva de dados é a ciência de dados.

A tese deste artigo é que a consolidação do processo eletrônico tornou a aplicação da ciência de dados na gestão de processos judiciais, não só desejável, mas obrigatória. Será o conjunto de tecnologias derivada dessa disciplina, que fará com que o judiciário consiga os altos níveis de produtividade almejados quando do surgimento do processo eletrônico a partir de 2006 (Atheniense, 2017; Pugliese e Brandão, 2015).

A literatura é pródiga em enumerar benefícios e aplicações de ciências de dados na justiça (Bruninghaus e Ashley, 2003; Florão, 2017; Kerr e Mathen, 2013; Malle, 2013; Mehr, 2017; Rover, 2011; Ruhl e al., 2017; Smart, 2013; Valentini, 2018; Vermeys e Benyekhlef, 2011). Floridi (2012) cita como ponto "nevrálgico do Big Data, o reconhecimento de padrões ou correlações em complexidades de dados, gerando informações e conhecimentos úteis e relevantes". Valentini (2018) por sua vez, seguindo a argumentação teórica de Rover (2011), foca na mudança da natureza do trabalho artesanal para o industrial, possibilitado pela mudança do processo do meio analógico para o digital, “cujo valor está lastreado na qualidade e rapidez do tratamento da informação para possibilitar maior capacidade de produção de peças jurídicas em menor tempo". Aletras et al. (2016) citam especificamente as técnicas de processamento de linguagem natural e aprendizado de máquina como ferramentas que já possibilitam o desenvolvimento de modelos preditivos que antecipem e revelem os padrões judiciais que levam à formação das decisões jurídicas de magistrados.

Este artigo propõe que a utilização da ciência de dados é ao mesmo tempo uma oportunidade e uma necessidade para a justiça. Como argumenta Atheniense (2017), o grande volume de dados e velocidade com que estes são gerados levam praticamente à "incapacidade humana de ter acesso total e eficiente ao conteúdo" destes dados. Ele acrescenta ainda que 
"somente com a utilização de robôs torna-se eficientemente possível a extração dos dados sobre os processos em tramitação".

Para ilustrar os ganhos proporcionados e proporcionáveis pelo emprego de ciência de dados em processos eletrônicos, este artigo apresenta o resultado de um estudo exploratório do Laboratório de Ciência de Dados da Unidade de Justiça da Softplan sobre a aplicação de técnica de análise semântica latente para identificação de processos candidatos a sobrestamento em temas de incidente de resolução de demanda repetitiva.

\section{Quem é a Softplan}

A Softplan é uma empresa de tecnologia da informação e desenvolvimento de sistemas sediada na cidade de Florianópolis, Brasil, com 27 anos de atuação no mercado da justiça. Entre outras soluções, ela é a desenvolvedora do SAJ (Sistema de Automação da Justiça), sistema de gestão de processos judiciais privado com maior abrangência no Brasil, em uso atualmente em Ministérios Públicos (Mato Grosso do Sul, Santa Catarina, Acre, entre outros), Procuradorias Jurídicas Municipais e Estaduais (São Paulo, Pernambuco, Distrito Federal, Santa Catarina, entre outros), e Tribunais de Justiça (São Paulo, Santa Catarina, Amazonas, Ceará, entre outros). Além do SAJ e desses segmentos, a Softplan desenvolve soluções, produtos e análises para a advocacia privada. Aproximadamente $50 \%$ dos processos na justiça estadual do Brasil tramitam no SAJ.

Frente a este cenário de consolidação do processo eletrônico na justiça, no ano de 2016 a empresa criou uma equipe dedicada à ciência de dados, o Laboratório da Justiça. Seu objetivo é congregar iniciativas orientadas a aplicação de ferramentas e técnicas de ciência de dados, em seu sentido mais amplo, abarcando aprendizado de máquina, inteligência artificial, computação cognitiva e analytics. O projeto objetivo deste estudo foi executado por essa equipe.

\section{O expediente do IRDR}

O novo Código de Processo Civil (CPC) estabeleceu, em seus artigos 976 a 987 (Lei No 13105, de 16 de março de 2015), o expediente do Incidente de Resolução de Demanda Repetitiva (IRDR). Este juntou-se ao arcabouço legal dos precedentes que já dispunha dos expedientes afins de Repercussão Geral e Recurso Repetitivo.

O Conselho Nacional de Justiça define esse conjunto de processos repetitivos como: 
"Processos nos quais a mesma questão de direito se reproduz de modo que a solução pelos Tribunais Superiores ou pelos próprios Tribunais locais pode ser replicada para todos de modo garantir que essas causas tenham a mesma solução, ganhando-se, assim, celeridade, isonomia e segurança jurídica no tratamento de questões com grande repercussão social” (CNJ 3, 2018, p. 1).

Segundo o CNJ (CNJ 2, 2018), 2,5\% dos processos pendentes na Justiça estão suspensos, e vinculados a um dos aproximadamente dois mil temas de precedentes existentes. Isso equivale a 2,1 milhões de processos judiciais. Ou seja, esse é um expediente que já está em uso, porém ainda pendente de alcance de uma maior abrangência. $\mathrm{O}$ próprio $\mathrm{CNJ}$ destaca que a partir de 2016 os instrumentos dos tribunais tendem a se aprimorar com "o aumento da capacidade de coleta" dos dados primários (CNJ 2, 2018).

Sob o aspecto legal do instituto de precedentes, há concordância quanto à sua aplicabilidade. Moraes (2011) argumenta que "demandas de massa devem receber uma solução uniforme". Essa é a mesma posição de Macedo (2013) quando propõe "uma solução padronizada para situações padronizadas". Esse mesmo ponto de vista é sintetizado por Marinoni (2013), que considera "imprescindível, zelar pela igualdade de tratamento em decisões judiciais", que prega pela racionalidade de decisões uniformes para casos iguais ou similares.

Os precedentes, e o IRDR em particular, funcionam a partir da instauração de incidentes pelas partes e/ou por outros partícipes de processos judiciais. Uma vez aceito e instaurado determinado tema, os processos considerados como vinculados ao processo que originou o incidente serão suspensos até o julgamento do mérito do processo original. A tese jurídica que prevalecer nesse julgamento será pacificadora da jurisprudência e uniformizará a decisão dos processos suspensos vinculados ao tema, assim como os entrantes a partir dessa data.

De acordo com Oliveira (2016), o IRDR tem o objetivo de "dar utilidade e praticidade às respostas judiciais em face da pluralidade de demandas repetidas, que precisam de um enfrentamento judiciais adequado e eficiente".

A consolidação do instituto do IRDR tem o potencial de reduzir sobremaneira o congestionamento de processos no judiciário, em um cenário de extrema sobrecarga de trabalho, especialmente os intensivos em conhecimento, ou seja, os gabinetes de magistrados. O relatório do Justiça em Números de 2016 já instituiu um indicador de taxa de congestionamento líquida, que deduz dos processos em andamento os suspensos por sobrestamento em temas repetitivos. Esse sobrestamento em lote beneficiará particularmente 
os tribunais de justiça estadual classificados como de grande porte, cujos magistrados possuem uma carga de trabalho média de 9,11 mil processos/magistrado (Justiça em Números, 2017).

A despeito de eventuais críticas de um apoio informatizado às atividades de um magistrado, como por exemplo, a sugestão de sobrestamento de processos, Álvares da Silva (2009), afirma que o "julgamento por computador de casos repetitivos não é o aviltamento do Judiciário". Ele argumenta a favor do deslocamento da "atividade exaustiva" do juiz apenas para os casos complexos.

\section{Introdução sobre aplicações de ciência de dados}

A aplicação de técnicas de ciência de dados em processos eletrônicos, como já argumentado, apresenta uma oportunidade ímpar de melhorar os patamares de produtividade e celeridade na justiça, que outrora fora tida como consequência natural da mera substituição do meio de processo físico pelo digital. A oportunidade, na verdade e como será proposto neste capítulo, torna-se uma exigência dadas as características do processo eletrônico.

O volume de dados e informações presentes em documentos digitais dos processos eletrônicos hoje disponíveis ao judiciário resultam em um repositório de tal tamanho, que faz de sua análise e consulta um trabalho humanamente impossível. De acordo com Pugliese e Brandão (2015), a análise "da massiva quantidade de dados criada e recriada a todo o momento requer ferramentas diversas da ciência tradicional, principalmente pela necessidade de velocidade no processamento".

Baseando-se nos estudos seminais dos professores Kahneman e Tversky (1972), Read (2008) pontuou as importantes limitações cognitivas humanas para o processamento e entendimento de quantidades massivas de dados e documentos. Kahneman e Tversky (1972) listaram alguns desses vieses: "ancoragem, ilusão da frequência, viés da confirmação, ilusão da validação, viés do otimismo", entre outros.

A limitação humana também é levantada por Florão (2017) que considera que uma inteligência baseada na máquina poderia ampliar a capacidade humana para, por exemplo, estabelecer inferências na relação semântica a partir de um mecanismo de leitura automática de petições iniciais, em que pudessem ser feitas recomendações ou sugestões de textos ou marcações a partir da capacidade cognitiva das máquinas. Katz (2013) e Rover (2011) chegam a conclusão similar. Este segundo, argumenta que o apoio de uma inteligência artificial, "liberta 
[os humanos tomadores de decisão] para as atividades mais nobres", ao assumir parte do peso cognitivo da tomada de decisão rotineira.

Este artigo apresenta a aplicação real de uma técnica de ciência de dados, posicionada dentro da área de processamento de linguagem natural, inserida na disciplina de inteligência artificial (Katz, 2013), a um problema real do judiciário, que é a identificação de processos candidatos a sobrestamento a temas de IRDR, repercussão geral ou recursos repetitivos.

\subsection{Análise de conteúdo e a semântica}

Inteligência artificial é um termo tão abrangente e mal utilizado tanto na vida cotidiana quanto na academia, que decidimos, para este estudo exploratório, utilizar uma técnica das mais tangíveis e palpáveis possíveis, que se relaciona com a semântica e a análise de conteúdo.

De forma bastante didática, Bardin (2009) define a técnica de análise de conteúdo como um "conjunto de técnicas de análise de comunicações que utiliza procedimentos sistemáticos e objetivos de descrição do conteúdo das mensagens". A partir de determinado texto objetivo, inferências são feitas para extração de elementos de interpretação que podem agrupar, classificar ou melhor explicar o texto original.

Ainda seguindo Bardin (2009), para fins deste estudo, a análise semântica é definida como uma "decomposição" do corpus textual em unidades de análise "a partir da qual se torna possível uma reconstrução de significados que apresentem uma compreensão mais aprofundada da interpretação de realidade do grupo estudado". Ou seja, a análise de conteúdo expande a capacidade de comunicação do texto ou discurso original.

Os recentes avanços na disciplina de ciência de dados, e em particular na subárea foco desse estudo que é a de processamento de linguagem natural, preenchem justamente o vácuo já apontado relacionado à limitada capacidade cognitiva do ser humano (potencializado pela massiva quantidade de documentos eletrônicos agora disponíveis) e nossa particular dificuldade em interpretação de textos. De forma exagerada, talvez para provar seu ponto, Cooper (2011), argumenta que "qualquer computador está melhor equipado [que os humanos] para identificar a frequência em que uma frase em particular ocorre em uma linguagem normal". Avançando um pouco sobre a análise de conteúdo, especificamente em textos de cunho legal, Siegel (2009) aponta que o objetivo desta técnica é "identificar o significado objetivo do texto legal, desconsiderando o que o legislador [ou formulador do texto] pretendeu que ele significasse", ou seja, independentemente de seu significado subjetivo. 
O conceito de semântica é complementar à análise de conteúdo. Enquanto que a primeira "preocupa-se com a interpretação do argumento" (Rover, 1999); o segundo "é justamente o material e o conjunto de técnicas que permitam a explicitação e a sistematização do conteúdo das mensagens e da expressão deste conteúdo" (Ximenes, 2011). De uma forma mais filosófica, Bardin (2009), afirma que "textos são manifestações que contém índices que a análise fará falar".

A análise de conteúdo não é novidade no contexto do judiciário. Hall e Wright (2008) listam um caso de uma publicação de 1957 por parte de um cientista político estadunidense que utilizou essa técnica para explorar decisões criminais de 26 processos judiciais. Aplicando o conceito básico presente até hoje de apontamento das características mais consistentes, e extraindo inferências de seus usos e significado, o cientista político obteve êxito em decodificar esses resultados e criar um sistema de pontuação em que, partir do aparecimento de determinadas palavras e seus contextos, ele conseguiu prever o resultado de $86 \%$ de casos que faziam parte de seu experimento.

Também em um artigo seminal onde o termo Jurimetria é introduzido, Loevinger (1963) já identificava no seu tempo, a recuperação de dados (data retrieval) como uma das tarefas mais críticas de advogados e magistrados, para buscar similaridades, termos análogos e de relevância precedentária.

\subsection{Latent semantic analysis (LSA)}

A análise de semântica latente (LSA na sigla inglês - latent semantic analysis) busca uma forma de inferência do valor semântico das palavras e expressões, fazendo uso de recursos matemáticos e trazendo consigo fatores cruciais para a interpretação textual no contexto da massa de dados disponível no judiciário. De acordo com Landauer e Dumais (1997), a LSA se constitui como uma teoria fundamental para a aquisição e representação do conhecimento. Em um artigo seminal definindo conceitos e linhas de pesquisa relacionadas à LSA, Deerwester et al. (1990) contextualizam o problema da interpretação de texto da seguinte forma:

\footnotetext{
"Existem geralmente diferentes formas de expressar um determinado conceito, dessa forma, um termo literal de uma pesquisa textual pode não encontrar relevância em um determinado documento. Nós assumimos que existe uma estrutura semântica latente subjacente nos dados que são parcialmente obscurecidos pela aleatoriedade da escolhe da palavra no que concerne sua recuperação”. (Deerwester et al., 1990,p. 1).
} 
A técnica da LSA é aplicada através de uma transformação matricial chamada Singular Value Decomposition (SVD), a partir de uma matriz de termos buscados frente ao componente textual do documento, matriz termo-documento (Turnball, 2016). O termo buscado e objeto de estudo é formado por um conjunto de componentes que, de forma coletiva, individual ou em pares, trios, etc., explicam ou inferem uma explicação sobre o termo em si, a partir de uma relação de afinidade entre esses documentos.

Inserido no contexto de álgebra linear, a SVD produz bases ortogonais de v's e u's para subespaços fundamentais; supondo que $\mathrm{M}$ é uma matriz $\mathrm{m} \times \mathrm{n}$ :

$\mathrm{M}=\mathrm{U \Sigma} \mathrm{V}$

Onde:

U é $\mathrm{m}$ x m, matriz unitária sob $\mathrm{K}(\mathrm{se} \mathrm{K}=\mathrm{R})$

$\Sigma$ é uma $\mathrm{m} x \mathrm{n}$ diagonal de número não negativo

V é uma n x n matriz unitária sob $\mathrm{K}$, e V*.

Para sua operacionalização, dada a grande massa de documentos, são empregadas técnicas de normalização para redução do peso de palavras irrelevantes, porém com alta frequência na matriz. Isso garante que a própria SVD implemente uma redução de dimensionalidade, permitindo que a busca por similaridade e significado aconteça sem ruído (Altszyler et al., 2016).

O objetivo da LSA, segundo Chen et al. (2011) é "treinar uma matriz de projeção que mapeie a alta dimensionalidade de representação vetorial de palavras de um texto em um conjunto dimensional mais reduzido, latente"; fazendo com que a estratégia de estudo tenha efeito mais prático, tais como: “detecção de sinônimos, clusterização de termos, clusterização de documentos, classificação automática de documentos ou compressão da matriz de termodocumento" (Turnball, 2016).

Um dos grandes benefícios da LSA é redução da dimensionalidade. Através da substituição dos termos individuais encontrados no documento por "conceitos artificiais" independentes, a LSA melhora significativamente o tratamento de múltiplos termos referindose ao mesmo objeto (Deerwester et al., 1990). Assim, documentos que eventualmente não tenham afinidade aparente ou ainda que tenham uma afinidade oculta ou indireta com o objeto de estudo podem ser categorizados e pontuados quantitativamente pelo grau de similaridade; e essa afinidade poderá ser rastreável e recuperável de forma estruturada.

Outro significativo benefício da LSA reside em seu caráter "estéril e 'sem sangue",, como definido por Landauer et al. (1998). Os autores afirmam que a matriz de correlação resultante da LSA, quando bem construída, apresenta uma semelhança bastante próxima da 
forma como as pessoas leem e escutam, fazem inferências lógicas, interpretam textos e escolhem palavras para compor seus textos. Ao contrário da uma construção humana em que o conhecimento vem diretamente de informação capturadas no meio físico, de instintos ou relações derivadas de funções corpóreas, sentimentos e intenções; a aquisição do conhecimento via LSA é científico, sem emoções.

\section{O experimento: operacionalizando a LSA}

Este estudo exploratório tem como objetivo classificar processos judiciais em temas candidatos a se tornarem tema de IRDR por meio de petição formal a um tribunal superior por uma parte ou partícipe de processo judicial.

A Softplan foi contatada recentemente por uma empresa do segmento de planos de saúde para realizar um estudo, em forma de parecer técnico. O objetivo é informar quantos processos existem nos tribunais estaduais de São Paulo, do Rio de Janeiro e no Superior Tribunal de Justiça relacionados a seis temas judiciais específicos, inerentes à atividade de operador de plano de saúde, quais sejam:

- Questionamentos acerca do art 30 e 31 da Lei 9656/98;

- Questionamento acerca da legalidade da coparticipação em plano de saúde (art 16 da Lei 9656/98);

- $\quad$ Possibilidade da operadora rescindir de contrato de plano de saúde;

- $\quad$ Obrigatoriedade de fornecer fertilização in vitro;

- $\quad$ Medicamento sem registro na ANVISA;

- Coparticipação em internações psiquiátricas.

Ao decidir aplicar a técnica de LSA em petições iniciais digitais, a literatura oferece duas possibilidades de abordagem técnica para o estudo: indutiva ou baseado em casos.

A abordagem baseada em casos é caracterizada por um "sistema baseado em conhecimento previamente modulado" (Valentini, 2018). Essa técnica foi imediatamente abortada, pois os temas elencados ainda são candidatos a se tornar um IRDR. Em caso de que já fossem temas oficiais de IRDR, essa abordagem proporia: (1) buscar as petições iniciais dos processos que já estivessem sobrestados a cada tema; (2) desenvolver, (por um método não supervisionado ou semi-supervisionado, seguindo Chen et al. (2011) e Katz (2013)) uma matriz 
termo-documento específica para cada tema. E seria essa matriz o operador que orientaria a LSA nas buscas por similaridade nas petições iniciais candidatas.

Partiu-se, portanto, para uma abordagem indutiva, baseada na (1) construção de um dicionário semântico, caracterizando cada um dos seis temas a serem analisados, seguido (2) pela aplicação da LSA nos documentos sendo induzida pelos termos presentes neste dicionário. Conceitualmente, essa é uma abordagem similar à proposta por Rover (1999) como Indexação, que, segundo ele, "nada mais é do que tomar as características dos casos em índices, isto é, marcar as características do caso que definirão a recuperação na base e darão o grau de similaridade com o caso de entrada”. Esses índices, ainda segundo Rover, criariam um rótulo, delimitando a busca da solução. Essa é a mesma abordagem descrita em Souto e Souto (2003) e Lima e Sotto Mayor (2015); assim como conceitualmente por Loevinger (1963), quando sugere a utilização de vocabulários legais e sistemas de indexação legal para realizar a "árdua tarefa de recuperação dos dados".

A atividade mais crítica dessa abordagem é a construção de um dicionário semântico, ou um thesaurus (Deerwester et al., 1990) que atua como guia (Pugliese e Brandão, 2015), induzindo a LSA na recuperação dos dados em cada petição inicial buscada. Cada referência encontrada gerou um score, que corresponde à aproximação percentual do grau de similaridade aferido entre o thesaurus de cada tema e matriz termo-documento de cada petição inicial.

\section{Resultados}

Por respeito a acordos de confidencialidade e atenção às regras de proteção de propriedade intelectual da Softplan, estamos impedidos de revelar o nome do operador de plano de saúde que contratou o estudo. Tampouco podemos apresentar o thesaurus criado para os temas candidatos a IRDR, e os resultados específicos da análise. No Anexo I deste artigo listamos, em forma de amostra, um conjunto de processos judiciais, que por seu caráter público, podem ser consultados livremente nos websites públicos do seu respectivo tribunal de justiça.

A população possível de processos judiciais candidatos à vinculação a cada um dos temas objetos deste estudo ficou restrita aos processos eletrônicos, ou seja, com petição inicial digital disponível, que tiveram como parte um dos operadores de plano de saúde acreditados pela ANS (2018). A Tabela 1 detalha a população total de cada tribunal foco da análise e os resultados alcançados.

$\underline{\text { Tabela I - População de Processos nos Tribunais de Origem }}$ 


\begin{tabular}{|l|r|r|r|r|}
\hline \multicolumn{2}{|c|}{ Item } & \multicolumn{1}{c|}{ TJSP } & \multicolumn{1}{c|}{ TJRJ } & \multicolumn{1}{c|}{ STJ } \\
\hline $\begin{array}{l}\text { População total aproximada de } \\
\text { processos }\end{array}$ & 44.000 .000 & 19.000 .000 & 2.146 .160 & 65.146 .160 \\
\hline $\begin{array}{l}\text { De operadoras de planos de } \\
\text { saúde }\end{array}$ & 541.383 & 98.508 & 3.521 & 643.412 \\
\hline Petição inicial digital capturada & 176.918 & 46.500 & 1.662 & 225.080 \\
\hline Referências com os 6 temas & 7.085 & 1.380 & 242 & 8.706 \\
\hline
\end{tabular}

Fonte: Laboratório de ciência de dados da Softplan (2018).

A matriz termo-documento específica de cada tema foi aplicada de forma individual em cada uma das 225.080 petições iniciais digitais disponíveis de operadores de plano de saúde. Foi considerada como métrica aceitável o score mínimo de $80 \%$ de convergência de similaridade a cada dicionário, o que resultou em um total de 8.706 processos judiciais, ou 3,8\% da população.

A Tabela II detalha as ocorrências por tema buscado. O tema de maior convergência foi o de "Questionamentos acerca do art. 30 e 31 da Lei 9656/98" com 5.698 processos judiciais. Tabela II - Total de referências por temas

\begin{tabular}{|l|r|}
\hline \multicolumn{1}{|c|}{ Tema } & \multicolumn{1}{c|}{ Total } \\
\hline Questionamentos acerca do art. 30 e 31 da Lei 9656/98 & 5.698 \\
\hline Possibilidade da operadora rescindir de contrato de plano de saúde & 1.099 \\
\hline Medicamento sem registro na ANVISA & 853 \\
\hline $\begin{array}{l}\text { Questionamento acerca da legalidade da coparticipação em plano de } \\
\text { saúde (art. 16 da Lei 9656/98) }\end{array}$ & 528 \\
\hline Coparticipação em internações psiquiátricas & 344 \\
\hline Obrigatoriedade de fornecer fertilização in vitro & 184 \\
\hline Total & $\mathbf{8 . 7 0 6}$ \\
\hline
\end{tabular}

Fonte: Laboratório de ciência de dados da Softplan (2018).

\section{Conclusões}

A LSA soluciona, de forma elegante e conclusiva o que Ashley e Brüninghaus (2009) e Katz (2013) consideram como uma das questões mais basilares da investigação jurídica, que é a busca por similaridades e dissimilaridades. 
Neste artigo - mesmo limitados por termos de confidencialidade e questões de propriedade intelectual - é apresentada uma aplicação real de inteligência artificial na justiça do Brasil.

Selecionou-se para esse estudo, a utilização da técnica de análise semântica latente para vinculação de processos judiciais a temas candidatos a Incidente de Resolução de Demanda Repetitiva (IRDR). Esse instrumento legal, introduzido no novo código de processo civil, admite o sobrestamento de processos a temas definidos por Tribunais Superiores, permitindo que as decisões destas cortes sejam seguidas, de forma automática e instantânea aos processos vinculados e suspensos em instâncias inferiores.

Este artigo propõe que a transformação da tramitação judicial do meio físico (em papel) para o digital (em bits), exige a aplicação de novas tecnologias por parte do judiciário, em particular os Tribunais. A simples substituição do processo físico pelo digital não foi suficiente para a solução do centenário problema de produtividade da justiça. Muito pelo contrário. Como demonstramos na seção de Introdução, enquanto que o percentual de entrada de novos processos eletrônicos passou de 12\% a 70\%, de 2009 a 2016; a quantidade de processos pendentes cresceu $31 \%$ no mesmo período.

O caso dos precedentes (aqui incluindo os IRDRs, repercussão geral e recurso repetitivo) apresenta uma oportunidade ímpar para a suspensão de um grande volume de processos judiciais, possibilitando uma significativa diminuição na carga de trabalho de magistrados e seus assessores (sobrecarregados pela velocidade com que os processos passaram a chegar a suas mãos pela automatização de tarefas intensivas em mão de obra). De acordo com os dados do CNJ, apenas 2,5\% de processos estão hoje vinculados a temas de precedentes.

Este estudo utiliza o estado da arte da análise semântica latente para buscar processos vinculados a temas ainda pendentes de formalização como IRDR. Em um conjunto específico de 225.080 petições iniciais digitais de processos digitais, foi encontrado um total de 8.706 casos de referências cientificamente comprováveis a um dos seis temas candidatos. Ou seja, um total de 3,8\%, um percentual já 50\% maior do que os 2,5\% dos processos hoje suspensos.

O sucesso do presente estudo deriva da consolidação do processo eletrônico na justiça brasileira e dos avanços tecnológicos relacionados a processamento de linguagem natural e em especial à difusão da técnica de análise semântica latente.

E se essa mesma técnica, com matrizes termo-documento abrangendo todos os dois mil temas de precedentes, fosse aplicada, por exemplo, no maior Tribunal do Brasil, o Tribunal de Justiça do Estado de São Paulo, em seus aproximadamente nove milhões de processos em andamento? 
Juridicamente e socialmente, esse é um expediente de um grande impacto, pois, além de aliviar as unidades judiciais de análise e atenção em uma quantidade significativa de processos, permitirá, que as decisões em instâncias superiores sejam aplicadas de forma homogênea, elevando significativamente seus patamares de produtividade.

A aplicação da técnica de análise semântica latente nos IRDRs é um dos muitos exemplos de utilização da inteligência artificial na justiça. Análises preditivas e geração e entendimento de linguagem natural (natural language understanding and generation), por exemplo, são outras técnicas já utilizadas e massificadas em outros segmentos - de importância estratégica tão grande quanto a justiça - que podem ser aplicadas na justiça, de forma cientificamente responsável e com potencial de apoiar os tomadores de decisão e os operadores do direito como um todo para fazer com que a justiça seja mais previsível e célere.

\section{Referências Bibliográficas}

Aletras, N., Tsarapatsanis, D., Preoţiuc, Pietro, D., e Lampos, V. Predicting judicial decisions of the European Court of Human Rights: a Natural Language Processing perspective Peer. J Computer Science 2:e93, 2016 Disponível em:

$<$ https://peerjcom/articles/cs93/>.. Acesso em: 14 abr. 2018.

Altszyler, E., Sigman, M., Ribeiro, S. e Slezak, D.F. Comparative study of LSA vs Word2vec embeddings in small corpora: a case study in dreams database, Cornell University Library, 2016. Disponível em: $<$ https://arxivorg/pdf/161001520.pdf $>$. Acesso em: 14 abr. 2018.

Álvares da Silva, A. Informatização do Processo: Realidade ou Utopia? In: Cinco Estudos de Direito do Trabalho São Paulo: LTR, 2009.

ANS. Agência Nacional de Saúde. Disponível em: < http://www.ans.gov.br/planos-de-saudee-operadoras/informacoes-e-avaliacoes-de-operadoras/acreditacao-de-operadoras $>$. Acesso em 14 abr. 2018.

Ashley, K.D. e Brüninghaus, S. Automatically Classifying Case Texts and Predicting Outcomes, Artificial Intelligence and Law, no 17, 2009. 
Atheniense, A. A inteligência artificial e o direito Revista Fonte, no 17, jul. 2017.

Disponível em: <https:/www.prodemge.gov.br/images/com_arismartbook/ download/19/revista_17.pdf $>$. Acesso em 14 abr. 2018.

Bardin, L. Análise de Conteúdo Lisboa: Editora Edições 70, 2009.

Bruninghaus, S. e Ashley, K.D. Predicting Outcomes of Casebased Legal Arguments. Proceedings of the 9th international conference on Artificial intelligence and law, 2003. Disponível em:

$<$ http://citeseerx.ist.psu.edu/viewdoc/download?doi=10.1.1.90.327\&rep=rep1\&type=pdf $>$. Acesso em: 14 abr.. 2018.

BRASIL. LEI N 13.105, DE 16 DE MARÇO DE 2015. Código de Processo Civil, Brasília, DF, mar 2015. Disponível em: <http://www.planalto.gov.br/ccivil_03/_ato20152018/2015/lei/113105.htm>. Acesso em: 14 abr. 2018.

Chen, X., Qi, Y., Bai, B., Lin, Q. e Carbonell, J.G. Sparse Latent Semantic Analysis. Proceedings of the 2011 SIAM International Conference on Data Mining. Disponível em: $<$ https://www.cs.cmu.edu/ jgc/publication/PublicationPDF/Sparse_Latent_Semantic_Analysi s.pdf $>$. Acesso em: 14 abr. 2018.

Conselho Nacional de Justiça (1). Relatório Causas recorrentes que incham e atrasam a justiça Brasília, Conselho Nacional de Justiça, 2018. Disponível em: <http://cnj.jus.br/ files/conteudo/arquivo/2018../02/9713790dc724bd649ecc373c44a6b60f.pdf > . Acesso em 14 abr. 2018.

Conselho Nacional de Justiça (2). Relatório do banco nacional de dados de demandas repetitivas e precedentes obrigatórios. Brasília, Conselho Nacional de Justiça, 2018. Disponível em <http://cnj.jus.br/files/conteudo/arquivo/2018/02/03a6c043d7b9946768ac 79a7a94309af.pdf $>$. Acesso em 14/04/2018.

Conselho Nacional de Justiça (3). Demandas repetitivas, Conselho Nacional de Justiça, 2018. Disponível em <http://www.cnj.jus.br/pesquisas-judiciarias/demandas-repetitivas>. Acesso em 14/04/2018. 
Cooper, B. Judges in Jeopardy!: Could IBM's Watson Beat Courts at Their Own Game? The Yale Law Journal online 121:87, 2011. Disponível em: <https://www.yalelawjournal.org/ pdf/999_gqgj98ui.pdf>. Acesso em: 14 abr. 2018.

Deerwester, S., Dumais, S. T., Furnas, G. W., Landauer, T. K. e Harshman, R. Indexing By Latent Semantic Analysis. Journal of the American Society For Information Science, no 41, 391-407. Disponível em: <http://lsa.colorado.edu/papers/JASIS.1si.90.pdf>. Acesso em: 14 abr. 2018.

Florão, M. Como a computação cognitiva pode revolucionar a Justiça brasileira. Revista Fonte, no 17, jul. 2017. Disponível em: <https://www.prodemge.gov.br/images/com arismartbook/download/19/revista_17.pdf>. Acesso em 14 abr. 2018.

Floridi, L. Big data and Their Epistemological Challenge Philosophy and Technology, no 25, 2012. Disponivel em:

$<$ https://linkspringercom/content/pdf/101007\%2Fs1334701200934.pdf >. Acesso em: 14 abr. 2018.

Hall, M.A. e Wright, R.F. Systematic Content Analysis of Judicial Opinions. California Law Review, vol 96, 2008. Disponível em: <https://scholarship.law.berkeley.edu/cgi/ viewcontent.cgi article $=1186 \&$ context $=$ californialawreview $>$. Acesso em: 14 abr. 2018 .

Justiça em Números 2017. Conselho Nacional de Justiça, Brasília, 2017. Disponível em: <www.cnj.jus.br/files/conteudo//2017/12/b60a659e5d5cb79337945c1dd137496c.pdf>. Acesso em: 14 abr. 2018.

Kahneman, D. e Tversky, A. Subjective Probability: A Judgment of Representativeness, Cognitive Psychology, no 3, 1972.

Katz, D.M. Quantitative Legal Prediction or How I Learned to Stop Worrying and Start Preparing for the Data Driven Future of the Legal Services Industry, 62 Emory Law Journal 909, 2013. Disponível em: 
$<$ http://law.emory.edu/elj/_documents/volumes/62/4/contents/katz.pdf $>$. Acesso em 14 abr. 2018.

Kerr, I. e Mathen, C. Chief Justice John Roberts is a Robot, Miami, We Robot 2013 Conference University of Miami School of Law, 2013. Disponível em: <http://robots. law.miami.edu/2014/wp-content/uploads/2013/06/Chief-Justice-John-Roberts-is-a-RobotMarch-13-.pdf>. Acesso em: 14 abr. 2018.

Landauer, T.K. e Dumais, S.T. A solution to Plato's problem: The Latent Semanctic Analysis theory of the acquisition, induction, and representation of knowledge Psychological Review, no 104, 1997. Disponível em: <http://sa.colorado.edu/papers/plato/plato.annote. html>. Acesso em: 14 abr. 2018.

Landauer, T.K., Foltz, P.W. e Laham, D. Introduction to Latent Semantic Analysis, Discourse Processes, 25, 259-284, 1998. Disponível em: <http://lsa.colorado.edu/ papers/dp1.LSAintro.pdf>. Acesso em: 14 abr. 2018.

Lima, A.J.C.B. e Sotto Mayor, L.C.V. Análise Pragmática das Decisões Judiciais Finais do Tribunal de Justiça do Estado de Alagoas em Habeas Corpus: Opções Metodológicas e Tratamento Conferido ao Material de Pesquisa João Pessoa, Prima Facie Direito, História e Política, no 27, 2015. Disponível em: <http://www.periodicos.ufpb.br/ojs/index.php/ primafacie/article/view/20080/15425>. Acesso em: 14 abr. 2018.

Loevinger, L. Jurimetrics: the methodology of legal inquiry New York, Basic Books, 1963.

Macedo, E.H. Novos conflitos e o processo adequado: o conflito repetitivo e as soluções processuais (capitulo 1) In: AK Trindade e JC Kraemer Direitos fundamentais e democracia constitucional Florianópolis, Conceito Editorial, 2013.

Madalena, P. Advogando com Peticionamento e Processo Eletrônicos In: Revista CEJ, Brasília, n 56, p 117-127, jan/abr. 2012. Disponível em: <http://www.jf.jus.br/ojs2/index.php/ revcej/article/viewFile/1609/1552>. Acesso em: 14 abr. 2018. 
Malle, J.P. Big Data: farewell to Cartesian thinking? Paris Innovation Review, 201.3 Disponível em: $<$ http://parisinnovationreview.com/articles-en/big-data-farewell-to-cartesianthinking >. Acesso em: 14 abr. 2018.

Marinoni, L.G. O STJ enquanto corte de precedentes: recompreensão do sistema processual da corte suprema. São Paulo: Revista dos Tribunais, 2013.

Mehr, H. Artificial Intelligence for Citizen Services and Government. Harvard Kennedy School, Boston, 2017. Disponível em <https://ash.harvard.edu/files/ash/files/artificial_ intelligence_for_citizen_services.pdf>. Acesso em 14 abr. 2018.

Moraes, V.C.A. Demandas repetitivas decorrentes de ações ou omissões da administração pública: hipótese de soluções e a necessidade de um direito processual público fundamentado na Constituição Dissertação (Mestrado Profissional Justiça Administrativa) - Universidade Federal Fluminense, Niterói, 2011. Disponível em: $<$ https://app.uff.br/riuff/bitstream/1/4474/1/Demanda\%20Repetitivas\%20\%20Vanila\%20Cardoso.pdf $>$. Acesso em: 14 abr. 2018.

Oliveira, V.S. Demandas Repetitivas introduzido no Direito brasileiro pelo Novo Código de Processo Civil RIL Brasília no 210, 2016. Disponível em: <http://www2.senado.leg.br/ bdsf/bitstream/handle/id/522898/001073189.pdf $>$. Acesso em: 14 abr. 2018.

Pugliesi, M. e Brandão, A.M. Uma conjectura sobre as tecnologias de big data na prática jurídica, Revista da faculdade de direito da UFMG, no 67, 2015. Disponível em: <https:// www.direito.ufmg.br/revista/index.php/revista/article/view/1731/_>. Acesso em 14 abr. 2018.

Read, D.W. Working Memory: A Cognitive Limit to Non-Human Primate Recursive Thinking Prior to Hominid Evolution, Evolutionary Psychology, 676, 2008. Disponível em: $<$ http://journals.sagepub.com/doi/pdf/10.1177/147470490800600413>. Acesso em: 14 abr. 2018.

Rover, A.J. Informática no direito: inteligência artificial. Curitiba: Juruá, 2011. 
Rover, J.A. Representação do conhecimento legal em sistemas especialistas: o uso da técnica de enquadramentos Florianópolis, Tese (Doutorado em Direito), Curso de PósGraduação em Direito, Universidade Federal de Santa Catarina, 1999.

Ruhl, J.B., Katz, D.M. e Bommarito, M. Harnessing Legal Complexity, 355 Science 1377, 2017.

Ruschel, A.J. Modelo de Conhecimento para apoio ao Juiz na fase processual trabalhista. Tese (Doutorado em Engenharia e Gestão do Conhecimento) - Universidade Federal de Santa Catarina, Florianópolis, 2012. Disponível em: <http://www.egov.ufsc.br/portal/sites/ default/files/airtonjoseruschel2012_206pg.pdf>. Acesso em: 14 abr. 2018.

Siegel, J.R. The Inexorable Radicalization of Textualism University of Pennsylvania Law Review, no 118, 2009. Disponível em: <https://scholarshiplawupennedu/cgi/viewcontentcgi? article $=1124 \&$ context=penn_law_review $>$. Acesso em: 14 abr. 2018.

Smart, W.D. What do We Really Know About Robots and the Law? Miami, We Robot 2013, Conference University of Miami School of Law, 2013. Disponível em: <http:// robots.law.miami.edu/2016/wp-content/uploads/2015/07/Smart-robots-law.pdf $>$. Acesso em: 14 abr. 2018.

Souto, C, e Souto, S, Sociologia do direito: uma visão substantiva 3 ed, Porto Alegre: Sérgio Fabris, 2003

Turnball, D. Semantic Search with Latent Semantic Analysis, Opensource connections, 2016. Disponível em: <https://opensourceconnections.com/blog/2016/03/29/semantic-searchwith-latent-semantic-analysis/>. Acesso em: 14 abr. 2018.

Valentini, R.S. Julgamentos por computadores? As novas possibilidades da juscibernética no século XXI e suas implicações para o futuro do direito e do trabalho dos juristas Tese (Doutorado em Direito). Universidade Federal de Minas Gerais, Belo Horizonte, 2018.

Vermeys, N.W. e Benyekhlef, K. Buenas Prácticas en Aplicaciones de Ciberjusticia, In: JA Caballero, CG De Gracia e L Hammergren Buenas prácticas para la implementación de 
soluciones tecnológicas en la administración de justicia, Buenos Aires, II Justicia, 2011, p 29. Disponível em < http://www.iijusticia.org/docs/VERMEYS_BENYEKHLEF.pdf $>$. Acesso em: 14 abr. 2018.

Ximenes, J.M. Levantamento de dados na pesquisa em direito: A técnica da análise de conteúdo. In: Vladmir Oliveira da Silveira (Org) Anais do XX Congresso Nacional do CONPEDI,Tema: “A Ordem Jurídica Justa: um diálogo Euro-americano Vitória, 2011. Disponível em: <http://www.idp.org.br/component/docman/doc_download/145->. Acesso em: 14 abr. 2018.

\section{Anexo I - Lista amostral de processos vinculados a temas candidatos a IRDR}

\begin{tabular}{|c|c|c|}
\hline Número de processo & Tribunal & Tema candidato \\
\hline 10239668720158260506 & TJSP & Coparticipação em internações psiquiátricas \\
\hline 10245055320158260506 & TJSP & Coparticipação em internações psiquiátricas \\
\hline 11035421820178260100 & TJSP & Coparticipação em internações psiquiátricas \\
\hline 00514687320158190001 & TJRJ & Coparticipação em internações psiquiátricas \\
\hline 01219472320178190001 & TJRJ & Coparticipação em internações psiquiátricas \\
\hline 01148134220178190001 & TJRJ & Coparticipação em internações psiquiátricas \\
\hline 10642806120178260100 & TJSP & Medicamento sem registro na ANVISA \\
\hline 10004383920158260016 & TJSP & Medicamento sem registro na ANVISA \\
\hline 10116531420168260004 & TJSP & Medicamento sem registro na ANVISA \\
\hline 04964951420158190001 & TJRJ & Medicamento sem registro na ANVISA \\
\hline 01663931420178190001 & TJRJ & Medicamento sem registro na ANVISA \\
\hline 04843805820158190001 & TJRJ & Medicamento sem registro na ANVISA \\
\hline 10137967520168260068 & TJSP & Obrigatoriedade de fornecer fertilização in vitro \\
\hline 10053656520178260020 & TJSP & Obrigatoriedade de fornecer fertilização in vitro \\
\hline 00230049420158190209 & TJRJ & Obrigatoriedade de fornecer fertilização in vitro \\
\hline 03957170220168190001 & TJRJ & Obrigatoriedade de fornecer fertilização in vitro \\
\hline 10380165020178260506 & TJSP & Possibilidade da operadora rescindir de contrato de plano de saúde \\
\hline 10023897520148260704 & TJSP & Possibilidade da operadora rescindir de contrato de plano de saúde \\
\hline 10010035220168260247 & TJSP & Possibilidade da operadora rescindir de contrato de plano de saúde \\
\hline 00666316120138190002 & TJRJ & Possibilidade da operadora rescindir de contrato de plano de saúde \\
\hline 00211875720178190004 & TJRJ & Possibilidade da operadora rescindir de contrato de plano de saúde \\
\hline 04228831420138190001 & TJRJ & Possibilidade da operadora rescindir de contrato de plano de saúde \\
\hline 10031421820168260007 & TJSP & Quest acerca da leg da copart em plano de saúde (art 16 da Lei 9656/98) \\
\hline 10329362820178260564 & TJSP & Quest acerca da leg da copart em plano de saúde (art 16 da Lei 9656/98) \\
\hline 00315808420168190001 & TJRJ & Quest acerca da leg da copart em plano de saúde (art 16 da Lei 9656/98) \\
\hline 00062919120178190203 & TJRJ & Quest acerca da leg da copart em plano de saúde (art 16 da Lei 9656/98) \\
\hline 10031935320178260020 & TJSP & Questionamentos acerca do art 30 e 31 da Lei $9656 / 98$ \\
\hline 10183139020168260564 & TJSP & Questionamentos acerca do art 30 e 31 da Lei $9656 / 98$ \\
\hline 10021894620178260451 & TJSP & Questionamentos acerca do art 30 e 31 da Lei $9656 / 98$ \\
\hline 00203261620168190066 & TJRJ & Questionamentos acerca do art 30 e 31 da Lei $9656 / 98$ \\
\hline 00259527920178190066 & TJRJ & Questionamentos acerca do art 30 e 31 da Lei $9656 / 98$ \\
\hline 01213444720178190001 & TJRJ & Questionamentos acerca do art 30 e 31 da Lei $9656 / 98$ \\
\hline
\end{tabular}




\title{
FREIOS E CONTRAPESOS NA CONCESSÃO DE MEDICAMENTOS DE ALTO CUSTO. POLITIZAÇÃO DA JUSTIÇA OU JUDICIALIZAÇÃO DA POLÍTICAS PÚBLICAS DE SAÚDE?
}

\author{
Adriana Freitas Antunes Camatta \\ Escola Superior Dom Helder Câmara-Belo Horizonte/ MG \\ Lívia Maria Cruz Gonçalves de Souza ${ }^{1}$ \\ Escola Superior Dom Helder Câmara-Belo Horizontel MGe \\ Pontificia Universidade Católica de Minas Gerais- PUC Minas
}

\section{Resumo}

Com o objetivo de fornecer uma reflexão sobre a judicialização das políticas públicas de saúde no ordenamento jurídico brasileiro, o artigo busca analisar o posicionamento do Supremo Tribunal Federal no Recurso Extraordinário no 566.471, por ora suspenso. Tal julgamento, pendente de repercussão geral, se refere a concessão de medicamentos de alto custo não disponíveis na lista do Sistema Único de Saúde e de medicamentos não registrados na Agência Nacional de Vigilância Sanitária. Sob a teoria da tripartição dos poderes de Montesquieu, pretende-se abordar os limites do ativismo judicial e os rumos a serem tomados pelo Judiciário frente às exigências sociais.

Palavras-chave: Ativismo judicial, Judicialização, Políticas públicas, Medicamentos.

\section{Abstract/Resumen/Résumé}

With the purpose of providing a reflection on the judicialization of public health policies in the Brazilian legal system, the article seeks to analyze the position of the Federal Supreme Court in Extraordinary Appeal 566.471, which is currently suspended. This judgment, pending general repercussion, refers to the granting of high-cost medicines not available in the list of the Unified Health System and medicines not registered in the National Sanitary Surveillance

\footnotetext{
${ }^{1}$ O presente trabalho foi realizado com apoio da Coordenação de Aperfeiçoamento de Pessoal de Nível Superior - Brasil (CAPES) - Código de Financiamento 001, conforme Art. 3 da Portaria 206 de 2018, no programa de Pós Graduação Istricto senso - Doutorado - Linha de Pesquisa em Direito Público da PUC Minas.
} 
Agency. Under the theory of the tripartition of the powers of Montesquieu, it is intended to address the limits of judicial activism and the directions to be taken by the judiciary against social demands.

Keywords/Palabras-claves/Mots-clés: Judicial activism, Related searches, Public policy. Medicines.

\section{Introdução}

Notadamente as Cortes Superiores de vários países são chamadas a resolver litígios que envolvem a Administração Pública de um lado e de outro algum ou vários administrados que dissentem quanto à concessão ou custeio de medicamentos e ou tratamentos de alto custo. No Brasil, o Supremo Tribunal Federal está em vias de decidir sobre a questão, mas os juízes e Tribunais já vem sentenciando favoravelmente à concessão de medicamentos órfãos ou terapias isoladas e dispendiosas.

A justificativa para a judicialização em regra é de cunho econômico, pois mesmo possuindo planos de saúde, os pacientes não conseguem recursos financeiros suficientes para iniciar e ou manter o tratamento. Ao considerar que a saúde é constitucionalmente um direito de todos e que compete ao Estado assegurar esse acesso por meio de políticas públicas, poderse-ia indagar: é cabível assegurar de forma individualizada um medicamento cujo custo pode chegar a mais de dois milhões por ano, comprometendo políticas públicas de saúde que poderiam beneficiar grande parte da população? Por outro lado, qual seria o preço de uma vida?

A problemática suscitada diz respeito à pertinência da judicialização nas políticas públicas de saúde no ordenamento jurídico brasileiro. Poderia o Poder Judiciário decidir sobre políticas públicas como as da saúde, adentrando as áreas afetas ao Legislativo e ao Executivo?

Por uma breve compreensão da obra Espírito das Leis de Montesquieu, percebe-se que a resposta à indagação acima se perfaz negativa, pois os poderes são harmônicos e independentes entre si, logo cada um exerce sua função sem interferência do outro.

Ademais, se a hermenêutica utilizada para compreender os ditames constitucionais for de cunho positivista ou mera aplicação da subsunção, ao juiz será negado o criativismo, mesmo que este interprete princípios constitucionais aplicados ao caso concreto.

Por outro lado, não se vislumbra interferência de um Poder ao outro, haja vista que ao juiz, principalmente representando o Supremo Tribunal Federal, compete assegurar o 
cumprimento da Constituição de 1988. Logo, na inércia do Executivo e do Legislativo caberia a ele fazer cumprir o Direito fundamental à saúde e ou à vida.

O artigo tem por objetivo analisar o posicionamento do STF no Recurso Extraordinário $\mathrm{n}^{\mathrm{o}} 566.471$, por ora suspenso, pendente de julgamento de repercussão geral. Tal procedimento, ponto chave para a reflexão do ativismo judicial e seus respectivos desdobramentos, se refere à concessão de medicamentos de alto custo não disponíveis na lista do Sistema Único de Saúde (SUS) e de medicamentos não registrados na Agência Nacional de Vigilância Sanitária (ANVISA).

O método de pesquisa se volta para o hipotético indutivo, por meio de pesquisa exploratória de doutrina, legislações e jurisprudência. No primeiro tópico apresenta-se a teoria da tripartição dos poderes de Montesquieu no livro “O Espírito das Leis". Em seguida adentrase na discussão do ativismo judicial diferenciando-o da judicialização. Num terceiro momento busca-se explanar o conteúdo dos recursos extraordinários, a posição dos relatores e dos demais ministros, contextualizando-os com a atual situação das políticas públicas brasileiras.

\section{Montesquieu - liberdade, poder e constituição}

$\mathrm{Na}$ teoria da tripartição, Montesquieu defendia a independência e harmonia entre os Poderes, mas também esclarecia que cada qual estaria interligado ao outro, ora fiscalizando ora prestando conta. Frise-se que nas funções típicas de cada Poder caberia ao Poder Legislativo legislar, ou seja criar leis ou corrigi-las, ao Poder Executivo caberia a função de chefe de Estado e chefe de governo e ao Judiciário, poder nulo segundo o filósofo, competiria julgar os crimes comuns.

$\mathrm{O}$ autor ainda pondera, que a desarmonia entre os Poderes levaria à tirania, arbitrariedade ou opressão. Chama atenção que a desordem ocorre quando uma entidade exerce mais de uma função. Por exemplo, se o Poder julgador fosse ao mesmo tempo Poder Legislativo, ele atuaria com arbitrariedade na vida e liberdade dos cidadãos. Do mesmo modo, se o poder de julgar se unisse ao Poder Executivo, o magistrado seria opressor, ao passo que se o Poder Legislativo fosse também Poder Executivo, as leis tenderiam a ser tiranas. Por fim, se os três Poderes estivessem reunidos numa só pessoa estar-se-ia diante de um governo déspota. (MONTESQUIEU, 2000).

Frise-se que em nenhum dos casos haveria liberdade, pois não havendo harmonia a insegurança estaria instalada no âmago dos cidadãos. (FERRAZ JUNIOR, 1994). 
Num Estado livre o que se espera é que qualquer indivíduo possa ser governado por si mesmo, mas isso poderia gerar inconvenientes o que justificava, e continua justificando, a necessidade da escolha de representantes, aqueles que dentre tantos conhecessem de fato as necessidades locais e regionais. Destaca-se que essa escolha deveria vincular o deputado eleito a prestar contas ao seu eleitorado, além de incumbi-lo da função meramente legislativa. Significa dizer que, já àquela época, o Poder Legislativo não se ocupava, portanto, da tomada de decisão ativamente, pois esta era de competência do Poder Executivo. (MONTESQUIEU, 2000).

No caso da Inglaterra, Montesquieu esclarece, que o Legislativo seria formado por duas Casas, uma com os representantes dos nobres e outra com representantes do povo que se reuniriam separadamente. A dos nobres seria ocupada por critério de hereditariedade, diferentemente da do povo que seria eleita. As Casas exerciam funções independentes, mas uma limitava a outra, justamente para não ocorrer a concretização de interesses particulares e o abandono dos interesses do povo. Era vedado à Casa dos nobres exercer o poder de estatuir, mas em contrapartida esta poderia anular resoluções feitas pela Casa do povo. O Executivo não participava do momento dos debates e feitura das leis, mas ao revés, ele poderia, se assim entendesse, vetar ou anular o que havia sido feito pela outra Casa. (MONTESQUIEU, 2000). Muito se assemelha ao modelo adotado ainda hoje em diversos países, inclusive no Brasil, quanto ao veto presidencial no processo legislativo, haja vista o parágrafo primeiro do art. 66 da $\mathrm{CR} / 88$.

Nessa perspectiva, nenhum poder interfere na função do outro, mas todos de certa forma estão interligados de maneira que um exerce certo controle ao outro. Nesse viés, ao Poder Judiciário não convém intervir nos demais Poderes, exceto em caso de arbitrariedades e desrespeito à Constituição.

A questão do ativismo judicial está exatamente nesse atuar. Os juízes ou tribunais estão presos aos limites constitucionais expressamente estabelecidos pela descrição da norma jurídica ou haverá margem para hermenêutica constitucional viabilizando a efetividade dos princípios constitucionais, mesmo que tal ação possa interferir no campo das políticas públicas, sabidamente seara do Executivo ou do Legislativo?

Nesse contexto, serão analisados os processos de concessão de medicamentos de alto custo que implicam a reflexão sobre ação do Poder Judiciário frente aos limites impostos pelo Poder Executivo no atendimento às demandas sociais. 


\section{Ativismo judicial, medicamento de alto custo e situação das políticas públicas brasileiras}

Se por um lado a ideia do neoconstitucionalismo trouxe para o âmbito interno do ordenamento jurídico um plus, modificando conceitos e ampliando a perspectiva de uma hermenêutica normativa, por outro, ele é teoria frágil e tem efeitos negativos. Por isso os positivistas defendem o seu afastamento e, ao mesmo tempo, estimulam um positivismo renovado e criativo, fundamentando seus preceitos a partir da Teoria do Direito e Teoria da Interpretação (RAMOS, 2015).

Elival da Silva Ramos (2015) alerta uma concreta interferência na função típica do Legislativo com a contínua feitura e inclusão das medidas provisórias e dos julgados da Suprema Corte no Ordenamento Jurídico Brasileiro.

Se observada a atuação do Supremo Tribunal Federal no Brasil percebe-se que, cada vez mais, suas decisões judicializam situações que competiriam ao Executivo ou ao Legislativo. Seria a própria assunção do Judiciário que, abandonando a tecnicidade das decisões para se utilizar da teoria argumentativa, provoca reflexões significativas na vida social. Em outras palavras, o Poder Judiciário se torna um poder eminentemente político para fazer valer a Constituição mesmo que confrontando os demais Poderes. (BARROSO, 2008).

O termo judicialização, ocorre a partir da Constituição de 1988, trazendo a redemocratização e maior sentimento de cidadania à população, com a introdução de matérias que eram de competência do Executivo e do Legislativo dentro do próprio texto constitucional e com a utilização do controle de constitucionalidade no Ordenamento Jurídico Brasileiro. Nesse sentido, tudo que adentra à Constituição pode ser potencializado no âmbito judicial, significa transformar questões que antes eram políticas em direito. (BARROSO, 2009).

Seja um caso particular ou uma política pública qualquer, se há afetação a Direito Constitucional como à saúde, educação, meio ambiente, propriedade e tantos outros, pode-se recorrer ao Judiciário para resolver a questão. Ou seja, ninguém pode ser privado do acesso à jurisdição.

Já no ativismo judicial, esclarece José Adércio Leite Sampaio (2013), o Supremo Tribunal Federal passa a ser um órgão mais proativo, na garantia dos direitos prestacionais e no âmbito do processo penal. Há uma intensificação do controle de constitucionalidade com modulação dos efeitos, no qual utiliza-se a arguição de descumprimento de preceito fundamental (ADPF) como instrumento auxiliar do controle concentrado de constitucionalidade, provocando um afastamento do método de subsunção para abrir espaço à 
hermenêutica mais aberta, pautada na jurisprudência dos valores que se utiliza dos critérios de proporcionalidade e razoabilidade.

A depender do que se conceba como ativismo judicial, pode se ter dois resultados contrastantes: um num sentido mais ativo que efetiva os direitos constitucionais como mencionado anteriormente, mais afeto aos preceitos da Common Law; e outro de cunho negativo, pois para efetivar a Constituição, o Judiciário criacionista decide questões adentrando ao campo político ou ao âmbito das políticas públicas, interferindo _ o que se torna questionável_ nos demais Poderes. Significa dizer que, ao fazer o exercício hermenêutico complexo, ele escapa a linha divisória presente no texto descritivo da norma.

Não há dúvida de que o interprete final da Constituição é o STF, mas isso não significa que ele pode decidir livremente e subjetivamente às demandas impostas. Pelo contrário, a Suprema Corte Brasileira deve e precisa atuar dentro dos preceitos constitucionais e legais estabelecidos. Cite-se, por exemplo, decisões do STF que asseguram Direitos Fundamentais, mesmo que tal conduta entre em confronto com o desejo da maioria, ou quando declara a inconstitucionalidade de qualquer lei. Nesse raciocínio, não há que se falar em ativismo, mas na defesa da própria democracia.

De certo que o juiz ao julgar, deva buscar a forma mais justa possível, usando como instrumento a razoabilidade e a proporcionalidade. É claro que em algumas situações a interpretação carece de argumentações mais complexas e sistemáticas que busquem atingir a finalidade da norma e não a sua literalidade. É o que acontece diante de conceitos indeterminados. Essa valoração principiológica, criticada pelos positivistas, é a que mais se adequa ao desenrolar do tempo. O juiz deve estar atento ao desenvolvimento da própria sociedade e estar apto a dar uma solução para o problema apresentado. Isso não significa legitimar um atuar desmedido e arbitrário do Judiciário.

A celeuma se instala quando as questões conflituosas envolvem direitos fundamentais, como à saúde e à vida, situações que não se resolvem por simples decisão. Há vários aspectos que carecem de acurado olhar, para que decisões judiciais não sejam prolatadas a toque de caixa.

Para ilustrar tal fato, serão apresentados exemplos de medicamentos de alto custo a serem utilizados contra enfermidade hereditária. Estes voltam-se especificamente a EMA (Atrofia Muscular Espinhal), doença degenerativa que causa atrofia muscular em razão da degeneração dos neurônios motores. (ARAÚJO, et al, 2005).

Estudos apontam um novo medicamento no combate à EMA, denominado de Nusinersen (Spinraza). Acredita-se que ele aumenta a função do neurônio motor, retardando a 
atrofia, melhorando os movimentos musculares (FINKEL et al, 2017). Ocorre que, a terapêutica inicial no primeiro ano preconizada pelos responsáveis pelo medicamento, alcança a casa de US\$ 750.000,00 (setecentos e cinquenta mil dólares) e cada injeção do Nusinersen pode custar US\$125.000,00 (cento e vinte e cinco mil dólares) ao indivíduo. A expectativa é que nos anos seguintes o total possa cair pela metade (TAPETY, 2017).

Analisando os casos judicializados no tocante ao pedido de custeio de medicamento para EMA, percebe-se que o número não é expressivo. Ao pesquisar no banco de acórdãos do Tribunal de Justiça de Minas Gerais (âmbito estadual), nota-se a existência de 8 processos referentes à Atrofia Muscular Espinhal. Nestes, a maioria dos pedidos efetuados se referem à concessão de tratamentos propedêuticos, que apenas tratam as consequências da EMA e não combatem efetivamente a sua causa. Apenas duas demandas pleiteiam o custeio de outros medicamentos, com custo bem reduzido se comparado com o Spinraza.

Já no Tribunal de Justiça de São Paulo existem trinta e nove acórdãos que se relacionam direta ou indiretamente à EMA. Desses, nove se referem a custeio de medicamento, inclusive do Nursinersen. No Tribunal do Rio Grande do Sul de dez acórdãos que julgam pedidos que de uma forma ou de outra envolvem a doença degenerativa em comento, apenas 2 tratam de medicamentos de alto custo, mas também não alcançam nem um por cento do medicamento em estudo. (RIO GRANDE DO SUL, 2006).

No Distrito Federal os gastos com medicamentos específicos fora da lista do SUS, ou melhor dizendo na Relação Nacional de Medicamentos (RENAME), alcançaram o montante aproximado de quarenta e quatro milhões em dois anos, dos quais quatro milhões foram destinados ao tratamento de Hemofilia B, o mais dispendioso em relação aos demais. (SILVA, et al, 2017).

Segundo os autores especializados no tema, deveria ser feita uma avaliação dos benefícios esperados pelos pacientes, bem como avaliar se a propedêutica traçada pelo médico que prescreveu o tratamento é clara quanto aos resultados favoráveis.

Contudo, vale a pena ressaltar, que a conduta exigida por parte dos autores supracitados, beira a um determinismo que muitas vezes o médico responsável pelo tratamento não consegue precisar, haja vista que cada paciente possui uma resposta à terapia ministrada. O mesmo tratamento pode gerar resultados excelentes em um paciente, mas não em outro. Não que se queira eximir a responsabilidade do profissional da saúde em questão, mas transferir toda responsabilidade para ele e para o paciente torna-se inviável. 
Segundo relatório apresentado pelo Secretário de Saúde do Município de Belo Horizonte, a capital contabilizou em 2016 pouco mais de dois milhões em medicamentos decorrentes de pedidos judicializados. (PIMENTA JUNIOR, 2016).

Considerando que a receita e despesa com a saúde ainda não estão equilibradas nesse estado, pois só nesse ano ocorreu um déficit de mais de quatro milhões, poder-se-ia dizer que a quantia gasta com medicamentos judicializados de certo estaria impactando nas outras políticas públicas de saúde, que beneficiariam a coletividade. Entrementes há outros pontos que devem ser analisados, como por exemplo, a gestão dos recursos pela própria Secretaria de Saúde.

A defasagem percebida em alguns orçamentos públicos estaduais seria ocasionada de fato pela judicialização da saúde, comprometendo outras políticas públicas? Ou talvez o déficit possa estar em uma má gestão generalizada e hereditária que permeia as contas públicas não só da capital mineira, mas de todos os entes federados?

A Organização Mundial de Saúde no relatório de 2010 já alerta que nenhum país, rico ou pobre, consegue atender a todas as pessoas de forma igualitária nessa seara, tampouco colocar todas as tecnologias e ou intervenções ao alcance da população de forma ampla, contribuindo para a melhora da qualidade de vida e prolongamento dela, mas, são necessários recursos para tanto (OMS, 2010). O que se percebe é que o bom gerenciamento de recursos torna-se imprescindível à coleta de bons resultados.

O Tribunal de Contas da União (2017), em estudo feito sobre o impacto da judicialização da saúde nos gastos da União, Estados e Municípios, concluiu que houve um aumento de mil e trezentos por cento em sete anos. Somente pedidos de medicamentos correspondem a um percentual de oitenta por cento. Em regra, os medicamentos pleiteados não estão na lista do Sistema Único de Saúde (SUS) e são, em sua maioria, de ordem terapêutica, ou seja, influenciam diretamente no tratamento das consequências das doenças não sendo, portanto, preventivos.

Apesar do impacto da saúde no orçamento público dos estados, o estudo acima mencionado indica que os entes responsáveis pela diminuição da judicialização pouco tem feito para tanto, pois os resultados são inexpressivos (seja no âmbito municipal, estadual e ou federal). Essa constatação só reforça a preocupação com a sistematização da má gestão, descaso não só com o dinheiro público, mas também com a falta de interesse dos governantes em melhorar de fato a situação.

Outro ponto relevante, destacado pelo órgão de controle externo que corrobora com o mencionado acima, é ausência de gerenciamento no processo de coleta e processamento dos dados de medicamentos judicializados de pacientes beneficiários. A ausência de cruzamento de 
informações favorece fraudes que prejudicam ainda mais o orçamento público. De uma forma ou de outra, a responsabilidade será do erário que arcará com o prejuízo e, consequentemente, toda população.

A questão da judicialização da saúde é complexa, não há como negar a discussão sobre direitos fundamentais em choque: saúde ou vida? Qual deve preponderar? A complexidade exigirá análise minuciosa da situação concreta, caso a caso. A simples fundamentação na teoria da tripartição de poderes não pode se justificar pois, o Poder que deveria agir muitas vezes demonstra-se inerte, o que propicia a judicialização.

Retomando Montesquieu, um dos males que faz com que um Estado perca sua liberdade política outrora mencionada é a corrupção implantada nos Poderes, que afeta sobremaneira a gestão pública, pois coloca o povo descrente nas políticas públicas, leis e nas autoridades, só restando ao Estado perecer.

Talvez a onda de corrupção que assola o Brasil, o mau uso do dinheiro público e a má gestão dos recursos justifique o aumento da judicialização de medicamentos de alto custo, colocando na mão da justiça a solução de problemas que poderiam ser resolvidos ou amenizados se houvesse interesse de fato para tanto a quem de direito.

\section{Freios e contrapesos na concessão de medicamentos de alto custo}

Os direitos sociais passaram a ser incorporados nas constituições como necessidade de regularização das contradições sociais. A Constituição Brasileira de 88 erigiu o direito à saúde como garantia fundamental, primeiramente no Título II, que corresponde aos Direitos e Garantias Fundamentais, incluindo no Capítulo II, que trata especificamente dos direitos sociais, o direito à saúde expressamente descrito no artigo 6º (BRASIL, 1988).

Ademais, em dispositivo próprio, o artigo 196 (BRASIL, 1988) estipula que "a saúde é direito de todos e dever do Estado, garantido mediante políticas sociais e econômicas que visem à redução do risco de doenças e de outros agravos e ao acesso universal igualitário às ações e serviços para sua promoção, proteção e recuperação".

É evidente por esse dispositivo, que a saúde corresponde a um direito público subjetivo, a ser promovido pelo Estado, em todas as suas acepções. Para tanto, o ente deve valer-se de políticas púbicas para a implementação de tais garantias.

A Organização Mundial de Saúde (OMS), define a saúde como sendo "o estado de completo bem-estar físico, mental e social, e não somente a ausência de enfermidades". Este conceito amplo envolve medidas de alcance coletivo e nesse sentido a Constituição Brasileira 
priorizou a adoção de um sistema público de saúde unificado, denominado SUS, que adveio como alternativa a um precário sistema de saúde anterior que foi substituído por uma "Reforma Sanitária” em 1987. (MEDEIROS, 2011).

Nesse contexto, o texto constitucional brasileiro deixa claro no art. 198, que "as ações e serviços públicos de saúde integram uma rede regionalizada e hierarquizada e que constituem um sistema único", sendo este financiado, nos termos do art. 195, com recursos do orçamento da seguridade social, da União, dos Estados, do Distrito Federal e dos Municípios, além de outras fontes. (BRASIL, 1988)

O artigo 198 ainda acrescenta que "a União, os Estados, o Distrito Federal e os Municípios aplicarão, anualmente, em ações e serviços públicos de saúde recursos mínimos derivados da aplicação de percentuais", não podendo ser inferior a 15\% para a União, decorrentes da receita corrente líquida do respectivo exercício financeiro e derivando do produto de arrecadação de impostos para Estados, Distrito Federal e Municípios nos termos estipulados em lei complementar que será reavaliada pelo menos a cada cinco anos (art. 198, § $\left.3^{\circ}, \mathrm{CR} / 88\right)$.

Para que o Direito à saúde seja elaborado de forma efetiva e não se torne mera promessa constitucional, necessário se faz reconhecer que seja estabelecido um direito público subjetivo que possa ser provocado perante o Estado. Dessa forma poder-se-ia conciliar um protagonismo que chame à responsabilidade o legislador infraconstitucional e o administrador público.

Torna-se importante reforçar que, se a priori, o cidadão pode usufruir de um direito social à saúde garantido pelo Estado de forma universal e igualitária, de acordo com os ditames programáticos constitucionais, não será menos certo de que esse mesmo direito não poderá ser restringido por embargos materiais, no caso ausência de leis reguladoras orçamentárias ou repasses indevidos. Isso significa que o acesso à Justiça deve ser amplo para se tornar efetivo.

É inegável que a Administração Pública age adstrita aos orçamentos públicos e que os recursos públicos são, por vezes, limitados e finitos. Tal razão explica porque alguns remédios são contemplados aos usuários do SUS em listas próprias e outros não. Não há como a Administração abarcar todas as demandas advindas de indivíduos em situações adversas e específicas.

Contudo, uma vez que a Constituição adotou um modelo que favorece a judicialização, cada vez que uma pretensão é frustrada, nasce para o indivíduo o direito subjetivo de exigir a plena realização de sua garantia. Judicializa-se assim, a exigência dos Direitos Fundamentais 
(como a saúde) fazendo com que o Judiciário debata sobre políticas públicas e as respectivas condutas concretas ${ }^{2}$.

Como bem descreve o Ministro Barroso, a judicialização não ocorreu em virtude de uma "concepção ideológica, filosófica ou metodológica da Corte". Ela é fruto dos contornos constitucionais estabelecidos pela própria Constituição que, por ser abrangente e ter caráter democrático, ainda permite a atuação do Judiciário por meio do controle de constitucionalidade. (BARROSO, 2009).

É de inteira responsabilidade do Poder Executivo, com o auxílio do Poder Legislativo, analisar numa complicada avaliação de quais medicamentos serão fornecidos gratuitamente pelo Estado e quais não serão. É sabido que, faticamente, não há como suprir todas as demandas exigidas. Contudo, em determinadas situações concretas, caberá ao Judiciário acolher pedidos excepcionais e urgentes, sobretudo quando invocam o direito fundamental à vida, como consequência da morosidade e ingerência administrativa do Estado.

Nesse sentido, o ativismo se manifesta no momento em que a Suprema Corte precisa concretizar valores e finalidades constitucionais de forma mais efetiva, uma vez nem todas as condutas estão explicitamente contempladas no texto constitucional ou, se estão, não são observadas pelo Poder competente, impondo ações proativas ao Poder Judiciário.

É notório que o Judiciário Brasileiro tem assumido posturas ativistas. Exatamente por essa razão, este trabalho se propôs a analisar a atuação das Cortes Brasileiras no tocante à distribuição de medicamentos e determinadas terapias.

A situação em apreço trata-se de um Recurso Extraordinário (RE 566.471) interposto pelo Estado do Rio Grande do Norte em face de acórdão proferido pelo Tribunal de Justiça que julgou procedente o fornecimento de medicação de alto custo considerado imprescindível, condenando o estado apelante à obrigação de fazê-lo.

O caso paradigma refere-se à ação de obrigação de fazer, proposta por Carmelita Anunciada de Souza, paciente carente e idosa, que alegou ser portadora de miocardia isquêmica

\footnotetext{
${ }^{2}$ Nesse sentido, Luís Roberto Barroso assinala tão importante distinção:

A judicialização, no contexto brasileiro, é um fato, uma circunstância que decorre do modelo constitucional que se adotou, e não um exercício deliberado de vontade política. Em todos os casos referidos acima, o Judiciário decidiu porque era o que lhe cabia fazer, sem alternativa. Se uma norma constitucional permite que dela se deduza uma pretensão, subjetiva ou objetiva, ao juiz cabe dela conhecer, decidindo a matéria. Já o ativismo judicial é uma atitude, a escolha de um modo específico e proativo de interpretar a Constituição, expandindo o seu sentido e alcance. Normalmente ele se instala em situações de retração do Poder Legislativo, de um certo descolamento entre a classe política e a sociedade civil, impedindo que as demandas sociais sejam atendidas de maneira efetiva. (BARROSO, 2009. p. 21-22)
} 
e hipertensão pulmonar arterial e não possuir condições financeiras para arcar com os medicamentos.

$\mathrm{Na}$ ação, a paciente pede a condenação do Estado do Rio Grande do Norte ao fornecimento ininterrupto de Sildenafil 50mg (princípio ativo do Viagra), medicamento de custo expressivo, superior a $\mathrm{R} \$ 20$ mil reais por caixa, que, à época da propositura da ação, não constava da relação de tratamentos fornecidos gratuitamente pelo Sistema Único de Saúde SUS. $^{3}$ (BRASIL, 2016)

Essa demanda, resumidamente, refere-se ao custeio de uma cirurgia e fornecimento de fármaco de alto custo amparado por conteúdo constitucional que garante que o custeio do Sistema Único de Saúde (SUS) se dê por meio de recursos orçamentários da seguridade social. Estes recursos, como anteriormente explicados, são comuns a todos os entes e o Tribunal alega que a utilização dos valores reservados à saúde, previstos na lei orçamentária estadual, não possuem destinatários pré-estabelecidos.

Nesse sentido, o Tribunal de Justiça entende que deve o Estado priorizar o atendimento às pessoas mais necessitadas, inclusive os idosos. O Estado do Rio Grande do Norte, em sua defesa, pondera que não há obrigação no cumprimento da sentença, uma vez que não existe o dever de sua parte em promover o fornecimento de determinado medicamento que não esteja contemplado na lista dos 36 medicamentos de alto custo destinados ao SUS. Aduz ainda que tal determinação fere de imediato o princípio da dotação orçamentária prévia, razão pela qual pugnou pela reforma da sentença. (BRASIL, 2016).

Diante do caso narrado, a Suprema Corte Brasileira suscitou a necessidade de debater a questão da judicialização da saúde entre seus Ministros, para que o próprio Tribunal estabeleça parâmetros.

O Ministro Luís Roberto Barroso (BRASIL, 2016 ${ }^{4}$ ), defende a posição de que é necessário desjudicializar o debate sobre a saúde pública no Brasil. Ele (BRASIL, 2016 ${ }^{5}$ ) se posiciona no sentido de que o papel do Judiciário deve ser o de "efetivar as políticas públicas já formuladas no âmbito do SUS" e não fazer com que o "Poder Judicário seja a instância adequada para a definição de políticas públicas de saúde". Até porque a definição e implementação de política pública não é função do Judiciário, configurando um ativismo exacerbado.

\footnotetext{
3 Vide http://www.luisrobertobarroso.com.br/wp-content/uploads/2016/10/RE-566471-Medicamentos-de-altocusto-versa $\%$ CC\%83o-final.pdf

${ }^{4}$ Vide http://www.stf.jus.br/portal/cms/verNoticiaDetalhe.asp?idConteudo=326275. Acesso em 14/02/18.

${ }^{5}$ Vide http://www.stf.jus.br/portal/cms/verNoticiaDetalhe.asp?idConteudo=326275. Acesso em 14/02/18.
} 
Fato é que tal matéria suscita importante divergência. Por essa razão o Supremo Tribunal Federal decidiu suspender, em 16/09/2016, o julgamento conjunto dos dois Recursos Extraordinários (o RE $n^{\circ} 566.471$ - em apreço como exemplo - e n ${ }^{\circ}$ 657.718) que versam sobre o fornecimento de remédios de alto custo não disponíveis na lista do Sistema Único de Saúde e de medicamentos não registrados na Agência Nacional de Vigilância Sanitária (ANVISA), por se tratarem de temas conexos.

O relator, Ministro Marco Aurélio, foi o único a votar na sessão em que a matéria teve início. À época, manifestou pelo provimento dos dois recursos, ao argumento de que, nos casos de remédios de alto custo não disponíveis no sistema, o Estado pode ser obrigado a fornecê-los, desde que comprovadas a imprescindibilidade do medicamento e a incapacidade econômica do paciente e de sua família. E que o Estado não pode ser obrigado a fornecer fármacos não registrados na agência reguladora, a ANVISA, no caso. (BRASIL, 2016) ${ }^{6}$

Em seguida, a análise do recurso foi suspensa a pedido do Ministro Luís Roberto Barroso. Ao ser retomada a sessão, o ministro Marco Aurélio aditou seu voto reformulando a tese inicial para análise do Plenário, acrescentando novas considerações, de que o medicamento de alto custo depende da demonstração da imprescindibilidade - adequação e necessidade -, da impossibilidade de substituição do fármaco por outro e da falta de espontaneidade dos membros da família, de forma solidária, em custeá-lo. (BRASIL, 2016).

Daí em diante as opiniões divergiram. O Ministro Barroso afirmou quanto à demanda judicial por medicamento não incorporado pelo SUS, incluindo os de alto custo, o entendimento de que o Estado não pode ser obrigado a fornecê-lo sob o argumento de que não há nenhum sistema de saúde que resista a um modelo em que todos os remédios, independente do custo, devam ser oferecidos pelo Estado.

Para reforçar o seu posicionamento, propôs cinco requisitos cumulativos que devem ser observados pelo Poder Judiciário para o deferimento das pretensões: (I) incapacidade financeira; (II) demonstração que a não incorporação do medicamento não resultou de decisão expressa dos órgãos competentes; (III) inexistência de substituto terapêutico, (IV) comprovação de eficácia do medicamento pleiteado e (V) propositura da demanda em face da União. (BRASIL, 2016).

Dessa forma, o citado Ministro desproveu o RE 566.471 que dispunha sobre o fornecimento de remédios de alto custo não disponíveis na Lista do SUS e formulou a propositiva tese de repercussão geral: “O Estado não pode ser obrigado por decisão judicial a

\footnotetext{
${ }^{6}$ Vide http://www.stf.jus.br/portal/cms/verNoticiaDetalhe.asp?idConteudo=326275. Acesso em 14/02/18.
} 
fornecer medicamento não incorporado pelo SUS, independentemente de custo, salvo hipóteses excepcionais, em que preenchidos os cinco requisitos". (BRASIL, 2016).

Já o Ministro Edson Fachin, votou pelo provimento parcial do RE 566.471 alegando a tese de que existe direito subjetivo às políticas públicas de assistência à saúde, conformando violação direta a direito líquido e certo, sem contar que a omissão na prestação, quando injustificada, pode configurar mora na sua implementação. Nesse raciocínio, complementa, contudo, que as ações coletivas devem ter preferência em relação às prestações individuais e que deve existir ampla produção de provas. (BRASIL, 2016).

Da mesma forma que o Min. Luís Roberto Barroso, Edson Fachin também propõe cinco parâmetros para que seja solicitado ao Poder Judiciário essa demanda específica: “(I) necessária demonstração do prévio requerimento administrativo na rede pública; (II) preferencial prescrição por médico da rede pública; (III) preferencial designação do medicamento pela Denominação Comum Brasileira (DCB) e não havendo pela Denominação Comum Internacional (DCI); (IV) justificativa da inadequação ou inexistência de medicamento/tratamento na rede pública e (V) necessária realização de laudo médico." (BRASIL, 2016).

Nesse sentido, resta sobrestado o julgamento até que a presente questão constitucional seja submetida à repercussão geral e optou-se por preservar os efeitos das decisões judicias em consonância com o princípio da segurança jurídica.

O recurso extraordinário apresentado demonstra que o debate sobre o ativismo judicial na esfera da saúde pública ainda está longe de consenso. A apreciação da demanda torna-se essencial para que se possa refletir sobre os efeitos e impactos do ativismo judicial na esfera público-social, sem perder de vista os limites entre política e justiça na sociedade contemporânea, que por sinal se mostram muito tênues.

As decisões do Supremo Tribunal Federal, no exercício do poder político e não da vontade política, podem se sobrepor às decisões do Poder Legislativo e do Poder Executivo, quando necessárias ao atendimento das necessidades fundamentais de uma sociedade democrática de Direito.

A crença de que o Direito é lastreado por uma objetividade absoluta é ilusória. Tanto o intérprete quanto o legislador não são imbuídos de pura neutralidade uma vez que possuem noções pré-concebidas de mundo e o ordenamento jurídico não se encerra em sua completude. Existem lacunas que precisam ser preenchidas pelo Judiciário. Numa análise contemporânea do Direito, imprescindível se faz sua proximidade com um conteúdo ético, fazendo a justiça se aproximar da legalidade, legitimidade e dignidade das pessoas. (BARROSO, 2009). 
O setor de saúde tem sido um exemplo prático dessa experiência. Diante de intervenções necessárias e avaliativas, o Poder Judiciário tem proferido decisões impactantes na esfera pública em matéria de concessão de medicamentos e terapias. É perceptível que algumas decisões individualizadas, se massificadas, podem comprometer a própria continuidade das políticas públicas de saúde planejadas para toda sociedade, desorganizando e comprometendo a locação de recursos do orçamento público. Por outro lado, não se pode ponderar ou precificar qual vida vale mais que outra.

Seguindo esse raciocínio pressupõe-se que o Poder Judiciário pode ser chamado a intervir em várias demandas da área da saúde, o que não quer dizer que ele sempre deva fazêlo. Nas palavras do Ministro Luís Roberto Barroso (2009, p.30) o ativismo judicial

expressa uma postura do intérprete, um modo proativo e expansivo de interpretar a Constituição, potencializando o sentido e alcance de suas normas, para ir além do legislador ordinário. Trata-se de um mecanismo para contornar, bypassar o processo político majoritário quando ele tenha se mostrado inerte, emperrado ou incapaz de produzir consenso. Os riscos da judicialização e, sobretudo, do ativismo envolvem a legitimidade democrática, a politização da justiça e a falta de capacidade institucional do Judiciário para decidir determinadas matérias. (BARROSO, 2009, p.30)

Outra questão complexa levada ao Poder Judiciário é o pedido para fornecimento de medicamentos que não estão elencados na lista do Sistema Único de Saúde. Existe toda uma análise técnico-científica das opções terapêuticas existentes, considerando a relação custobenefício e custo-efetividade, realizada de forma criteriosa pelo Ministério da Saúde. (BRASIL, 2016).

Por mais que as realidades vivenciadas pelos demandantes induzam ao raciocínio da primazia dos princípios relacionados aos Direitos Humanos e aos Direitos Fundamentais em conflito com as possibilidades orçamentárias, o que se percebe ao final é que alguns poucos jurisdicionados sairão privilegiados.

O Ministro Luis Roberto Barroso (BRASIL, 2016. p.12) ressalta em seu voto no julgamento do RE 566.471 que:

quando o Judiciário assume o papel de protagonista na implementação dessas políticas, em regra, privilegia aqueles que possuem acesso qualificado à Justiça, seja por conhecerem seus direitos, seja por poderem arcar com os custos do processo judicial.

(...) A transferência, pelo Estado, de recursos que seriam aplicados em prol de todos os beneficiários do SUS para o cumprimento de decisões judiciais prejudica sobretudo os mais pobres, que constituem a clientela preferencial do sistema.(BRASIL, 2016. p. 12). 
Como destaca o autor, alguns jurisdicionados restarão prejudicados, uma vez que tais medidas judiciais acabam por confrontar valores basilares do Estado Democrático de Direito como a igualdade de acesso à justiça.

Para que um medicamento seja incorporado à lista do SUS, é necessária medida de política pública restritiva ao próprio sistema, contabilizando o impacto financeiro, em consonância com os princípios da universalidade, integridade e equidade. Seara impassível de interferência por parte do Poder Judiciário. (MATTOS E SOUZA, 2011, p.18)

Tais critérios concentram-se nas prioridades nacionais de promoção da saúde, segurança e eficácia terapêutica comprovada, qualidade e disponibilidade dos produtos que visam atender de maneira satisfatória à maioria da população. A segurança não pode, em hipótese alguma, ser negligenciada para permitir o emprego clínico de qualquer produto que não seja aprovado pela Agência Nacional de Vigilância Sanitária (ANVISA).

É dever do Estado garantir a seus cidadãos o Direito à vida e à saúde. Mas tal assertiva autoriza o Poder Judiciário intervir na gestão administrativa, em virtude da reconhecida ineficiência da Administração? Diante de variados argumentos essa é a celeuma que se estabelece.

O controle das políticas públicas embora provoque resultados e tenha contemplado a satisfação social, ainda divide opiniões. A matéria é delicada pois não possui limites objetivos específicos que possam mensurar essa intervenção que legitima, muitas vezes, o juiz assumir o papel do administrador.

A reserva do possível ${ }^{7}$ inspira a conduta do administrador público para que paute suas ações dentro dos critérios de oportunidade e conveniência, típicos da valoração administrativa. Contudo, ressalta-se a existência dos princípios da razoabilidade e da proporcionalidade como norteadores do controle da discricionariedade na Administração Pública.

Essa reflexão aponta como possível solução a busca pelo caso concreto, a situação fática, apta a demonstrar se a Administração comportou-se com equilíbrio necessário nas suas

\footnotetext{
${ }^{7}$ Segundo o autor Ingo Wolfgang Sarlet, a colocação dos direitos sociais deve observar as prestações que se sustentam no que se denominou de uma "reserva do possível". Nesta, apesar de o Estado dispor efetivamente de recursos, deve-se observar a possibilidade jurídica quanto o poder de disposição por parte do destinatário da norma. Para o autor a reserva do possível apresenta uma tríplice dimensão: a) a efetiva disponibilidade fática dos recursos para a efetivação dos direitos fundamentais; b) a disponibilidade jurídica dos recursos materiais e humanos e c) a proporcionalidade da prestação, em especial no tocante à sua exigibilidade e da sua razoabilidade. (SARLET, 2012. p. 287-288)
} 
condutas ou se apresenta-se de forma desidiosa com as questões urgentes, como a da saúde pública, por exemplo.

Nesse aspecto, o ativismo judicial encontra guarida, ao mesmo tempo que exige cautela para que o princípio republicano da separação dos Poderes não seja mitigado, ferindo o sistema dos freios e contrapesos.

Por não ser tarefa simples, o Supremo Tribunal Federal entendeu por bem suspender o recurso extraordinário apresentado neste trabalho, para melhor discutir essa temática tão complexa que implica, para todo o contexto e sociedade, repercussão geral.

\section{Considerações finais}

O Supremo Tribunal Federal no ímpeto de efetivar a Constituição Federal de 1988 no plano das garantias e Direitos fundamentais, vem se tornando grande protagonista no cenário nacional, seja no plano político-institucional, seja em sua função precípua de controle aos ditames constitucionais.

Ao Estado que se propõe democrático, vários desafios são impostos, inclusive a realização e implementação de direitos sociais que visem promover um equilíbrio e um nivelamento das fraturas propiciadas pela má distribuição de renda.

A Constituição pátria abarcou esses direitos de forma prospectiva e, em sua grande maioria, limitados à edição de leis ou políticas públicas que implementem de fato sua condição. A dependência desses fatores para a execução das políticas públicas faz com que, na prática, a máquina estatal se configure morosa e ineficiente em decorrência das inúmeras responsabilidades assumidas.

$\mathrm{Na}$ área da saúde então, graves entraves são enfrentados vez que, nesta seara, faz-se necessária a comunhão do planejamento e execução de determinada política pública para a implementação do que tenha de ser realizado. As demandas são constantes e o fornecimento de remédios de alto custo para determinados indivíduos se torna urgente, implicando para o Estado o dever de garantir a efetivação do Direito Fundamental, qual seja, a vida.

Tal fato por si só não justifica que, levianamente, possa o Poder Judiciário intervir de forma expressiva, irracional e desmedida na esfera da saúde pública a ponto de desestruturar todo o sistema público planejado ou comprometer a meta de acesso universalizante à toda sociedade. Este poder deve estar longe de ser um poder absoluto e incontestável.

Contudo, não há como negar que o Poder Judiciário vem sendo gradativamente invocado para ser o garantidor da efetividade constitucional. Muitas vezes o seu atuar vem 
transmudando a promoção da efetividade social para um ativismo invasivo. Este não seria o ponto mais adequado, pois ao Judiciário não compete extrapolar os limites da Constituição.

Inegável a inércia do Poder Legislativo e Executivo em determinadas condutas na promoção de políticas públicas, inclusive quando a temática envolve fornecimento de remédios e realização de intervenções cirúrgicas pelo Sistema Único de Saúde. Haja vista o próprio estudo realizado pelo Tribunal de Contas da União, apontando a letargia dos responsáveis na tomada de decisão para diminuição da judicialização dos medicamentos de alto custo e ou tratamentos específicos não contemplados pelo SUS. Nestes casos, percebe-se o dilema instaurado, se convém ou não ao Judiciário resolver a questão.

A melhor opção talvez seria que não só a Suprema Corte, mas, todo judiciário estivessem atentos ao descrito na norma constitucional utilizando-se de hermenêutica complexa, sistemática, que garanta o objetivo, qual seja, efetivar a Constituição, solucionando o conflito sem exacerbar seus poderes e sem adentrar funções atribuídas ao legislativo e ao judiciário.

Nesse sentido o juiz deve estar atento ao desenvolvimento da própria sociedade e estar preparado para dar uma solução para o problema apresentado. De certo que não há uma resposta correta para a judicialização pois cada enfermidade tem uma incidência, umas mais outras menos, como o caso da Atrofia Muscular Espinhal, cada paciente demanda um tratamento específico com preços diferenciados.

A simples alegação de respeito à tripartição de Poderes não deve ser utilizada para impedir a atuação do Judiciário nesses casos de judicialização da saúde. Existem outras variantes envolvidas como má gestão de recursos públicos da saúde, má gestão dos próprios dados sobre potenciais pacientes a receber o medicamento ou que já receberam. Sem falar na corrupção e fraude que rondam a Administração Pública.

Talvez esse seja o ponto de legitimação para a intervenção do Judiciário, omissão e ou ineficiência do Poder Legislativo e ou Executivo. O ativismo judicial, evidentemente com a devida parcimônia, não ofende os princípios democráticos, mas ao revés, procura defendê-los.

Nessa turbulência sistêmica de imperícias, negligências e imprudências administrativas e legislativas, resta ao Judiciário levar segurança jurídica e resguardar os Direitos Fundamentais, de acordo com cada caso concreto, sem perder de vista os preceitos constitucionais.

A celeuma está para ser decidida pelo STF no julgamento do recurso $\mathrm{n}^{\circ} 566.471 \mathrm{em}$ repercussão geral. Enquanto isso, compete ao meio acadêmico interdisciplinar, acompanhar a gestão dos recursos da saúde e as ações dos Poderes Executivo e Legislativo no tocante a 
minimização da judicialização da saúde para então averiguar se o ativismo judicial em questão é tão prejudicial quanto sugerem os positivistas de plantão.

\section{Referências bibliográficas}

ARAÚJO, A. P. Q. C. et al. Dificuldades diagnósticas na atrofia muscular espinhal. ArqNeuropsiquiatr, v. 63, n. 1, p. 145-149, 2005.

BARROSO, Luís Roberto. Judicialização, ativismo judicial e legitimidade democrática. Anuário iberoamericano de justicia constitucional, n. 13, p. 17-32, 2009.

BRASIL, Supremo Tribunal Federal. Recurso Extraordinário 566.471. Relator: Marco Aurélio. 15 de setembro de 2016. Disponível em: http://www.stf.jus.br/arquivo/cms/noticia NoticiaStf/anexo/RE566471.pdf. Acesso em 14 fev. 2018.

BRASIL, Supremo Tribunal Federal. Pedido de vista adia julgamento sobre acesso a medicamentos de alto custo por via judicial. Relator: Marco Aurélio. Notícias STF, 28 de setembro de 2016. Disponível em: http://www.stf.jus.br/portal/cms/verNoticiaDetalhe. asp?idConteudo=326275. Acesso em 14 fev. 2018.

FERRAZ JUNIOR, Tercio Sampaio Ferraz. O Judiciário frente à divisão dos poderes: um princípio em decadência? Revista Usp, n. 21, p. 12-21, 1994.

FINKEL, Richard S. et al. Treatment of infantile-onset spinal muscular atrophy with nusinersen: a phase 2, open-label, dose-escalation study. The Lancet, v. 388, n. 10063, p. 3017-3026, 2017. Disponível em: http://www.sciencedirect.com/science/article/ pii/S0140673616314088. Acesso em: 05 jan. de 2018

MEDEIROS, Fabrício Juliano Mendes. O ativismo judicial e o direito à saúde. Belo Horizonte: Fórum, 2011.136p.

MINAS GERAIS, Tribunal de Justiça- TJ-MG, 2017. In: Jurisprudências. Disponível em: http://www5.tjmg.jus.br/jurisprudencia/pesquisaPalavrasEspelhoAcordao.do?\&numeroRegist ro $=1 \&$ totalLinhas $=8 \&$ paginaNumero $=1 \&$ linhasPorPagina $=1 \&$ palavras $=\% 2522$ atrofia $\% 20 \mathrm{mu}$ 
scular\%20espinhal\%2522\&pesquisarPor=ementa\&pesquisaTesauro=true\&orderByData $=1 \& \mathrm{r}$ eferenciaLegislativa $=$ Clique $\% 20$ na $\% 201$ upa $\% 20$ para $\% 20$ pesquisar $\% 20$ as $\% 20$ refer $\%$ EAncias $\% 20$ cadastradas...\&pesquisaPalavras=Pesquisar\&

Acesso em: 05 jan. de 2018.

MINAS GERAIS, Tribunal de Justiça- TJ-MG, 2017. In: Jurisprudências. Disponível em: http://www5.tjmg.jus.br/jurisprudencia/pesquisaPalavrasEspelhoAcordao.do?\&numeroRegist ro $=3 \&$ totalLinhas $=8 \&$ paginaNumero $=3 \&$ linhasPorPagina $=1 \&$ palavras $=\% 2522$ atrofia $\% 20 \mathrm{mu}$ scular\%20espinhal\%2522\&pesquisarPor=ementa\&pesquisaTesauro=true\&orderByData $=1 \& \mathrm{r}$ eferenciaLegislativa $=$ Clique $\% 20$ na $\% 201$ upa $\% 20$ para $\% 20$ pesquisar $\% 20$ as $\% 20$ refer $\%$ EAncias \%20cadastradas...\&pesquisaPalavras=Pesquisar\&. Acesso em: 05 jan. de 2018.

MONTESQUIEU. O espírito das leis. Martins Fontes, 2000.

OMS, Organização Mundial de Saúde. Relatório Mundial de Saúde 2010. O Financiamento da cobertura universal. Disponível em: http:/www.who.int/eportuguese/publications/ WHR2010.pdf?ua=1. Acesso em: 05 jan. de 2017.

PIMENTA JUNIOR, Fabiano Geraldo. O sistema de saúde de Belo Horizonte. Disponível em: <portalpbh.pbh.gov.br/pbh/ecp/files.do?evento=download\&urlArqPlc.>. Acesso em: 05 jan. de 2018 .

RAMOS, Elival da Silva. Ativismo Judicial Parâmetros Dogmáticos. 2 Ed. São Paulo: Saraiva, 2010. 349 p.

RIO GRANDE DO SUL. Tribunal de Justiça do Rio Grande do Sul. Apelação Civil 70014991244. Disponível em: http://www.tjrs.jus.br/busca/search?q=atrofia+muscular+ espinhal\&proxystylesheet $=$ tjrs_index $\&$ getfields $=* \&$ entsp $=$ a_politicasite $\& w c=200 \& w c \_m c=$ $1 \&$ oe $=U T F-8 \& i e=U T F-8 \& u d=1 \&$ sort $=$ date:D:S:d1\&as_qj=nusinersen\&as_epq $=\&$ as_oq $=\&$ as_eq $=\&$ as_q $=+\&$ ulang $=p t-B R \& i p=186.206 .183 .68 \&$ access $=$ p $\&$ entqr $=3 \&$ entqrm $=0$ $\&$ client $=$ tjrs_index \&filter $=0 \&$ start $=10 \& a b a=j u r i s \&$ site $=$ ementario\#main_res_juris. Acesso em: 05 de jan. 2018 
SARLET, Ingo Wolfgang. A eficácia dos direitos fundamentais: uma teoria geral dos direitos fundamentais na perspectiva constitucional. 11. ed. Porto Alegre: Livraria do Advogado Editora, 2012. p.287-288.

SILVA, Everton; DE ALMEIDA, Keyla Caroline; PESSOA, Glaucia Silveira Carvalho. Análise do gasto com judicialização de medicamentos no Distrito Federal, Brasil. Cadernos ibero-americanos de direito sanitário, v. 6, n. 1, p. 112-126, 2017.

SOUSA, Isabella Saldanha de. GOMES, Magno Federici. Ativismo judicial, democracia e sustentabilidade. Rio de Janeiro: Lumen Juris, 2015. 245p.

TAPETY, Sergio Eduardo de Freitas. Parecer Referencial sobre o medicamento Spinraza (Nusinnersen), Advocacia Geral da União, n. 00016/2017/CONJUR-MS/CCGU/AGU. Brasília, 2017. Disponível em: https://sapiens.agu.gov.br/documento/39364561.

TRIBUNAL DE CONTAS DA UNIÃO (TCU). Aumentam os gastos públicos com judicialização da saúde. In: Imprensa, notícias, 23 ago. 2017. Disponível em: http://portal.tcu.gov.br/imprensa/noticias/aumentam-os-gastos-publicos-com-judicializacaoda-saude.htm. Acesso em: 05 jan. 2018 


\title{
INTELIGÊNCIA ARTIFICIAL E JUIZ NATURAL - \\ QUANDO A PREVISIBILIDADE E A PADRONIZAÇÃO PODEM TOMAR O ASSENTO DO JUIZ ORDINÁRIO
}

\author{
Conceição de Maria de Abreu Ferreira Machado \\ Universidade Federal de Sergipe
}

Clara Angélica Gonçalves Cavalcanti Dias

Universidade Federal de Sergipe

\begin{abstract}
Resumo
O presente artigo tem por objetivo avaliar se o uso da inteligência artificial como política judiciária, a partir do uso de ferramentas que propiciem um julgamento previsível, pode ocasionar ofensa ao juiz natural. O estudo aborda a problemática da morosidade processual e a tendência de padronização de decisões, por meio do microssistema de precedentes vinculantes e casos repetitivos, interligando recursos tecnológicos. A pesquisa bibliográfica foi realizada a partir da revisão de literatura e jurisprudência que abordam princípio do juiz natural e o acesso à obtenção de decisão justa e adequada.
\end{abstract}

Palavras-chave: juiz natural, inteligência artificial, precedentes vinculantes, morosidade, política judiciária.

\section{Abstract/Resumen/Résumé}

The aim of this article is to evaluate if the use of artificial intelligence as a judicial policy, based on the use of tools that provide for a predictable judgment, can cause offense to the natural judge. The study deals with the problem of procedural slowness and the tendency to standardize decisions, through the microsystem of binding precedents and repetitive cases, interconnecting technological resources. The bibliographical research was carried out from the literature review and jurisprudence that deal with the principle of the natural judge and the access to the fair and adequate decision making.

Keywords/Palabras-claves/Mots-clés: natural judge, artificial intelligence, binding precedents, morosity, judicial policy. 


\section{Considerações Iniciais}

A Revolução tecnológica dos últimos anos tem apresentado vasta gama de inovações para facilitar tarefas, vidas, propiciando novos conhecimentos, novas transformações, novos estilos e capacidades. Não é diferente na seara jurídica: desenvolvimento de máquinas, softwares potentes, propõem a redução do trabalho em grandes escritórios, resultando na confecção de peças padronizadas. Mas as inovações não se limitam a isso, programas também desejam atender a tarefa de julgar.

Inicialmente, o trabalho aborda os aspectos do princípio do juiz natural, os pressupostos de legitimidade quanto à determinação da competência daquele que vai julgar a causa, tendo como razão e função fundante o Estado Democrático de Direito, predispostos a oferecer uma solução para a lide que seja justa, reta e imparcial, devendo observar as jurisprudências dos órgãos superiores que o vinculam, de modo a não haver julgamentos discrepantes.

Após a explicitação do princípio, demonstra que a padronização de julgamentos tão valorizada no Novo Código de Processo Civil, vem desempenhando um papel relevante para a política de organização judiciária, posto que busca enfatizar e vincular não só por meio de decisões abstratas, mas também de conteúdo concreto, estendendo seus efeitos extraprocesso.

Evidencia-se que essa padronização propicia uma busca de ferramentas para auxiliar o juiz a encontrar a decisão mais correta para determinado caso, considerando semelhantes proposições e opções para o juiz escolher. Todavia, indaga-se até que ponto a máquina pode ser mera auxiliar e a partir de que momento pode passar a ser o próprio juízo da causa.

É proposta uma reflexão da assertiva de que a crise judiciária exige que juízes sejam sobrenaturais, em vista do quantitativo de processos crescente, sem notícia de melhoramentos imediatos, devido à cultura da litigiosidade e a quantidade insuficiente de juízes investidos, o que torna as opções pela automatização uma realidade.

O tema ganha relevância no cenário atual, em que se discutem propostas para desafogar o Judiciário, com a oferta de sotftwares que prometem agilizar a prestação jurisdicional e auxiliar o juiz. O questionamento central do trabalho é investigar se é possível que a convicção do juiz ordinário seja substituída pela inteligência artificial, diante do nosso ordenamento jurídico atual, em ofensa ao princípio do juiz natural.

O desenvolvimento do trabalho compreende como tendência a gestão judiciária focada na automação dos processos judiciais e a disponibilidade de recursos tecnológicos inovadores 
capazes de atender ao interesse pela celeridade processual e enxugamento das demandas que causam congestionamento no Poder Judiciário, como um desafio a ser enfrentado.

Para tanto, a pesquisa consiste em levantamento bibliográfico, baseado em material publicado em livros, internet, periódicos, revistas de jurisprudência, entre outros, utilizando a metodologia qualitativa. O tema é tratado com suporte em autores que debatem as bases filosóficas da construção e evolução do princípio do juiz natural, o desenvolvimento da inteligência artificial e as possibilidades do uso de ferramentas tecnológicas no ramo jurídico.

\section{Razões e importância do princípio do juiz natural}

A noção do Juiz Natural surgiu juntamente com a idealização do Estado Moderno, na construção do processo democrático, em ruptura com o Estado Absolutista. Durante o período feudal, os julgamentos eram realizados pela pessoa do rei, chamado de jus representationis omnimodae (MAZZUOLI, 2011, p. 327), que concentrava todos os poderes do Estado, inclusive o de julgar e condenar. Portanto, não havia imparcialidade nesses julgamentos.

A necessidade de combater o poder absolutista na Inglaterra culminou na edição da Magna Carta, em 1.215, através do qual o rei João Sem Terra restringe seus poderes e compromete-se a respeitar as regras da lei da terra, conforme dispunha o artigo 21: "condes $e$ barões não serão multados senão pelos seus pares, e somente de conformidade com o grau de transgressão". A partir desse momento, o juiz natural passa a ser concebido como princípio a ser seguido com intuito de separar o acusador do julgador e de direcionar a decidibilidade das causas às pessoas legitimadas por lei, expurgando juízes extraordinários. Assim, o termo apareceu expressamente em texto legal na legislação francesa de 24.08.1790, em seu artigo 17 do título II.

Trata-se, portanto, do direito fundamental de ser julgado e processado por sujeito competente, imparcial e independente, que no Brasil está consagrado implicitamente no artigo $5^{\circ}$, incisos XXXVII E LII, coibindo a criação de juízes extraordinários e o julgamento por autoridades não competentes.

O instituto compõe o rol de direitos fundamentais constitucionais que perfaz a cláusula maior do princípio do Devido Processo Legal, de forma a viabilizar o objetivo fim da República que é a Justiça. Em verdade, o Estado Principiológico instituído no sistema jurídico construído no período pós-positivista, dá ao princípio do juiz natural grande relevância, posto que sem sua observância não se perfaz a justiça em sua integridade. 
Fredie Didier (2013, p. 130) apresenta o conteúdo do princípio do juiz natural citando a doutrina de Luigi Ferrajoli e delimita dois aspectos: um formal e outro substancial. O aspecto formal apresenta-se ligado ao princípio da legalidade, em sua acepção restrita da reserva de lei, coibindo a existência de tribunais de exceção, ou seja, constituídos ad hoc (especificamente para julgar determinado caso) ou ex post facto (constituído após a ocorrência dos fatos); a lei deve estabelecer de forma prévia, abstrata e geral a competência do juiz, tornando ordinária a vinculação de causa a determinado juízo por atribuições objetivas, de modo a afastar-se da discricionariedade de fixação de competência.

O aspecto substancial, por sua vez, está relacionado a assegurar a imparcialidade e independência do juiz ordinário, para garantir atuação impessoal, rechaçando interesses próprios, a fim de que a decisão seja conduzida para a realização dos fins constitucionais do Estado. Nesse aspecto, o juiz natural relaciona-se diretamente com um dos princípios pilares do devido processo legal, que é a igualdade entre as partes. É pelo conteúdo material do princípio do juiz natural que se garante a realização do princípio democrático durante o desenvolvimento do processo, disponibilizando às partes igual oportunidades para se chegar a um resultado justo e adequado.

Nesse escopo, a Carta Maior prevê, em seu artigo 93, as garantias para o exercício da função jurisdicional isenta e autônoma, quais sejam, vitaliciedade, independência política e irredutibilidade de seus vencimentos, objetivando manter o juiz imune às pressões exteriores.

\section{Crise Judiciária - Ponderação entre o princípio do juiz natural e o princípio da eficiência}

Para que o Estado realize a função jurisdicional, o faz por meio de pessoas físicas, investidas da função judicante, garantidas as prerrogativas e privilégios para atuação imparcial, sob competência pré-fixada. Os juízes são presentantes da função Estado-juiz, incorporados à estrutura estatal com poder decisório indelegável.

Assumindo o monopólio da jurisdição, não é dado ao Poder Público esquivar-se de atuar diante dos conflitos que lhes são submetidos. Assim, o direito de ação é franqueado a todos que busquem o judiciário, havendo lesão ou ameaça ao direito, é o que preceitua o princípio da inafastabilidade encontrado no inciso XXXV do artigo $5^{\circ}$ da Constituição Federal.

Para Margarida Lacombe, o direito, propriamente dito, não é a norma posta, geral e abstrata, mas é o resultado das decisões dos juízes que se consubstanciam em norma individual 
e concreta, a qual contém comando de imposição. Apoiando-se na concepção ôntica e historicista da situação hermenêutica de Gadamer, a autora explicita:

(...)“a norma atua apenas como parâmetro e orientação para a conduta, sem imputar qualquer dever, como diria Kelsen. Para nós, o direito apresenta-se jungido à própria hermenêutica uma vez que a sua existência, enquanto significação, depende da concretização da aplicação da lei em cada caso julgado. Assim, apoiamo-nos na filosofia de Hans-Georg Gadamer, que se baseia na relação fática entre compreensão e interpretação, no âmbito da experiência, conforme estabelecido anteriormente por Heidegger, e Dilthey, que já havia referenciado a hermenêutica à dinâmica da vida" (2003, p. 17).

Como pessoa física que é, está imbuído de sua história de vida, de seu desenvolvimento humano, trazendo sua experiência a somar na sua tarefa de solucionar os casos. Assim, a visão de mundo do magistrado, e consequentemente dos fatos, estará impregnada de concepções próprias inerentes à sua formação, as quais irão delimitar qual a solução adequada para as demandas submetidas.

O juiz atua no processo exercendo a jurisdição para realização dos fins do Estado, é o que Cândido Rangel Dinamarco (2.000) denomina de "instrumentalidade do processo", o qual tem três escopos: o social, político e jurídico. Cassio Scarpinella Bueno (2014) analisa o escopo social como sendo a ideia de justiça, de paz social e apaziguação, cujo processo é o meio de realizar os valores do Estado-juiz, de atingir suas finalidades e necessidades. Por escopo político, entende ser a afirmação da autoridade, explicitação de seu poder perante a sociedade, de forma mitigada e limitada a considerar as finalidades públicas, diante do modelo democrático. No que concerne ao escopo jurídico, entendem-se os institutos processuais de acesso à justiça.

Nesse sentido, o processo interpretativo a ser desenvolvido pelo juiz natural deve levar em conta, portanto, o vetor jurídico-constitucional democrático, neoconstitucionalista, construído a partir da concepção histórica da humanidade, considerando a evolução dos direitos fundamentais refletido por meio da percepção hermenêutica do julgador, adicionado as suas influências pessoais que condicionam a compreensão do contexto fático e da aplicabilidade do direito.

Pois bem, é a essa pessoa competente e ordinária, revestida em juiz natural, a quem cabe apreciar fatos, colher provas e julgar segundo a interpretação dada. Como ser humano, o juiz natural é limitado e vem sofrendo com a enxurrada de processos que lhes são atribuídos, devido à crescente demanda judicial, gerada pela cultura da litigiosidade moderna e a escassez 
de recursos humanos, problema que vem sendo repensado e refletido nas políticas públicas judiciárias.

Os estudos quanto às causas do quantitativo estratosférico das demandas que abarrotam o judiciário têm sido objeto de constates análises, na tentativa de cortar o mal pela raiz. Mas, o intuito logo se depara com diversas questões, dentre as quais a questão da ampliação de acesso à justiça frente à multiplicidade de questões controvertidas na sociedade complexa e plural; o volume de interesses metaindividuais polarizados e as decisões com efeitos sistêmicos; pelos constantes desmandos frente ao ordenamento constitucional, em especial, a necessidade e legitimidade de intervenção judicial nas políticas públicas, atos e condutas da Administração, no sentido de fazer cumprir normas assecuratórias e de conteúdo fundamental, não implementadas pelo Poder Público, dentre tantas outras.

Ressalta Boaventura de Souza Santos, a frustração gerada na sociedade, que tinha grandes expectativas em relação ao sistema judiciário, decorrente da visibilidade pública e mediática do protagonismo judicial, mas que na realidade, não ocorreram; ao contrário, em sua opinião ocasionou a crise, é o que revela em artigo público na revista do Ministério Público: "E é exatamente esta disjunção entre as expectativas e o desempenho real que cria a crise" (2000).

Mancuso (2012, p. 194) chama atenção para a sobrecarga excessiva no sistema de juizados especiais, devido a demandas reprimidas, o que provocou colapso nessa instância, já que apresente índices de congestionamentos parecidos com os da justiça de primeiro grau.

Inobstante a administração do crescente número de processos judiciais, revela-se de repercussão importante o enfrentamento para o juiz natural, no cumprimento de seu mister, o fato do quantitativo expressivo de legislações sobre os temas variados, cujos textos tentam abarcar e delimitar fatos, juridicizando-os sobremaneira, seja pelo legislativo, seja pela Administração Pública. Todavia, como bem salientado por Mancuso ${ }^{1}$ (2012), essa produção exacerbada de normas brasileiras não significa a solução de problemas sociais, pois os mesmos persistem a incidir nas artimanhas para burlar e evadir-se do cumprimento das mesmas, afirmando: "Tal estado de coisas evidencia ser verdadeira a (desoladora) afirmação de Jean Cruet: "Vê-se todos os dias a sociedade reformar a lei; nunca se viu a lei reformar a sociedade"" (2012, p. 63).

\footnotetext{
${ }^{1} \mathrm{O}$ autor fala numa compulsão normativa e enfatiza que fúria legislativa "é onipresente, não poupa nenhum tema, ocorrência ou situação fática ou jurídica, e não dá mostras de arrefecer, chegando à culminância de consentir a edição de normas cujo objetivo é alertar para a necessidade de serem cumpridas outras normas pré-existentes (!), desprezando-se o milenar aviso de que a lei se presume conhecida (ignorantia Iegis neminem excusat)" (2012, p. 63)
} 
O fenômeno contemporâneo da nomogênese $e^{2}$ compartilhada, que dá vazão a que órgãos e instâncias diversos, além do legislativo, venham a produzir normas, dificulta a missão de interpretação judicial. A vasta gama de normas legais, judiciais e administrativas que juiz natural se depara, enseja possibilidades de interpretação múltiplas, em virtude de redações truncadas, de valores isolados nos textos, sejam políticos, econômicos e culturais, de incompletude no teor do instrumento, tudo resultando num esforço maior do julgador para desconstruir as vicissitudes encontradas e delimitar os aspectos jurídicos, de modo a identificar o direito.

Esse mesmo juiz natural deve entregar a sua prestação adequada e justa em prazo razoável, a fim de atender o comando constitucional da razoável duração do processo, inserto na Constituição Federal, por meio da Emenda Constitucional $n^{\circ} 45$, que inseriu o inciso LXXVIII do artigo $5^{\circ}$, evitando-se o perecimento do objeto salvaguardado.

Conclui-se que se faz necessário, além dos requisitos do princípio do Juiz Natural (competente, imparcial e independente), a pessoa que desempenha a função jurisdicional deve ser também um juiz sobrenatural, para atender adequadamente a norma constitucional.

Para suprir essas necessidades, a política judiciária nacional, por meio de construção jurisprudencial, vem adotando postura flexibilizadora para aplicação do princípio do Juiz Natural, que como, todo princípio fundamental, não é absoluto e admite ponderação.

Da análise de julgados que questionam ofensa ao Juiz Natural, observa-se a tendência de privilegiar a celeridade do processo, no afã de legitimar a política de redução do quantitativo de processos, em detrimento dos pressupostos principiológicos do Juiz Natural, o que tem levado, não a uma ponderação entre princípios, mas à exclusão dos aspectos formais circunscritos ao Juiz Natural, com ofensa direta a esse princípio tão caro à democracia e a história dos direitos fundamentais.

Decisões dos Tribunais Superiores vem convalescendo normas administrativas que investem juízes para julgar processos, ainda que a competência não tenha sido reservada por

\footnotetext{
${ }^{2}$ Afirma Mancuso que: "nomogênese não mais se concentra exclusivamente na função legislativa do Estado ( $a$ poiicy determination, na terminologia norte-americana), mas está compartilhada, senão já pulverizada em diversas fontes, podendo ser lembrada a lei de iniciativa popular $(\mathrm{CF} / 1988, \S 2.0$ do art. 61), a proliferação das ordens jurídicas menores, assim ao interno da Administração Pública (decretos, portarias, normatizações decorrentes da atuação de ofício, do poder de polícia ou do poder regulamentar) como do Judiciário (regimentos internos, resoluções, 'normações derivadas do autogoverno da magistratura), tudo levando a que a outrora rígida separação entre os Poderes hoje esteja convertida a pouco mais do que uma referência histórica. Isso se deveu, principalmente, ao gradual reconhecimento do exercício de funções atípicas por parte de cada um dos Poderes, a par daquelas que constituem o espaço precípuo de cada qual: legislar, julgar, administrar. op. Cit. p. 230
} 
lei ${ }^{3}$. É o que se verifica em julgados que trataram de mutirões judiciários ${ }^{4}(\operatorname{Resp} 389516 / \mathrm{PR}, \mathrm{RE}$ 413898/SC), convocação de juízes para compor turmas colegiadas nos Tribunais Superiores ${ }^{5}$ (Tema de Repercussão Geral no 1706), ainda que de forma majoritária (STJ - HC 120652-SP7).

Em todos os julgados, evidencia-se a prevalência da celeridade processual e o manejo massivo de processos e recursos como estratégia pragmática da política judiciária para evitar a morosidade dos processos.

Mas, indaga-se, em outro viés, quanto ao aspecto qualitativo e de justiça como fim e objetivo da tutela jurisdicional, que se espera um resultado desenvolvido de acordo com os critérios democraticamente fixados, não se concebendo uma prestação justa se não houver a garantia da determinação imparcial, objetiva e prévia, que é reservada por lei, desenvolvida a partir da construção histórica da modernidade, para determinar qual a pessoa física que deverá atuar no processo, investida no poder estatal que irá subjugar uma das partes.

A política judiciária aparenta realizar boas ações para concretizar julgamentos de processos. Porém, ações desprovidas de roupagem legislativa caminham em sentido oposto à imparcialidade, isenção e igualdade quista pela sociedade moderna nas causas judiciárias. A reflexão de muitos autores, como Leonardo Carneiro (2008), é no sentido de que a garantia do Juiz Natural é fundamental para que o processo decisório não dependa da boa vontade dos homens ou daquele que vai julgar, pois deve fazê-lo nos estritos termos da lei.

\section{A tendência de padronização de decisões judiciárias e a disponibilidade de recursos tecnológicos}

\footnotetext{
${ }^{3}$ Para saber mais, vide tese de mestrado apresentada à banca da Universidade Federal da Bahia, de Edval Borges da Silva Segundo. Conteúdo e Aplicabilidade do Princípio do Juiz Natural, 2009. Disponível em: $<$ https://repositorio.ufba.br/ri/bitstream/ri/9293/1/Edval\%20Borges\%20da\%20Silva\%20Segundo.pdf $>$

${ }^{4} \mathrm{O}$ julgamento de processos por meio de mutirões promovidos pelo Conselho Nacional de Justiça, desloca juízes que, originariamente, não detém competência ou atuam no processo, mas que passam a ser investidos a partir de norma administrativa, por meio de designação posterior.

${ }^{5}$ Nos julgados em relação à convocação de juízes singulares para atuar em tribunais superiores, a análise jurisprudencial é pela uma exceção à regra de julgamento ordinário, ou seja, os processos de competência dos tribunais, independente de ser originária ou não, devem ser julgados ordinariamente pelo colegiado composto pelos membros do respectivo tribunal. A atuação estaria legitimada pelo fato de haver regras de convocação previa e objetivamente estabelecidas, o que se garantiria a independência e a imparcialidade do órgão judicante.

${ }^{6}$ No exame do RE 597.133/RS, cujo julgamento serviu de paradigma ao Tema de Repercussão Geral no 170 , o Ministro Ricardo Lewandowski entendeu ser louvável o escopo de desafogar ao Tribunal a quo, e de materializar o ideal de uma prestação jurisdicional célere e efetiva, tendo analisado a EC 45/2004, que estabelece a duração razoável do processo e determinou a distribuição imediata dos processos aos Tribunais. $\mathrm{O}$ entendimento exarado no sentido de que, considerando o sistema judiciário preestabelecido, a LC 35/89 admite a convocação de juízes, em caráter excepcional e transitório.

${ }^{7}$ No HC 84.414/SP, o Ministro Ayres Brito consignou a não ofensa ao Juiz Natural em julgamento de composição majoritária de juízes de primeiro grau em turmas julgadores de Tribunais, afirmando que "Quando a turma julgadora é composta, na sua maioria, por convocados, há um risco de se fugir da tendência do Tribunal, daí a dizer que o princípio constitucional do Juiz Natural restou vulnerado, parece-se que vai uma distância"
} 
Analisada a política judiciária, passemos a verificar as investidas legislativas para inovar o processo judicial a fim de dar maior dinamicidade e celeridade, de modo a engendrar uma resposta satisfatória em tempo hábil aos jurisdicionados, como esperado pela sociedade.

Em que pese a constituição do sistema jurídico brasileiro estar definida inicialmente como civil law, de tradição romana-germânica, levando em conta que o primado de direitos e obrigações situa-se na norma legal, de acordo com o inc. II do artigo $5^{\circ}$ da Constituição Federal, possuindo um aparato de legislações em vigor, vimos nas últimas décadas, a forte e crescente tendência de implementação de mecanismos próprios do sistema common law, no qual vigora o precedente judiciário (binding precedentes), caracterizados pela intensificação dos efeitos de decisões judiciárias, formando um arcabouço jurisprudencial vinculativo.

A súmula vinculante (EC 45/2004: art. 103-A e parágrafos) é um instituto que demonstra claramente essa nova perspectiva processual e a transição do regime jurídico-político brasileiro, em relação à primazia da norma legal aos comandos jurisprudenciais, com intuito de possibilitar que os efeitos do julgado de caso paradigma venham a incidir e irradiar em vários outros processos, de modo a resolver demandas com maior celeridade.

Outros institutos que visam limitar e uniformizar jurisprudência com o fito de criar padrões de julgamento para causas ditas por repetitivas e similares são o incidente de uniformização, os quais congelam causas à espera da decisão que venha a ser aplicada em todas elas, de modo a encurtar o processo judicial. Cite-se, ainda, o protagonismo do Relator nos Tribunais superiores, a quem é confiado poderes para julgar o recurso de forma monocrática, ensejando a resolução rápida e certeira.

Portanto, Mancuso (2012, p. 171) assevera que a vinculação dos precedentes é uma realidade de padronização das decisões judiciais. O juiz natural da causa deve estar apto a replicar a solução de conflitos de acordo com a ratio decidendi dos precedentes, dela não podendo se afastar por lhe ser cogente.

Contudo, a tarefa de identificar o elemento vinculante também é um desafio para o juiz natural, pois nem sempre é clara a enunciação fixada pelo tribunal, havendo necessidade de interpretação para verificação de aplicação do padrão decisório; outra questão, é a mudança de posicionamento de um mesmo tribunal, ocasionando por vezes, insegurança jurídica; por outro lado, o fenômeno dialético e complexo dos fatores históricos, culturais e sociais deixam de ser analisados pelo juiz natural, o que pode causar o engessamento e distanciamento das decisões em relação à realidade fática. 
Revela-se que a padronização obtida é valorizada e vem sendo possibilitada com o uso de recursos tecnológicos, ferramentas de buscas, catologação de julgados e teses nos sítios dos tribunais, desenvolvimento de sistemas aperfeiçoados para a captura de elementos identificadores, capazes de selecionar jurisprudências correlatas, tudo com o slogan de dar maior uniformidade às decisões, o que possibilita a igualdade de soluções para os diferentes litigantes em qualquer juízo.

O parque tecnológico disponibilizado para o ramo judiciário realizou inúmeras transformações no processo judicial, com alterações de procedimentos, de forma a automatizálos e otimizá-los no intuito de assegurar um trâmite fluido e mais econômico. Ferramentas de gestão de processos e disponibilização de autos eletrônicos em tempo real, interligação de partes e realização de diligências e interrogatórios virtuais são benefícios conquistados nas demandas brasileiras.

Festeja-se o aspecto imparcial decorrente de um sistema objetivo e abstrato de precedentes que pode determinar a solução adequada para os casos similares e agilizar procedimentos, através das políticas judiciárias que vêm prestigiando a eficiência conjugada à celeridade processual.

A previsibilidade das decisões judiciais é fator que cativa a população, tão desgastada com a morosidade e a desconfiança em relação a tratamento anti-isonômico de jurisdicionados.

Porém, nem sempre o aparato disponibilizado para o tratamento massivo de processos, por meio de índices sofisticados, significa a imparcialidade e a isonomia pretendida, pois a atividade de interpretação permanece centrada na figura do juiz, razão pela qual devem sempre ser resguardadas as garantias fundamentais intrínsecas ao princípio do juiz natural.

\section{Inteligência artificial e a função judicante automatizada - consequências ao princípio do juiz natural}

O termo Inteligência artificial foi cunhado em meados de 1950, nos Estados Unidos, quando pesquisadores lançaram um projeto de rede neural, sob a coordenação do americano Marvin Minsky, tendo por marco uma conferência ocorrida em 1956, na cidade de Hanover, em New Hampshire.

Inicialmente, os computadores competiam com a inteligência humana e a forma de medir essa inteligência era, comumente, por meio de resolução de jogos de tabuleiro ou de perguntas e respostas. Em 2011, dois campeões humanos foram vencidos pelo computador 
Watson (sistema de inteligência artificial da IBM), num programa de TV americano; o computador Deep Bue (IBM) venceu Garry Kasparov no xadrez.

O avanço das pesquisas do poder artificial começou a despontar nas décadas de 1980 e 1990, com a inovação de recursos de reconhecimento de voz, imagem e letras. A partir da última década, grandes empresas de tecnologia vêm apostando no avanço da IA (Inteligência Artificial), o que engendrou financiamentos consideráveis para o progresso dos sistemas, que tem alcançado êxito em diversas áreas.

Um dos objetivos de experimentos de programações modernas é a simulação do comportamento humano, trazendo interações com noções de inteligência, raciocínio e criatividade, de modo a possibilitar que a máquina virtual tenha uma atuação autônoma e independente. A finalidade buscada é propiciar o aprendizado da máquina, machine learning, para o desempenho de tarefas sem a interferência humana.

Vemos a tecnologia aplicada em interfaces virtuais de programas de internet, automação de indústria de carros autônomos (self-driving cars) e todos os derivados: GPS, radares, câmeras; assistentes pessoais de sistemas operacionais, tais como smartphones; reconhecimento de palavras em tradutores, serviços variados e fixação de diagnósticos médicos.

Pois bem, como visto no título anterior, a inteligência artificial já se faz presente na seara jurídica, mas não está limitada apenas a otimizar procedimentos e facilitar buscas, a potencialidade virtual vem sendo testada ao longo dos últimos anos, na promessa de ser possível oferecer decisões, ainda que não padronizadas, no cumprimento de metas judiciárias e de antever futuras demandas judiciais com base em acontecimentos e comportamentos humanos.

É fato que a automação já se faz presente em escritórios de advocacia, procuradorias e promotorias, nas quais plataformas virtuais geram automaticamente as peças processuais com a inserção objetiva de dados, a partir de caracterizações predefinidas.

Noutro viés, a capacidade limitada do judiciário, concentrada na função jurisdicional exercida pela pessoa física do juiz natural, pode ser somada à virtual para atender aos superpoderes exigidos ao juiz, nos comandos constitucionais, com o objetivo de exercer suas atribuições de modo imparcial, independente, competente e célere.

Essas premissas do exercício da função judicante vêem encetando esforços para aproveitamento da inteligência artificial também na tarefa de julgar. O sistema de gestão da automação do judiciário já vem sendo gestado no sentido de buscar soluções virtuais, trata-se de uma jurimetria artificial, de modo a permitir plataformas que possibilitem antever possibilidades, mensurar fatos jurídicos e calcular probabilidades. 
A promessa já se faz visível no Tribunal de Justiça São Paulo, com a implementação do software e-SAJ (Sistema de Automação da Justiça), business inteligence, que incialmente pretende dar solução auxiliar na administração judiciária.

O equipamento tecnológico é propício à tendência contemporânea de padronização de decisões e foi apresentado como um assessor virtual do juiz, de acordo com o que explica o analista de negócios Alexandre Golin, da empresa Softplan ${ }^{8}$, em notícia veiculada.

O sistema possui base de dados suficiente com capacidade para analisar a jurisprudência determinante e de aprender padrões de comportamento com base nas informações que os magistrados incluem no sistema. $\mathrm{O}$ maquinário virtual que vem sendo desenvolvido agrega computação cognitiva para desenvolver o conhecimento de linguagens e padrões jurídicos, somado à interação com seres humanos.

$\mathrm{O}$ avanço da IA incide num aperfeiçoamento a se equiparar à inteligência humana no julgamento de processos.

Em pesquisa realizada em relação aos julgados da Suprema Corte americana, em casos entre os anos de 1953 e 2004, o acerto de decisões propostas pelo computador foi de $83 \%$. Em 2004, computados os votos de nove juízes que compunham a corte desde 1994, houve acerto de 75\%, em amostragem dos anos de 2002 a 2003. Experimentos também anteveram resultados de 584 casos do Tribunal Europeu dos Direitos Humanos, com acerto de 79\%. ${ }^{9}$

Notícia da revista Veja ${ }^{10}$ revela publicação da revista científica Plos One, em abril de 2017, relatando um experimento de desenvolvimento de algoritmo que possibilitou computadores a prever decisões tomadas pela Suprema Corte dos Estados Unidos, com acerto de $70,2 \%$ dos casos julgados entre os anos de 1816 e 2015 .

Assim, há disponibilidade tecnológica para comparativos de casos e proposta computadorizada para o desfecho de processos judiciais, com possibilidade de controle humano, a partir de relatórios estatísticos que demonstram como o sistema chegou ao veredicto.

Soma-se à oferta de programas virtuais de inteligência artificial, a potencialização hodierna da função paradigmática da jurisprudência brasileira, o que torna atrativo a implantação de sistema virtual com capacidade para analisar precedentes, de acordo com a base

\footnotetext{
${ }^{8}$ Vide notícias: Disponível em: <https://www.conjur.com.br/2017-ago-26/robos-permitem-juizes-deixem-ladofuncao-gestor>, acesso em 03.abr.2018; <http://politica.estadao.com.br/blogs/fausto-macedo/a-judicializacao-naera-da-inteligencia-artificial-cotidiana/>, acesso em 03.abr.2018

$9 \quad$ Fonte: $\quad<$ https://www.nexojornal.com.br/explicado/2017/02/07/Intelig\%C3\%AAncia-artificial-entre-apr\%C3\%B3xima-revolu $\% \mathrm{C} 3 \% \mathrm{~A} 7 \% \mathrm{C} 3 \% \mathrm{~A} 30$-tecnol $\% \mathrm{C} 3 \% \mathrm{~B} 3$ gica-e-o-fim-da-humanidade>, acesso em 03.abr.2018

10 Disponível em: <https://veja.abril.com.br/ciencia/algoritmo-supera-juristas-ao-prever-decisoes-da-justicaamericana/>. Acesso em 03.abr.2018
} 
de dados comportada e viabilizar uma ou algumas minutas de decisões, para atender à solução de acordo com o ordenamento jurídico e precedentes, encontrada pela máquina.

A minuta do juiz artificial pode ser comemorada se o no resultado obtido verificar-se uma aplicação isonômica, imparcial, a partir de um banco de dados alimentado de maneira a propiciar uma contextualização de julgamentos, eliminando-se a instabilidade e oscilação próprios da pessoa humana. Diminuição desses riscos indesejáveis na produção de decisões judiciais, de modo a privilegiar a previsibilidade do sistema e prestigiar precedentes, são méritos desejáveis pela sociedade democrática.

Futurólogos como Richard e Daniel Susskind ${ }^{11}$ pesquisaram acerca da forma como a internet vem transformando profissões e preveem um futuro de uma sociedade da internet, onde os serviços on line preponderam, com a substituição gradual de profissionais por sistemas.

Questiona-se se o uso dessa tecnologia pode ofender o princípio do juiz natural, considerando o papel integrativo na sociedade e a hermenêutica jurídica.

Pois bem, para responder ao questionamento do trabalho, construídas as premissas iniciais, é preciso fixar dois momentos distintos, um atual e outro previsível.

No momento atual, em que verificamos que a inteligência artificial é criada com a capacidade de auxiliar o juiz natural, propondo opções de julgamento, não identificamos ofensa ao princípio do juiz natural, posto que a função de julgamento continua concentrada no poder do juiz ordinário, fixado previamente, mediante distribuição aleatória e de forma objetiva, garantindo-lhe a solução que entender justa e adequada.

Na mesma ideia de Mancuso, a decisão implica sempre a escolha de uma solução entre as diversas possíveis, nessa hipótese, permanece preservada a escolha do juiz natural, incidindo num recurso de curadoria de dados.

Num outro momento, previsível, imaginário ou futurista, verificado o aperfeiçoamento da inteligência artificial aplicado aos casos judiciais, a história da humanidade vem demonstrando a transmutação da tarefa de auxilio destinada aos instrumentos tecnológicos, em instrumentos imprescindíveis para a conclusão das ações, passando de meros auxiliares para verdadeiros executores.

O que se delineia nesta fase, é a possibilidade de o juiz natural deixar de ser a pessoa física para se tornar a máquina, na medida em que a opção virtual seja a preferencial e haja discordância pelo juiz natural em relação ao resultado apresentado pela inteligência artificial.

\footnotetext{
${ }^{11}$ Temas explorados nas obras dos autores: "The End of Lawyers", "The Future Of The Professions", "Tomorrows Lawuers", "Transforming The Law".
} 
Observe-se que a apresentação da escolha virtual é desenvolvida por algoritmos de forma concatenada, passível de análise relatorial que ordenada fatos, provas, partes, precedentes, leis, portanto, com um aparato procedimental de racionalização artificial, para determinar a validade das respostas.

Logo, a não aceitação da minuta proposta pela máquina pode gerar o dever de motivação do juiz ordinário para a rejeição do raciocínio artificial, tirando-lhe assim, a função judicante inicial de escolha, submetida, desta vez, a uma justificativa por não ter seguido o proposto virtual.

Essa consequência permite ser vislumbrada na tendência de controle e validade da sociedade moderna, onde será possível antever qual a resposta que será fornecido pelo computador, em virtude da uniformização de jurisprudências.

Assim, a decisão do juiz natural, propriamente dita, pode tornar-se complexa e problemática na tentativa de desconstituir a solução virtual, passando a ser a inteligência artificial o juiz ordinário da causa.

\section{Considerações finais}

Após todas as considerações feitas, evidenciam-se as seguintes ideias construídas:

O princípio do Juiz Natural consubstancia-se como um direito e garantia fundamental inserido na cláusula maior do devido processo legal, tendo sido construído no contexto histórico da modernidade, como um princípio caro para a consecução de uma decisão justa e adequada, a partir da determinação de critérios objetivos, prévios e imparcial para a fixação da competência do juiz vinculado à causa.

A tarefa interpretativa do juiz ordinário deve estar concatenada com os escopos processuais de realização do Estado Democrático de Direito, somado às suas percepções de vida e a dinamicidade da realidade fática, plural e multifacetária.

Todavia, a crise judiciária brasileira, vem desafiando a política pública judiciária a inovar na condução e julgamento dos processos, dando feições mais dinâmicas e de limitação dos recursos, em virtude das estatísticas quantitativas que atravancam o processo.

Observou-se que a jurisprudência pátria vem adotando postura institucional no sentido de dar preferência à celeridade judicial em detrimento às regras objetivas de definição do juiz ordinário para a causa, sem contudo, refletir as consequências dessas decisões que violam o princípio do juiz natural. 
A padronização inserida na legislação de institutos de vinculação de precedentes, oportuniza a previsibilidade de decisões em casos repetitivos e similares, de modo a permitir a uniformização de jurisprudência. Esse panorama das decisões judiciais, permite a utilização de recursos tecnológicos, com ferramentas capazes de assimilar o conteúdo de precedentes e escolher a melhor opção para a concretização da prestação do juiz natural.

$\mathrm{O}$ avanço da política judiciária sem impor limites de eticidade e garantias dos direitos fundamentais processuais pode gerar distorções no conteúdo das decisões, deixando de ser justas e adequadas.

A inteligência artificial como ferramenta não só de gestão de processos, mas também de cognição para a tarefa jurisdicional de decidir vem sendo implementada e desenvolvida. Contudo, a história nos mostra a trajetória evolutiva da máquina na sociedade: primeiro a máquina vem para auxiliar, porém, num momento posterior, diante dos aperfeiçoamentos, já se torna imprescindível e de difícil superação.

Assim, a inteligência artificial pode tomar o lugar do juiz natural do processo, na medida que tornar necessário que o mesmo justifique porquê não optar pelo provimento virtual, composto de racionalidade artificial demonstrada em relatórios, e tiver que justificar o repúdio à previsibilidade apresentada pela máquina, cujo controle será realizado pela própria sociedade.

Portanto, nessa fase, pode ser verificada uma ofensa ao juiz natural, na medida em que a competência de julgamento do juiz ordinário passa a ser, precipuamente, do juiz artificial.

\section{Referências bibliográficas}

ALVES, Wilson de Souza. Acesso à Justiça: conceito, problemas e a busca da sua superação. Evocati revista n. 42, Aracaju, jun. 2009. Disponível em: $<$ http://www.evocati.com.br/ evocati/interna.wsp?tmp_page $=$ interna\&tmp_codigo $=332 \& \mathrm{tmp} \_$secao $=15 \& \mathrm{tmp}$ topico $=$ direit oproccivil\&wi.redirect=TSYF3OORMKDXVA6XL7J B>. Acesso em: 03 abr. 2018.

\section{BUENO, Cassio Scapinella. Curso sistematizado de direito processual civil: teoria geral}

do direito processual civil, vol. 1. 8. Ed.. rev. e atual. São Paulo: Saraiva, 2014.

CAMARGO, Magarida Maria Lacombe. Hermenêutica e Argumentação - Uma

Contribuição ao Estudo do Direito. 3 ed rev. e atual. RJ: Renovar, 2003. 
CANOTILHO, José Joaquim Gomes. Estudos sobre Direitos Fundamentais. São Paulo: RT, 2009.

CAPPELLETTI, Mauro; GARTH, Bryant. Acesso à justiça. Tradução de Ellen Gracie Northfleet. Porto Alegre: Sérgio Antonio Fabris, 1988.

COMPARATO, Fábio Konder. A Afirmação Histórica dos Direitos Humanos. 8. Ed. São Paulo: Editora Saraiva, 2013.

CUNHA, Leonardo José Carneiro da. Jurisdição e Competência. São Paulo: Revista dos Tribunais, 2008.

DAVENPORT, Thomas H. Big data no trabalho: derrubando mitos e descobrindo oportunidades. Rio de Janeiro: Elsevier, 2014.

DIDIER JR., Fredie. Curso de Direito Processual Civil. Introdução ao Direito Processual Civil e Processo de Conhecimento. Vol. 1. 15 ed. Salvador: Editora JusPodivm, 2013.

DINAMARCO, Cândido Rangel. Tutela jurisdicional: fundamentos do processo civil moderno, t. II, 3 ed., São Paulo: Malheiros, 2000.

HOLLIDAY, Gustavo César de Mello; HOLLIDAY, Pedro Alberto Calmon. A gestão de demandas repetitivas e as técnicas uniformizadoras: uma promessa de racionalização dos julgamentos. In: XXIV Encontro Nacional do CONPEDI - UFS, 2015. Disponível em Acesso em: 12 nov. 2015.

MANCUSO, Rodolfo de Camargo. Acesso à Justiça. Condicionantes Legítimas e Ilegítimas. Editora Revista dos Tribunais. São Paulo: 2012.

MARINONI, Luis Guilherme. Novas linhas do processo civil. 4. ed. São Paulo: Malheiros, 2000.

MAZZUOLI, Valerio de Oliveira. Curso de Direito Internacional Público. 5 ed. rev., atual. e ampl. São Paulo: Editora Revista dos Tribunais, 2011. 
NUNES, Marcelo Guedes. Jurimetria: como a estatística pode reinventar o direito. Revista dos Tribunais, 2016.

PESSOA, Flávia Moreira Guimarães. Organizadora. Constituição e Processo. Aracaju: Evocati, 2014.

SANTOS, Boaventura de Sousa. Introdução à sociologia da administração da justiça. In Revista de Processo. São Paulo: Revista dos Tribunais, 1985, vol. 37. , Boaventura de Souza. Que formação para os magistrados nos dias de hoje. Revista do Ministério Público Lisboa: $3^{\circ}$ trimestre, 2000.

SARLET, Ingo Wolfgang. Dignidade da pessoa humana e direitos fundamentais na Constituição Federal de 1988. 9. ed. Porto Alegre: Livraria do Advogado, 2011.

SARMENTO, Daniel. Direitos fundamentais e relações privadas .2. ed. Rio de Janeiro: Lúmen Júris, 2006.

SILVA SEGUNDO, Edval Borges da. Conteúdo e Aplicabilidade do Princípio do Juiz Natural. Tese de mestrado apresentada à banca da Universidade Federal da Bahia, 2009. Disponível em: <https://repositorio.ufba.br/ri/bitstream/ri/9293/1/Edval\%20Borges \%20da\%20Silva\%20Segundo.pdf. Acesso em: 05 dez.2017.

TARUFFO. Michele. Uma simples verdade. $O$ juiz e a construção dos fatos. Tradução de Vitor de Paula Ramos. Disponível em: <http://www.marcialpons.com.br/wpcontent/uploads/2014/03/L-06_tira-gosto_Uma-simples-verdade-o-juiz-e-a-construcao-dosfatos-Michele-Taruffo.pdf>. Acesso em 05 dez.2017 


\title{
O MAGISTRADO GESTOR ESTRATÉGICO DE UNIDADES JUDICIÁRIAS
}

\author{
Adriano da Silva Ribeiro \\ PPGD/FCH da FUMEC e UMSA
}

\begin{abstract}
Resumo
Com a elaboração deste artigo, espera-se contribuir para a discussão e reflexão sobre o aperfeiçoamento da prestação jurisdicional, exercida por Juiz de Direito, com perfil de Gestor Judicial Estratégico. Evidenciam-se, assim, que o emprego dos modelos de administração, organização, gestão, planejamento estratégico e liderança, extraídos da Ciência da Administração e, portanto, aplicados na estrutura administrativa e judicial afeta positivamente, além de evidenciar e viabilizar aplicação do princípio da eficiência. Constata-se que o juiz não está somente para julgar, mas, para gerenciar, liderar e melhorar a atuação administrativa, com a finalidade de a função jurisdicional ser mais eficiente.
\end{abstract}

Palavras-chave: Poder Judiciário, Morosidade processual, Ciência da Administração, Juiz de Direito, Gestor Judicial Estratégico.

\begin{abstract}
Resumen/Résumé
With the elaboration article, it is hoped to contribute to discussion and reflection on the improvement of the judicial performance, exercised by Judge of Law, with profile of Strategic Judicial Manager. Thus, the use of models of administration, organization, management, strategic planning and leadership, extracted from Science of Administration and, therefore, applied in administrative and judicial structure, positively affects and makes possible application of the principle of efficiency. It is noted that judge is not only to judge, but to manage, lead and improve the administrative performance, in order for the jurisdictional function to be more efficient.
\end{abstract}

Keywords/Palabras-claves/Mots-clés: Judicial Power; Procedural delays; Administration Science; Judge of Law; Strategic Judicial Manager. 


\section{Introdução}

Com a elaboração deste artigo, espera-se contribuir para a discussão e reflexão sobre o aperfeiçoamento da prestação jurisdicional, exercida por Juiz de Direito, com perfil de Gestor Judicial Estratégico.

No Brasil, extrai-se do Relatório Justiça em Números, quanto à gestão judiciária e litigiosidade, que o Poder Judiciário finalizou o ano de 2016 com aproximadamente 80 milhões de processos em tramitação. Durante o ano de 2016, o estoque de processos cresceu em 2,7 milhões, ou seja, em 3,6\%, e chegou ao final do ano de 2016 com 79,7 milhões de processos em tramitação aguardando alguma solução definitiva (Justiça em Número, 2017, p. 65).

Nesse contexto, o presente artigo busca, objetivamente, avaliar se o Magistrado na sua Unidade Judiciária, ao utilizar os modelos extraídos da Ciência da Administração, quais, sejam, administração, organização, gestão, planejamento estratégico e liderança, melhorará a estrutura administrativa e judicial. Objetiva, também, certificar se esses modelos afetarão, positivamente, na prestação jurisdicional.

A importância do tema avulta, especialmente, pois ainda há consenso sobre o problema da morosidade na prestação jurisdicional, a exigir dos magistrados atuação, firme, com o propósito de viabilizar práticas de gestão para aperfeiçoar a tramitação de um processo judicial.

Para o desenvolvimento do trabalho, utiliza-se o método dedutivo, com base na pesquisa bibliográfica e exploratória.

Este trabalho estrutura-se, partindo, inicialmente, de uma caracterização da prestação jurisdicional e o que se cunhou de morosidade. A seguir, examinar-se-á a situação do magistrado, a fim de saber se está somente para julgar ou para gerenciar, liderar e melhorar a atuação administrativa e jurisdicional. Nas considerações finais, procurar-se-á sintetizar o estado atual do tema.

\section{Morosidade na prestação jurisdicional}

O enfoque do tema morosidade, a ser estudado neste capítulo, perpassará pela compreensão do que seja prestação jurisdicional e para as causas da morosidade, também acerca da necessária intervenção do Juiz para uma razoável duração do processo.

\subsection{Prestação Jurisdicional}


Cabe ao Poder Judiciário, no Estado Democrático de Direito, a tarefa de prestar jurisdição, tendente à pacificação dos conflitos sociais. Cappelletti e Garth, na obra "Acesso à justiça", no intuito de buscar o conceito de acesso à justiça, como meta maior de garantia de tutela jurisdicional assegurada aos cidadãos, afirmaram:

\begin{abstract}
A expressão "acesso à justiça" é reconhecidamente de difícil definição, mas serve para determinar duas finalidades básicas do sistema jurídico - o sistema pelo qual as pessoas podem reivindicar seus direitos e/ou resolver seus litígios sob os auspícios do Estado.

Primeiro, o sistema deve ser igualmente acessível a todos; segundo, ele deve produzir resultados que sejam individual e socialmente justos. (CAPPELLETTI e GARTH,1988, p. 8)
\end{abstract}

É oportuna a lição de Watanabe, vez que não se pode estudar o tema simplesmente em decorrência de acesso aos órgãos judiciais existentes. Em razão disso, afirma que "não se trata apenas de possibilitar o acesso à Justiça enquanto instituição estatal, e sim viabilizar o acesso à ordem jurídica justa”. (WATANABE, 1988, p. 128)

Defende Carmem Lúcia Antunes Rocha que não quer justiça amanhã. Quer-se justiça hoje. Logo, a presteza da resposta jurisdicional pleiteada no próprio conceito de direito-garantia que a justiça representa. E acrescenta:

\begin{abstract}
A liberdade não pode esperar, porque enquanto a jurisdição não é prestada, ela pode estar sendo afrontada de maneira irreversível; a vida não pode esperar, porque a agressão ao direito à vida pode fazê-la perder-se; a igualdade não pode esperar, porque a ofensa a este princípio pode garantir a discriminação e o preconceito; a segurança não espera, pois a tardia garantia que lhe seja prestada pelo Estado terá concretizado o risco por vezes com a só ameaça que torna incertos todos os direitos. (ROCHA, 1993, p. 37)
\end{abstract}

Mauro Cappelletti e Bryant Garth, já em 1978, quanto aos efeitos da espera de três anos ou mais, pelas partes, por uma decisão, asseveravam: “[...] Os efeitos desta delonga, especialmente se considerados os índices de inflação, podem ser devastadores" (CAPPELLETTI e GARTH,1988, p. 20).

\title{
2.2 Causas da morosidade
}


As principais causas da morosidade da Justiça são os excessos de processos; a falta de recursos materiais (espaço físico adequado, informatização, materiais de expediente); a deficiência de seus recursos humanos (número insuficiente de funcionários e de juízes); advogados mal preparados para o exercício da profissão; e a profusão de leis.

Registre-se que o Poder Judiciário vive uma crise, e o tema, de forma recorrente, nos últimos anos, está na agenda dos tribunais superiores, federais e estaduais, do Conselho Nacional da Justiça, dos magistrados, dos membros do Ministério Público, da mídia e da sociedade. Cobra-se e exige-se atuação transparente do Poder Judiciário, principalmente, focada nos resultados.

Assim, Luiz Umpierre de Mello Serra descreveu o quadro:

\begin{abstract}
A atuação do Judiciário como prestador de serviços era deficiente e deixava de apontar que não eram aplicadas técnicas de gestão. Destacava-se que a maior parte das serventias autuavam acima dos limites de suas capacidades produtivas, sofriam de uma sistemática carência de investimentos em organização, layout e de informática, e as estatísticas exibiam números grandiosos de demanda.

Após alguma análise diagnóstica, pôde-se perceber que ocorria manifesta a ausência de uma política pública, clara, transparente, objetiva, de contratação e movimentação de pessoal de treinamento específico dos servidores para o desempenho de suas atividades, de treinamento para o atendimento ao público, que levasse ao aprimoramento dos serviços prestados, visando torna-los mais simplificados, ao alcance e de fácil compreensão por aqueles de menor preparação técnica ou intelectual. (SERRA, 1996, p. 7-8)
\end{abstract}

Afirma Marcos Alaor Diniz Grangeia, a respeito da lentidão do sistema, já se falaram dos elementos gerados da ineficiência, quais sejam, anacronismo das leis, falta informatização, reduzidos orçamentos financeiros do Poder Judiciário. Esses fatores, entende, está relacionado a gestão ineficiente de recursos e meios para a solução dos conflitos (GRANGEIA, 2011, p. 6).

Existem, ainda, as causas estruturais.

Nas palavras de Dalmo de Abreu Dallari, as condições de trabalho de alguns juízes são precárias e incompatíveis em comparação com sua responsabilidade social. Relaciona isso a deficiência material, com destaque para as instalações físicas precárias até as obsoletas organizações dos feitos: o arcaico papelório dos autos, os fichários datilografados ou até manuscritos, os inúmeros vaivens dos autos, numa infindável prática burocrática de acúmulo de documentos (DALLARI, 1996, p. 156/157).

Ronaldo Brêtas de Carvalho Dias chama a atenção, no Brasil, para o fato de que não basta apenas produzir reformas na legislação para que a morosidade da atividade jurisdicional 
do Estado seja combatida. Para esse jurista, a solução reside na alteração da estrutura dos órgãos jurisdicionais, juízes em proporção adequada à população, recursos materiais suficientes, pessoal treinado e tecnicamente qualificado (DIAS, 2007, p. 218).

Sobre a cultura do litígio, percebe-se que o cidadão se encontra ansioso por uma solução mínima de sua demanda, a partir da decisão proferida por um juiz. Observa-se que a sociedade está acostumada e acomodada ao litígio e ao célebre pressuposto básico de que justiça só se alcança a partir de uma decisão proferida pelo juiz togado. Em muitas decisões, verificase que a aplicação pura e simples de previsão legal, o que explica o vasto universo de normas no ordenamento jurídico brasileiro. A atuação do Poder Judiciário, através da decisão judicial, é colocar em prática e aplicar as normas jurídicas para a regulação da sociedade (BRAGA NETO, 2003, p. 20).

Segundo Humberto Thedoro Júnior, ao se falar da demora em se alcançar um provimento judicial definitivo, sustenta, estamos falando de tempo, em alguns casos o tempo de uma vida. Mas o prazo (processual) - e sua plena observância - é um dos componentes que pode reduzir o tempo que o processo leva para chegar ao seu termo (THEODORO JÚNIOR, 2004, p. 223).

A propósito, a legislação processual brasileira já estabeleceu prazos para o Juiz cumprir, de modo a melhor aproveitar o tempo dos e para os jurisdicionados receberem a solução do litígio. Anote-se que os prazos, na prática, são fixados, mas, com conceito de prazos impróprios. Assim, para que o juiz profira decisões ou exare despachos. Esse conceito, historicamente, já estava inserido no Código de Buzaid.

Nessa perspectiva, Humberto Theodoro Júnior é da opinião de que:

São os atos desnecessariamente praticados e as etapas mortas que provocam a perenização da vida dos processos nos órgãos judiciários. De que adianta reformar as leis se é pela inobservância delas que o retardamento dos feitos se dá? A verdadeira reforma do Poder Judiciário começará a acontecer quando os responsáveis por seu funcionamento se derem conta da necessidade de modernizar seus serviços (THEODORO JÚNIOR, 2007, p. 213).

A demora crônica, nesse contexto, surge do descumprimento do procedimento legal.

\subsection{Intervenção gerencial do Juiz de Direito no Processo Judicial}


A lentidão do processo, como ressalta Renato Nalini, não é fenômeno exclusivamente brasileiro, mas, admite tratamento apropriado, a partir da consciência do juiz. A despeito da falta de estrutura material e da multiplicação de demandas, o magistrado pode conferir celeridade aos processos, desde que se sirva adequadamente dos fundamentos constitucionais e confira ao feito sua destinação instrumental (NALINI, 1997, p. 19).

Acerca da necessária intervenção do juiz no processo, asseveram Cappelletti e Garth que os juízes passivos, apesar de suas outras e mais admiráveis características, exacerbam claramente os problemas processuais, por deixarem às partes a tarefa de obter e apresentar provas, desenvolver e discutir a causa (CAPPELLETTI e GARTH, 1988, p. 22). Em suma, a burocratização do Judiciário, os longos prazos.

Sidnei Agostinho Beneti afirma que o juiz não deve ser responsável apenas pelo ato de julgar, mas também pelas atividades que se desenvolvem nas unidades durante a tramitação dos processos. De nada adiantaria os processos serem julgados pelos magistrados, trazendo soluções brilhantes, se estas chegarem tarde demais aos interessados, salienta o autor.

Bem claro o exemplo trazido por Sidnei Agostinho Beneti, no sentido de que o juiz pode ser também considerado profissional de produção, sendo imprescindível que mantenha um ponto de vista gerencial no aspecto da atividade judicial. Sustenta o autor que é falsa a separação estanque entre as funções de julgar e dirigir o processo. Alerta, nesse contexto, que o maior absurdo derivado desse nocivo ponto de vista dicotômico é a alegação que às vezes alguns juízes manifestam, atribuindo culpa pelo atraso dos serviços judiciários ao cartório que também esta sob a sua orientação e fiscalização (BENETI, 2003, p.12).

A estrutura física e a rotina do judiciário não sofrem alterações há muitos anos e, segundo Facchini (2007), justifica-se tal situação ao comodismo de muitos operadores do direito.

\subsection{Direito Fundamental: a Razoável Duração do Processo}

Com efeito, a inclusão formal e explícita no texto da Constituição Federal deu-se com a aprovação de Emenda Constitucional $\mathrm{n}^{\circ} 45$, ao inserir no art. 5º , inciso LXXVIII. Acrescentou, portanto, no Titulo II - Dos Direitos e Garantias Fundamentais, Capítulo I - Dos Direitos e Deveres Individuais e Coletivos, com a seguinte redação: 
Art. $5^{\circ} \ldots$

(...)

LXXVIII - a todos, no âmbito judicial e administrativo, são asseguradas a razoável duração do processo e os meios que garantam a celeridade de sua tramitação.

Seria, talvez, pensar que é o mais programático dos dispositivos sugeridos, que exigirá toda a regulamentação para definir e tornar eficaz a garantia enunciada. Assim, sucede que a expressão "razoável duração" do processo é indeterminada, visto que não fornece ao operador do direito critérios objetivos para a sua fiel aplicação.

Registre-se, nesse momento, a palavra de Humberto Theodoro Júnior, a propósito da Reforma do Poder Judiciário: "na pura realidade, não está no âmbito das normas jurídicas a causa maior da demora na prestação jurisdicional, mas na má qualidade dos serviços forenses”. Nessa linha de pensamento, "nenhum processo duraria tanto como ocorre na justiça brasileira se os atos e prazos previstos nas leis processuais fossem cumpridos fielmente" (THEODORO JÚNIOR, 2007, p. 213).

Afirma José Afonso da Silva que a celeridade processual seria uma garantia constitucional especial, haja vista que confere "aos titulares dos direitos fundamentais, meios, técnicas, instrumentos ou procedimentos para impor o respeito e a exigibilidade de seus direitos" (SILVA, 1996, p. 186).

Importante, nesse contexto, a manifestação de José Afonso da Silva, ao defender que:

\begin{abstract}
Ora, a forte carga de trabalho dos magistrados será, sempre, um parâmetro a ser levado em conta na apreciação da razoabilidade da duração dos processos a seu cargo. É, nesse contexto, que entra o outro aspecto da norma em análise, qual seja: a organização dos meios que garantam a celeridade da tramitação dos processos. A garantia de celeridade de tramitação dos processos constitui um modo de impor limites à textura aberta da razoabilidade, de sorte que, se o magistrado demora no exercício de sua judicatura por causa, por exemplo, de excesso de trabalho, a questão se põe quanto à busca de meios para dar maior celeridade ao cumprimento de suas funções, prevendo-se mesmo que o Congresso Nacional promova alterações na legislação federal objetivando tornar mais amplo o acesso à Justiça e mais célere a prestação jurisdicional (EC-45/2004, art. $7^{\circ}$ ).” (SILVA, 2007, p. 432/433)
\end{abstract}

Em princípio, a deficiente prestação jurisdicional revela imperfeição de um serviço público, que o Estado tomou para si o dever de prestar. Nesse sentido, alega-se que essa crise estaria a atingir os próprios operadores do direito, especialmente os magistrados, "impotentes diante da complexidade dos problemas que afligem o exercício da função jurisdicional, desdobram-se em greves e protestos de servidores; ricocheteia-se pelas páginas da imprensa e 
ressoa pelos anais de comunicação de massa, assumindo, dessa forma, dimensões alarmantes" (GRINOVER, 1989, p. 18).

Diante disso, aponta-se para o sentido de que a atividade judiciária continua praticamente estagnada há mais de século e, nos dias atuais, vem encontrando grande resistência no aprimoramento (STEIN JUNIOR, 2011, p. 18). Além disso, constata-se ausência de estabelecimento de rotinas de trabalho, destinadas a uma padronização dos serviços forenses.

Como se poder perceber, muitas críticas quanto à lentidão do processo, como ressalta Renato Nalini, não é fenômeno exclusivamente brasileiro, mas, admite tratamento apropriado, a partir da consciência do juiz (NALINI, 1997, p. 19).

\section{Práticas de gestão na tramitação de processo judicial}

A propósito da questão do acesso à Justiça, descumprimento do princípio da razoável duração do processo, necessidade de modernização da gestão judiciária, conforme demonstrado anteriormente. Nas palavras de Marcos Grangeia, a crise do Poder Judiciário, não pode ser observada apenas da atuação do magistrado, das partes ou da falência do instrumento legislativo em prevenir ou dirimir os conflitos. Alerta que "o viés da gestão administrativa do Poder Judiciário, do cartório ou de casos passou a integrar o cotidiano da discussão como perspectivas da solução para o problema da ineficiência do Judiciário Brasileiro" (GRANGEIA, 2009, p. 4).

Para Sálvio de Figueiredo Teixeira, a "transformação do Judiciário brasileiro é tarefa complexa e difícil". E acrescenta "mas é viável e imperiosa. Se quisermos todos, poderemos realizá-lo, com determinação e idealismo. A mesma determinação e o mesmo idealismo que de tempos em tempos têm mudado os horizontes do mundo em que vivemos" (TEIXEIRA, 2000, p. 319).

\subsection{Sistema de Administração Judiciária}

A análise realizada no item anterior, é suficiente para revelar que o Sistema de Administração Judiciária, está a exigir modernização da gestão judiciária. Porém, também mostra que a atuação do juiz de direito tem que ser desenvolvida, a permitir "ampliar e desenvolver um maior contingente técnico e pessoal" (VUCETIC, 2008, p. 45).

Evidentemente, são necessárias a união de outras áreas do conhecimento essenciais à judicatura, seja no recrutamento atual dos juízes, seja na prestação jurisdicional. Em particular, 
é preciso consolidar os parâmetros para a eficácia da aplicação do direito fundamental à razoável duração do processo no Sistema de Administração da Justiça.

Daí a pertinência de se examinar a possível contribuição dos modelos de organização e gestão, oriundos da Ciência da Administração. A palavra administração, ensina Chiavenato, vem do latim, "ad" que significa direção, tendência para, e "minister" que significa subordinação ou obediência, ou seja, quem realiza uma função sob o comando de outra ou presta serviço a outro.

No conceito de Administração, Antônio Maximiano ressalta ainda que: "significa em primeiro lugar ação. [...] é um processo dinâmico de tomar decisões e realizar ações”. Portanto, sustenta que "a administração é uma arte no sentido de profisssão ou área de ação humana. [...] As pessoas que administram organizações precisam de competências, que incluem diversas habilidades gerenciais" (MAXIMIANO, 2004, p. 35).

Segundo Reinaldo Silva, a administração consiste em "um conjunto de atividades dirigidas à utilização eficiente e eficaz dos recursos, no sentido de alcançar um ou mais objetivos ou metas da organização" (SILVA, 2013, p. 6).

Alexandre Costa de Luna Freire afirma, a respeito dos serviços judiciários, o que se aplica em todo o serviço público, que "a tendência é, todavia, convergente no sentido da paulatina discussão e implementação da interdisciplinariedade nos serviços públicos". Revela, ainda, que, "para atingir eficiência e eficácia como finalidade coletiva e individual, tem hoje desafios inéditos e entraves seculares inseridos na cultura social e coletiva" (FREIRE, 2004, p. $53 / 54)$.

Bem destacou Luiz Mello Serra:

O "Juiz Gestor" deve estar focado no futuro, de forma a poder preparar sua serventia para enfrentar os novos desafios que surgem, seja por meio de novas tecnologias, novas condições sociais e culturais e a par de novas modificações legislativas. Para levar sua serventia à excelência, o juiz deve ter espírito empreendedor, aceitar desafios, assumir riscos e possuir um senso de inconformismo sistemático (SERRA, 1996, p. 8.

E para exercer satisfatoriamente esse encargo, inegavelmente, o magistrado precisa do auxílio da Ciência da Administração e de técnicas administrativas modernas.

\subsection{O Planejamento na Gestão Administrativa Judiciária}


Nesse contexto, é plenamente possível afirmar que "o planejamento é imprescindível à gestão administrativa judiciária" (STEIN JUNIOR, 2011, p. 89). É importante ponderar que, em relação à efetividade da razoável duração, no âmbito do Poder Judiciário, necessária se faz identificar, no juiz de direito, o líder para fazer gestão nos processos sob sua responsabilidade e entre os servidores sob sua orientação nas varas judiciais. Com isso, os instrumentais oferecidos pela Ciência da Administração, conforme acentuado, são fundamentais para dar à gestão pública do Poder Judiciário novo modelo de organização que se busca mais eficiente e eficaz.

Nesse contexto, foi possível entender que o Planejamento Estratégico, a adoção de indicadores de desempenho, no caso, o modelo do "Balanced Scorecard" (BSC), são procedimentos formais e importantes para o pensar a organização judiciária no seu contexto.

Assim, segundo Tatiane de Abreu Fuin, todo o país clama por um novo Judiciário, mais organizado, menos moroso e que realmente ofereça justiça e tudo isso está sendo visualizado com a implantação e a execução do planejamento estratégico no Poder Judiciário.

É de se concluir que o Conselho Nacional de Justiça, com as medidas traçadas, de modo geral, busca as soluções para os principais problemas e dificuldades enfrentadas pelo Poder Judiciário, a fim de que proporcione prestação jurisdicional de excelência e seja "reconhecido pela Sociedade como instrumento efetivo de Justiça, Equidade e Paz Social" (STEIN JUNIOR, 2011, p. 91).

\subsection{Liderança no Setor Público}

Quanto ao exercício da liderança no setor público, os seguintes princípios: o primeiro, seria conhecer e refletir sobre os padrões sistêmicos da organização e sua dinâmica, em vez de agir de forma diretiva e pontual; o segundo, seria viabilizar a descrição, em definição e análise das reais ameaças enfrentadas pela organização; o terceiro, seria moderar a angústia resultante das pressões pelas mudanças; o quarto princípio, seria direcionar o esforço do grupo para efetivamente solucionar os problemas identificados; o quinto, assegurar que todos os integrantes da organização engajem-se na solução dos problemas adaptativos, de modo a desenvolverem novas competências; e, o sexto princípio, seria apoiar as pessoas que manifestam opiniões, críticas e sugestões (SCHWELLA, 2005).

O mais relevante, para fins deste estudo, é o debate sobre o juiz-líder e juizadministrador, na prestação jurisdicional, a fim de "transformar a realidade do Judiciário, moroso e desacreditado, em produtor eficiente de justiça" (FUIN, 2013, p. 126). 
A esse respeito, defende Vanderlei Deolindo:

\begin{abstract}
A liderança do juiz e o seu efetivo comprometimento com a gestão é o princípio. E essa análise deve ser reflexiva, intrínseca, individual, dele em relação a ele mesmo. Queira ou não, o juiz é visto por todos como protagonista da Vara onde atua. [...] Não havendo o protagonismo do magistrado nesse processo de mudança, não será o escrivão ou qualquer outro funcionário, por mais qualidades de liderança que apresente, que vai resultar num sistema de melhoria contínua, em trabalho de excelência firmado em resultados. Certo é que a soma de esforços e o comprometimento desses outros agentes também serão fundamentais para que resultados positivos sejam alcançados, mas não sem a liderança do chefe da unidade de trabalho que é o magistrado (DEOLINDO, 2011, p. 69-70).
\end{abstract}

Importante destacar, defende Vanderlei Deolindo, que "a liderança do juiz é essencial para a melhoria na administração e na prestação jurisdicional” (DEOLINDO, 2011, p. 69-70).

\title{
3.4 Implementação da Gestão Administrativa Judiciária
}

Para implementação da gestão administrativa judiciária, portanto, de forma efetiva, exige-se que o gestor conheça cada um dos elementos, suas funções e seus limites, e as suas deficiências, bem como se faça com uma visão de futuro desraigando-se de um simples cumprimento de orçamento para a adoção de estratégias de administração pública. Tudo objetivando a eficiência do serviço judicial (STEIN JÚNIOR, 2011, p. 89).

O Poder Judiciário, a partir das normas de organização judiciária, ao outorgarem ao magistrado a função de gestor da serventia a seu cargo, o fizeram instituindo um dever, o que significa que além da função jurisdicional o juiz tem a obrigação de exercer a função administrativa (RUSSO, 2009, p. 35).

Escreveu Higyna Bezerra, que essa mudança transformaria o juiz-juiz em juiz-gestor, pois, "de posse do conhecimento das técnicas advindas da ciência da Administração, o juiz passaria a estabelecer metas de trabalho para cumpri-las". Além disso, sustenta, "preocupar-seia mais com a busca da excelência nos serviços prestados, na racionalização de material, no modo como o público e os advogados são atendidos em sua unidade judiciária”. E arremata, "essa mudança também traria benefícios para a temática da celeridade processual, como resultado normal do processo de gestão" (BEZERRA, 2012, p. 101).

Dessa forma, Administração Judiciária e técnicas de administração da unidade judicial passaram a ser abordadas nas escolas de Magistratura, demonstrando que a eficácia de um bom 
administrador pode ser aprendida (FUIN, 2013, p. 90). Nesse sentido, Peter Drucker (1981) conclui que:

\begin{abstract}
Se eficácia fosse um dom com que as pessoas nascessem, do mesmo modo como nascem o dom da música ou a inclinação para a pintura, estaríamos em má situação. Por que sabemos que apenas uma pequena minoria nasce com grandes dons para qualquer dessas atividades. Ficaríamos, então, reduzidos a tentar localizar pessoas com alto potencial de eficácia, o mais cedo possível, e treiná-las o melhor que pudéssemos para desenvolver-lhes o talento. Mas dificilmente podemos esperar encontrar, desse modo, um número suficiente para as funções de gerência da sociedade moderna. Na verdade, se a eficácia fosse um dom, nossa atual civilização seria altamente vulnerável, se não insustentável; porque uma civilização de grandes organizações depende de um grande suprimento de pessoas capazes de ser gerentes, com uma parcela de eficácia (DRUCKER, 1981, p. 28/29).
\end{abstract}

A respeito da figura desse novo juiz, “o exercício da gestão pelo Juiz no eixo jurisdicional/administrativo", exigirá a reconstrução do "ser juiz", necessitando, para tanto, “ampliar e desenvolver um maior contingente técnico e pessoal" (VUCETIC, 2008, p. 45).

Dentro desta perspectiva, Vicente de Paula Ataíde Júnior afirma que "o juiz de hoje não mais pode estar identificado com o juiz de ontem". Entende que, perante a sociedade moderna, "o novo juiz é aquele que está em sintonia com a nova conformação social e preparado para responder, com eficiência e criatividade, às expectativas da sociedade". Conclui Vicente Ataíde Júnior que o juiz de hoje, na sociedade moderna, tem que levar "em consideração as promessas do direito emergente e as exigências de uma administração judiciária compromissada com a qualidade total”. (ATAÍDE JÚNIOR, 2006, p.67)

Para Adriano de Mesquita Dantas, em atendimento aos anseios e valores da sociedade atual, Juiz de Direito é aquele que tem boa desenvoltura na atividade jurisdicional e, também, na administrativa. Deve, então, desempenhar com presteza e eficiência as funções de administrador, seja como presidente de Tribunal, vice-presidente, corregedor, ouvidor, diretor ou coordenador de Escola Judicial, diretor de Fórum ou mesmo como administrador e responsável pela sua unidade - vara (DANTAS, 2009; STEIN JUNIOR, 2011, p. 91).

Nesse contexto de organização nas atividades dos servidores e do magistrado, observase que "todo o sistema judiciário tem como vértice a figura do juiz. Ele continuará a ser a figura de maior significado no esquema da Justiça". Além disso, adverte, "sem a colaboração entusiasta dos demais envolvidos, produzirá menos do que suas potencialidades o permitiriam" (NALINI, 2008, p. 219). 
Portanto, percebe-se a necessidade de maior disposição pessoal do juiz de enfrentar o problema "passa por uma revisão interna do seu próprio comportamento e grau de comprometimento com a instituição que serve" (ABREU, 2012, p. 349/350). Justamente, entende César Abreu, "com vistas a verificar e detectar as causas e os problemas, e, com base neles, implementar as soluções pessoais ou coletivas para melhor atender às expectativas do Judiciário". E sintetiza, “ao juiz não basta mais somente saber julgar; tem que adotar práticas de gestão para conseguir desempenhar bem as suas funções”. Com essa mudança de percepção, a postura do juiz "não é suficiente dizer do problema nem questionar sobre o que a instituição fará para superá-lo. Antes, cabe ao juiz dizer o que pode e como fazer para ajudar a instituição a superar as dificuldades sentidas" (ABREU, 2012, p. 349/350).

Por conseguinte, Tatiane Fuin afirma que os juízes:

"cumprindo os prazos, organizando a unidade de jurisdição em que exerce suas funções, delegando funções por meio da gestão por competências, organizando a pauta e estabelecendo prioridades, bem como cumprindo as metas do Conselho Nacional de Justiça, o juiz, como administrador, poderá transformar a realidade do Judiciário, moroso e desacreditado, em produtor eficiente de justiça" (FUIN, 2013, p. 126).

Segundo Tatiane Fuin, “o novo juiz, portanto, deverá estar imbuído dessa rebeldia para transformação do processo, tornando-o mais célere e trazendo justiça no caso concreto". E acrescenta a jurista, “o juiz deverá desempenhar a função jurisdicional da melhor forma possível, imprimindo marcha mais acelerada ao processo, além de zelar pelo equilíbrio processual, não deixando que nenhuma parte saia prejudicada" (FUIN, 2013, p. 95).

José Renato Nalini sugere a adoção de outro modelo, a fim de tornar a aplicação da Justiça mais eficiente:

\footnotetext{
Além de se transferir ao pessoal de apoio maior responsabilidade, com a prática de atos de administração de mero expediente, estimule-se o funcionalismo a repensar as rotinas irracionais. Eliminem-se ainda aquelas dispensáveis, num enxugamento de fluxos. Introduza-se a crítica e a reflexão, mediante adoção de metas quais: aprenda, pense, analise, avalie e aperfeiçoe e ouça, pergunte e fale. [...] Detectar os talentos, as vocações, cultivar a autocrítica, reconhecer a diversidade intelectual só faria de uma unidade judicial uma equipe mais empenhada em atingir metas e a trabalhar mais coesa. Induvidoso que disso resultaria uma Justiça melhor (NANLINI, 2008, p. 208).
}

No mesmo sentido, sustenta-se que o papel ativo do juiz é visto com estreita relação com a reivindicação de uma razoável aceleração do processo. Portanto, a atuação do juiz 
“deveria impedir a prolongação injustificada ou inútil do processo; e mais, deveria velar para que a parte mais fraca não tivesse desvantagens" (BAUR, 1982, p. 186). Com isso, "a aceleração do processo e sua função social são dois postulados políticos que devem ser alcançados por meio de uma atividade mais decisiva e significativa da parte do juiz" (BAUR, 1982, p. 199).

\subsection{Gestão de Gabinete de Magistrados}

Defende Ney Wiedemann Neto, quanto à gestão de gabinete de magistrados, especificamente no Tribunal de Justiça do Rio Grande do Sul, cinco aspectos relevantes na atuação do magistrado/gestor, quais sejam: conduta, valorização, atualização, delegação e integração. Esses cinco pontos foram assim explicados:

- O primeiro aspecto está associado à conduta do magistrado como condição de sua respeitabilidade. Assim, deve exercer um papel de líder, antes de chefe, sendo respeitado pela sua conduta, pelo seu exemplo ante os demais, antes do poder inerente ao próprio cargo.

- O segundo aspecto aponta que deve o magistrado valorizar a equipe, procurando mantê-la unida, coesa, em torno de algum objetivo comum, dando voz aos servidores e importância, tomando conhecimento da sua realidade.

- O terceiro aspecto recomenda que o magistrado esteja atualizado com relação às modernas técnicas de gestão de pessoas e de processos e aberto às inovações tecnológicas para ganhos de produtividade da equipe especialmente associados à informática.

- O quarto aspecto orienta que o magistrado deve definir para cada membro da equipe de forma clara e precisa as suas tarefas, delegando-lhes as devidas atribuições e procurando estabelecer metas razoáveis para que elas sejam atingidas. Quanto isso for obtido, os resultados positivos devem ser valorizados e, eventualmente, recompensados, em situações especiais.

- O quinto aspecto sugere que o magistrado deve estar integrado com as diversas instâncias hierárquicas onde atua, procurando conhecer as pessoas e promovendo a sua integração, visitando os setores administrativos e conversando com os funcionários. Da mesma forma, no âmbito externo, deve buscar o entrosamento com o Ministério Público, com a Ordem dos Advogados e com demais Poderes, prestigiando a comunidade (WIEDEMANN NETO, 2009, p. 57-58).

No âmbito do Poder Judiciário, "o magistrado deve procurar ser, antes de um chefe dos servidores, o líder de sua equipe, propondo uma gestão participativa, descentralizada e aberta à participação do grupo". Sustenta, assim, a diminuição da "hierarquia, estabelecendo com todos os objetivos e as metas, formalizando os processos e dividindo o trabalho" 
(WIEDEMANN NETO, 2009, p. 58). Oportuna a lição de Ney Wiedemann Neto, ainda a respeito da gestão de gabinete, no sentido de que "é atividade de administração judiciária fundamental para o aprimoramento da própria prestação jurisdicional”. E orienta:

\begin{abstract}
Uma boa organização das rotinas de trabalho e a correta distribuição das tarefas à equipe poderão contribuir para que os julgamentos se produzam de forma mais célere e adequada. Uma política de valorização das pessoas e a liderança do magistrado, como líder dessa equipe, serão de importância vital para manter a motivação do grupo e o foco nos objetivos propostos, visando a alcançar metas de alto desempenho. (WIEDEMANN NETO, 2009, p. 168)
\end{abstract}

Na obra “Gestão Estratégica de Unidades Judiciárias”, de Marcus Vinícius Mendes do Valle, e para confirmar a liderança e atuação do juiz para que seja gerada efetiva melhoria da entrega da justiça, busca-se afirmar que o Planejamento Estratégico, antes restrito à alta administração (ver item 3 deste capítulo VI), também pode ser adotado nas Unidades Judiciárias de Primeiro Grau. A adoção do "novo modelo de gestão" tem como pilares a diagnose; plano estratégico de Unidade Judiciária; plano de ação; e acompanhamento permanente. Essa implementação do Plano permitiu ao magistrado elaborar formulários e aplicá-los, com êxito.

Segundo Marcus do Valle, “os quatro pilares a gestão estratégica [...] representam uma mudança significativa em antigos paradigmas de gestão estratégica, cuja ineficácia precisa ser enfrentada". Defende, mais, que a prática desse modelo a todos incentiva "o protagonismo, o aproveitamento das experiências profissionais, o desenvolvimento contínuo e a vontade perene de servir mais e melhor à causa da Justiça, sacerdócio comum de todos os operadores da máquina judiciária" (VALLE, 2017, p. 102).

Para melhor compreender a atuação do magistrado, na qualidade de líder no seu ambiente de trabalho, importante transcrever "Os Dez Mandamentos do Juiz Administrador", da autoria Vladimir Passos de Freitas, contendo orientações dos aspectos relevantes na gestão:

\title{
Os dez mandamentos do juiz administrador
}

1. O juiz nas funções de administrador, como Presidente de Tribunal, Vice-Presidente, Corregedor, Coordenador de Juizados Especiais, Diretor de Escola de Magistrados, Diretor do Foro ou Fórum, ou administrando a sua Vara, deve saber que a liderança moderna se exerce com base na habilidade de conquistar as pessoas e não mais em razão do cargo, perdendo a hierarquia seu caráter vertical para assumir uma posição mais de conquista do que de mando.

2. Ao administrar, cumpre-lhe deixar a toga de lado devendo: a) obrigação à lei e não à jurisprudência; b) inteirar-se das técnicas modernas de administração pública e empresarial; c) adaptar-se aos recursos tecnológicos; d) decidir de maneira ágil e direta, sem a burocracia dos processos judiciais; d)manter o bom e corrigir o ruim; 
e)delegar, se tiver confiança; f) atender a imprensa; g) lembrar que não existe unidade judiciária ruim, mas sim mal administrada.

3. No âmbito externo, deve prestigiar as atividades da comunidade jurídica e dos órgãos da administração dos três Poderes, participando de solenidades, estabelecendo parcerias em projetos culturais e alianças que possam diminuir os gastos públicos. No âmbito interno, deve visitar periodicamente os setores administrativos, ouvindo os funcionários, demonstrando o seu interesse em conhecer os serviços e atender as necessidades, quando possível.

4. Ter em mente que suas palavras e ações estão sendo observadas por todos e que elas transmitem mensagens explícitas ou implícitas que podem melhorar ou piorar a Justiça. Por isso, devem ser evitadas críticas públicas a outros magistrados de qualquer Justiça ou instância, ou a autoridades de outros Poderes, atitudes estas que nada constroem e que podem resultar em respostas públicas de igual ou maior intensidade.

5. Manter a vaidade encarcerada dentro dos limites do tolerável, evitando a busca de homenagens, medalhas, retratos em jornais institucionais, vinganças contra os que presumidamente não lhe deram tratamento adequado, longos discursos enaltecendo a si próprio ou o afago dos bajuladores, ciente de que estes desaparecerão no dia seguinte ao da posse de seu sucessor.

6. O Presidente - e os demais administradores, no que compatível - deve manter um ambiente de cordialidade com os colegas do Tribunal, ouvindo-os nas reivindicações, explicando-lhes quando negá-las e não estimulando os conflitos. Com os juízes de primeiro grau, lembrar que o respeito será conquistado pelo exemplo e não pelo cargo, que eles pertencem a gerações diferentes, que devem ser estimulados na criatividade, apoiados nos momentos difíceis e tratados sem favorecimento. Nas infrações administrativas praticadas por magistrados, cumprir o dever de apurar, com firmeza, coragem e lealdade.

7. No relacionamento com o Ministério Público e a $\mathrm{OAB}$, deve atender as reivindicações que aprimorem a Justiça, não criar empecilhos burocráticos que dificultem as atividades desses profissionais (p. ex. na retirada de processos) e, quando não atender a um pedido, explicar os motivos de maneira profissional evitando tornálo um caso pessoal.

8. No relacionamento com os sindicatos, manter um diálogo respeitoso, baseado na transparência administrativa. Quanto aos servidores, motivá-los, promover cursos de capacitação, divulgar as suas boas iniciativas, promover concursos sobre exemplos de vida, envolvê-los na prática da responsabilidade social e da gestão ambiental. Com relação aos trabalhadores indiretos (terceirizados), promover, dentro do possível, sua inclusão social.

9. Nos requerimentos administrativos, quando negar uma pretensão, seja de magistrados ou de servidores, fazê-lo de forma clara e fundamentada, não cedendo à tentação de concedê-la para alcançar popularidade, pois sempre haverá reflexos em relação a terceiros e novos problemas.

10. Ter presente que administrar significa assumir uma escolha e um risco e que aquele que nada arrisca passará o tempo do seu mandato em atividades rotineiras, limitando-se ao fim por colocar um retrato na galeria de fotografias, passando à história sem ter dado qualquer contribuição à sociedade, ao Poder Judiciário, ao Brasil. (FREITAS, 2006)

José Renato Nalini sustenta, ainda, que o magistrado, centro e motor da função estatal de resolver conflitos, "pode fazer tudo funcionar, como pode ser uma âncora que imobiliza a 
unidade judicial, imersa na burocracia, no formalismo, na generalizada ineficiência que nela enxergam os destinatários" (NALINI, 2011, p. 31).

Constata-se, assim, que Juiz Direito/Magistrado atuando, efetivamente, "como administrador, poderá transformar a realidade do Judiciário, moroso e desacreditado, em produtor eficiente de justiça" (FUIN, 2013, p.126).

\section{Considerações finais}

Diante de todo o conteúdo desenvolvido, chegou-se às seguintes considerações.

No capítulo primeiro, a partir do marco teórico pesquisado, é suficiente para revelar que o Sistema de Administração Judiciária, está a exigir modernização da gestão judiciária, evitando-os a morosidade na prestação judiciária. Também mostra que a atuação do Magistrado tem que ser desenvolvida, mediante utilização de modelos de organização e gestão.

Evidentemente, conforme registrado, são necessárias a união de outras áreas do conhecimento essenciais à judicatura, seja no recrutamento atual dos juízes, seja na prestação jurisdicional. Em particular, é preciso consolidar os parâmetros para a eficácia da aplicação do direito fundamental à razoável duração do processo (art. 5º inciso LXXVIII, da CF/88).

Em razão disso, foi possível identificar que o integrante do Poder Judiciário, no caso, o Magistrado, está em condições, e também deverá possuir, além de sua função eminentemente jurisdicional, conhecimentos e práticas de gestão estratégica. Assim, com base no conteúdo pesquisado, pode-se afirmar que Magistrado - O Juiz Líder -, portanto, é o responsável pelo êxito da unidade judicial, seja quanto ao trabalho da sua equipe, como as pessoas executam o trabalho, as expectativas, a motivação, o estabelecimento de metas e resultados de curto, médio e longo prazo.

Com isso, o Poder Judiciário, então taxado de improdutivo e lento, passou, com a ideia de estratégia, a buscar excelência na gestão.

Dito isso, resta destacar que, quando se fala em planejamento estratégico implantado, e mudanças positivas alcançadas com sua implementação, a efetiva atuação do juiz de direito, principalmente por meio de sua liderança na administração da unidade de jurisdição, permitirá a razoável duração do processo.

\section{Referências bibliográficas}


ABDALA, Kaliny Belchior. Proteção constitucional/internacional do direito à razoável duração do processo. 2008. 224 f. Dissertação (Mestrado em Direito) - Pontifícia Universidade Católica de São Paulo, São Paulo, 2008.

ABREU, Cesar Augusto Mimoso Ruiz. Judiciário do novo tempo. Revista da Escola Nacional da Magistratura. Ano VII, ed. no 6, p.334/355. Brasília: Escola Nacional da Magistratura, 2012.

ATAÍDE JÚNIOR, Vicente de Paula. O novo juiz e a administração da justiça: repensando a seleção, a formação e a avaliação dos magistrados do Brasil. Curitiba: Juruá, 2006.

AVIS, Warren. Atreva-se a ser líder (os segredos do sucesso empresarial): autobiografia do fundador da Avis Rent-A-Car. São Paulo: Maltese, 1989.

BATISTA JUNIOR, Onofre Alves. Princípio Constitucional da Eficiência Administrativa. Belo Horizonte: Mandamentos, 2004.

BAUR, Fritz. O papel ativo do juiz. Revista de Processo, São Paulo, n. 27, p. 186-199, ano 7, julho-setembro 1982.

BENETI, Sidnei Agostinho. Da conduta do juiz. São Paulo: Saraiva, 1997.

BEZERRA, Higyna Josita Simões de Almeida. Papel das Escolas na Formação do Magistrado: Curso Obrigatório de Gestão Jurisdicional. Revista da Escola Nacional da Magistratura. Ano VII, ed. no 6, p. 99/101. Brasília: Escola Nacional da Magistratura, 2012.

BRAGA NETO, Adolfo. Alguns aspectos relevantes sobre mediação de conflitos. In:SALES, Lilia Maia de Morais(org.). Estudos sobre mediação e arbitragem. Rio de Janeiro: ABC Editora, 2003.

BRASIL. Conselho Nacional de Justiça. Justiça em Números 2017: ano-base 2016/Conselho Nacional de Justiça.Brasília: CNJ, 2017. Disponível em: <http://www.cnj.jus.br/files/ conteudo/arquivo/2017/09/904f097f215cf19a2838166729516b79.pdf>. Acesso em 10 abr. 2018. 
BRASIL. Conselho Nacional de Justiça. Concorrência no 1/2009. Disponível em:

$<$ http://www.cnj.jus.br/images/conteudo2008/dge/edital_consultoria_gestao_estrategica.pdf $>$. Acesso em: 03 set. 2012.

BRASIL. Conselho Nacional de Justiça. Normas e Orientações da Gestão Estratégica. Disponível em: <http:/www.cnj.jus.br/gestao-e-planejamento/normas-e-orientacoes-dagestao-estrategica>. Acesso em: 28 abr. 2018.

CAPPELLETTI, Mauro. Juízes irresponsáveis? Porto Alegre: Sérgio Antônio Fabris, 1989.

CHIAVENATO, Idalberto. Introdução à teoria da administração. 4. ed. São Paulo: MacGraw-Hill, 2000.

CHIAVENATO, Idalberto. Teoria Geral da administração. v. 1. 6. ed. ver. e atualizada. Rio de Janeiro: Elsevier, 2001.

CHIAVENATO, Idalberto; SAPIRO, Arão.Planejamento estratégico.Rio de Janeiro: Elsevier, 2003.

DALLARI, Dalmo de Abreu. O poder dos juízes. 2 ed. São Paulo: Saraiva, 2007.

DANTAS, Adriano Mesquita. Planejamento, gestão estratégica e o novo Poder Judiciário. Instrumento efetivo de justiça, equidade e paz social. Revista Jus Navigandi, ISSN 15184862, Teresina, ano 14, n. 2310, 28 out. 2009. Disponível em: <https://jus.com.br/ artigos/13757>. Acesso em: 10 set. 2017.

\section{DEOLINDO, Vanderlei. Planejamento Estratégico em Comarca do Poder Judiciário}

(Dissertação de Mestrado, 2011) Porto Alegre: TJRS, Departamento de artes gráficas, 2011. (Coleção Administração Judiciária, vol. XIII). Disponível em: < http://www.tjrs.jus.br/ export/poder_judiciario/tribunal_de_justica/corregedoria_geral_da_justica/colecao_administr acao_judiciaria/doc/CAJ12.pdf>. Acesso em: 08 set. 2017. 
DIAS, Ronaldo Brêtas de Carvalho. Direito à jurisdição eficiente e garantia da razoável duração do processo na reforma do judiciário. Revista da Faculdade Mineira de Direito, Belo Horizonte, v. 8, n. 15, p.230-240, 2005.

DONNELLON, Anne. Liderança de equipes: escolha a equipa, comunique as metas, defina as funções, crie um clima de confiança: soluções práticas para os desafios do trabalho. Rio de Janeiro: Elsevier, 2004.

DRUCKER, Peter Ferdinand. O gerente eficaz. Trad. William Heinemann. 9. ed. Rio de Janeiro: Zahar Editores, 1981.

FREIRE, Alexandre Costa de Luna. Administração Judiciária. Revista da ESMAFE. $5^{\text {a }}$ Região, Recife, n. 8, 2004.

FREITAS, Vladimir Passos de; FREITAS, Dario Almeida Passos de (coord.). Direito e administração da justiça. Curitiba: Juruá, 2006.

FUIN, Tatiane de Abreu. O Planejamento Estratégico no Poder Judiciário e o Aperfeiçoamento na Prestação Jurisdicional. Dissertação de Mestrado. Universidade Estadual do Norte do Paraná. Centro de Ciências Sociais Aplicadas - Jacarezinho. Curitiba: UENP, 2013.

GADELHA, Francisca Cristina Freire. A crise política no Poder Judiciário Brasileiro: causas e implicações. Monografia apresentada à Universidade Vale do Acaraú Fortaleza/CE. Disponível em: $<$ http://esmec.tjce.jus.br/wpcontent/uploads/2014/12/Francisca-Cristina-Freire-Gadelha.pdf>. Acesso em 10 set. 2017.

GRANGEIA, Marcos Alaor Diniz. A crise de gestão do Poder Judiciário: o problema, as consequências e os possíveis caminhos para a solução. Disponível em: $<$ http://www.enfam.jus.br/wpcontent/uploads/2013/01/2099_Des_Marcos_Alaor_Artigo_E NFAM_28_4_2011_editado.pdf $>$.Acesso em: 30 ago. 2014.

GRINOVER, Ada Pelegrini; DINAMARCO, Cândido Rangel; WATANABE, Kazuo (coord.). Participação e processo. São Paulo: Revista dos Tribunais, 1988. 
GUSTIN, Miracy Barbosa de Souza. (Re)pensando a pesquisa jurídica: teoria e prática. 3ed. rev. atual. Belo Horizonte: Del Rey, 2010.

HADDAD, Carlos Henrique Borlido. Fatores de produtividade: proposta de avaliação do desempenho do magistrado federal. In: Administração da Justiça Federal: Concurso de monografias - 2004. Série Monografias do CEJ, v.10. Brasília: CJF, 2005.

KOUZES, Jim; POSNER, Barry. Líder-mestre: o verdadeiro líder serve aos outros e se sacrifica por eles. Rio de Janeiro: Elsevier, 2007.

MAXIMIANO, Antonio Cesar Amaru. Teoria Geral da Administração: da revolução urbana à revolução digital. 7. ed. São Paulo. Atlas. 2012.

MELO, Flávio Henrique de. A Gestão em Vara Judicial sob a visão do Juiz pro ativo. 80 pg. Rio de Janeiro. 2012.

MINAS GERAIS, Tribunal de Justiça. Manual de Boas Práticas de Gestão de Gabinetes. Disponível em: <http:/www.tjmg.jus.br/data/files/5F/F5/06/0F/5EE1B51081D271B54 80808A8/MANUAL\%20DE\%20BOAS\%20PRATICAS\%20DE\%20GESTAO\%20DOS\%20 GABINETES\%20-\%20Versao\%201.2\%20-\%202016.pdf>. Acesso em 12 out. 2017.

NALINI, José Renato. Novas perspectivas do acesso à justiça. Lex. São Paulo.v.224, ago/1997.

NALINI, José Renato. Hora de desequilibrar: judiciário será descartado se insistir em não funcionar - entrevista por Lílian Matsuura. Disponível em: < http://www.conjur.com.br/2007mar-25/judiciario_descartado_insistir_nao_funcionar>. Acesso em: 22 mar. 2017.

NALINI, José Renato. A rebelião da toga. Campinas: Millenium, 2006.

NOGUEIRA, José Marcelo Maia. A gestão do Poder Judiciário: uma análise do sistema de mensuração de desempenho do Judiciário brasileiro. Dissertação Mestrado em 
Administração Pública e Governo. Escola de Admin. Empresas de São Paulo da Fundação Getúlio Vargas. 2010. Disponível em: <http://bibliotecadigital.fgv.br/dspace/handle/ 10438/8218>.Acesso 13 out. 2017.

ONODERA, Marcus Vinícius Kiyoshi. Gerenciamento do processo e acesso à justiça. Belo Horizonte: Del Rey, 2017.

PRÊMIO INNOVARE. Edição VI, 2009: “Celeridade processual na 14ª Vara”, do juiz federal Evaldo de Oliveira Fernandes Filho, da 14ª Vara de Belo Horizonte-MG. Disponível em: $<$ http://www.premioinnovare.com.br/praticas/l/celeridade-processual-na-14a-vara $>$.A 8 set 2017 .

RIBEIRO, Adriano da Silva [et all]. Economia processual e limite constitucional. In: TAVARES, Fernando Horta (org.). Novíssimos estudos de direito público: direito constitucional, direito internacional, direito penal e direito processual. 1ed. Curitiba: CRV, 2011.

RIBEIRO, Adriano da Silva. Indicações literárias: Princípio da eficiência na gestão e no procedimento judicial: a busca da superação da morosidade na atividade jurisdicional. ROCHA, Daniel de Almeida. Curitiba: Juruá Editora, 2012, 146p. Disponível em: $<$ http://www.jf.jus.br/ojs2/index.php/revcej/article/viewFile/1797/1764>.Acesso em 12 out 2017.

ROCHA, Cármen Lúcia Antunes. Constituição e constitucionalidade. Belo Horizonte: Lê, 1993.

ROSSI, Giancarlo. A Gestão Estratégica de Pessoas e de Competências no Cartório Judicial da Justiça de $1^{\circ}$ Grau do Poder Judiciário do Estado de Santa Catarina.

Disponível em: $<$ http://tjsc25.tjsc.jus.br/academia/arquivos/Giancarlo_Rossi.pdf $>$. Acesso em 13 out. 2017.

RUSSO, Andréa Rezende. Uma moderna gestão de pessoas no Poder Judiciário. Tribunal de Justiça do Estado do Rio Grande do Sul. (Coleção Administração Judiciária, v. 8). Porto Alegre: Departamento de Artes Gráficas, 2009. 
SCHWELLA, Erwin. Inovação no governo e no setor público: desafios e implicações para a liderança. Revista do Serviço Público, v. 56, n. 3, p. 259-276, 2005.

SERRA, Luiz Umpierre de Mello. Gestão de Serventias. V. 1 Rio de Janeiro: FGV, 1996.

SILVA, José Afonso da. Curso de direito constitucional positivo.28.ed. São Paulo: Malheiros, 2007.

SILVA, José Afonso da; FLORÊNCIO, P. A. L. Políticas judiciárias no Brasil: o Judiciário como autor de políticas públicas. Revista do Serviço Público. Brasília, p. 119-134, abr/jun. 2011.

SLAIBI FILHO, Nagib. Magistratura e gestão judiciária. Rio de Janeiro: Forense, 2016.

STEIN JUNIOR, Irineu. Poder Judiciário e gestão: uma parceria de sucesso para impulsionar a prestação jurisdicional. Dissertação de Mestrado da PUC do Paraná. Curitiba, 2011.

TEIXEIRA, Sálvio de Figueiredo.Reforma do Judiciário:reflexões e prioridades.In: Dimensões do Direito Contemporâneo:estudos homenagem Geraldo de Camargo Vidigal,São Paulo:IOB, 2001,p.55-61.Disponível em:<http://bdjur.stj.jus.br//dspace/ handle/2011/369>. Acesso 13 fev 2017.

THEODORO JÚNIOR, Humberto. Celeridade e efetividade da prestação jurisdicional. Insuficiência da reforma das leis processuais. In: Revista de Processo. Ano 30, n. 125. São Paulo: Revista Tribunais, jul. 2005.

THEODORO JÚNIOR, Humberto. A Onda Reformista do Direito Positivo e suas Implicações com o Princípio da Segurança.In:CALDEIRA, Adriano,FREIRE, Rodrigo da Cunha Lima (orgs). A Terceira Etapa da Reforma do Código de Processo Civil. Salvador: Editora Podivm, 2007. 
VALLE, Marcus Vinícius Mendes do. Gestão estratégica de unidades judiciárias:

desdobramento de $4^{\mathrm{o}}$ nível - gestão judiciária aplicada. Belo Horizonte: Conhecimento, 2017.

VIEIRA, José Luiz Leal. Um novo desafio para o Judiciário: o juiz líder. Dissertação do Mestrado Profissionalizante em Poder Judiciário. Rio de Janeiro: FGV Direito Rio, 2008.

VUCETIC, Miriam Lopes. Resultado: um desafio da gestão “com” pessoas para a magistratura do $3^{\circ}$ milênio. MULTIJURIS. Primeiro Grau em Ação, Porto Alegre, n. 6, 2008 .

WATANABE, Kazuo. Acesso à justiça e sociedade moderna. In: GRINOVER, Ada Pelegrini; DINAMARCO, Cândido Rangel; WATANABE, Kazuo (coord.). Participação e processo. São Paulo: Revista dos Tribunais, 1988.

WIEDEMANN NETO, Ney. Gestão de gabinetes de magistrados nas Câmaras Cíveis do Tribunal de Justiça do Rio Grande do Sul. v. 1, 207. Rio de Janeiro, 2009. Disponível em: $<$ http://www.escoladaajuris.org.br/phl8/DISSERTACAO\%20NEY\%20WIEDEMANN\%2 0NETO.pdf $>$. Acesso em 10 set. 2017. 


\title{
O MINIMALISMO JUDICIAL DE CASS SUNSTEIN COMO ALTERNATIVA HERMENÊUTICA AO SISTEMA DE PRECEDENTES DO CÓDIGO DE PROCESSO CIVIL DE 2015
}

\author{
Bruno Paiva Bernardes \\ Universidade FUMEC \\ Sérgio Henriques Zandona Freitas \\ Universidade FUMEC
}

\begin{abstract}
Resumo
O presente artigo, cuja produção se dá na vertente jurídico-dogmática, tendo raciocínio predominante o hipotético-dedutivo, tem como temática o minimalismo judicial de Cass R. Sunstein, marco teórico do trabalho, aplicado ao sistema de precedentes do Código de Processo Civil de 2015. Como problema de pesquisa, indaga acerca da viabilidade de aplicação da referida teoria como alternativa hermenêutica para superação do potencial quadro de engessamento jurisprudencial no modelo do referido diploma legal.
\end{abstract}

Palavras-chave: Sistema de precedentes, Código de Processo Civil brasileiro (2015), Jurisprudência, Minimalismo judicial, Cass Sunstein.

\begin{abstract}
Resumen/Résumé
This article, whose production takes place in the juridical-dogmatic aspect, with a predominant hypothetical-deductive reasoning, has as its theme the judicial minimalism of Cass R. Sunstein, the theoretical framework of the work, applied to the doctrine of precedents of the Brazilian Civil Procedural Code's. As a research problem inquires about the feasibility of applying this theory as a hermeneutical alternative to overcome the potential framework of the jurisprudential casing in the model of the mentioned law.
\end{abstract}

Keywords/Palabras-claves/Mots-clés: Doctrine of precedents, Brazilian procedural civil code (2015), Case law, Judicial minimalism, Cass Sunstein. 


\section{Introdução}

O Código de Processo Civil de 2015 (BRASIL, 2015), entre suas inovações, ampliou significativamente o papel da jurisprudência, elevando-a a condição de fonte normativa do direito, a ser uniformizada pelos tribunais, jungida aos critérios de estabilidade, integralidade e coerência.

Erguida a tal condição, inevitável questionar acerca da proximidade do sistema jurídico brasileiro, de tradição romano-germânica (ou da civil law), com a família da common law. Ainda que não se possa falar em ingresso do Brasil no sistema da common law, o que é absolutamente correto, resta cada vez mais clara a interpenetração dessas diferentes famílias jurídicas, o que, por si só, é bastante salutar para busca de saídas aos diferentes problemas vividos.

Porém, ao se destacarem institutos típicos da common law no sistema jurídico brasileiro, outros problemas surgem, mormente pela tendência à abstrativização e generalidade que, ainda que por instinto, busca-se em um sistema da civil law, ou mesmo pela distinção entre o raciocínio predominante nos sistemas; no primeiro, o indutivo, e, no segundo, o dedutivo.

Quer por importar institutos sem a devida compatibilização, quer por não respeitar os contornos democráticos, o sistema de precedentes do Código de Processo Civil de 2015 (BRASIL, 2015) tende, no modelo posto, a emperrar o avanço e as modificações jurisprudenciais que naturalmente devem ocorrer diante da multiplicidade de fatos e de relações da sociedade contemporânea.

Nesse contexto, o presente artigo se propõe a apontar as incongruências do sistema de precedentes do Código de Processo Civil de 2015 (BRASIL, 2015) e, em seguida, como problema de pesquisa, indagar acerca da viabilidade de aplicação da referida teoria como alternativa hermenêutica para superação do potencial quadro de engessamento jurisprudencial no modelo do referido diploma legal.

Cass R. Sunstein é um dos juristas norte-americanos que mais contribuem na atualidade para o enriquecimento da análise filosófica, hermenêutica e constitucional do direito estadunidense. Autor de uma vasta bibliografia, especialmente a partir da década de 1990 (HARVARD, 2016), foi o jurista mais citado nos Estados Unidos no período de 2009 e 2013 (LEITER, 2014). Tem uma ampla área de interesse, incluindo o Direito Constitucional, o Direito Administrativo, a interpretação jurídica e a relação entre Direito e Economia, inclusive no âmbito da Economia Comportamental. 
Tendo, portanto, como marco teórico o minimalismo judicial de Cass R. Sunstein, o artigo se desenvolve em quatro tópicos, seguidos pela conclusão. No tópico dois o sistema de precedentes do Código de Processo Civil de 2015 (BRASIL, 2015) é abordado buscando explicitar a aproximação entre o sistema jurídico brasileiro e a common law. No tópico três, dada essa aproximação, no Brasil, de sistemas jurídicos distintos, e a prevalência do raciocínio indutivo no sistema da common law, o artigo objetiva indicar as lacunas da indução, transpondo para a aplicação jurisprudencial no sistema do Código de Processo Civil de 2015 (BRASIL, 2015), parte das críticas de Karl Popper ao raciocínio indutivo, como exposto na obra A lógica da pesquisa científica (POPPER, 2013). O tópico quatro aborda o risco de engessamento da jurisprudência tal como apresentado no Código de Processo Civil de 2015 (BRASIL, 2015). O tópico cinco enfatiza o minimalismo judicial de Cass R. Sunstein, destacando suas premissas básicas, e propõe a sua utilização para o sistema de precedentes como resposta ao risco de congelamento da jurisprudência, tudo seguido de conclusão e referências.

Quanto aos aspectos metodológicos, a produção do trabalho científico se dá na vertente jurídico-dogmática (GUSTIN; DIAS, 2015, p. 21) e tem como raciocínio predominante o hipotético-dedutivo. O trabalho foi desenvolvido mediante pesquisa bibliográfica norteamericana e brasileira e é de perspectiva interdisciplinar, pois combina Direito Processual, Hermenêutica e Filosofia do Direito. Tem como dados primários da pesquisa à legislação, e como dados secundários as doutrinas referentes à temática, especialmente Direito Processual, Hermenêutica e Filosofia do Direito.

\section{O sistema de precedentes do Código de Processo Civil de 2015}

O sistema de precedentes no Brasil vem gradativamente sendo incrementado, sobretudo a partir da Lei n. 8.038 de 1990 (BRASIL, 1990) ${ }^{1}$, com destaque especial, ainda, para a Emenda Constitucional n. 45 de 2004 (BRASIL, 2004), que introduziu institutos como a repercussão geral no recurso extraordinário e as súmulas vinculantes, além da Lei n. 11.672 de 2008 (BRASIL, 2008), que introduziu no Código de Processo Civil de 1973 (BRASIL, 1973) o regime de processamento dos recursos especiais repetitivos.

\footnotetext{
${ }^{1} \mathrm{O}$ art. 38 da Lei 8.038 de 1990, revogado expressamente pelo Código de Processo Civil de 2015, dispunha que "o Relator, no Supremo Tribunal Federal ou no Superior Tribunal de Justiça, decidirá o pedido ou o recurso que haja perdido seu objeto, bem como negará seguimento a pedido ou recurso manifestamente intempestivo, incabível ou, improcedente ou ainda, que contrariar, nas questões predominantemente de direito, Súmula do respectivo Tribunal" (BRASIL, 1990, grifos nossos).
} 
Com o Código de Processo Civil de 2015 (BRASIL, 2015) inaugura-se nova etapa na construção e organização desse sistema. Compondo as disposições gerais do Livro III, título I, da parte especial do referido código, os artigos 926 a 928 estabelecem aquilo que se pode denominar de premissas desse sistema de precedentes judiciais, inovando substancialmente na alocação das construções jurisprudenciais. Inevitável, pois, em razão de tais institutos do sistema de precedentes judiciais do Código de Processo Civil de 2015 (BRASIL, 2015), (tentarse) estabelecer o ponto de contato do sistema da common law e sua stare decisis ${ }^{2}$ com as inovações apresentadas.

O Código de Processo Civil de 2015 (BRASIL, 2015) não obedece ao rigor conceitual dos termos "precedente", "jurisprudência" e "súmula", como destacam Alexandre Freitas Câmara (2016), Cassio Scarpinella Bueno (2016), Daniel Assumpção Amorim Neves (2016), Lenio Streck (2016) e Humberto Theodoro Júnior (2015). Isso porque o vocábulo "jurisprudência" tem sido ampla e indevidamente associado a "precedentes". A palavra "jurisprudência" refere-se a "[...] um conjunto de decisões judiciais, proferidas pelos tribunais, sobre uma determinada matéria, em um mesmo sentido" (CÂMARA, 2016), diferenciando-se, pois, quantitativamente do termo "precedente". O precedente, por sua vez, é apenas um julgado que serve de suporte para decisões futuras, podendo ser persuasivo ou vinculante, diferenciação que leva em conta a capacidade (ou não) de vincular pronunciamentos futuros naquele sentido firmado. Já o que comumente denominamos de "súmula", de fato são os "enunciados da súmula", i.e., a suma ou síntese da jurisprudência dominante dos Tribunais (BUENO, 2016).

Justificando a exigência de padrões de decisão adequados aos preceitos de um Estado Democrático de Direito, o artigo 926 do Código de Processo Civil de 2015 (BRASIL, 2015) assinala que "os tribunais devem uniformizar sua jurisprudência e mantê-la estável, íntegra e coerente" (BRASIL, 2015), na tentativa de impedir variações atreladas a convicções fugazes. O texto do art. 926 soa, de certa maneira, redundante, já que, como visto, a jurisprudência é o de conjunto de decisões reiteradas de um tribunal sobre uma mesma matéria e em um mesmo sentido. À luz da segurança jurídica, do princípio da proteção da confiança e da isonomia reputa-se louvável o destaque feito pelo dispositivo.

O caput do art. 927 do mesmo código (BRASIL, 2015) complementa o sentido do art. 926, ao impor aos juízes e tribunais a obrigação de observar o rol daquelas que, agora,

\footnotetext{
${ }^{2}$ Também chamada de doctrine of precedents. Guido Fernando Silva Soares (2000) afirma que "[...] a melhor tradução para doctrine, no presente contexto, seria regra e portanto doctrine of precedents seria, em português, 'regra do precedente'. Precedent é a única ou várias decisões de um appelate court, órgão coletivo de segundo grau, que obriga sempre o mesmo tribunal ou os juízes que lhe são subordinados." (SOARES, 2000, p. 40, grifos do autor).
} 
compreendem a jurisprudência vinculante, a saber, (i) decisões do Supremo Tribunal Federal em controle concentrado de constitucionalidade, como previsto no art. 102 , §2 $2^{\circ}$, da Constituição da República (BRASIL, 1988); (ii) enunciados de súmulas vinculantes, como também já previsto no art. 103-A, da Constituição da República (BRASIL, 1988); (iii) acórdãos em incidente de assunção de competência e em julgamento de casos repetitivos, quais sejam, o incidente de resolução de demandas repetitivas e os recursos extraordinário e especial repetitivos; (iv) enunciados de súmulas do Supremo Tribunal Federal em matéria constitucional e do Superior Tribunal de Justiça em matéria infraconstitucional; e (v) a orientação do plenário ou do órgão especial aos quais juízes e Tribunais estiverem vinculados. (BRASIL, 2015).

Convém salientar também as pontuações da doutrina acerca da distinção entre o que vige no sistema da common law e o aqui aplicado, de raiz romano-germânica.

Para Alexandre Freitas Câmara (2016), “[...] o que se tem no Brasil é a construção de um sistema de formação de decisões judiciais com base em precedentes adaptado às características de um ordenamento de civil law". (CÂMARA, 2016). Nesse sentido, Cássio Scarpinella Bueno (2016) repele o que denomina “[...] afirmativas genéricas, que vêm se mostrando comuns, no sentido de que o direito brasileiro migra em direção ao common law ou algo do gênero" (BUENO, 2016).

Em sentido parcialmente oposto, mas consentâneo com o teor do art. 927 do Código de Processo Civil de 2015 (BRASIL, 2015), que amplia o rol de pronunciamentos judiciais a que juízes e tribunais estão vinculados, Humberto Theodoro Júnior (2015) afirma:

O Novo Código de Processo Civil vai muito além e encaminha-se para uma aproximação maior com a common law, estendendo o dever de submissão ao precedente, principalmente àquele dos tribunais superiores, como regra geral, sem limitar-se às súmulas qualificadas como vinculantes (art. 926). (THEODORO JÚNIOR, 2015).

A razão dessa maior vinculação aos precedentes está na força normativa da jurisprudência, como também destaca Humberto Theodoro Júnior (2015), ao esclarecer que as construções jurisprudenciais deixaram o campo de pura especulação doutrinária, não se negando mais o aspecto primário da jurisprudência, compreendidas agora como normas jurídicas. No mesmo sentido, Daniel Assumpção Amorim Neves (2016) afirma que o sistema processual brasileiro vigente colocou a jurisprudência na categoria de fonte de direito (NEVES, 2016). Na tradição romano-germânica - que o Brasil se distancia em parte com o novel sistema 
de precedentes - "[...] a jurisprudência possui uma maior autolimitação em relação à legislação" (STRECK; ABBOUD, 2013, p. 31) e se apresenta com força normativa inferior à legislação.

É tênue, portanto, a linha que separa a interpenetração dos sistemas e a adaptação improvisada de institutos pelo sistema jurídico brasileiro.

\section{As lacunas do raciocínio indutivo e a aplicação jurisprudencial}

Essa aproximação entre as famílias da civil law e da common law no sistema jurídico do Brasil, com a adoção adaptada de institutos do segundo no primeiro, impõe, especialmente pelo enfoque dado no presente trabalho, descrever comparativamente as características marcantes dos dois sistemas jurídicos, sobretudo na aplicação do precedente, seja ele persuasivo ou vinculante.

A família romano-germânica ou da civil law estrutura-se a partir da ideia de que o direito só ganha sentido quando visto sob perspectiva lógica e hierarquicamente sistematizada, sendo a pirâmide normativa de Hans Kelsen (KELSEN, 1998) a expressão gráfica mais significativa dessa nomogênese.

Nessa linha, estando as normas dispostas em um uma estrutura lógica, qualquer ponto de incerteza compromete por completo a higidez do sistema jurídico. Por essa razão é que os sistemas de raiz romano-germânica temem as lacunas das normas e as combatem com as diferentes formas de integração. Busca-se a todo custo o estabelecimento de regras abstratas e gerais.

No sentido oposto apresenta-se o sistema da common law. Nele, “[...] a ideia que permeia o sistema é de que o direito existe não para ser um edifício lógico e sistemático, mas para resolver questões concretas" (SOARES, 2000, p. 53). Assim, a lacuna, que na civil law é o ponto cego da estrutura hierarquizada de normas, na common law é a razão de ser e força motriz do próprio sistema.

Por trás dessa dicotomia está o tipo de raciocínio predominante em cada um dos sistemas: o indutivo, na common law, e o dedutivo, na civil law.

A indução, argumentação dominante na Common Law, é definida como aquela que conclui pelo particular, seja aquela do tipo generalizadora (parte do particular, vai ao geral e conclui pelo particular), seja a analógica ou empírica (que parte de um particular e conclui outro particular). No primeiro tipo, conforme nos ensina a Lógica Menor, o predicado que convém ao particular equivalente ao geral convém ao geral, caso em que o particular deve ser suficientemente enumerado, para poder equivaler ao geral; no caso da indução empírica ou analógica, o princípio é de que o predicado 
que se diz de um sujeito semelhante a outro se diz deste outro, com probabilidade. $\mathrm{Na}$ indução empírica ou analógica, distinguem-se as espécies: $1^{\circ}$ ) indução a pari (baseada na semelhança positiva e de paridade: a casu pari ad casum pare); $2^{\circ}$ ) indução ao contrário, ou seja, estabelecendo-se os extremos da mesma espécie; $3^{\circ}$ ) indução $a$ fortiori (vai-se de um caso mais forte para um menos forte, sendo que o caso menos forte é aceito, com maioria de razão), que num case law se apresentaria da seguinte forma: no leading case XYZ, num acidente automobilístico, houve danos pessoas leves e o causador foi obrigado a pagar indenização de $N$ moedas (caso forte); no caso sub studio, num acidente automobilístico, houve morte da vítima (caso menos forte) e, portanto, a fortiori, a indenização deverá ser de $\mathrm{N}+\mathrm{n}$ moedas, apoiado com maioria de razão (SOARES, 2000, p. 55-56, grifos do autor).

Embora fundamentadas tendo como pano de fundo a pesquisa científica, Karl Popper (2013) é quem oferece as mais fundadas objeções ao raciocínio indutivo. Tais objeções podem ser adequadamente transpostas para a ciência do Direito.

Para Karl Popper (2013) o raciocínio indutivo não permite, como querem seus adeptos, que uma inferência conduza de enunciados particulares para enunciados universais, “[...] independentemente de quão numerosos sejam estes" (POPPER, 2013, p. 27), conceito que pode ser resumido em seu célebre aforismo: "independentemente de quantos casos de cisnes brancos possamos observar, isso não justifica a conclusão de que todos os cisnes são brancos" (POPPER, 2013, p. 28, grifo do autor). A isso Karl Popper chamava de "problema da indução" (POPPER, 2013, p. 28), ou seja, “[...] a indagação acerca da validade ou verdade de enunciados universais que encontrem base na experiência [...]" (POPPER, 2013, p. 28).

O problema da indução, para Karl Popper, conduz àquilo que denomina de "regressão infinita", pois, ao se tentar considerar verdade um enunciado universal inferido a partir de enunciados particulares, “[...] surgirão de novo os mesmos problemas que levaram à sua formação" (POPPER, 2013, p. 29), levando a novas inferências indutivas para justificar os enunciados universais extraídos.

Nessa linha, não se pode negar, ainda que assentindo que o Brasil continua mantendo a tradição romano-germânica, que as construções jurisprudenciais vinculantes do Código de Processo Civil de 2015 (BRASIL, 2015) partem de um raciocínio indutivo do tipo generalizador, à semelhança do que ocorre no sistema da common law, ou seja, "parte do particular, vai ao geral e conclui pelo particular" (SOARES, 2000, p. 55).

Transpondo essas objeções à indução de Karl Popper para o sistema de precedentes do Código de Processo Civil de 2015 (BRASIL, 2015), verifica-se, portanto, a vagueza e o plano de incerteza em que são construídos e aplicados os enunciados e as teses vinculantes dos pronunciamentos descritos no rol do art. 927 do citado código, independentemente de quão numerosos tenham sido os julgados que contribuíram para a formação da jurisprudência. 
À luz do pensamento popperiano, haverá, sempre, situações em descoberto nas teses jurisprudenciais e passíveis de falseamento do enunciado universal.

\section{O risco de engessamento da jurisprudência}

Sobre os problemas e limitações do raciocínio indutivo, poder-se-ia argumentar que o Código de Processo Civil de 2015 (BRASIL, 2015) dispõe de meios adequados e suficientes para revisão das teses veiculadas nos pronunciamentos vinculantes. No entanto, na contramão do sentido democrático que se espera, vê-se que o código não dispôs de mecanismos para revisão das teses tão assertivos quanto aqueles que se propõem à sua fixação.

O $\S 4^{\circ}$ do art. 927 do Código de Processo Civil permite "a modificação de enunciado de súmula, de jurisprudência pacificada ou de tese adotada em julgamento de casos repetitivos [...]” (BRASIL, 2015), sempre observando a necessidade de fundamentação adequada e específica, à luz dos princípios da segurança jurídica, da proteção da confiança e da isonomia. A previsão estaria perfeitamente adequada, não fosse o rigor imposto na admissibilidade de recursos, principalmente os recursos especial e extraordinário, inclusive com o uso da chamada "jurisprudência defensiva"”.

Para Lenio Streck e Georges Abboud,

$\mathrm{O}$ risco aumenta quando constatamos que o CPC cria uma verdadeira barreira à possibilidade de revisão da tese jurídica em causas futuras, por meio de diversos mecanismos processuais, tais como a improcedência liminar do pedido, a monocratização de decisões dos tribunais, a inexistência de reexame necessário quando sucumbente a fazenda pública, o risco de multa por litigância de má-fé etc. Há, dessa forma, um sério risco de engessamento da jurisprudência. (STRECK; ABBOUD, 2016, p. 1193).

Outro instituto previsto no Código de Processo Civil de 2015 que paira significativa omissão é o incidente de assunção de competência, previsto no art. 947 , cujo $\S 3^{\circ}$ se limita apenas a indicar a possibilidade de revisão da tese, sem, contudo, explicitar o seu procedimento (BRASIL, 2015).

\footnotetext{
${ }^{3}$ À criação de requisitos e obstáculos, bem como o excessivo apego à formalidade, na tentativa de obstaculizar a admissão de recursos, sobretudo o recurso especial e o recurso extraordinário, valendo-se os tribunais, muitas vezes, de interpretações extra ou contra legem, convencionou-se chamar eufemisticamente de jurisprudência defensiva.
} 
O mesmo ocorre quanto à possibilidade de revisão da tese do incidente de resolução de demandas repetitivas, prevista no art. 986, do Código de Processo Civil de 2015 (BRASIL, 2015). Sobre esse ponto, inclusive, Cassio Scarpinella Bueno sustenta que

[...] importa entender aplicável, ao menos por analogia, o disposto na Lei $\mathrm{n}$. 11.417/2006, que deve guiar, embora não exclusivamente, a disciplina regimental que venha a ser dada a esta iniciativa, sempre franqueada a ampla participação de amici curiae nesta empreitada, ainda que no ambiente das audiências públicas. (BUENO, 2016, grifos do autor).

No entanto, merece indicação ainda, e até com maior destaque, a restrição no rol de legitimados à revisão da tese no incidente de resolução de demandas repetitivas, que excluiu as partes, pois o art. 986 do Código de Processo Civil de 2015 só faz menção à possibilidade de iniciativa pelo tribunal, ou pelos legitimados descritos no art. 977, III, a saber, o Ministério Público e a Defensoria Pública (BRASIL, 2015).

Como denuncia Cassio Scarpinella Bueno (2016), a restrição imposta padece, inclusive, de inconstitucionalidade formal, já que o inciso III do art. 977 só se materializou na etapa de revisão do texto do projeto de lei, não tendo retornado à casa revisora, como impõe o parágrafo único do art. 65 da Constituição da República (BRASIL, 1988).

\section{O minimalismo judicial como alternativa hermenêutica}

Alicerçado nos acordos não totalmente teorizados e no conservadorismo político de Edmund Burke, Cass R. Sunstein desenvolve o seu conceito de minimalismo judicial, movimento que "[...] tem por proposta uma retomada do papel que o Judiciário deveria ocupar em um Estado que se considera democrático" (FERNANDES, 2012, p. 10569) com o uso de decisões caracterizadas pela estreiteza e superficialidade.

A adoção do minimalismo como técnica hermenêutica para os pronunciamentos vinculantes no Código de Processo Civil de 2015 (BRASIL, 2015) representa alternativa viável contra o engessamento das teses, na medida em que propõe um limite na teorização e na abstração dos pronunciamentos judiciais, favorecendo, indiretamente, o permanente "falsear" - no sentido popperiano -, deixando sempre abertas as possibilidades da distinção ou alteração do sentido jurisprudencial.

Contudo, antes de descer às minúcias, convém explicitar aquelas que podem ser consideradas como premissas para o minimalismo judicial de Cass R. Sunstein: os acordos não 
totalmente teorizados e o conservadorismo na acepção desenvolvida por Edmund Burke (2014).

\subsection{Os acordos não totalmente teorizados}

Segundo o próprio Cass R. Sunstein em entrevista ao professor da George Mason University, Tyler Cowen (2016), o que melhor define todo seu pensamento são os incompletely theorized agreements, em tradução livre, os acordos não totalmente teorizados. Nos acordos não totalmente teorizados é possível descobrir quais direitos cabem a cada grupo ou indivíduo e, ainda, como agir em relação a estes, sem que se comprometa determinada concepção sobre os fundamentos da moralidade ou mesmo sem saber exatamente o que os envolvidos pensam sobre os fundamentos dela. Em outras palavras, com os acordos não totalmente teorizados podese concordar sobre abstrações sem concordar sobre o significado delas.

Assim, nos casos difíceis, pode-se chegar a um consenso sobre o direito mesmo quando as teorias que se digladiam sejam completamente divergentes (SUNSTEIN, 2007). Isso porque, como premissa para seu funcionamento, há o que Sunstein denomina de "descida conceitual" (SUNSTEIN, 2007, p. 3, tradução nossa) ${ }^{4}$, isto é, uma caracterização especial do silêncio, que age como um dispositivo capaz de "[...] produzir convergência apesar do desacordo, da incerteza, dos limites do tempo e de capacidade, e da heterogeneidade." (SUNSTEIN, 2007, p. 3, tradução nossa) ${ }^{5}$. Dessa maneira, os acordos não totalmente teorizados permitiriam que as pessoas pudessem "aceitar um resultado [...] sem compreender ou convergir sobre o fundamento último para essa aceitação.” (SUNSTEIN, 2007, p. 3, tradução nossa) ${ }^{6}$.

Os acordos não totalmente teorizados são cruciais no esforço de construir decisões efetivas em diversas áreas da vida pública ou privada, como, por exemplo, no trabalho ou mesmo no ambiente familiar.

Um grande exemplo de aplicação de acordo não totalmente teorizado está na Declaração Universal dos Direitos Humanos, proclamada em 10 de dezembro de 1948, cujo processo de elaboração se deu por meio de representantes das mais variadas origens e culturas e, como afirma Sunstein (2007), recusando o envolvimento em teorias e construindo amplas

\footnotetext{
${ }^{4}$ Texto original: "conceptual descent”.

${ }^{5}$ Texto original: "[...] producing convergence despite disagreement, uncertainty, limits of time and capacity, and heterogeneity.”

${ }^{6}$ Texto original: "They may accept an outcome [...] without understanding or converging on an ultimate ground for that acceptance."
} 
compreensões baseadas em práticas compartilhadas. Em uma determinada fase do projeto, “[...] as pessoas envolvidas na elaboração da declaração produziram 'uma lista de quarenta e oito itens que representavam... o núcleo comum de' uma ampla gama de documentos e propostas [...]." (SUNSTEIN, 2007, p. 7, tradução nossa) ${ }^{7}$. O resultado pode ser expresso pela frase de Jacques Maritain (1948), filósofo envolvido no processo de elaboração da Declaração Universal de Direitos Humanos: "Sim, [...] estamos de acordo sobre os direitos, mas na condição de que ninguém nos pergunte o porquê." (MARITAIN, 1948, p. i, tradução nossa) ${ }^{8}$.

Assim, o uso dos acordos não totalmente teorizados no processo decisório representa a chave que abre as portas para o minimalismo judicial. Sunstein (2007) argumenta que as pessoas, quando teorizam em um alto nível de abstração, o fazem para demonstrar um viés, confusão ou inconsistência; um esforço que os operadores do Direito não devem abandonar, já que "não seria sensato celebrar a modéstia teórica em todos os momentos e em todos os contextos" (SUNSTEIN, 2007, p. 13, tradução nossa) ${ }^{9}$. Isso porque, em determinados casos, os operadores do Direito têm informação suficiente para adotar uma abordagem ou interpretação ambiciosa; em outros, precisam adotá-las.

Contudo, os operadores do Direito - entre eles os juízes - não são infalíveis. É aqui que os julgamentos não totalmente teorizados exercem uma importante função. Afirma Cass R. Sunstein:

Eles ajudam fazer as constituições e o Direito Constitucional possível; ajudam até a tornar a vida social possível. O silêncio - em algo que pode se comprovar falso, obtuso ou excessivamente contencioso - pode ajudar a minimizar o conflito, permitindo que o presente aprenda com o futuro e que se economize muito tempo e dinheiro (SUNSTEIN, 2007, p. 13, tradução nossa) ${ }^{10}$.

Outra vantagem reside no fato de que quando a decisão está fundamentada em um princípio ou regra de menor abstração, aquele que sucumbe não perde os argumentos de sua tese. Isso porque ela não foi rejeitada ou declarada inadmissível, já que a análise é feita através de um corte menos profundo no plano da abstração de uma teoria.

Cass R. Sunstein (2007), ainda, argumenta que os acordos não totalmente teorizados evitam um antagonismo desnecessário, quer entre cidadãos, quer entre juízes, sobretudo quando

\footnotetext{
7 Texto original: "[...] the people involved in drafting the declaration produced 'a list of forty-eight items that represented ... the common core of' a wide range of documents and proposals [...]."

${ }^{8}$ Texto original: "Yes, [...] we agree about the rights but on condition that no one asks us why."

${ }^{9}$ Texto original: "It would not be sensible to celebrate theoretical modesty at all times and in all contexts."

${ }^{10}$ Texto original: "They help make constitutions and constitutional law possible; they even help make social life possible. Silence - on something that may prove false, obtuse, or excessively contentious - can help minimize conflict, allow the present to learn from the future, and save a great deal of time and expense."
} 
estes estiverem deliberando em colegiado. Isso se dá através do uso de princípios ou regras de "baixo nível”, isto é, de menor grau de abstração.

\subsection{O conservadorismo de edmund burke}

Cass R. Sunstein vê no pensamento de Edmund Burke e no seu conservadorismo político um importante referencial teórico. Edmund Burke (1729-1797) foi um filósofo e político anglo-irlandês, autor da obra Reflexões sobre a Revolução na França, publicada em novembro de 1790 e encarada como "um manifesto da contrarrevolução [...]"11 (MACKINTOSH, 1791, p. xi, tradução nossa). A obra Reflexões é tida, hoje, como a fundadora do moderno conservadorismo político (SOARES, 2014; MANNHEIN, 1963).

Na obra, Burke critica a Revolução Francesa não propriamente pelos seus ideais, mas pela adoção da forma de revolução. Compreendia que as entranhas do poder e da Constituição na França estavam comprometidas, mas entendia que a reforma - não a revolução - seria o processo mais adequado para a França.

A conceituação do minimalismo judicial de Sunstein tem forte influência do pensamento de Burke. Como afirma o próprio Sunstein, "aqueles que enfatizam os acordos não totalmente teorizados têm um débito evidente com Edmund Burke, que foi, em certo sentido, o grande teórico da teorização incompleta" (SUNSTEIN, 2007, p. 15, tradução nossa) ${ }^{12}$, sendo esta a abordagem característica do minimalismo.

Para Sunstein há duas espécies de minimalismo; uma racionalista e outra mais "burkeana", também chamada por ele de "minimalismo burkeano"13. Entretanto, em maior ou menor grau, é evidente a inflexão burkeana em ambas as formas do minimalismo.

\subsection{O minimalismo judicial}

Segundo explica Rogério Gesta Leal (2008, p. 10), os minimalistas não acreditam em nenhuma teoria da jurisdição salvadora ou emancipatória. Nesse sentido, Cass R. Sunstein

\footnotetext{
${ }^{11}$ Texto original: "It is the manifesto of a Counter Revolution [...]".

12 Texto original: "Those who emphasize incompletely theorized agreements owe an evident debt to Edmund Burke, who was, in a sense, the great theorist of incomplete theorization."

${ }^{13}$ Cf. SUNSTEIN, 2015, p. 68.
} 
afirma que o "minimalismo não é uma completa teoria da interpretação [...]". (SUNSTEIN, 2015, p. xvi, tradução nossa) ${ }^{14}$.

O minimalismo judicial de Cass R. Sunstein prefere passos pequenos e cautelosos, gradualmente sedimentados em decisões e práticas do passado, enfatizando, sobretudo, “[...] os limites das teorias de grande escala" (SUNSTEIN, 2015, p. 16, tradução nossa) ${ }^{15}$, o que confirma a ligação e a opção pelos acordos não totalmente teorizados, como descrito anteriormente, e sua proposta de limites às abordagens teóricas abstratas. Em verdade, o minimalismo não quer adotar qualquer tipo de teoria fundamental, preferindo "superficialidade à profundidade" (SUNSTEIN, 2015, p. 16, tradução nossa) ${ }^{16}$.

O minimalismo caracteriza-se, portanto, por decisões restritas e focadas nos casos e nas suas particularidades. Ou seja, os minimalistas “[...] preferem estreiteza à extensão." (SUNSTEIN, 2015, p. 16, tradução nossa) ${ }^{17}$, propósito que pode ser exemplificado pela afirmação do Chief Justice Roberts, in verbis: "Se não é necessário decidir mais, é necessário não mais decidir." (ESTADOS UNIDOS, 2004, tradução nossa) ${ }^{18}$.

Essas características, segundo Cass R. Sunstein (2008), estão ligadas a razões essencialmente pragmáticas, já que o minimalismo atenta para os custos das decisões e para os custos dos seus erros, acreditando que tal abordagem poderá minimizar tanto um, quanto outro. Cass R. Sunstein argumenta:

Os minimalistas acreditam que deixando as questões centrais não decididas, podem manter um amplo espaço para o autogoverno, demonstrando, ao mesmo tempo, respeito às pessoas que discordam sobre questões fundamentais (SUNSTEIN, 2008, p. 1 , tradução nossa $)^{19}$.

Ao deixar em descoberto as questões que não mais precisam ser decididas, os minimalistas, por meio de abordagens menos abstratas, atuam como importantes catalisadores desses processos e dos respectivos resultados políticos.

Há diferentes graus de minimalismo. Alguns minimalistas o elegem para quase todos os contextos, embora advirta Cass R. Sunstein (2015) que o minimalismo não é uma abordagem para todas as épocas ou períodos. Outros, de uma forma mais consciente e cuidadosa, entendem

\footnotetext{
${ }^{14}$ Texto original: "Minimalism is not a full theory of interpretation [...]".

15 Texto original: "[...] the limits of large-scale theories."

16 Texto original: "[...] shallowness to depth."

17 Texto original: "[...] prefer narrowness to width."

${ }^{18}$ Texto original: "[...] if it is not necessary to decide more, it is necessary not to decide more [...]."

${ }^{19}$ Texto original: "Minimalists believe that by leaving central issues undecided, they can maintain ample space for self-governance while also demonstrating respect to people who disagree on fundamental matters.”
} 
que a adoção da abordagem minimalista é casuística. Nesse sentido, ressalva Cass R. Sunstein (2008), em muitos contextos, argumentos como os de que a abordagem minimalista reduz os custos das decisões ou de seus erros, não proporcionam uma defesa adequada do minimalismo judicial. Isso porque, nesses casos, ao dar pequenos passos, os tribunais que adotam uma postura minimalista impõem graves encargos, especialmente para instâncias inferiores, podendo levar a muitos erros. "Previsibilidade é um importante valor, e decisões minimalistas tornam a previsibilidade impossível de ser alcançada." (SUNSTEIN, 2008, p. 2, tradução nossa) ${ }^{20}$.

Com o uso do minimalismo como recurso hermenêutico para a fixação das teses jurisprudenciais vinculantes do Código de Processo Civil de 2015 (BRASIL, 2015), abre-se a possibilidade de, sem comprometer a estabilidade, integralidade e coerências preconizadas pelo art. 926, fixar teses que reflitam e abordem somente o que seja estritamente necessário (estreiteza e superficialidade) para o sentido de uniformização que o Código busca, e deixar suficientemente aberto o campo para o distinguish e, especialmente, para o overruling, sem que a estabilidade seja confundida com a perpetuação.

\section{Conclusão}

Negar a interpenetração dos mais variados sistemas jurídicos em um mundo cuja globalização é a marca, equivale a negar as transformações e sentido da pós-modernidade. Propôs-se nesse artigo explicitar a fragilidade conceitual que marca o sistema de precedentes do Código de Processo Civil de 2015 (BRASIL, 2015), enfrentando-a com uma hipótese: a aplicação do minimalismo judicial de Cass R. Sunstein como alternativa hermenêutica.

O sistema de precedentes do Código de Processo Civil de 2015 (BRASIL, 2015) propõe considerável intensificação no fenômeno da interpenetração das famílias ou sistemas jurídicos mais proeminentes no mundo, a civil law e a common law, fato, por si só, digno de nota. Contudo, como cada um dos sistemas possuem suas imperfeições, cada instituto ou modelo importado ou exportado deve ser submetido a um rigoroso processo de validação científica. Quando isso não é feito, emergem incongruências que acabam por sacrificar o valioso intuito de evolução da ordem jurídica e democrática.

Assim, a imperfeição do raciocínio indutivo, aliada ao propósito de, na civil law, sempre se buscar regras gerais e abstratas, transformam o almejado sentido de estabilidade da

\footnotetext{
${ }^{20}$ Texto original: "Predictability is an important value, and minimalist rulings make predictability impossible to achieve."
} 
jurisprudência em enrijecimento dos precedentes vinculantes, limitando o potencial de renovação de suas próprias teses e adaptações necessárias.

Desse modo, o minimalismo judicial deve ser encarado como alternativa hermenêutica, ainda que episódica, para a superação desse quadro de potencial congelamento da jurisprudência. Não se trata de violar - nem veladamente - o disposto no art. $489, \S 1^{\circ}, I V$, do Código de Processo Civil de 2015 (BRASIL, 2015), deixando de enfrentar aqueles argumentos deduzidos no processo, capazes de enfraquecer as conclusões do julgador. O que o minimalismo judicial propõe, com a defesa da estreiteza e da superficialidade nas decisões $\mathbf{e}$ com a necessária adaptação ao sistema jurídico brasileiro, é restringir as manifestações judiciais ao que somente se mostrar imprescindível para decisão. E essa imprescindibilidade abrange, por óbvio, os argumentos capazes de infirmar a conclusão do julgador, sob pena de nulidade pela violação frontal do dispositivo supra e do art. 93, IX, da Constituição da República (BRASIL, 1988).

Em verdade, a abordagem minimalista pelo Judiciário só terá sentido se adotada como profilaxia, ou seja, como terapia que antecipa e minimiza os riscos do engessamento da jurisprudência. Caso contrário, será inócua, principalmente diante de um sistema recursal repleto de barreiras, em especial para a instância extraordinária.

\section{Referências bibliográficas}

BRASIL. Constituição (1988). Emenda Constitucional n. 45, de 30 de dezembro de 2004. Altera dispositivos dos arts. $5^{\circ}, 36,52,92,93,95,98,99,102,103,104,105,107,109,111$, 112, 114, 115, 125, 126, 127, 128, 129, 134 e 168 da Constituição Federal, e acrescenta os arts. 103-A, 103B, 111-A e 130-A, e dá outras providências. Disponível em: <http://www. planalto.gov.br/ccivil_03/constituicao/emendas/emc/emc45.htm>. Acesso em: 15 maio 2018.

BRASIL. Constituição da República Federativa do Brasil de 1988. Disponível em: $<$ http://www.planalto.gov.br/ccivil_03/constituicao/constituicaocompilado.htm>. Acesso em: 15 maio 2018.

BRASIL. Lei n. 11.672, de 8 de maio de 2008. Acresce o art. 543-C à Lei no 5.869, de 11 de janeiro de 1973 - Código de Processo Civil, estabelecendo o procedimento para o julgamento de recursos repetitivos no âmbito do Superior Tribunal de Justiça. Disponível em: 
$<$ http://www.planalto.gov.br/ccivil_03/_Ato2007-2010/2008/Lei/L11672.htm>. Acesso em: 15 maio 2018.

BRASIL. Lei n. 13.105, de 16 de março de 2015. Código de processo civil. Disponível em: $<$ http://www.planalto.gov.br/ccivil_03/_ato2015-2018/2015/lei/113105.htm>. Acesso em: 15 maio 2018.

BRASIL. Lei n. 5.869, de 11 de janeiro de 1973. Institui o Código de Processo Civil. Disponível em: $<$ http://www.planalto.gov.br/ccivil_03/leis/L5869.htm>. Acesso em: 15 maio 2018.

BRASIL. Lei n. 8.038, de 28 de maio de 1990. Institui normas procedimentais para os processos que especifica, perante o Superior Tribunal de Justiça e o Supremo Tribunal Federal. Disponível em: <http://www.planalto.gov.br/ccivil_03/leis/L8038.htm>. Acesso em: 15 maio 2018.

BUENO, Cassio Scarpinella. Manual de direito processual civil: inteiramente estruturado à luz do novo CPC, de acordo com a Lei n. 13.256, de 4-2-2016. 2. ed. rev., atual. e ampl. São Paulo : Saraiva, 2016.

BURKE, Edmund. Reflexões sobre a Revolução na França. Tradução, apresentação e notas de José Miguel Nanni Soares. São Paulo: Edipro, 2014.

CÂMARA, Alexandre Freitas. O novo processo civil brasileiro. 2. ed. São Paulo: Atlas, 2016.

COWEN, Tyler. Conversations with Tyler: A Conversation with Cass Sunstein. Washington, 15 jun. 2016. Disponível em: <https://www.mercatus.org/events/conversationstyler-conversation-cass-sunstein>. Acesso em: 15 maio 2018.

DONIZETTI, Elpídio. A força dos precedentes no novo Código de Processo Civil. Direito UNIFACS, n. 175, p. 2472-2052, jan. 2015. Disponível em: <http://www.revistas. unifacs.br/index.php/redu/article/view/3446/2472>. Acesso em: 15 maio 2018. 
ESTADOS UNIDOS. Suprema Corte. Petition for judicial review n. 03-1008. PDK Laboratories Inc., v. United States Drug Enforcement Administration. Washington, 26 de março de 2004. Disponível em: <http://caselaw.findlaw.com/us-dc-circuit/1207124.html>. Acesso em: 15 maio 2018.

FERNANDES, Bernardo Gonçalves Alfredo. A teoria da interpretação judicial para além do interpretativismo e do não-interpretativismo. In: Anais do XXI Encontro Nacional do CONPEDI. Florianópolis: Fundação Boiteux, 2012, p. 10564-10582. Disponível em: $<$ http://www.publicadireito.com.br/artigos/?cod=f3173935ed8ac4bf $>$. Acesso em: 15 maio 2018.

GUSTIN, Miracy Barbosa de Sousa; DIAS, Maria Tereza Fonseca. (Re)pensando a pesquisa jurídica: teoria e prática. 4. ed. rev. e atual. Belo Horizonte: Del Rey, 2015.

HARVARD LAW SCHOOL. Faculty Profiles. Cass R. Sunstein. 2016. Disponível em: $<$ http://hls.harvard.edu/faculty/directory/10871/Sunstein/>. Acesso em: 15 maio 2018.

KELSEN, Hans. Teoria pura do direito. Trad. João Baptista Machado. 6. ed. São Paulo: Martins Fontes, 1998.

LEAL, Rogério Gesta. Perfis democrático-procedimentais da jurisdição comunitária: uma possibilidade para o Brasil. In: Revista eletrônica de Direito do Estado. Salvador, n. 16, out.-dez. 2008. Disponível em: <http://www.direitodoestado.com/revista/REDE-16OUTUBRO-2008-ROGERIO\%20GESTA\%20LEAL.pdf>. Acesso em: 15 maio 2018.

LEITER, Brian. Top Ten Law Faculty (by area) in Scholarly Impact, 2009-2013. 2014. Disponível em: $<$ http://www.leiterrankings.com/faculty/2014_scholarlyimpact.shtml>. Acesso em: 15 maio 2018.

MACKINTOSH, James. Vindiciae gallicae: defence of the french revolution and its English admires, against the accusations of the right Hon. Edmund Burke. 3. ed. London: GGJ \& J. Robinson, 1792. Disponível em: <https://books.google.com.br/books?id=ltdBAAAAc AAJ\&dq=vindiciae $\% 20$ gallicae $\% 20$ james $\% 20$ mackintosh \&hl=pt-BR\&pg=PP7\#v= onepage \&q\&f=false $>$. Acesso em: 15 maio 2018. 
MARITAIN, Jacques. In: UNESCO. Organização das Nações Unidas para a Educação, a Ciência e a Cultura. Human Rights: Comments and interpretation. Paris, 25 jul. 1948. Disponível em: <http://unesdoc.unesco.org/images/0015/001550/155042eb.pdf > . Acesso em: 15 maio 2018.

NEVES, Daniel Amorim Assumpção. Manual de direito processual civil. 8. ed. Salvador: JusPodivm, 2016.

POPPER, Karl Raimund. A lógica da pesquisa científica. Trad. Leonidas Hegenberg e Octanny Silveira da Mota. 2. ed. São Paulo: Culturix, 2013.

REISSINGER, Simone. Ativismo judicial e o minimalismo de Cass Sunstein: uma abordagem interpretativa do direito à saúde no Brasil. 2016. 243f. Tese (Doutorado) Pontifícia Universidade Católica de Minas Gerais, Belo Horizonte, 2016.

SOARES, Guido Fernando Silva. Common law: introdução ao direito dos EUA. 2. ed. São Paulo: Revista dos Tribunais, 2000.

STRECK, Lenio Luiz. Art. 927. In: STRECK, Lenio Luiz; NUNES, Dierle; CUNHA, Leonardo (orgs.). Comentários ao Código de Processo Civil. São Paulo: Saraiva, 2016.

STRECK, Lenio Luiz; ABBOUD, Georges. O que é isto - o precedente judicial e as súmulas vinculantes? Porto Alegre: Livraria do Advogado, 2013.

SUNSTEIN, Cass R. Beyond judicial minimalism. Public Law \& Legal Theory Working Paper, Chicago, n. 237, set. 2008. Disponível em: <http://chicagounbound.uchicago. edu/cgi/viewcontent.cgi? article $=1041 \&$ context $=$ public_law_and_legal_theory $>$. Acesso em: 15 maio 2018.

SUNSTEIN, Cass R. Constitution of many minds. New Jersey: Princeton University Press, 2009.

SUNSTEIN, Cass R. Constitutional personae. New York: Oxford University Press, 2015. 
SUNSTEIN, Cass R. Incompletely theorized agreements in Constitutional Law. Public Law \& Legal Theory Working Paper, Chicago, n. 147, jan. 2007. Disponível em: <http://chicago unbound.uchicago.edu/cgi/viewcontent.cgi? article $=1149 \&$ context $=$ public_law_and_legal_the ory>. Acesso em: 15 maio 2018.

SUNSTEIN, Cass R. One case at a time: judicial minimalism on the Supreme Court. Massachusetts: Harvard University Press, 1999.

THEODORO JÚNIOR, Humberto. Código de processo civil anotado. 20. ed. rev. e atual. Rio de Janeiro: Forense, 2016.

THEODORO JÚNIOR, Humberto. Curso de Direito Processual Civil: Teoria geral do direito processual civil, processo de conhecimento e procedimento comum. 56. ed. rev., atual. e ampl. Rio de Janeiro: Forense, 2015. v. I. 


\title{
O MODELO DE ADMINISTRAÇÃO DE CONFLITOS NO CONTEXTO DO SISTEMA DE JUSTIÇA BRASILEIRO E AS CONSEQUÊNCIAS DE SUA ADOÇÃO COMO PARTIDA PARA A NECESSÁRIA AMPLIAÇÃO DE FOCO E DE PARADIGMAS
}

\author{
Magda Fiegenbaum \\ Tribunal de Justiça de Santa Catarina \\ Universidade Federal de Santa Catarina \\ Grazielly Alessandra Baggenstoss \\ Universidade Federal de Santa Catarina
}

Resumo: A partir da análise do relatório "Justiça em Números 2017" e do "Relatório do Índice de Confiança na Justiça no Brasil”, o presente escrito questiona, pelo método dedutivo e por pesquisa documental e bibliográfica, o formato e finalidades do atual modelo de sistema de Justiça. Assim, perquire também sobre as causas e consequências de sua adoção, propondo a reflexão sobre a legitimidade do Poder Judiciário enquanto instituição que se pretende pacificadora, mas, contraditoriamente, não oportuniza os meios para tanto.

Palavras-chave: modelo judiciário, eficiência e produtividade, formas adequadas de solução de conflitos.

\begin{abstract}
Resumen/Résumé
Based on the analysis of the "Justice in Numbers 2017" report and the "Report on the Confidence Index in Brazil", by deductive method and by documentary and bibliographic research, this paper questions the format and purposes of the current model of Brazilian Justice system. Thus, it also search for the causes and consequences of its adoption, proposing a reflection on the legitimacy of the Judiciary as an institution that is intended to be a peacemaker, but, contradictorily, does not.
\end{abstract}

Keywords/Palabras-claves/Mots-clés: judicial model, efficiency and productivity, appropriate forms of conflict resolution. 


\section{Considerações iniciais}

Segundo o Instituto Brasileiro de Geografia e Estatística - IBGE, o Brasil conta com cerca de 209 milhões de habitantes. Paralelamente, a 13ª edição do Relatório "Justiça em Números", do Conselho Nacional de Justiça ${ }^{1}$, aponta que o Poder Judiciário finalizou o ano de 2016 com 79,7 milhões de processos em tramitação aguardando alguma solução definitiva (CNJ, 2017). Considerando que cada processo é composto de, pelo menos, duas partes, poderse-ia concluir que se está a caminho da existência de um processo para cada brasileiro ${ }^{2}$.

Apenas no decorrer de 2016, 29,4 milhões de casos novos ingressaram na Justiça e 29,4 milhões foram baixados ${ }^{3}$. Embora a baixa tenha sido praticamente a mesma que o quantitativo ingressado, o estoque do acervo cresceu em 2,7 milhões (CNJ, 2017). Assim, "mesmo que o Poder Judiciário fosse paralisado sem o ingresso de novas demandas e mantida a produtividade dos magistrados e dos servidores, seriam necessários aproximadamente 2 anos e 8 meses de trabalho para zerar o estoque." (CNJ, 2017, p. 67)

Além disso, hoje o tempo médio de tramitação dos processos até que se considere "baixado" é de 1 ano e 9 meses na fase de conhecimento e de 4 anos e 10 meses na fase de execução no $1^{\circ}$ grau de jurisdição, e de 8 meses no $2^{\circ}$ grau.” (CNJ, 2017, p. 134)

A taxa de produtividade da justiça brasileira, embora possa ser considerada alta - dada a capacidade de finalizar uma quantidade de processos ligeiramente superior à quantidade de casos novos ingressados -, por si só, não tem conseguido amenizar o excesso de demanda e a crescente litigância, fatores que contribuem sobremaneira para o retardamento da prestação jurisdicional e o atual cenário de congestionamento, gerando insatisfação e descrédito da população quanto à instituição.

Tal panorama parece recomendar a busca por outras formas de atuação e mudanças quanto à prestação jurisdicional. Não obstante a isso, cada vez mais se recorre ao Judiciário.

\footnotetext{
${ }^{1}$ Principal fonte de divulgação de dados estatísticos do Poder Judiciário desde 2004, com detalhamentos da estrutura e litigiosidade, além dos indicadores e de análises para subsidiar a Gestão Judiciária brasileira (CONSELHO NACIONAL DE JUSTIÇA, 2017).

${ }^{2}$ Boa parte de tais cifras é preenchida por "usuários recorrentes", os denominados litigantes habituais (empresas de telefonia, instituições bancárias e a Fazenda Pública), que figuram em inúmeras demandas e ocupam grande parcela da estrutura da Justiça. As autoras optaram por não discorrer exaustivamente sobre este ponto, apesar de entende-lo como grande fator contributivo para o congestionamento detectado. Todavia, consideram que essa é apenas consequência de uma causa anterior: a lesão ou ameaça a direito pelo próprio Estado, seja diretamente (pela Fazenda Pública) ou indiretamente (se considerarmos que empresas de telefonia e instituições bancárias podem ser fiscalizadas por Agências Reguladoras antes de serem judicializadas).

3 “Conforme o glossário da Resolução CNJ n. 76/2009, consideram-se baixados os processos: remetidos para outros órgãos judiciais competentes, desde que vinculados a tribunais diferentes; remetidos para as instâncias superiores ou inferiores; arquivados definitivamente; em que houve decisões que transitaram em julgado e iniciouse a liquidação, cumprimento ou execução.” (BRASIL, 2009, p. 67)
} 
Em que pese muitas pesquisas demonstrem o questionamento da legitimidade desse Órgão sob o enfoque da eficiência desde início da década de 80 e, com mais intensidade, a partir dos anos 2000, com levantamento de dados sobre o número de processos novos e em andamento a cada ano - a exemplo do Justiça em Números, do CNJ -, as informações disponibilizadas não mostram objetivamente a forma pela qual o Judiciário aparece como instituição confiável em termos de eficiência, imparcialidade e honestidade e, tampouco, indicam as motivações do cidadão em recorrer ao Judiciário para solucionar seus conflitos. (FGV, 2016, p. 02)

É o que aponta o Relatório do Índice de Confiança na Justiça no Brasil - ICJBrasil, criado há oito anos pela Fundação Getúlio Vargas com o escopo de aferir a capacidade do Judiciário como instância legítima na solução de conflitos. (FGV, 2016, p. 02)

Em pesquisa realizada entre maio e junho de 2016, mediante utilização de subíndices de percepção e de comportamento, o estudo evidenciou que, embora $29 \%$ dos entrevistados confiassem no Poder Judiciário e apenas metade dos entrevistados acreditarem que juízes são honestos, mais de $80 \%$ afirmou que recorreria a este Órgão para solucionar algum conflito em que estivesse envolvido (FGV, 2016, p. 14-17).

Em outros termos, apesar do descontentamento relativamente à confiança, rapidez na solução dos conflitos, aos custos e à facilidade no acesso, à honestidade, à capacidade de solucionar demandas levadas à sua apreciação, caso estivesse envolvido em alguma das situações hipotéticas apresentadas, a tendência do cidadão seria recorrer ao Judiciário.

O estudo, todavia, não evidenciou as motivações do cidadão para tanto, pois, quando questionado sobre qual a chance de procurar a instituição, o entrevistado tinha como únicas respostas possíveis: não; dificilmente; possivelmente; e sim, com certeza. Da mesma forma, no que pertine à metodologia do subíndice de percepção, especificamente em relação ao grau de confiança, por exemplo, o entrevistado atribuía notas de 0 a 3 às respostas: nada confiável, pouco confiável, confiável e muito confiável, sem retratar, porém, os motivos da escolha.

Frente a tal cenário, este trabalho intenciona elencar algumas das possíveis razões de o cidadão ter apenas o Judiciário como referência ao se ver envolvido em alguma situação conflituosa, tal como apontado no estudo ICJBrasil e, por consequência, demonstrar que o modelo de sistema judicial brasileiro tradicional com foco na produtividade, além de não se sustentar, está gerando um ambiente de trabalho insalubre e doenças em seus funcionários. Propõe-se, assim, a reflexão quanto ao estímulo a outras formas de administração de conflitos para além do modelo atual.

Para atingir a proposta, parte de delineamento de pesquisa dedutivo, de tipo documental e bibliográfico, e estrutura-se em três partes: explanações gerais sobre os fatores 
contributivos para a insustentabilidade do atual sistema e ao modelo eficientista de Justiça, reforçados pelo foco do Relatório "Justiça em Números" do CNJ, as consequências da adoção desse modelo e a ampliação de foco, a bem de se cogitarem possíveis caminhos rumo a mudanças que possam conjugar o atendimento efetivo dos anseios do jurisdicionado e a satisfação dos atores da Justiça.

\section{Fatores contributivos para a insustentabilidade do modelo de administração de conflitos no sistema de justiça brasileiro}

\subsection{Sistemas de Justiça: romano-germânico (civil law) e common law}

Ao introduzir brevemente o estudo sobre a história do Direito Processual Civil, SILVA, 2006) informa a existência de uma classificação dos sistemas jurídicos no que denomina de "famílias jurídicas", a partir dos estudos promovidos por um dos especialistas na área, René David, e que podem ser descritas em três grandes grupos: a romano(-canônico ${ }^{4}$ )germânica (também conhecida pela designação civil law), a dos sistemas socialistas e os sistemas filiados à common law.

O direito brasileiro integra a família denominada romano-germânica [...], de que fazem parte os sistemas jurídicos da Europa continental, especialmente a Alemanha e os países de origem latina, como França, Itália, Portugal e Espanha, e, fora da Europa, os países da América de colonização espanhola, francesa e holandesa e até alguns países da África, por influência da colonização europeia. (SILVA, 2006, p. 12)

As bases de tal modelo se assentam no direito escrito e no apego ao formalismo, e o papel do Poder Judiciário restringe-se à "[...] aplicação da vontade concreta da lei aos casos que lhe são submetidos." (GRECO, 2011,p. 02). A jurisdição é função característica do magistrado, tido como a "boca da lei", motivo pelo qual as decisões judiciais são, via de regra, consideradas atos vinculados, é dizer, atos cujos requisitos estão estabelecidos pela lei, já que o critério de decisão é rigorosamente de legalidade. (GRECO, 2011, p. 06)

Essa é a linha da doutrina do processualista italiano Chiovenda, que se embasa “[...] no postulado de que o ordenamento jurídico estatal seja, para o juiz, um dado prévio, uma coisa

\footnotetext{
${ }^{4}$ Dada a influência que o direito romano original recebeu do direito canônico (e do cristianismo), o direito dos imperadores cristãos do período bizantino, no que se designa como "período oriental do direito romano tardio" que foi o direito romano por nós herdado, e não o "originário" -, conforme SILVA, 2006, p. 13-22.
} 
existente, como se fora uma constelação posta completa e definitivamente pelo legislador, restando ao juiz a tarefa de pura aplicação da lei ao caso concreto.” (SILVA, 2006, p. 65).

Daí a administração da justiça ser moldada, necessariamente, dentro de um sistema hierárquico, dada a pequena liberdade dos juízes de primeiro grau, que são "[...] rigidamente controlados pelos tribunais superiores para que se mantenham fiéis a essa missão de serem o instrumento de cumprimento da lei." (GRECO, 2011, p. 03).

Outra característica é a repetição de decisões, de modo que casos considerados "idênticos", de similitude quanto à matéria fática, acabam sendo decididos da mesma forma. Com isso, cria-se jurisprudência e, toda vez que há divergência entre a opinião dos juízes, a resolução se dá hierarquicamente, pela atuação dos tribunais superiores. Há, portanto, "uma tendência à manutenção da ordem jurídica e à uniformização das decisões através de um sistema de recursos bastante amplo" (GRECO, 2011, p. 07), e a pacificação social acaba sendo apenas um objetivo remoto.

Uma vez que o Brasil foi colonizado por portugueses e espanhóis, tal formato acabou sendo importado, incorporado e constituindo o fundamento da formação jurídica brasileira (mesmo porque a edificação da disciplina de Teoria Geral do Processo se dá essencialmente pela doutrina dos países que adotam o sistema do direito escrito, hierárquico, do processo como instrumento do direito objetivo) e do funcionamento das instituições e atores que compõem, servem e existem em função desse sistema Justiça.

Quando se fala da Teoria Geral do Processo como uma teoria que assenta e estrutura os princípios básicos de uma ciência ou de um ramo de uma ciência, temos de ter consciência de que essa teoria, entre nós difundida, é a do sistema jurídico romano-germânico, que está crescentemente em busca da efetividade do processo e, portanto, de soluções para os pontos de estrangulamento da máquina da justiça e para o déficit garantístico do processo, no sentido de insuficiência das suas técnicas para assegurar respeito à dignidade humana de todos os seus atores e a qualidade e confiabilidade das suas decisões. (GRECO, 2011, p. 03-04, grifou-se)

Importa considerar, portanto, que esse modelo está ligado à nossa civilização e à nossa cultura. Todavia, como bem pondera Leonardo Greco ${ }^{5}$, ao estudar Teoria Geral do Processo, fundamental se apresente uma abordagem em função de diferentes paradigmas para derrubar a falsa ideia de que esse modelo de justiça seja universal e de que as suas características tradicionais devam ser aceitas como absolutas e imutáveis.

Neste sentido, apresenta o paradigma jurídico da common law, cujas bases se estruturam em uma concepção diferente de justiça. (GRECO, 2011, p. 02)

\footnotetext{
${ }^{5}$ A partir da análise da obra "The faces of justice and state authority" de Mirjan Damaska.
} 
Característico de países como Inglaterra, Austrália, Estados Unidos e Canadá, implantado, sobretudo, em países que tiveram colonização britânica, o sistema da common law tem por objetivo principal, direto e imediato, a pacificação dos litigantes - pouco importando se essa reconciliação será por meio da lei ou de outro critério mais apropriado ao caso concreto. Isso porque "a justiça da common law tem um profundo enraizamento na vida da comunidade e tem por função primordial preservar a coesão e a solidariedade entre os seus membros, interdependentes entre si." (GRECO, 2011, p. 03)

Enquanto a justiça da civil law tem sido a justiça do rei, do soberano, do Estado, a justiça da common law é a justiça paritária, da comunidade. (GRECO, 2011, p. 03)

Nesse sistema, o juiz de primeiro grau tem muito mais poder do que os tribunais superiores, que, diferentemente da civil law, exercem supervisão muito distante e excepcional sobre as instâncias inferiores. Também por esse motivo a justiça de primeiro grau é considerada mais próxima dos cidadãos, como justiça da comunidade. (GRECO, 2011, p. 08)

Uma das implicações dessa diferença de paradigmas é a de que os tribunais superiores no Brasil julgam um número infinitamente maior de recursos do que em países da common law, onde não há preocupação em rever decisões dos juízes inferiores para verificarem se são justas ou não, por entenderem que, se estes órgãos são representativos da comunidade, suas decisões, de modo geral, devem ser consideradas justas. (GRECO, 2011, p.08)

Sobretudo, o grande diferencial em relação ao modelo implantado em nosso País reside na preocupação em saber se o litígio foi resolvido com equidade, se as partes se rearmonizaram, independente da aplicação da lei; esse é o espírito predominante. (GRECO, 2011, p. 08)

Uma vez que nosso modelo e doutrina foram concebidos à luz do sistema continental europeu, com todas as suas características, naturalmente

as importações que se fazem de institutos da common law sempre entram no nosso sistema de uma forma um pouco extravagante, anômala e o sistema tem dificuldade de assimilar esses novos institutos ou até mesmo acaba por desvirtuar as suas finalidades ou características. (GRECO, 2011, p. 05)

Assim, por exemplo, apesar de o novo Código de Processo Civil (Lei n. 13.105/2015) ter tornado obrigatória a realização de audiência prévia de conciliação e mediação, a resolução de casos por meio de conciliação ainda apresenta desempenho tímido, pois das 30,7 milhões de sentenças e decisões terminativas, apenas 11,9\% foram homologatórias de acordo. (CNJ, 2017)

Vale mencionar, a propósito, que essa foi uma das tentativas de conciliar nosso paradigma de justiça com o da common law - o que vem sendo feito ao longo das últimas 
décadas por meio de sucessivas reformas processuais, a bem de sistematizar um modelo jurídico e processual que conjugue as virtudes de ambos os sistemas.

\subsection{Modelo eficientista de gestão e a lógica do "Justiça em Números"}

Ao modelo jurídico instituído no país, agregam-se fatores de ordem histórica, social, cultural e econômica contributivos para a insustentabilidade do modelo de administração de conflitos tradicional. O presente tópico restringe-se, essencialmente, à análise de alguns aspectos pertinentes ao âmbito econômico e de gestão, sem intenção de esgotar o tema.

Segundo consta do estudo de SANTOS (2017, p. 46), até o século XIX, o modelo de administração pública no País era predominantemente patrimonialista, legado das monarquias absolutistas, marcado pela confusão entre os patrimônios público e privado, dando ensejo, por exemplo, a situações de nepotismo, empreguismo, corrupção. Com as transformações advindas do Estado Liberal do século XIX, sucedeu a primeira reforma administrativa brasileira, com a implantação da administração pública burocrática, em substituição ao modelo então vigente.

Apesar dos avanços em comparação ao paradigma antecedente, SANTOS (2017, p. 46) aponta algumas desvantagens desse modelo administrativo, tais como o exagerado apego aos regulamentos, excesso de formalismo, despersonalização dos relacionamentos, resistência a mudanças, dificuldade no atendimento de clientes, conflitos com o público - particularidades que o transformaram, ao longo do tempo, em sinônimo de lentidão, rigidez, onerosidade e incapacidade de atendimento às demandas sociais.

\footnotetext{
No século XX, ocorreu a transformação do Estado Liberal para o Estado Social, com consequente aumento dos serviços sociais. A complexidade dos encargos atribuídos à administração pública passou a ser muito maior, como a educação, a saúde, a cultura, a previdência, a assistência social, a pesquisa científica, regulação do sistema econômico e financeiro, infraestrutura, entre outros [...]. (SANTOS, 2017, p. 48)
}

A promulgação da Constituição da República Federativa do Brasil de 1988, fruto da queda de um regime ditatorial, reflete esse movimento. Ela “[...] traduz a tomada de consciência e os desejos da maioria excluída da população por profundas mudanças sociais traduzidas nas narrativas constitucionais emancipatórias das normas programáticas e em sua força de transformação da sociedade" (MORAES, 2014, p. 280).

Em que pese o Poder Judiciário, enquanto instituição, não tenha sido envolvido de forma direta no processo da transição do período autoritário para a democracia, "permanecendo como árbitro do contrato básico que persistia na sociedade brasileira de então, distanciado da cena política", isso é quebrado "no momento seguinte, quando a ordem democrática se 
consolida. De mero coadjuvante, $[. .$.$] passa a ser mobilizado para uma posição de protagonismo$ ativo, instado por um poderoso processo de democratização social” (ABREU, p. 10).

A garantia do amplo acesso à Justiça vem nesse sentido, ao colocar o cidadão a defender seus direitos civis e sociais, procurando cada vez mais este Órgão por falta de Estado e de outras instituições. (ABREU, p. 7)

O incremento na demanda por serviços de justiça, porém, afetou significativamente a agilidade do Judiciário (GOMES, 2017, p. 568), uma vez que a administração burocrática, aliada à crise de governabilidade e credibilidade do Estado, não foi capaz de corresponder à agilidade, economicidade e boas práticas exigidas no trato do cidadão. (SANTOS, 2017, p. 48)

Assim, a partir da década de 1990, o Estado brasileiro foi alvo de uma ampla reforma gerencial que pretendia preparar o país para uma nova realidade mundial em que o mercado passaria a ter um papel com maior protagonismo, o que provocou mudanças expressivas no modelo de administrar o aparato público. (MARCELLINO JR, 2016, p. 127)

Passou-se a considerar a necessidade de um "choque de gestão" para tornar a máquina pública mais produtiva e eficiente, ideia que passou a prevalecer entre os gestores e que provocou grandes transformações e ajustes da máquina administrativa (MARCELLINO JR, 2016, p. 127-128), tomando-se "produtividade e a celeridade como parâmetros vinculadores de mensuração de desempenho. Quase tudo no Estado e, também, no Judiciário, seria avaliado a partir desses pressupostos". (MARCELLINO JR, 2016, p. 136)

O Poder Judiciário, que, há muito, era visto como “[...] deficitário, lento, precário e com grandes dificuldades para cumprir com sua missão constitucional de dissuadir conflitos" (MARCELLINO JR, 2016, p. 128), não ficou alheio a esse "receituário eficientista de gestão" e também passou a tomar medidas administrativas pautado no novo formato gerencial, de modo a oferecer respostas aos problemas de funcionamento de sua estrutura e da demora na resolução das demandas judiciais (MARCELLINO JR, 2016, p. VII e 128).

Tais providências sucederam, sobretudo, por influência do Banco Mundial (EUA), que, por meio do relatório designado “Documento Técnico n. 319”, produzido em 1996, efetuou uma avaliação e diagnóstico do Poder Judiciário brasileiro, apresentando recomendações direcionadas ao aperfeiçoamento da gestão, dentre as quais a mais importante foi em relação à necessidade de implantação de um programa de reforma administrativa, cujo norte não foi outro senão a lógica da eficiência e celeridade na tramitação de processos.

Tal recomendação acabou repercutindo diretamente na atuação dos magistrados, que “[...] passou a ser repensada levando-se em consideração a previsibilidade das decisões 
judiciais, a segurança para contratos, e até mesmo sua capacidade de interferir no chamado 'Risco Brasil'.” (MARCELLINO JR, 2016, p. VII)

A promulgação da Emenda Constitucional n. 45/2004 é um dos maiores reflexos dessa nova diretriz, contendo, em seu bojo, vários mandamentos e inovações voltados à abreviação de procedimentos e à velocidade na tramitação processual, tais como a súmula vinculante (art. 103-A, da CRFB/88), "instituída com o intuito de combater a morosidade da Justiça e agilizar a solução de processos que veiculem teses jurídicas repetitivas" (MACÉA, 2011, p. 68), além da criação do CNJ (inserção no art. 92, I-A, da CRFB/88), responsável pela normatização e controle administrativo do Judiciário e acompanhamento do desempenho dos juízes a partir do estabelecimento de metas de resultado. (MARCELLINO JR, 2016, p. VIII)

“Criou-se um plano estratégico de ação, em superação ao modelo tradicional, chamado Justiça em Números, que bem reflete a inegável influência do pensamento econômico na administração do Estado brasileiro.” (MARCELLINO JR, 2016, p. VIII)

Ainda, inseriu-se a alínea “c” no art. 93, II, da Constituição da República, a qual passou a exercer interferência direta na progressão do magistrado ao estabelecer a "aferição do merecimento conforme o desempenho e pelos critérios objetivos de produtividade [...]”.

A eficiência passa a ser o parâmetro vinculador ético de atuação do magistrado e de todos os funcionários e serventuários da Justiça. O trabalho é analisado predominantemente pelo aspecto quantitativo e estatístico, de maneira a exigir cada vez mais produtividade e celeridade. (MARCELLINO JR, 2016, p. 137-139, grifou-se)

Vários trabalhos, pesquisas acadêmicas e iniciativas da administração dos Tribunais do País se fundamenta(ra)m sobre o viés pró-eficiência, em decurso de expectativas quanto às garantias constitucionalmente asseguradas de agilidade e celeridade na tramitação processual, sendo este igualmente o mote e a essência do Relatório Justiça em Números, como se extrai da última edição, de 2017 (relativa ao ano-base de 2016).

\subsection{Produtividade, celeridade e visão mecanicista das organizações humanas}

Segundo Carmen Lúcia, atual Presidente do CNJ, o relatório estampa "os problemas que precisam ser resolvidos para a prestação da jurisdição em tempo razoável, como constitucionalmente assegurado ao cidadão", buscando-se perceber em que áreas o Poder 
Judiciário há de atentar prioritariamente em prol dos interesses do jurisdicionado, "por ser indiscutível que a tardia prestação jurisdicional é inaceitável”.(CNJ, 2017, p.5-6, grifou-se)

O documento, que reúne informações de todos os órgãos do Judiciário brasileiro (exceto STF e CNJ), tem como foco principal os dados de litigiosidade ${ }^{6}$, com detalhamento dos indicadores de acordo com o grau de jurisdição e a fase processual em que os processos se encontram, considerando-se as peculiaridades de cada segmento de justiça e os portes dos tribunais (CNJ, 2016, p. 09), e adota, para tanto, a seguinte metodologia:

O Sistema de Estatística do Poder Judiciário (SIESPJ) conta com 810 variáveis encaminhadas pelos tribunais e posteriormente transformadas em indicadores pelo CNJ. São muitos os indicadores que podem mensurar a eficiência de um tribunal, e o grande desafio da ciência estatística consiste em transformar dados em informações sintéticas, que sejam capazes de explicar o conteúdo dos dados que se deseja analisar. Para alcançar tal objetivo, optou-se por construir o IPC-Jus ${ }^{7}$, uma medida de eficiência relativa dos tribunais, utilizando-se uma técnica de análise denominada DEA (do inglês, Data Envelopment Analysis) ou Análise Envoltória de Dados. O método estabelece comparações entre o que foi produzido (denominado output, ou produto) considerando-se os recursos (ou insumos) de cada tribunal (denominados inputs). Trata-se de metodologia de análise de eficiência que compara o resultado otimizado com a eficiência de cada unidade judiciária em questão. Dessa forma, é possível estimar dados quantitativos sobre o quanto cada tribunal deve aumentar sua produtividade para alcançar a fronteira de produção, observando-se os recursos que cada um dispõe, além de estabelecer um indicador de avaliação para cada unidade. O método DEA foi desenvolvido por Charnes et al. (1978) e aplicado inicialmente com maior frequência na área de engenharia de producão. Recentemente, passou a ser aplicado no Brasil na área forense, com o intuito de medir o resultado de tribunais [...]. (CNJ, 2017, p. 17-18, grifou-se)

Vê-se, pois, que a análise de eficiência dos tribunais, cuja atribuição é tratar de fenômenos relativos ao comportamento humano e social, tem por base modelo aplicado a área de ciências exatas, orientado ao output, cujo foco consiste em identificar quanto o tribunal pode aumentar em termos de produto, maximizando o resultado, mantendo seus recursos fixos.

Neste sentido, “com relação ao output, a variável total de processos baixados é aquela que melhor representa o fluxo de saída dos processos do Judiciário sob a perspectiva do jurisdicionado que aguarda a resolução do conflito." (CNJ, 2017, p. 18). Não consta do anuário (2017), porém, qualquer referência a levantamento ou pesquisa de campo efetuada no sentido de averiguar se essa é, de fato, a variável de satisfação sob a perspectiva do jurisdicionado.

\footnotetext{
${ }^{6}$ Número de processos recebidos, em trâmite e solucionados.

7 Índice de Produtividade Comparada: “[...] o IPC-Jus é um índice que compara a produtividade entre tribunais do mesmo ramo e com estruturas similares (pequeno, médio ou grande porte)", e "estabelece uma relação entre o que foi produzido (denominado output) e os recursos disponíveis para cada tribunal (denominados inputs).” Disponível em: $<$ http://cnj.jus.br/noticias/cnj/60897-cinco-tjs-estaduais-e-dois-trts-alcancam-resultado-maximo-deprodutividade $>$. Acesso em: 01 maio 2018.
} 
Ademais disso, ao trabalhar com "processos baixados" como sendo a melhor variável sob a perspectiva do jurisdicionado, "que aguardaria a resolução do conflito", o relatório não define o que seja "resolução do conflito".

Aparentemente, presume-se que "resolução do conflito" seria sinônimo da baixa do processo, a partir de colocação relativa à exclusão deste modelo em relação à Justiça Eleitoral, por exemplo, “[...] tendo em vista que, neste caso, o objetivo principal dos tribunais regionais consiste na realização das eleições e não somente na atividade jurisdicional na forma de baixa de processos (output do modelo)." (CNJ, 2017, p. 19). Também fica evidente nesta passagem:

Se todos os tribunais conseguirem baixar significativamente a cada ano mais processos, o ótimo alcançado pela curva de eficiência se tornará cada vez mais próximo do ótimo subjetivo, que seria, de fato, um patamar mais satisfatório de taxas de congestionamento para o Poder Judiciário. (CNJ, 2017, p. 148, grifou-se)

O Relatório Justiça em Números CNJ 2017 apresenta, inclusive, tópico com os índices de produtividade dos magistrados e dos servidores, que são calculados pela relação entre o volume de casos baixados e o número de magistrados e servidores na jurisdição, respectivamente (p. 71), restando manifesta a relevância conferida a "dados quantitativos sobre o quanto cada tribunal deve aumentar sua produtividade para alcançar a fronteira de produção" (p. 17-18, grifou-se).

Entende-se, no entanto, que a mensuração de produtividade vinculada apenas ao critério "processos baixados" resulta em dados irreais e incompletos, bem como na nem sempre verdadeira conclusão de que resolução do processo significa resolução do conflito.

A adoção do critério pode ter relação com a própria definição do que se entende por atividade ou prestação jurisdicional. A propósito, SILVA (2006) ensina que Calamandrei, um dos influentes processualistas do sistema jurídico brasileiro, defendia que só haveria

[...] legítima e autêntica atividade jurisdicional na sentença declarativa, no ato do juiz que decide uma controvérsia ou, em última instância, no ato de julgamento. Quando o juiz dirige o processo, praticando os inúmeros e diferentes atos necessários para coordená-lo e conduzi-lo à finalidade que o anima, não pratica ato jurisdicional, mas, ao contrário, age como administrador do processo. Ao presidir uma audiência, inquirir testemunhas, promover os atos de impulso de relação processual, designando audiências ou provendo sobre a regularidade formal do procedimento, o juiz não exerce jurisdição, porque 'ao efetuá-lo o juiz nada decide'. (p. 69-70, grifou-se).

Ocorre que, dessa forma, fatores importantes e, muitas vezes, decisivos, no tempo de tramitação acabam excluídos do cálculo estatístico e do índice de produtividade, tais como: a complexidade e a singularidade das causas; os diferentes níveis de produtividade de cada 
magistrado e servidor de acordo com essa complexidade e com a qualidade de seus trabalhos (ou ausência de qualidade, com necessidade de retrabalho); a atuação das partes durante a tramitação processual, com atenção à quantidade de pessoas envolvidas em cada processo (ações coletivas, litisconsórcios) e peculiaridades dos atores (Fazenda Pública, por exemplo) ${ }^{8}$ - o que influencia diretamente nos prazos e, também, no tempo de análise e trabalho dispendido; a avaliação quanto ao número de processos da unidade judiciária versus o número de serventuários; o tempo de atendimento aos advogados e às partes em balcão e no telefone; a postura exigida do magistrado como administrador da unidade judiciária ${ }^{9}$; a satisfação da população quanto à qualidade da entrega da prestação jurisdicional e sua eficácia, no sentido de ter efetivamente resolvido a questão e não apenas terminado o processo.

Como afirmam GOMES; FREITAS (2017, p. 571), com base em estudo de RosalesLópez, não há como negar que o desempenho judicial é "afetado por fatores externos, associados ao contexto mais amplo em que as atividades judiciais são realizadas, além dos fatores internos, associados aos juízes e tribunais.”. Logo, refuta-se a afirmação de que:

O conjunto de indicadores apresentados na edição de 2017 do Relatório Justiça em Números sumariza a realidade da justiça brasileira, propiciando a identificação de avanços, como o incremento da informatização, e dos gargalos ainda existentes na busca por maior eficiência e qualidade na prestação jurisdicional, como a demora na fase de execução, os baixos índices de conciliação e o constante congestionamento processual. (CNJ, 2017, grifou-se)

Não é possível falar em realidade quando não se consideram os mais variados fatores e contextos implicados na tramitação processual, diretamente ligados aos óbices relativos à demora na fase de execução, aos baixos índices de conciliação e constante congestionamento. Tampouco parece legítimo o discurso no sentido de maior qualidade na prestação jurisdicional se o foco está, preponderantemente, na quantidade.

[...] não se deve comparar uma unidade jurisdicional a uma unidade administrativa de uma fábrica, ainda que queiram alguns economistas ou administradores de empresa. A atividade judicante possui peculiaridades e a missão constitucional outorgada aos magistrados é complexa e dificilmente poderia ser aferida apenas por critérios quantitativos.

Aumentaram o número de juízes, os gastos com informática, com pessoal, e a demanda ainda assim não foi solucionada a contento. A tendência, inclusive, é que a demanda aumente com o crescimento da estrutura. É da essência da atividade, quanto mais estrutura, mais justiça será demandada pelos jurisdicionados, que

\footnotetext{
8 “[...] importante ressaltar que a administração do Judiciário envolve também a participação de inúmeros outros atores, como os advogados, os funcionários administrativos dos tribunais, os representantes do Ministério Público, os usuários, entre outros (SILVA, 2006)." (GOMES; FREITAS; 2017, p. 571)

${ }^{9}$ A propósito, veja-se GOMES; FREITAS, 2017 (p. 572); REIS, 2013; e BEZERRA, 2018.
} 
tenderão a judicializar todas as questões que não encontrarem soluções por outros métodos. [...]

É claro que o controle e o monitoramento estatístico do Judiciário são importantes e podem ser utilizados como parâmetro relevante para a administração da Justiça. Contudo, o que preocupa é este método passar a ser utilizado como uma lógica absoluta ou prevalente.

O projeto "Justiça em Números" do CNJ, ressalvando os avanços e méritos da iniciativa, tem seguido muito por essa lógica eficientista [...]. Para o repensar de uma justiça efetiva, é claro que aspectos econômicos têm de ser levados em consideração. No entanto, deve-se compreender o fenômeno do acesso à justiça como algo mais complexo que não se resolverá apenas com as medidas que partam de um olhar matematizado e calcado na eficiência. (MARCELLINO JR, 2016, p. 152-153, grifou-se)

Como se vê, os paradigmas sobre os quais sistema jurídico e seu controle externo (CNJ) estão atualmente alicerçados são insuficientes para dar respostas aos conflitos humanos, justificando a insatisfação da população mensurada na pesquisa ICJBrasil. Soa hipócrita, inclusive, falar em pacificação em um sistema de Justiça no qual a pacificação social é apenas um objetivo remoto e a produtividade e eficiência são o mote.

A preponderância da mentalidade litigiosa e do processo judicial como única forma de resolução de conflitos estão intimamente arraigados na sociedade, no ensino de Direito brasileiro, nas instituições e atores que compõem o sistema de Justiça.

O imaginário popular remete aos arquétipos de que "bom advogado" e "bom promotor" são os de perfil combativo, que "lutam"/“brigam" pelo cliente e desenvolvem as melhores teses jurídicas, dentro de uma cultura de vencer e perder e do paradigma do certo e errado.

O aspecto econômico pautado no modelo eficientista, igualmente, é fator de peso para a manutenção desse protótipo e da cultura da sentença, como se constata ao refletir sobre o tempo exíguo reservado às audiências de conciliação e mediação - as quais, até o último anuário do CNJ, não constavam do mapa estatístico como indicadores de produtividade ${ }^{10}$.

A adoção de sistema próprio de medição de eficiência de magistrados e de unidades judiciárias no Ceará Justiça do Ceará, denominado "Eficiência.jus”, que engloba mais variáveis do que a "baixa de processos" (OLIVEIRA et al., 2016), é um forte indicativo da incompletude do sistema de aferição de produtividade pelo $\mathrm{CNJ}$ e, sobretudo, da satisfação do jurisdicionado.

Além de não se sustentar e nutrir o descrédito da população, tal modelo está gerando um ambiente de trabalho insalubre e doenças nos funcionários, como se verá a seguir.

\footnotetext{
${ }^{10} \mathrm{O}$ que mudou em abril deste ano, como se extrai da notícia do CNJ "Conselho amplia o Sistema de Estatísticas do Poder Judiciário”, publicada em 19.04.2018. Disponível em: <http://cnj.jus.br/noticias/cnj/60897-cinco-tjsestaduais-e-dois-trts-alcancam-resultado-maximo-de-produtividade>. Acesso em: 28 abr. 2018
} 


\section{Reflexos na prática: adoecimento dos membros do judiciário}

O relatório do $\mathrm{CNJ}$ mostra que a soma dos magistrados atuando em cada área é de 18.998, em que pese existam 15.507 juízes de direito. Tal fato demonstra que há 3.491 com acúmulo de atividades. (CNJ, 2017, p. 15)

Além disso, os juízes e servidores brasileiros não produzem pouco: o Índice de Produtividade dos Magistrados (IPM) foi de 1.749 processos. Considerando apenas os dias úteis do ano de 2016, excetuadas as férias, tal valor implica a solução de mais de sete processos ao dia. O Índice de Produtividade dos Servidores da Área Judiciária cresceu 2\%, o que significa uma média de dois casos a mais baixados por servidor em relação a 2015. (CNJ, 2017)

Mesmo em Tribunais já totalmente digitalizados, como é o caso do de Tocantins, que conta com o sistema e-Proc e uma série de iniciativas visando uma prestação jurisdicional célere e efetiva, o índice na taxa de congestionamento permanece alto (SANTOS, 2017).

A demanda do Judiciário se tornou explosiva, e os efeitos desse quadro sobre seus membros são comumente ignorados. A afirmação é assentada na própria experiência da primeira autora, enquanto servidora da justiça estadual catarinense, atuante no primeiro grau de jurisdição, bem como nos relatos colhidos em estudo da percepção de magistrados de primeiro grau do Poder Judiciário de Santa Catarina sobre trabalho, saúde e democracia, realizados em 2002 retratado na obra "O juiz sem a toga", de Herval Pina Ribeiro" ${ }^{11}$ em parceria com o Sindicato dos Servidores do Judiciário do Estado de Santa Catarina - SINJUSC.

Além de jogar luz sobre as relações autoritárias e verticais de poder e das particularidades do nosso paradigma de administração de justiça, o presente tópico intenciona estimular a reflexão acerca das "sequelas vivas" resultantes da adoção do discurso no sentido pró-eficientista e produtivista, calcado em critérios quantitativos.

A partir da transcrição de aspectos destacados de alguns depoimentos, questiona se, nesse formato, o Judiciário está genuinamente legitimado a cumprir a missão de "realizar Justiça por meio da humanização e da efetividade na prestação adequada da solução de conflitos”. (TRIBUNAL DE JUSTIÇA DO ESTADO DE SANTA CATARINA, 2018)

Juiz I: "O Tribunal é pouco sensível à melhoria das condições de trabalho e cobra produção, [...] uma das razões do meu mal-estar no trabalho. Quer números: de audiências, de despachos e de sentenças"; "Faltam juízes, faltam servidores e as condições materiais de

\footnotetext{
11 "há trinta anos estuda as relações entre trabalho e saúde e há mais de dez anos concentra suas pesquisas nas doenças contemporâneas do trabalho, dando especial atenção às lesões por esforços repetitivos (LER)" (2005, p. 18)
} 
trabalho deixam a desejar"; "Todo juiz principiante tem insegurança e medo de errar. Minha angústia foi tão grande que perdi dez quilos no meu primeiro mês de magistratura. Cobrava-me a obrigação de saber tudo, resolver tudo. [...] E, ao Tribunal, cabia cobrar quantas audiências, despachos e sentenças que eu fizera"; “Acho injusto cobrar produção de um juiz. Não se deve tomar como parâmetro a quantidade do que faz. Ao fazê-lo, não se privilegia o diálogo que o juiz tem que manter com as partes e advogados para solucionar amigavelmente uma questão e assim evitar que se transforme em processo. A prática da conciliação é difícil, demorada e deveria ser estimulada. Só que não é contabilizável"; "Entendo a função do juiz como relacional, de procurar manter ou restabelecer vínculos sociais rompidos. [...] Muitas vezes, nem os demandantes estão certos do que querem ou que pretendem dos demandados. Se o juiz não ouvir com ouvidos bem abertos, como se aperceberá da natureza dos conflitos e exercerá a função legítima de mediador antes de julgador?"; "Claro que há pendências de ordem estritamente material, objetivas, [...] mas há sempre pessoas envolvidas e elas têm nome. São Maria, José, Antônio e é preciso dialogar com eles"; "Quantificar o trabalho do juiz não afere mérito e estimula a competição; e competição não é um estímulo saudável, por embargar a solidariedade"; “[...] o trabalho do juiz não se circunscreve à permanência no fórum; prolongase nos fins de semana e em sua casa. Dificilmente o juiz se desliga do que faz e não leva trabalho para casa”. (RIBEIRO, 2005, p. 23-25)

Juiz II: “O trabalho do juiz é exaustivo [...]. Ninguém o procura de bom humor, de bem com a vida, para contar piadas. O que lhe chega são problemas de toda sorte, quinze a trinta vezes por dia, em reuniões, consultas, audiências e processos. São sempre problemas"; "Acho que a maioria dos juízes, quando ingressa no Judiciário [...] desconhece que a aplicação da lei pode não significar fazer justiça e que muitas vezes dói”; “A intensidade e o ritmo do trabalho do juiz está aumentando [...]”; “A informatização [...] o que faz é intensificar e acelerar o ritmo do trabalho do juiz e dos servidores. Como o crescimento do número de processos é inadministrável e são muitas as insuficiências, sempre sobra muito trabalho por fazer. Resultado: pressão de todo lado, do Tribunal, dos advogados e das partes, dos órgãos de segurança pública e da imprensa"; "Se alguém disser nessas oficinas que está tudo bem no Judiciário estará faltando com a verdade e quem, de fora, disser que nossas condições de trabalho são boas, não as conhece"; (RIBEIRO, 2005, p. 26-27) "Há comarcas recebendo quinhentos processos por mês. Impressiona, mas há um aspecto esquecido quando se lida com essas estatísticas: o juiz precisa ler os processos, apreciar-lhes o mérito. Trabalho hoje três vezes mais que há um ano”; “[...] uma sentença judicial não cabe em fórmulas preconcebidas e em súmulas” (RIBEIRO, 2005, p. 65-67); "E, faça-se justiça aos nossos servidores: eles estão 
dando muito mais do que podem de si e por isso estão adoecendo mais que os juízes. Se os juízes antigos nos visitassem, ficariam assombrados com o número de processos que entram todos os dias e com as novas atribuições dos magistrados”. (RIBEIRO, 2005, p. 28)

Juiz III: “O que incomoda não é este controle quantitativo do trabalho do juiz, mas a perda de sua qualidade técnica e, pior, da qualidade das suas decisões"; "Como se passa para as pessoas comuns a controvérsia sobre processos parados há anos e perda da qualidade dos julgados? [...] A resposta é uma só: estamos quantificando, quantificando e, ao mesmo tempo, desqualificando"; "Tudo isso traz angústia, deprime, gera dúvidas e crises. Dúvidas sobre a concepção, o papel e a competência do Judiciário; crise política e da instituição judiciária e, para nós, operadores do Direito, crises de existência.” (RIBEIRO, 2005, p. 30-31).

Juiz IV: “Em uma reunião como esta, o que logo vem à cabeça é a pilha de processo em minha mesa aguardando despacho. [...] Quando imagino ter acabado, chegam mais processo e a pilha torna a crescer"; "Você tem que ler os processos um a um com atenção, estuda-lo e criar um juízo antes de decidir. Requer tempo, conhecimento, maturidade jurídica e consciência social. O tempo é curto para analisar tantos processos e fazer outras coisas que a função exige"; "Pesam, também, as tarefas administrativas." (RIBEIRO, 2005, p. 32-33)

Juiz V: "Somos pressionados para sentenciar com rapidez; isto garante justiça? O juiz corre para esvaziar sua mesa de trabalho, 'derrubar' a pilha de processos; isto se faz com a garantia de qualidade do que despacha?” (RIBEIRO, 2005, p. 33)

Juiz XII: "Se não tomarmos consciência de que o servidor, não apenas o servidor juiz, é insubstituível, a reforma administrativa do Judiciário estará indo por um caminho totalmente errado. Há unidades judiciais em que o único servidor concursado é o juiz. Algumas sequer têm cargos, os funcionários vêm de outras varas [...]. Se um servidor adoece ou o estagiário falta, é o caos.” (RIBEIRO, 2005, p. 42)

Juiz XV: “O que desanima e faz adoecer é o juiz trabalhar, os servidores trabalharem e ninguém se dar conta do volume de trabalho que só faz crescer. Isto tem um impacto psicológico grande, que cresce à medida que o volume de trabalho cresce. [...] Os servidores me dizem: 'Doutor, eu não consigo dar conta'...” (RIBEIRO, 2005, p. 48-49).

Juiz XIV: "Pior do que a sensação de impotência do juiz e dos servidores, é perceber que as pessoas que recorrem ao Judiciário não sabem das dificuldades que estamos passando e aguardam anos por uma decisão judicial. Essas frustrações ficam em nossas cabeças, mas para as partes, fica um branco [...]”; "Despacho dez processos, entram quinze novos. Sem o público saber, a fama que corre é que o juiz não trabalha e isso tem desdobramentos e repercussões sociais desfavoráveis". (RIBEIRO, 2005, p. 78-79) 


\title{
4. A necessária ampliação de foco e de paradigmas
}

Para início de mudança deste panorama, acredita-se que alguns mitos e conceitos devem ser reelaborados no âmbito do Direito. Dentre eles, destaca-se:

1) Acesso à justiça, uma das garantias fundamentais dos cidadãos no Estado Democrático de Direito, não significa acesso ao Poder Judiciário.

\begin{abstract}
'O acesso à justiça não se esgota no acesso ao Judiciário. É necessário, portanto, ter o cuidado de não reduzi-lo à criação de mecanismos processuais e seus problemas aos existentes nesse âmbito. $\mathrm{O}$ acesso à justiça representa mais do que o ingresso no processo e o acesso aos meios que ele oferece.' [...]

[...] é necessário destacar, frente à vagueza do termo acesso à Justiça, que a ele são atribuídos pela doutrina diferentes sentidos, sendo eles fundamentalmente dois: o primeiro, atribuindo ao significante justiça o mesmo sentido e conteúdo que o de Poder Judiciário, torna sinônimas as expressões acesso à Justiça e acesso ao Poder Judiciário; o segundo, partindo de uma visão axiológica da expressão justiça, compreende o acesso a ela como o acesso a uma determinada ordem de valores e direitos fundamentais para o ser humano. [...] esse último, por ser mais amplo, engloba no seu significado o primeiro. (MARCELLINO JR, 2016, p. 115-116)
\end{abstract}

Assim, abre-se um leque de possibilidades para abarcar outras formas de administração de conflitos. Há que se tomar o cuidado, porém, para que tais métodos não se destinem, precipuamente, a reduzir o congestionamento do Judiciário: “[...] devemos certificar-nos de que os resultados representem verdadeiros êxitos, não apenas remédios para problemas do judiciário, que poderiam ter outras soluções.” (CAPPELLETTI, 1988, p. 87)

Oportuna, ainda, a colocação de GRECO (2011, p. 12):

Mesmo adotando uma perspectiva exclusivamente processual, de qualquer modo transparece como indispensável a necessária associação da idéia de acesso à justiça à idéia de acesso ao direito. Essa associação surgiu na Constituição Portuguesa de 1976, que, no seu artigo 20, estabeleceu que "a todos é assegurado o direito de acesso ao Direito e à Justiça", o que significa que, antes de assegurar o acesso à proteção judiciária dos direitos fundamentais, o Estado deve dedicar-se diretamente à concretização da expectativa de gozo dos direitos dos cidadãos.

2) O Judiciário não é o único responsável pelo incremento e excesso de litigiosidade.

O acesso ao direito, nas sociedades contemporâneas, depende de inúmeros pressupostos, vários deles extrajurídicos. Assim, o ideal de realização do direito, como instrumento de convivência pacífica e harmoniosa de todos os cidadãos, depende de vários pressupostos que o Estado precisa prover. (GRECO, 2011, p. 13, grifou-se.) 
"Não são os direitos que causam problemas e demandas judiciais, mas o seu não cumprimento, a começar [...] pelo próprio Estado. Se o Executivo e o Legislativo se omitem, pode o Judiciário se omitir? Não. Ele é o último poder para o qual o cidadão pode recorrer [...]”. (RIBEIRO, 2005, p. 67-68) A propósito, existe expressão própria para retratar o fenômeno:

[...] a incapacidade do Estado em concretizar direitos fundamentais tem exigido, cada vez mais, uma atuação mais operosa do Poder Judiciário, que tem ganhado espaço por meio de um fenômeno que vem sendo apelidado de "judicialização da política". Nesse contexto, tem-se experimentado um alargamento progressivo dos poderes judiciais no processo, não obstante infindáveis críticas da doutrina. (TUPINAMBÁ, 2013, p. 56).

3) A adoção de novas formas de administração de conflitos pelos advogados não implica, necessariamente, perda financeira.

Pelo contrário. Uma vez que o advogado assume cada vez mais relevância na construção desse novo paradigma, automaticamente passa a ser mais valorizado, com repercussão positiva nos honorários - os quais não poderão ser em valor menor do que o indicado na Tabela de Honorários instituída pelo respectivo Conselho Seccional onde for realizado o serviço. É vedada, inclusive, em qualquer hipótese, a diminuição dos honorários contratados em decorrência do litígio ter sido solucionado por qualquer mecanismo adequado de solução extrajudicial ${ }^{12}$.

A fixação dos valores a serem pagos nos casos de adoção de métodos extrajudiciais e autocompositivos obedece aos mesmos critérios e parâmetros requeridos para o ingresso de uma ação judicial, com a vantagem de considerar, quanto ao trabalho e ao tempo a serem empregados, aliados à competência do profissional, a possibilidade de entregar um resultado prático mais rápido e efetivo ao cliente, com maior possibilidade de satisfação, obtendo-se, assim, um fluxo maior de caixa, sem necessidade de aguardar o prazo final de tramitação do processo para recebimento, sempre incerto.

Este profissional haverá de ser construtor de uma nova realidade, na qual "advogado bom" é o que resolve o problema. Não sob o arquétipo de "salvador", mas no sentido pedagógico, auxiliando o cliente a resolver com independência sua questão por meio das ferramentas e métodos mais apropriados às peculiaridades que a envolvem, sendo apoio na construção da autonomia da vontade do sujeito, a bem de que este possa, por si, buscar a solução mais adequada. Isso porque, como já defendido, os envolvidos no litígio "[...] é que vivem o

\footnotetext{
${ }^{12}$ Conforme $\S \S 5^{\circ}$ e $6^{\circ}$ do art. 48 do Código de Ética e Disciplina da Ordem dos Advogados do Brasil - OAB. Anexo Único da Resolução N. 02/2015 - Cfoab. Brasília, DF, p. 1-19. Disponível em: $<$ http://www.oab.org.br/arquivos/resolucao-n-022015-ced-2030601765.pdf>. Acesso em: 14 maio 2018.
} 
conflito e somente eles podem decidir sobre a melhor solução" (BAGGENSTOSS; FIEGENBAUM, 2017).

Cada vez mais, é aconselhável aos operadores do Direito que passem a "[...] utilizar lentes que permitem enxergar o mundo com os interesses e necessidades dos nossos próprios usuários - porque os seus interesses devem ser os prioritários.” (AZEVEDO, 2014).

Constatar que o saber está nas pessoas envolvidas nos conflitos e que elas são as mais aptas a decidir segundo suas necessidades e projetos de futuro, envolve humildade.

Deveria constituir, igualmente, parâmetro de aferição de um bom profissional.

4) Sugere-se a realização de estudo que apure, efetivamente, a variável que retrata a satisfação do jurisdicionado e se amplie o número de variáveis e de parâmetros para além da produtividade e efetividade.

Neste sentido, a título de exemplo, convém mencionar estudo prático realizado entre o período de 2015 e fevereiro de 2017 no Tribunal de Justiça do Estado do Paraná, com aferição da satisfação dos participantes de audiências de mediação no CEJUSC da Comarca de Toledo e posterior verificação dos resultados de análise de formulários. A pesquisa evidenciou, justamente, índices altíssimos de satisfação dos envolvidos nas sessões de mediação. Do total de 1.349 pessoas que responderam o questionário, apurou-se que:

\footnotetext{
No índice de satisfação geral, de todas as audiências realizadas, respondido o questionário pelas partes, mesmo estando no polo ativo ou passivo, bem como pelos advogados que acompanhavam as sessões, $33 \%$ das pessoas saíram muito satisfeitas, enquanto $60 \%$ satisfeitas e somente $7 \%$ ficaram insatisfeitas.

Em resposta à pergunta de recomendação da mediação a outras pessoas para solução de seus conflitos, bem como se eles voltariam a utilizar ou participar de uma sessão de mediação para resolver eventuais conflitos, $95 \%$ das pessoas responderam que sim. A resposta que mais salta os olhos em tal pesquisa [...] trata-se do índice de satisfação das pessoas nos casos em que não foi celebrado acordo: $88 \%$ das pessoas saíram satisfeitas ou muito satisfeitas com o atendimento dado pelo Poder Judiciário às suas demandas.

Desta forma, vê-se que tais dados, mesmo que decorrentes de um único ambiente, contribuem para a análise de expansão da implantação dos métodos autocompositivos na estrutura do Poder Judiciário brasileiro, o que por vezes é desafiado por inúmeras questões ainda ligadas à "cultura do litígio" que ainda impregna nesta sociedade. (HAAS; HOFFMANN, 2017)
}

\section{Considerações finais}

O presente trabalho é de reflexão. Todo tempo é tempo de se repensar o papel do sistema de justiça, dos operadores do Direito, e de avaliar até que ponto a aplicação tecnicista da lei, com mera reprodução do modelo posto, o discurso de lide, de pretensões resistidas e 
"soluções" impostas, ignorando as deficiências do sistema, satisfaz as reais necessidades do jurisdicionado.

“A paz na sociedade [...] reclama um novo olhar, uma percepção de que o sujeito de direito é também um sujeito de desejos, que vive situações de conflito cotidianamente, mas que precisa encontrar canais de desinstalação e não de acentuação dos problemas relacionais vividos" (MÜLLER, 2005, p. 147).

Algumas opções de gerenciamento de conflitos sensíveis a essas particularidades vêm despontando como alternativas de grande eficácia à satisfação e entendimento das partes. Todavia, não encontram espaço frente ao sistema posto, que se retroalimenta dele mesmo e não dá abertura a novas possibilidades, porque não contabilizadas na forma de produtividade e eficiência.

Não é possível vislumbrar caminhos de solução sem saber o porquê das escolhas e do comportamento do cidadão e, tampouco, servir à sociedade sem saber o que ela espera do Judiciário, sem descobrir quais são suas reais necessidades e interesses.

Do mesmo modo, parece incoerente mensurar a capacidade de o Judiciário se apresentar como instância legítima na solução de conflitos sem procurar saber junto ao jurisdicionado o que ele entende por solução de conflito.

Se a satisfação do jurisdicionado importa e, da mesma forma, a saúde dos trabalhadores que movem tal engrenagem, necessário se promova uma ampliação de foco e se promovam estudos mais atuais, a bem de que os relatórios do CNJ possam também se pautar em dados fidedignos que retratam a realidade e considerem, em seus diagnósticos, os inúmeros fatores que estão relacionados ao sistema de justiça brasileiro - para, a partir daí, serem tomadas providências condignas com a realidade, que é o que de fato importa.

\section{Referências bibliográficas}

ABREU, Pedro Manoel. "Crise do judiciário, globalização e o papel do Juiz orgânico na sociedade brasileira." Disponível em

$<$ http://tjsc25.tjsc.jus.br/academia/arquivos/crise_poder_papel_juiz_pedro_abreu.pdf $>$. Acesso em: 10.05.2018.

AZEVEDO, André Gomma de. "De quem é o conflito? Do interessado, do advogado ou do magistrado?". 2014. Disponível em: <http://justificando.cartacapital.com.br/2014/10/31/dequem-e-o-conflito-interessado-advogado-ou-magistrado/> Acesso em 29.12.2017. 
BAGGENSTOSS, G. A.; FIEGENBAUM, M. “A eficácia das constelações sistêmicas como método de pacificação dos conflitos familiares". In Formas consensuais de solução de conflitos [Recurso eletrônico on-line] organização CONPEDI/ UMinho. Coordenadores: Francivaldo Gomes Moura; Jacyara Farias Souza Marques; Romulo Rhemo Palitot Braga Florianópolis: CONPEDI, 2017. ISBN: 978-85-5505-492-1. Acesso em 05.01.2018.

BEZERRA, Hygina Josita Simões de Almeida. Educação para formação de juízes-gestores: um novo paradigma para um Judiciário em c. Disponível em: $<$ http://emam.web2004. uni5.net/arquivo/documentos/4f24e31b-5c30-4a5b-9ee9-88974c123691.pdf>. Acesso em: 01 maio 2018.

BRASIL. Instituto Brasileiro de Geografia e Estatística - IBGE. Disponível em: $<$ http://www.ibge.gov.br/apps/populacao/projecao/> Acesso em: 29.12.2017

. CONSELHO NACIONAL DE JUSTIÇA - CNJ. Justiça em Números 2017: anobase 2016/Conselho Nacional de Justiça - Brasília: CNJ, 2017. Disponível em: $<$ http://www.cnj.jus.br/> Acesso em: 20.12.2017.

. CONSELHO NACIONAL DE JUSTIÇA - CNJ. Resolução n ${ }^{\circ}$ 76, de 12 de maio de 2009. Dispõe sobre os princípios do Sistema de Estatística do Poder Judiciário, estabelece seus indicadores, fixa prazos, determina penalidades e dá outras providências. - Brasília: CNJ, 2009. Disponível em: $<$ http://www.cnj.jus.br/busca-atos-adm?documento=2764> Acesso em: 20.12.2017

. Constituição da República Federativa do Brasil, de 05 de outubro de 1988. Diário Oficial da União. Brasília, 1988. Disponível em: <http://www.planalto.gov.br/ ccivil_03/constituicao/constitui\%C3\%A7ao.htm>. Acesso em: 29.12. 2017.

. Lei no 13.105, de 16 de março de 2015. Diário Oficial da União. Brasília, 2015. Disponível em: <http://www.planalto.gov.br/ccivil_03/_ato2015-2018/2015/lei/113105.htm>. Acesso em: 29.12.2017.

CAPPELLETTI, Mauro. “Acesso à justiça”. Porto Alegre: Fabris, 1988. 
FGV DIREITO SP - Índice de Confiança na Justiça Brasileira - ICJBrasil: Relatório com os dados da pesquisa Índice de Confiança na Justiça (ICJBrasil) referente ao $1^{\circ}$ semestre de 2016. Disponível em: <http://hdl.handle.net/10438/17204>. Acesso em: 19 dez. 2017.

GOMES, Adalmir Oliveira; FREITAS, Maria Eduarda Mendonça de. “Correlação entre demanda, quantidade de juízes e desempenho judicial em varas da Justiça Federal no Brasil”. Revista Direito Gv, [s.1.], v. 13, n. 2, p.567-585, ago. 2017. FapUNIFESP (SciELO). Disponível em <http://dx.doi.org/10.1590/2317-6172201722>. Acesso em: 09.05.2018.

GRECO, Leonardo. "Paradigmas da justiça contemporânea e acesso à justiça". 2011. In Revista de Direito da Unigranrio. Disponível em: $<$ http://www.egov.ufsc.br/portal/ conteudo/paradigmas-da-justi\%C3\%A7-contempor\%C3\%A2nea-e-acesso-\% $\%$ C3\%A0justi\%C3\%A7> Acesso em: 22.12.2017

HAAS, Adriane; HOFFMANN, Eduardo. "Mediação de conflitos e uma breve análise da experiência do CEJUSC no TJPR”. In Formas consensuais de solução de conflitos [Recurso eletrônico on-line] organização CONPEDI/ UMinho. Coordenadores: Francivaldo Gomes Moura; Jacyara Farias Souza Marques; Romulo Rhemo Palitot Braga - Florianópolis: CONPEDI, 2017. ISBN: 978-85-5505-492-1.

MACÉA, Clarissa Marcondes. In Vade Mecum jurídico / coordenação Alvaro de Azevedo Gonzaga, Nathaly Campitelli Roque - 2 ed. - São Pualo: Editora Revista dos Tribunais, 2011.

MARCELLINO JR, Julio Cesar. “Análise econômica do acesso à justiça: a tragédia dos custos e a questão do acesso inautêntico”. - Rio de Janeiro: Lumen Juris, 2016.

MORAES, Ricardo Quartim de. “A evolução histórica do Estado Liberal ao Estado Democrático de Direito e sua relação com o constitucionalismo dirigente". In Revista de informação legislativa, v. 51, n. 204, p. 269-285, out./dez. 2014. Disponível em: $<$ http://www2.senado.gov.br/bdsf/handle/id/509938> Acesso em: 11.05.2018. 
MÜLLER, Fernanda. "Insuficiência da justiça estatal, mediação e conflito". In "O trabalho do psicólogo no campo jurídico" / Roberto Moraes Cruz, Saidy Karolin e Dario Cunha Ramirez, organizadores. - São Paulo: Casa do Psicólogo, 2005, p. 143-156.

OLIVEIRA, Leonel Gois Lima et al. Medição da eficiência de magistrados e de unidades judiciárias no Ceará, Brasil: o sistema Eficiência.jus. Cadernos Ebape.br, [s.1.], v. 14, n. 3, p.836-857, set. 2016. FapUNIFESP (SciELO). Disponível em: <http://dx.doi.org/ 10.1590/1679-395131041>. Acesso em: 06.05.2018.

REIS, Wanderlei José dos. JUIZ-GESTOR: UM NOVO PARADIGMA. Ridb - Revista do Instituto do Direito Brasileiro: Faculdade de Direito da Universidade de Lisboa, Lisboa, v. 8, n. 2, p.8697-8707, 2013. Disponível em: <https://www.cidp.pt/publicacoes/revistas/ridb/ 2013/08/2013_08_08697_08707.pdf>. Acesso em: 01 maio 2018.

RIBEIRO, Herval Pina. “O juiz sem a Toga: um estudo da percepção dos juízes sobre trabalho, saúde e democracia no judiciário" / Coordenação Herval Pina Ribeiro. 1. ed. Florianópolis: Lagoa Editora, 2005.

SANTOS, Zilmária Aires dos. "Diagnóstico da aplicação de critérios para o alcance de produtividade e celeridade na distribuição de atribuições dentro das serventias judiciais: o estudo do caso da comarca de Dianópolis-TO”. 2017. 113f. Disponível em: <http:// repositorio.uft.edu.br/handle/11612/864> Acesso em: 08.05.2018.

SILVA, Ovídio Araújo Baptista da. "Teoria geral do processo civil”. - 4. ed. rev. e atual. São Paulo: Editora Revista dos Tribunais, 2006.

TRIBUNAL DE JUSTIÇA DO ESTADO DE SANTA CATARINA - TJSC. Missão e visão. Disponível em <https://www.tjsc.jus.br/missao-e-visao>. Acesso em 26.12.2017.

TUPINAMBÁ, Carolina. "Premissas Teóricas Para Constitucionalização do Processo do Trabalho" in Processo Constitucional, (coord.) Luiz Fux. Forense, 2013. 


\title{
O OFICIAL DE JUSTIÇA COMO CONCILIADOR EXTERNO: O PERFIL ADEQUADO A ATENDER A PERSPECTIVA AUTOCOMPOSITIVA DO NOVO CÓDIGO DE PROCESSO CIVIL E AS POLÍTICAS JURÍDICO-LEGISLATIVAS DE TRATAMENTO ADEQUADOS DOS CONFLITOS
}

\author{
Ricardo Tadeu Estanislau Prado
}

Tribunal de Justiça de Santa Catarina e Universidade Federal de Santa Catarina Pedro Manoel Abreu Tribunal de Justiça de Santa Catarina e Universidade Federal de Santa Catarina

\section{Resumo}

O presente estudo teve como objetivo identificar o perfil do Oficial de Justiça adequado a atender a perspectiva autocompositiva do novo Código de Processo Civil e as políticas jurídicolegislativas de tratamento adequados conflitos. Utilizou-se do método dedutivo e levantamento bibliográfico. Ao final concluiu que as várias políticas jurídico-legislativas em comento, que surgiram para tornar a Justiça mais eficiente e promover a paz, refletiram na necessidade de mudança do perfil do Oficial de Justiça para o transformar num conciliador externo com o dever primário de executar as ordens judicias e dever secundário de estimular a autocomposição.

Palavras-chave: Oficial de Justiça, conciliador externo, conflitos, autocomposição.

\begin{abstract}
Resumen/Résumé
The purpose of this study was to identify the profile of the appropriate Officer of Justice to take into account the self-composition perspective of the new Code of Civil Procedure and the legallegislative policies of treatment appropriate conflicts. Deductive method and bibliographic survey were used. In conclusion, the various legal and legislative policies that have emerged to make justice more efficient and promote peace reflected the need to change the profile of the Officer of Justice to become an external conciliator with the primary duty of executing judicial orders and secondary duty to stimulate self-composition.
\end{abstract}

Keywords/Palabras-claves/Mots-clés: Officer of Justice, external conciliator, conflicts, selfcomposition 


\section{Introdução}

Os operadores do direito têm buscado incessantemente formas alternativas de resolução do conflitos para melhorar a vazão dos processos e têm encontrado na desjudicialização dos conflitos, na desburocratização da justiça, no estímulo à autocomposição e nos métodos de tratamento adequado dos conflitos um gargalo que pode contribuir para o desafogamento do Judiciário e consequentemente melhorar o acesso à Justiça.

Neste sentido, a Lei n.13.105 de 16 de março de 2015 que instituiu o Código de Processo Civil (novo CPC) demonstrou sua tendência autocompositiva ao incluir em suas normas fundamentais a obrigação do Estado promover, sempre que possível, a solução consensual dos conflitos, determinando de forma expressa aos juízes, advogados, defensores públicos e membros do Ministério Público a obrigação de estimular à conciliação, mediação e outros métodos de solução consensual de conflitos. Ao Oficial de Justiça passou-se a exigir que fosse certificada a proposta de autocomposição apresentada por qualquer uma das partes, silenciando quanto sua obrigação ou não de estimular a autocomposição.

Por isso é suma importante estudar a atuação do Oficial de Justiça frente aos conflito, até porque ele é o personagem estatal que mais tem acesso aos jurisdicionados e que não deixa de ser um "conciliador natural" na medida em que o primeiro conflito que ele resolve é a resistência da parte em recebê-lo, ouvi-lo, aceitar cópia do mandado e apor sua assinatura. Deve-se reconhecer que esse servidor naturalmente está obrigado a desenvolver ferramentas de persuasão para execução das ordens judiciais, o que justifica analisar com maior propriedade sua correlação e contribuição com autocomposição das partes envolvidas no conflito.

Porém, emerge-se a dúvida: qual seria perfil do Oficial de Justiça da atualidade adequado à atender a perspectiva autocompositiva do novo CPC e as políticas jurídicolegislativas de tratamento adequados?

Para responder a esse questionamento esse estudo tem por objetivo identificar o perfil do Oficial de Justiça adequado à atender a perspectiva autocompositiva do novo CPC e das políticas jurídico-legislativas voltadas ao tratamento adequados conflitos.

Para tanto o presente estudo será divididos em três partes, sendo a primeira destinada a fazer um levantamento da trajetória histórico-funcional do Oficial de Justiça, o segundo a pesquisar as políticas jurídico-legislativas voltadas à desjudicialização, autocomposição e ao 
tratamento adequado dos conflitos e o terceiro a abordar aspectos jurídicos da autocomposição pelo Oficial de Justiça e análise sistêmica do seu perfil.

\section{Trajetória histórico-funcional do Oficial de Justiça}

O Oficial de Justiça é servidor permanente do Poder Judiciário a quem compete cumprir todas as ordens do juízo ou Tribunal emanadas através de mandado para as determinações externas, tais como citações, intimações, prisões e outros atos processuais. (RODRIGUES; LAMY, 2016)

Contudo a origem da função do atual Oficial de Justiça se perde na história, tendo seus primeiros indícios no Direito Hebraico, como pode ver na passagem bíblica passagem pertinente ao tema extraída do versículo 58, capítulo 12, versículo 58 do livro de Lucas, o qual estima-se que tenha sido escrito entre 59 a 75 a.c., com a seguinte redação:

\footnotetext{
Quando algum de vocês estiver indo com seu adversário para o magistrado, faça de tudo para se reconciliar com ele no caminho; para que ele não o arraste até o juiz, o juiz o entregue ao Oficial de Justiça, e o Oficial de Justiça o jogue na prisão. Eu digo que você não sairá de lá enquanto não pagar o último centavo. (BÍBLIA, 2008, p. 1298)
}

No curso da história percebe-se que o Oficial de Justiça recebia um aglomerado de atribuições fazendo as vezes de auxiliar do juiz, policial, guarda real, carcereiro, etc.

No direito romano a figura similar ao atual Oficial de Justiça recebia o nome de apparitores, os quais eram incumbidos de cumprir as ordens emanadas dos magistrados, como bem relata Pedro Bonfante (1959), ao citar uma situação de determinação de um ato que se assemelha a atual penhora.

Também no direito romano encontram-se ainda duas outras figuras que se assemelham ao atual Oficial de Justiça: os viatores, que eram incumbidos de levar as comunicações dos magistrados à determinada pessoa e os praecones que eram incumbidos de anunciar as comunicações dos magistrados dirigidas ao público geral. (BÖETTCHER, 2011)

Porém foi no Direito Romano e no Direito Canônico que se consagrou a necessidade de um auxiliar do juiz, para cumprir suas ordens. (VEADO, 1997)

Nas legislações medievais os executores das ordens dos magistrados não apresentavam grande importância, porém à medida em que foi difundindo o Direito Canônico e o Direito Romano esses executores foram readquirindo a posição de auxiliares do juiz. (PIRES, 2001) 
No século XX o território da Inglaterra era percorrido por juízes itinerantes, que se ocupavam de resolver processos de interesses do rei. Esses juízes necessitavam de pessoas “('sherriff')" para auxiliá-los no cumprimento das "decisões ('writ')", por isso dias antes de empreenderam viagem convocassem os homens mais importantes da região para auxiliar nas atividades. (CEDRO, 2009, p. 25)

No século XIII o rei de Portugal Dom Afonso II estabeleceu "uma política de centralização jurídico-administrativa inspirada em princípios do direito romano: supremacia da justiça real em relação à senhorial e a autonomia do poder civil sobre o religioso" e uma das suas medidas foi nomear o primeiro "meirinho-mor" do reino encarregado a garantir o poder real na esfera judicial e que tinha à sua disposição outros merinhos para cumprir suas ordens e realizarem diligências. (CEDRO, p. 29)

Com relação a essa nomenclatura Gerges Nary (1985) afirma que no direito português o meirinho se referia ao Oficial de Justiça e o termo meirinho-mor ao magistrado.

Durante o período compreendido de 1063 até o final do século XIX, as ordenações Filipinas representavam a espinha dorsal do ordenamento jurídico português e nelas estavam previstas atribuições dos meirinhos, que agiam em nome do Rei ou do Corregedor de Justiça, merecendo destaque o título 17 do Livro I, no qual previa que "ao meirinho-mor pertence pôr em sua mão, um meirinho que ande continuamente na corte, o qual será seu escudeiro de boa linhagem, e conhecimento bom." (CEDRO, p. 28)

O Direito Francês antigo dividiu em duas categorias os auxiliares de justiça da época, ou seja, havia o Oficial Judiciário e o huissier. O primeiro era comparável aos escrivães e escreventes da atualidade, enquanto que o segundo se comparava aos atuais Oficiais de Justiça. (PIRES, 2001)

No Brasil Império, a figura do meirinho seguiu os mesmos moldes da legislação portuguesa e era aquele que tinha por encargo executar as ordens e os mandados dos juízes e os juízes de direito e de paz podiam nomear e demitir livremente os Oficiais de Justiça. (Souza Pinto apud NARY,1985)

O termo meirinho foi caindo em desuso e foi substituído no Decreto n 737/1850 pelo termo official de justiça, permanecendo nas legislações posteriores, sendo importante destacar que no Decreto $\mathrm{n}^{\circ} 737 /$ 1850, no Código de Processo Civil de 1939 e no Código de Processo Penal de 1941 não havia um tópico próprio destinado a condensar e enumerar as atribuições dos Oficiais de Justiça, as quais eram mencionadas de forma aleatórias, mas sempre relacionadas ao cumprimento das determinações judiciais. 
Contudo, no código de processo civil de 1973 as atribuições do Oficial de Justiça ganharam um artigo próprio (artigo 143) assim como no novo CPC (artigo 154).

Dentre as alterações resultantes do novo CPC em relação ao CPC de 1973 a mais inovadora foi a do inciso VI, onde passou a exigir que o Oficial de Justiça certificasse a proposta de autocomposição apresentada pelas partes. Essa inovação demonstra não só a primazia do novo CPC às formas consensuais de resolução de conflitos como também uma inédita atribuição frente aos conflitos, o que será tratado mais adiante.

Desse levantamento histórico-funcional do Oficial de Justiça resta evidente que toda sua existência está atrelada à função precípua de auxiliar da Justiça e de dar cumprimento as ordens judiciais, não sendo errado afirmar com base nisso que sua atuação deverá sempre ser pautada nos interesses da Jurisdição.

\section{Das políticas jurídico-legislativas voltadas à desjudicialização, autocomposição e ao tratamento adequado dos conflitos}

Embora a existência do Estado se justifique para garantir o convívio harmônico do homem em sociedade e a existência da Justiça à dirimir os conflitos à vista da pacificação social, o bom senso recomenda adoção de postura de boa convivência e autodeterminação na solução de problemas interpessoais, de modo que o Estado-Juiz somente deveria ser provocado na impossibilidade absoluta do conflito ser dirimido pelos indivíduos, o que nem sempre ocorre.

O Judiciário possui limitação da sua capacidade julgadora e encontra-se imerso numa crise caracterizada, dentre outros fatores, pela burocratização e lentidão procedimento e pelo engessamento da máquina judiciária ante sua incapacidade de assimilar o assoberbamento de ações geradas por uma sociedade impelida, nos dizeres de Kazuo Watanabe (2008, p. 7), por uma "cultura da sentença".

Neste ponto se justifica a necessidade de estimular a sociedade a dirimir, por si, seus conflitos através da autocomposição, sem a necessidade da intervenção estatal.

O estímulo e incentivo da lei pela autocomposição não é tema atual e encontra-se guarida nas legislações mais remotas, como por exemplo a previsão no art. 161 da Constituição de 1823 e artigo 23 do Decreto $\mathrm{n}^{\circ} 737$ de 1850, nos quais previam que o processo algum seria iniciado senão se fizesse constar a tentativa de reconciliação.

Nos anos 70 a ampliação do conceito de acesso à justiça a partir do Projeto Florença reverteu na necessidade implementação de políticas de melhorias na prestação jurisdicional, de 
modo a propiciá-la de forma célere e rápida, cuja repercussão não ocorresse somente no plano abstrato (processo material e processual), mas também na restruturação física do Judiciário. (CAPPELLETTI; GARTH, 1988)

A partir do projeto florentino, voltado à efetividade do acesso à justiça, as formas alternativas de resolução dos conflitos ganharam mais destaque e atenção dos juristas, por permitirem alcançar mais rapidamente a solução dos litígios do que método tradicional do processo judicial e inflamaram o discurso sobre a resolução alternativa das disputas (RAD's), cujo nome foi posteriormente alterado para Resolução adequada das disputas e consistiam em métodos alternativos para julgamento do Judiciário (diferentes do processo judicial), como por exemplo: negociação, conciliação, mediação, arbitragem, justiça restaurativa, etc. (BRASIL, 2016)

A institucionalização desses métodos alternativos iniciou-se nos Estados Unidos a partir do professor Frank Sender, com a apresentação dos Multidoor Courthouse (Fórum de Multiplas Portas), baseando-se que o processo judicial seria uma da várias “portas’ para resolver o conflito e que o Judiciário deveria disponibilizar outras "portas" como a conciliação, mediação, etc., direcionadas ao tratamento adequado de cada disputa. (AZEVEDO, 2011, p. 16)

No Brasil a institucionalização desses métodos foram aparecendo de forma tímida, como por exemplo no art. 447, caput e parágrafo único do Código de Processo Civil de 1973, onde previa conciliação somente na audiência de instrução e julgamento, quando o litígio versasse sobre direitos patrimoniais de caráter privado e nas causas relativas à família.

A partir de 1982 foram instituídos no Brasil os Conselhos de Conciliação com objetivo de solucionar, extrajudicialmente, lides de pequenas causas. Essa primeira experiência se deu no Estado do Rio Grande do Sul, cujos resultados positivos inspiraram a criação em outros estados da federação. (BACELLAR, 2003, p. 31)

A necessidade de um modelo de Justiça mais célere e simples para as causas de pequeno valor e menor complexidade foi propulsora da Lei Federal $n^{\circ}$. 7.244/84 que instituiu a criação e funcionamento dos Juizados de Pequenas Causas, consolidando e legitimado o sucesso da experiência obtida com os Conselhos de Conciliação e Arbitragem, representando um marco no sistema processual brasileiro, como bem observa Kazuo Watanabe (1985).

$\mathrm{Na}$ Constituição Federal de 1988 o legislador incorporou ao texto constitucional a necessidade da criação dos chamados "juizados especiais" (em substituição aos juizados de pequenas causas), competindo à União, ao Distrito Federal e aos Estados a sua implantação no 
território nacional, fazendo com a criação, antes facultativa (art. $1^{\circ}$ da Lei 7244/84) tornasse medida obrigatória.

Também na Constituição de 1988 (inciso XIX do art. 37), surgiram entidades (agências) ligadas ao poder público e para desempenhar funções precipuamente de regular e fiscalizar a prestação de serviços públicos, afim de que ele sejam colocados à disposição da população de forma eficiente. Essas agências têm natureza de autarquia e podem decidir com autonomia sobre de determinados setores da atividade econômica e social. (BRASIL, 1988)

Cumpre destacar que além de regular e fiscalizar a prestação de serviços pelas empresas privadas as agências reguladoras podem exercer um papel de suma importância no processo de desjudicialização dos conflitos porque podem "solucionar as controvérsias que porventura surjam entre o poder concedente, concessionárias, permissionárias, autorizatárias e seus consumidores e usuários" (BACELLAR, 2004, p. 163). Ou seja, podem resolver conflitos que envolvem falha na dispensação dos serviços vitais, tais como luz, água, telefone antes que eles cheguem ao Judiciário ou até mesmo deferir indenizações no âmbito de sua competência.

$\mathrm{Na}$ área do Direito do Consumidor, por exemplo, encontra-se a reestruturação de órgãos de proteção como o Órgão de Proteção ao Consumidor (PROCON), não apenas para fiscalização e aplicação de multas, mas também para solucionar os conflitos através da mediação.

Em 26 de setembro de 1995 surge a Lei $n^{\circ} 9.099$ que dispõe sobre os Juizados Especiais Cíveis e criminais, regulamentando o dispositivo constitucional (CF/88, art. 98, I). Ela revogou os termos da Lei 7.244/84 que tratava dos juizados de pequenas causas e surgiu como um novo paradigma para as soluções dos conflitos, "com propostas de tutela diferenciada ou de vias alternativas de tutelas e modelos de justiça popular, participativa, democrática, e com expressão de justiça coexistência”. (ABREU, 2004, p.252)

A conciliação passou a ganhar destaque e mais espaços nas práticas processuais com o advento das reformas ocasionadas pelas Leis $n^{\circ} 8.952 / 94$ e 9.245/95. A primeira lei por instituir ao juiz o dever de tentar, a qualquer tempo, conciliar as partes, o que evitava a concentração do empenho conciliatório na Audiência de Instrução e Julgamento. A segunda lei por ter firmado a posição de destaque da conciliação no procedimento sumário, o que incluía uma audiência somente para tentar conciliar as partes e permitia-se a resposta do réu apenas nesse momento.

Nesse contexto de implementação de institutos de desjudicialização e a latente urgência em alcançar meios alternativos para buscar a desejada celeridade no sistema processual é que surgiu a Lei de Arbitragem, Lei n 9.307 de setembro de 1996, que possibilitou 
as partes eleger um árbitro para resolver seus conflitos que versassem sobre direitos patrimoniais disponíveis, podendo ainda escolher os critérios para julgamento, se com base no direito ou na equidade.

Segundo Tania Muniz (2003, p. 19), o instituto da arbitragem possui duas características principais: "acordo de vontades das partes e o poder de julgar que recebem os árbitros, subtraindo o julgamento estatal". Para a autora, a segunda característica retrata o objetivo da desjudicialização.

Outra tentativa de desjudicialização pode ser visto na lei de recuperação extrajudicial de empresas, a Lei 11.101 de 9 de fevereiro de 2005, que substituiu o Decreto-Lei 1661/45, uma vez que viabiliza a recuperação de empresas através de um procedimento de negociação direta entre os interessados, criando-se a recuperação extrajudicial de empresas, sujeitando matéria à apreciação do magistrado tão somente para homologação. Sua aplicação substitui o instituto da concordata, procedimento moroso e submetido a intervenções judiciais.

Em 23 de agosto de 2006, o Conselho Nacional de Justiça (CNJ) deu início ao programa "Movimento pela conciliação", tendo como objetivo a divulgação e incentivo à solução dos conflitos por meio do diálogo, com vistas a garantir maior efetividade e celeridade na prestação jurisdicional. (BRASIL, 2006)

Em 2009, a Lei Complementar $n^{\circ} 132$, que trata sobre a organização da Defensoria Pública, inovou prescrevendo expressamente no inciso II do artigo $4^{\mathrm{a}}$ a determinação para "promover, prioritariamente, a solução extrajudicial dos litígios, visando à composição entre as pessoas em conflito de interesses, por meio de mediação, conciliação, arbitragem e demais técnicas de composição e administração de conflitos". (BRASIL, 2009)

Em 29 de novembro de 2010 o Conselho Nacional de Justiça aprovou a Resolução n. ${ }^{\circ}$ 125/CNJ que dispõe sobre a Política Nacional Judiciária de tratamento adequado dos conflitos de interesses no âmbito do Poder Judiciário, representando um marco na institucionalização de meios 'alternativos' de resolução dos conflitos pelo Judiciário e a mudança de mentalidade dos operadores do direito e das partes, trazendo uma nova imagem do Poder Judiciário.

A referida resolução propõe a criação dos Centros Judiciários, disponibilizando em um único local variados mecanismos de solução de conflitos, com ênfase na conciliação e mediação.

No dia 18 de março de 2016 entrou em vigor a Lei Federal n. ${ }^{\circ}$ 13.015, de 16 de março de 2015, que instituiu o Código de Processo Civil (novo CPC), no qual percebeu-se um novo momento dos métodos alternativos de soluções de controvérsias no contexto brasileiro e de desburocratização da justiça. 
O novo CPC primou que o Estado promoverá, sempre que possível, a solução consensual dos conflitos (art. $3^{\circ}, \S 2^{\circ}$ ) e incumbiu de forma expressa aos juízes, advogados, defensores públicos e membros do Ministério Público a estimulação à conciliação, mediação e outros métodos de solução consensual de conflitos (art. $3^{\circ}, \S 3^{\circ}$ ), além de inserir significativas mudanças, dentre elas: a possibilidade das partes modificarem procedimentos (art. 190), a contagem do prazo em dias úteis (art. 219), citação por meio eletrônico (art. 246, V), a necessidade de prévia audiência de conciliação ou mediação (art. 334), etc. (BRASIL, 2015).

No capítulo dedicado aos auxiliares da justiça, o novo CPC um capítulo destinado aos “Conciliadores e Mediadores Judiciais”, especificando no art. 165, $\S 2^{\circ}$ que o Conciliador atuará preferencialmente nos casos em que não tiver vínculo anterior entre as partes, podendo sugerir soluções, sendo vedado constranger ou intimidar as partes, ao passo que no art. $165, \S 3^{\circ}$, determinou que o Mediador atuará preferencialmente nos casos houver vínculo anterior e auxiliará as partes a compreenderem e identificarem por si próprios as soluções.

A leitura de desses e de outros vários dispositivos do novo CPC emerge as impressões e os reflexos da tendência autocompositiva, de tratamento adequado dos conflitos e desburocratização da Justiça no cenário brasileiro, tal como vinham ocorrendo em outras mudanças legislativas.

Essa realidade está criando uma necessidade de se trabalhar uma nova mentalidade de uma cultura de pacificação que não esteja ligada necessariamente a uma sentença dada por um juiz (WATANABE, 2008), mas sim pela construção de um novo paradigma do ordenamento jurídico através de métodos alternativos de solução de conflitos, os quais priorizam as soluções consensuais das controvérsias, sejam elas através de métodos auto compositivos (conciliação ou mediação) ou heterocompositivos privados (arbitragem). Afinal, hoje, "o conceito de acesso à Justiça está intrinsecamente ligado à contínua redução de insatisfações com o sistema público de resolução de conflitos". (AZEVEDO, 2011, p. 11)

\section{Aspectos jurídicos da autocomposição pelo Oficial de Justiça e análise sistêmica do seu perfil}

O Código de Processo Civil de 2015 (novo CPC) dedicou o artigo 154 para enumerar o rol das atribuições do Oficial de Justiça, sendo inédita a contida no inciso VI, cujo conteúdo e o parágrafo único decorrente impera transcrever: 
Art. 154. Incumbe ao oficial de justiça:

VI - certificar, em mandado, proposta de autocomposição apresentada por qualquer das partes, na ocasião de realização de ato de comunicação que lhe couber".

Parágrafo único. Certificada a proposta de autocomposição prevista no inciso VI, o juiz ordenará a intimação da parte contrária para manifestar-se, no prazo de 5 (cinco) dias, sem prejuízo do andamento regular do processo, entendendo-se o silêncio como recusa. (BRASIL, 2015).

Das inovações do novo CPC em relação aos auxiliares da justiça, a certificação da proposta de autocomposição pelo Oficial de Justiça, prevista no art. 154, VI, é a mais interessante porque o antigo CPC jamais previu tal atribuição e por restar manifesto o bom propósito do legislador no sentido de dar privilégio à solução consensual dos conflitos, como, por exemplo, se verifica a teor do art. $2^{\circ}, \S 3^{\circ}$, art. $3^{\circ}, \S 2^{\circ}$, art. 165, art. 359, art. 694, todos do novo CPC.

Essa nova atribuição ao Oficial de Justiça foi recebida com bons olhos e otimismo por Silas José da Silva (2016), por entender justificável e razoável, uma vez que é esse servidor que tem o primeiro contato com os jurisdicionado, podendo inclusive conferir sua vida pessoal e obter a proposta de autocomposição, o que representará significativa agilidade ao tramite processo à medida em que o acordo poderá ser homologada antes mesmo do comparecimento pessoal das partes ao órgão jurisdicional competente.

Porém, alguns pontos não foram esclarecidos pelo novo $\mathrm{CPC}$ em relação ao procedimento gerado pela certificação da proposta de autocomposição, não ficando claro, por exemplo, se havendo a anuência da parte contrária acerca da proposta de acordo dirigida ao Oficial de Justiça deveria então o juiz homologar o acordo ou encaminhar os autos para ratificação em audiência com a presença de advogado, bem como não ficou claro se Oficial de Justiça tem o dever de inquerir ou ainda estimular a parte acerca de eventual interesse em compor o litígio.

A maioria dos doutrinadores citados pesquisados nada falam a respeito da necessidade ou não de ratificação de proposta por advogado, mas referida dúvida se mostra pertinente ainda mais quando se verifica que é obrigatório as partes estarem acompanhadas de por advogado ou defensor público na audiência preliminar de conciliação ou mediação, conforme $\S 9^{\circ}$, do artigo 334, do novo CPC.

Cristiano Imnhof (2016) entente que a aceitação da proposta pela parte contrária não induz imediatamente à homologação e a consequentemente extinção do feito, afirmando que então deverão ser adotadas as técnicas de conciliação e mediação, mencionando inclusive o art. 
334, deixando implícito seu entendimento da necessidade do acordo ser assistido por advogado ou defensor público porque é essa a determinação contida no $\S 9^{\circ}$ do referido artigo.

Nelson Nery Júnior (2015) enfrenta a questão e entende que o juiz é que deverá sopesar as situações em que os termos ou objeto do acordo devem ser ratificados ou retificados por advogado, deixando transparecer que alguns casos à proposta feita pelo demandado e aceita pelo demandante poderá induzir à sentença homologatória com a consequente extinção do feito.

O oficial deverá registrar e certificar a proposta, a qual deverá, depois, seguir para apreciação da parte contrária. A princípio, a pretensão do réu, revelada informalmente ao oficial e certificada no mandado, dará ensejo às providências do CPC 2015 par. Ún. Ao juiz caberá, diante da aquiescência do autor, sopesar se é o caso de o réu assistir-se por advogado. (NERY JÚNIOR, 2015. p.629)

Jonathan Porto Galdino do Carmo (2015) entende ser perfeitamente possível a homologação do acordo proposto pelo réu ao Oficial de Justiça, com a consequente extinção do processo com julgamento de mérito, fazendo coisa julgada material se não houver recurso.

Antônio do Passo Cabral e Ronaldo Cramer (2016) ao comentarem o inciso VI do art. 154 do novo CPC, entendem que havendo aceitação pela parte contrária acerca da proposta feita para o Oficial de Justiça, o acordo será levado à homologação, transparecendo o que entendimento de desnecessidade de ratificação por advogado.

Por outro lado, a necessidade de ratificação por advogado da proposta de acordo colhida pelo Oficial de Justiça poderá representar um ato formal no qual esbarra a autonomia da vontade das partes, revertendo num formalismo excessivo de modo a destoar dos fins a que o novo CPC se propõe. Até porque o novo CPC buscou estabelecer processo democrático, tendo como primazia a autonomia da vontade das partes, como pode se extrair por exemplo do artigo 190, o qual permite que as partes convencionarem acerca de procedimentos a serem adotados, o que até então era impensável.

À luz da análise sistêmica do ordenamento jurídico não seria incorreto afirmar que se a representação por advogado tivesse de ser observada a rigor, como pressuposto absoluto para manifestação de vontade em juízo, inaplicável seria a presunção de veracidade dos fatos alegados pela parte demandante nos casos de revelia do demandado porque seu silêncio ficaria sem ratificação por advogado.

Foi esse formalismo excessivo que buscou-se evitar ao criar o novo CPC, como colhese da sua apresentação pelo Ministro Luiz Fux (2015), presidente da comissão que o organizou: 
O novel código enfrentou as barreiras da morosidade mediante criativas soluções. [...] A primeira, tributada ao excesso de formalidades do processo oriunda da era do iluminismo, na qual reinava profunda desconfiança sobre o comprometimento do Judiciário com o ancião regime, razão que conduziu os teóricos da época a formular técnicas de engessamento dos poderes judiciais. (FUX, 2015, P. 14).

E prossegue Luiz Fux, dizendo que a cultura ultrapassada do formalismo foi superada mediante a adoção de uma série de medidas, dentre elas, citada com ênfase, "a possibilidade de adoção de um procedimento das partes" e a "conciliação initio litis". (FUX, 2015, p. 16)

E por derradeiro a proposta de autocomposição pela parte ao Oficial de Justiça é direcionada à parte contrária e não ao juiz, por isso não pode ser entendida como uma ato postulatório e desnecessitando portanto de ratificação por advogado ou defensor público, a medida de revela o interesse da parte em acordar para não submeter o conflito ao crivo da Jurisdição.

Outro ponto pertinente é se realizada a proposta perante o Oficial de Justiça suspendese ou não o processo até manifestação da outra parte, assunto que rende comentários dos doutrinadores.

As principais causas de suspensão do processo estão previstas no art. 313 do CPC, dentre as quais não se vislumbra a proposta de autocomposição registrada pelo Oficial de Justiça.

A proposta realizada pela parte diretamente ao Oficial de Justiça tem o condão exclusivo de prospectar um acordo e não necessariamente de satisfazer imediatamente o objeto da ação de modo a extingui-la. Em outras palavras, não se enquadra na concepção de motivo justo para suspensão do processo ou para deixar o Oficial de Justiça de realizar o ato, bem como a não suspensão evita o surgimento de propostas frívolas com intuito de procrastinar o feito e impedir a realização dos atos processuais.

Por derradeiro o próprio parágrafo único do art. 154 prevê que certificada a proposta de autocomposição o juiz ordenará a intimação para contrária para manifestar-se, no prazo de 5 (cinco) dias, "sem prejuízo do andamento regular do processo", restando evidente com isso que a proposta não tem o condão de suspender o processo.

Assim, o oficial não poderá deixar de praticar o ato a pretexto do oferecimento de proposta de acordo, sob pena de incorrer em ilícito administrativo por deixar de cumprir no prazo os atos impostos por lei, conforme preceitua o artigo 155, I do CPC.

Neste sentido ensina José Miguel Medina defende que o Oficial de Justiça não está autorizado "a suspender ou retardar o início de atividade que dever realizar (p. ex., algum ato 
executivo) pelo fato de ter ouvido proposta de composição de uma das partes (p. ex., do executado)". (MEDINA, 2016, p. 285)

Quanto à possibilidade do oficial agir de forma ativa em relação ao estimulo à resolução consensual pelas partes, a legislação também foi omissa e poucos doutrinadores falam a respeito.

Para José Miguel Medina (2016), André Pagani Souza (2016) e Tereza Arruda Alvim Wambier (2016) a obrigação do Oficial de Justiça é somente certificar a proposta de acordo, ao passo que para Daniel Amorim Assumpção Neves (2017) a inédita atribuição em comento seria mais significativa se o oficial esclarecesse à parte a possibilidade de autocomposição.

Com entendimentos diferentes estão os doutrinadores Jonatas Luiz Moreira de Paula (2016), Lenio Streck e Diele Cunha (2016), ao defenderem que o Oficial de Justiça tem o dever de agir proativamente incentivando à parte a oferecer uma proposta, até porque essa seria a atitude que mais se amolda ao modelo de processo proposto pelo novo CPC, pautado na primazia do estímulo a autocomposição.

\footnotetext{
O dispositivo traz nova atribuição para o oficial de justiça, que se amolda ao modelo de processo que se quer estabelecer, de nítido estímulo a autocomposição (art. $3^{\circ}$, do CPC/2015). Assim, incumbe-lhe, quando da realização do ato de comunicação, cerificar no mandado a proposta de autocomposição apresentada pelo sujeito cientifica. Por certo que entra aí o importante papel de sugestionamento, que proativamente conduza a parte a vonluntariamente oferecer a proposta, a qual dificilmente seria feira de maneira espontânea. (STRECK; NUNES, 2016).
}

Sob o olhar de uma visão sistêmica, a Constituição Federal de 1988, diga-se de passagem situada no ápice do sistema jurídico, em seu preâmbulo esclarece instituir o Estado Democrático comprometimento socialmente com a "solução pacífica das controvérsias" e traz em no seu corpo institutos que permitam que isso ocorra também no âmbito judicial.

Não parece diferente o novo $\mathrm{CPC}$, baseados num processo democrático alinhado à Constituição e às políticas jurídico-legislativas voltadas ao tratamento adequado dos conflitos e que traz em seu bojo norma fundamental de carácter pragmático voltada à solução consensual dos conflitos, como pode ser extrair do $\S 2^{\circ}$ do art. $3^{\circ}$, ao primar que o Estado promoverá, sempre que possível, a solução consensual dos conflitos, parecendo referir-se ao Estado em sentido amplo.

Embora o novo CPC tenha silenciado quanto a obrigatoriedade do Oficial de Justiça estimular a autocomposição, diferentemente do que fez em relação aos juízes, advogados, defensores públicos e membros do Ministério Público, para os quais incumbiu de forma 
expressa o dever de estimular a conciliação, mediação e outros métodos de solução consensual de conflitos (art. $3^{\circ}, \S 3^{\circ}, \mathrm{CPC}$ ), sob análise sistêmica resta demonstrada a intenção do legislador em buscar a autocomposição em todo momento processual e através de todos os sujeitos do processo.

Logo não seria incorreto concluir que se a todos os órgãos da Justiça compete o estímulo à resolução consensual dos conflitos, tal postura também se estende ao Oficial de Justiça, porque além de ser reconhecidamente um auxiliar da Justiça (art. 135, CPC), que age em nome e sob os interesses da Jurisdição, é 'um agente estatal' investido por meio de concurso público, subordinado aos princípios da administração pública $(\mathrm{CF} / 88$, art. 37), podendo, neste sentido, integrar o termo amplo de "Estado" empregado no $\S 2^{\circ}$ do art. $3^{\circ}$ do CPC.

E esse entendimento pode ser corroborado com os ensinamentos de Nelson Nery Júnior:

No CPC/1973, apenas do juiz tinha o estrito dever de promover e estimular a conciliação das partes. Todavia, esse dever, por imperativo ético, também se estende a todo e qualquer operador do direito envolvido em determinado feito. A solução deve ser o mais harmônica possível para todas as partes, e apenas em caso de grave desacordo deve ser depositada sobre os ombros do juiz - isso contribui para um maior grau de satisfação das partes e maior celeridade na distribuição da justiça. (NERY JR, 2015, p. 192)

Respeitas opiniões contrárias, resta nítido o propósito do novo $\mathrm{CPC}$ em estabelecer um processo democrático alinhado à Constituição e pautado como direito fundamental à solução consensual dos conflitos, de modo que para atender essa perspectiva impensável a atuação de um Oficial de Justiça que não seja proativo no sentido de estimular às partes a solução consensual dos conflitos.

Ao Oficial de Justiça estimular o acordo e sugerir solução para o litígio estará fazendo as vezes do Conciliador, funcionando neste caso como um "Conciliador Externo", sendo-lhe vedada a utilização de qualquer tipo de constrangimento ou intimidação para que a parte concilie, conforme prevê o $\S 2^{\circ}$, do art. 165, do CPC.

Não se vislumbra, por ora, o Oficial de Justiça fazer as vezes do Mediador, porque a mediação exige um processo mais elaborado e caracterizado pelo restabelecimento da comunicação entre as partes $\left(\mathrm{CPC}\right.$, art. $\left.165, \S^{\circ}\right)$, sendo que na grande maioria das vezes esse servidor estará na presença de somente uma das partes.

Porém, esse simples acréscimo às atribuições do Oficial de Justiça trouxe uma dimensão capaz de mudar toda sua atividade, da qual passa-se a exigir um caráter mais 
operativo e dinâmico, estabelecendo-se um novo perfil desse servidor. Daí surge a importância dos Tribunais promoverem a "devida capacitação desse servidores com técnicas voltadas à conciliação, pois também exercerão uma das funções judicantes, o que, no passado era privativa apenas aos magistrados, conciliadores, mediadores e árbitros judiciais.” (CARMO, 2015)

Embora o dispositivo em comento mencione que o Oficial de Justiça deva certificar a proposta de acordo nos atos de comunicação, entende-se que ele a colha também nos demais atos de mera ciência ou de constrição, desde que em primeiro momento execute a ordem do mandado.

Nessa perspectiva autocompositiva o Oficial de Justiça, como auxiliar do juízo, continua tendo o dever primário de cumprir às determinações judiciais e, como agente estatal, passa a ter o dever secundário de estimular a autocomposição, sendo que jamais deverá preterir essa em detrimento daquelas, sob pena de responsabilização.

\section{Conclusão}

O presente trabalho teve por objetivo identificar o perfil do Oficial de Justiça adequado à atender a perspectiva autocompositiva do novo $\mathrm{CPC}$ e das políticas jurídico-legislativas voltadas ao tratamento adequados conflitos.

Realizado o levantamento histórico-funcional do Oficial de Justiça apurou-se que sua função tem origem no direito Hebraico e percebeu-se que ao longo da história recebia um aglomerado de atribuições fazendo as vezes de auxiliar do juiz, policial, guarda real, carcereiro, etc. Mas toda sua existência está atrelada à função precípua de auxiliar da Justiça.

Apurou-se a evolução das políticas jurídico-legislativas voltadas a desjudicialização dos conflitos, a desburocratização da justiça, ao estímulo à autocomposição e aos métodos de tratamento adequado dos conflitos, refletiu no do Oficial de Justiça, o qual passou a ter uma nova atribuição com a edição do novo $\mathrm{CPC}$, consistente em certificar a proposta de autocomposição oferecida pela parte.

Embora novo CPC tenha sido omisso em relação a forma de agir do Oficial de Justiça, no sentido de estimular ou não a autocomposição, a partir de uma pesquisa bibliográfica, colhendo-se opiniões de doutrinadores e numa análise sistêmica do ordenamento jurídico, foi possível apurar um novo perfil do Oficial de Justiça, adequado à tendência autocompositiva do novo CPC e as políticas jurídico-legislativas de tratamento adequado dos conflitos.

Neste ponto prospecta o Oficial de Justiça como um conciliador externo, continuando com o dever primário de cumprir às determinações judiciais e passando a ter o dever secundário 
de estimular a autocomposição, sendo que jamais deverá preterir essa em detrimento daquelas, sob pena de responsabilização.

É de suma importância atribuir ao Oficial de Justiça a função secundária de conciliador externo por ser ele o primeiro agente estatal a ter contato com o jurisdicional e por adquirir uma habilidade natural de persuadir e conciliar, na medida em que o primeiro conflito que enfrenta e compõe é o de ser recebido e ouvido pela parte, que ao final aceita a contrafé e apõe sua assinatura no mandado.

A conciliação pelo Oficial de Justiça poderá prospectar significativos ganhos à Jurisdição à medida que esse servidor passa a contribuir com a atividade fim da Jurisdição de pacificação dos conflitos, como também contribuir para que muitos processos sejam julgados no início e sem a possibilidade de recurso, uma vez que as decisões proverão das próprias partes.

Conclui-se também que a proposta de autocomposição dirigida ao Oficial de Justiça reforça a autonomia sua vontade da parte em acordar para evitar a Jurisdição e é direcionada à parte contrária e não ao juiz, por isso a desnecessidade de não ser ratificada por advogado, por não tratar-se de um ato postulatório.

Porém, para o otimizar essa inovadora atribuição do Oficial de Justiça será necessária uma mudança de mentalidade através do incentivo e cursos de capacitação pelos Tribunais com técnicas voltadas ao tratamento adequado dos conflitos.

Por derradeiro, essa nova atribuição tem uma razão de existir, pois se o novo CPC incumbiu o Oficial de Justiça de certificar a proposta de autocomposição é porque pretende que elas venham à tona através desse servidor e que referida prática tenha aplicabilidade e eficácia. E, para que isso aconteça, é indispensável que o oficial seja proativo, inquira, sugestione e estimule às partes a solução consensual dos conflitos.

\section{Referências bibliográficas}

ABREU, Pedro Manoel. Acesso à justiça e juizados especiais cíveis: o desafio histórico da consolidação de uma justiça cidadã no Brasil. Florianópolis : Fundação Boiteux, 2004 .

\section{AZEVEDO, André Gomma. Desafios de Acesso à Justiça ante o Fortalecimento da}

Autocomposição como Politica Pública Nacional. In: RICHA, Morgana de Almeida; PELUSO, Antonio Cezar (Coords.). Conciliação e mediação: estruturação da politica judiciária nacional. Rio de Janeiro: Forense, 2011. 
BACELLAR, Luiz Ricardo Trindade: In Revista de Direito Administrativo. V. 236: 164-174 - Abril/junho 2004. Solução de controvérsias pelas agências reguladores - pg. Rio de Janeiro: Renovar, 2004.

BACELLAR, Roberto Portugal. Juizados especiais: a nova mediação paraprocessual. São Paulo: Editora Revista dos Tribunais. 2003.

BÍBLIA de estudo Plenitude para Jovens. Barueri: Sociedade Bíblica do Brasil, 2008.

BRASIL. Conselho Nacional de Justiça. AZEVEDO, Andre Gomma de. (Org.). Manual de

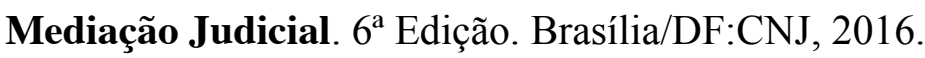

Conselho Nacional de Justiça. Movimento da conciliação e mediação. 2006. Disponível em $<$ http://www.cnj.jus.br/programas-e-acoes/conciliacao-e-mediacao-portal-daconciliacao/movimento-conciliacao-mediacao>. Acesso em 02 abr .2017.

\section{. Constituição da República Federativa do Brasil de 1988.}

Decreto $\mathbf{n}^{\mathbf{0}} \mathbf{7 3 7}$, de 25 de novembro de 1850. Determina a ordem do Juízo no Processo Commercial. Disponível em $<$ http://www.planalto.gov.br/ccivil_03/decreto/ historicos/dim/dim737.htm>. Acesso em 11 Abr. 2017.

. Lei Complementar $\mathbf{n}^{0} .132$ de 7 de outubro de 2009. Altera dispositivos da Lei Complementar no 80 e dá outras providências. Disponível em http://www.planalto.gov.br/ ccivil_03/leis/lcp/lcp132.htm>. Acesso em 03 abril 2017.

Lei $n^{0}$. 5.869 de 11 de janeiro de 1973. Institui o Código de Processo Civil. Disponível em $<$ http://www.planalto.gov.br/ccivil_03/Leis/L5869.htm>. Acesso em 03 abr. 2017.

Lei $\mathbf{n}^{0}$. 13.105 de 16 de março de 2015. Código de Processo Civil. Disponível em $<$ http://www.planalto.gov.br/ccivil_03/_ato2015-2018/2015/lei/113105.htm>. Acesso em 18 jan. 2018. 
Resolução no 125 de 29 de novembro de 2010. Conselho nacional de Justiça

-CNJ. Disponível em < http://www.cnj.jus.br/atos-normativos?documento=156 >. Acesso em 08 jan. 2018.

BÖETTCHER, Carlos Alexandre. História da Magistratura: o Pretor no Direito Romano. São Paulo: LCTE Editora, 2011.

BONFANTE, Pedro. Instittuiciones de derecho romano. Madrid: Instituto Editorial réus, 1959.

CABRAL, Antônio do Passo; CRAMER, Ronaldo. Comentários ao novo Código de Processo Civil. $2^{\mathrm{a}}$ ed. rev. atual. e amp. Rio de Janeiro : Forense, 2016.

CAPPELLETTI, Mauro; GARTH, Bryant. Acesso à justiça. Porto Alegre: Ed. Fabris, 1988.

CARMO, Jonathan Porto Galdino De. A indispensabilidade da atividade do Oficial de Justiça para o novo Código de Processo Civil. 2015. Disponível em: $<$ https://

jus.com.br/artigos/42566/a-indispensabilidade-da-atividade-do-oficial-de-justica-para-o-novocodigo-de-processo-civil>. Acesso em 2 mai 2017.

CEDRO, Marcelo. Oficial de Justiça na história. Belo Horizonte: Del Rey, 2009.

FUX, Luiz. Novo código de processo civil temático. São Paulo: Editora Mackenzie, 2015.

IMNHOF, Cristiano. Novo código de processo civil comentado. 2. Ed. rev. aum. e atual. São Paulo : BookLaw, 2016.

MEDINA, José Miguel. Novo Código de Processo Civil comentado: com remissões e notas comparativas ao CPC/1973 - 4 ed. rev., atual. e ampl. São Paulo: Editora Revista dos Tribunais, 2016.

MUNIZ, Tânia Lobo. Arbitragem no Brasil e a Lei 9.307/96. 1. ed. Curitiba: Juruá, 2003. 
NARY, Gerges. Oficial de Justiça. Teoria e prática. São Paulo: Universitária de Direito, 1985.

NERY JÚNIOR, Nelson. NERY, Rosa Maria de Andrade. Comentários ao Código de Processo Civil. São Paulo: Revista dos Tribunais,2015.

NEVES, Daniel Amorim Assumpção Neves. Novo Código de Processo Civil Comentado. 2 ed. rev. e atual. Salvador : Ed. JusPodivm, 2017.

PAULA, Jonatas Luiz Moreira de. In Código de processo civil comentado. Coor. José Sebastião Fagundes Cunha. São Paulo : Revista dos Tribunais, 2016.

PIRES, Leonel Baldasso. Oficial de Justiça. Princípios e prática. Porto Alegre: Livraria do Advogado, 2001.

RODRIGUES, Horácio Wanderlei. LAMY, Eduardo de Avelar. Teoria Geral do Processo. 4. Ed. rev., atual. E ampl. - São Paulo: Atlas, 2016.

SILVA, Silas José da. Novas atribuições do Oficial de Justiça no CPC/2015. 2016. Disponível em: < https://jus.com.br/artigos/47298/novas-atribuicoes-do-oficial-de-justica-nocpc-2015>. Acesso em 21 de setembro de 2016.

SOUZA, André Pagani. In. Comentários ao novo código de processo civil. Coordenadores Angélica Arruda Alvim... [et. al.]. São Paulo Paulo: Saraiva, 2016.

STRECK, Lenio Luiz; NUNES, Dierle; CUNHA, Leonardo Carneiro. Comentários ao código de processo civil. São Paulo: Saraiva, 2016.

VEADO, Carlos Weber ad-Vícula Veado. Oficial de Justiça e sua Função nos Juízos Cível e Criminal. Leme:Editora de Direito, 1997.

WAMBIER, Tereza Arruda Alvin... [et. al.]. Primeiros comentários ao novo código de processo civil: artigo por artigo. $2^{\mathrm{a}}$. ed. rev. atua. e ampl. São Paulo : Editora Revista dos Tribunais, 2016. 
WATANABE, Kazuo. A Mentalidade e os Meios Alternativos de Solução de Conflitos no Brasil. In: GRINOVER, Ada Pelegrini et al (Coor.). Mediação e gerenciamento do processo: revolução na prestação jurisdicional: guia prático para a instalação do setor de conciliação e mediação. 2. reimpr. São Paulo: Atlas, 2008.

. Juizado Especial de pequenas causas: Lei n.7.244, de 7 de novembro de 1984. São Paulo : Revista dos Tribunais, 1985. São Paulo : Revista dos Tribunais, 1985. 


\title{
PERSPECTIVAS DO ACESSO À JUSTIÇA NA GARANTIA DO DIREITO À ÁGUA POTÁVEL E AO SANEAMENTO BÁSICO EM DUQUE DE CAXIAS
}

\author{
Alessandra Bentes Teixeira Vivas \\ Universidade Católica de Petrópolis \\ Mônica Micaela de Paula \\ Universidade Católica de Petrópolis
}

\section{Resumo}

$\mathrm{O}$ acesso à Justiça é garantia constitucional no ordenamento jurídico brasileiro, assegurado pela Constituição da República de 1988. Além da garantia formal em não excluir nenhum assunto da apreciação e crivo do Poder Judiciário, deve esta ser constituinte de instrumentalização a fim de que seu alcance possa ser amplo e não se restrinja apenas àqueles que possam dispor de recurso para pagar os custos de um processo judicial e de um profissional habilitado, in casu, um advogado. Pensando justamente nessa instrumentalização, o legislador constituinte, ainda no corpo do mesmo artigo $5^{\circ}$, reconheceu como obrigação do Estado a prestação de assistência jurídica integral e gratuita àqueles que puderem comprovar a insuficiência de recursos. No mesmo caminho, elevou a Defensoria Pública a instituição essencial à função jurisdicional do Estado, de maneira que se tornasse efetivo o acesso, não somente ao processo judicial, mas também a toda a orientação jurídica, promoção de direitos humanos e defesa nas esferas judicial e extrajudicial, de forma individual ou coletiva, daqueles que não tivessem condições de pagar advogado e custas processuais. O presente artigo analisará através de estudo de caso o município de Duque de Caxias no que toca ao acesso à água e saneamento, bem como se a garantia constitucional do acesso à justiça foi observada no âmbito da proteção desse direito humano naquela localidade, o longo do ano de 2017.

Palavras-chave: acesso à justiça, direitos humanos, defensoria pública, água potável, saneamento básico

\section{Abstract/Resumen/Résumé}

Access to justice is a constitutional guarantee in the Brazilian legal system, guaranteed by the Constitution of the Republic of 1988. In addition to the formal guarantee in not excluding any 
subject from the appreciation and sifting of the Judiciary, this should be constituent of instrumentalization in order that its scope can be broad and not restricted to those who may have recourse to pay the costs of legal proceedings and of a qualified professional, in casu, a lawyer. Thinking precisely on this instrumentalization, the constituent legislator, still in the body of the same article 5, recognized as an obligation of the State to provide full and free legal assistance to those who can prove the insufficient resources. Along the same path, the Office of the Public Defender was the institution essential to the jurisdictional function of the State, so as to ensure effective access not only to the judicial process, but also to all juridical guidance, promotion of human rights and defense in the judicial and extrajudicial, individually or collectively, of those who could not afford attorney's fees and procedural costs. This article will analyze, through a case study, the municipality of Duque de Caxias regarding access to water and sanitation, as well as if the constitutional guarantee of access to justice was observed in the scope of protection of this human right in that locality, the during the year 2017.

Keywords/Palabras-claves/Mots-clés: access to justice, human rights, public defense, drinking water - basic sanitation.

\section{Introdução}

Dentro de um sistema de justiça que se pretenda democrático, é imprescindível que o Estado assegure o acesso amplo e irrestrito, não só a decisões judicias justas, mas também a todo o arcabouço de aconselhamento, educação em direitos, assistência extrajudicial e principalmente defesa dos direitos fundamentais dos indivíduos.

Contudo, na sociedade contemporânea, já ultrapassamos as ideias de que apenas aqueles que têm condições de arcar com os altos custos do processo judicial e extrajudicial podem se valer do sistema. Inúmeras reflexões têm sido feitas há algumas décadas sobre os meios pelos quais pode-se chegar ao melhor conceito de acesso à justiça, assim como qual seria a real constatação da efetividade dos resultados para que sejam individual e socialmente justos.

Em verdade, busca-se, com o entendimento dos conceitos sobre acesso à justiça e direito humano à água potável e ao saneamento e dos motivos pelos quais as demandas judiciais e extrajudiciais não são propostas, ou se propostas, se tornam-se efetivas ou apenas circunstanciais.

Assim, serão analisadas a propositura de ações judicias naquele período e naquela comarca. O objetivo é identificar o que realmente impede ou estimula a busca pela solução 
desse tipo de conflito, através da comparação do número de demandas ou de acordos propostos em contraposição a dados territoriais de população.

A hipótese levantada aqui é a de que o desconhecimento de maneiras pelas quais a população possa provocar o Judiciário, de forma individual ou coletiva ou mesmo por meios extrajudiciais a efetivar esses direitos e a dificuldade do próprio acesso a instituições do sistema de justiça, como Ministério Público e Defensoria Pública, seja crucial para entendermos de que maneira o acesso à justiça, como garantia constitucional, é efetivamente assegurado.

Analisaremos brevemente os conceitos e metodologias contemporâneos utilizados no Brasil no que se refere ao acesso à justiça, bem como o papel da Defensoria Pública na Comarca de Duque de Caxias e a propositura de ações judiciais e medidas extrajudiciais no período estudado relativos ao tema.

\section{Breves considerações sobre o acesso à justiça no Brasil}

Inicialmente o que deve ser levado em conta é o conceito de acesso à justiça, na medida em que este não pode representar apenas a possiblidade de propositura de ações judiciais ou defesa em processos judiciais e extrajudiciais em andamento. Tal afirmativa se justifica uma vez que a mera positivação do acesso ao sistema de justiça não assegura que esta seja universalmente alcançada por aqueles que dela dependam. Isto porque o próprio conceito do que é justiça é bastante relativo, sendo necessária uma análise crítica acerca de todo o sistema de justiça.

Por sistema de justiça, há que se entender os órgãos e instituições envolvidos na dinâmica das soluções de conflito. Desta forma, não significa que a única maneira de se buscar a justiça no caso concreto seja através de Poder Judiciário.

Já se evoluiu para o entendimento de que as formas extrajudiciais de resolução de conflitos também integram o conceito de justiça, independente de serem exercidas ante a existência de jurisdição. Vale ser ressaltado que o conceito de justiça é baseado na concepção aristotélica de justiça como virtude de distribuição e retificação, ou seja, no conceito de dar a cada um o que lhe é devido. Constitui-se a base do sistema de retribuição, podendo ainda ser entendida a justiça como instituição, ou seja, como a própria realização da sociedade justa. Todavia, há que se ter o cuidado, uma vez que a retribuição carrega em si a presença da emoção e da razão, porém, no momento em que os envolvidos entendem que cada um deles é 
responsável por práticas que permitam se alcançar o que lhes e devido, chega-se à ampla perspectiva do que é de fato o acesso à justiça.

Sendo assim, uma vez que não se faz imprescindível a jurisdição para que se alcance a justiça, parte-se do entendimento de que o conflito é precedente do consenso e, portanto, esse consenso pode e deve ser buscado de maneiras autônomas, restando ao Poder Judiciário a apreciação residual, quando não se façam mais possíveis quaisquer negociações diretas entre os envolvidos, ou mesmo com a intervenção de terceiros, através de técnicas específicas.

No Brasil, a par dos preceitos constitucionais que garantem o amplo acesso à justiça, não somente do ponto de vista formal mas também do ponto de vista material, o advento do novo código de processo civil veio corroborar ainda mais a preferência pelos métodos alternativos para a solução de conflitos. Nesse particular, o novo Código de Processo Civil instituiu a obrigatoriedade de mediação ou da conciliação antes da resposta do réu - art. 334 da Lei 13.105/2015, sendo o réu citado já para comparecer à audiência. Já o art. $3^{\circ}$ deixa clara a ênfase que o legislador procurou implementar ao dispor que o Estado deverá estimular os métodos alternativos de solução de conflitos, como mediação e conciliação.

Apesar da previsão constitucional da existência de Defensoria Pública no papel de instituição responsável por assegurar o amplo e efetivo acesso à justiça, como será mais detalhadamente demonstrado, em muitas comarcas ao redor do país não se conta com a estruturação necessária e com isso a figura do Defensor Público se torna, em várias cidades, inexistente.

A existência de toda a legislação e instituições estabelecidas para o funcionamento do sistema de justiça pode dar a falsa impressão de que está sendo assegurado o pleno acesso a todos os interessados na solução dos conflitos. Contudo, a falta de nitidez quando ao manejo desses instrumentos deve, de algum modo, ser suprida a fim de que seja assegurada também a igualdade de oportunidades e o tratamento proporcional às desigualdades de fato.

Segundo o professor Garapon (2003):

C'est porquoi les avocats et les juges d'un pays donné peuvent apprendre des constructions et des solutions juridiques inventées par leurs colègues étrangers. L'étude d'autres systèmes juridiques fait aussi mieux comprendre son propre système, ce qu'il est, ce qu'il doit être et ce qu'il peut devenir. (p. 8)

Seguindo-se ao raciocínio comparativo entre alguns sistemas de ampliação de solução de conflitos, vale se destacar a ideia de que as cortes de vários países deveriam estar mais abertas a "litígios de direito público", o que é crucial para que esses procedimentos, que são altamente especializados e estruturados, tenham o fôlego necessário para se tornarem efetivos. 
Tais litígios seriam os direitos os direitos difusos, com mecanismos como a abertura de legitimidade ativa (no Brasil pode-se citar o exemplo do artigo $2^{\circ}$ Código de Defesa do Consumidor, que cria a figura do consumidor por equiparação, fugindo da correlação clássica entre relação jurídica e relação processual), os ombudsmen de empresas (dentro do direito do consumidor, sendo uma criação sueca na qual os consumidores podem ter acesso diretamente a áreas das empresas fornecedoras especializadas em diálogo com o mercado), os advogados de interesse público e as class action (que correspondem a nossas ações coletivas, privilegiando a proteção de direitos coletivos, individuas homogêneos e difusos).

Além da especialização das cortes por assuntos, se faz imprescindível pensar em outros caminhos de fóruns mais acessíveis, a fim de preservar os tribunais. No Brasil, considerando que o fornecimento de água e do saneamento básico são estruturados por empresas, públicas e privadas, é estabelecida entre as partes verdadeira relação de consumo, enquadrando-se também nas diretrizes legais do Código de Defesa do Consumidor, além de todo o arcabouço dos direitos humanos e das questões ambientais envolvidas.

Uma das maneiras de dar ênfase à criação de sociedades mais justas e igualitárias seria estimular a atenção a pessoas comuns, ou seja, propiciar instrumentos para que essas pessoas possam enfrentar organizações fortes e burocracia governamental. Esses instrumentos podem ser fóruns efetivos onde os indivíduos possam reivindicar seus direitos. No Brasil, por exemplo, existe a ferramenta denominada "Consumidor.gov", que possibilita acesso direto aos fornecedores com a supervisão do Ministério da Justiça - https://www.consumidor.gov.br, que por ser ferramenta oficial, serve como fonte de dados oficiais. Há ainda a prática do Tribunal de Justiça do Rio de Janeiro, no âmbito dos Juizados Especiais, de realizar conciliações préprocessuais através de endereços eletrônicos específicos de empresas credenciadas http://www.tjrj.jus.br/web/guest/institucional/conciliacao-pre-processual/proj-pre-proc).

$\mathrm{O}$ acesso à justiça precisa englobar ambas as formas de processo, ou seja, demandas judiciais e demandas extrajudiciais, sendo necessário mais do que cortes especializadas e sim um novo enfoque do processo civil, até se levando à reflexão dos limites do princípio processual da inércia, na medida em que se admitem, como é o caso das conciliações pré-processuais dos Juizados Especiais Cíveis do Rio de Janeiro, a existência de atuação judicial antes da jurisdicional. O questionamento que se faz, portanto, é o de que até onde ferem ou não a atuação jurisdicional.

As causas que apresentem pequenos valores normalmente têm sido direcionadas para tribunais menos formais em diversos países. No Brasil, a Lei 9.099/99 criou os Juizados Especiais Cíveis e Criminais e dispensa a necessidade de advogado para a propositura de ações 
cíveis de menor complexidade, com valor menor ao correspondente a 20 salários mínimos. A rigor, o próprio interessado pode elaborar relato ao Juízo sobre a situação da qual pretende solução e o processo deve ser aberto.

Ocorre porém, que mesmo os tribunais de causas de menor valor (pequenas causas), têm enfrentado críticas em razão da excessiva formalidade dos advogados e julgadores, que se recusam a abandonar o estilo formal e reservado, como por exemplo, a indicação de que as causas demandam perícia e não poderiam ser julgadas pelo Juizados Especiais Cíveis, quando na verdade se trata de complexidade de prova e não necessariamente perícia.

O desafio que se faz é criar foros atraentes para que as pessoas busquem essas soluções, não só do ponto de vista econômico, mas também do ponto de vista psicológico e físico, sentindo-se à vontade para utilizá-los, não se intimidando com a excessiva formalidade dos envolvidos ou com o linguajar técnico exacerbado.

Dentro da ideia de que a função jurisdicional abrange também a obrigação de assegurar que o acesso à justiça não seja meramente formal, mas consubstanciado na busca por decisões justas, há que se levar em consideração uma atuação mais ativa do juiz nos Juizados Especiais visando minimizar a diferença entre partes que possuam assistência de advogados e as que não possuem.

No Brasil, considerando que o fornecimento de água e saneamento básico são estruturados por empresas, públicas e privadas, é estabelecida entre as partes verdadeira relação de consumo, enquadrando-se também nas diretrizes legais do Código de Defesa do Consumidor, além de todo o arcabouço dos direitos humanos e das questões ambientais envolvidas.

Além disso, verifica-se ainda o grande número de revelias nos tribunais nacionais e acredita-se que tal se dá em razão do desconhecimento da população sobre a possibilidade de ter assistência jurídica ou mesmo ser aconselhado quanto ao direito a ser defendido, seja por ausência do profissional indicado, nesse caso o Defensor Público, seja por mero desconhecimento da necessidade de constituir ou aconselhar-se com advogado.

$\mathrm{Na}$ medida em que o conhecimento daquilo que está disponível constitui pré-requisito da solução do problema da necessidade jurídica não atendida, é preciso fazer muito mais para aumentar o grau de conhecimento público a respeito dos meios disponíveis e de como utilizálos. (ABEL-SMITH apud CAPPELLETTI, 1973, p.23)

O que se conclui de tais observações é que a educação em direitos, aliada a todos os instrumentos jurídicos disponíveis para se acessar o sistema de justiça, deve ser considerada também como caminho para a efetivação do acesso à justiça. Muito mais do que possibilitar o 
acesso irrestrito ao judiciário e a toda a máquina estatal de solução de conflitos, propicia que as próprias partes resolvam diretamente seus problemas jurídicos, como exercício de cidadania.

\section{A Defensoria Pública com forma de ampliação do acesso à justiça no Brasil}

O modelo adotado pelo legislador brasileiro quanto a assegurar que todos tenham acesso à justiça foi o de criar instituição própria, autônoma, independente, permanente e essencial à função jurisdicional do Estado, que cumpra o papel de orientação jurídica, promoção dos direitos humanos e defesa em todos os graus de jurisdição, judicial e extrajudicial e nas modalidades individuais e coletiva para aqueles que não disponham de capacidade financeira, conforme estatui o artigo 134 da Constituição da República.

Ainda sob o ponto de vista legal, a Defensoria Pública se organiza em Defensoria Pública da União, Distrito Federal e Territórios e Defensorias Públicas Estaduais, atendendo as normas gerais prescritas na Lei Complementar 80/94 em especial com as inovações trazidas a ela pela Lei Complementar 132/99, e ainda as leis estaduais que disciplinam as atribuições em cada unidade própria da federação.

O que se observa no contexto da Lei Complementar 80/94 com as mudanças introduzidas pela Lei Complementar 132 é, a grosso modo, a ampliação da atuação da Defensoria Pública na defesa e orientação de direitos, haja vista que o artigo $4^{\mathrm{o}}$ daquela lei detalha todas as funções institucionais, o que, se levado à risca e considerando a estruturação necessária para atuação, poderá representar de fato um enorme avanço no sentido de traduzir o verdadeiro sentido do acesso à justiça.

A importância do advento da lei complementar se verifica na consolidação da institucionalização da Defensoria Pública como o compromisso do Estado Brasileiro em assegurar a efetivação do acesso à justiça em todas as suas vertentes.

Para tanto, assegurou a autonomia e a independência da instituição e de seus membros, quando elencou garantias no exercício de suas funções. Dentre tais funções, é imprescindível citar alguns dos incisos do artigo $4^{\circ}$ da Lei Complementar 80, tais como: prestar orientação jurídica e exercer a defesa dos necessitados, em todos os graus, promover prioritariamente solução extrajudicial dos litígios, promover a difusão e a conscientização dos direitos humanos, da cidadania e do ordenamento jurídico, promover ação civil pública e todas as espécies de ações na tutela de direitos coletivos ou individuais homogêneos quando o resultado da demanda puder beneficiar um grupo de pessoas hipossuficientes e promover a mais ampla defesa dos 
direitos fundamentais dos necessitados, abrangendo seus direitos individuais, coletivos, sociais, econômicos, culturais e ambientais.

A ênfase dada pelo legislador para que a Defensoria Pública possa atuar também na fase extrajudicial objetiva a mudança da cultura de judicialização das demandas, o que possibilita que as partes cheguem por si a consenso, tornando-se protagonistas das soluções. Tais medidas representam um avanço na busca pela pacificação e harmonização social. Nesse sentido, aponta Cleber Alves (2006):

Essa missão institucional deve ser destacada, na medida em que a Defensoria não pode se omitir no desempenho do importante papel de contribuir de modo decisivo para a mudança da mentalidade, digamos, "judicialista" ainda marcante no âmbito das profissões jurídicas. A atuação preventiva e a busca de meios alternativos de solução de conflitos deve ser a tônica da atuação da Defensoria Pública. (p.318)

Dentre a maior parte dos modelos que buscam cercar todas as hipóteses de acesso à justiça, a existência de instituição autônoma, com profissionais qualificados, com estrutura adequada e com o conhecimento da população sobre sua atuação e funções tornará, quando implementada em todo o país, efetiva a garantia constitucional do acesso à justiça.

É de se notar que, em um mundo ideal, as próprias partes deveriam ter a capacidade de solucionarem seus conflitos autonomamente. Todavia, dada a realidade brasileira onde se desconhece sequer quais sejam os direitos fundamentais do indivíduo, imprescindível que haja instituição que viabilize o acesso e a orientação jurídica como um todo, especialmente para aqueles que não possuem condições de arcar com o aconselhamento de advogados privados.

Como forma de cercar todas as hipóteses em que o acesso à justiça deva ser respeitado e em consonância ainda com os princípios constitucionais da ampla defesa e do contraditório, é possível que a atuação do defensor se dê independentemente da situação econômica do eventual beneficiário, como acontece em questões que envolvem direitos indisponíveis (citando-se, por exemplo, a liberdade na esfera criminal).

É de curial importância destacar ainda que, apesar de órgão independente dentro do aparelhamento estatal, a Defensoria pode, por expressa disposição legal, acionar também os órgãos estatais de qualquer dos poderes em nome de seus assistidos, bastando que sejam preenchidos os critérios de atribuições funcionais.

Vale notar que, muito embora a Defensoria Pública seja a instituição estatal com atribuição constitucional de promover o acesso à justiça, não podem ser descartadas outras soluções, uma vez que isso representaria obstáculo ao exercício da garantia. É extremamente relevante que a sociedade civil se mobilize para o exercício da garantia do acesso à justiça, vez 
que este não deve ser objeto de monopólio pelo Estado, seja através da solução de conflitos exclusivamente pela via judicial, seja pela falta de diálogo e comprometimento do poder público ou de empresas fornecedoras, ou mesmo até entre os próprios cidadãos.

\section{Direito Humano à água e ao saneamento}

O reconhecimento do direito humano à água potável e ao saneamento básico como direito fundamental teve seu advento após a Resolução da Assembleia Geral das Nações Unidas de 2010, muito embora tenha sido objeto de amplas discussões anteriores e até mesmo de Conferências próprias sobre o tema, culminando com o enquadramento formal na categoria de direitos do homem. No direito pátrio, são reconhecidos dentro do direito interno como norma constitucional, na medida em que os tratados internacionais levados ao Congresso Nacional ingressam em nosso ordenamento jurídico através dos ritos de emenda constitucional, incorporando-se com esta natureza.

O acesso à água e ao saneamento, como direitos fundamentais que são, podem e devem ser suscetíveis de demandas judiciais a fim de serem garantidos nas hipóteses em que não haja fornecimento regular. Para tanto, necessário inicialmente que esse direito seja reconhecido como inerente às pessoas. Ultrapassado esse reconhecimento, necessário verificar se é assegurado no ordenamento jurídico e a partir daí quais as maneiras de se manejar o aparelho judiciário para que a percepção de água potável e saneamento seja efetivada.

O fornecimento de água potável regular, assim como a existência de rede de coleta e tratamento de esgoto domiciliar, constituem dados essenciais ao conceito de desenvolvimento de uma sociedade. Contemporaneamente, não somente os aspectos econômicos são considerados para a aferição do nível de desenvolvimento humano. Fatores como acesso a educação, saúde, liberdades individuais, exercício dos direitos políticos e condições dignas de higiene e habitação são hoje preponderantes para o desenvolvimento. Tal conclusão se dá através da perspectiva de essencialidade de liberdades substantivas aos indivíduos como fatores primordiais ao desenvolvimento de uma sociedade e não somente a ultrapassada concepção baseada apenas em aspectos econômicos e financeiros.

Quando direitos básicos como o direito ao acesso à água e ao saneamento são suprimidos, os indivíduos passam a ter suas liberdades individuais e de autodeterminação também cerceadas, uma vez que o exercício dos diversos direitos fundamentais está interligado. Desta forma, toda a sociedade é atingida e consequentemente prejudicada, uma vez que as 
ausências de direitos podem impedir os indivíduos de fazerem suas próprias escolhas (SEN, 1999).

Em comunidades extremamente pobres, como é o caso do município de Duque de Caxias, observa-se que a falta de planejamento urbanístico e a dificuldade de implementação de políticas públicas seriam as causas do quase inexistente saneamento básico e água potável em determinadas localidades.

Por outro lado, a educação em direitos pode levar os indivíduos a, não só buscarem assegurar esses direitos diretamente junto ao poder público, como exigir que sejam criadas políticas públicas no sentido de estimular empresas a realizarem o fornecimento de água potável e saneamento básico. No mesmo sentido, caso não sejam suficientes os esforços das comunidades em buscarem a efetivação desses direitos, devem ter conhecimento de instrumentos através dos quais possam salvaguardar-se no Poder Judiciário e obter guarida à sua pretensão.

No Brasil, a questão da exploração da água potável e do saneamento é competência exclusiva da União Federal, conforme estatuído na Constituição, em seu artigo 23, inciso VI. Contudo, considerando que os municípios possuem competência legislativa para assuntos de interesse local (artigo 22, inciso IV), deve este aplicar a legislação federal sobre águas e saneamento dentro de seu território e ainda pode estabelecer medidas para sua utilização e proteção. Diante de tal perspectiva, conclui-se que o fornecimento de água e a coleta de esgoto são serviços públicos através dos quais o Estado pode promover a satisfação dos interesses e das necessidades coletivas, obedecendo a diretriz imposta pelo artigo $3^{\circ}$, IV da Constituição, quando elenca os objetivos da República.

Por se tratar de bem essencial à vida humana e ao desenvolvimento saudável, a água, muito embora necessária a legitimação de quem vá legislar e fiscalizar seu bom uso, não pode ser objeto de apropriação ou mesmo de exploração discriminatória.

O uso da água não pode ser apropriado por uma só pessoa física ou jurídica, com exclusão absoluta dos outros usuários em potencial; o uso da água não pode significar a poluição ou a agressão a esse bem; o uso da água não pode esgotar o próprio bem utilizado e a concessão ou a autorização (ou qualquer tipo de outorga) do uso da água deve ser motivado ou fundamentado pelo gestor público. (MACHADO, 1999, p.352)

Há que se notar que a distribuição e o fornecimento de água têm íntima ligação com o controle que se pretenda da saúde coletiva e da própria vida. Nesse escopo, em sendo serviço público, pode ser prestado de forma direta através dos órgãos da administração pública ou de forma indireta, através de concessão e permissões ou mesmo através de pessoas jurídicas 
especialmente criadas para determinado objetivo, conforme o disposto no art. 175 da Constituição da República.

O Estado do Rio de Janeiro em particular possui uma autarquia estadual, a Companhia Estadual de Águas e Esgoto (CEDAE), criada a partir da unificação de empresas existentes no antigo Estado da Guanabara com o Estado do Rio de Janeiro, sendo elas a Companhia Estadual de Águas da Guanabara (CEDAG), Empresa de Saneamento da Guanabara (ESAG) e a Companhia de Saneamento Estadual do Rio de Janeiro (SANERJ), com o advento Decreto-Lei estadual n ${ }^{0} 39$ de 04/03/1975. Dentre suas diretrizes, estava a de criação de orientações quanto ao exercício dessa temática para toda a região metropolitana do Rio de Janeiro. A Cedae está presente em 63 municípios fluminenses, inclusive a capital, segundo fontes do Sistema Nacional de Informação de Saneamento - SNIS.

Através de consórcio firmado com o município de Duque de Caxias, a Cedae promove o serviço de exploração, captação e distribuição de água e esgoto na localidade, bem como o serviço público de recolhimento e tratamento do esgoto sanitário.

Ante a breve conceituação e da dinâmica da legislação envolvendo a essencialidade do bem, qual seja a água potável e o saneamento básico, bem como das maneiras através das quais o Estado efetiva a entrega desse bem, necessário analisar se a população tem esse fornecimento, busca as politicas públicas municipais nesse sentido, conhece e se utiliza de instrumentos extrajudiciais para sua obtenção ou propõe ações judiciais, individuais ou coletivas.

\section{Propositura de processos e soluções extrajudiciais em Duque de Caxias durante o ano de} 2017

A fim de avaliar o acesso à justiça neste estudo de caso, foram coletados dois tipos de dados: a atuação extrajudicial das partes para solução de problemas relacionados ao fornecimento de água e esgoto no município, onde foram analisados os dados dos atendimentos realizados pela Defensoria Pública daquela comarca durante o ano de 2017, considerando-se o acesso à justiça dentro da perspectiva de modos alternativos de solução de conflitos; a propositura de ações judiciais individuais e coletivas relacionadas ao fornecimento de água e esgoto.

Para tanto, a busca foi orientada nos arquivos do Núcleo de Primeiro Atendimento em matéria de consumidor da Defensoria Pública de Duque de Caxias, bem como dados coletados do sítio do Tribunal de Justiça do Rio de Janeiro quanto às ações individuais distribuídas 
naquela Comarca e dados de ações coletivas em trâmite, obtidos junto ao Ministério Público da região.

Inicialmente, no que se refere a atuação extrajudicial, cumpre esclarecer que em geral os indivíduos não procuram o Núcleo de Primeiro Atendimento da Defensoria Pública relatando problemas quanto à ausência de fornecimento do serviço de água e esgoto. Na maioria das vezes, os indivíduos são instados a procurar orientação jurídica após receberem contas de fornecimento de consumo indicativas de valores a pagar, muito embora não haja o regular fornecimento.

Observou-se que em locais onde não existe absolutamente nenhum fornecimento regular, como é o caso de parte do bairro de Jardim Gramacho que tem população extremamente carente e com parcas informações, não busca auxílio nos órgãos do sistema de justiça ou do Poder Executivo municipal, como a Defensoria Pública, Câmara de Vereadores, o Ministério Público ou Associações Civis que possam pleitear administrativamente o acesso à água e saneamento (e por via de consequência, assegurar o acesso à justiça).

O contexto onde essas pessoas residem, chamado de favela, já possui inserido dentro de si a ideia de que os direitos básicos não podem ser pleiteados porque não há regularização fundiária ou urbanística. Sendo assim, usam de toda a sorte de manobras para conseguir água potável, especialmente através do carregamento de galões de localidades próximas, às vezes sem as mínimas condições de higiene e regularidade. Quanto ao esgoto, o despejo se faz desordenadamente, através de valas a céu aberto ou sumidouros subterrâneos, prática ambientalmente rechaçada por contaminar o solo.

Nesse sentido, a noção de direitos básicos muitas vezes gira apenas em torno do acesso a escolas e hospitais, desconhecendo até que podem ter o fornecimento gratuito de documentação, por exemplo.

Os números de atendimentos extrajudiciais onde se pleiteava o fornecimento regular de água e esgoto é ínfimo, se comparado a quantidade da população de Duque de Caxias, que hoje é o segundo maior município do Estado do Rio de Janeiro, contendo cerca de 890.997 de habitantes em 2017, conforme população estimada pelo Instituto Brasileiro de Geografia e Estatística (IBGE). Foram atendidos no ano de 2017 extrajudicialmente pela Defensoria Pública, através de intervenções junto à companhia fornecedora (CEDAE) apenas 7 indivíduos que pleiteavam o fornecimento de água ou esgoto. Desse universo, 100\% deles foram em busca de soluções após terem recebido contas com débitos relativos a fornecimento inexistente.

Por um outro lado, o sítio do Tribunal de Justiça do Estado do Rio de Janeiro, quando em pesquisa pelo nome da CEDAE, que é a única responsável pelo fornecimento de água e 
esgoto na região, indica a existência de apenas 126 processos distribuídos em 2017 relativos ao fornecimento de água e esgoto ou a falhas na prestação desses serviços.

O IBGE ainda indica em seus dados que $85,3 \%$ de suas residências possui esgoto. Sendo assim, considerando a população estimada acima indicada e o percentual apresentado pelo IBGE, conclui-se que 760.020,441 casas dispõem de esgoto residencial.

Onde estariam os demais 130.976 habitantes do município que não dispõem de esgoto residencial? Esse número seria correspondente a verdadeira população de uma cidade pequena inteira e são pessoas que oficialmente não dispõem de acesso à agua e saneamento e possivelmente desconhecem que podem pleitear tal serviço através do sistema de justiça.

O Ministério Público do Rio de Janeiro ingressou com duas ações civis públicas (números 2201585-21.2011.8.19.0021 e 0001465-06.2005.8.19.0021) no município pleiteando fornecimento de água para determinados bairros, porém não todos, ambas distribuídas antes de 2017 e ainda sem decisão final. Ambas objetivam que a Cedae realize investimentos no sistema de abastecimento sanitário em Duque de Caxias. Tais ações foram originadas em razão de reclamações de moradores junto a vereadores de regiões que não dispõe de serviço regular de fornecimento de água e esgoto e de localidades que, muito embora tenham o serviço, estes são de péssima qualidade.

Após a realização de audiência pública em fevereiro de 2002 no Plenário da Câmara dos Vereadores de Duque de Caxias, onde vários moradores deram depoimentos quanto à inexistência de fornecimento regular de água e esgoto relatando que alguns deles faziam uso de poços artesianos ou semi-artesianos e captavam água de chuva em recipientes inadequados como piscinas de plástico, houve representação ao Ministério Público solicitando soluções ao problema.

Além dessas práticas, os moradores relataram ainda a existência do que eles chamaram de "máfia do carro-pipa", através da qual pessoas captam e vendem água para moradores dos bairros atingidos por preços estabelecidos entre os vendedores.

O fundamento das ações civis públicas é no sentido de que há deficiências estruturais e operacionais no serviço de fornecimento de água potável e saneamento básico, que não obedecem critérios de segurança e regularidade. Esses fatores impactam sobremaneira na qualidade de vida e, como medida última, nas próprias liberdades e autodeterminação das pessoas, contribuindo para que se mantenham em situação de sub-desenvolvimento. Não havendo o fornecimento regular de água e esgoto e desconhecendo os indivíduos que podem pleitear esse serviço público, percebe-se que o acesso à justiça em todo o seu sentido mais amplo e diante desse aspecto não vem sendo efetivado. 


\section{Considerações Finais}

O acesso à justiça não se limita apenas à garantia positivada no ordenamento de que todos possam buscar o Poder Judiciário para pleitear os direitos que possuem através da propositura de ações judiciais. A amplitude de seu alcance atualmente já é entendida como a atuação extrajudicial e a própria educação em direitos, uma vez que visa dar maior concretude ao próprio conceito de justiça, na busca por cidadania.

Por outro lado, os direitos relativos ao desenvolvimento, como é o caso do direito à água e ao saneamento, são relativamente recentes e ainda precisam ser inseridos no arcabouço de direitos aos quais os indivíduos conhecem como potestativos, ou seja, direitos dos quais as pessoas sabem que podem cobrar das autoridades. Do mesmo modo. Como direito fundamental que é, pode e deve ser suscetível a demandas judiciais a fim de ser garantido, nas hipóteses em que não há fornecimento regular.

Para tanto, necessário inicialmente que esse direito seja reconhecido como inerente às pessoas. Ultrapassado esse reconhecimento, necessário verificar se é assegurado no ordenamento jurídico e a partir daí, quais as maneiras de se manejar o aparelho judiciário para que o direito à percepção de água potável e saneamento seja efetivado.

No estudo em exame se verificou que os indivíduos somente buscaram a Defensoria Pública para propor ações judiciais quanto à água e ao saneamento após receberem contas de consumo, nas quais eram cobrados sem ter a prestação do serviço. Também desconheciam e existência das ações civis públicas em curso e, se as conheciam, não acreditavam que pudessem ter os problemas solucionados. Muito menos tinham ciência de possibilidades de solução extrajudicial de conflitos.

O que se conclui com a observância dos conceitos relativos a acesso à justiça, dos métodos pelos quais pode-se obter a garantia do acesso à justiça, da atuação do sistema de justiça consistente na Defensoria Pública, no Ministério Público, no Tribunal de Justiça e nos advogados e partes, é que estamos longe de assegurar amplo e efetivo acesso a esta garantia constitucional.

Acredita-se que o desconhecimento da população sobre a própria existência do direito à água potável e ao saneamento básico, demonstrada através do enorme abismo entre o número de pessoas habitantes da comarca e a quantidade de ações propostas, é o principal fator que desestimula a procura por métodos que assegurem esses direitos. Além disso, a crença de que de nada adiantará buscar a justiça, construída pela morosidade dos processos, pela excessiva burocracia quanto aos documentos que formaram o processo e o imediatismo de obter água e 
saneamento, podem contribuir para que a busca por instrumentos concretizadores desse direito seja ainda incipiente.

\section{Referências bibliográficas}

ALVES, Cleber Francisco; Justiça para Todos! Assistência Jurídica Gratuita nos Estados Unidos, na França e no Brasil. Rio de Janeiro: Editora Lumen Juris, 2006.

GONZÁLEZ, Pedro. Defensoria Pública no século XXI. Rio de Janeiro: Lumen Iuris, 2017.

BRASIL. Constituição (1988). Constituição da República Federativa do Brasil. Brasília, DF, out 1988. Disponível em http://www.planalto.gov.br/ccivil_03/constituicao/ constituicao.htm

BRASIL. Instituto Brasileiro de Geografia e Estatística. 2017.

Cidades.ibge.gov.br/brasil/rj/duque-de-caxias/panorama

BRASIL. Lei Complementar 80 de 12 de jan. de 1994. Organiza a Defensoria Pública da União, do Distrito Federal e dos Territórios e prescreve normas gerais para a organização nos Estados. Brasília, DF, jan. 1994. Disponível em http://www.planalto.gov.br/ccivil_03/ leis/lcp/lcp80.htm

BRASIL. Lei Complementar 132 de 07 de out. de 2009. Altera Dispositivos da lei Complementar $n^{\circ}$ 80, de 12 de janeiro e 1994, que organiza a Defensoria da União, do Distrito Federal e dos Territórios e prescreve normas gerais para a organização nos Estados, e da Lei $\mathrm{n}^{\mathrm{o}} 1.060$, de 05 de fevereiro de 1950. Brasília, DF, out. 2009. Disponível em http://www.planalto.gov.br/ccivil_03/leis/lcp/Lcp132.htm

BRASIL. Lei 8078 de 11 de set. de 1990. Código de Defesa do Consumidor, Brasília, DF, 1990. Disponível em http://www.planalto.gov.br/ccivil_03/Leis/L8078.htm

BRASIL. Lei 9099 de 26 de set. de 1995. Dispõe sobre os Juizados Especiais Cíveis e Criminais. Brasília, DF, set. de 1995. Disponível em http://www.planalto.gov.br/ccivil_03/ leis/19099.htm 
BRASIL. Lei 10.406 de 10 de jan. de 2002. Código Civil, Brasilia, DF, jan. 2002. Disponível em http://www.planalto.gov.br/CCivil_03/Leis/2002/L10406.htm

BRASIL. Lei 11.445 de 05 de jan. de 2007. Estabelece diretrizes nacionais para o saneamento básico. Brasília, DF, jan 2007. Disponível em http://www.planalto.gov.br/ccivil_03/_ato20072010/2007/lei/111445.htm

BRASIL. Lei 13.105 de 16 de mar. de 2015. Código de Processo Civil, Brasília, DF, mar. 2015. Disponível em http://www.planalto.gov.br/ccivil_03/_ato20152018/2015/ lei/113105.htm

BRASIL. Sistema Nacional de Informação de Saneamento - SNIS http://www.snis.gov.br/diagnóstico_agua_e_esgotos/diagnostico_ae_2016

CAPELlETTI, Mauro; GARTH, Bryant; Tradução de Ellen Gracie Northfleet. Acesso à Justiça. Porto Alegre: Sérgio Antonio Fabris Editor, 1988.

FERRAZ JR., Tércio Sampaio. Estudos de Filosofia do Direito - Reflexões sobre o poder, a liberdade, a justiça e o direito. São Paulo: Editora Atlas, 2002.

GARAPON, Antoine; PAPADOPOULOS, Ioannis. Juger en Amerique et en France. Paris: Odile Jacob, 2003, p.8.

MACHADO, Paulo Affonso Leme. Direito Ambiental Brasileiro. São Paulo: Malheiros Editores, 1999, p. 352.

RIO DE JANEIRO (Estado). Decreto-Lei n. 39, de 24 de mar. de 1975. Dispõe sobre entidades da Administração Indireta e Fundação, no âmbito da Secretaria de Obras e Serviços Públicos. Rio de Janeiro, RJ, mar. 1975.

RIO DE JANEIRO (Estado). Tribunal de Justiça do Estado do Rio de Janeiro. Consulta Processual por nome: Cedae. 2017. Rio de Janeiro, RJ, 2017. Disponível em www4.tjrj.jus.br/consultaProcessoNome/consultaNome 
RIO DE JANEIRO (Estado). Tribunal de Justiça do Estado do Rio de Janeiro. (4 ${ }^{\text {a }}$ Vara Cível de Duque de Caxias) Processo $n^{\circ}$ 0001465-06.2005.8.19.0021. Autor: Ministério Público do Estado do Rio de Janeiro. Réu: Companhia Estadual de Águas e Esgoto do Rio de Janeiro Rio de Janeiro. Disponível em: http://www4.tjrj.jus.br/consultaProcessoWebV2/consultaProc. $\mathrm{do} ? \mathrm{v}=2 \&$ FLAGNOME $=\& \mathrm{back}=1 \&$ tipoConsulta $=$ publica\&numProcesso $=2011.021 .033013-7$

RIO DE JANEIRO (Estado). Tribunal de Justiça do Estado do Rio de Janeiro. (4 ${ }^{a}$ Vara Cível de Duque de Caxias) Processo $n^{\circ}$ 2201585-21.2011.8.19.0021. Autor: Ministério Público do Estado do Rio de Janeiro. Réu: Companhia Estadual de Águas e Esgoto do Rio de Janeiro. Disponível em: http://www4.tjrj.jus.br/consultaProcessoWebV2/consultaProc.do?v= 2\&FLAGNOME=\&back=1\&tipoConsulta=publica\&numProcesso=2011.021.033013-7 .

SEN, Amartya; Tradução de Laura Teixeira Motta. Desenvolvimento como liberdade. São Paulo: Companhia das Letras, 1999. 


\title{
SISTEMA PROCESSUAL E ACESSO À JUSTIÇA. A EFETIVIDADE JURISDICIONAL NA PERSPECTIVA SISTÊMICA FUNCIONAL- INSTRUMENTALISTA E JURISPRUDENCIALISTA.
}

\author{
Sílzia Alves Carvalho \\ PPGDP/FD/Universidade Federal de Goiás
}

\section{Resumo}

Este pesquisa apresenta uma abordagem sistêmica sobre o acesso à justiça a partir da crítica ao racionalismo abstrato e formalista. Considerando a hermenêutica processual no Brasil, que tem se desenvolvido a partir do funcional-instrumentalismo, sobretudo após o movimento reformista do direito processual, esta metodologia foi tratada com vista a demonstrar os riscos que apresenta quanto aos seus limites para a efetividade do acesso material à justiça. $\mathrm{O}$ pensamento jurisprudencialista foi apresentado como uma possível alternativa que possa assegurar o acesso material à justiça, em um sentido humano-comunitário e praticamente realizada.

Palavras-chave: Acesso à justiça, sistema, processo, funcional-instrumentalismo, jurisprudencialismo.

\begin{abstract}
Resumen/Résumé
This research presents a systemic approach on access to justice from criticism to abstract and formalistic rationalism. Considering the procedural hermeneutics in Brazil, which has developed from the functional-instrumentalism, especially after the reformist movement of procedural law, this methodology was treated in order to demonstrate the risks that it presents as to its limits for the effectiveness of the material access to the justice. The jurisprudentialist thought was presented as a possible alternative that could guarantee the material access to justice, in a human-community sense and practically realized.
\end{abstract}

Keywords/Palabras-claves/Mots-clés: Access to justice, system, process, functionalinstrumentalism, jurisprudencialismo. 


\section{Introdução}

O pensamento jurídico na modernidade pode ser caracterizado pela atitude racionalista dos seus operadores, compreendendo-se isso como a prevalência das elaborações teóricas e filosóficas que buscaram uma concepção do direito formalmente neutra e materialmente abstrata. Assim, o direito tem estado ligado ao Estado, à política e ao social; o modo como estas relações se constituem e se desenvolvem tem sido demonstrado de diferentes formas.

A respeito da complexidade atual do direito, se admite sua vinculação às ideias que reconhecem o caráter sistêmico do direito, em oposição à sua cientificidade, em processo de superação a partir do início do Século XX. Trata-se, portanto, de uma proposta de discussão a respeito do direito como sistema aberto, mas que deve preservar sua autonomia.

O problema a ser abordado tem como objetivo principal o estudo a respeito do acesso à justiça, sob o ponto de vista formal e material; tendo como referência o reconhecimento da autonomia do direito como um sistema. O método de abordagem será dedutivo, e o método de procedimento será a revisão-bibliográfica. A pesquisa trata a hermenêutica jurídico-processual a partir do funcional-instrumentalismo sociológico e do jurisprudencialismo proposto por Castanheira Neves.

No desenvolvimento do trabalho não será objeto de estudos o pensamento do direito cujas vertentes sejam jusnaturalistas, se justificando esta postura em decorrência do risco de se elaborar uma narrativa horizontal e que se apresente insignificante quanto às possibilidades de contribuição para o debate jurídico atual.

Acredita-se que as discussões sobre o direito como sistema sejam oportunas, sendo o funcional-instrumentalismo metodológico significativo diante das tendências teóricas e hermenêuticas de se realizar a interpretação do sistema processual no Brasil atualmente com base nesse referencial. Parece, contudo, adequado ampliar esses debates, considerando a relevância de se pensar a efetividade jurisdicional sob o ponto de vista do acesso material à Justiça, e neste sentido, se propõem a abordagem sistêmica-jurisprudencialista, tendo como foco a autonomia do direito e a compreensão sobre a Justiça.

\section{Contextualização do racionalismo}


A Modernidade pode ser caracterizada pela mudança quanto aos modos de compreensão do mundo pelo Homem ${ }^{1}$, sendo que isto decorreu de um processo histórico, cultural e econômico complexo e lento. A Revolução Copernicana é significativa neste processo por representar uma ruptura inicial, com as discussões sobre a separação entre os conhecimentos da natureza e os conhecimentos inerentes ao Homem e a respeito da sua condição. Pode ser afirmado que este fato foi muito importante para a secularização, e, portanto, para o surgimento do Estado Moderno e, posteriormente para o Estado de Direito.

The most obvious examples of scientific revolutions are those famous episodes in scientific development that have often been labeled revolutions before. Therefore, in Sections IX and $X$, where the nature of scientific revolutions is first directly scrutinized, we shall deal repeatedly with the major turning points in scientific development associated with the names of Copernicus, Newton, Lavoisier, and Einstein. (KUHN, 1970, p. 6)

Conquanto o direito seja parte da história da humanidade, o pensamento jurídico como é conhecido na atualidade está diretamente relacionado com os ideais da Modernidade, no sentido que o direito tem sido pensado sob a perspectiva das relações que mantém com o Estado, assim, se invoca o resguardo ao Estado de Direito, como o estado democrático, como o estado social; ou seja, o direito estruturalmente mantém relações de poder com o Estado. O que se alterou profundamente foi a compreensão do direito como um sistema fechado, cuja fonte principal era a Lei, e cujo intérprete originário era o Estado-Juiz; entende-se que as concepções teóricas vinculadas ao pensamento positivista-legalista esteja superada.

As concepções normativistas pós-positivistas, nas suas diferentes matizes, contudo, mantém-se ligadas ao racionalismo jurídico com forte vieses e aproximações com a intersecção entre o direito e o Estado. Assim, o racionalismo normativista, caracteristicamente formal, abstrato e conceitualmente vinculado às ideias científicas do direito se expressão por meio de diferentes correntes teóricas.

A autonomia do direito intencionada pelo normativismo era, pois, a autonomia de uma normatividade constituída e sustentada no sistema autorreferente da sua abstrata racionalidade dogmática. Reconheça-se ter sido ela o resultado de um poderoso e empenhado esforço intelectual alimentado desde a normatividade pelo objetivo cultural e epistemológico último de reconduzir a juridicidade à razão teórica (sistemático-construtivista-dedutiva). [...] É que, se uma tal autonomia se construía segundo uma normatividade que dogmaticamente acabava por se fechar sobre si própria num sistema formal, o "direito formal" segundo M. Weber, por isso mesmo se alienava de uma realidade social que evoluía e assim se furtava não só aos compromissos políticos, sociais, económicos, etc. mas sobretudo aos problemas que essa nova realidade lhe exigia - nem o expediente das "cláusulas gerais" e o

\footnotetext{
${ }^{1}$ Homem será escrito com letra maiúscula no início para indicar a espécie humana, portanto, não há conotação sexista na utilização do palavra.
} 
reconhecimento das "lacunas" a integrar seriam formas suficientes de superação. (CASTANHEIRA NEVES, 2012, p. 29)

O pensamento racionalista do direito justifica seu caráter abstrato na busca por uma concepção moderno-iluminista, em que através do Estado se constituísse um tipo de direito específico, que assegurasse a realização da liberdade, da igualdade e da fraternidade com segurança e efetividade. Assim, o Estado atua entre o Século XIX e o Século XX, fundamentalmente a partir de direito como prescrição legal sancionatória, como instrumento de programação social e em uma perspectiva pós-instrumental, que de acordo com Neves (2012, p. 28) “[...] como a horizontalidade de um direito [...] de imediata e espontânea expressão social, resultante de contínuas acções concertadas, de transacções e precários acordos segundo o lema each with each ou provindo de uma espécie de forum de abertas negociação social [...]”. Desse modo, observa-se que o racionalismo no direito se constituiu e se desenvolveu como um sistema de elaborações abstratas, que em última análise asseguram ao direito certo grau de neutralidade axiológico-normativa, no sentido de que sua aplicação e seus resultados apresentem-se indistintos em relação ao indivíduo.

Sob o ponto de vista dessa abordagem do direito, o problema se desloca dos contrapontos que se possa identificar entre o racionalismo do direito e suas concepções metafísicas, para os problemas relacionados com a possibilidade de reconhecimento de autonomia do direito na perspectiva do funcional-instrumentalismo, que pode ser considerada uma teoria racionalista do direito em seu viés pós-positivista.

\section{O funcional-instrumentalismo}

Superado o legalismo jurídico, os ideais iluministas se mantiveram no Século XX, sendo que o pensamento a respeito do direito passou por modificações teóricas profundas, que discutiram aspectos como a possibilidade de que este assumisse funções programáticas do ambiente social. O contexto histórico desse período é marcado pela oposição entre as concepções neoliberais da economia e as concepções sociológicas a respeito da sociedade. Assim, ocorreu um movimento de polarização entre o indivíduo e o coletivo; entre a sociedade civil e o Estado, e entre o Estado liberal e o, Estado providência. O funcionalismo é um movimento que procura reconhecer as funções dos sistemas e subsistemas que formam essa 
complexa estrutura. Por sua vez, o instrumentalismo apresenta um caráter procedimentalizante ${ }^{2}$ pelo qual, adotados os meios adequados, seja possível realizar as funções de cada sistema. Este esquema se apresenta como uma possibilidade para a solução a complexidade sistêmica que se formou com a polarização.

O direito regulatório que na Modernidade tem funções políticas de controle dos indivíduos, sobretudo diante dos seus agrupamentos, formados pelos excluídos das esferas de poder após a Revolução Francesa, e que durante o Século XIX se reconhecem entre si na sua condição de proletários. Sob o ponto de vista funcionalista, o direito passa a ser predominante programático do ambiente social, no início do Século XX. Não se trata de regular as condutas individuais, mas de planejar a organização do ambiente social, neste contexto o direito valida e legitima o, Estado providência. Assim ocorre a parcial intervenção do Estado na liberdade individual, bem representada até então, pela cláusula pacta sunt servanda. Assim o, Estado providência, criou um sistema de normas caracterizadas como sendo de ordem pública, e tendo uma incidência social e econômica, são desenvolvidas, neste contexto histórico as concepções a respeito das políticas públicas.

Quanto ao instrumentalismo, o pensamento sobre o direito como um sistema fechado, é substituído pelas ideias de sistemas abertos. Desenvolvem-se as teorias criticistas do racionalismo legalista, reconhecendo-se os aspectos contextuais que envolvem o direito, e as relações que se formam. Observe-se, entretanto, que a reação ocorre sem que se altere a perspectiva abstrata e formal das estruturas do direito, conquanto, tenha sido modificada em parte a função do direito, se admitindo a existência de contingências sistêmicas que interferem no sistema do direito, este se manteve vinculado às esferas de poder do Estado. As questões sistêmicas, na perspectiva funcional-estruturalista autopoiética tem em Luhmann seu principal expoente, tendo este abordado algumas questões relevantes da teoria, no seguinte texto;

\footnotetext{
There are two variants for operative couplings. One is called autopoiesis. It involves the production of operations of the system by the operations of the system. Teh other is based on a synchronicity of the system and the environment, which must be presumed at all times. It allows na instantanteous coupling of the operations of the system with operations that the system attribugutes to the environment, for instance, with the possibility of fulfilling a legal obligation y making a payment or symbolizing political disent or consensus by passing a law. However, operative couplings between the and teh environmente brought about by such identifications are possible onlu for the duration of the event. They do not last and the dependo $\mathrm{n}$ a certain ambiguity their identification. (LUHMANN, 2008, p. 381)
}

\footnotetext{
${ }^{2} \mathrm{O}$ termo procedimentalizante foi usado para ressaltar a natureza formal e estrutural do modo de atuação específico no instrumentalismo. Neste sentido, os resultados são definidos por meio do procedimento adotado. Assim, as questões relacionadas com a eficiência e a eficácia são objeto de destaque.
} 
A liberdade do indivíduo contra o Estado absolutista foi superada pela afirmação dos direitos individuais, mas a ideia de efetividade da igualdade entre os indivíduos somente se apresenta através do Estado social, ao criar um sistema de direito que reconhece a existência de fatores de exclusão social e econômica do Homem, e que programaticamente planeja através do direito a inclusão desses indivíduos. Este Estado intervencionista, apoiado no funcionalinstrumentalismo, parece ter encontrado o seu ocaso nos limites impostos pela economia baseada no princípio da escassez dos recursos. À respeito dos problemas referidos, observa-se:

O modelo de "justiça científica", que "é essencialmente funcional, teleológica, instrumental, evolutiva e pragmática", e segundo a qual "é tida como justa a solução mais adequada ao objetivo proposto pelo planificador social, sendo neste caso secundária a consideração de valores materiais ou de regras formais". Será este um "modelo post-liberal", que consagraria "o declínio da rule of law", onde "the judicialpower" (PH. Selzinik), aquele em que o juiz seria constitutivamente interventor, criador autônomo das soluções exigidas pelos fins e interesses sociais. (NEVES, 2013, p. 59)

O Século XX terminou com a crise no paradigma racionalista; o direito parece ter alcançado seus limites quanto aos ideais moderno-iluministas, contudo, não se observou a realização da fraternidade. Acredita-se que nesse processo de elaboração de abstrações racionais em que a complexidade da existência Humana foi reduzida às proposições científicas através do pluralismo metodológico, teve consequências que impedem a realização da fraternidade na medida em o Homem se tornou um objeto da ciência, um objeto do direito e do Estado. Por outro lado, somente o Homem portador de uma irredutível complexidade, como sujeito da história, da cultura e de uma subjetividade imperscrutável poderia realizar a fraternidade; este Homem, entretanto, foi excluído no processo de compreensão do mundo a partir dos pressupostos da ciência.

O paradigma da ciência baniu a filosofia e posteriormente baniu o Homem, na busca da compreensão racional, abstrata, formal, antimetafísica e linguística das coisas do mundo, desde aquelas conhecidas como naturais, até outras que se identificam pelo seu caráter social. É necessário um novo paradigma que renunciando ao reducionismo metodológico da ciência, ou ao pensamento sistêmico autoreferente do direito, bem ilustrado pelo funcionalismo instrumentalista, resgate a complexidade inerente à existência humana e própria à filosofia, para que seja possível a realização da fraternidade iluminista.

Diante das dificuldades que representa o abandono do paradigma do racionalismo, se desenvolveram as concepções que reconheceram o fim da Modernidade, ainda que esta não tenha se realizado plenamente. A pós-modernidade, pós-instrumental reconhece os problema da complexidade, mas não compreende a necessária reconstituição do pensamento filosófico a 
respeito do Homem, e sua multifacetada existência. Sob o ponto de vista do direito, se admite a necessidade de se estudar seus fundamentos axiológicos, humanos e sua específica autonomia, agora como sistema aberto, cuja normatividade ultrapasse os limites políticos e sociais do Estado, podendo ser encontrada em um sentido de realização efetiva do acesso material à justiça.

\section{Processo Instrumental}

O pensamento jurídico a respeito da instrumentalidade do processo se relaciona com o problema da abertura do direito ao ambiente e, portanto, da possibilidade de se estabelecerem trocas sistêmicas. No caso da instrumentalidade se reconhece as trocas do sistema jurídico com o sistema social e político. Assim, o direito se legitimaria por um tipo de Justiça com reflexos sociológicos, um direito justo a partir dos seus resultados sociais, nesta concepção o processo seria o instrumento de realização dessa justiça. Nessa perspectiva o processo sociológico e instrumental ultrapassaria as fronteiras do formalismo como um dos elementos da segurança jurídica; da prestação jurisdicional como exclusividade do Estado-Juiz; do sistema recursal e da conflituosidade como meio de acesso à justiça; e, do modelo adversarial e heterocompositivo como garantias da imparcialidade e devido processo legal ${ }^{3}$.

A compreensão do processo como instrumento pode significar um compromisso com a efetividade jurisdicional, como meio de realização da Justiça. Neste sentir, a Justiça depende da realização do direito na dimensão prática e social do jurisdicionado. As formalidades que integram o procedimento não tem uma finalidade em si mesma, devendo voltar-se para a economia processual e a razoável duração do processo ${ }^{4}$. Neste contexto se afirma as ideias ligadas à instrumentalidade das formas processuais e ao aproveitamento dos atos processuais que alcancem seus fins sem comprometer a ampla defesa e o contraditório ${ }^{5}$.

A afirmação dos valores da Modernidade quanto à "fraternidade, igualdade e liberdade" determinaram um modelo de prestação jurisdicional centralizado na heterocomposição estatal. Sob o ponto de vista da liberdade, a Modernidade se compromete com o pensamento econômico liberal, que no início do Século XX estava fundamentado em

\footnotetext{
${ }^{3}$ Artigo $5^{\circ}$, inciso LIV, CF/88 - ninguém será privado da liberdade ou de seus bens sem o devido processo legal. ${ }^{4}$ Artigo $5^{\circ}$, inciso LXXVIII, CF/88 - a todos, no âmbito judicial e administrativo, são assegurados a razoável duração do processo e os meios que garantam a celeridade de sua tramitação.

${ }^{5}$ Artigo $5^{\circ}$. LV, CF/88 - aos litigantes, em processo judicial ou administrativo, e aos acusados em geral são assegurados o contraditório e ampla defesa, com os meios e recursos a ela inerentes.
} 
três pilares: não intervenção estatal na economia (livre iniciativa), engenharia social e Poder Judiciário forte e independente ${ }^{6}$.

Os liberais clássicos desconsideraram os problemas criados pelo individualismo e pelo aumento da vulnerabilidade social de determinados grupos excluídos em consequência da atuação do Estado de forma absenteísta. O direito, na perspectiva liberal, tem sido utilizado para a constante afirmação dos valores romanísticos, ou seja, o patrimonialismo, o patriarcalismo e o individualismo. De fato, o direito se revelou como um legitimador dos Estados totalitários europeus e em outras partes do mundo, levando às profundas discussões que florescem nas Critical Legal Studies ${ }^{7}$.

Ainda quanto aos problemas que relacionam o direito ao Estado, a reação ao totalitarismo e ao liberalismo individualista, levou ao desenvolvimento das concepções instrumentais de caráter sociológico, que se adequaram às demandas do Estado pós-II Guerra, e legitimou o, Estado providência. São conhecidos os déficits nas prestações públicas devidas e insatisfeitas, que levaram às discussões a respeito da 'falência' do Estado social, sendo, no âmbito deste trabalho, relevantes os problemas relacionados ao acesso à justiça ${ }^{8}$. Compreendese que os jurisdicionados devem ter assegurados além do direito de petição com as garantias Constitucionais de processo, a possibilidade de obter um resultado baseado na concepção democrática de Estado.

O processo instrumental pode ser identificado como um fenômeno do Estado Democrático e Social de Direito. De um lado, sendo um sustentáculo do pensamento liberal, ora em suas conexões com a política e, portanto, com a democracia; ora, em suas conexões com a engenharia social, uma vez que a economia da escassez dos meios limita a atuação do Estado. Assim, a prestação jurisdicional estatal poderia ser contingenciada a determinados casos que envolvessem a segurança jurídica. Questões de ordem privatística, cujos interesses se restringissem aos sujeitos em conflito, poderiam ser resolvidas por métodos, outros, fora da jurisdição do Estado. O direito, assim poderia assegurar os meios formais para que determinados resultados fossem alcançados pelo Estado, como o acesso formal à justiça.

O atual Código de Processo Civil brasileiro ao constitucionalizar-se através da principiologia processual contida na Constituição Federal de 1988 mudou a perspectiva do

\footnotetext{
${ }^{6}$ Tomou-se como referência o pensamento de Hayek, em "O caminho da Servidão" que atualizou o pensamento econômico liberal clássico, discutindo os problemas entre liberalismo e totalitarismo. Deve ser observado que em 1944, ano da primeira edição dessa obra, a Europa vivia a experiência do nacionalismo totalitário e do comunismo stalinista na União Soviética.

${ }^{7}$ Critical Legal Studies, é indicativo neste contexto do movimento americano identificado por legal realism, e na Europa pelo movimento da Escola de Franckfurt.

${ }^{8}$ Artigo $5^{\circ}$, inciso XXXV, CF/88 - a lei não excluirá da apreciação do Poder Judiciário lesão ou ameaça a direito.
} 
Poder Judiciário brasileiro, intensificando as trocas ambientais com o sistema político. Disso decorre um problema, pois a exigida autonomia e preponderância do sistema judiciário poderá se converter em ativismo judicial baseado no desequilíbrio nas trocas sistêmicas com o ambiente político. O direito processual no Brasil corre o risco de se instrumentalizar de forma anômala, se tornando incapaz de realizar a prestação jurisdicional de forma a assegurar uma Justiça consentânea com o Estado Democrático e Social de Direito. Sobre a Constitucionalização do direito, deve-se observar o seguinte;

[...] a constituição não é senão o estatuto jurídico do político - formulação que vimos aceite e se repete em outras análogas: "ordenação constitucional do político", "forma jurídica do político" (Gomes Canotilho). O que nos permite duas inferências imediatas, que acabam por se traduzir numa alternativa. Ou se reconhece o que a própria objectividade manifesta, que o estatuto constitucional está longe, mesmo no seu nuclear projecto político-jurídico, de esgotar todo o universo jurídico [...]. Ou,, num radicalismo político, recusa-se esta conclusão para impor a exclusiva aceitação do jurídico intencionado e proclamado político-constitucionalmente, numa estrita identificação da juridicidade com a constitucionalidade [...]. (NEVES, 2012, p. 57)

A concepção funcional-instrumentalista do direito processual embasada na principiologia Constitucional poderá constituir um ambiente propício à criação de uma jurisprudência com interferências políticas, baseada em uma hermenêutica que possibilite uma resposta ao problema da decisão jurídica fundamentada de forma aberta, a partir dos efeitos da decisão ${ }^{9}$. A complexidade, portanto, decorrente dos riscos da abertura sistêmica do direito, a partir do viés funcional-instrumentalista é alto, uma vez que a adequação do meio poderá se considerar como um legitimador dos resultados.

\section{Efetividade jurisdicional}

A efetividade da prestação jurisdicional se relaciona com a eficiência procedimental e com a eficácia da sentença, considerando-se o referencial do funcional-instrumentalismo. Assim a justiça efetiva se relaciona com a adequação dos procedimentos e do tempo necessário para sua execução no sentido de que deve haver o maior aproveitamento dos atos processuais com o menor sacrifício possível de tempo. Por outro lado, exige-se também que o resultado seja alcançado, e neste aspecto há observações interessantes.

Até a concepção instrumental a respeito do processo se entendia que a sua finalidade seria a decisão final de mérito a respeito do objeto dos pedidos. O processo poderia ser

\footnotetext{
${ }^{9}$ Neste sentido, as teorias da escola de Chicago a partir do pensamento da Economic and Law.
} 
contencioso ou voluntário, de acordo com existência da lide, ou não, entretanto, o Estado-Juiz teria a titularidade da decisão, ainda que esta tivesse um caráter homologatório da vontade das partes interessadas. A própria jurisdição estava diretamente vinculada ao poder atribuído ao Estado para se sub-rogar aos interessados parciais para resolver o conflito pendente. Segundo a fase histórica do direito processual, e a partir do processo romano, foram se alterando os conceitos a respeito dos institutos de processo e os meios usados para se alcançar aquele resultado até a fase do processualismo científico, que inovou ao reconhecer a autonomia do direito processual em face do direito material. A estruturação do Código de Processo Civil de 1973 ilustra essas características ao compartimentar os processos e os procedimentos, criando um isolacionismo entre os processos de conhecimento, execução, cautelares, e ações de procedimentos especiais; e ainda, a generalização do efeito suspensivo no sistema recursal, entre outros aspectos.

No Brasil a década de 90 do Século XX representa um momento de ruptura com o pensamento processual baseado naquela concepção teórica. As mudanças no sistema processual, contudo, tiveram fases, que se sucederam, em reformas parciais daquele Código de processo civil de 1973, até a promulgação do Código de processo civil de 2015 . Há ponderosas razões que justificam a opção do legislador pela adoção de um novo código, destacando-se a promulgação da Constituição de 1988 e a crise de efetividade jurisdicional e da segurança jurídica que se instalou no Judiciário, diante da necessária construção jurisprudencial que atualizasse o direito processual civil, compatibilizando seus institutos com os princípios Constitucionais de processo. Se some a isto, a nova realidade social e política que se estabeleceu com a redemocratização, sendo aprovados os microssistemas jurídicos, como o Código de Defesa do Consumidor, que representa, juntamente com outros textos legais, a ampliação das garantias jurídicas que devem ser tutelados pelo Estado.

Há, ainda, um déficit na alocação das vagas de Juízes, havendo vagas ociosas de acordo com o relatório Justiça em números de 2017 do CNJ, sendo que, “Ao final de 2016, havia 18.011 cargos de magistrados providos no Poder Judiciário, de um total de 22.450 cargos criados por lei. Havia, portanto, 4.439 cargos vagos (19,8\%)". Observe-se, ainda, que o Brasil é um país, que tem um número de juízes por grupo populacional, que pode ser considerado baixo em relação ao satisfatório, sendo que neste sentido o Conselho Nacional de Justiça no Relatório Justiça em números de 2017 traz a seguinte informação; “Além do número total de cargos de magistrados existentes e providos, outro indicador relevante é a média de magistrados 
existentes a cada cem mil habitantes: 8,2 magistrados a cada cem mil habitantes em 2016". ${ }^{10}$ Nesse cenário a modificação do sistema processual é indicativa de uma possibilidade de ganho de efetividade. Os meios consensuais de resolução de conflitos, ampliados e reestruturados, nessa nova sistemática são significativos, sendo que estes problemas e modelos de enfrentamento foram objeto de discussão e adoção em outros países.

\begin{abstract}
Muito em mudado na forma tradicionalmente ligada às expressões aceder à justiça e fazer Justiça. Pensamos não estar longe da realidade se concluirmos que, se as décadas de sessenta e setenta do século passado poderão ficar conhecidas como o período de outro do direito de acesso à Justiça enquanto sinónimo de direito de acesso aos tribunais, de lá para cá assiste-se a uma reiterada dissuasão do recurso a esquemas formais e de base estadual de resolução de controvérsias e de satisfação efectiva de situações jurídicas prestacionais. Agora, o direito de acesso aos tribunais é um direito de retaguarda, sendo o seu exercício legítimo antecedido de uma série de filtros. (SILVA, 2009, p. 20/21)
\end{abstract}

Observa-se que há uma tendência internacionalmente reconhecida em conferir ao acesso à justiça atributos de segurança jurídica e efetividade jurisdicional, na perspectiva da eficiência e da eficácia como meio para a obtenção de resultados coincidentes com a expectativa quanto à razoável duração do processo e à desobstrução do poder judiciário. Neste sentido, se admite estar diante da ampliação das concepções próprias do Estado liberal.

Assim, o caminho teórico tomado tem sido a adoção de uma sistemática processual hermeneuticamente ligada ao instrumentalismo metodológico, visando estabelecer um novo referencial, que possibilitasse a descentralização da jurisdição, o reconhecimento de que os conceitos de processo e procedimento são complementares e inseparáveis. Desse modo, a fim de que seja garantida a efetividade da jurisdição se reconhece que o processo carece de uma finalidade específica que lhe empreste uma autonomia ontológica. Essencialmente o direito processual é o meio através do qual o Estado realiza praticamente a Justiça. O acesso à justiça se relaciona com a redução da complexidade do processo, que deve assegurar a aplicação do direito material, estando este e o direito processual vinculados à prestação jurisdicional justa, segura, célere e efetiva.

\title{
6. Problemas metodológicos no sistema processual brasileiro
}

O sistema processual brasileiro pode ser compreendido como o conjunto das regras e dos princípios jurídicos que formam a complexa normatividade do direito processual,

\footnotetext{
${ }^{10}$ A última consulta ao CNJ foi realizada no dia 10 de maio de 2018, sendo que ainda não havia sido publicado o Relatório justiça em números de 2018.
} 
destacando-se seus fundamentos. Como referido anteriormente, este sistema foi revisto a partir da década de 90 do último Século, tendo este movimento culminado com a alteração do sistema, que sob o ponto de vista metodológico se filiou ao funcional-instrumentalismo sistêmico. Entende-se que o sistema foi adequado à principiologia de processo contida da Constituição de 1988; questiona-se, entretanto, sobre os eventuais problemas metodológicos dessa escolha, considerando-se que o instrumentalismo propõe que o processo seja um meio eficiente para a aplicação eficaz do direito material, mas não reconhece os aspectos axiológicos desse mesmo direito material. Assim, processo e procedimento são convertidos em tecnologias que, conforme sua eficiência e eficácia serão consideradas adequadas para o acesso à justiça.

Sob o ponto de vista do instrumentalismo metodológico as discussões a respeito da validade e da axiologia do direito são mitigadas. A análise instrumental está vinculada à ideia segundo a qual, o método adotado será considerado apropriado ou não, segundo a coerência entre os problemas a serem resolvidos pela sua aplicação e os resultados desse processo no ambiente social e político. O risco desse pensamento está em que, qualquer resultado pode ser justificado, desde que se evidenciem os vieses entre o método e o resultado esperado. Poderia se alegar que os aspectos axiológicos na aplicação do direito se observariam por seus efeitos no ambiente social e político, conforme sua cultura e história.

Outras críticas ao instrumentalismo metodológico se referem a que nessa perspectiva os problemas seriam sempre de natureza tecnológica. Logo, as possíveis respostas aos problemas se localizariam no meio para a sua apreciação, ou seja, na adequação ou não da metodologia para a aplicação do direito. Os fatos, e os seus problemas e as possibilidades de soluções, considerando-se a complexidade do direito, se apresentam secundários. Pode ser firmado que o pensamento instrumentalista poderia levar à estagnação do conhecimento, pois as discussões estariam vinculadas aos meios, às possibilidades de explicação da realidade ou não.

$\mathrm{Na}$ busca pela redução da complexidade através de tecnologias que visam a procedimentos eficientes e a resultados eficazes, se observa a relativização do próprio direito, que politicamente se compromete com o acesso formal à justiça, e socialmente se compromete com a resolução do conflito. Os fins axiológicos do processo e da jurisdição quanto à prestação jurisdicional justa, e capaz de realizar a Paz social, poderá ser contingenciada, na perspectiva do processo instrumental.

Assim, a especificidade da problematização quanto a autonomia do direito, que poderia lhe reconhecer atributos e características axiológicas, e, próprias para a garantia do acesso material à justiça, cede lugar às questões tecnológicas e procedimentais, que possam 
justificar os resultados esperados. Portanto, não importa a resposta oferecida, mas sim a adequação dos meios para obtê-la. O instrumentalismo pode ser entendido como um pensamento abstrato e estrutural que se abre sistematicamente para o ambiente político e social, em busca de um tipo de conhecimento mais humanizado. Contudo, seu pragmatismo sociológico se revela relativista ao abordar a problematicidade sob o prisma tecnológico.

No ambiente do direito processual se desenvolveu o instrumentalismo jurídico, inspirado por Mauro Cappelletti que a partir da análise antropológica e social a respeito da resolução dos conflitos em diferentes sociedades, defende a adoção de modelos de procedimentos distintos, os quais devem ser adotados de acordo com a tipologia da disputa.

Six basic types of procedures can be distinguished in terms of the degree to which litigants maintain control over the dispute process, and each type insvolves different structural constraints on the degree to which litigants can adjust their claims in the interest of a settlement acceptable to both. Two dimensions suffice to identify these procedural types: [...] (CAPPELLETTI, 1979, p. 3)

A partir da perspectiva da adoção de modelos ou tipos de procedimentos como meios para a obtenção da resolução dos conflitos, se desenvolve o pensamento sobre uma concepção sociológica do direito processual, ao afirmar que a jurisdição é uma garantia Constitucional no Estado Democrático de Direito visando assegurar o acesso à Justiça, podendo presta-la de diferentes maneiras, desde que exista a adequação metodológica para a efetividade jurisdicional. A questão, portanto, não é o ato decisório como um “dever" ou um "poder" do Estado, mas a garantia do procedimento adequado para que socialmente seja solucionado o conflito de interesses.

\footnotetext{
Desses pressupostos metodológicos, surge a necessidade de reestruturar os conceitos clássicos dos institutos fundamentais do direito processual: a jurisdição não pode mais ser definida como poder, função e atividade, pois na justiça conciliativa não há exercício do poder. Ela passa a ser, em nossa visão, garantia do acesso à justiça, que se desenvolve pelo exercício de função e atividade respeitadas pelo corpo social para a solução de conflitos (conforme elementos do ordenamento jurídico) e legitimada pelo devido processo legal. Seu principal escopo social é a pacificação com justiça. E esta se atinge por intermédio do processo e procedimentos adequados, que levam. à tutela jurisdicional adequada. (GRINOVER, 2016, p. 4)
}

O conceito de jurisdição, processo e procedimento e sua adequação às demandas dos jurisdicionados deve ser considerada relevante no sentido do acesso formal e material à justiça, sendo oportunas as discussões a respeito da possibilidade de realização da Justiça em sentido material, tomando-se como referencial o funcional-instrumentalismo.

Entende-se que há uma impropriedade fundamental quanto a adoção do paradigma funcional-instrumentalista, a qual se refere à irredutível complexidade do direito. Pode-se 
pensar esse aspecto apriorístico do direito de diferentes maneiras, como seu acoplamento estrutural ao ambiente, ou suas intersecções com a política, e com o Estado; ou mesmo, possíveis aspectos ontológicos que o vinculariam à natureza. Nos limites tratados nesse trabalho, a complexidade do direito é abordada sob o ponto de vista da realização da Justiça, como aspecto essencial para a sua efetividade.

As discussões teóricas e metodológicas a respeito do direito assumiram tanta relevância que os problemas sobre a efetividade da Justiça, como um prius em relação ao acesso à prestação jurisdicional efetiva, segura e célere, parece ter se tornado um problema da filosofia do direito, não sendo reconhecida sua especificidade própria no direito, a qual lhe confere a autonomia sistêmica e crítica.

Portanto, o pensamento sobre o acesso à justiça deve ser compreendido como garantia material e substantiva própria do direito. Os efeitos da efetividade do direito serão sentidos por Seres Humanos. Ainda que a controvérsia seja relativa a aplicação de direitos coletivos, difusos, entre entes de direito público, ou sujeitos sem personalidade jurídica, não se vislumbra hipóteses em que a efetividade do direito seja abstrata, a tal ponto, que o Homem possa ser excluído de seus efeitos diretos ou indiretos. Assim, entende-se que o direito se autonomiza a partir do reconhecimento da essencialidade quanto à complexidade inerente às relações Humanas, e que, portanto, todo o pensamento sobre o direito deve ser também um pensamento sobre o Humano e sobre a Justiça humana e materialmente reconhecida.

\section{O sistema processual pensado a partir da autonomia sistêmica e crítica do direito}

$\mathrm{O}$ acesso material à justiça como efetividade substancial do direito diz respeito à realização dos direitos fundamentais como princípios Constitucionais de processo e como garantia de aplicação dos direito materiais infraconstitucionais. O direito se faz como direito na dimensão do Humano-indivíduo, esse sujeito de direitos e obrigações se revela para o direito na dimensão da pessoa. A persona resguarda duas dimensões, a individual e a comunitária, sendo inconfundíveis e inseparáveis entre si. As responsabilidades inerentes à dimensão comunitária da pessoa se referem ao contexto social e político. Por sua vez, o indivíduo é titular de determinados direitos que devem ser plenamente afirmados. Recusa-se a afirmação que o interesse público e coletivo tem preponderância sobre o interesse individual. Esta é uma afirmação reducionista da complexidade do direito, e, portanto, problemática quanto às possibilidades do acesso material à justiça. 
As classificações quanto às ondas de afirmação dos direitos perderam o significado ${ }^{11}$ no Século XXI, pois, a complexidade das relações teve como consequente o necessário reconhecimento de que os direitos são independentes, não havendo hierarquizações entre as tutelas jurídicas. O direito como um sistema autônomo apresenta uma específica abrangência do humano e de sua complexidade. Assim, o logos do indivíduo e o logos do comunitário são distintos e impenetráveis, não se reconhecendo, neste sentido, um tipo de hermenêutica jurídica que estabeleça gradações valorativas entre as esferas pública e privada do direito. Contudo, a pessoa, na sua dimensão comunitária, conquanto preserve suas garantias individuais, se submete às limitações ao individualismo, na medida das responsabilidades que lhe são impostas diante das tutelas coletivas e públicas. Ao direito cabe demarcar as fronteiras a partir da definição da extensão das responsabilidades e dos efeitos das tutelas jurídicas nas dimensões individual-privatística e comunitária-coletiva-publicística.

O sistema processual, considerado a partir da autonomia sistêmica e crítica do direito ultrapassa as concepções metodológicas que tratam o processo como uma técnica para a obtenção de determinados resultados, restritos ao acesso formal à justiça. Assim sendo, a resolução dos conflitos pode ser tratada como um problema de redução da judicialização dos conflitos sociais, ou como meio de se obter a extinção do processo sem que se adentre ao mérito da causa. As mudanças no sistema processual brasileiro foram norteadas pela Constitucionalização principiológica do processo, pela busca da adoção de procedimentos menos formais, pela abertura do sistema às partes, entendidas a partir da possibilidade de maior participação destas no procedimento, sempre com vista à efetividade e celeridade processual. Boaventura de Sousa Santos ao tratar sobre a democratização do acesso à justiça, considera os seguintes aspectos.

Com as reformas que incidem sobre a morosidade sistêmica poderemos ter uma justiça mais rápida, mas não necessariamente uma justiça mais cidadã. Ao contrário, com a revolução democrática da justiça a luta não será apenas pela celeridade (quantidade da justiça), mas também pela responsabilidade social (qualidade da justiça). [...] do ponto de vista de uma revolução democrática da justiça, não basta a rapidez. É necessária, acima de tudo, uma justiça cidadã. (SANTOS, 2015, p. 45)

Na concepção sistêmica do direito, e considerando o paradoxo criado pelo funcionalinstrumentalismo entre o acesso formal e material à justiça, foi admitido certo tipo de pragmatismo que adotou como ponto focal para as reformas processuais, aspectos formais relacionados aos procedimentos e aos métodos para a resolução dos conflitos, tendo como um

\footnotetext{
${ }^{11}$ A afirmação se refere às ondas geracionais dos direitos humanos, como proposto por Karel Vasak, que se entende ter estabelecido as condições para o desenvolvimento de hierarquizações entre os direitos quanto à sua dimensão pública ou privada. Ressalva-se, contudo, que a classificação proposta por Vasak foi importante no Século XX, sobretudo para a afirmação dos direitos humanos.
} 
de seus objetivos o alcance de resultados quantitativos quanto à prestação jurisdicional. Os relatórios "Justiça em Números" do CNJ a partir da publicação de 2016 divulgaram indicadores quanto à conciliação, sendo que, em seu histórico de publicações ${ }^{12}$, não há significativa redução quanto à litigiosidade ou à taxa de congestionamento de processos.

A ampliação dos sistemas autocompositivos e de heterocomposição de resolução paraestatal de conflitos, são ilustrativos de que o sistema de processo no Brasil foi modificado em suas bases. As mudanças introduzidas na jurisdição brasileira devem incorporar quanto à interpretação e aplicação do sistema processual metodologias que possibilitem a superação do funcional-instrumentalismo, tendo em vista os problemas apontados anteriormente. Deve-se reconhecer que o direito exige o reconhecimento de sua autonomia, da sua dimensão humana e do seu caráter aberto, sistemático e crítico para alcançar a realização do acesso material à justiça.

Nessa perspectiva se propõem uma interpretação do sistema processual, a partir da releitura da filosofia do direito segundo o jurisprudencialismo de Castanheira Neves. A completude teórica de sua proposta, sobretudo quanto a metodologia para a abordagem da dialética sistema-problema, tendo o caso como um prius, lhe confere uma singularidade e especificidade que determina, para esfera desse trabalho, a delimitação do seu enfoque à compreensão sobre a Justiça, e sua aplicação aos estudos sobre o acesso material à prestação jurisdicional.

Esta possibilidade se abre na medida em que no jurisprudencialismo apresentado há um sentido prático-humano para a Justiça, a fim de lhe reconhecer um caráter histórico-cultural comunitário. Desse modo, o direito se autonomiza das contingências do ambiente, para se efetivar como um direito da pessoa como integrante de uma determinada comunidade, constituída axiologicamente com referências históricas e culturais. Trata-se de um pensamento que reivindica a complexidade, reconhecendo que a adequação do acesso material à justiça depende do reconhecimento quanto à sua inafastabilidade. Desse modo, o acesso à justiça ultrapassa questões procedimentais, ou mesmo a respeito de sua jurisdicionalização no plano estatal do Poder Judiciário.

Na perspectiva jurisprudencialista apresentada por Castanheira Neves, a racionalidade se abre à realidade prática da comunidade humana, histórica e culturalmente constituída axiologicamente. $\mathrm{O}$ acesso material à justiça se apresenta como uma possibilidade da prestação jurisdicional efetiva porque se realiza independentemente dos aspectos estruturais e

\footnotetext{
${ }^{12}$ Em 2017 foi publicada a 13a edição do Relatório Justiça em Número do Conselho Nacional de Justiça-CNJ.
} 
contingentes, se concretiza na aplicação de um direito metodologicamente comprometido com a complexidade da pessoa, em sua dimensão individual e comunitária.

A resolução do conflito ocorre tendo como referência os problemas humanos cunhados pelo sistema jurídico em sua complexidade normativa, principiológica e jurisprudencial. $\mathrm{O}$ direito, nestes termos, se potencializa para a realização do acesso efetivo à justiça, assegurando aos jurisdicionados fronteiras demarcadas por uma juridicidade axiologicamente determinada histórica e culturalmente.

\section{Considerações finais}

Os paradoxos presentes no direito no inicio do Século XXI desafiam seus estudiosos, e suscitam sua recompreensão. Neste trabalho tratou-se a respeito do problema do acesso à justiça, seus aspectos formais e materiais, optando-se por uma abordagem a respeito de duas metodologias sistêmicas, o funcional-instrumentalismo e o jurisprudencialismo. São dois referenciais de envergadura e importância indiscutível, não sendo possível, portanto a análise completa de suas proposições. Desse modo, o enfoque foi delimitado às questões específicas do problema. O referencial teórico-metodológico sistêmico pode interferir na compreensão a respeito do acesso à justiça?

Entendeu-se que a resposta é afirmativa, pois uma alternativa metodológica racionalista de caráter abstrato poderá assegurar o acesso formal à jurisdição. Contudo, sua vinculação aos efeitos, ou resultados quantitativos, colocam em risco as possibilidades de efetividade material quanto ao acesso à justiça. $\mathrm{O}$ funcional-instrumentalismo tem sido convocado a orientar a hermenêutica processual no Brasil, especialmente em face da crise que afeta o Poder Judiciário, com altos índices de congestionamento. Reconhecida a gravidade da morosidade e da baixa efetividade jurisdicional, contudo, se recusa as ideias que apresentam como soluções, a perca da autonomia do direito, a fim de lhe atribuir uma natureza marcadamente sociológica ou política. Desse modo, se reivindica a partir do pensamento jusfilosófico de Castanheira Neves a reconstituição de uma normatividade sistêmica aberta que reconheça na pessoa, em sua dimensão individual e comunitária, o destinatário do acesso material à justiça. Assim, a concepção sobre a justiça como prática aplicação do direito poderá superar as questões abstratas e formalistas, que colocam em risco a efetividade material do acesso à jurisdição.

A complexidade neste sentir, é assumida e tratada como inerente ao humano e ao direito, sendo metodologicamente abordada a partir do prius do caso, e da dialética sistema- 
problema. A normatividade do sistema jurídico assume-se axiologicamente comprometida com a constituição histórico-cultural da comunidade. Neste quadro, se vislumbra uma proposta metodológica capaz de efetivar o acesso material à justiça.

Pode-se questionar a respeito da morosidade e da efetividade, ao se propor uma metodologia que opera com referenciais qualitativos, tendo a realização dos valores humanos constituídos cultural e historicamente como referência. Acredita-se que ao admitir uma racionalidade prática que reconheça autonomia ao direito, tenha como consequência a redução da litigiosidade, uma vez que a democratização dos meios como reconhecimento da ampliação da cidadania do jurisdicionado, determinará o resgate da confiança na justiça, que se viu abalada com a crise do Estado moderno-iluminista.

Por outro lado, o pensamento jurisprudencialista convoca na pessoa a dimensão comunitária de suas responsabilidades, e também neste sentido, se entende que os sujeitos em situação conflitiva assumam a titularidade ativa na solução dos conflitos e na pacificação social. Desse modo, será possível a real participação dos interessados na solução dos conflitos, restando ao Estado, por meio do Poder Judiciário, as questões consideradas como de alta complexidade sistêmico-normativa.

\section{Referências bibliográficas}

ACEMOGLU, Daron. ROBINSON, James. Por que as nações fracassam. As origens do poder, da prosperidade e da pobreza. Tradução Cristina Serra. Rio de Janeiro: Editora Elsevier, 2012.

BRASIL. http://www.cnj.jus.br/files/conteudo/arquivo/2017/12/b60a659e5d5cb79337945 c1dd137496c.pdf.

BRASIL. http://www.planalto.gov.br/ccivil_03/constituicao/constituicaocompilado.htm

CAPPELLETTI, Mauro. Acess to Justice. The anthropological perspective, Vol. IV. Edited by Klaus-Friedrich Koch. Milão: Dott. A. Giuffrè Editore, 1979.

GRINOVER, Ada Pellegrin. Ensaio sobre a processualidade: fundamentos para uma nova teoria geral do processo. Brasília: Gazeta Jurídica, 2016. 
KUHN, Thomas Samuel. The Structure of Scientific Revolutions. Second Edition, Enlarged. United States of America: Editor-in-Chief Otto Neurath, 1970.

LOSANO, Mário. Sistema e estrutura do direito. Vol. 1. Tradução de Carlo Alberto Dastoli. $1^{\text {a }}$ ed. São Paulo: WMF Martins Fontes, 2008.

LUHMANN. Niklas. Law as a social system. Translatede by Klaus A. Ziegert. New York. USA: Edited by Fatima Kastner and other.Oxford University Press, 2008.

NEVES, Antonio Castanheira. O direito hoje e com que sentido? O problema atual da autonomia do direito. $3^{\mathrm{a}}$ edição. Lisboa: Coleção Pontos de Vista, 2012.

. O "Jurisprudencialismo" - proposta de uma reconstituição crítica do sentido do direito. Teoria do Direito. Direito interrogado hoje - jurisprudencialismo: uma resposta possível?, Salvador: Editora JusPodivn, p. 9-79, 2012.

. Metodologia Jurídica. Problemas fundamentais. Stvdia Ivridica I. Coimbra: Coimbra Editora, Reimpressão, 2013.

SANTOS, Boaventura de Sousa. Para uma revolução democrática da justiça. Coimbra: Edições Almedina, 2015.

SILVA, Paula Costa e. A nova face da justiça. Os meios extrajudiciais de resolução de controvérsias. Lisboa: Coimbra Editora, 2009.

WATANABE, Kazuo. Acesso à justiça e sociedade moderna. In, Participação e processo. Coordenação de Ada Pellegrini Grinover, Cândido Rangel Dinamarco, Kazou Watanabe. São Paulo: Editora Revista dos Tribunais, 1988. 


\section{FORMAS CONSENSUAIS DE SOLUÇÃO DE CONFLITOS}

\section{APRESENTAÇÃO}

É com muita satisfação que apresentamos o Grupo de Trabalho e Pesquisa (GT) denominado "FORMAS CONSENSUAIS DE SOLUÇÃO DE CONFLITOS” do VIII Encontro Internacional do CONPEDI Zaragoza/Espanha promovido pelo CONPEDI em parceria com a Universidade de Zaragoza (UNIZAR), com enfoque na temática "Direito, argumentação e comunicação: Desafios para o século XXI", o evento foi realizado entre os dias 06 e 08 de setembro de 2018 na Faculdade de Direito, no Campus da Universidade de Zaragoza, na Calle Pedro Cerbuna s/n . 50009 - Cidade de Zaragoza/Espanha.

Trata-se de publicação que reúne artigos de temáticas diversas atinentes às formas consensuais de solução de conflitos, apresentados e discutidos pelos autores e coordenadores no âmbito do Grupo de Trabalho. Compõe-se de artigos doutrinários, advindos de projetos de pesquisa e estudos distintos de vários programas de pós-graduação, em especial do Brasil e da Espanha, que colocam em evidência para debate da comunidade científica assuntos jurídicos relevantes.

Assim, a coletânea reúne gama de artigos que apontam questões relativas as soluções extrajudicias de conflitos, com a utilização de técnicas como por exemplo, a avaliação por terceiro neutro, o mini-trial, o rent-a-judge e o baseball arbitration; a legitimidade do consenso na mediação de conflitos, com estímulo à comunicação produtiva entre os participantes diretamente afetados, e a análise reflexiva no contexto jurídico brasileiro e espanhol; a busca de novos caminhos para a solução de conflitos judiciais, a partir do estudo do direito sistêmico e a pesquisa da questão na Espanha; a utilização da estrutura do Judiciário para viabilizar o consenso, pelas Ouvidorias Judiciais, e os CEJUSCs, além do aprimoramento dos Magistrados e Servidores pela ENFAM e as Escolas Judiciais dos Tribunais Estaduais e Federais; a cooperação judicial e a mediação; debate sobre a tradição histórico-jurídica de proteção ao menor no Brasil e reflexões sobre o papel da Justiça Restaurativa Criminal no Brasil, com reflexões sobre o diálogo entre réu e vítima, e o afastamento do Estado para facilitar o consenso; e, finalmente, o estudo sobre a visão humanista necessária ao Magistrado, nas conciliações judiciais no âmbito da Justiça do Trabalho, como forma de adequado tratamento de conflitos face ao princípio da indisponibilidade de direitos laborais. 
Em linhas gerais, os textos reunidos traduzem discursos interdisciplinares maduros e profícuos. Percebe-se a salutar preocupação dos autores em combinar o exame dos principais contornos teóricos dos institutos abordados, aliando a efetividade, o acesso a justiça e as formas de soluções consensuais de conflitos. A publicação apresentada ao público possibilita acurada reflexão sobre tópicos avançados e desafiadores do Direito Contemporâneo. Os textos são ainda enriquecidos com investigações legais e doutrinárias da experiência jurídica estrangeira a possibilitar um intercâmbio essencial à busca de soluções para as imperfeições do sistema processual brasileiro e de acesso à justiça, ainda muito focado no forma adjudicada de solução de litígios entre partes.

É imprescindível dizer que os trabalhos apresentados são de extrema relevância para a pesquisa em direito no Brasil e na Espanha, demonstrando notável rigor técnico, sensibilidade e originalidade, desenvolvidos em uma perspectiva contemporânea. De fato, a teoria a respeito das formas de solução de conflitos, bem como a aplicação, especialmente aquela orientada a efetividade dos direitos fundamentais e a materialização da Justiça, fortalece o desenvolvimento e a construção de uma sociedade mais justa e menos desigual. A presente publicação coletiva demonstra uma visão lúcida e enriquecedora sobre a solução de conflitos, suas problemáticas e sutilezas, sua importância para o direito e os desafios na temática para o século XXI, pelo que certamente será de vigorosa aceitação junto à comunidade acadêmica.

O fomento das discussões a partir da apresentação de cada um dos trabalhos ora editados, permite o contínuo debruçar dos pesquisadores do Direito visando ainda o incentivo aos demais membros da comunidade acadêmica à submissão de trabalhos aos vindouros encontros e congressos do CONPEDI.

Sem dúvida, esta publicação fornece instrumentos para que pesquisadores e aplicadores do Direito compreendam as múltiplas dimensões que o mundo contemporâneo assume na busca da conjugação da promoção dos interesses individuais e coletivos para a consolidação de uma sociedade dinâmica, multifacetada e de consenso.

$\mathrm{Na}$ oportunidade, os Organizadores prestam sua homenagem e agradecimento a todos que contribuíram para esta louvável iniciativa do Conselho Nacional de Pesquisa e Pós-Graduação em Direito (CONPEDI) e da Universidade de Zaragoza (UNIZAR) por sua Faculdade de Direito e, em especial, a todos os autores que participaram da presente coletânea de publicação, 
com destaque pelo comprometimento e seriedade demonstrados nas pesquisas realizadas e na elaboração dos textos de excelência.

Convida-se a uma leitura prazerosa dos artigos apresentados de forma dinâmica e comprometida com a formação de pensamento crítico, a possibilitar a construção de um Direito voltado à concretização de preceitos insculpidos pela Constituição da República.

Zaragoza/Espanha, setembro de 2018.

Coordenadores do GT:

Professora Dra. Adriana Goulart de Sena Orsini - Faculdade de Direito da Universidade Federal de Minas Gerais (UFMG)

Professor Dr. Sérgio Henriques Zandona Freitas - Universidade FUMEC e Instituto Mineiro de Direito Processual (IMDP) 


\title{
A CONCILIAÇÃO JUDICIAL COMO FORMA ADEQUADA DE TRATAMENTO DE CONFLITOS FACE AO PRINCÍPIO DA INDISPONIBILIDADE DE DIREITOS LABORAIS
}

\author{
Adriana Goulart de Sena Orsini \\ Universidade Federal de Minas Gerais
}

\begin{abstract}
Resumo
O presente trabalho objetiva questionar como, em um sistema sobre o qual incide o princípio da indisponibilidade, legitima-se a conciliação e, consequentemente, a disponibilidade dos direitos do empregado por sua própria vontade, contexto que não foi alterado pela lei 13.467/2017. A partir da observação de audiências trabalhistas, entrevistas e da pesquisa doutrinária, a síntese que se segue pretende fazer uma leitura das razões pelas quais as partes se conciliam, a atuação do Juiz do Trabalho em prol da conciliação, suas repercussões e os aspectos endoprocessuais, partindo-se da concepção que o conflito não apenas em uma dimensão formal-processual.
\end{abstract}

Palavras-chave: Acesso à Justiça, Conciliação, Justiça do Trabalho.

\begin{abstract}
Resumen/Résumé
This paper aims to question how, in a system over which hovers the principle of unavailability, conciliation is legitimized and, therefore, the availability of employee rights by their own will. From the observation of labor hearings, interviews and doctrinal research, the following synthesis intends to make a reading of the reasons why the parties reconcile, the work of the Labor Judge in favor of conciliation, its repercussions and the endoprocessing aspects, starting from the conception that the conflict not only in a formal-procedural dimension.
\end{abstract}

Keywords/Palabras-claves/Mots-clés: Access to Justice, Conciliation, Labor Justice. 


\section{Introdução}

O cenário constitucional-processual preza, cada vez mais, por soluções que primam pela efetividade e eficácia material, bem como processual, destacando-se a conciliação como meio consensual de solução de litígios e substitutivo da atividade jurisdicional clássica de prolação de uma decisão final ao caso concreto, a chamada solução adjudicada.

Por sua vez, rege na sistemática trabalhista, mesmo após a Lei 13467/17, o princípio da indisponibilidade dos direitos do empregado que, revelando o caráter imperativo das normas protetoras para aqueles que prestam trabalho subordinado e sendo de essência notadamente social, restringe a negociação entre as partes da relação de emprego para resguardar os direitos da parte hipossuficiente da relação.

Diante disso, questiona-se uma plausível incompatibilidade inicial entre a indisponibilidade dos direitos do trabalhador e a conciliação na Justiça do Trabalho, de onde exsurge o tema-problema, da legitimação da atividade conciliatória frente ao princípio da indisponibilidade.

\section{Conflitos de interesses e a conciliação como princípio}

O ser humano é um ser social e, como tal, tende a buscar o seu convívio em comunidades e em grupos, com o fito de promover a sua formação sociocultural e firmar a sua personalidade. Ocorre que a convivência em sociedade, não raras vezes, propicia o surgimento de conflitos de interesses, tendo em vista os diversos anseios, pontos de vista, direitos e deveres de cada indivíduo.

Conflitos de interesses são, portanto, situações em que as pretensões de um indivíduo ou de um grupo social vão de encontro às de outro, no que concerne a um mesmo bem da vida, ou até mesmo frente a recursos que são ou se tornam escassos. Conquanto conflitos sejam de incidência habitual na realidade social contemporânea, merecem ser melhor abordados, pois o desenvolvimento de uma cultura voltada à paz social há de levar em conta que conflitos existem, que não se tratam de chagas e/ou problemas e, inclusive, podem ser uma potencial forma de gerar avanços sociais e/ou cumprimento dos direitos fundamentais sociais.

A busca do Poder Judiciário pelos cidadãos brasileiros, com o intuito de resolver algum conflito de interesses que os envolva, tornou-se mais frequente com o passar dos anos, o que provocou um acúmulo da máquina jurisdicional e de gastos não condizentes com os corolários de efetividade e razoável duração do processo. Aliado a tais fatos, existe, em especial na área 
trabalhista, condutas empresariais descumpridoras da legislação trabalhista de forma recorrente, ocasionando, necessariamente, o ajuizamento da ação trabalhista para que o trabalhador receba direitos que deveriam ter sido pagos de forma espontânea e durante o pacto laboral.

Portanto, é possível detector que ocorrem no espaço institucional jurisdicional estratégias de apropriação privada deste espaço público, seja por meio das lides simuladas, seja por meio da litigação passiva de contumazes descumpridores do direito material do trabalho em sede da relação de emprego.

Assim, desde 2007, quando tem início o movimento "Conciliar é Legal" tem se verificado um cenário de ênfase cada vez maior à autocomposição, inclusive em esfera extrajudicial, bem como à conciliação das partes em juízo. Estas ações, desde o nascedouro, pretendem reduzir e interferir no exacerbado número de demandas que abarrotam o Judiciário, com o fito de rechaçar qualquer maculação à sua atividade.

No presente estudo, será tomado como base de investigação a conciliação judicial trabalhista, aquela apta a trazer benefícios tanto voltados ao empregado quanto ao empregador, objeto de livre acordo de vontade e frente a direitos que podem ser transacionados. A conciliação que será objeto de análise é a conciliação realizada como atividade jurisdicional prevista na Consolidação das Leis do Trabalho e realizada pelo Magistrado do Trabalho. Tratase de exercício de juízo conciliatório consoante determina a CLT, em nada alterada pela lei $13.467 / 2017$.

A conciliação judicial se caracteriza pela efetiva participação tanto das partes quanto do Magistrado para a composição do litígio. Trata-se, pois, de um modelo cooperativo do processo, em que se vislumbra uma participação tríade: a do reclamante, a do reclamado e a do Magistrado.

DELGADO conceitua a conciliação judicial:

[...] ato judicial, através do qual as partes litigantes, sob interveniência da autoridade jurisdicional, ajustam solução transacionada sobre matéria objeto de processo judicial. A conciliação, embora próxima das figuras anteriores, delas se distingue em três níveis: no plano subjetivo, em virtude da interveniência de um terceiro e diferenciado sujeito, a autoridade judicial; no plano formal, em virtude de ela se realizar no corpo de um processo judicial, podendo extingui-lo parcial ou integralmente; no plano de seu conteúdo, em virtude da conciliação poder abarcar parcelas trabalhistas não transacionáveis na esfera estritamente privada.

Segundo NASSIF: 
O conceito de conciliação judicial, tal como disposto pelo ordenamento jurídico brasileiro, é: o procedimento irritual, oral e informal, realizado antes ou depois de instaurado o processo (contraditório), com vistas a buscar uma solução da controvérsia fora da jurisdição e do processo, mediante a elaboração de um acordo que, após homologado por despacho, substitui eventual medida cautelar ou sentença, faz coisa julgada imediata e adquire a qualidade de título executivo judicial. (NASSIF, 2005, p. 152)

No âmbito do processo do trabalho, o tratamento conferido pelo art. 764 da CLT e seus parágrafos, bem como outros dispositivos com similar abordagem levam a crer que a conciliação é priorizada como forma de resolução dos conflitos trabalhistas. E a preferência para a solução conciliatória não se restringe aos dissídios individuais, na medida em que os $\S \S$ $1^{\circ}$ e $2^{\circ}$ do art. 114 da CR/88 estabelecem a tentativa prévia de solução conciliatória como um dos pressupostos para a instauração de dissídios coletivos, diante das inúmeras vantagens obtidas, notadamente de natureza subjetiva.

Sobre as motivações específicas para a conciliação, NASSIF diz que a motivação do juiz estaria ligada à melhoria das estatísticas que atestam a produtividade dos magistrados; a do empregador consistiria na possibilidade de pagar menos ou de forma parcelada e de não ser acionado pelo mesmo empregado em momento posterior devido ao efeito da coisa julgada; as razões do empregado seriam variadas, podendo ser destacada a questão da imediatidade no recebimento dos valores pleiteados; já o interesse do advogado relacionar-se-ia ao recebimento rápido dos honorários.

Nesse contexto, importa mencionar a presença das chamadas "lides simuladas" (que recebem de NASSIF a denominação “demanda patológica"), segundo a qual as partes procuram o Judiciário com a pretensão previamente de lograr vantagens, especialmente através da conciliação, mas também através de revelias ou de defesas mal formuladas, ante o intuito, muitas vezes, de fraudar terceiros (INSS, por exemplo).

O problema é que a legislação trabalhista nem sempre é cumprida de forma espontânea, muitas vezes ela só ocorre por meio da coerção via Estado, seja via sentença, seja por meio da fiscalização do trabalho.

Nessa ordem de ideias, a interveniência do órgão estatal para a realização da conciliação, seguindo a forma preconizada em lei (art. 129, CPC/73 e art. 764 da CLT), é justamente a garantia capaz de conferir legitimidade aos efeitos jurídicos advindos do acordo homologado, já que as tratativas não correm somente ao alvedrio das partes envolvidas no litígio. 


\subsection{A conciliação como princípio}

A conciliação, como princípio, consiste na promoção pelo Magistrado, a qualquer tempo, da conciliação entre as partes (art. 764 da CLT), com o fito de por fim ao processo, garantindo, a um só tempo, a composição pacífica do litígio analisado, além de espaço para se considerar demais dimensões do conflito (v.g. sociológica, psicológica, econômica, humana). A doutrina desenvolvida após a Resolução $125 / \mathrm{CNJ}$ tem trabalhado a ideia de que a dimensão jurídica do conflito não é a única que deve ser tratada pelo Poder Judiciário quando o enfoque é a solução do conflito voltada ao desenvolvimento da cultura da paz social.

Aliás, a Constituição da República, na antiga redação do art. 114, estabelecia a competência da Justiça do Trabalho para "conciliar" e julgar os dissídios trabalhistas. A alteração trazida com a reforma constitucional implementada em 2004, contudo, não pode ser encarada no sentido de mitigar a aplicação do princípio em referência, conforme corrobora LEITE $(2009$, p. 82) ao afirmar que a omissão “[...] não desnatura o princípio em estudo, pois ele continua existindo no plano infraconstitucional e não se mostra incompatível com o novo texto da Carta de outubro de 1988". (destaques no original)

Embora a celebração do acordo possa ocorrer em qualquer tempo e grau de jurisdição, o diploma justrabalhista cuida de exigir que o Juiz proponha a conciliação em certos estágios no curso do processo. Pelo art. 846 da CLT, logo na abertura da audiência, antes da apresentação de contestação, o Juiz é obrigado a promover a tentativa de conciliação das partes envolvidas. O segundo momento, conforme preceituado no art. 850 da CLT, ocorre após as razões finais orais no processo do trabalho, em quaisquer de seus ritos (ordinário, sumaríssimo e o sumário, também denominado de processo de alçada).

Acaso inexistentes as propostas de conciliação, o que pode ser constatado por meio da ata da audiência, o processo torna-se eivado de nulidade, atentando-se que se trata de matéria de ordem pública. De certo modo, a cominação de nulidade corrobora para a afirmação de que a conciliação adquire um significado peculiar na sistemática processual trabalhista.

No tocante à obrigatoriedade das propostas de conciliação, tem-se entendido que a falta da primeira tentativa conciliatória pode ser suprida pela realização da segunda proposta, pois a ausência da proposta inicial não gera qualquer prejuízo para as partes, as quais já detêm os elementos de convicção quando da tentativa final.

Analisando a conciliação sob uma perspectiva extraprocessual, NASSIF (2005, p. 176) diverge sobre o assunto ao afirmar que a conciliação não é princípio do processo do trabalho, pois é "justamente uma forma de não haver processo algum”. (grifos no original) 
Destarte, a condição de princípio é negada em razão de a conciliação não ser instituto do processo, segundo a autora. Todavia, ainda que se reconheça que a conciliação é instituto à parte, nada impede que seja considerada princípio do processo do trabalho, já que a valorização da solução conciliatória é externada pelas próprias normas processuais trabalhistas. Além disso, fatores como a participação do juiz na conciliação e os efeitos advindos da homologação do acordo (extinção do processo, coisa julgada, etc.) evidenciam que a previsão constante na sistemática processual trabalhista, compatibiliza-se com os fins almejados nesta quadra histórica pós-Resolução 125/CNJ e CPC/2015 mudar a cultura da sentença com o desenvolvimento da cultura da conciliação, bem como contribuir para a cultura da paz.

De acordo com a previsão dos dispositivos celetistas ora citados, não restam dúvidas de que a conciliação deve ser cogitada pelo Juiz durante todo o trâmite do processo. Como tal orientação, por exigência expressa legal, deve permear a condução do processo judicial, em especial o trabalhista, torna-se justificável e coerente a abordagem da conciliação como diretriz principiológica processual.

\section{Conciliação e concretização do acesso à justiça}

O preceito da inafastabilidade da jurisdição, segundo o qual "nenhuma lesão ou ameaça a direito será excluída da apreciação do Poder Judiciário", somente prospera diante de um cenário fático-jurídico em que seja possibilitado ao cidadão o acesso à justiça, especialmente quando se está a tratar da égide do Estado Democrático de Direito.

A partir do século XX, especialmente, verificam-se várias tentativas de consolidação da noção de "justiça" e de seu "acesso", sendo evidentes as reformas nos procedimentos jurisdicionais de diversos países, seja através da introdução de institutos como a conciliação e a arbitragem, seja através da criação de novas estruturas e órgãos jurisdicionais, com princípios e desenvolvimento procedimentais próprios.

Nessa conjuntura dogmática em prol da consolidação de conceitos jurídicos basilares, foram diversos os doutrinadores que objetivaram traçar as etapas necessárias a um processo eficaz e atento à razoável duração do processo, não só analisado sob o viés de atividade estatal substitutiva, para aplicação do direito objetivo ao caso concreto, mas também atento ao acesso à justiça e à composição das partes.

Dentre esses doutrinadores, merecem destaque o italiano Mauro Cappelletti e o norteamericano Bryant Garth, segundo os quais, para o pleno desenvolvimento do acesso à justiça, ter-se-ia que observar três ondas renovatórias do direito processual: 
Podemos afirmar que a primeira solução para o acesso - a primeira 'onda' desse movimento novo - foi a assistência judiciária; a segunda dizia respeito às reformas tendentes a proporcionar representação jurídica para os interesses "difusos", especialmente nas áreas de proteção ambiental e do consumidor; o terceiro - e mais recente - é o que nos propomos a chamar simplesmente "enfoque de acesso à justiça" porque inclui os posicionamentos anteriores, mas vai muito além deles, representando, dessa forma, uma tentativa de atacar as barreiras ao acesso de modo mais articuloso e compreensivo. (CAPPELLETTI; GARTH, 1988, p. 31)

Na doutrina brasileira, defende Watanabe (1988, p. 128) que a problemática do acesso à justiça merece ser analisada em atenção às esferas socioeconômica e política do País, devendo ser ajustada à realidade social. Por isso, ela não pode ser desenvolvida de modo alheio à realidade forense, "[...] não pode ser estudada nos acanhados limites do acesso aos órgãos judiciais já existentes”. Esse também é o entendimento de Almeida (2010, p. 171), para quem se requer a análise do acesso à justiça “[...] para além do Judiciário”, não só analisado como direito de ingresso ou de respeito aos princípios constitucionais, mas especialmente como direito a um processo de resultados, “[...] direito constitucional fundamental de obtenção de um resultado adequado da prestação jurisdicional”.

A partir dessa perspectiva doutrinária adotada, podemos enquadrar a conciliação como destaque do acesso à justiça por ser uma efetiva forma de solução de conflitos, atenta à razoável duração do processo e alternativa à jurisdição (terceira onda renovatória de CAPPELLETTI e GARTH), bem como por estar atenta à realidade social vivenciada pelas partes (união entre praxis e nomos).

Na conciliação, a solução do problema é próxima da realidade vivenciada pelas partes porque parte da vontade dos próprios sujeitos envolvidos no conflito, diante de uma intervenção de um terceiro. Assim, frente a uma argumentação em torno do problema, junto ao terceiro interveniente (magistrado em atividade jurisdicional de conciliação), as partes vão atentar para as suas responsabilidades na questão, aprendendo (educação como missão/empoderamento), além de compor total ou parcialmente a sua pretensão em prol de um convívio mais justo e mais harmônico.

A conciliação judicial, em especial aquela que possa ser obtida logo no início do iter procedimental, é extremamente interessante, por razões de funcionalidade do próprio sistema e, também, porque atende aos princípios da celeridade e efetividade, tão importantes quando se trata de tutela jurisdicional desejável. 
Por outro lado, a conciliação recupera faixas contenciosas que ficariam em estado potencial (as chamadas pequenas causas). E, uma vez que atenua a pressão numérica dos processos judiciais, contribui para reduzir o tempo de tramitação global dos processos, preservando a qualidade da atuação dos organismos judiciários.

Sempre que as partes estão envolvidas em relações multiplexas, isto é, relações de múltiplo vínculo (opostas às relações circunstanciais, de vínculo único, que se estabelecem entre estranhos), a continuidade das relações por sobre o conflito tende a criar um peso estrutural a cujo equilíbrio só a conciliação pode adequar. (SENA, 2007, p. 144)

Afirma-se, portanto, que a conciliação prima pela solução do problema colacionado ao Poder Judiciário, colaborando para a não continuidade conflituosa, bem como do desgaste processual pelas partes e de eventuais atos processuais protelatórios, o que atende a preceitos constitucionais, especialmente aqueles concernentes à efetividade e razoável duração do processo. A conciliação bem conduzida prima por resultados práticos, factíveis na realidade forense e voltados à consolidação de uma cultura voltada à paz.

\section{Princípio da indisponibilidade e sua aplicação no caso concreto frente ao princípio da conciliação}

As regras dispositivas são exceções no Direito do Trabalho, em harmonia com o princípio da imperatividade. Dessa feita, a limitação da autonomia da vontade é necessária porque as garantias do trabalhador esvaziar-se-iam não fosse a restrição para abdicar o direito, haja vista o desnível criado com a relação de emprego.

Despontando como projeção da imperatividade segundo boa parte da doutrina, o princípio da indisponibilidade informa que o empregado não pode abrir mão de um direito que lhe confere proteção, quer previsto em norma jurídica, quer no contrato, por sua simples manifestação de vontade, tendo em vista o desequilíbrio de ordem econômica, social e cultural entre os sujeitos da relação empregatícia.

Conquanto seja vedado ao trabalhador despojar-se de seus direitos, há meios de disposição previstos, dentre os quais a prescrição, a decadência, a renúncia, a transação e, é claro, a conciliação, acerca do que surge acirrado debate.

Para DELGADO, as definições da renúncia e da transação são traçadas da seguinte forma: 
Renúncia é ato unilateral da parte, através do qual ela se despoja de um direito de que é titular, sem correspondente concessão pela parte beneficiária pela renúncia. Transação é ato bilateral (ou plurilateral), pelo qual se acertam direitos e obrigações entre as partes acordantes, mediante concessões recíprocas (despojamento recíproco), envolvendo questões fáticas ou jurídicas duvidosas (res dubia). (DELGADO, 2010, p. 200)

Nessa linha de pensamento, a renúncia é permitida em situações excepcionais no Direito do Trabalho, expressamente previstas em lei, fazendo-se necessário verificar se os clássicos requisitos jurídico-formais foram satisfeitos: capacidade do agente, livre manifestação de vontade, forma prescrita ou não defesa por lei.

No intuito de determinar a extensão da indisponibilidade, DELGADO propõe uma distinção entre indisponibilidade absoluta e indisponibilidade relativa. Constata-se a primeira se a proteção do direito envolver interesse público, caso em que será encarado como um padrão civilizatório mínimo, a exemplo das normas de proteção à saúde e segurança do trabalhador, do salário mínimo, etc.

No campo do direito individual do trabalho, a indisponibilidade também é absoluta quando se trata de interesses abstratos de determinada categoria. Já no direito coletivo do trabalho, os direitos consubstanciados em normas que impliquem interesses de certa categoria podem ser transacionados mediante negociação coletiva. A temática referente aos direitos que podem ou não ser transacionados não foi alterada no regime da Lei 13.467/17. Todavia, o espaço da conciliação judicial com a introdução da homologação de avença realizada extrajudicialmentem parece indicar que a nova legislação buscou enfatizar o acordo de vontade das partes. E não é apenas neste ponto da homologação extrajudicial que é possível observar o destaque ao convencionado extrajudicialmente.

Todavia, é inadmissível a renúncia ou transação envolvendo direitos absolutamente indisponíveis, pois o ato tornar-se-á eivado de nulidade absoluta. Em relação à distribuição do ônus da prova, não será necessário que o empregado autor prove a ocorrência de prejuízo, pois que a nulidade é automaticamente declarada pelo Juiz por se tratar de indisponibilidade de direitos, atraindo toda a proteção normativa.

A indisponibilidade relativa, por sua vez, alberga direitos que traduzem interesses individuais ou bilaterais, os quais não correspondem a patamar civilizatório mínimo fixado em dado momento histórico. Somente a transação, não a renúncia, é admitida quando em voga direitos relativamente indisponíveis, desde que não implique prejuízo ao trabalhador, com fulcro no art. 468 da CLT. 
No tocante à validade dos atos de disposição após o rompimento do vínculo empregatício, coerente a seguinte explanação:

\begin{abstract}
Mesmo após a ruptura do contrato, filiamo-nos aos que sustentam que a renúncia do empregado deve ser vista com desconfiança, pelas seguintes razões: em primeiro lugar, pela condição de desempregado, que necessita de recursos imediatos para continuar se mantendo até que obtenha novo emprego; em segundo lugar, pelo temor de enfrentar a demora de uma demanda judicial e, por fim, dada a necessidade de obtenção da carta de referência do antigo empregador para candidatar-se a um novo emprego. (LIMA, Francisco Meton Marques de apud BARROS, 2010, p. 202-203)
\end{abstract}

Portanto, para o referido autor o obreiro só pode renunciar seus direitos em juízo a fím de evitar a ocorrência de fraudes, ao passo que é admitida a transação (justamente por isso denomina o princípio como da irrenunciabilidade), visto que importa em concessões recíprocas, exigindo-se, em determinados casos, a assistência de terceiro.

Conclui-se que só é permitido transacionar se existe res dubia (incerteza do direito) ou qualquer espécie de dúvida na relação jurídica. Ademais, considerando que o objetivo é prevenir conflitos, a conciliação deve ser interpretada restritivamente, sem que implique renúncia. O entendimento esposado não se altera pela Reforma Trabalhista, pois o que inadmite, o autor, é a renúncia que, seja no contrato, seja ao fim da relação empregatícia, deve ser vista com desconfiança.

Depreende-se que, quando se fala em princípio da indisponibilidade dos direitos do trabalhador, a tendência é adotar o posicionamento no sentido de serem inadmissíveis, na ordem justrabalhista, tanto a renúncia, enquanto ato unilateral, quanto a transação que signifique prejuízo ao obreiro. Quando se trata do princípio da irrenunciabilidade, acredita-se que a limitação da autonomia da vontade se refere somente aos atos próprios de renúncia.

NASSIF afirma existir um paradoxo entre a regra de indisponibilidade dos direitos trabalhistas e a adoção de meios de disposição, a exemplo da conciliação judicial e da prescrição. Segundo a autora, as construções perpetradas pela doutrina não tiveram êxito em eliminar o paradoxo, resultando na mitigação do princípio da proteção, basilar do Direito do Trabalho.

Entretanto, torna-se evidente que NASSIF enfoca a conciliação como disposição de direitos, olvidando-se que nos processos judiciais existe "res dúbia". E a dúvida surge, se instala ou opera pela inexistência de provas quanto a existência do direito que seria indisponível, no processo, se o trabalhador não tem nenhuma prova, por exemplo, do salário pago "por fora", os 
reflexos em todas as verbas rescisórias, por exemplo, verbas que seriam indisponíveis, se não se tornam "res dubia", ao menos, não mais possuem o manto da indisponibilidade.

Em uma visão unívoca quanto a indisponibilidade do direito, negando a dimensão processual probatória, o empregado-autor pode ser guindado a uma experiência nefasta de Justiça, pois ao assumir uma postura irrascível direcionada unicamente à litigação, ainda que sem provas, pode ter como resultado de sua demanda a improcedência, o que talvez não seja, a melhor escolha, inclusive por tal análise em contexto de perda financeira, inclusive. A essa altura, valem constar as ponderações de BARROS:

A conciliação não implica necessariamente transação, pois poderá ocorrer de o empregador pagar tudo o que é devido ao empregado, mas, em geral, ela se subsume à transação. (BARROS, 2010, p. 208)

$[\ldots]$

Para finalizar, salientamos que a transação é de grande utilidade social, pois transforma o litígio em estado de paz. Entretanto, é bom lembrar que "transigir não é tudo conceder sem nada receber". (BARROS, 2010, p. 211)

Nesse contexto, deve-se observar que o princípio da indisponibilidade informa a regra geral, sem, contudo, vedar hipóteses de exceção, permissivas da transação, sobre as quais mantém sua força normativa, impondo limitações e requisitos, até porque somente o acordo adequado às partes será homologado pelo Magistrado do Trabalho.

Sem se olvidar da mitigação da aplicação do princípio em voga no processo trabalhista devido à ampliação de competência da Justiça do Trabalho, a disponibilidade terminantemente vedada concerne aos direitos absolutamente indisponíveis, aos direitos incontroversos, àquela conduzida pela vontade exclusiva dos sujeitos ou, ainda, a que causará prejuízos ao trabalhador. Portanto, a conciliação estimulada pelo ordenamento não é a que se presta à desconstrução das garantias ao trabalhador, mas a que representa uma forma mais democrática, justa e ágil de concretizar os direitos assegurados aos empregados pela ordem justrabalhista.

Após essa breve explanação, deve-se ter em mente que parte dos direitos dos trabalhadores pode ser conciliado sob a égide processual trabalhista, em razão da própria natureza principiológica da indisponibilidade. Sendo princípio, cabe ao Magistrado atribuir-lhe um peso e aferir a sua incidência na hipótese vertente. Portanto, frente à incidência concomitante de demais princípios, como o da utilidade social e o da conciliação, cabe ao Magistrado sopesá-los de acordo com as circunstâncias e peculiaridades do caso concreto, atendo-se, principalmente, à proporcionalidade analisada em seu sentido estrito. 
Quando a transação ocorre perante o Estado, o princípio da utilidade social prepondera. O Estado entende que é melhor, politicamente, terminar a lide e que, assim celebrada, a transação não serviu como um instrumento para a derrogação de institutos básicos. A transação judicial está dentro do sistema de legislação social, na medida em que concilia a necessidade de segurança dos negócios com a necessidade de tutela da ordem econômica e social.

Ademais, a unidade do ordenamento jurídico deve sr levada a efeito, pelo que a mitigação da indisponibilidade se justifica para que sejam observados outros princípios de igual ou maior valor que incidam no caso concreto levado ao Poder Judiciário. Como qualquer outro princípio, a indisponibilidade dos direitos dos trabalhadores apenas indica uma diretriz a ser seguida, cabendo uma análise proporcional de sua incidência, que poderá ou não ocorrer à integralidade.

\section{Ativismo judicial e juízo conciliatório trabalhista}

A flexibilização do princípio da indisponibilidade dos direitos do trabalhador é também possibilitada pela superação da imagem do Magistrado como mero expectador do processo. Assim é que, diante da versatilidade e das peculiaridades dos problemas levados ao Judiciário, bem como da impossibilidade de que todo e qualquer conflito fosse resolvido pela subsunção do fato à lei positiva, requer-se do Estado-Juiz uma atuação mais ativa e atenta à realidade das partes e do processo, quando do exercício da jurisdição.

Por conseguinte, afastou-se o brocardo segundo o qual o Juiz é "le bouche de loi" para compreender que a inércia do Magistrado não mais condiz com as perspectivas processuais e materiais contemporâneas, as quais prezam pelo ativismo judicial. Ativismo judicial corresponde, portanto, à postura prática, ativa e participativa do Magistrado no que atine à construção, juntamente com as partes e terceiros interessados, do advento processual. A atividade do Magistrado no processo deixa de ser vislumbrada sob uma perspectiva inerte, de "mero expectador do processo", para se substituir à ativa, de exercício de poderes e faculdades instrutórias e diretivas.

Como postura "pró-ativa" do juiz entende-se uma participação efetiva do juiz na condução do processo, usando seu poder diretivo (formal e material) e suas faculdades instrutórias, sem se afastar, é claro, da condição e garantia que as partes têm de ter um Juiz imparcial.

No Estado Democrático de Direito, a jurisdição merece ser analisada sob uma perspectiva ampla, e não meramente simplória, quer de "atuação da vontade concreta da lei" 
(CHIOVENDA), quer de "justa composição da lide" (CARNELUTTI). A atividade jurisdicional envolve também, dentre outras atividades, a uniformização de jurisprudência, a criação de súmulas vinculantes e a própria ênfase ao acesso à justiça. Preza-se por enfoques tanto formais quanto materiais do direito, pelo que se requer uma atuação judicial pró-ativa, que permita a construção do processo em conjunto pelas partes e pelo Magistrado, com o fito de resolver o conflito de maneira mais econômico-processual e condizente com a realidade fática vivenciada por aquelas.

Sem dúvida, a conciliação judicial permite essa postura pró-ativa do juiz, uma vez que resulta da participação e colaboração conjunta do juiz-conciliador e das partes no advento processual. Aliás, não bastasse a concepção doutrinária em prol do ativismo judicial, a própria legislação trabalhista, especificamente os artigos 764, 831, 850 e 852-E da CLT, determina a obrigatoriedade de tentativa de conciliação pelo Juiz para resolução do conflito, o que facilmente rechaça a concepção de Magistrado como mero aplicador da lei ao caso concreto, vislumbrando-o também como pacificador social.

Assim é que se deve falar na possibilidade de realização da justiça social pelo Poder Judiciário, uma vez que é permitido ao Magistrado adequar a amplitude e conteúdo da norma à situação concreta, pelo uso, por exemplo, da equidade. É o que prontifica GAJARDONI:

\footnotetext{
Com efeito, o juiz, na atividade de julgar, define o alcance dos comandos normativos, convertendo-os de gerais/abstratos em individuais/concretos, impondo, ainda, sanções coativas, nos casos de violação. $\mathrm{O}$ julgador, na atividade de conciliar, define às partes o conteúdo e alcance das normas, encaradas sob um prisma de equidade, não as impondo, mas persuadindo-as à observação espontânea. No julgamento da ação, vige o princípio da legalidade estrita, não havendo campo para inovações. Entretanto, no exercício da atividade conciliatória, age o magistrado livremente, por equidade, o que demonstra que, no exercício dessa função, os poderes/deveres do juiz são ainda maiores. (GAJARDONI, 2003, p. 142-143)
}

Cumpre salientar que os Magistrados possuem cautela e experiência jurídica suficientes para saber analisar toda a conjuntura processual, inclusive a adequação ou não da conciliação num caso concreto. Com efeito, a forma de investidura, as responsabilidades e atribuições do cargo da Magistratura exigem do profissional conhecimento jurídico e social necessário para a análise de cada caso concreto. Por isso, como importantes agentes na formação da solução do conflito, não são meros homologadores de acordos e não pretendem o acordo a qualquer custo. 
Inexorável a conclusão de que o Juiz do Trabalho não é um mero "homologador passivo" de todo e qualquer acordo que lhe seja submetido pelos litigantes (arts. 125, III, e 129 do CPC). Na homologação que corresponde ao ato judicial praticado pelo Juiz do Trabalho, compete-lhe avaliar com percuciência e profundidade pertinente a forma e o conteúdo que lhe estão sendo submetidos. Tudo de modo a assegurar livre e consciente manifestação da vontade das partes e, também, para evitar ofensas a normas de ordem pública, assegurando a presença de uma genuína transação.

NICACIO relembra que o Poder Judiciário “...continua a "enviar mensagens” ao público de cidadãos no que concerne à forma a partir da qual alguns temas e domínios são interpretados pelo direito oficial e suas autoridades constituídas" e isso também se aplica à conciliação. Prossegue a autora que essas "mensagens", "desveladas no seio da cena social, prestam-se a refundar a maneira segundo a qual os cidadãos, público da justiça, mas também atores de direito, continuarão a tratar os conflitos e influenciar suas decisões no que toca às estratégias a adotar para a gestão da vida em sociedade."

\section{Audiências, conciliação e jurisdicionados}

Inicialmente, buscou-se o entendimento da doutrina sobre a situação-problema da pesquisa, analisando as diversas concepções acadêmicas dos institutos estudados, quais sejam: o princípio da indisponibilidade e a conciliação, especialmente a judicial. Assim, foram analisadas diversas obras de autores renomados e conhecidos no meio jurídico-acadêmico, bem como colhidos dados estatísticos, elaborados por órgãos públicos, para que, partindo da hipótese apresentada, fosse complementada a fundamentação e conclusão da pesquisa.

Os efeitos da situação-problema na conjuntura social e na praxe forense, foram analisados em audiências na Justiça do Trabalho, em Belo Horizonte. Aproximando-se do público, foi possível examinar as questões psicológicas verificadas no universo da prática conciliatória e verificar como e até qual ponto a análise doutrinária se compatibilizava com a realidade forense.

Dessa forma, com o propósito de evidenciar os aspectos pragmáticos da conciliação judicial, foram analisadas as conclusões obtidas a partir de casos concretos observados em audiências, com os quais foi possível perscrutar motivação das partes.

Em geral, observou-se que os empregados não compareceram à primeira audiência, predeterminados a firmar um acordo. No entanto, oferecida a proposta pelo empregador e feitas 
as negociações, surge o interesse em conciliar, tendo o Magistrado advertido sobre os benefícios e vantagens obtidas, ainda que não atendida a integralidade das pretensões.

Já os empregadores pesquisados, em sua maioria, disseram que vão ao Poder Judiciário com o intuito de conciliar, em razão das benesses que a conciliação lhes proporciona. Outros dizem que a possibilidade de previsão do acordo depende do caso concreto e do perfil do Magistrado condutor da audiência.

Foi constatado que as propostas de conciliação que partiam dos empregados eram de valor excessivamente elevado, ao passo que as propostas dos empregadores, de valor baixo, notadamente irrisório em relação ao pedido inicial. Com o advento da audiência conciliatória, após a atuação conciliatória do Magistrado, especialmente por meio da confecção de cálculos balizadores do risco para as partes e da atuação das próprias partes, o valor acordado aproximava-se de média dos dois valores apresentados frente aos riscos calculados.

As partes apresentaram diversos benefícios que justificaram a feitura do acordo entre elas, dentre os quais convém citar: 1) a natureza célere da conciliação, de trazer mais rápido a solução do problema, evitando o desgaste psicológico; 2) o fato de a natureza das verbas guerreadas em juízo serem de cunho alimentar, pelo que o trabalhador precisa do dinheiro de forma mais rápida possível; 3) o afastamento de quaisquer riscos de um provimento jurisdicional que não lhes sejam favoráveis, haja vista a existência de entendimentos doutrinários e judiciais diferentes sobre as questões acordadas; 4) a redução de gastos, evitando o dispêndio de verbas com o trâmite processual; 5) a possibilidade de parcelamento do débito pelo empregador; 6) a possibilidade de o empregado ser recontratado posteriormente pelo empregador, evitando um litígio entre eles, eis que a conciliação é uma solução amigável; 7) razões tributárias, porquanto, quando da conciliação, permite-se às partes acordar como e quando pagar, sem que haja imediata retenção de imposto de renda na fonte.

Vale ressaltar que a atuação do advogado é positiva para a conciliação, na medida em que o fato de a parte remoer previamente as informações, dicas, questões favoráveis e desfavoráveis envolvidas no processo possibilita que decida com maior segurança, no momento da audiência, se aceitará ou não a proposta formulada pela parte contrária, especialmente no que tange ao valor oferecido. O conhecimento desses subsídios fornecidos ao cliente pelo advogado antes da ocorrência da audiência contribui para elevar a probabilidade e o grau de satisfação da parte com a conciliação a ser realizada, reduzindo proporcionalmente as chances de arrependimento.

A participação dos advogados de forma ativa na condução da negociação, dentro e fora da audiência, foi fator impactante observado. Se não há tal atuação e se o magistrado também 
não atua com tal diretiva, a possibilidade da transação fica esmaecida, até porque, como se salientou, nem sempre a primeira opção é a conciliação, considerando a cultura de litigação que ainda marca a sociedade brasileira e que as normativas e sua alterações (CLT, Res. 125/2010 CNJ, CPC/2015, Lei da Mediação, v.g.) se direcionam a fazer frente.

As conclusões desta pesquisa corroboram alguns aspectos que foram apresentados por NASSIF, para quem a conciliação na Justiça do Trabalho é possibilitada por diversas razões, inclusive aquelas extrínsecas ao conflito em concreto e à relação jurídica travada. Verificou-se que a conciliação não permite um ambiente tão propício à fraude, exatamente porque há a participação e o controle do Magistrado quando da celebração do acordo. Novamente, ressaltase a sabedoria do sistema processual publicista e equalizador previsto na Consolidação das Leis do Trabalho. Ademais, o acordo também pode vir a ser controlado pelo Ministério Público, quando de sua atividade fiscalizatória ou até judicial.

Por fim, não se pode olvidar do importante papel exercido pelo Juiz, na atividade jurisdicional de conciliação no transcorrer da audiência, estimulando a realização do acordo e intervindo para assegurar a razoabilidade dos termos e valores fixados. Nesse sentido, deve o Magistrado atentar para qual o tipo de solução de controvérsias que garanta o efetivo acesso à justiça por parte dos jurisdicionados, bem como o tratamento adequado voltado a concretude dos direitos fundamentais sociais.

\section{Conclusão}

O sistema jurídico brasileiro deve ser interpretado como um todo unitário, sistêmico e coerente, em prol da consolidação e efetividade de suas normas. Assim, nenhum primado pode ser aplicado e entendido com viés absoluto, devendo a análise de sua incidência ser feita em cada caso concreto, de maneira proporcional e atenta aos aspectos teleológicos da norma.

Assim, cabe ressaltar que a aplicação ponderada dos princípios da indisponibilidade e da conciliação, o ativismo judicial e a equidade são algumas das razões que justificam a análise do princípio da indisponibilidade dos direitos dos trabalhadores frente a conciliação. Acrescenta-se que a conciliação coaduna com a égide constitucional brasileira, que pretende cada vez mais ressaltar a efetividade e duração razoável do processo, bem como fortalecer o acesso à justiça, de modo a fazer com que cada parte compreenda e participe da decisão prolatada, em verdadeira atenção ao princípio da cooperação, sendo o processo construído pelo autor, pelo Juiz e pelo réu conjuntamente, em prol de uma justiça não meramente formal, mas especialmente material. A participação do Magistrado na audiência, exercendo juízo 
conciliatório na lide proporciona a garantia de que não haverá renúncia a direitos indisponíveis, nem muito menos formulação de cláusulas abusivas ou aviltantes para qualquer das partes.

Por fim, diante de uma análise concreta, vislumbrou-se que as partes se conciliam por acreditar que a conciliação é uma forma benéfica de resolução de conflitos, atenta à razoável duração do processo e que lhes possibilita conjuntamente construir a solução do litígio. Em sua maioria, saem satisfeitas da Justiça Especializada do Trabalho por observar que as benesses e os efeitos da conciliação extrapolam - e em muito - os aspectos endoprocessuais, findando o conflito não apenas numa dimensão formal-processual, mas também em seus aspectos econômicos, sócio-familiares, dentre outros, que extrapolam a relação jurídica travada no Judiciário e que não seriam logrados com a atividade jurisdicional clássica de prolação de uma decisão final frente a um caso concreto.

\section{Referências bibliográficas}

ALEXY, Robert. Teoria dos direitos fundamentais. São Paulo: Malheiros, 2008.

ALMEIDA, Gregório Assagra de. Teoria crítica do direito e o acesso à justiça como novo método de pensamento. In SALIBA, Aziz Tuffi, GOMES JÚNIOR, L M e ALMEIDA G A (Coords.). Direitos fundamentais e sua proteção nos planos interno e internacional. Belo Horizonte: Arraes Editores, 2010.

BARROS, Alice Monteiro de. Curso de direito do trabalho. 5. ed. rev. e ampl. São Paulo: LTr, 2009.

CAPPELLETTI, Mauro; BRYANT, Garth. Acesso à justiça. Tradução de Ellen Gracie Northfleet. Porto Alegre: Sérgio Antonio Fabris Editor, 1988.

CHIOVENDA, Giuseppe. Instituciones de derecho procesal civil. (Conceptos

Fundamentales La Doctrina de Las Acciones; v. 1). Tradução de E. Gómez Orbaneja. Madrid: Editorial Revista de Derecho Privado, 1948

DELGADO, Mauricio Godinho. Curso de direito do trabalho. 17. ed. São Paulo: LTr, 2018. 
Arbitragem, mediação e comissão de conciliação prévia no direito do trabalho brasileiro. In RENAULT, L O L; VIANA, M T (Coords.). Comissões de conciliação prévia: quando o direito enfrenta a realidade: análises críticas em memória de Alaor Satuf Rezende. São Paulo: LTr, 2003.

DWORKIN, Ronald. Levando os direitos a sério. Tradução de Nelson Boeira. 2. ed. São Paulo: Martins Fontes, 2007.

GAJARDONI, Fernando da Fonseca. Técnicas de aceleração do processo. São Paulo: Lemos \& Cruz, 2003.

GIGLIO, Wagner. A conciliação nos dissídios individuais do trabalho. São Paulo: LTr, 1982.

LEITE, Carlos Henrique Bezerra. Curso de direito processual do trabalho. 15. ed. São Paulo: LTr, 2017.

MARTINS, Sérgio Pinto. Direito do trabalho. 21. ed. São Paulo: Atlas, 2005.

Direito processual do trabalho: doutrina e prática forense; modelos de petições, recursos, sentenças e outros. 25. ed. São Paulo: Atlas, 2006.

NASSIF, Elaine Noronha. Conciliação judicial e indisponibilidade de direitos: paradoxos da "justiça menor" no processo civil e trabalhista. São Paulo: LTr, 2005.

NICACIO, C S. Direito e mediação de conflitos: entre a metamorfose da regulação social e a administração plural da justiça. REVISTA FDUFMG. Belo Horizonte, n.59, 2011. ISSN Eletrônico: 1984-184. Disponível em: <https://www.direito.ufmg.br/revista/index.php/ revista/article/view/148>. Acesso em 28 nov. 2018.

SENA, Adriana Goulart de. Juízo conciliatório trabalhista. Belo Horizonte: Revista do Tribunal Regional do Trabalho da $3^{\text {a }}$ Região, v. 45, n. 75, p. 139-161, jan./jun. 2007. 
SENA, Adriana Goulart; RENAULT, L O L; VIANA, M T; CANTELLI, P O (Coords.).

Processo do trabalho atual e temas conexos. Belo Horizonte: Mandamentos, 2004.

SENA, Adriana Goulart de. Resolução de conflitos e acesso à justiça: efetividade material e judicial. In SENA, Adriana Goulart de; DELGADO, G N; NUNES, R P (Coords.). Dignidade humana e inclusão social: caminhos para a efetividade do direito do trabalho no Brasil. São Paulo: LTr, 2010.

THEODORO JÚNIOR, Humberto. Curso de direito processual civil: teoria geral do direito processual civil e processo de conhecimento. V. 1, Rio de Janeiro: Forense, 2008.

. Os princípios do direito processual civil e o processo do trabalho. In BARROS, Alice Monteiro de (Coord.). Compêndio de direito processual do trabalho. São Paulo: LTr, 2002 .

WATANABE, Kazuo. Acesso à justiça e sociedade moderna. In GRINOVER, A P; DINAMARCO, C R; WATANABE, K (Coords.). Participação e processo. São Paulo: Editora Revista dos Tribunais, 1988. 


\title{
A LEGITIMIDADE DO CONSENSO NA MEDIAÇÃO DE CONFLITOS: ANÁLISE REFLEXIVA NO CONTEXTO JURÍDICO BRASILEIRO
}

\author{
Carla Maria Franco Lameira Vitale \\ Universidade Federal de Sergipe \\ Luciana Aboim Machado Gonçalves da Silva \\ Universidade Federal de Sergipe
}

\begin{abstract}
Resumo
Entre os métodos consensuais de resolução de conflitos, a mediação destaca-se por melhor trabalhar a autonomia de vontade dos envolvidos, especialmente em situações com vínculo anterior e previsão de relacionamento continuado. É considerada, também, uma forma eficaz de obtenção da pacificação social, através do estímulo à comunicação produtiva. Nessa trilha, pretende-se evidenciar os pressupostos da comunicação não violenta, bem como as técnicas de mediação, aptas a empoderar os envolvidos para a construção da melhor solução. Propõe-se reflexão quanto à legitimidade do consenso no judiciário brasileiro, sobretudo quanto às circunstâncias em que o efetivo acesso à justiça será alcançado.
\end{abstract}

Palavras-chave: mediação, empoderamento, comunicação, legitimidade, consenso.

\section{Abstract/Resumen/Résumé}

Among the consensual methods of conflict resolution, the mediation stands out by better working the autonomy of will of those involved, especially in situations with previous link and prediction of continued relationship. It is also considered an effective way to obtain social pacification through the stimulus to productive communication. In this way, it is intended to highlight the assumptions of non-violent communication, as well as mediation techniques, able to empower those involved to build the best solution. It is proposed to reflect on the legitimacy of consensus in the Brazilian judiciary, especially regarding the circumstances in which the effective access to justice will be achieved.

Keywords/Palabras-claves/Mots-clés: mediation, empowerment, communication, legitimacy, consensus. 


\section{Introdução}

Como método autocompositivo de resolução de conflitos, a mediação diferencia-se dos demais por privilegiar a participação dos envolvidos como responsáveis pela melhor solução a ser construída, ensejando maior satisfação das partes e a pacificação social. Dessa forma, busca atender os interesses, necessidades e sentimentos relacionados aos envolvidos no conflito, a partir do estímulo a uma comunicação produtiva.

Com o presente estudo, pretende-se analisar o contexto em que a mediação foi introduzida no cenário jurídico brasileiro, que tratatava somente da conciliação, a exemplo da Consolidação das Leis Trabalhistas - CLT, da Lei Complementar 75/93 do Ministério Público da União e também da Lei n. 9.099/95, que trata dos Juizados Especiais e que, naquele momento, primaram pela celeridade e meio de desafogar o Judiciário, sem que houvesse maior preocupação com a técnica e formação do conciliador.

Como forma de promessa de pacificação social e com uma preocupação voltada à humanização das relações, a mediação começa a ser difundida como política pública, junto ao poder Judiciário, por orientação do Conselho Nacional de Justiça, através da Resolução n. ${ }^{\circ}$ 125/2010, na qual houve o estímulo à criação de Centros Judiciários de Solução de Conflitos e Cidadania (Cejusc's), bem como de Núcleos Permanentes de Métodos Consensuais de Solução de Conflitos nos Tribunais brasileiros (Nupemec's), a fim de repaginar a conciliação e, sobretudo, introduzir a mediação como método adequado para trabalhar o conflito, com foco na capacitação dos facilitadores.

Em decorrência desse movimento, o instituto da mediação foi objeto de legislação específica, através da Lei n. 13.140/2015, em vigor desde dezembro de 2015, como também foi recentemente positivado no atual Código de Processo Civil, em vigência desde março de 2016, o qual evidenciou as formas consensuais, em especial a conciliação e a mediação, reservandolhes capítulo específico e elevando-as à categoria de norma fundamental.

A mediação também mereceu destaque na Resolução 118/2014, do Conselho Nacional do Ministério Público, na qual há o fomento pela mediação comunitária e escolar, como também na Resolução 225/2016 do Conselho Nacional de Justiça, onde a mediação vítima-ofensor ganha relevo pelo seu forte viés restaurativo e na Resolução 174/2016, do Conselho Superior da Justiça do Trabalho, que dispõe sobre a política judiciária nacional de tratamento adequado de disputas de interesses no âmbito do Poder Judiciário trabalhista. 
Aliado a todo esse fomento aos métodos autocompositivos, com ênfase para a mediação, necessário se faz evidenciar o papel da comunicação, como fundamento necessário para empoderar os indivíduos a construir consensos que atendam a justiça de cada um e que, dessa forma, promova o efetivo acesso à justiça, capaz de alcançar a dignidade humana e os valores de um processo justo.

Para perseguir tal intento, salutar se faz pesquisar de que forma os aspectos práticos da comunicação não-violenta servem como instrumento de diálogos construtivos, em especial, através do estudo de técnicas promotoras de mudanças no comportamento dos envolvidos no conflito, ao tempo em que se propõe uma análise reflexiva do papel do Judiciário nesse contexto.

O mediador, que deverá ser devidamente capacitado e possuir habilidades técnicas e cognitivas, será o agente garantidor do equilíbrio de poder entre os envolvidos, de maneira a proporcionar o empoderamento igualitário das partes e, dessa forma, garantir a legitimidade do consenso.

Para o desenvolvimento desta pesquisa, utilizar-se-á o método teórico-bibliográfico, através da análise de livros, artigos, revistas científicas, dissertações, entre outros, em meio impresso ou digital, a fim de demonstrar que a mediação, quando bem conduzida, através de técnicas autocompostivas, baseadas na comunicação não violenta, é o método de tratamento de conflitos que promove o empoderamento dos envolvidos e os torna aptos a construírem consensos legítimos.

\section{A comunicação não violenta como instrumento de promoção da transformação do conflito através da Mediação}

A concepção negativa do conflito é algo que vem sendo evidenciado ao longo da existência humana, de forma que a ideia de competição é inerente ao seu sentido, o que faz com que reflexões acerca dessa tema ganhem cada vez mais propriedade. Para Deutsch (2004, p. 35), há uma confusão de sentidos, como se vê:

Apesar de toda competição produzir um conflito, nem todo conflito reflete uma competição. Esta implica uma oposição entre os objetivos das partes interdependentes, de maneira que a probabilidade de uma parte alcançar sucesso diminui à medida que a da outra parte aumenta. Em um conflito que provém de competição, as ações incompatíveis refletem objetivos também incompatíveis. 
Conforme o autor, pode-se afirmar que, na maioria dos contextos conflituosos, as partes se posicionam como adversárias e vencer a disputa torna-se o único objetivo dos envolvidos. Por esse motivo, a palavra "conflito" recebe uma conotação pejorativa, na maioria das vezes em que é referida.

É sob essa perspectiva que Deutsch (2004, p. 41) distingue os conflitos destrutivos e construtivos. As consequências de um conflito serão destrutivas quando algum de seus participantes sentem que perderam; enquanto que as consequências serão produtivas quando o resultado implica satisfação de todos os envolvidos no contexto conflitivo.

Esse mesmo autor define os processos cooperativos e competitivos, no que concerne aos seus efeitos ao dizer que:

(...) o ponto central das diferenças entre cooperação e competição residia na natureza da forma pela qual se dá a ligação entre os objetivos dos participantes em cada situação. Em uma situação cooperativa, os objetivos estão tão ligados que todos "afundam ou nadam" juntos, enquanto que, na situação competitiva, se um nada o outro deve afundar. (DEUTSCH, 2004, p. 42).

Na mesma linha de pensamento Vezzulla (2013, p. 74) expõe que só haverá a satisfação de todos por igual quando for garantida a coparticipação e corresponsabilidade dos envolvidos na situação fática.

Para Radulescu (2012, p. 280): " If the conflicts are resolved constructively they create a satisfactory outcome for all parties and improve the relationship between opposing parties and the ability to resolve future conflicts in a constructive way ${ }^{1 "}$. Parte-se do pressoposto de que de trabalhar os conflitos de forma construtiva é essencial para que futuras controvérsias sejam, da mesma forma, melhor solucionadas.

A partir dessa ideia, pode-se concluir que em situações onde há cooperação na busca da melhor solução para a controvérsia, há uma soma de esforços, de maneira que todos serão responsáveis pelo resultado obtido. Assim, haverá uma maior percepção de que o conflito, se bem trabalhado pelos envolvidos, pode ser visto como algo positivo.

\footnotetext{
${ }^{1}$ Se os conflitos são resolvidos de forma construtiva, eles criam um resultado satisfatório para todas as partes e melhoram a relação entre as partes opostas e a capacidade de resolver futuros conflitos de uma forma construtiva. (tradução livre).
} 
A mediadora Lisa Parkinson (2016, p. 32) analisa o conflito em si com algo nem positivo nem negativo, "é uma força natural necessária ao crescimento e transformação das relações humanas." Para a autora, a depender da maneira como o conflito é tratado, a energia por ele fará com que seja produzida uma energia construtiva ou destrutiva.

No mesmo sentido é o pensamento de Azevedo (2013, p. 41), quando expõe: "a partir do momento em que se percebe o conflito como um fenômeno natural na relação de quaisquer seres vivos é que é possível se perceber o conflito de forma positiva". É essa a proposta trazida pela "Moderna Teoria do Conflito".

De forma prospectiva, Lederach $(2012$, p.21), nos anos 80, começou a utilizar a expressão "transformação de conflitos", com ideias baseadas na importância de se construir relacionamentos e estruturas sociais com foco no respeito aos direitos humanos e à vida. Buscou examinar o conflito sob uma abordagem transformativa, nos seguintes termos:

\begin{abstract}
A Transformação de Conflitos é mais do que um conjunto de técnicas específicas; é um modo de olhar e ao mesmo tempo enxergar, tanto para olhar como para enxergar precisa de lentes. Portanto, a transformação de conflitos sugere um conjunto de lentes pelas quais conseguiremos enxergar o conflito social.
\end{abstract}

Dessa forma, o conflito pode ser trabalhado de forma mais restrita, ao tratar questões pontuais apenas, ou de forma ampla, quando interesses subjacentes, sentimentos e todo o aspecto sociológico será estimulado. É o que Lederach (2012, p.15) denomina de "resolução" e "transformação" do conflito, respectivamente.

Para Lederach (2015, p. 16-17), o termo "resolução" significa uma tentativa de se livrar do conflito, sem a preocupação com os aspectos relevantes que merecem ser trabalhados, a partir de reações construtivas entre os envolvidos, para que haja mudanças também construtivas. Assim, o conflito pode ser visto como um "motor de mudanças", através do qual constrói-se "relacionamentos e comunidades saudáveis, tanto local como globalmente".

Nesses termos, o conflito, quando bem trabalhado em sua amplitude, pode ser um mecanismo promotor de mudanças construtivas. A obtenção de um acordo ao final de uma demanda, muitas vezes resolve determinada questão pontual, mas deixa em aberto outras questões que, eventualmente, retornarão ao conflito em momento posterior.

Vezzulla (2013, p. 74) ressalta que quando as necessidades de todos os conflitantes não são reconhecidas e atendidas, eventuais soluções só serão cumpridas pela ameaça ou uso da violência, e questões que circundam o mesmo problema voltarão a tona, em forma de revanche por quem ficou insatisfeito. 
Corrobora com esse entendimento Tartuce (2016, p. 17), quando esclarece que "muitas vezes o impasse tem fases e só é efetivamente superado após uma série de experiências vividas ao longo do tempo pelos envolvidos. Sobreleva aqui a já mencionada noção de "transformação do conflito".

Ainda segundo Lederach $(2015$, p.32; 46), para que o conflito migre do seu estado destrutivo para o construtivo, é preciso que sejam estimuladas as capacidades de ver, compreender e reagir a todas as questões que envolvem o contexto relacional e de mudança em curso. O movimento transformativo foca os aspectos dinâmicos do conflito social, como uma oportunidade e incentivo a processos de mudança criativos.

Nesse contexto, pode-se afirmar que a transformação do conflito está intimamente vinculada ao conceito de "comunicação não violenta", por promover uma oportunidade de abordagem mais ampla das questões que o envolvem, a partir de uma linguagem construtiva, na busca de soluções legítimas.

Ao utilizar-se da comunicação não violenta nas interações uns com os outros, colocamo-nos em nosso estado compassivo natural. Dessa forma, alcança-se uma abordagem que se aplica de maneira eficaz a todos os níveis de comunicação e a diversas situações, a exemplo dos relacionamentos íntimos, relações familiares, escolas, organizações e instituições, terapia e aconselhamento, negociações diplomáticas e comerciais, disputas e conflitos de toda natureza. (ROSENBERG, 2006, p. 27).

Esse modelo de comunicação contém alguns pressupostos fundamentais: "observar sem avaliar", "expressar como nos sentimos", o "reconhecer as necessidades que estão por trás de nossos sentimentos" e "perceber o que gostaríamos de pedir aos outros". Rosenberg (2003, p. 76) entende que a percepção de sentimentos é o primeiro passo para que se consiga conectar uns com os outros, através da identificação de emoções próprias. A comunicação não violenta permite a distinção entre a expressão de sentimentos verdadeiros de palavras e afirmações descritivas de pensamentos, avaliações e interpretações.

A utilização de uma linguagem positiva, clara e de ações concretas, além da preocupação com o que o ouvinte está sentindo e pensando é o caminho a ser trilhado para uma comunicação não violenta, capaz de demonstrar empatia, sinceridade e cuidado com quem se interage. (ROSENBERG, 2003, p. 106-107).

Como visto, a comunicação, quando bem trabalhada, é o vetor principal para que aspectos positivos do conflito sejam extraídos e desenvolvidos. Constata-se que o conflito está inserido no contexto das relações interpessoais, de maneira que se torna necessário saber como melhor administrá-lo, a fim de que se possa filtrar experiências positivas, que sirvam de 
experiência para o crescimento pessoal dos envolvidos.

É o que pontua Luciana Aboim Silva (2013, p. 166), quando afirma que o mediador, através do conhecimento das técnicas, deve ter habilidade para identificar os interesses reais trazidos ao conflito pelos envolvidos e criar "condições para promoção do diálogo entre as partes, o restabelecimento da comunicação e a transformação do conflito".

A mediação de conflitos está inserida entre os métodos autocompositivos de tratamento de conflitos e, como tal, diferencia-se dos demais por trabalhar o conflito e todas as possíveis ramificações advindas das questões principais, com ênfase nos interesses e necessidades de todos os envolvidos. Assim, a comunicação deve ser o foco principal a ser trabalhado pelo mediador, de maneira a atingir um nível de igualdade e reconhecimento recíproco que torne possível a construção da melhor solução.

Nesse sentido, Warat (2001, p. 9) salienta que a mediação tem como escopo intervir basicamente no aspecto emocional, a fim de transformar a relação conflituosa em algo saudável, a partir da compreensão do conflito em sua amplitude. Para tanto, deve-se compreender os desejos e interesses das partes, para que seja possível perceber o conflito como algo positivo e estimular o aumento de cooperação entre as partes.

Para que esse objetivo seja alcançado, é salutar que a comunicação promova igualdade de forças entre os envolvidos, para que, de forma isonômica, os interesses sejam convergentes, de forma a preservar a legitimidade do consenso alcançado. Assim, o mediador dever ter habilidade para rechaçar possíveis desequilíbrios de poder entre os mediandos e evitar acordos insatisfatórios.

Lisa Parkinson (2016, p. 320) evidencia que: "Os mediadores precisam demonstrar uma combinação de empatia e de firmeza na gestão de desequilíbrios de poder e, caso tais questões tornem o processo insustentável, a mediação deve ser interrompida".

Sarlet (2012, p. 101) pontua, inclusive, que o conteúdo da dignidade humana integra a garantia de uma identidade pessoal dos indivíduos, bem como o direito de autodeterminação sobre os assuntos que dizem respeito a sua esfera particular.

Nesse aspecto, numa sociedade eminentemente litigante, o papel da mediação ganha relevo ao estimular e educar a sociedade para que, de forma autônoma e legítima, transforme seus próprios conflitos.

Destarte, Alessandra Pera (2011, p. 2-5) pontua que a passagem do modernismo para o pós-modernismo é caracterizado pela mudança de perspectiva das funções institucionais do Judiciário, imprimindo relevo aos métodos autocompositivos, posto que enfatiza "a importância e a centralidade do consenso nos procedimentos de solução da controvérsia, o valor da 
autorealização, a legitimação ética e a superioridade qualitativa do acordo em relação à decisão judicial". Ressalta, ainda, que a nível europeu, os mecanismos de resolução de controvérsias estão sendo incentivados pela Recomendação da Comissão Europeia, de 30 de março de 1998 e de 04 de abril de 2001, bem como na Diretiva n. 52/2008/CE.

\section{O Judiciário brasileiro como protagonista do fomento à mediação de conflitos: preocupações reflexivas quanto à legitimidade do consenso}

Como já visto, os processos de resolução de conflitos foram definidos por Deutsch (2004, p. 41) como construtivos ou destrutivos. No primeiro, ocorre o fortalecimento da relação social preexistente à demanda; enquanto no segundo há o rompimento ou enfraquecimento das relações sociais outrora existentes.

Nesse toar, os métodos autocompositivos, em especial a mediação, por trabalhar o conflito de maneira mais profunda, é a que mais se aproxima da plena satisfação das partes, por valorizar as necessidades, interesses e sentimentos dos envolvidos, a fim de restabelecer laços eventualmente rompidos, os empoderando em busca do efetivo acesso à justiça das partes.

De forma crítica, Owen Fiss (2007, p.131 apud Jobim, 2016, p.75) pontua que: "Ainda, há que ser recordado que uma das questões negativas que existe em meios que apontam serem ditos como conciliatórios de conflitos é a questão do desequilíbrio de poderes".

Jobim (2016, p. 82), inclusive, classifica a mediação e conciliação como métodos heterocompositivos, por entender que a presença de um terceiro alheio aos interesses das partes, com ou sem poder decisional, assim as configura. Cita, como referência, a explicação de Gorczevski (1999, p. 15):

\footnotetext{
A história nos indica que as primeiras formas assumidas para a resolução de conflitos entre os homens foram produto de suas próprias decisões, ou porque aplicavam a lei dos mais forte, ou porque convencionavam uma forma que evitava aprofundar a crise. Em qualquer caso, partia-se do enfrentamento individual, não existiam terceiros envolvidos e, se, eventualmente, participava um terceiro, na realidade compartilhava $o$ interesse de um outro litigante.
}

Essa não é a posição que prevalece, já que, para a maioria, o que vai diferenciar a autocomposição da heterocomposição é a titularidade do poder decisório. Ou seja, na conciliação e na mediação, a presença do terceiro imparcial não retira das partes o poder de 
decidir pelo acordo, já que acobertadas pelo princípio da voluntariedade.

Nessa linha de entedimento estão José de Albuquerque Rosa e Araken de Assis, apud Jobim (2016, p. 79-80), André Gomma de Azevedo (2013, p. 7), Fernanda Tartuce (2016, p. 47), Luciana Aboim Silva (2013, p. 176), entre outros. A própria Lei de Mediação, em seu art. $1^{\circ}$, traz em seu bojo o seguinte enunciado: "Esta Lei dispõe sobre a mediação como meio de solução de controvérsias entre particulares e sobre a autocomposição de conflitos no âmbito da administração pública".

Contudo, essa preocupação com eventual desequilíbrio de poder é pertinente e merece ser valorada, na medida em que deve o mediador buscar a todo tempo, de forma imparcial e firme, a promoção da igualdade entre os envolvidos. Para tanto, deve possuir habilidades cognitivas e ser devidamente capacitado para bem aplicar as técnicas ou ferramentas de provocação de mudanças nas partes, sob pena de contribuir para eventual desequilíbrio.

Como atestam Cappelletti e Bryant (1988, p. 6): "A efetividade perfeita, no contexto de um dado direito substantivo, poderia ser expressa como a completa 'igualdade de armas"'.

Ora, sendo a mediação um método em que se valoriza e estimula a participação dos envolvidos, há que se garantir um tratamento igualitário, onde a parte não se sinta intimidada a concluir o acordo por estar no ambiente do judiciário, muito menos desprotegida por ser a parte hiposuficiente da relação.

Também é nesse sentido a ponderação feita por Tartuce (2016, p. 89):

As dificuldades que empecem a prestação jurisdicional podem acabar conduzindo à tendência de celebração de acordos a qualquer custo, mesmo em situações excessivamente gravosas para uma ou ambas as partes. Em tal circunstância, não se estará distribuindo justiça, mas se negando a atribuir a cada um o que é devido por questões pragmáticas, utilitárias e ilegítimas. Ao pautar-se pela diretriz consensual, deve o órgão responsável pela administração do conflito atuar segundo as técnicas previstas para tal mister, com eficiência e respeito em relação à vontade real das partes.

Salienta a mesma autora a importância de se buscar "consensos legítimos" e que se a autocomposição for imposta, corre-se o risco de estar diante de uma "pseudoautocomposição", onde as partes, ao invés de serem estimuladas a compor seus conflitos, são coagidas a tanto. Tal conduta compromete a credibilidade dos meios consensuais e, também, do sistema judiciário. (TARTUCE, 2016, p. 89-90).

É nesse sentido que a comunicação se destaca como propulsora de um ambiente promotor de igualdade de forças entre os envolvidos. Aspectos positivos do conflito podem ser 
evidenciados por meio de uma comunicação não violenta, através de uma linguagem clara, que assegure, sobretudo, o entendimento de todos.

Esse pensamento corrobora com a ideia de que, sobretudo na âmbito do judiciário, o cuidado com a promoção de autonomia igualitária entre as partes, principalmente quanto à questão do entendimento, deve ser garantido. Os programas de formação de conciliadores e mediadores devem ser amplamente supervisionados para que situações de desequilíbrio não sejam convalidadas sob o manto do Judiciário.

Críticas existem sobre o fato do Estado pegar para si o controle e regulamentação da mediação, quando deveria ser algo a ser trabalhado longe dos mecanismos formais. Assim, Meirelles e Marques (2015, p. 128) chamam atenção para o fato de que:

(...) há muitos pontos que ainda merecem reflexão, a começar por se saber se realmente a mediação deve ser regulamentada e até que ponto o Estado deve definir quem pode ser mediador. Também merece ser problematizado o protagonismo do Judiciário no modelo de capacitação, bem como se o mediador deve pautar sua conduta na construção de acordos meramente econômicos ou gerenciais.

Tratam-se de situações que, na prática, vêm sendo questionadas. No entanto, diante de uma cultura litigante, a busca pelo Judiciário para resolver qualquer tipo de demanda, fez com que este se tornasse o ambiente mais propício para investir nos meios autocompositivos, já que, nesse momento, é onde todos buscam a solução de suas contendas. Trabalhar os conflitos pelas formas consensuais, ainda que no Judiciário, é uma maneira de devolver à sociedade a autonomia para gerenciar suas vidas e seus conflitos que, como visto, são inerentes à condição humana.

Esse é o principal desafio da mediação de conflitos, promover a construção de um consenso, pelas próprias partes, que seja justo para ambas. Onde houver desequilíbrio de poder, não cabe a atuação do mediador, que deverá encerrar a sua atuação, sob pena de promover a já citada "pseudoautocomposição". Até porque, o objetivo maior da mediação não é o acordo em si, mas o restabelecimento da comunicação e a promoção da pacificação.

Como afirma Tartuce (2016, p. 275), o mediador precisa ter perfil para vencer os obstáculos que decorrem de posições antagônicas. Cabe a ele facilitar a comunicação entre os envolvidos, através de diálogos construtivos, a fim de que os envolvidos protagonizem a condução do resultado de forma cooperativa. Para tanto, evidencia-se a preocupação com a devida capacitação dos mediadores para o aperfeiçoamento e seriedade da atividade. 
A normatização em vigor chama atenção para a capacitação do mediador judicial e deve haver um cuidado muito grande para que todos as exigências sejam observadas, além da aptidão natural. Devem órgãos competentes, direcionadores dessa política consensual, através de seus mecanismos de fiscalização, primar pela excelência desse trabalho desenvolvido no âmbito jurídico, que nesse momento de litigiosidade acentuada, faz-se necessário.

Vezzulla (2013, p. 82) evidencia sua preocupação com a capacitação do mediadores ao afirmar que em certos estados ou regiões "a capacitação é pobre em horas, mas também é não presencial, o que impede o necessário contato direto com os formandos para auxiliá-los a desenvolver as habilidades para um correto desempenho da função de mediador".

Semelhante preocupação demonstra Arruda (2015, p. 91) ao se manifestar sobre o tema: "Para assegurar a prática da mediação, na plenitude de sua nobreza, é necessário que a formação do mediador seja criteriosa, estabelecida com a clareza de fundamentos teóricos desse conhecimento a favor do aprimoramento do acesso à justiça".

Dessa forma, se os mediadores não tiverem acesso à capacitação devida e, consequentemente, se o conflito não for trabalhado de forma adequada, não haverá legitimidade no consenso dos envolvidos e não se terá atingido o efetivo acesso à justiça.

\section{A comunicação construtiva a partir das técnicas de mediação}

De acordo com o Manual de Mediação Judicial, organizado por Azevedo (2013, p. 195), técnicas de mediação "são ferramentas que, se bem utilizadas, podem alterar o curso da mediação e a percepção de satisfação do jurisdicionado quanto ao serviço autocompositivo prestado". Enumera como técnicas para facilitar a comunicação entre os envolvidos em um conflito: a recontextualização (ou paráfrase); audição de propostas implícitas; afago ou reforço positivo; silêncio; sessões privadas ou individuais; inversão de papeis; geração de opções ou perguntas orientadas a geração de opções; normalização; organização de questões e interesses; enfoque prospectivo; teste de realidade; validação de sentimentos.

Pode-se afirmar que as técnicas trabalhadas na mediação de conflitos em muito se assemelham às que Marshall Rosenberg (2003) desenvolve em sua obra "Comunicação nãoviolenta", que denomina de "técnicas para aprimorar relacionamentos pessoais e profissionais", a exemplo da empatia, ouvir com atenção, parafraseamento, silêncio, o que evidencia a intrínseca conexão entre a mediação e a comunicação. 
A mediação, em suas fases iniciais, consiste na identificação das questões e interesses que serão trabalhados no decorrer da sessão, bem como na administração dos sentimentos que as partes demonstram e que as influenciam na percepção do conflito. Dessa forma, é de suma importância a utilização das técnicas de mediação, como ferramentas aptas a provocar mudanças de comportamentos nos envolvidos em um conflito.

O entendimento de Tartuce (2013, p.55) é no sentido de reconher a técnica como elemento fundamental à prática da mediação e ter como finalidades "restabelecer a comunicação, prevenir conflitos, incluir o cidadão e promover a pacificação social permitindo a continuidade da relação interpessoal (...)".

A mesma autora (2013, p. 49-50) evidencia que através da técnica da escuta ativa:

o mediador não só ouve, mas considera atentamente as palavras ditas e as mensagens não expressas verbalmente (...) Como se percebe, a percepção do mediador supera a mera consideração das palavras. Eis porque se costuma afirmar que "escutar é diferente de ouvir"...

Ou seja, mediador deverá ser receptivo com a parte interlocutora e demonstrar uma atitude positiva de atenção, sempre mantendo o contato visual, de maneira que o falante se sinta ouvido. A linguagem corporal do mediador neste momento é de suma importância.

Sobre essa técnica, Azevedo expõe (2013, p. 161):

\begin{abstract}
Ouvir ativamente significa escutar e entender o que está sendo dito sem se deixar influenciar por pensamentos judicantes ou que contenham juízos de valor - ao mesmo tempo deve o ouvinte demonstrar, inclusive por linguagem corporal, que está prestando atenção ao que está sendo dito. (...) Além disso, apenas ouvindo ativamente poderá o mediador identificar as questões mais importantes, as emoções e a dinâmica do conflito - o que faz com que as intervenções do mediador sejam muito mais eficientes e oportunas".
\end{abstract}

Nesses termos, a escuta ativa poderá ser empregada durante toda a mediação, sempre de forma a demonstrar respeito e atenção com as partes.

Outra técnica muito utilizada é a da Recontextualização ou Paráfrase, baseada na ênfase que o mediador dá para aspectos positivos abordados implicitamente pelas partes, que quando ditos de outra maneira, servirão para amenizar o conflito. (AZEVEDO, 2013, p. 196). 
Trata-se da utilização de palavras semelhantes para repetir basicamente o que a pessoa disse, ressaltando os pontos positivos, de forma que ouçam seus relatos contados por um terceiro neutro e imparcial, sob uma outra perspectiva.

Através desta ferramenta, as partes serão estimuladas pelo mediador a prestarem atenção a determinado contexto fático por outro enfoque. Dessa forma, o mediando tende a entender uma questão, um interesse, um comportamento ou uma situação de forma mais positiva, e assim extrair soluções também positivas.

Também merece destaque a técnica da audição de propostas implícitas, através da qual o mediador deve ter a habilidade para extrair, daquilo que foi dito pela parte, uma possível solução para a demanda. (AZEVEDO, 2013, p. 196-197).

Em um conflito, geralmente as partes, em seus discursos, propõe soluções sem perceberem que estão assim procedendo. É muito importante que o mediador tenha habilidade para identificá-las.

O afago ou reforço positivo é uma técnica consistente em ressaltar e valorizar aspectos positivos das partes durante todo o procedimento. É mencionada por Azevedo (2013, p. 197) da seguinte forma:

O afago consiste em uma resposta positiva do mediador a um comportamento produtivo, eficiente ou positivo da parte ou do próprio advogado. Por intermédio do afago, busca-se estimular a parte ou o advogado a continuar com o comportamento ou postura positiva para a mediação. [...]

Há de se considerar a importância da técnica do silêncio, que segundo Azevedo (2013, p. 165) pode ser utilizada com vários objetivos no decorrer de um processo de resolução de disputa.

Geralmente, o silêncio do mediador provoca nas partes reflexão, ainda que momentânea, sobre a forma como estão agindo. Logo, quando uma parte dá sinais de que dará um passo importante para resolução de controvérsia (que pode ser uma concessão, o reconhecimento de um erro ou um pedido de desculpas), é conveniente que o mediador aplique essa técnica.

É o que Vasconcelos (2008, p.63) evidencia ao tratar da comunicação:

Comportamento é comunicação. Toda comunicação é interacional, é troca de mensagens. Por mais que um indivíduo se esforce é-lhe impossível não comunicar. Atividade e inatividade são comunicações. Portanto, palavra ou silêncio são comunicação. Possuem valor de mensagem e, dessa forma, influenciam outros e estes não podem não responder a essas comunicações e, portanto, também estão comunicando. 
Em algumas ocasiões, a parte age por impulso, na ânsia de solucionar logo a demanda. O silêncio do mediador provoca a atenção da parte, e a faz repensar, após esta breve pausa, sobre eventual atitude a ser tomada.

Lisa Parkinson (2016, p. 194) explica a técnica do silêncio como "uma forma de comunicação" e acrescenta que "o mediador não deve tentar se apressar para preencher o silêncio que muitas vezes está carregado de emoções". Evidencia, dessa forma, a importância dessa técnica para a reflexão.

As sessões individuais, também chamadas de caucus, são encontros privados entre os mediadores e cada um dos envolvidos, separadamente.

Preceitua Azevedo (2013, p. 146) que:

\begin{abstract}
Na sessão privada é comum a parte começar a ter uma proximidade mais acentuada com o mediador e, em razão desse fato, é possível que ela passe a acreditar que ele possa estar do seu lado. Deve, portanto, ter o mediador cautela ao demonstrar compreensão pelo que a parte está sentindo e, ao mesmo tempo, não deixar transparecer qualquer sinal de parcialidade.
\end{abstract}

É uma técnica que pode ser utilizada logo após a primeira sessão conjunta, quando as partes expuserem os fatos e o mediador perceber que a comunicação ou algum outro ponto precisa ser melhor trabalhado, bem como no decorrer da sessão, se o mediador ou qualquer das partes achar conveniente.

Recomenda-se que sempre que for realizada uma sessão privada com uma das partes, faça-o também com a outra. E caso venha a realizar mais de uma sessão privada com uma das partes, haja o cuidado de também realizá-las em igual número com as outras.

Muito utilizada e eficiente é a técnica da inversão de papéis. Trata-se de uma ferramenta que deve ser utilizada em sessões individuais, mediante a informação de que se trata de uma técnica de mediação e que também será utilizada com a outra parte. Assim, o mediador assegurará a sua imparcialidade e as partes o verão como um autocompositor neutro. (AZEVEDO, 2013, p. 200).

Através dessa ferramenta, o mediador estimula uma parte a se colocar no lugar da outra, para que perceba o contexto também sob a ótica da outra parte. O objetivo é fazê-las refletir sobre a situação do outro. 
Gerar opções significa estimular as partes a pensarem em possíveis soluções para resolver a demanda. É também chamada de brainstorming ou chuva de ideias.

A prática tem demonstrado que a primeira solução que vem à mente, geralmente, não é a que mais satisfaz ambas as partes. Pensar em outras alternativas faz com que surjam opções mais eficazes para o deslinde da questão. (AZEVEDO, 2013, p. 201).

Recomenda-se a técnica da normalização, a fim de que as partes sintam o conflito como algo normal, que faz parte do cotidiano das pessoas, e que sejam estimuladas a percebêlo como uma oportunidade de melhoria da relação entre os envolvidos. (AZEVEDO, 2013, p. 202).

É muito comum que os envolvidos no conflito se sintam constrangidos pelo fato de estarem litigando e, em razão desse desconforto, atribuam culpa ao outro. Cabe ao mediador promover um ambiente neutro, que permita tranquilidade e equilíbrio aos participantes da sessão.

A técnica da organização de questões pode ser utilizada quando os mediandos perderem o foco da discussão, deixando de lado as questões que precisam ser resolvidas e desviem a atenção para outros aspectos que, naquele momento, são sobrepostas. (AZEVEDO, 2013, p. 203).

Cabe ao mediador retomar a discussão e lembrar as partes das questões que foram pontuadas no início da sessão como agenda a ser seguida durante a mediação.

Pela técnica de validação sentimentos, o mediador irá identificá-los e abordá-los como uma consequência natural de interesses legítimos que a parte possui.

O mediador deve ter muita cautela para não demonstrar concordância ou apoio ao sentimento da parte, mas tão somente reconhecimento. Reconhecer significa validar o sentimento, através da percepção do que a parte está sentindo, além de demonstrar que esta foi ouvida com atenção.

No entender de Azevedo (2013, p. 139):

O papel do mediador ao validar sentimentos consiste em demonstrar às partes que é natural em qualquer relação haver conflitos e que se faz mais eficiente buscar soluções do que atribuir culpa. A expressão das emoções é de grande valia para as partes não só apenas para que estas se sintam mais descarregadas e tranquilas no processo de mediação, mas também para que demonstrem à outra parte a intensidade de seu sentimento com relação à determinada questão. 
Dessa forma, é importante que o mediador identifique os sentimentos desenvolvidos no decorrer do conflito e aborde-o como uma consequência natural de interesses legítimos que as partes possuem.

Essa técnica pode ser utilizada no decorrer da mediação e também em sessão individual, para sentimentos que somente uma parte venha manifestar, sendo utilizada na presença de ambas as partes somente se os sentimentos forem semelhantes.

Azevedo (2013, p. 204) ainda cita o enfoque prospectivo, onde recomenda que o mediador, ao conduzir a sessão, não foque em atribuições de culpa, mas em soluções possíveis e voltadas para o futuro. Cita, também, a técnica do teste de realidade, que "consiste em estimular a parte a proceder com uma comparação do seu 'mundo interno' com o 'mundo externo' - como percebido pelo mediador".

É importante pontuar, conforme depreende Tartuce (2016, p. 241), que "embora haja certas pautas de atuação e várias ferramentas úteis indicadas pelos diferentes modelos de mediação, não há um roteiro fixo e fechado a ser seguido durante a mediação". Ressalta que um dos mais importantes predicados da mediação é a flexibilidade. O mediador deve desenvolver a sensibilidade de atuar de forma diversificada entre as possíveis técnicas a serem utilizadas, para a realização de uma mediação proveitosa.

Como se vê, a habilidade de atuação do mediador é fundamental para promover a segurança e confiança nas partes, necessárias ao procedimento. Para tanto, deve ser devidamente capacitado e, além de conhecer as técnicas, saber o momento mais oportuno para sua aplicação, de acordo com as peculiaridades de cada caso.

Afinal, como conclui Luciana Aboim Silva (2013, p. 169) sobre a importâcia das técnicas: "(...) o sucesso da mediação requer o preparo de um terceiro facilitador, que empregará as técnicas de mediação, tendo em vista uma atuação voltada para a promoção do diálogo, restabelecimento da comunicação e o consenso efetivo nas relações de disputa".

Assim, evidencia-se o empoderamento proporcionado às partes, pela mediação de conflitos e a efetividade da comunicação para a construção de consensos legítimos.

\section{Conclusão}

Como método adequado de tratamento de conflitos, a mediação evidencia a importância da comunicação para o desenvolvimento de diálogos construtivos e valoriza o papel do mediador como agente facilitador do entendimento entre as partes, através de técnicas 
de mediação, também chamadas de ferramentas para provocar mudanças de comportamento.

Nesse contexto, o conflito pode ser trabalhado em sua amplitude e ser percebido de forma positiva, sem a ideia de oposição, inerente aos processos judiciais. Assim, a mediação poderá ser reconhecida como instrumento que mais se aproxima da plena satisfação das partes.

Infere-se do presente estudo que a mediação é um método de transformação de conflitos, que torna efetivo o acesso à justiça, por permitir a construção da solução que, de maneira isonômica, atende as necessidades e interesses dos envolvidos no conflito. Assim, trabalha a autonomia de vontade das partes, empoderando-as em busca da satisfação de cada um.

Evidencia-se a preocupação com a legitimidade do consenso, sobretudo no âmbito do judiciário, uma vez que os envolvidos precisam entender o procedimento, bem como todos os termos do que for acordado, de maneira voluntária, sem qualquer tipo de pressão ou intimidação. Se assim não for, convalidar-se-á o desequilíbrio de poder e uma "pseudoautocomposição" será imposta, ferindo de maneira abrupta a legitimidade do acordo eventualmente firmado.

O que se depreende do exposto é que o mediador, com suas habilidades cognitivas e utilização de técnicas apropriadas, tem o escopo de facilitar o diálogo entre as partes, que depois de estimuladas a perceberem o conflito de forma positiva, estarão aptas a refletir, de forma segura, sobre os reais interesses que envolvem as questões discutidas.

Essa tarefa requer o comprometimento de todos que estão direcionando essa política pública de tratamento adequado de conflitos, no sentido de valorizar os cursos de formação de mediadores, que devem rechaçar o modelo voltado somente ao acordo e focar nos interesses e sentimentos envolvidos no contexto fático. Somente assim, o antigo modelo da conciliação será readequado para um formato mais humanizado, que se aproxima da mediação, em sua forma mais ampla.

Para atingir tal intento, os preceitos de uma comunicação não-violenta, aplicados às técnicas de mediação, serão capazes de empoderar os indivíduos e educá-los para o novo tipo de justiça que se impõe, baseada em valores democráticos e fraternos, com vistas a concientizar a sociedade para a construção de consensos legítimos, na busca da pacificação social.

\section{Referências bibliográficas}


AZEVEDO, André Gomma de (Org.). Manual de mediação judicial. Brasília, DF:

Ministério da Justiça e Programa das Nações Unidas para o Desenvolvimento (PNUD), 2013.

AZEVEDO, André Gomma de. Novos desafios de acesso à justiça: novas perspectivas decorrentes de novos processos de resolução de disputas. In: SILVA, Luciana Aboim Machado Gonçalves da. (Org). Mediação de Conflitos. São Paulo: Atlas, 2013. p. 3-22.

BARBOSA, Águida Arruda. Mediação Familiar Interdisciplinar. São Paulo: Atlas, 2015.

BRASIL. Conselho Nacional de Justiça. Resolução 125/2010. Disponível em:

$<$ http://www.cnj.jus.br/busca-atos-adm?documento=2579>. Acesso em: 20mar. 2018.

BRASIL. Conselho Nacional de Justiça. Resolução 225/2016. Disponível em $<$ http://www.cnj.jus.br/atos-normativos?documento=2289>. Acesso em: 20mar. 2016.

BRASIL. Conselho Nacional do Ministério Público. Resolução 118/2014. < Disponível em http://www.cnmp.mp.br/portal_2015/images/Normas/Resolucoes/Resolução_n ${ }^{\mathrm{o}}$ _118_autoco mposição.pdf>. Acesso em: 20mar. 2016.

BRASIL. Lei n. ${ }^{0}$ 13.140, de 26 de junho de 2015. Disponível em: $<$ https://www.planalto. gov.br/ccivil_03/_Ato2015-2018/2015/Lei/L13140.htm>. Acesso em: 20mar. 2018.

BRASIL. Lei n.o 13.105, de 16 de março de 2015. Disponível em: < http://www. planalto.gov.br/ccivil_03/_ato2015-2018/2015/lei/113105.htm>. Acesso em: 20mar. 2016.

CAPPELLETTI, Mauro; BRYANT, Garth. Acesso à Justiça. Tradução e revisão Ellen Gracie Northfleet. Porto Alegre: Ed. Sérgio Antonio Fabris, 1988.

DEUSTCH, Morton. A Resolução do Conflito. : processos construtivos e destrutivos. new Haven (CT) Yale University Press, 1977 - traduzido e parcialmente publicado em AZEVEDO, André Gomma de (org.) Estudos em arbitragem, mediação e negociação. Brasília: Grupos de Pesquisa, 2004. v.3. 
HALE, Durval; PINHO, Humberto Dalla Bernadina de; CABRAL, Trícia Navarro Xavier CAbral (Orgs). O Marco Legal da Mediação no Brasil. Comentários à Lei n.13.140, de 26 de junho de 2015.

JOBIM, Marco Félix. Teoria, História e Processo. Porto Alegre: Livraria do Advogado, 2016 .

JOBIM, Marco Félix; MACEDO, Elaine Harzheim. Das normas fundamentais do processo e o novo Código de Processo Civil brasileiro: repetições e inovações. In: RIBEIRO, Darci Guimarães; JOBIM, Morco Félix (orgs.). Desvendando o novo CPC. 3 ed. amp. Porto Alegre: Livraria do Advogado, 2017. p.149-167.

PARKINSON, Lisa. Mediação Familiar. Tradução: Erica de Paula Salgado. 2 ed. Belo Horizonte: Del Rey, 2016.

PERA, Alessandra. Introduzione ai Modelli di ADR, profili storico-comparatistici. In: Mediazione e Conciliazione. Diritto Interno, Comparato e Internazionale. A cura di Alessandra Pera e Giovanni Maria Riccio. Italia: CEDAM, 2011.

RADULESCU, Dragos Marian. Mediation - a Method to Resolve Conflicts Without Going to Justice. Revista Română de Statistică - Supliment Trim IV/2012. p. 279-284. Disponível em: <http://www.revistadestatistica.ro/suplimente/2012/4/srrs4_2012a41.pdf> Acesso em: $22 \mathrm{fev} .2018$.

ROSEMBERG, Marshall B. Comunicação não-violenta. Técnicas para aprimorar relacionamentos pessoais e profisssionais. Tradução: Mário Vilela. 2 ed. São Paulo: Ágora, 2003.

SARLET, Ingo Wolfgang. A eficácia dos direitos fundamentais. Uma Teoria Geral dos Direitos Fundamentais na Perspectiva Constitucional. 11 ed. Porto Alegre: Livraria do Advogado, 2012. 
SILVA, Luciana Aboim Machado Gonçalves da. Mediação interdisciplinar de conflitos: mecanismo apropriado para resolução de conflitos familiares. In: (Org). Mediação de

Conflitos. São Paulo: Ed. Atlas, 2013. p. 160-180.

TARTUCE, Fernanda. Técnicas de Mediação. In: SILVA, Luciana Aboim Machado Gonçalves da (Org). Mediação de Conflitos. São Paulo: Atlas, 2013. p. 42-57.

. Mediação nos Conflitos Civis. 3 ed. rev. e amp. São Paulo: Forense, 2016.

VASCONCELOS, Carlos Eduardo. Mediação de Conflitos e Práticas Restaurativas. São Paulo: Método, 2008.

VEZZULLA, Juan Carlos. A mediação para uma análise da abordagem dos conflitos à luz dos direitos humanos, o acesso à justiça e o respeito à dignidade humana. In: SILVA, Luciana Aboim Machado Gonçalves da (Org). Mediação de Conflitos. São Paulo: Atlas, 2013. p. 6393.

WARAT, Luis Alberto. O Ofício do Mediador. Florianópolis: Habitus, 2001. 


\title{
A SOLUÇÃO EXTRAJUDICIAL DE CONFLITOS: UM OLHAR PARA ALÉM DA MEDIAÇÃO E DA CONCILIAÇÃO
}

\author{
Ana Paula Parra Leite \\ Universidade Estadual de Ponta Grossa - Brasil \\ Zilda Mara Consalter \\ Universidade Estadual de Ponta Grossa - Brasil
}

\begin{abstract}
Resumo
Objetivando mitigar a lentidão e onerosidade do sistema de justiça brasileiro, o CNJ editou a Resolução 125/2010, que incentiva a pacificação de conflitos. Após, o CPC e a Lei de Mediação trilharam igual direção. Nessa área, maior ênfase é dada à mediação e à conciliação, motivo pelo qual ora se analisa outras possibilidades: avaliação por terceiro neutro, mini-trial, rent- $a$ judge e baseball arbitration. Na abordagem aplicou-se o método dedutivo, mediante pesquisa teórica e com o uso de técnicas de documentação indireta (legislação e doutrina). O resultado principal é a identificação de quais dessas espécies podem ser utilizadas no ordenamento jurídico brasileiro.
\end{abstract}

Palavras-chave: Solução consensual de conflitos, Avaliação por terceiro neutro, Mini-trial, Rent-a-judge, Baseball arbitration .

\begin{abstract}
Resumen/Résumé
Aiming to mitigate the slowness and onerousness of Brazilian justice system, the CNJ issued the Resolution 125/2010, which encourages the pacification of conflicts. Afterwards, the CPC and the Mediation Law followed towards the same direction. In this area, emphasis is placed on mediation and conciliation but there are other possibilities which are analyzed: evaluation by a neutral third party, mini-trial, rent-a-judge and baseball arbitration. The deductive method was applied, through theoretical research and using indirect documentation techniques (legislation and doctrine). The main result is the identification of which of these species can be used in the Brazilian legal system.
\end{abstract}


Keywords/Palabras-claves/Mots-clés: Consensual solution of conflicts, Evaluation by a neutral third party, Mini-trial, Rent-a-judge, Baseball arbitration.

\section{Notas introdutórias}

De acordo com o Relatório nominado "Justiça em Números” (ano 2017, com ano-base 2016), o Poder Judiciário brasileiro encerrou o ano de 2016 com 79,7 milhões de processos em tramitação a um custo de $\mathrm{R} \$ 84,8$ bilhões, um crescimento de $0,4 \%$ com relação ao ano de 2015 . (CONSELHO NACIONAL DE JUSTIÇA, 2017).

Segundo o mesmo Relatório, o crescimento no número de demandas entre os anos de 2015 e 2016 foi de 5,6\% e o número é alarmante em um país embriagado por uma cultura beligerante e pela judicialização de litígios. (CONSELHO NACIONAL DE JUSTIÇA, 2017).

No entanto, não é apenas pelos números que se tem ciência que o sistema de justiça brasileiro é lento e oneroso, o que leva os jurisdicionados à descrença e desconfiança na tutela de seus direitos. Não obstante, para muitos, o Poder Judiciário ainda parece ser a única solução para os conflitos de interesses, como que houvesse um "fetiche pela toga", diante da falsa ideia de que aquele é o detentor do monopólio da atividade destinada a solucionar conflitos, o que, reconhece-se, por um tempo, foi a única verdade.

Todavia, diante do quadro grave que se mostra e tal como o que se enfrenta, faz-se necessária uma mudança na forma de acesso à Justiça, sendo que há alguns anos é visível a intervenção do Estado no sentido de diminuir o número de demandas e fomentar a solução pacífica de conflitos - não sendo de se olvidar, entretanto, que o próprio Estado é o maior litigante nos tribunais brasileiros.

Embora meios consensuais de solução de litígio não sejam criações recentes, o ordenamento jurídico brasileiro, apenas por mecanismos há pouco tempo adotados, parece ter compreendido as mudanças que se fazem necessárias para que a justiça concretize-se, também, de forma extrajudicial ou, ainda que se dê no curso de uma demanda, de forma consensual.

E esse novo olhar para o sistema de justiça - menos beligerante, mais conciliador e transformador de conflitos - deverá ser empregado pelos advogados e demais profissionais do Direito, sob pena de perderem o seu lugar no palco da vida onde os interesses são trilhados.

Nessa senda, ganham espaço os chamados "meios alternativos de solução de conflitos", uma expressão derivada do inglês alternative dispute resolution (ADR) e que "representa uma variedade de métodos de resolução de disputas de interesses, distintos e substitutivos da sentença proferida em um processo judicial” (ALVES DA SILVA, 2012, p. 1- 
25), e a sua utilização "prescinde em uma quebra de preconceitos, e para a sua realização é necessário reconstruir o paradigma da Justiça, acalmar animosidades, restabelecer a força decisória autônoma das partes, conferindo-lhes o poder que se perdeu durante a formação do conflito" (PEREIRA; CONSALTER, 2018, p. 24).

Entretanto, neste âmbito, muita ênfase ainda é dada apenas à mediação, à conciliação e à arbitragem, sendo que pouco se discute sobre outras formas de solução de litígios, mas que merecem divulgação e estudo a fim de que se possa verificar sua aplicabilidade ao ordenamento jurídico brasileiro. Para tanto, nesse texto, sem a pretensão de exaurir o tema, objetiva-se a realização de uma análise de outras técnicas de gestão de conflitos, mais especificamente, acerca da avaliação de terceiro neutro, do mini-trial, do rent-a-judge e da baseball arbitration.

Dessa maneira, e obedecendo ao método científico dedutivo de abordagem, inicia-se pela análise da evolução jurídico-legislativa nacional para, na sequência, delinear-se os principais contornos das medidas compositivas acima nominadas, a se averiguar se podem ser aplicadas, tal como a conciliação, mediação e arbitragem, pelo sistema de justiça pátrio.

Visando a execução da metodologia indicada, a técnica de pesquisa utilizada foi a documental indireta, com preponderância da fonte doutrinária, sem prejuízo da menção das fontes normativas úteis ao entendimento do tema.

No que tange à fonte doutrinária, o marco teórico textual adotado é a doutrina que versa sobre as medidas consensuais de solução de demandas proveniente de países da common law, notadamente Estados Unidos da América, Canadá e Austrália. Destaque-se, ainda, que para o desenvolvimento da teoria de base do pensamento esposado, contou-se com autores clássicos e contemporâneos sobre os pilares do estudo, dando-se ênfase às ideias defendidas quanto ao tema por Cidgem Hasan, Hedy Meggiorin, Brian R. Jerome, Raffaele Petruzi; Petra Koch e Laura Turcan, dentre outros.

\section{Breves pontuações sobre a evolução jurídico-legislativa da política de conciliação de demandas}

Quanto à forma de se enfrentar e solucionar - ou ao menos gestionar - litígios, algumas mudanças paradigmáticas sobrevieram no Brasil, exemplificativamente, com a edição da Resolução 125 do Conselho Nacional de Justiça, datada de 2010, que tratou, entre outras providências, da Política Judiciária Nacional de tratamento adequado dos conflitos de interesses no âmbito do Poder Judiciário. (CONSELHO NACIONAL DE JUSTIÇA, 2010).

$\mathrm{Na}$ referida Resolução, reconheceu-se, entre outros aspectos, que os conflitos de interesses ocorrem "em larga e crescente escala na sociedade"; que existe "a necessidade de se 
consolidar uma política pública permanente de incentivo e aperfeiçoamento de mecanismos consensuais de solução de litígios"; que "a conciliação e a mediação são instrumentos efetivos de pacificação social, solução e prevenção de litígios, e que a sua apropriada disciplina em programas já implementados no país tem reduzido a excessiva judicialização dos conflitos de interesses, a quantidade de recursos e de execução de sentenças"; e que há a "a relevância e a necessidade de organizar e uniformizar os serviços de conciliação, mediação e outros métodos consensuais de solução de conflitos, para lhes evitar disparidades de orientação e práticas, bem como para assegurar a boa execução da política pública, respeitadas as especificidades de cada segmento da Justiça”. (CONSELHO NACIONAL DE JUSTIÇA, 2010).

Diante deste cenário, ficou instituída a Política Judiciária Nacional de tratamento dos conflitos de interesses e a Resolução dispôs, exemplificativamente, sobre a criação dos núcleos permanentes de métodos consensuais de solução de conflitos, dos centros judiciários de solução de conflitos e cidadania, da manutenção de bancos dados estatísticos, do portal da conciliação e dos mediadores.

Em 16.03.2015 foi sancionada a Lei 13.105, que instituiu o Código de Processo Civil (em vigor desde 2016) e adotou, entre suas normas fundamentais, a promoção pelo Estado, sempre que possível, da solução consensual dos conflitos (artigo $3^{\circ}$, parágrafo $2^{\circ}$ ), o estímulo à conciliação, à mediação e outros métodos de solução consensual de conflitos por juízes, advogados, defensores públicos e membros do Ministério Público, inclusive no curso do processo judicial (artigo $3^{\circ}$, parágrafo $3^{\circ}$ ). (BRASIL, 2015a).

Também no ano de 2015 foi aprovada a Lei 13.140, conhecida como Lei de Mediação, que disciplinou o instituto da mediação entre particulares, seja judicial, seja extrajudicial e mais relevante ainda, tratou da mediação de conflitos em que for parte pessoa jurídica de direito público. (BRASIL, 2015b).

Nessa toada, em 31.05.2016, o mesmo Conselho editou a Resolução 225 que dispôs sobre a Política Nacional de Justiça Restaurativa no âmbito do Poder Judiciário, regulamentando uma prática que paulatinamente vem ganhando força no Brasil, não obstante com um certo retardo se comparado a países desenvolvidos como Canadá e Estados Unidos. (CONSELHO NACIONAL DE JUSTIÇA-CNJ, 2016).

Embora datada de 1995, mas tratando de um instituto ainda tímido na prática, a não ser nas grandes capitais, a Lei de Arbitragem (Lei n. 9.307) recebeu modificações no ano de 2015, sendo que a principal delas está na arbitragem no âmbito da administração pública direta e indireta, como que de uma vez diferenciando a questão da indisponibilidade do direito público da sua impossibilidade de transação. 
Entretanto, é importante ponderar que não somente o Estado deve se preocupar com o sistema de justiça, que passa a ser analisado como um sistema multiportas e retrata a "mais ampla oferta de meios, métodos, formas e mecanismos (vinculantes ou não) colocados à disposição do cidadão, com estímulo a fim de que ocorra o adequado encaminhamento dos conflitos para os canais disponíveis”. (BACELLAR, 2016, p. 79).

Isso porque essa mudança de paradigma deverá ser o resultado de esforços de toda a sociedade civil e, principalmente, da advocacia brasileira, que com seus quase um milhão de membros, deverá zelar pela melhor solução para os conflitos de interesses de seus clientes.

Com centenas de horas teóricas e práticas de processo (civil, penal, do trabalho, administrativo, tributário etc.) durante os Cursos de Graduação, os alunos dos bacharelados em Direito são formados para o litígio, para o conflito, para o combate, para um sistema adversarial que objetiva o ganha-perde, sendo inexpressiva a preparação técnica para a negociação, para a composição amigável de conflitos, sendo que apenas com a edição da Resolução 125 do CNJ é que as Instituições de Ensino Superior passaram a se preocupar com a oferta de uma disciplina voltada à solução pacífica de conflitos.

Desse modo, é preciso que cada vez mais se conheça - e se entenda - todas as possibilidades disponíveis voltadas a pacificação dos conflitos (em qualquer âmbito). E com esse mister, passa-se a analisar alguns deles que não são de amplo conhecimento pela comunidade jurídica, eis que geralmente, quem os busca lança mão da conciliação, mediação ou arbitragem, gerando a falsa noção de apenas essas três opções restam viáveis de ser utilizadas na atualidade.

\section{Outros meios alternativos de solução de conflitos}

Conforme já levantado, com uma grande tradição litigiosa no sistema de justiça brasileiro, avanços como a instituição de uma Política Judiciária Nacional de tratamento dos conflitos de interesses, em especial os consensuais, merecem aplausos.

Como meios consensuais de solução de conflitos, a mediação e a conciliação ganharam destaque na Resolução 125, no Código de Processo Civil (artigo $3^{\circ}$, parágrafo $3^{\circ}$ e artigo 165 e seguintes) e evidentemente, na já referida Lei de Mediação.

Entretanto, não são essas espécies as únicas a serem viáveis de aplicação no ordenamento jurídico pátrio. Isso porque, pela análise literal da Resolução 125, permite-se inferir que tais meios de solução de conflitos não são os únicos, ao prever que, 
[...] cabe ao Judiciário estabelecer política pública de tratamento adequado dos problemas jurídicos e dos conflitos de interesses, que ocorrem em larga e crescente escala na sociedade, de forma a organizar, em âmbito nacional, não somente os serviços prestados nos processos judiciais, como também os que possam sê-lo mediante outros mecanismos de solução de conflitos, em especial dos consensuais, como a mediação e a conciliação; [...]. (CONSELHO NACIONAL DE JUSTIÇA, 2010).

Ou seja, ao utilizar a conjunção "como", verifica-se que a mediação e conciliação foram citadas como meros exemplos de meios de solução de conflitos.

Mais clara é a redação do artigo $3^{\circ}$, parágrafo $3^{\circ}$, do Código de Processo Civil que contempla outros métodos de solução consensual ao prever que "A conciliação, a mediação e outros métodos de solução consensual de conflitos deverão ser estimulados por juízes, advogados, defensores públicos e membros do Ministério Público, inclusive no curso o processo judicial".

Assim, resta evidente que o ordenamento jurídico brasileiro permite a aplicação de outros métodos de solução de conflitos de interesses, passando-se a uma breve análise dos mesmos, bem como quanto a sua compatibilidade com o sistema vigente.

\subsection{Avaliação do terceiro neutro}

Também conhecida simplesmente como "avaliação neutra" ou "avaliação preliminar imparcial" a avaliação do terceiro neutro consiste, nas palavras de Marco Antônio Garcia Lopes Lorencini (2012, p. 57-85), em “[...] um método de resolução de disputas na qual uma pessoa, que não o julgador, depois de analisar o caso, pode, além de ter acesso a documentos, entrevistar partes, seus advogados, colher elementos de convencimento, para em seguida emitir seu parecer fundamentado". Trata-se de um método utilizado em países como Estados Unidos (AMERICAN BAR ASSOCIATION, 2018), Canadá (2018) e Austrália (2018), sob a nomenclatura early neutral evaluation ou simplesmente neutral evaluation.

A avaliação neutra e prévia é um processo que toma lugar após um caso ter sido ajuizado em face de um Tribunal. Ele é examinado por um especialista, geralmente advogado, que deve fornecer uma avaliação equilibrada e imparcial acerca da disputa. As partes enviam seus comentários por escrito ou pessoalmente ao especialista. Ele identifica os pontos fortes e fracos de cada parte e oferece uma avaliação do provável resultado do julgamento. Essa avaliação pode ajudar as partes a ponderar o seu caso e pode impulsioná-las a um acordo. (AMERICAN BAR ASSOCIATION, 2018).

Quanto a essa técnica, é importante ressaltar que o parecer é elaborado por um terceiro neutro (normalmente um advogado, mas não necessariamente um) com expertise e 
conhecimento em formas de solução de conflitos na área da disputa, que o emite sem força vinculante e é "indicado principalmente nos casos em que grassa forte polêmica em torno de um elemento de prova ou, ainda, quando uma das partes tem uma expectativa exagerada de sua posição na disputa". (LOPES LORENCINI, 2012, p. 57-85).

Entre as características da avaliação neutra estão: a voluntariedade, a informalidade e a confidencialidade. O método é voluntário, pois as partes estão livres para aceitar ou rejeitar o resultado da avaliação feita e podem deixar o processo a qualquer momento. A informalidade é representada pela ausência de regras rígidas de procedimento que poderiam até mesmo ser engendradas pelas próprias partes de acordo com o tipo de disputa, a complexidade da causa e o número de partes envolvidas. As suas razões poderiam ser apresentadas de forma escrita ou oral, para um ou vários avaliadores, que poderiam ou não questionar diretamente os advogados objetivando esclarecer o caso e identificar o litígio. A confidencialidade é a regra no método (podendo haver convenção em contrário), quando então as partes poderão livremente discutir o caso sem que seus argumentos e provas apresentadas sejam utilizados em uma demanda judicial. (CANADA, 2018).

O papel do advogado como procurador da parte está em, exemplificativamente: aconselhar seu cliente quanto a "se", "quando" e "perante quem" submeter um conflito à avaliação neutra; preparar seu cliente para as várias estratégias de negociação; preparar e apresentar seus argumentos de forma oral ou escrita ao avaliador. (CANADA, 2018).

A avaliação deve ser fundamentada de forma a não restar dúvida quanto às bases em que a opinião foi emitida e, então, o terceiro neutro poderá sugerir às partes a possibilidade de discutirem um acordo, podendo, inclusive, sugerir reuniões posteriores. Caso o avaliador perceba que as partes não estão propensas ao acordo naquele momento, poderá sugerir outras formas de resolução do conflito, como a arbitragem, por exemplo. (CANADA, 2018).

Também é relevante que se informe que as custas da avaliação neutra normalmente são divididas entre as partes o que proporciona às mesmas uma participação igual no resultado do parecer. (CANADA, 2018).

A avaliação neutra possibilita às partes confrontar e analisar sua própria situação antes de ingressar com uma demanda judicial; oportuniza ouvirem o posicionamento da parte contrária e, com isso, podem reavaliar o caso evitando uma demanda judicial de êxito duvidoso. E após a avaliarem os riscos do conflito, as chances de um acordo acabam aumentando.

Segundo Luiz Fernando do Vale de Almeida Guilherme (2016, p. 16), o parecer emitido pelo terceiro neutro consiste em um laudo para que as partes entendam melhor o que está acontecendo e o que está por vir, "apontando pós e contras, distinções e repercussões”. 
Com a avaliação feita pelo terceiro neutro, as partes passam a " $[. .$.$] entender que as$ soluções propostas são razoáveis, e o acordo que é feito costuma alcançar muito mais respaldo, porque o avaliador, que é um ente neutro, configura-se em um especialista na matéria objeto da discussão". (GUILHERME, 2016, p. 16).

A grande vantagem da técnica está em conferir às partes um reality check ou "teste de realidade", pois muitas vezes, mantêm posições não razoáveis, não compreendem o conflito ou o avaliam de forma equivocada. A avaliação neutra é vantajosa para hipóteses em que as partes tenham a intenção de manter o relacionamento, pois o meio adversarial pode tornar difícil a continuidade de um relacionamento produtivo. Por se tratar de procedimento sigiloso, não podendo o parecer ser utilizado posteriormente, as partes não correm risco se a decisão não lhes for favorável. (FINDLAW, 2018).

Além disso, importa considerar que o método não vincula as partes de forma que, não havendo acordo, poderão levar o conflito a outras formas de solução tais como mediação, arbitragem ou até mesmo buscar a decisão judicial.

A Corte Distrital do Estado da Califórnia nos Estados Unidos é pioneira na técnica e traz diretrizes sobre a avaliação neutra. Entre as diretrizes quanto ao procedimento, referida Corte faz menção a que cada uma das partes apresentaria suas evidências e argumentos que dão suporte ao caso. O avaliador identificaria as áreas de consenso, clarificaria e focaria nos problemas. A avaliação feita de forma privada incluiria entre outros aspectos, uma avaliação sobre a força ou fraqueza do caso apresentado por cada uma das partes e os motivos que baseiam a avaliação. (FINDLAW, 2018).

Entretanto, o procedimento não é isento de críticas, entre as quais: a avaliação por um terceiro neutro poderia refletir um passo a mais até que se obtivesse uma decisão por um tribunal; há certa preocupação quanto a uma possível duplicação entre a avaliação por terceiro neutro e outras formas de solução de disputas; aumento nos custos se não houver um acordo ou se o procedimento for desenvolvido com má-fé; a sua brevidade pode produzir um resultado injusto; a avaliação pode ser vulnerável à manipulação podendo ser usada para se antecipar o caso da parte contrária. (CANADA, 2018).

Também é importante efetuar-se a diferenciação entre a avaliação neutra da mediação e de outras formas extrajudiciais de solução de conflitos: tanto na mediação quanto na conciliação, os facilitadores não emitem uma opinião quanto ao conflito, o que é inerente à avaliação por terceiro neutro. Já com relação à arbitragem, o terceiro neutro, que no caso é o árbitro, decidirá o litígio emitindo sentença que tem a natureza de título executivo judicial, ou seja, não se trata de mera opinião. Inclusive, embora sem poder executório, na arbitragem, o 
árbitro poderá deferir medidas liminares, o que não é possível em se tratando da avaliação neutra.

Quanto a aplicabilidade da técnica em território nacional, Marco Aurélio Garcia Lopes Lorencini (2012) afirma que: "Não existe impedimento legal nem necessidade de maior regulamentação para que a técnica do terceiro neutro seja adotada na realidade brasileira", sendo, então, uma ilação plausível a sua aplicabilidade pelo sistema de justiça nacional.

Dessa maneira, e mesmo não havendo disposição legal específica disciplinando o tema, entende-se possível a utilização da avaliação do terceiro neutro no ordenamento jurídico brasileiro. Isso porque, tivessem as partes, antes de levar um conflito a juízo, o acesso a um parecer fundamentado sobre a sorte da demanda, parece razoável compreender-se que estariam mais propensas a uma solução amigável e menos propensas a aventuras jurídicas.

\subsection{Mini-trial}

O termo mini-trial foi cunhado em 1977 por um jornalista do New York Times para descrever uma disputa em um complexo caso de violação de patente entre TRW Inc. e a Telecredit Inc. No caso, as partes concordaram com uma audiência secreta durante dois dias em que apresentaram seus casos diante de um avaliador neutro ou conselheiro. As apresentações seriam feitas por advogados diretamente aos executivos das empresas envolvidas. (LOPES LORECINI, 2012, p. 57-85).

O mini-trial é um processo privado e consensual de resolução de conflitos em que os advogados de cada parte fazem uma breve apresentação do caso como se estivessem em um julgamento. As apresentações são observadas por um consultor neutro e por representantes das partes envolvidas (normalmente executivos de alto nível que têm poderes para resolver a disputa). Se os representantes não conseguirem resolver a disputa, o consultor neutro, a pedido das partes, poderá emitir uma opinião não vinculante sobre o provável resultado em um tribunal. (AMERICAN BAR ASSOCIATION, 2018).

É importante destacar a participação dos altos executivos das empresas no mini-trial porque, normalmente, são esses profissionais que conhecem o negócio, sua margem de lucro ou outros dados sobre estratégias da empresa, dados estes que são alheios aos advogados ou meros prepostos. Esse contato direto com os executivos acaba por facilitar a obtenção de uma composição.

O mini-trial tenta reproduzir o trial judicial, ou seja, reproduzir o julgamento judicial, porém, "sem a tensão que uma disputa no tribunal envolve, já que as decisões não são 
vinculantes nem o terceiro neutro que preside os trabalhos tem poderes de coerção". (LOPES LORECINI, 2012, p. 57-85).

Mediante essa técnica, cada parte tem a oportunidade de fazer um breve relato sobre o caso, sobre as provas, exibir documentos e utilizar recursos visuais, quando então, terão acesso ao ponto de vista da outra. Além disso, o consultor neutro poder emitir sua opinião sobre o provável resultado caso as partes optem pela demanda judicial e então, enveredar para um acordo. Entretanto, ainda que o acordo não tenha sido exitoso, a vantagem do método está em que "as partes podem antecipar, em certa medida, a discussão de temas que podem ocorrer em juízo". (LOPES LORECINI, 2012, p. 57-85).

Visando trazer maiores esclarecimentos sobre essa e outras técnicas, o Departamento de Justiça do Canadá elaborou um guia de referência sobre a resolução de conflitos e abordou o mini-trial como um método desenvolvido de forma confidencial, destacando seu caráter voluntário (pois somente será utilizado se houver o consentimento das partes que poderão ou não compor). Isso porque, mesmo que não haja composição, as partes estariam livres para procurar outro método de solução do seu conflito. (CANADA, 2018).

Entre os poderes do consultor neutro estariam: dispor sobre um calendário para a realização do mini-trial caso as partes não o tenham feito; zelar para que o mesmo seja respeitado; questionar testemunhas ou os representantes das partes e emitir um parecer não vinculante. (CANADA, 2018).

Também de acordo com o referido guia, alguns questionamentos podem ser feitos para a análise de adequação do método: a) se as partes têm o desejo de ter um maior grau de envolvimento e controle do que aquele que é permitido no processo adjudicativo; b) se a disputa envolve matéria de direito público que demandaria uma decisão judicial; c) se a disputa é suficientemente substancial para justificar o esforço e o custo exigido para a sua realização (pois embora seja mais rápido e barato que a demanda judicial, certamente o mini-trial requererá preparação e custos); d) indagar se a questão conflituosa envolve questões de fato ou de direito (considerando que as questões de fato são sempre mais receptivas a um processo de resolução consensual que as questões de direito); e) se as partes têm uma relação negocial que pretendem manter, pois a relativa velocidade desse processo e a cooperação demandam que as partes façam uso de ferramentas para preservar essa relação; e f) se há várias partes envolvidas no conflito, pois a estrutura do método exerce uma influência positiva nesses conflitos. (CANADA, 2018).

O termo de acordo que estabelece o mini-trial deverá conter entre outros aspectos: uma breve descrição da disputa e identificar os temas controvertidos; o calendário para a sua 
realização; a forma de seleção do terceiro neutro; especificar os poderes do terceiro neutro; como os custos do mini-trial serão alocados; o local de sua realização; se testemunhas serão ouvidas; se documentos que estão na posse das partes serão examinados; se as partes resumirão suas posições documentalmente e quando isso ocorrerá; especificar o grau de confidencialidade que pretendam empregar ao procedimento e como eventual acordo será firmado. (CANADA, 2018).

Entre as vantagens do mini-trial estão: menores custos e duração do que o litígio; a solução da demanda está nas mãos das partes; permite às partes ter acesso à posição da outra e então considerar seus pontos fortes e fracos; e o grau de preparação necessário para cada minitrial será útil para processos subsequentes caso o mini-trial venha a ser infrutífero.

Por outro lado, algumas desvantagens podem ser apontadas: o esforço e custo do minitrial pode ser perdido se as partes pudessem ter resolvido seus conflitos por meio de negociação direta ou mediação; se não houver composição, o tempo perdido com o mini-trial pode atrasar a solução que pode ser alcançada por intermédio do processo judicial ou da arbitragem, por exemplo; a natureza similar ao julgamento poderá continuar a polarizar as posições das partes ao invés de promover uma atmosfera de cooperação. (CANADA, 2018).

Quanto ao Brasil, parece que nada há que proíba a utilização do mini-trial no ordenamento jurídico, sendo, inclusive, de ser recomendar a sua utilização a fim de que as partes possam avaliar suas pretensões, evitando-se a propositura de demandas infundadas ou com elevado risco de julgamento contrário ao interesse da parte.

Importa destacar, todavia, que no Canadá, o mesmo avaliador neutro poderia atuar como um mediador ou conciliador caso as partes quisessem levar o conflito para solução através dessa forma de solução de conflitos e que, para o ordenamento jurídico brasileiro, Marco Antônio Garcia Lopes Lorencini (2012, p. 57-85) afirma que "Embora não seja o mais recomendável, o terceiro neutro que preside os trabalhos do mini-trial pode atuar como conciliador ou mediador, chegando a emitir um documento em que expõe os principais pontos do caso".

Entretanto, considerando-se o disposto no art. $2^{\circ}$, inciso I da Lei de Mediação, que tem como princípio informador da mediação a imparcialidade do mediador, bem como diante do entendimento doutrinário de que a postura do mediador é mais passiva do que a postura do conciliador, entende-se que o avaliador neutro somente poderia atuar posteriormente como conciliador sobre o mesmo conflito de interesses apresentado, mas não lhe sendo permitido atuar como mediador. 


\subsection{Rent-a-judge}

A origem dessa modalidade de solução de conflitos remonta a um estatuto do Estado norte americano da Califórnia datado de 1972, mas foi somente na década de 1970 que se tornou popular. (KIM, 1994).

Nesta modalidade de solução extrajudicial de conflitos, as partes escolhem um magistrado privado, normalmente um juiz aposentado, para ouvir o conflito e decidir, sendo que sua decisão seria obrigatória, valendo como um título executivo judicial. As próprias partes teriam liberdade para escolher o seu juiz de aluguel que decidiria de acordo com as regras de direito material e essa decisão seria passível de recurso perante uma Corte de Apelação.

No sistema norte-americano, essa modalidade de solução de conflitos é vantajosa porque eliminaria o julgamento por um júri que nesse país pode vir a ocorrer até mesmo em demandas de natureza civil, o que no Brasil, não ocorre, pois, sabidamente, o procedimento do júri somente ocorre em casos de crimes dolosos contra a vida. Ao poderem escolher o juiz, as partes certamente escolherão aquele que tenha maior experiência no assunto apresentado, o que levará a uma maior qualidade e eficiência do julgamento. (HASAN, 2009).

Outras vantagens dessa modalidade de solução de conflitos estão em possibilitar a flexibilização das regras de procedimento (KIM, 1994), maior rapidez na solução (HASAN, 2009) e a confidencialidade. (GOODPASTER, 1993, p. 299-360).

A rapidez na solução do conflito através do rent-a-judge reflete-se no fato de que o caso não sofre com o abarrotamento do Poder Judiciário e porque a flexibilidade de horários do juiz de aluguel pode torná-lo mais eficiente.

Entretanto, a doutrina norte-americana faz uma crítica ao rent-a-judge aduzindo que esse sistema criaria duas espécies de justiça: uma para os ricos que podem contratar um juiz "privado" e uma para os pobres. (HASAN, 2009).

Segundo Hedy Meggiorin (1999, p. 92-95), como os mais ricos poderiam alcançar a justiça fora do Poder Judiciário, haveria pouco ímpeto para pressionar o Estado por uma reforma para enfrentar os atrasos nos tribunais, bem como para exigir mais recursos para tais reformas.

No Brasil, um modelo tal como o rent-a-judge encontra barreiras. Se não, veja-se:

Primeiramente, porque uma decisão proferida por um juiz exige investidura por meio de um concurso público de provas e títulos para ingresso na carreira da magistratura. Caso se trate de um magistrado aposentado, uma "decisão" por ele proferida como um juiz de aluguel não tem o valor de um título executivo judicial. 
Segundo, não se trata, também, de um acordo que pudesse ser homologado judicialmente, pois o acordo pressupõe a obtenção de um consenso pelas próprias partes, enquanto que no rent-a-judge, a natureza da decisão tomada pelo juiz de aluguel é impositiva.

Terceiro, também não se trata de sentença arbitral, pois conforme visto acima, a arbitragem exige formalidades que não são aplicadas ao sistema ora analisado.

Dessa maneira, parece inequívoco que no sistema de justiça pátrio não seja possível a utilização dessa alternativa, face aos obstáculos legais e conceituais acima mencionados.

\subsection{Baseball arbitration}

Essa técnica de solução de conflitos recebe esse nome porque foi originariamente criada para solucionar conflitos relativos aos salários de jogadores da Liga de Baseball dos Estados Unidos. (JEROME, 2018).

É também conhecida nos Estados Unidos por pendulum arbitration. No caso dessa técnica, o jogador e o time apresentariam cada um o valor do salário para vigência na temporada seguinte e que seria submetido a um árbitro, seguindo-se uma audiência em que ambas as partes teriam a oportunidade de fazer uma apresentação e o árbitro escolheria um dos valores propostos e esse seria o salário fixado para a temporada seguinte. (JEROME, 2018).

Posteriormente, essa técnica passou a ser aplicada em outros conflitos, ainda que não envolvessem o esporte em questão. A doutrina, inclusive, recomenda essa modalidade de solução de conflitos quando as partes estiverem em uma relação de longo-termo. Para alguns, seria uma ramificação da arbitragem, sendo que há duas espécies de baseball arbitration: a day baseball arbitration e a night baseball arbitration. (JEROME, 2018).

Na primeira modalidade, as partes em conflito apresentam ao árbitro o seu caso e fazem uma proposta que ao final será escolhida pelo árbitro na íntegra, ou seja, sem possibilidade de alteração da proposta que for escolhida, não podendo, portanto, escolher um meio termo. A modalidade também é conhecida como final-offer arbitration ou seja, "oferta final". (PETRUZI; KOCH; TURCAN, 2015, p. 139-158).

Como exemplo de aplicação da modalidade está: locador e locatário discutem o valor da locação e cada um propõe um valor que julguem justo e de acordo com o mercado. O árbitro escolherá aquela que acredita ser a mais razoável e realista, mas sem a possibilidade de alterar a proposta escolhida.

A vantagem da baseball arbitration está em que as partes acabam fazendo propostas razoáveis para que a sua proposta seja aceita. (PETRUZI; KOCH; TURCAN, 2015, p. 139158). 
Já na night baseball arbitration as partes apresentam o seu caso ao árbitro que proferirá uma decisão às escuras, ou seja, sem ter acesso às propostas firmadas pelas partes anteriormente. Uma vez lançada a sua decisão, somente então o árbitro terá acesso às propostas e escolherá aquela que mais se aproximar de sua decisão. (PETRUZI; KOCH; TURCAN, 2015, p. 139-158).

No caso da day baseball arbitration, se a parte fizer uma proposta desarrazoada, o árbitro poderá decidir em favor da outra parte. $\mathrm{O}$ mesmo ocorrerá na night baseball arbitration, pois se a proposta for desarrazoada, está mais distante da decisão do árbitro que terá que escolher a outra proposta. Ou seja, na baseball arbitration, a razoabilidade é premiada e a sua falta é punida. (PETRUZI; KOCH; TURCAN, 2015, p. 139-158).

Ainda, outra vantagem estaria em que, nas relações jurídicas de longa duração, a razoabilidade da proposta diminui o senso de antagonismo entre as partes. (HABBU; BUONAGURO, 2011).

Verifica-se que o árbitro na baseball arbitration não tem liberdade para decidir de acordo com o seu livre entendimento, ficando atrelado às propostas feitas, o que diferencia a técnica da arbitragem em geral. Como vantagem da baseball arbitration está uma maior rapidez e economia da solução do litígio, em razão do menor número de audiências. (HABBU; BUONAGURO, 2011).

Trata-se de procedimento adequado a casos de disputa simplesmente monetária, ou seja, quando as partes discordam quanto ao preço a ser estipulado em determinado negócio jurídico. A decisão tratará meramente de valores.

Nos Estados Unidos, não é necessário que o árbitro fundamente sua decisão nessa modalidade de arbitragem, embora haja entendimento de que a fundamentação aumenta a aceitação do resultado. (PETRUZI; KOCH; TURCAN, 2015, p. 139-158).

Já no Brasil, entretanto, a arbitragem, que é regida pela Lei 9.307 de 1996, exige formalidades para a sua instauração, processamento e decisão, sob pena de invalidade, seja do processo como um todo, seja da sentença proferida, conforme dispõe o seu artigo $32^{1}$. A sentença arbitral, por exemplo, dever ser fundamentada, conforme dispõe o inciso II do artigo 26, sendo que o referido artigo 32, em seu inciso III prevê sua invalidade em hipótese de sua inobservância.

\footnotetext{
${ }^{1}$ LA, Art. 32. É nula a sentença arbitral se: I - for nula a convenção de arbitragem; II - emanou de quem não podia ser árbitro; III - não contiver os requisitos do art. 26 desta Lei; IV - for proferida fora dos limites da convenção de arbitragem; V - (revogado); VI - comprovado que foi proferida por prevaricação, concussão ou corrupção passiva; VII - proferida fora do prazo, respeitado o disposto no art. 12, inciso III, desta Lei e VIII - forem respeitados os princípios de que trata o art. $21, \S 2^{\circ}$, desta Lei.
} 
Uma vez instituída a arbitragem nos moldes previstos pela Lei de Arbitragem, o julgamento poderá ser de direito ou de equidade, a critério das partes (caput do artigo $2^{\circ}$ ), sendo que as partes também poderão "escolher, livremente, as regras de direito que serão aplicadas na arbitragem, desde que não haja violação aos bons costumes e à ordem pública" $\left(\S 1^{\circ}\right.$ do artigo $\left.2^{\circ}\right)$.

No parágrafo $2^{\circ}$ do referido artigo, possibilita-se às partes "convencionar que a arbitragem se realize com base nos princípios gerais de direito, nos usos e costumes e nas regras de direito internacionais de comércio". Exceção à flexibilidade na escolha das regras a serem aplicadas ao litígio está no $\S 3^{\circ}$ que prevê que a arbitragem que envolva a administração pública será sempre de direito.

Considerando-se que as partes podem escolher as regras de julgamento do conflito privilegiando-se a autonomia privada, não há óbice a que convencionem que a arbitragem se dê na modalidade analisada no presente item, limitando a decisão do árbitro a uma das propostas realizadas ou àquela que mais se aproxime da proposta realizada, conforme se trate de day baseball arbitration ou night baseball arbitration, respectivamente. Entretanto, a decisão do árbitro deverá ser sempre fundamentada, sob pena de nulidade da sentença, como já mencionado.

É de se ressaltar que não se institui a arbitragem como uma forma de solução de conflitos sem que haja o acordo de vontade das partes.

Uma vez acordando com a instituição da arbitragem e se for regular o seu processamento, uma desistência de qualquer das partes dependeria da anuência da outra. $\mathrm{Ou}$ seja, também o acordo de vontades seria necessário para desconstituir a arbitragem anteriormente convencionada. Não havendo o acordo de vontades para a desconstituição, a sentença arbitral se impõe e merecerá o cumprimento forçado por intermédio do Poder Judiciário por intermédio do procedimento de cumprimento de sentença adequado para o caso (obrigação de dar coisa certa, pagar uma quantia em dinheiro, não fazer etc.).

\section{Notas conclusivas}

Como pode constatar-se pelos números trazidos nesse texto, o sistema de justiça brasileiro, apesar de seu alto custo, não vem cumprindo a contento o seu papel de pacificar os conflitos de interesses de forma eficiente. Então, objetivando mitigar os efeitos da morosidade e da onerosidade no sistema de justiça, paulatinamente, o Estado tem adotado medidas para fomentar a solução de conflitos de forma consensual e fora do Poder Judiciário. 
Exemplos destas iniciativas podem ser extraídos das Resoluções 125 e 225 do Conselho Nacional de Justiça, que tratam, respectivamente, da Política Judiciária Nacional de tratamento adequado dos conflitos de interesses e da Política Nacional de Justiça Restaurativa, ambas no âmbito do Poder Judiciário.

Além da instituição das Políticas pelo CNJ, o Código de Processo Civil, que entrou em vigor em 2016, adotou como norma fundamental que o Estado promoverá "sempre que possível, a solução consensual dos conflitos" e que a "A conciliação, a mediação e outros métodos de solução consensual de conflitos deverão ser estimulados por juízes, advogados, defensores públicos e membros do Ministério Público, inclusive no curso do processo judicial”. Por seu turno, a Lei de Mediação representou outro marco na solução consensual de conflitos.

Daí pode-se verificar que há muita ênfase doutrinária e legal dada à mediação e à conciliação, mostrando-se importante a análise e divulgação de outros meios de solução de conflitos, bem como se estes podem ser utilizados no ordenamento jurídico brasileiro.

Assim, neste texto foram abordadas outras formas de solução de conflitos, quais sejam: a avaliação por terceiro neutro, o mini-trial, o rent-a-judge e o baseball arbitration.

E conforme se averiguou, tanto na avaliação por terceiro neutro, quanto no mini-trial as partes em conflito terão a oportunidade de vislumbrar os argumentos a favor e contra a sua pretensão e ter acesso, antes da propositura da demanda judicial, a um parecer fundamentado elaborado por sujeito imparcial e com experiência na temática apresentada. Nesses casos, o parecer não tem força vinculante, mas diante do prognóstico nele apresentado, as partes acabam por ficar mais propensas a uma composição, avaliando previamente os riscos da demanda judicial.

Por outro lado, a modalidade rent-a-judge não pode ter admitida a sua aplicação no Brasil, pois reflete a possibilidade de uma decisão ser proferida por um juiz privado, escolhido pelas partes e ter força vinculativa. No ordenamento nacional, a atividade jurisdicional é privativa de magistrados que possuem investidura e tenham sido aprovados em concurso público, fator que inviabiliza a sua aplicação em terras brasileiras.

Poder-se-ia argumentar que se assemelha à arbitragem, mas para a instituição dessa modalidade de solução de conflitos são necessárias formalidades legais, previstas na Lei 9.307 de 1995, sob pena de, conforme o caso, acarretar uma nulidade da sentença ou do processo arbitral como um todo. Isso porque nos Estados Unidos, a decisão proferida pelo juiz de aluguel seria passível de apelação, enquanto no Brasil somente uma sentença judicial seria passível de tal recurso. Com relação à sentença arbitral, a decisão é irrecorrível. 
Por fim, analisou-se a chamada baseball arbitration, que foi criada para solucionar a disputa de salários entre jogadores de baseball e seus respectivos times, mas que depois foi ampliada para outros tipos de disputa.

Na sua variação day baseball arbitration, cada uma das partes apresenta a sua proposta e ao final, o árbitro escolha uma delas sem a possibilidade de alterá-la. Já na variação night baseball arbitration as partes apresentam o seu caso ao árbitro que proferirá uma decisão sem ter tido acesso às propostas formuladas, ou seja, às escuras. Uma vez lançada a sua decisão, somente então o árbitro terá acesso às propostas e escolherá aquela que mais se aproximar de sua decisão. Em ambas as modalidades, verifica-se que as partes farão esforços para firmar propostas razoáveis, sob pena de verem escolhida a proposta da parte contrária.

No Brasil, considerando-se que a Lei de Arbitragem permite que as partes escolham as regras de direito que serão aplicadas na arbitragem ( $\operatorname{art.} 2^{\circ}$, parágrafo $1^{\circ}$ ), nada impede que, uma vez observados os requisitos necessários para a sua instituição, processamento e decisão, que o árbitro possa decidir escolhendo uma ou outra proposta (day baseball arbitration) ou aquela proposta que mais se aproximar de sua decisão (night baseball arbitration). Desse modo, pode-se entender como plenamente cabível a utilização dessa alternativa como mais uma que visa gestionar conflitos no Brasil.

$\mathrm{O}$ fato é que o sistema de justiça nacional abriu-se às medidas alternativas que visam a solução de conflitos entre os litigantes, postura que se alterou por diversas razões, sejam elas numéricas, financeiras, instrumentais ou eficaciais.

No entanto, também é verdade que a utilização dessas medidas ainda é tímida e que poucos conhecem o prisma de possibilidades, ficando-se restrito apenas as técnicas mais conhecidas, como a mediação e a arbitragem por exemplo.

Dessa maneira, esse texto traz e descreve algumas outras opções que se disponibilizam a aplicação pelo ordenamento jurídico brasileiro e algumas que, mesmo descritas, não podem ser utilizadas em terras nacionais.

O que falta, então, além do conhecimento destas noveis técnicas, é a disposição cada vez mais veemente no sentido de buscar alternativas viáveis fática e juridicamente que alcancem o fim desejado pelas partes, que é, em regra, a solução do seu conflito ou, na pior das hipóteses, a sua gestão de modo adequado.

\section{Referências bibliográficas}


ALVES DA SILVA, Paulo Eduardo. Solução de controvérsias: métodos adequados para resultados possíveis e métodos possíveis e para resultados adequados. In: SALLE, Carlos Alberto; LOPES LORENCINI, Marco Antônio Garcia; ALVES DA SILVA, Paulo Eduardo (Coord.). Negociação, mediação e arbitragem. São Paulo: Método, 2012.

AMERICAN BAR ASSOCIATION. Dispute Resolution Processes. Disponível em: https://www.americanbar.org/groups/dispute_resolution/resources/DisputeResolutionProcesse s/early_neutral_evaluation.html Acesso em: 01 maio 2018.

AUSTRALIA. Business Law Branch Attorney-General's Department. Your guide to dispute resolution. Disponível em: https://www.ag.gov.au/LegalSystem/AlternateDispute Resolution/Documents/Your\%20Guide\%20to\%20Dispute\%20Resolution.pdf. Acesso em: 01 maio 2018.

BACELLAR, Roberto Portugal. Mediação e arbitragem. 2. ed. São Paulo: Saraiva, 2016.

BRASIL. Lei no. 13.105, de 16 de março de 2015. Código de Processo Civil. Publicado no DOU de 17.3.2015. Brasília, DF, 2015a. Disponível em: http:/www.planalto.gov.br/ ccivil_03/_Ato2015-2018/2015/Lei/L13105.htm. Acesso em: 01 maio 2018.

BRASIL. Lei no. 13.140, de 26 de junho de 2015. Dispõe sobre a mediação entre particulares como meio de solução de controvérsias e sobre a autocomposição de conflitos no âmbito da administração pública; altera a Lei no 9.469, de 10 de julho de 1997, e o Decreto no. 70.235, de 6 de março de 1972; e revoga o $§ 2^{\circ}$ do art. $6^{\circ}$ da Lei no 9.469, de 10 de julho de 1997. Publicado no DOU de 29.6.2015. Brasília, DF, 2015b. Disponível em: http://www.planalto.gov.br/ccivil_03/_ato2015-2018/2015/lei/113140.htm. Acesso em: 01 maio 2018.

BRASIL. Lei no. 9.307, de 23 de setembro de 1996. Dispõe sobre a arbitragem. Publicado no DOU de 24.9.1996. Brasília, DF, 1996. Disponível em: http://www.planalto.gov.br/ ccivil_03/leis/19307.htm. Acesso em: 01 maio 2018. 
CANADA. Department of Justice. Dispute Resolution Reference Guide: Neutral Evaluation. Disponível em: www.justice.gc.ca/eng/rp-pr/csj-sjc/dprs-sprd/resdrrgmrrc/eval.html. Acesso em: 30 mar. 2018.

CONSELHO NACIONAL DE JUSTIÇA-CNJ. Justiça em Números 2017: ano base 2016. 13. ed. Brasília: CNJ, 2017. Disponível em: www.cnj.jus.br/files/conteudo/arquivo/2017/ 09/e5b5789fe59c137d43506b2e4ec4ed67.pdf. Acesso em: 30 abr. 2018.

CONSELHO NACIONAL DE JUSTIÇA-CNJ. Resolução 125, de 29 de novembro de 2010. Dispõe sobre a Política Judiciária Nacional de tratamento adequado dos conflitos de interesses no âmbito do Poder Judiciário e dá outras providências. Disponível em: www.cnj.jus.br/ busca-atos-adm?documento=2579. Acesso em: 01 maio 2018.

CONSELHO NACIONAL DE JUSTIÇA-CNJ. Resolução 225, de 31 de maio de 2016. Dispõe sobre a Política Nacional de Justiça Restaurativa no âmbito do Poder Judiciário e dá outras providências. Disponível em: http://www.cnj.jus.br/images/atos_normativos/resolucao/ resolucao_225_31052016_02062016161414.pdf. Acesso em: 01 maio 2018.

FINDLAW. Neutral Evaluation: An ADR Technique Whose Time Has Come. Disponível em: http://corporate.findlaw.com/litigation-disputes/neutral-evaluation-an-adr-techniquewhose-time-has-come.html. Acesso em: 01 maio 2018.

GOODPASTER, Gary. Rational Decision-Making in Problem-Solving Negotiation: Compromise, Interest-Valuation, and Cognitive Error. Ohio State Journal on Dispute Resolution, Columbus, Oh, EUA, Vol. 8, no. 2, p. 299-360, 1993. Disponível em: https://kb.osu.edu/dspace/bitstream/handle/1811/79711/OSJDR_V8N2_299.pdf?sequence=1. Acesso em: 23 out. 2017.

GUILHERME, Luiz Fernando do Vale de Almeida. Manual dos MESC's: meios extrajudiciais de solução de conflitos. Barueri : Manole, 2016.

HABBU, Aditya (Adi); BUONAGURO, Paul V. A Game Theoretic Model for Determining When Baseball Arbitration Creates the Proper Incentives for Litigants. Social Sciences 
Research, July 19, 2011. Disponível em: https://ssrn.com/abstract=1889768 ou http://dx.doi.org/10.2139/ssrn.1889768. Acesso em: 23 out. 2017.

HASAN, Cidgem. Rent-a-judge. Lund, De: Faculty of Law, University of Lund, 2009. Master Tesis (Master in Law), Faculty of Law, University of Lund, 2009. Disponível em: http://lup.lub.lu.se/luur/download?func=downloadFile\&recordOId=1558154\&fileOId=15645 59. Acesso em: 02 maio 2018.

JEROME, Brian R. Baseball (Pendulum) Arbitration. Massachusetts Dispute Resolution Services. Disponível em: http://www.mdrs.com/baseball-pendulum-arbitration/. Acesso em: 02 maio 2018.

KIM, Anne S. Rent-a-Judge and the Cost of Selling Justice, Duke Law Journal, Durnham, NC, EUA, vol. 44, p. 166-199, 1994. Disponível em: https://scholarship.law.duke.edu/ dlj/vol44/iss1/4. Acesso em: 02 maio 2018.

LOPES LORENCINI, Marco Antônio Garcia. "Sistema multiportas": opções para tratamento de conflitos de forma adequada. In: SALLE, Carlos Alberto; LOPES LORENCINI, Marco Antônio Garcia; ALVES DA SILVA, Paulo Eduardo (Coord.). Negociação, mediação e arbitragem. São Paulo: Método, 2012.

MEGGIORIN, Hedy. Issues in Australian private judging: understanding the pitfalls. ADR Bulletin, Queensland, Au, Vol. 1, No. 7 p. 92-95, 1999. Disponível em: https://epublications. bond.edu.au/cgi/viewcontent.cgi?referer=https:/www.google.com.br/\&httpsredir=1\&article= 1033\&context=adr. Acesso em: 23 out. 2017.

PEREIRA, Dirce do Nascimento; CONSALTER, Zilda. Soluções consensuais de conflitos no âmbito do direito das famílias: uma análise em três atos. In: PEREIRA, Dirce do Nascimento; CONSALTER, Zilda (Coord.). Práticas consensuais para a pacificação dos conflitos no âmbito familiar. Curitiba: Juruá, 2018. 
PETRUZI, Raffaele; KOCH, Petra; TURCAN, Laura. Baseball arbitration in comparison do other types of arbitration. In: LANG, M. OWENS, J. International Arbitration in Tax Matters, Amsterdam, IBFD, 2015, p. 139-158. Disponível em: https://www.wu.ac.at/file

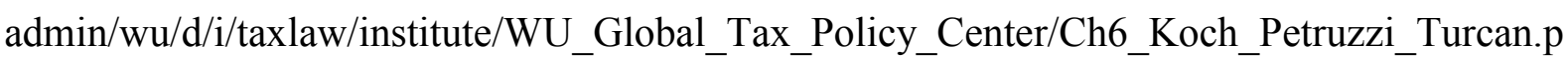
df. Acesso em: 02 maio 2018. 


\title{
NOVOS CAMINHOS PARA A SOLUÇÃO DE CONFLITOS JUDICIAIS A PARTIR DA EXPERIÊNCIA BRASILEIRA COM O DIREITO SISTÊMICO: POSSIBILIDADES DE APLICAÇÃO NA ESPANHA
}

\author{
Tatiane Silva Ferreira \\ Universidade de Itaúna - MG - Brasil \\ Márcio Eduardo Senra Nogueira Pedrosa Morais \\ Universidade de Itaúna - MG - Brasil
}

\section{Resumo}

Atualmente há uma excessiva quantidade de conflitos levados ao Poder Judiciário, tanto no Brasil, quanto na Espanha, dificultando a celeridade, como também a resolução das questões envolvidas, o que motiva tentativas e propostas de modernização da prestação jurisdicional. Objetiva-se, com este artigo, promover o debate acerca do Direito Sistêmico, como método inovador de solução de conflitos. O Brasil é pioneiro mundial, com números expressivos de acordos, aplicando essa inovação. Pela pesquisa, bibliográfica e documental, indutiva e de análise interpretativa e comparativa, conclui-se a efetividade prática do método e são traçadas possibilidades de aplicação na Espanha.

Palavras-chave: Acesso à Justiça, Formas Consensuais de Resolução de Conflitos, Direito Sistêmico, Brasil, Espanha.

\section{Abstract/Resumen/Résumé}

There is an excessive amount of conflicts brought to the Judiciary in Brazil and in Spain, making it difficult to speed up, as well as the resolution of the issues involved, which motivates attempts and proposals to modernize the jurisdictional provision. The objective is to promote the debate about Systemic Law as an innovative method of conflict resolution. Brazil is a world pioneer, with expressive numbers of agreements, applying this innovation. The research, bibliographical and documentary, inductive and of interpretative and comparative analysis, the practical effectiveness of the method is concluded and possibilities of application in Spain are traced. 
Keywords/Palabras-claves/Mots-clés: Access to Justice, Consensus Forms of Conflict Resolution, Systemic Law, Brazil, Spain.

\section{Introdução}

Um dos maiores desafios que se apresentam ao Direito deste século é fornecer prestação jurisdicional adequada, que garanta acesso à justiça perante os conflitos levados ao Poder Judiciário, não num viés utilitarista, mas sim para todos aqueles que necessitam da atuação efetiva e justa desse poder. Deste modo, diz-se da necessidade de um acesso material à Justiça.

A tradicional prestação jurisdicional e a decisão judicial impositiva, em geral, não trazem paz às partes envolvidas, como também os métodos tradicionais se mostram insuficientes para a promoção de uma real conciliação, o que se observa pelos conflitos acirrados em longos processos, interposição de recursos e novas ações. Partindo-se dessa colocação, é importante que sejam estimuladas as formas consensuais de solução de conflitos.

Uma dessas formas consensuais é o Direito Sistêmico, que, ainda sem regulamentação específica, vem adquirindo cada vez mais respeito, no Brasil e em outros países, diante de seus resultados expressivos.

Por Direito Sistêmico entende-se um método sistêmico-fenomenológico de solução de conflitos, com viés terapêutico, que tem por objetivo conciliar, profunda e definitivamente, as partes, em nível anímico, mediante o conhecimento e a compreensão das causas ocultas geradoras das desavenças, ocasionando paz e equilíbrio para os sistemas envolvidos. (ROSA, 2018). Por sua vez, por Constelações Sistêmicas entende-se uma terapia complementar que objetiva, para se chegar à solução, trazer à luz, por meio da representação, as questões sistêmicas familiares mal resolvidas, principalmente de antepassados, por violação das leis e princípios sistêmicos, violações estas que levam seus integrantes - ainda aqueles que não têm ou tiveram nada a ver com o problema - a um redemoinho de doença, dor, sofrimento, tristeza, solidão, atraindo para si, sem querer, contextos de violência. (ROSA, 2018).

Diante dessas rápidas considerações, é crucial destacar o objetivo do trabalho, que é promover reflexões e contribuir para o debate acerca da adequação do uso das Constelações Sistêmicas como método complementar de solução de conflitos - tema relevante para a compreensão do direito fundamental de acesso material à justiça -, além de traçar possibilidades para sua utilização na Espanha. 
A problemática do trabalho gira em torno da busca pela paz social, pela real superação do conflito, em detrimento de considerá-lo resolvido quando terminado formalmente, por imposição da decisão judicial. Há necessidade de debate jurídico do tema por ser o Direito Sistêmico, potencialmente, uma das formas mais eficazes para se resolver os conflitos consensualmente - ao menos em algumas áreas, haja vista seus resultados - e que vem sendo usado por profissionais do Direito no Brasil, à margem de regulamentação específica.

Deste modo, questiona-se: a busca por soluções consensuais para os conflitos, de acordo com as leis sistêmicas descobertas por Bert Hellinger, deve ser institucionalizada no Poder Judiciário brasileiro? Considerando os resultados brasileiros e a validade universal das leis sistêmicas, há diálogo entre o Direito brasileiro e o Direito espanhol que permita possibilidades de aplicação do método na Espanha, tendo como paradigma a experiência brasileira?

Para responder a essa problematização, este artigo se subdivide em duas partes, respectivamente intituladas: i) $O$ acesso à justiça como direito fundamental no Estado Democrático de Direito; ii) Direito sistêmico no Brasil e possibilidades de interlocução com o direito espanhol - seção subdividida na apresentação da filosofia básica das Constelações segundo Bert Hellinger, no entendimento do Direito Sistêmico a partir de Sami Storch e da experiência brasileira - incluindo a análise interpretativa de dados secundários confrontados com dados de métodos tradicionais de solução de conflitos - e, por último, na análise da possibilidade de aplicação do método na Espanha.

A pesquisa é bibliográfica, com a utilização de livros e trabalhos científicos que contribuam para o embasamento teórico necessário, como também documental, por intermédio da utilização de dados quantitativos da realidade brasileira.

Enfatiza-se que ainda são escassos os trabalhos científicos específicos sobre o tema Direito Sistêmico - um recorte dentro do tema Constelações Sistêmicas -, o que evidencia ainda mais a importância do presente estudo. Importante ressaltar que a escassez de livros se dá em decorrência do pouco tempo de desenvolvimento do tema.

Ademais, após pesquisa na bibliografia jurídica espanhola, não foram encontrados estudos em relação à temática, o que aumenta a sua importância e pode trazer subsídios para a reflexão da doutrina desse país europeu.

Por fim, o foco do presente trabalho está na adequação do método como novo caminho que se mostra para o Direito a partir do Brasil, não sendo objeto, portanto, aprofundar ou questionar os mecanismos de funcionamento da Constelação e leis sistêmicas, bastando, para o proposto, a ciência de seus conceitos básicos. 


\section{O acesso à justiça como direito fundamental no Estado Democrático de Direito}

De acordo com o texto da Constituição da República Federativa do Brasil de 1988 (2018c) o acesso ao Poder Judiciário é um direito fundamental, constituindo um dos mais importantes direitos distributivos a serem materialmente concretizados no Estado Democrático de Direito.

Ao se abordar a temática do acesso à justiça, é sobejamente conhecida a Teoria das Ondas de Acesso à Justiça de Mauro Cappelletti e Bryan Garth (1998). Esquematicamente, a primeira "onda" é a assistência judiciária. A segunda onda se refere às reformas tendentes a proporcionar representação jurídica para os interesses "difusos”, especialmente nas áreas da proteção ambiental e do consumidor. Por sua vez, a terceira onda, a mais recente, é o "enfoque de acesso à justiça" que inclui os posicionamentos anteriores, mas vai muito além deles, representando, dessa forma, uma tentativa de atacar as barreiras ao acesso de modo mais articulado e compreensivo. (CAPPELLETTI, GARTH, 1998).

É dessa terceira onda, de acesso efetivo (material) à justiça, que é considerado o Direito Sistêmico. Entende-se como acesso material à justiça a efetividade de uma justiça democrática, justa, que represente não somente algumas classes, mas a todos indistintamente, ou seja, a justiça de uma sociedade inclusiva, que rompa com todos os postulados ideológicos de um direito utilitário, que tenha a democracia como sustentáculo, democracia essa ligada à ideia de liberdade. (BURDEAU, 1960).

No Brasil, a tradição jurídica constitucional durante muito tempo esteve alicerçada sob um acesso formal à justiça, por intermédio do acesso ao Poder Judiciário por si só, sem se considerar os resultados sociais e distributivos do acesso à justiça, desconsiderando a necessidade e a condição de ter o Poder Judiciário uma função social de relevância no Estado Democrático.

Estruturadas através de relações privadas, tendo como fundamento o mando e a obediência, "disso decorre a recusa tácita (às vezes, explícita) de operar com os direitos civis e a dificuldade para lutar por direitos substantivos e, portanto, contra formas de opressão social e econômica". (CHAUI, 2004, p. 90). Nestes moldes, de acordo com Marilena Chauí:

[...] para os grandes, a lei é privilégio; para as camadas populares, repressão. Por esse motivo, as leis são necessariamente abstratas e aparecem como inócuas, inúteis ou incompreensíveis, feitas para ser transgredidas e não para ser cumpridas nem, muito menos, transformadas. (CHAUI, 2004, p. 90). 
Para que democracia e direito se materializem, ou seja, para que o direito possa ser exercido democraticamente, deve esse estar assentado numa cultura democrática, sendo tais condições, nos dizeres de Boaventura de Sousa Santos (2007), muito difíceis em decorrência de duas razões: uma em relação à distância que separa os direitos formalmente concedidos das práticas sociais que impunemente os violam; de outro lado, devido ao fato de as vítimas de tais práticas, longe de se limitarem a chorar na exclusão, reclamam serem, individualmente e coletivamente, ouvidos. "A frustração sistemática das expectativas democráticas pode levar à desistência da democracia e, com isso, à desistência da crença no papel do direito na construção da democracia”. (SANTOS, 2007, p. 10).

Sendo frustradas as expectativas, resta ao cidadão a busca pela concretização do seu direito no Poder Judiciário, o qual tem um papel no Estado Democrático de Direito muito além de mero aplicador da "lei seca", de mero intérprete, um papel de garantidor, de distribuidor dos direitos, direitos da maioria, da minoria, mas além disso, dos direitos individuais, sem os quais não há que se falar em cidadania, em dignidade da pessoa humana, e consequentemente em Estado Democrático de Direito, além de ser esse Poder um meio importante como parte das estratégias de superação do subdesenvolvimento.

A participação do Poder Judiciário se faz ainda mais importante na realidade brasileira, haja vista a necessidade de se garantir direitos sociais que não são distribuídos satisfatoriamente pelo Estado, que não cumpre efetivamente prestações distributivas como acesso à educação, saúde, segurança, mínimos necessários para que se possa falar em princípio da dignidade da pessoa humana.

No Brasil, historicamente, a prestação judicial, representada pelo Poder Judiciário, está presente na vida nacional desde a primeira constituição, outorgada por D. Pedro I em $1824,{ }^{1}$ a Constituição Política do Império do Brasil, que trazia no seu título sexto, capítulo único, a estrutura do Poder Judicial, ${ }^{2}$ demonstrando ser o Poder Judicial independente e composto de juízes e jurados, cíveis e criminais, sendo os juízes perpétuos e passíveis de remoção dentro dos critérios legais. ${ }^{3}$ Porém, em realidade, a sociedade imperial tinha na pessoa do imperador o centro das decisões e influências judiciárias, haja vista o Poder Moderador, por intermédio do qual o monarca podia intervir nos demais poderes.

\footnotetext{
${ }^{1}$ Apesar das críticas contundentes recebidas, acabou por ser assimilada por imposição.

${ }^{2}$ Expressão utilizada pela Constituição Política do Império do Brasil de 25 de março de 1824. (BRASIL, 2018b).

${ }^{3}$ Conforme artigos 151 e 153 da Constituição do Império.
} 
Com a queda da monarquia em 1891, o Brasil inicia sua primeira fase democrática, seguida de momentos, inclusive de ditadura militar, mesmo após a era do incremento dos direitos humanos - haja vista a elaboração da Declaração de Direitos Humanos da Organização das Nações Unidas de 1948.

Infelizmente, enquanto havia crescimento nos índices de eleitores, o partido de oposição (Movimento Democrático Brasileiro - MDB) não detinha poder efetivo perante a realidade política brasileira e a desigualdade social aumentava consideravelmente, Carvalho (2007) mostra que em 1960 os 10\% mais ricos detinham 39,6\% da renda, ao passo que em 1980 sua participação subira para $50,9 \%$, todavia esse aumento da desigualdade não era evidente à sociedade da época. Estrategicamente, os militares investiram na expansão dos direitos sociais ${ }^{4}$ e promoveram o enxugamento dos direitos civis e políticos, ou seja, dar-se-ia vantagens típicas de um Estado Social ${ }^{5}$ (Welfare State), em compensação, não haveria direitos políticos e civis que pudessem obstruir ou desestruturar a severa ditadura implantada no país.

Em 1985, demonstrando a intenção de redemocratização, são lançadas eleições, vencendo o candidato oposicionista Tancredo Neves, chegando-se ao fim o período dos governos militares.

A democracia no Brasil ainda é um projeto em construção, tendo havido momentos de democracia. O período pós-1985, tendo como marco a Constituição de 1988 é ainda um período curto de maturação democrática. No geral, a sociedade brasileira é marcada por desigualdade social e por consideráveis períodos de alijamento da população do processo democrático, tanto no aspecto formal quanto material.

Essas considerações são importantes para situar a importância do acesso material à justiça no Estado Democrático de Direito, que é um modelo inclusivo e radicalmente democrático, no sentido de tutelar todos os projetos de vida, tanto os majoritários, quanto os minoritários.

\section{Direito sistêmico no Brasil e possibilidades de interlocução com o direito espanhol}

Tendo em mente o considerável número de conflitos que, de forma extrema, são levados ao Poder Judiciário, ${ }^{6}$ e que o Direito deve ser capaz de responder às demandas por

\footnotetext{
${ }^{4}$ Dentre os institutos típicos do Estado Social é de se salientar a criação do INPS em 1966 e do FGTS em 1966.

${ }^{5}$ Sobre as características do Estado Social ver ABENDROTH; FORSTHOFF; DOEHRING (1986).

${ }^{6}$ No ano de 2016, no Brasil, para cada 1.000 habitantes, 129,07 ingressaram com uma nova ação judicial (BRASIL, 2017). Este número aproxima-se ao da Espanha, que foi de 124,9. (PODER JUDICIAL DE ESPAÑA, 2018).
} 
justiça que cheguem ao Estado, apresenta-se o uso do Direito Sistêmico como forma consensual de solução dos conflitos, iniciado mundialmente no Brasil.

\subsection{As leis sistêmicas e o conceito de consciência na abordagem das constelações sistêmicas: aplicabilidade ao direito}

Objetivando apresentar uma noção acerca da Teoria das Constelações, necessário para o entendimento da sua relação com o Direito, é importante frisar dois conceitos: o das leis sistêmicas e o conceito de consciência de Bert Hellinger, que desenvolveu o método das Constelações Sistêmicas.

A Constelação Sistêmica ${ }^{7}$ considera a atuação de leis sistêmicas no relacionamento entre as pessoas, independentemente de estas terem conhecimento - o que mostra o caráter atemporal e a aplicabilidade universal da teoria. Considera que as pessoas fazem parte de sistemas, pertencendo-se em primeiro lugar ao sistema da família e, a partir deste - motivo pelo qual as Constelações necessariamente envolvem questões familiares -, aos outros dos quais fazem parte na vida.

Parte-se do princípio de que cada pessoa traz consigo informações ocultas e transgeracionais $^{8}$ do seu sistema. Assim, em qualquer relacionamento interpessoal, não são apenas duas pessoas que se relacionam - ainda que estejam sozinhas em dada relação tempoespaço -, mas sim dois sistemas (HELLINGER, 2005).

Forças resultantes de histórias familiares muitas vezes não conhecidas pelos advogados, juízes e nem pela própria pessoa, podem ser responsáveis por manifestações de vontade das partes em conflito.

Não se trata de questionar a existência do livre-arbítrio ou de adentrar no âmbito da Psicologia - com a qual a Constelação não se confunde -, mas de contextualizar o leitor no sentido de que as Constelações parecem permitir a identificação pelas próprias pessoas do que realmente buscam com o conflito, muitas vezes de forma inconsciente.

\footnotetext{
${ }^{7}$ Modelo atual, referido neste trabalho. A Constelação Familiar - já existente anteriormente (HELLINGER; HÕVEL, 2006, p. 31) -, tal como Hellinger a desenvolveu, recebeu várias influências da terapia familiar, da Programação Neolinguística, da Psicologia, da sua experiência como missionário, e foi inovada pelos seus conceitos das leis sistêmicas, de consciência e transgeracionalidade.

${ }^{8}$ Embora não se questione, neste trabalho, a transmissão de informações, sensações e emoções entre gerações além de ser tida como através do campo mórfico -, cita-se, como contribuição transdisciplinar, estudo em camundongos, publicado na revista Nature Neuroscience, que sugere a transmissão genética de traumas e fobias dos antepassados (DIAS; RESSLER, 2014).
} 
Analiticamente, são três as leis que atuam nos sistemas de cada pessoa: a lei do pertencimento, a lei da ordem e a lei do equilíbrio, assegurando, o respeito a estas leis, de forma consciente ou inconsciente, uma vida harmoniosa e em paz. (HELLINGER, 2005). A pessoa, ao não respeitá-las, situa-se fora de seu lugar no sistema, podendo criar emaranhamentos ${ }^{9}$, que são reproduzidos nos relacionamentos.

A lei do pertencimento estatui que todos os integrantes do sistema têm direito de pertencimento, inclusive o imperfeito - aquele que, a princípio, não é aceito -, devendo haver a aceitação de todos que fazem parte do sistema, ainda não sendo da forma desejada. (HELLINGER, 2017).

Importante perceber que o direito de o imperfeito pertencer não se trata de ter misericórdia por outro indivíduo inferiorizado pelos seus defeitos, mas em estar nesta inclusão a paz da pessoa que o tem em seu sistema. Não se deve confundir que, embora possa parecer uma aceitação da outra parte, até quando não tenha razão, na verdade, implica em mudança de percepção do conflito após aceitação da imperfeição no próprio sistema.

Quanto à lei da ordem ou hierarquia, o respeito à prioridade por ordem de idade, pela função e pela precedência dos antepassados em relação às gerações futuras, traz paz a qualquer sistema. Aqui, não cabe autoritarismo ou inflexibilidade; apenas a consciência da precedência de quem veio antes. (HELLINGER, 2001).

A terceira lei é a do equilíbrio entre o dar e o tomar, que diz respeito à vida como constante jogo de trocas, frequentemente incompreendida. O desequilíbrio costuma ter origem na tríade formada por pai, mãe e filho - fonte de aprendizado sobre todas as relações.

Segundo a lei, quem dá demais não recebe e, se este equilíbrio for desfeito em uma relação, deve haver uma ação contrária para que volte à harmonia. Simplesmente perdoar, embora bem visto na concepção cristã, é tido como um ato de arrogância, pois houve julgamento de que algo é errado e merece perdão. É salutar compreender que não cabe a esta lei exigir o reconhecimento de volta ou ainda devolver o mesmo mal e procurar vingança pela indignação. (HELLINGER, 2001).

Extrapola-se, buscando a percepção de que a forma tradicional da prestação jurisdicional, muitas vezes, alcança apenas a vingança, seja pela simples sensação do Estado ter dado razão a uma parte, seja pelo sentimento não raro de que "foi feita a justiça" quando

\footnotetext{
9 “Acontece, porém, que na nossa família alguns foram excluídos, rejeitados, esquecidos, dados ou talvez abortados. E agora essa consciência arcaica procura reestabelecer a ordem de tal forma que toma a serviço um inocente, alguém de uma geração posterior, uma criança, um neto ou alguém que veio muito mais tarde para que ele ou ela represente essa pessoa excluída" (HELLINGER, 2017, p. 92).
} 
ocorre a condenação da outra parte, em uma visão equivocada de equilíbrio - que, em geral, não é reestabelecido na relação conflituosa. Além disso, muitas tentativas conciliatórias buscam o perdão, ou seja, que uma parte ceda - ainda que parcialmente -, até em detrimento da falta de compreensão da outra parte.

Todas as leis dizem respeito ao amor, como também às pessoas terem intenções positivas em seus relacionamentos familiares, inclusive quando ferem as leis sistêmicas e criam emaranhamentos que refletirão nos seus relacionamentos futuros.

Pela Constelação, não se deve buscar corrigir o que, aparentemente, precisa ser corrigido, e sim olhar com amor. Por isso a importância em fazer com que cada pessoa olhe primeiramente para seu próprio sistema, ao invés de procurar o erro do outro. No Direito tradicional, em geral, a imperfeição em relação aos padrões estabelecidos é condenada, e o olhar de uma parte no conflito busca o erro da outra.

Hellinger diz que "toda pessoa que lamenta não quer agir. Todo consolo para alguém que se lamenta apoia a sua não ação". (HELLINGER, 2005b, p. 58).

Explicadas as leis, ainda que perfunctoriamente, outro conceito importante das Constelações é o de consciência - envolvida na transgeracionalidade -, de interesse para as tentativas de acordo e para as argumentações utilizadas no Direito, sendo dividida em três níveis.

A consciência pessoal depende do que o pai e a mãe, principalmente, esperam da pessoa e relacionam-se ao pertencimento ao sistema familiar. A consciência coletiva ou de grupo abarca as individuais e guarda a memória transgeracional, inconsciente. A terceira consciência trata-se da universal ou espiritual, uma consciência que une todas as pessoas, em que uma força maior atua universalmente, movendo o indivíduo.

A mudança da consciência pessoal influencia os outros níveis de consciência em um sistema. A realidade normativa rege determinada época, de acordo com a moral, o senso comum. Este é resultado das percepções de mundo individuais, cada cosmovisão, de acordo com realidade sensorial. O senso comum é modificado após questionamentos individuais da realidade, que provocam ressonância no campo ${ }^{10}$ e impactam pessoa a pessoa até ocorrer uma mudança cultural e alterar a realidade normativa.

Tornam-se importantes os conceitos de boa e de má consciência de Bert Hellinger, principalmente em se tratando do Direito. A boa consciência diz respeito ao sentimento de

\footnotetext{
${ }^{10}$ Campo mórfico ou morfogenético. “(...) campo de força que é dotado de saber e o transmite através da simples participação, sem mediação externa” (HELLINGER, 2001, p. 12). Por isto, pessoas estranhas podem se sentir como os representados, revelando os destinos ocultos.
} 
inocência quando se age de acordo com o que a família espera - lealdade em manter o status quo. Ocorre conflito de consciência quando se vai além desta consciência restrita e se faz algo que a família ou grupo não gostam - efeito da consciência coletiva, sentida como um instinto. (HELLINGER, 2005). Considera-se certo, com mais razão, quando se age de acordo com as leis do Direito ou com o que espera a sociedade, o que nem sempre é conseguido.

Isto porque, a simples imposição de normas, se não estiver de acordo com a consciência, não garante o seu cumprimento. Fato observado tanto pelo descumprimento de normas legais ${ }^{11}$, quanto pelas tentativas de comunicação que buscam convencer qual parte possui razão e direito, sem sucesso, até que o juiz decida.

É importante que não haja julgamentos nas Constelações e no uso das leis sistêmicas. $\mathrm{O}$ raciocínio deste trabalho, assim como a própria filosofia hellingeriana ${ }^{12}$, não é contrário à aplicação das normas do Direito. Inclusive, o culpado tem não apenas o dever de assumir as consequências de seus atos, mas também o direito de fazê-lo. (HELLINGER, 2017).

A Constelação trata da ampliação da consciência das pessoas, para compreenderem o que está por trás do conflito - não alterando a responsabilidade por seus atos perante o Direito -, mas alterando, por elas próprias, suas percepções e ações, que influem na resolução do conflito. Esta ampliação ocorre pelo conhecimento das leis sistêmicas e pela abordagem fenomenológica das Constelações, através de representações de pessoas. Fenomenológico porque não analisa, mas favorece nova compreensão a partir da experiência, além de não se tratar de uma terapia de acompanhamento, nem anterior, nem posterior ao fenômeno.

Neste modelo, as informações ocultas emergem do campo no momento presente, sendo diferente o fenômeno em cada Constelação, que costuma ser surpreendente, por mostrar a atitude que a pessoa deve ter em sua vida, e que até então não era percebida. Explica-se melhor a Constelação - o que não é objeto específico do trabalho -, vivenciando-a.

Diferentemente do Direito tradicional, a Constelação utiliza, em sua maior parte, a comunicação não verbal, e a imagem formada internamente é responsável pelo trabalho de ressignificação, que provoca mudanças e produz impacto no conflito judicial. (HELLINGER, 2017). Assim, o processo de tomada de consciência envolve, mais do que entendimento racional do que a outra parte tenta comunicar em seu discurso, a compreensão alcançada com a

\footnotetext{
${ }^{11}$ Em relação ao descumprimento de medidas protetivas previstas na Lei Maria da Penha, o Senado aprovou, recentemente, projeto que criminaliza esta prática.

(https://www12.senado.leg.br/noticias/materias/2018/03/07/descumprimento-de-medidas-protetivas-da-leimaria-da-penha-vai-dar-cadeia) - usando, novamente, a imposição legal na tentativa de reprimir a violência.

12 "Considerá-los responsáveis por seus atos e, ao mesmo tempo, compreender que estavam envolvidos num mal bem maior é diferente de julgá-los moralmente como pessoas perversas - e sentir-se moralmente superior a eles. Você tem de decidir se vai pensar moralmente, legalmente ou sistemicamente" (HELLINGER, 1998, p. 137).
} 
linguagem não verbal, pela vivência e sentimentos - o que propicia a mudança da situação, pela nova visão que a pessoa percebe do mundo (visão sistêmica).

Houve importante contribuição da PNL (Programação Neurolinguística) quanto aos movimentos corporais e à comunicação não verbal, para o desenvolvimento do método de constelação de Hellinger, como se depreende da passagem seguinte:

[...] aprendi muito com isso. Por exemplo, quando alguém conta alguma coisa e sacode levemente a cabeça, muitas vezes não é verdade o que ele diz. Ou a pessoa faz que sim com a cabeça, mas nega com as palavras o que eu afirmei. Então vejo que acertei. Numa constelação pode acontecer que alguém recue um passo ou olhe por cima de alguém. Então sei que devo introduzir ali uma outra pessoa. Esses pequenos movimentos são, muitas vezes, os mais importantes. E Milton Erickson imediatamente aceitava tudo o que o cliente mostrava. Reparava nos mínimos sinais corporais e lia neles a verdadeira questão do cliente, que muitas vezes é algo totalmente diferente da questão apresentada. Erickson conduzia o cliente por desvios, sem que fosse imediatamente visível aonde o caminho levava, até chegar ao que the correspondia de modo mais profundo (HELLINGER; HÕVEL, 2006, p. 28-29).

Importante frisar que, embora o facilitador da Constelação (constelador) desempenhe um importante papel ativo nas Constelações, não sugere nenhuma solução para os casos específicos, em relação aos quais, inclusive, recebe poucas informações.

Diferente da nobreza vista nas pessoas que se envolvem em ajudar os outros - inclusive conciliadores e advogados tradicionais - para Hellinger, a melhor ajuda é a que não tem intenção, porque não possui julgamento, e as interpretações atrapalham. Diz-se que o campo conhece a solução; não o facilitador. (HELLINGER, 2005).

Finalizando o entendimento, a Constelação acontece quando há a mudança de percepção internamente, após entender as leis sistêmicas e vivenciar o fenômeno da Constelação. O ponto primordial a ser fixado, para a continuidade do trabalho, é que a maneira de buscar a solução para o conflito, através da Constelação, não se resume às partes envolvidas, mas encontra-se no sistema de cada uma delas, e que não recebe tentativas de convencimento externas, muito menos julgando moralmente a atitude do outro no conflito.

De aplicabilidade potencial a várias áreas, a Constelação contribui muito para o Direito, pelo poder de mudar a consciência das pessoas, solucionando os seus conflitos, sendo um meio auxiliar para a efetivação do acesso material à justiça no Estado Democrático de Direito.

\subsection{A experiência brasileira com o direito sistêmico: o uso natural a legitimar a norma}


Segundo Sami Storch, o Direito Sistêmico é a aplicação das leis do Direito, com base nas leis sistêmicas, tendo, por isto, origem nas Constelações Sistêmicas, que precisam ser estudadas e vivenciadas para serem compreendidas. Para Storch:

O conhecimento de tais ordens (ou leis sistêmicas) nos conduz a uma nova visão a respeito do direito e de como as leis podem ser elaboradas e aplicadas de modo a trazerem paz às relações, liberando do conflito as pessoas envolvidas e facilitando uma solução harmônica. (STORCH, 2016).

Destaca-se que este artigo delimita o Direito Sistêmico em âmbito judicial, em relação ao trabalho de juízes e voluntários envolvidos nas tentativas de conciliação - onde se encontram as principais experiências relatadas no Brasil -, embora seu potencial de aplicação envolva o âmbito extrajudicial e todos os profissionais do Direito.

Ademais, deve-se estar atento para que não haja confusão com outras visões e terapias sistêmicas que, embora considerem o indivíduo parte de um sistema, não consideram a atuação das ordens descobertas por Bert Hellinger, sua ideia de transgeracionalidade e abordagem fenomenológica.

Storch é pioneiro mundial na aplicação do conhecimento das Constelações Sistêmicas no Poder Judiciário, não havendo ainda registro no Direito Comparado, embora se perceba o interesse, cada vez maior, pelo assunto.

O magistrado Storch, sentindo necessidade de pacificação dos longos e acirrados conflitos judiciais $^{13}$, iniciou esta prática em audiência, ao identificar leis sistêmicas violadas o que continua fazendo. Em 2012, passou a realizar vivências em grupo, que prefere. Nestas, permite poucas informações - em geral, tipo de processo e número de filhos -, inclusive pelo risco de ferir princípios processuais. (STORCH, 2015).

No entendimento de Storch - importante para a comparação de como o Direito Sistêmico vem sendo aplicado no Brasil -, no âmbito judicial, não há necessidade de que seja constelado cada caso separadamente, por haver excelentes resultados em conjunto e por ser alto o volume de processos para os quais o Estado deve garantir prestação jurisdicional.

\footnotetext{
${ }^{13}$ Ao perceber que, muitas vezes, as leis eram cumpridas de forma desarmônica em sua profissão - quando as leis do Direito não consideravam as leis sistêmicas -, juntamente à percepção da necessidade de produção de provas durante a instrução processual sem acirrar os conflitos e de que estes eram resolvidos pela decisão judicial de forma disfarçada, tendo em vista os recursos interpostos, o não cumprimento das sentenças, a insatisfação das partes e novas ações, passou a buscar a pacificação, pela compreensão do que estava além dos casos levados até ele em sua função pública, adaptando a forma das leis sistêmicas.
} 
Chama atenção a junção do pioneirismo do juiz com os excelentes resultados apresentados por ele em análise estatística de processos. O índice de conciliação - que corrobora sua opinião sobre vivências coletivas de Constelações - foi de 91\%, com a participação de pelo menos uma das partes; e de 100\%, quando ambas as partes participaram. (STORCH, 2016).

A partir destes resultados - ainda que não esteja diretamente relacionado -, observase muito interesse pelo método no Brasil, tanto pelo Conselho Nacional de Justiça (CNJ) órgão de administração da Justiça -, quanto por facilitadores voluntários em aplicar as Constelações Sistêmicas aos conflitos judiciais, e por juízes, responsáveis por autorizar essa aplicação a seus processos - já que, no Brasil, até o momento, não há legislação que trate especificamente dessa aplicação, embora já se discuta sua regulamentação ${ }^{14}$.

Entende-se que o uso do Direito Sistêmico, quando no curso normal do processo, especialmente quanto à comunicação verbal com os jurisdicionados, encontra-se dentro da liberdade argumentativa dos juízes e conciliadores, não sendo o foco da discussão deste trabalho. O foco encontra-se na utilização das Constelações em si como método peculiar, utilizado em momento próprio no processo.

Atualmente, o fundamento legal para sua autorização encontra-se - além da Lei n. ${ }^{o}$ 9.099 de 1995 (Lei dos Juizados Especiais) e do Código de Processo Civil, de 2015, que estimulam a conciliação -, principalmente, na Resolução n. ${ }^{\circ}$ 125/2010 do Conselho Nacional de Justiça (CNJ), que assegura um importante espaço para a utilização de outros métodos de solução de conflitos, onde se enquadra a Constelação - já que não são determinados quais métodos seriam esses, além da conciliação e da mediação ${ }^{15}$.

Inclusive, percebe-se como tendência o uso das Constelações Sistêmicas no Poder Judiciário ser caracterizado como mediação, em sentido lato. Neste sentido, o Projeto de Lei

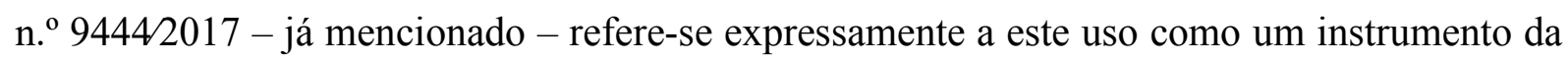
mediação. O Tribunal de Justiça do Estado de Goiás premiou o trabalho "Mediação baseada na técnica da constelação familiar", realizado com 256 famílias, com o "V Prêmio Conciliar é Legal” do CNJ. (ARAÚJO, 2015).

\footnotetext{
${ }^{14}$ Foi apresentado pela Associação Brasileira de Constelações Sistêmicas, o Projeto de Lei 9444/2017, que dispõe sobre "o emprego da constelação sistêmica como um instrumento de mediação entre particulares a fim de assistir a solução de controvérsias". Aguarda audiência pública atualmente (CAMARA DOS DEPUTADOS, 2018).

15 “Art. $1^{\text {}}$. Parágrafo único. Aos órgãos judiciários incumbe, (...) antes da solução adjudicada mediante sentença, oferecer outros mecanismos de soluções de controvérsias, em especial os chamados meios consensuais, como a mediação e a conciliação [...]" (CNJ, 2018, grifo nosso).
} 
Analisando o uso das Constelações, comparado à mediação, ambos não são utilizados como modalidade decisória no conflito e sim como meio - que utiliza a comunicação verbal e não verbal para o esclarecimento de percepções equivocadas nas relações interpessoais - para que as próprias partes sejam responsáveis em buscar a solução do conflito, com a ajuda de um terceiro imparcial, visando ao reestabelecimento do diálogo. Isto faz com que a Constelação seja uma possibilidade a mais de potencializar a mediação. Observa-se também que, assim como a Constelação, a própria mediação já era praticada antes da publicação de sua lei.

Além do espaço assegurado pela Resolução 125 de 2010, o CNJ tem apoiado seu uso nas tentativas conciliatórias, enfatizando a humanização da prática e seus resultados expressivos. Para o órgão, a técnica auxilia no tratamento adequado dos conflitos, sendo utilizada em diversos estados, antes das tentativas de conciliação. (BANDEIRA, 2016). Observa-se o apoio ao método, também, pela sua rápida incorporação aos Tribunais brasileiros.

Os resultados do uso das Constelações Sistêmicas no Judiciário - embora sem dados nacionais oficiais - são confiáveis, sendo divulgados por juízes e Tribunais. Acredita-se que avaliar os índices de conciliação após as vivências das Constelações em si, individuais ou coletivas, seja a forma mais fidedigna cientificamente para a mensuração de resultados ${ }^{16}$.

Embora sem tratamento estatístico adequado, por não serem aplicadas as Constelações a todos os processos e pelo recorte temporal não ser o mesmo da publicidade de dados dos órgãos oficiais, pode-se comparar os primeiros resultados do uso das Constelações Sistêmicas com os das conciliações tradicionais ${ }^{17}$, tamanha discrepância em relação a estes e coincidência de altos índices quando usadas as Constelações.

De acordo com o Anuário Justiça em Números (2017), edição de 2017 - ano base de 2016, percebe-se o seguinte percentual de conciliação nos seguintes Estados: no Estado da Bahia: enquanto o índice de conciliação é de aproximadamente 14,8\% com o método tradicional, por intermédio das constelações esse número passa para $100 \%$. Por sua vez, no Distrito Federal, enquanto o percentual com o método tradicional é de 12,7\%, esse número sobe para $86 \%$ de conciliação com as constelações. No Estado de Goiás, o índice tradicional é de $12,7 \%$, por sua vez, com a utilização das constelações esse número passa para $94 \%$. No Rio de Janeiro, o percentual tradicional é de $13,9 \%$, subindo para $85 \%$ com o uso das constelações.

\footnotetext{
${ }^{16}$ Resultados importantes para o meio científico, mas, paradoxalmente - tendo em vista os excelentes resultados -, sem importância para a Constelação, que, lembrando, deve se dar com ausência de intenção e julgamento. "Portanto, aqui a atitude do terapeuta é bem diferente da atitude no caso de uma terapia com controle de resultado. Nessa, tem-se a intenção de controlar e pondera-se como se pode alcançar um determinado resultado" (HELLINGER, 2005, p. 209).

17 “O índice de conciliação abrange o percentual de sentenças e decisões resolvidas por homologação de acordo em relação ao total de sentenças e decisões terminativas proferidas” (BRASIL, 2017, p. 125).
} 
Em contraposição à uniformidade de bons resultados, a falta de legislação sobre o uso das Constelações no âmbito judiciário provoca diferentes abordagens no uso do método (BANDEIRA, 2016), não havendo um padrão rigoroso sobre sua utilização no Poder Judiciário brasileiro, embora possa se traçar um paradigma a partir do panorama geral de como vem sendo aplicado no Brasil - tanto para a uniformidade a ser construída internamente, quanto para a reprodução em outros países.

Observa-se que, até então, o uso das Constelações Sistêmicas para a solução dos conflitos tem se dado, principalmente, em âmbito judicial. Na maioria das vezes, a aplicação tem começo discreto, através de facilitadores voluntários ${ }^{18}$, além de serem realizadas também por juízes - tanto a casos separadamente, quanto na forma de vivências coletivas -, em fase anterior às tentativas conciliatórias, identificando-se com o procedimento de mediação.

Geralmente as constelações são aplicadas após convite às partes, envolvidas nos mesmos tipos de processos ${ }^{19}$ - quando na forma coletiva -, ocorrendo audiência de conciliação poucas semanas depois. A aplicação principal tem sido no Direito de Família, mas também em questões envolvendo infância e juventude, violência doméstica, justiça restaurativa, dívidas, além de já estar sendo usado na Justiça Federal e Justiça do Trabalho.

Seu processo de implementação no Poder Judiciário tem se dado não por imposição legal, mas através de aplicação prática, validada pelos resultados, que levaram ao reconhecimento do método e à rápida expansão. Até a regulamentação, o papel do magistrado se mostra muito importante, por ser ele o responsável pela autorização do uso das Constelações no Poder Judiciário.

É possível visualizar a elaboração de legislação específica sobre o assunto em tempos vindouros, objetivando o acesso material à justiça e a pacificação social, sendo o Direito Sistêmico um novo caminho para a solução consensual de conflitos que se mostra ao mundo, a partir do Brasil.

\footnotetext{
${ }^{18}$ Segundo Adhara Campos Vieira, sua experiência dois anos à frente do voluntariado no Projeto "Constelar e Conciliar" do TJDF foi importante "para consolidar a prática [...], cuja adesão cada vez maior pelos magistrados, endossa o crescimento do projeto" (VIEIRA, 2018, p. 215). Houve, inclusive, a publicação de edital para a atuação de outros voluntários, o que mostra a institucionalização do projeto no âmbito do Tribunal (VIEIRA, 2018, p. 215), em detrimento da falta de legislação específica.

${ }^{19}$ Merece discussão a forma de seleção dos casos. No TJDF, por exemplo, são selecionados os de temas semelhantes - critério adotado por todos os tribunais, quando na forma coletiva -; os mais antigos e os mais conflituosos, sem êxito em outras audiências da instrução processual. Nisto, se diferencia da aplicação ao início do processo, observada na maioria dos tribunais. Também discutível, a juíza do TJDF, Magãli Dellape, intima as partes a comparecerem às sessões de Constelação, o que não parece adequado, frente ã filosofia do método, que requer disposição da parte em participar. ("Workshop Inovações na Justiça: O Direito Sistêmico como meio de Solução Pacífica de Conflitos", realizado em 12/4/2018 no Conselho da Justiça Federal, com apoio do Superior Tribunal de Justiça, em Brasília. Disponível em: $<$ https://www.youtube.com/watch? $=\mathrm{gN} 8 \mathrm{tJ} 9$ Oypcs $>$. Acesso em: 04 maio 2018.
} 
3.3 Interlocução entre o direito brasileiro e o direito espanhol: possibilidades de aplicação do direito sistêmico na espanha, tendo como paradigma a experiência brasileira

Em decorrência do estudo realizado nos itens anteriores, pode-se perceber que a aplicação do Direito Sistêmico - especificamente de uso das Constelações - como método para a solução consensual de conflitos é possível a todos os países, pela ótica das relações humanas, dependendo, para sua utilização no Judiciário - mesmo antes de haver regulamentação -, de haver espaço no Direito referente às tentativas conciliatórias, especificamente à mediação.

Em relação ao Direito espanhol, percebe-se, de acordo com a doutrina, a formulação crescente, nos últimos tempos, de alternativas distintas ao processo como modo de solução de conflitos, ou seja, os chamados medios alternativos (ADR).

A título de exemplo, tem-se atualmente na Espanha, meios alternativos díspares, tais como: i) negociación; ii) integración de relaciones jurídicas por médio de terceiros; iii) adaptación de contratos; iii) transacción; iv) pericia técnica; v) conciliación; vi) mediación; vii) mini trial; viii) réferé arbitral; ix) arbitraje $e^{20}$.

Porém, o mais relevante é a efusão de outros valores que surgem da reflexão sobre a posição do cidadão em relação ao sistema processual.

O sistema de solução de litígios espanhol é dividido, assim como no Brasil, em solução extrajudicial de litígios (ADR), onde se encontra a mediação - que tem os mesmos princípios e peculiaridades de aplicação que no Brasil - e no modelo público de administração da justiça, onde se encontram os processos judiciais. No entanto, "más que insistir em las características que diferencian a ambos sistemas lo que interessa es conocer que son plenamente compatibles" (MÉNDEZ, 2016, p. 34), sendo que a interação entre os modelos aumenta as possibilidades do usuário do sistema para a satisfação da necessidade. Interação observada em ambos os países, ao permitirem que a demanda iniciada judicialmente seja encaminhada para a mediação e viceversa, de acordo com a necessidade do caso.

Os meios alternativos têm sido prestigiados, de maneira crescente nos últimos tempos, pelo direito espanhol, tanto no nível legislativo, quanto judicial e doutrinário, que destaca como um de seus méritos o valor da liberdade e seu exercício legítimo através de decisões voluntárias, que não comprometem os direitos dos outros. Além disso, a identificação conceitual da

\footnotetext{
${ }^{20}$ Esses exemplos são trazidos por Francisco Ramos Méndez (2016).
} 
mediação espanhola com os princípios da Constelação favorece o contexto promissor para a aplicação das Constelações no Judiciário espanhol.

Mesmo não havendo diretriz legal específica sobre a utilização das Constelações Sistêmicas no Direito da Espanha - assim como no Brasil ainda não há -, existem possibilidades reais para que as Constelações sejam experimentadas em programas institucionais de acesso à justiça no país.

De acordo com Francisco Ramos Méndez (2016), a União Europeia vem estimulando sistematicamente o uso de ADR, como se pode perceber da Resolução do Parlamento Europeu sobre o Livro Verde da Comissão sobre as medidas alternativas de solução de conflitos no âmbito do direito civil e do direito comercial, que indica sua utilização no contexto geral de acesso à justiça (EU, p. 24).

Em relação à mediação, aplicada a direitos disponíveis, completa o autor: "a pesar desse caráter limitado, su fuerza expansiva busca siempre nuevas oportunidades de aplicación". A Constelação se encaixa nestas novas oportunidades para atingir o objetivo maior da mediação. Inclusive, pelo trecho abaixo colacionado, percebe-se que a mediação espanhola também tem sentido amplo, abrangendo outras formas de solução de conflitos, mesmo que ainda sem tratamento legislativo adequado:

\begin{abstract}
La noción de medios alternativos para la resolución de litigios se utiliza en un sentido amplio y desprovisto de toda connotación dogmática para englobar todas aquellas instituciones que contribuyen a la resolución de litigios jurídicos por una vía distinta al sistema estatal o con un modelo de instrumento diferente al sistema de acuerdo con las leyes de enjuiciamiento. Bajo esta nomenclatura se comprenden las culturas heterogéneas, que no siempre tiene un desarrollo legislativo adecuado, el cuya proyección práctica es sumamente desigual. (MEND EZ, 2016, p. 41).
\end{abstract}

Além disso, a Recomendación $n^{o} R$ (98) 1 del Comité de Ministros a los Estados miembros sobre la mediación familiar recomenda fortemente que os estados promovam ou reforcem a mediação existente, reconhecendo o aumento no número de conflitos familiares e todos os benefícios da mediação neste âmbito - inclusive a melhora da comunicação entre membros da família, a redução dos conflitos e a continuidade da relação, no interesse de seus membros e para a proteção das crianças. (ESPAÑA, 1998).

Interessante notar como os ideais de utilização de meios apropriados de resolução de conflitos familiares previstos na Recomendação se harmonizam perfeitamente aos objetivos e efeitos da utilização das Constelações no Judiciário, que, inclusive, são usadas no Brasil justamente neste âmbito. E como a Recomendação, no seu item VII ("Otros modos de solución 
de los conflictos") - em que estimula os estados a utilizarem os princípios da mediação a outros meios de solução de conflitos - se aproxima da Resolução n ${ }^{0}$ 125/2010 do CNJ, que estimula a utilização de "outros métodos de solução de conflitos" e é o principal espaço de autorização do uso das Constelações no judiciário brasileiro atualmente, a potencializar a mediação.

Pelo exposto, além de o Direito Sistêmico ser, principalmente, uma postura a ser usada judicialmente ou extrajudicialmente na solução dos conflitos, a utilização específica das Constelações Sistêmicas como forma de mediação - baseada na bem-sucedida experiência brasileira - torna-se uma opção a mais para que a Espanha forneça meios adequados para a solução dos conflitos em sua sociedade democrática, para o acesso à justiça no caminho da pacificação social.

\section{Conclusão}

$\mathrm{O}$ acesso material à justiça constitui direito fundamental, representando a necessidade de o ser humano pacificar os conflitos, inevitavelmente, presentes na vida em sociedade. $\mathrm{Na}$ realidade brasileira os estudos oficiais mostram a fragilidade dos índices de resolução de conflitos no Poder Judiciário, ainda após tentativas legislativas de mecanismos de pacificação social implementadas por intermédio de legislações esparsas, como também pelo novel Código de Processo Civil, de 2015.

Neste sentido, o Direito Sistêmico apresenta-se como uma forma visionária para a solução consensual dos conflitos e revolucionária para o Direito. Aferidos seus resultados, principalmente, pelo uso das Constelações Sistêmicas no Judiciário como forma de potencializar a mediação, o método tem uma visão inovadora em se tratando de reestabelecer o diálogo entre as partes.

A prestação jurisdicional tradicional foca no conflito, nas leis e na atitude das partes, de forma isolada, e então procede ao julgamento judicial - perante o qual a pessoa é impotente -, sem conhecer verdadeiramente os problemas que levaram à busca pela Justiça. Com a Constelação e identificação de leis sistêmicas violadas, o conflito é devolvido às partes, empoderadas para resolvê-lo, através de mecanismos para a ampliação da consciência, mais eficazes que a argumentação e tentativas conciliatórias tradicionais.

Enquanto os métodos tradicionais interferem no conflito - ainda que não diretamente, como na mediação -, almejando um acordo entre as partes, a Constelação Sistêmica não tem esta intenção e, no entanto, alcança melhores resultados. Resultados esses que, em uma visão 
epistemológica, afastam da discussão questionamentos sobre seu funcionamento ou a simpatia pelo método.

Por outro lado, merece o debate da comunidade científica acerca desse meio adequado para a real solução de conflitos, concluída sua efetividade prática.

Em síntese, retornando ao problema da pesquisa, quais sejam: a busca por soluções consensuais para os conflitos, de acordo com as leis sistêmicas descobertas por Bert Hellinger, deve ser institucionalizada no Poder Judiciário brasileiro? Considerando os resultados brasileiros e a validade universal das leis sistêmicas, há diálogo entre o Direito brasileiro e o Direito espanhol que permita possibilidades de aplicação do método na Espanha, tendo como paradigma a experiência brasileira? tem-se as seguintes conclusões a seguir expostas.

Os resultados sempre expressivos e a ampliação do uso das Constelações Sistêmicas no Poder Judiciário brasileiro, ainda que de maneira esparsa, permitem concluir que a prática deve ser institucionalizada oficialmente pelo Poder Judiciário brasileiro, como um todo, para que se garanta a continuidade e uniformidade de aplicação, e acesso a todos os jurisdicionados para os quais possa ser útil.

Além da institucionalização, o panorama geral da aplicação prática no Brasil permite a análise das possibilidades de replicação da experiência brasileira em outros países, como também no ordenamento jurídico espanhol, que também preza pela conciliação e mediação dos conflitos, sem que seja necessária uma decisão por parte do Poder Judiciário, ou seja, almeja uma decisão elaborada pelas partes.

Enfim, tem-se, no Direito Sistêmico, um novo instrumental potencialmente capaz de solucionar consensualmente os conflitos de forma efetiva, no caminho de uma justiça mais humana, que cumpra o desafio de oferecer acesso à justiça material e efetivação de direitos, através da paz alcançada pela mudança na consciência, pela compreensão mútua e melhora da comunicação nos relacionamentos.

\section{Referências bibliográficas}

ABENDROTH, Wolfgang; FORSTHOFF, Ernst; DOEHRING, Karl. El estado social. Madri: Centro de Estudios Constitucionales, 1986.

\section{ARAÚJO, Elisângela. TJGO é premiado por mediação baseada na técnica de constelação}

familiar. 2015. Disponível em: <http://cnj.jus.br/noticias/cnj/79702-tjgo-e-premiado-pormediacao-baseada-na-tecnica-de-constelacao-familiar>. Acesso em: 04 maio 2018. 
BANDEIRA, Regina. Constelação Familiar ajuda a humanizar práticas de conciliação no Judiciário. CNJ. 2016. Disponível em: <http://www.cnj.jus.br/noticias/cnj/83766constelacao-familiar-ajuda-humanizar-praticas-de-conciliacao-no-judiciario-2>. Acesso em: 27 abr. 2018.

BANDEIRA, Regina. Juiz consegue $100 \%$ de acordos usando técnica alemã antes das sessões de conciliação. 2014. Disponível em: <http://www.cnj.jus.br/noticias/cnj/62242-juizconsegue-100-de-acordos-usando-tecnica-alema-antes-das-sessoes-de-conciliacao $>$. Acesso em: 04 maio 2018.

BRASIL. Conselho Nacional de Justiça. Notícias. FARIELLO, Luiza. Constelação familiar: no firmamento da justiça em 16 estados e no DF. 2018. Disponível em: <http://www. cnj.jus.br/noticias/cnj/86434-constelacao-familiar-no-firmamento-da-justica-em-16-estados-eno-df>. Acesso em: 27 abr. 2018 a.

BRASIL. Constituição (1824) Constituição Política do Império do Brasil. Disponível em: $<$ http://www.planalto.gov.br/ccivil_03/constituicao/constituicao24.htm?TSPD_101_R0=7119 0a0f6548ab4dcd311e88c18ea355sJ90000000000000000631949bbffff0000000000000000000 0000000005af8c431008e15baba >. Acesso em: 20 abr. $2018 \mathrm{~b}$.

BRASIL. Constituição (1988) Constituição da República Federativa do Brasil. Disponível em: <http://www.planalto.gov.br/ccivil_03/constituicao/constituicao.htm>. Acesso em: 20 maio $2018 \mathrm{c}$.

BRASIL. Justiça em Números 2017: ano-base 2016 - Conselho Nacional de Justiça Brasília: CNJ, 2017.

BURDEAU, Georges. La democracia. Caracas-Barcelona, Ariel, 1960.

CÂMARA DOS DEPUTADOS. PL 9444 2017. "Dispõe sobre a inclusão da Constelação Sistêmica como um instrumento de mediação entre particulares, a fim de assistir a solução de controvérsias". Disponível em: 
$<$ http://www.camara.gov.br/proposicoesWeb/fichadetramitacao?idProposicao=2167164\&ord $=1>$. Acesso em: 03 maio 2018 .

CAPPELLETTI, Mauro; GARTH, Bryan. Acesso à justiça. Porto Alegre: Sergio Antonio Fabris, 1998.

CARVALHO, José Murilo de. Cidadania no Brasil: o longo caminho. Rio de Janeiro: Civilização Brasileira, 2007.

CHAUI, Marilena. Brasil: mito fundador e sociedade autoritária. São Paulo: Fundação Perseu Abramo, 2004.

CONSELHO NACIONAL DE JUSTIÇA. Resolução n 125, de 29 novembro de 2010.

Dispõe sobre a Política Judiciária Nacional de tratamento adequado dos conflitos de interesses no âmbito do Poder Judiciário e dá outras providências. Disponível em: $<$ http://www. cnj.jus.br/images/atos_normativos/resolucao/resolucao_125_29112010_11032016162839.pdf >. Acesso em: 26 mar. 2018.

DIAS, Brian G.; RESSLER, Kerry J. Parental olfactory experience influences behavior and neural structure in subsequente generations. Nature Neuroscience. V. 17. N. 1, Jan. 2014.

HELLINGER, Bert. A fonte não precisa perguntar pelo caminho. Patos de Minas: Atman, 2005a.

HELLINGER, Bert. A simetria oculta do amor: por que o amor faz os relacionamentos darem certo. Patos de Minas: Atman, 1998.

HELLINGER, Bert. O Amor do Espírito na Hellinger Sciencia. 4. ed. Belo Hrizonte: Atman, 2017.

HELLINGER, Bert. Ordens da ajuda. Patos de Minas: Atman, 2005b. 
HELLINGER, Bert. Ordens do Amor: um guia para o trabalho com constelações familiares. São Paulo: Cultrix, 2001.

HELLINGER, Bert; HÕVEL, Gabrielle Tem. Um lugar para os excluídos: conversas sobre os caminhos de uma vida. Patos de Minas: Atman, 2006.

MÉNDEZ, Francisco Ramos. El sistema procesal español. 10. ed. Barcelona: Atelier, 2016.

PODER JUDICIAL DE ESPAÑA. Plan Nacional de Estadística Judicial. Actividad de los órganos judiciales. Disponível em: <http://www.poderjudicial.es/cgpj/es/Temas/ Estadistica-Judicial/Estadistica-por-temas/Actividad-de-los-organos-judiciales/Juzgados-yTribunales/Indicadores-clave/>. Acesso em: 27 abr. 2018.

ROSA, Amilton Plácido da. Entrevista. Jornal Carta Forense. Disponível em: $<$ http://www.cartaforense.com.br/conteudo/entrevistas/direito-sistemico-e-constelacaofamiliar/16914>. Acesso em: 13 maio 2018.

SANTOS, Boaventura de Sousa. Para uma revolução democrática da justiça. São Paulo: Cortez, 2007.

STORCH, Sami. Direito Sistêmico: primeiras experiências com constelações no judiciário. In Filosofia, Pensamento e Prática das Constelações Sistêmicas - n. ${ }^{\circ}$ 4. São Paulo: Conexão Sistêmica, 2015.

STORCH, Sami. Direito Sistêmico: a resolução de conflitos por meio da abordagem sistêmica fenomenológica das constelações familiares. Entre aspas: revista da Unicorp / Tribunal de Justiça do Estado da Bahia - vol. 5, p. 305-316, 2016.

TRIBUNAL DE JUSTIÇA DE MINAS GERAIS. Comarca de Contagem adota Constelação sistêmica. TJMG. Disponível em: <http://www.tjmg.jus.br/portaltjmg/noticias/comarca-de-contagem-adota-constelacao-sistemica.htm\#.WuzRdYgvzIW >. Acesso em: 04 maio 2018. 
VIEIRA, Adhara Campos. A constelação sistêmica no judiciário. Belo Horizonte:

D’Plácido, 2018. 


\title{
REFLEXÕES SOBRE A TRADIÇÃO HISTÓRICO-JURÍDICA DE PROTEÇÃO AO MENOR NO BRASIL E A JUSTIÇA RESTAURATIVA
}

\author{
Conceição Aparecida Barbosa \\ Universidade Federal do Maranhão - UFMA
}

\begin{abstract}
Resumo
O presente trabalho versa sobre a proteção à criança e ao adolescente no Brasil de forma a desenvolver uma reflexão sobre a tradição jurídica de nossa história e a proposta atual de justiça restaurativa. A metodologia utilizada é de revisão bibliográfica sobre o tema, de abordagem qualitativa. O objetivo geral é refletir a justiça restaurativa como uma mudança de paradigma na solução do problema da criminalidade, além de investigar se a justiça restaurativa seria uma solução à base de um conjunto de valores morais que nos remetem a velhos posicionamentos conservadores de integração e coesão social presentes em visões sociológicas positivistas.
\end{abstract}

Palavras-chave: justiça restaurativa, proteção à criança e ao adolescente, justiça retributiva, criminalidade, história do direito.

\begin{abstract}
Resumen/Résumé
The present work deals with the protection of children in Brazil in order to develop a reflection on the legal tradition of our history and the current proposal of restorative justice. The methodology used is a bibliographical review on the subject, with a qualitative approach. The overall objective is to reflect restorative justice as a paradigm shift in the solution of the problem of crime, and to investigate whether restorative justice would be a solution based on a set of moral values that refer us old conservative stances of integration and social cohesion present in positivist sociological views.
\end{abstract}

Keywords/Palabras-claves/Mots-clés: Restorative justice, children and adolescent protection, retributive justice, crime, history of law. 


\section{Introdução}

O presente trabalho versa sobre a proteção à criança e ao adolescente no Brasil, de forma a desenvolver uma reflexão sobre a tradição jurídica e política no tratamento deste que lhes foi dedicado ao longo de nossa história e a proposta atual de justiça restaurativa.

A metodologia utilizada é de revisão bibliográfica sobre o tema, de abordagem qualitativa. A investigação está voltada para destacar questões pontuais da história da proteção da criança e do adolescente no país, com a hipótese de uma reiterada procrastinação na solução dos problemas de criminalidade por meio de um sistema penal ineficiente e voltado para a punição e privação da liberdade e refletir se uma modificação de paradigma por meio da abordagem da justiça restaurativa traria mais eficácia ao sistema socioeducativo.

O objetivo geral é refletir sobre como se deu historicamente esta proteção, de que forma nossa tradição de recolhimento, privação de liberdade e punição tem sido um fracasso na solução de problemas sociais e avançar na perscrutação das teorias que envolvem a justiça restaurativa neste momento atual em que a mediação e a reconciliação surgem como promessas de mudança de paradigma e de solução do problema da criminalidade.

Por outro lado, objetiva-se investigar se a justiça restaurativa seria um novo retorno a solução de problemas por meio de introjeção de valores morais no indivíduo/ofensor de modo a readequá-lo para o convívio social, comunitário, reavivando assim posicionamentos conservadores de integração e coesão social presentes em visões sociológicas positivistas.

A perspectiva da justiça restaurativa como um processo de reeducação também é perquirida na medida em que possibilita ao ofensor e à vítima (re) apropriarem-se do conflito e, por meio da mediação, exercerem protagonismo na solução deste. Desse modo, a hipótese que se levanta é a de que teríamos uma proposta de "educação" por meio do diálogo para a convivência e formação do indivíduo em busca de uma sociedade mais harmônica e menos conflituosa.

Como resultado aponta-se a reflexão sobre se a modificação do sistema (penal) socioeducativo pode de alguma forma modificar toda a sociedade baseada num sistema capitalista de desigualdade social e, apesar disso, surtir efeito em soluções comunitárias.

\section{Breve histórico sobre a proteção da criança e do adolescente no Brasil}

A proteção à criança e ao adolescente no Brasil tem acompanhado um desenvolvimento paralelo aos avanços internacionais no âmbito da adoção de procedimentos 
que podem ser considerados de vanguarda no cenário internacional somente se for levado em consideração o texto legislativo. Na prática, a realidade tem sido de completo abandono e, por outro, de manutenção das tradições de um distanciamento entre a teoria e a prática.

Até meados do século XIX vigorava no país uma prática de não acolhimento, mas de recolhimento das crianças e adolescentes, tanto que as teorias só passam a ter forma no país a partir do Código de Menores de 1830. Antes vigorava a proteção alcançada pela caridade da Igreja e pela bondade daqueles que possuíam bens para doação, pois a prática era não só de tirar das ruas os menores, mas das vistas da sociedade ${ }^{1}$.

A história da infância no país passa por termos que demonstram por si só como era a proteção oferecida aos menores: expostos, enjeitados, filho ilegítimo, infância desvalida, desvalidos, delinquentes e infratores. Essa passagem histórica ilustrada pelo léxico utilizado na legislação não vem sem acompanhamento: Roda dos Expostos, Casa de Correção, Instituto de Menores Artesãos, Instituição Disciplinar Industrial, Instituição Disciplinar Agrícola, Instituto de Proteção e Assistência à Infância, e, atualmente, Sistema Socioeducativo.

Todas as tentativas de modificação do sistema de proteção apresentaram como solução o controle e a correção, a disciplina rígida e a formatação para a sociedade e o trabalho e culminam, na atualidade, com a mesma ineficiência de outrora.

Assim que assumiu as rédeas de sua própria história, o Brasil independente esteve sob três correntes doutrinárias diferentes, conforme atesta Teixeira (1992): a Doutrina do Direito Penal do Menor, a Doutrina Jurídica do Menor em Situação Irregular e a Doutrina Jurídica da Proteção Integral.

A Doutrina do Direito Penal do Menor influenciou o Código Penal de 1830, o Código Penal de 1890 e o primeiro Código de Menores de 1927, tratando a questão do menor apenas sob o ângulo da delinquência.

De acordo com Pereira (1996, p. 52) os Códigos Penais de 1830 e 1890 tratavam da delinquência praticada pelo menor e estavam sob a teoria do discernimento para que se pudesse aplicar a imputabilidade.

Em relação ao Código Penal de 1830, Gomes (2007, p. 142) esclarece a Teoria do Discernimento e os critérios para sua aplicação:

\footnotetext{
${ }^{1}$ A respeito dessa temática muito ilustra esse cenário a obra de Moncorvo Filho "Histórico da proteção à Infância no Brasil - 1500-1922" que descreve a proteção do menor desde 1500 até 1922, principalmente no que concerne ao tratamento das crianças enjeitadas pela família como uma forma de não aceitar as novas configurações de relacionamentos familiares que já se faziam plurais. A "roda dos expostos" foi um mecanismo criado para descartar as crianças não desejadas, filhos e filhas ilegítimos, descartados pela sociedade.
} 
Pelo Código Penal do Império de 1830, os menores entre sete e 14 anos, que agissem com discernimento, seriam recolhidos à Casa de Correção pelo tempo que o Juiz julgasse necessário, não podendo passar dos 17 anos. Entre 14 e 17 anos, estariam sujeitos à pena de cumplicidade, ou seja, dois terços da pena que cabia ao adulto pela prática de idêntico crime. Menores entre 17 e 21 anos gozariam do benefício da atenuante da menoridade.

Apontam-se algumas questões relevantes tais como o fato de ser o adulto parâmetro do menor, ou melhor, a pena aplicável ao adulto é parâmetro para a pena aplicável ao menor; ao Juiz caberia decidir quanto tempo deveria ficar o menor recolhido; o discernimento era considerado por alguns doutrinadores como uma esfera bastante subjetiva; o menor é considerado incapaz e sua capacidade se configura para a punição.

A mesma teoria se mantém com a promulgação do Código Penal de 1890, o qual apresentou poucas inovações, conforme destaca Gomes (2007, p. 142):

O Código Penal de 1890, o primeiro da era republicana, seguiu a linha do Código do Império. No entanto, inovou ao declarar a irresponsabilidade de pleno direito em relação aos menores de nove anos. Manteve a pesquisa do discernimento para determinar a imputabilidade dos menores entre nove e 14 anos de idade, ordenando que fossem recolhidos a estabelecimento disciplinar industrial. Tornou obrigatória a pena da cumplicidade e manteve a atenuante da menoridade.

Embora o critério da teoria do discernimento fosse biopsicológico, não havia equipe interdisciplinar para realizar a análise psíquica da criança, conforme atesta Gomes (2007, p. 142). Desse modo, vários doutrinadores apontam a subjetividade da avaliação do juiz que se utilizava de critérios outros, bem como o caráter elitista e discriminatório dessa prática.

Sobre os critérios utilizados para avaliar se o menor teria cometido ato com discernimento, Siqueira (1979, p. 52, apud PEREIRA, 1996, p. 19) destaca os seguintes:

[...] ao Juiz se atribuía a conclusão sobre se um impúbere era ou não capaz de dolo, e, para tal fim, levaria em conta a vida pregressa, seu modo de pensar, sua linguagem, não justificando basear-se apenas numa razão, obrigando-o a pesquisar o conjunto de elementos informadores.

A crítica à subjetividade desses critérios se apresenta de forma bastante incisiva em Custódio (2006, p. 17) que considera as soluções apresentadas para resolver os "incômodos da delinquência, do abandono e da ociosidade" soluções meramente focadas nas consequências desses problemas, sem absolutamente atentar para a realidade social de exploração econômica: 
O Código de Menores brasileiro seria representativo das visões em vigor na Europa nesse período, segundo as quais, era necessário o estabelecimento de práticas psicopedagógicas, geralmente carregadas de um forte conteúdo moralizador, produzindo e reproduzindo uma visão discriminatória e elitista, que desencadeou as condições econômicas como fatores importantes na condição de exclusão.

Custódio (2006, p. 18) acrescenta ainda que a visão da política brasileira da época era romantizada, acreditando que "os problemas sociais seriam resolvidos por meio do assistencialismo e da propagação da autoritária representação da família estruturada".

Essa visão vai ao encontro da perspectiva positivista (MARTINS, 1994, pp.19-25) dos pioneiros da sociologia, os quais acreditavam na adoção de valores morais para a solução de problemas sociais e na reestruturação da família.

Autoridade, família e hierarquia social são as bases que sustentam o pensamento conservador da sociologia positivista. Assim, a família é a unidade social básica que precisa ser restabelecida e devolver a autoridade patriarcal para que possa se reestruturar e permitir a coesão social e a ordem para Le Play.

Outro representante do positivismo filosófico, Saint Simon acreditava que o progresso econômico acabaria com os conflitos sociais, bem como depositava grandes expectativas na liderança das elites científico-industriais e na atuação desta elite para trazer melhores condições de vida aos trabalhadores.

Além desses, o fundador da Sociologia, Augusto Comte, defendia a criação de um conjunto de crenças comuns para todos os homens para solucionar o caos social. Para seu sucessor, Durkheim, seria de fundamental importância encontrar novas ideias morais capazes de guiar a conduta dos indivíduos.

Todos os posicionamentos sociológico-conservadores tendem a acreditar num conjunto valorativo de crenças que possam reorganizar a sociedade e "curar" os problemas sociais sem modificar qualquer sistema, nem mesmo acreditam tais positivistas ter a economia alguma relação com as situações de caos que eles identificavam a partir das revoltas e conflitos sociais de suas épocas. Interessante que séculos depois ainda permanece a mesma solução para os problemas que se acumulam desde o Brasil Colônia.

Destaca-se, ainda, a Doutrina Jurídica do Menor em Situação Irregular que apresentava a partir do art. 2.o do Código de 1979, seis situações que caracterizavam essa irregularidade e direcionamento à marginalização.

Segundo Gomes (2007, p. 144), o Código Mello Mattos (Decreto n. 17.943 A/1927) rompe com a Teoria do Discernimento e efetiva-se a Doutrina da Situação Irregular: 
Embora a Doutrina da Situação Irregular tenha sua base legal no Código de Menores de 1979 (Lei n. 6.697/1979), onde foi efetivamente sistematizada, a ideia de intervenção do Poder Público de acordo com a ótica da tipicidade já vinha na situação que o antecedeu. O Código de 1927 classificava os menores em expostos (art. 14), abandonados (art. 26), vadios (art. 28), mendigos (art. 29) e libertinos (art. 30) e, a partir daí, criava mecanismos para sua assistência e proteção.

Custódio (2006, p. 26) destaca alguns pontos na doutrina da situação irregular que merecerem transcrição. Para ele, o Código trouxe uma responsabilização da criança individualmente pela própria condição "irregular" e assegurou uma garantia tanto para o Estado como para a Sociedade contra a infância e sua provável marginalização.

Ainda sobre a Doutrina da Situação Irregular, mister se faz apresentar o que o Código de Menores de 1979 entendia como situação irregular, conforme disposto no art. $2^{\circ}$. da Lei n. 6.697/1979 (RIZZINI, 2009, p. 157):

Art. 2. Dispõe sobre a "situação irregular" do menor, assim definida:

I. privado de condições essenciais a sua subsistência, saúde e instrução obrigatória, ainda que eventualmente, em razão de:

a) falta, ação ou omissão dos pais ou responsáveis;

b) manifesta impossibilidade dos pais ou responsáveis para provê-los;

II. vítima de maus tratos ou castigos imoderados impostos pelos pais ou responsável;

III em perigo moral, devido a:

a) encontra-se, de modo habitual, em ambiente contrário aos bons costumes;

b) exploração em atividade contrária aos bons costumes;

IV. privado de representação ou assistência legal, pela falta eventual dos pais ou responsável;

V. com desvio de conduta, em virtude de grave estado de inadaptação familiar ou comunitária;

VI autor de infração penal.

Segundo Gomes (2007, p. 144) A Lei de 1979 a doutrina da situação irregular pouco modificou a situação do menor no país, vindo a dar continuidade ao tratamento de caráter preventivo para evitar uma "marginalização mais ampla":

A Lei de 1979 continuou tratando da assistência, proteção e vigilância (art. $1^{\circ}$.) dos delinquentes e abandonados, pois a delinquência e o abandono representavam a síntese das chamadas situações irregulares, elencadas em seu art. $2^{\circ}$. A finalidade ainda era a ação preventiva, evitar a marginalização mais ampla, pois o abandono material ou moral é um passo para a criminalidade.

Em relação à legislação brasileira de proteção à infância de 1830 até 1990, Rizzini (2009, p. 167) faz um balanço geral das conquistas observadas e aponta uma preocupação que dificilmente se aproxima de uma solução dos problemas históricos com o menor "desamparado" pelo Estado: 
No passado, como no presente, a trajetória da legislação relativa à infância tem sido caracterizada pela expressão de uma dualidade, que, ao defender a sociedade, ataca e aniquila a criança. E, ao defender a criança, teme estar expondo a sociedade à sua pretensa periculosidade. A análise histórica deste processo não deixa dúvidas a respeito de sua infinita complexidade. São muitos os interesses em jogo. Não haverá heróis que salvem essa criança.

Hodiernamente tem-se a Doutrina da Proteção Integral e o Sistema Socioeducativo denominado Sinase - Sistema Nacional de Atendimento Socioeducativo, instituído pela Lei Federal 12.594/2012, que organiza e executa medidas socioeducativas aplicadas a adolescentes que praticaram atos infracionais.

O mais recente levantamento do Sinase é de 2016. Os números do Sinase mostram um total de 26.450 atendidos, sendo 18.567 em medida de internação (70\%), 2.178 em regime de semiliberdade (8\%) e 5.184 em internação provisória (20\%), 334 em atendimento inicial e 187 em internação sanção.

Em relação ao total, São Paulo lidera em número de adolescentes em praticamente 36,19 \% do número total de internações (26.450), ou seja, 9.572 internações.

Outro dado importante em relação ao Sinase é o número de óbitos de adolescentes e jovens em cumprimento de medida socioeducativa nas unidades de atendimento - $49 \mathrm{em} 2016$, sendo dentre esses 39 ocorridos dentro das unidades de atendimento e 10 fora dessas unidades, contra 53 em 2015.

O documento do Sinase aponta como principal causa do óbito dentro da instituição “em decorrência de conflito interpessoal" - 16, em decorrência de conflito generalizado - 15, além de 7 casos de suicídio e de 1 de homicídio por outro adolescente. Nos ocorridos fora do ambiente institucional foram 9 por homicídio e um por afogamento.

A situação do sistema socioeducativo tem-se demonstrado pouco eficiente em ressocializar o menor. Diante desse cenário recorre-se a alternativas. Historicamente, embora com perspectivas diversas, as doutrinas acima elencadas modificaram os procedimentos adotados, mas não modificara a punição para o menor, a privação de liberdade como um castigo àqueles que não se colocam ou não se adequam ao sistema vigente. No âmbito da situação dentro da instituição acolhedora do adolescente, menores em situação de internação, as mortes parecem ser em sua maioria em decorrência de conflito.

A justiça restaurativa é uma proposta que objetiva modificar a visão do crime e da solução do conflito, na medida em que transporta o agressor e a vítima de volta para o papel principal na solução do conflito e retira do sistema judiciário o poder de objetivar o conflito e torna-lo parte de um discurso. 
Desse modo, propomos entender o conceito de justiça restaurativa, refletir sobre suas origens, teorias e aplicações.

\section{Conceito de Justiça Restaurativa e visões sobre o crime}

De acordo com Achutti (2013, p. 156), a justiça restaurativa surgiu de um descontentamento com o sistema de justiça criminal/ tradicional.

Relata, ainda, que o interesse pela justiça restaurativa no ocidente surgiu a partir de uma reconciliação ocorrida entre vítima e ofensor no Canadá em 1974, num programa comunitário de mediação de conflitos (após a aplicação da decisão judicial).

A conceituação de justiça restaurativa é tida como complexa por Achutti. Este cita a definição de Johnstone e Ness (2007, p. 5, apud ACHUTTI, 2013, p. 156):

[...] alguns consideram a justiça restaurativa como uma nova técnica social ou programa que pode ser usado no interior dos nossos sistemas de justiça criminal. Outros procuram, em última análise, abolir grande parte do edifício de punição do estado e substituí-lo por respostas baseadas na comunidade que ensinam, curam, reparam e restauram vítimas, autores de crimes e suas comunidades. Outros, ainda, aplicam a visão de cura e restauração a todos os tipos de conflitos e danos. Na verdade, o objetivo final e foco principal, eles sugerem, deveria ser a mudança da maneira como vemos a nós mesmos e nos relacionamos com os outros na vida cotidiana.

De acordo com Sica (2007, p. 10) a justiça restaurativa é mais uma prática que uma teoria, ou melhor, é um conjunto de práticas em busca de uma teoria.

Desse modo, ela pode ser considerada uma técnica, um programa, uma resposta baseada na comunidade que "ensina, cura, repara e restaura vítimas e autores de crimes", mas restaura o quê? A situação anterior ao crime? O relacionamento? Qual o relacionamento existente entre duas pessoas - vítima e ofensor - no caso de roubo de celular? Seria essa técnica utilizada apenas em situações em que vítima e ofensor se conhecem e se relacionam? Em casos de violência doméstica, por exemplo, que vítima e ofensor convivem diariamente. Mas como restaurar a autoestima da mulher humilhada constantemente durante anos pelo agressor?

No caso de menores, que é o foco do presente artigo, seria a justiça restaurativa utilizada para a solução de conflitos que podem culminar em morte nas instituições de internação de menores? Seria utilizada para reconduzir ao centro da sociedade/comunidade o infrator que se coloca com a infração em situação à margem da sociedade? Seria uma forma de reeducar ou simplesmente educar o menor a se relacionar como nunca se relacionou no seu meio familiar/comunitário? 
Zehr (2008) esclarece algumas dessas questões ao tratar o relacionamento não como um único relacionamento pontual entre os indivíduos envolvidos no conflito, mas em relação a toda a comunidade e/ou sociedade, uma vez que para cada ofensor e vítima existe uma consequência que os afeta a partir desse conflito (crime), afeta e alcança seus familiares, seu trabalho, ou seja, na medida em que os conflitos se multiplicam tem-se uma teia de relações que se multiplicam e que são afetadas.

Na sua visão, Zehr (2008) acredita que ambos, ofensor e vítima precisam passar pela "cura" desses sentimentos que os alcançam a partir do conflito (crime). Isso implica em "lamento" para a vítima, para que ela possa se desvencilhar das emoções negativas que a atingiram com o crime e o ofensor, que precisa também entender a vítima e entender seu papel diante do ocorrido, na medida em que deve se responsabilizar pelo ato cometido, sendo, para o sociólogo, muitas vezes, um processo difícil e doloroso.

No âmbito da educação, há um documentário francês denominado "ser e ter" que geralmente é utilizado nas aulas de didática para demonstrar o sucesso da técnica de um educador, Georges Lopez, que educa 12 crianças na zona rural da França com idades variadas e que basicamente transporta o conflito das crianças para uma solução de mediação, na qual cada um diz como se sentiu e como esse conflito se originou. A partir dessa mediação eles próprios devem solucionar seu conflito e perceber o outro, desenvolver a empatia, condição sine qua non para a eliminação do conflito.

Esse exemplo traz indícios do que pode ocorrer no caso da aplicação da mediação na justiça restaurativa, principalmente no que concerne à visão de crime e à solução aplicada.

Achutti (2013, p. 157) destaca a concepção do crime como um dano causado a uma pessoa em contraposição à tradicional violação à lei, concepção esta que retoma para agressor e vítima o papel principal na solução do conflito, tomado pelo Estado na medida em que as partes são somente representadas pelo sistema penal e se tornam objeto do crime e não mais os protagonistas.

Outra perspectiva que se apresenta é a de Howard Zehr que a partir de sua profissão de fotógrafo faz relações com a visão da sociedade e do crime. Segundo Zehr (2008, p. 7), o fato de ser fotógrafo permite que entenda que a lente que aplica em suas fotografias afeta profundamente o resultado de seu trabalho. Desse modo, transpõe a relação da lente para a relação entre os indivíduos em conflito.

Uma lente mais seletiva "distorce" a imagem. Com essa afirmativa, Zehr (2008, p.8) faz a relação entre as duas situações - o resultado da fotografia e o resultado do conflito entre indivíduos: 
Portanto, a lente afeta aquilo que aparece no enquadramento da foto. Determina também o relacionamento e a proporção relativa dos elementos escolhidos. Da mesma forma, a lente que usamos ao examinar o crime e a justiça afeta aquilo que escolhemos como variáveis relevantes, nossa avaliação de sua importância relativa e nosso entendimento do que seja um resultado adequado.

Segundo Zehr, a justiça retributiva é como a lente seletiva, ela não permite coibir o crime e nem consegue atender às necessidades da vítima e do ofensor. Compara o que chama de "lente retributiva" com a "lente restaurativa" de modo a entender como se vê o crime.

Dessa forma, a visão de crime também se modifica como apontada anteriormente por Achutti, ou seja, para Zehr a lente retributiva vê o crime como uma violação contra o Estado, como uma desobediência à lei e como culpa e, portanto, deve aplicar uma “dor" para fazer pagar o mal exercido pelo autor contra a vítima, mas que o Estado se apropria, pois só ele tem o poder de fazer uso da força de forma legítima.

Ocorre que, ao mudar a lente, no caso a visão restaurativa do crime é outra, é de violação de pessoas e relações, portanto, há uma obrigação de corrigir o erro, promover a reparação que envolve vítima e ofensor como protagonistas da relação e não como meros espectadores do Estado.

Assim, tal solução parece envolver questões de educação além de questões sociológicas, na medida em que somente se educa se houver uma correção daquilo que foi feito de forma errada e não somente punição.

Além da questão da visão do crime, a justiça restaurativa se diferencia da justiça retributiva também quanto à questão da concretude naquela e abstração nesta, no que se refere aos danos; na valorização da dimensão interpessoal da justiça restaurativa que não ocorre na retributiva e no reconhecimento da natureza conflituosa do crime (ZEHR, 2008, p. 12).

Assim, Zehr (2008, p. 12) apresenta um quadro comparativo da justiça restaurativa e da justiça retribuitiva de modo a demonstrar as formas de ver o crime em cada uma: 


\begin{tabular}{|c|c|}
\hline Lente Retributiva & Lente Restaurativa \\
\hline 1. O crime é definido pela violação da lei & $\begin{array}{l}\text { 1. O crime é definido pelo dano à pessoa e ao } \\
\begin{array}{l}\text { relacionamento } \\
\text { relacionamento) }\end{array}\end{array}$ \\
\hline 2. Os danos são definidos em abstrato & 2. Os danos são definidos concretamente \\
\hline $\begin{array}{l}\text { 3. O crime está numa categoria distinta dos } \\
\text { outros danos }\end{array}$ & $\begin{array}{l}\text { 3. O crime está reconhecidamente ligado a } \\
\text { outros danos e conflitos }\end{array}$ \\
\hline 4. O estado é a vítima & $\begin{array}{l}\text { 4. As pessoas e os relacionamentos são as } \\
\text { vítimas }\end{array}$ \\
\hline $\begin{array}{l}\text { 5. O estado e o ofensor são as partes no } \\
\text { processo }\end{array}$ & $\begin{array}{l}\text { 5. A vítima e o ofensor são as partes no } \\
\text { processo }\end{array}$ \\
\hline $\begin{array}{l}\text { 6. As necessidades e direitos das vítimas } \\
\text { são ignorados }\end{array}$ & $\begin{array}{l}\text { 6. As necessidades e direitos das vítimas são } \\
\text { preocupação central }\end{array}$ \\
\hline $\begin{array}{l}\text { 7. As dimensões inter-pessoais são } \\
\text { irrelevantes }\end{array}$ & 7. As dimensões inter-pessoais são centrais \\
\hline $\begin{array}{l}\text { 8. A natureza conflituosa do crime é } \\
\text { velada }\end{array}$ & $\begin{array}{l}\text { 8. A natureza conflituosa do crime é } \\
\text { reconhecida }\end{array}$ \\
\hline 9. O dano causado ao ofensor é periférico & 9. O dano causado ao ofensor é importante \\
\hline $\begin{array}{l}\text { 10. A ofensa é definida em termos } \\
\text { técnicos, jurídicos }\end{array}$ & $\begin{array}{l}\text { 10. A ofensa é compreendida em seu } \\
\text { contexto total: ético, social, econômico e } \\
\text { político }\end{array}$ \\
\hline
\end{tabular}

Além disso, Zehr (2008, p. 24) aponta uma ressignificação da responsabilidade na qual os erros ao invés de gerarem uma culpa passam a gerar dívidas e obrigações, da culpa indelével para a culpa redimida, na qual o indivíduo ofensor passa pelo arrependimento e pela reparação do dano ocorrido, passa a assumir responsabilidade.

Isso significa que em vez de culpa e punição a justiça restaurativa visa à reparação do dano de modo a incutir a responsabilidade que o ofensor não possui e que precisa ser construída e ressignificada, bem como a própria imagem da vítima para o ofensor, caso contrário pode acarretar um comportamento de contínuas ofensas contra outras vítimas possíveis, bem como de "cura" e restituição para a vítima, criando assim uma sociedade com mais harmonia e menos conflitos.

\section{Justiça Restaurativa: uma teoria sociológica ou educativa?}

Ao comparar a visão da justiça retributiva que impera na Doutrina da Proteção Integral aplicável hodiernamente no país, com as visões apresentadas anteriormente no histórico da proteção ao menor no Brasil, percebe-se que há pelo menos uma mudança de comportamento.

O menor infrator não é visto como à margem, marginal, em processo de marginalização e, desse modo, deve ser recolhido das ruas para que não tenha contato com a sociedade. 
Diferentemente das soluções anteriormente aplicadas nas doutrinas do Direito Penal do Menor, na Doutrina Jurídica do Menor em Situação Irregular e na Doutrina Jurídica da Proteção Integral, há um movimento de reintegração do menor à sociedade, uma tentativa de ressocialização, reeducação do menor/da criança e do adolescente, para conviver com o conflito e solucioná-lo da melhor forma possível.

A visão da infração-punição é substituída pela responsabilização-conscientizaçãoreeducação do menor/da criança e do adolescente. Essa perspectiva demonstra que, diferentemente de todas as anteriores, não há que se falar em velar o conflito, pois esse é latente na sociedade e, conforme Durkheim, o crime é um fato social normal que todas as sociedades possuem.

O problema em se entender o crime/infração como um fato social anômico e tentar retirar o infrator/criminoso da sociedade não soluciona o problema, não melhora o convívio, somente reproduz o modelo de abandono e marginalização legado desde a colonização.

Para Sica (2007, p. 15) a desintegração social e a destruição dos laços comunitários tornaram-se marcas fortes de um sistema de privação de liberdade. Os dados do SINASE demonstram que há uma ênfase na privação da liberdade como solução para o problema da criminalidade, mas que isso não tem funcionado como solução nem diminuição da criminalidade no país. Ao contrário, há uma preocupação constante com o aumento da criminalidade no país.

Sica (2007, p. 15) destaca ainda a necessidade de, diante dessa crise de legitimidade e eficiência do sistema penal redefinir a missão da justiça penal, preservar a liberdade, superar a filosofia do castigo e trabalhar a integração social.

Dessa forma, reintroduzir a vítima no processo de resolução de conflitos, dando-lhe voz e permitindo-lhe reapropriar-se do conflito é uma solução das medidas alternativas à prisão e à pena.

Sica (2007, p. 18) destaca ainda a visão de Noam Chomsky quanto ao crescimento da população carcerária e a função primordial da prisão no sistema da democracia de mercados: a "limpeza social", o controle dos excluídos. Ocorre que esta não deveria ser a função social do direito penal. A justiça penal deveria garantir a convivência pacífica entre os membros da sociedade, racionalizando a resposta aos fatos criminosos.

A solução dada pela justiça restaurativa prima pela integração social do menor infrator, ou melhor, do ofensor, para que ele possa fazer parte da sociedade e assumir o seu papel de cidadão em relação à vítima, ou exercer a dignidade da pessoa humana nas suas relações. Mas o sistema capitalista permite, conforme destacado por Chomsky (2000, p. 38, apud SICA, 2007, 
p. 9), varrer da sociedade os indesejados, o surplus, a população que não se encaixa no âmbito de produtor-consumidor desse mercado e atrapalha as relações pacíficas estabelecidas por meio das regras do jogo.

Conforme o próprio Sica destaca, Bobbio (1996, p.19, apud SICA, 2007, p. 7) aponta que o regime democrático deve ser pautado pelo respeito às regras do jogo:

O regime democrático funda-se na existência e no respeito das regras do jogo, que devem ser definidas com o máximo grau de deliberação entre os "jogadores", pergunta-se: não é nos domínios da lei criminal onde as regras mais agudas são definidas, expressadas e, ao mesmo tempo, questionadas?

Bobbio conclui aqui que as instituições não democráticas são incapazes de garantir as mesmas liberdades fundamentais, mas, mesmo que fossem, será que o sistema capitalista permite a participação democrática dos grupos marginalizados para definirem as regras do jogo?

A tentativa de reformular a justiça penal deveria passar pela reformulação das condições que criam essa diferença entre marginalizados e cidadãos e não somente para a tentativa de reeducar ou ressocializar o ofensor para fazer parte da sociedade da qual ele já foi/encontra-se excluído. Não há que se pensar tão somente na escolha pelo livre arbítrio, mas também nas condições socioeconômicas do indivíduo que é depositado nas instituições do sistema socioeducativo.

A existência e manutenção do sistema penal tradicional denota a continuidade das instituições estatais não democráticas e da escolha pela privação de liberdade. Essa democracia deveria ultrapassar a esfera da justiça penal e alcançar a participação do indivíduo na escolha e refutação das "regras do jogo", permitindo a escolha pela participação em uma alternativa fora do âmbito processual.

Nesse cenário, parece figurar a justiça restaurativa, embora comece a funcionar numa sociedade capitalista, elitista, injusta na qual o direito é quase que exclusivamente erigido pela classe dominante para ser aplicado na classe dominada.

Essa luta é bem maior e não engloba tão somente o sistema da justiça penal, nem os sistema socioeducativo, mas o sistema econômico, de redistribuição de renda, de participação política, de justiça social.

\section{Considerações Finais}


A história da proteção do menor, da infância, da criança e do adolescente no país está voltada para a continuidade do sistema de desigualdade e manutenção da proposta de privação de liberdade para aqueles que não se adequam ao sistema.

O adolescente infrator no Brasil sempre foi tratado como um problema a ser retirado do meio social, a ser recolhido, descartado, disciplinado, marginalizado. A utilização de termos negativos para descrever a criança/o adolescente infrator atesta tal colocação: exposto, enjeitado, desvalido, ilegítimo, indesejado, marginal, vagabundo, vadio.

Assim se apresentam também os resultados das doutrinas que propõem a solução dos problemas de criminalidade do menor. Desde o Brasil Colônia vem se avolumando um número crescente de menores que são colocados à margem da sociedade e seus conflitos tomados pelo Estado para a solução: privação de liberdade, retirada das ruas, das calçadas, das famílias, da convivência. No entanto, essa solução só tem aumentado o problema.

Dessa forma, a justiça restaurativa tem sido adotada em diversos países, bem como no Brasil com visão do crime e das partes envolvidas diferente do sistema retribuitivo.

A justiça restaurativa aparece como solução para modificar o cenário de um sistema penal fracassado e de manutenção dessa desigualdade social e da crescente criminalidade.

Ela requer uma aceitação do papel de protagonista na solução de conflitos por meio da mediação. Além disso, a justiça restaurativa ressignifica a visão do crime. Alguns autores fazem uma comparação desse novo paradigma como uma forma de focar e usar perspectivas diferentes: substituir a punição pela responsabilização, substituir o erro pelo acerto e correção.

A justiça restaurativa pode ser vista como solução na medida em que se coloca como uma apropriação do indivíduo pela responsabilização de seus atos e pelo interesse em participar da comunidade, deixar de ser excluído, e ser integrado à sociedade.

A responsabilização do indivíduo e a "cura" para ambas as partes, ofensor e vítima, podem ser alcançadas por meio do diálogo e da negociação, restaurando, assim, a relação entre ambos e a comunidade. Ocorre que essa construção de novos valores diante de uma sociedade capitalista de competição, individualismo e desigualdade pode parecer aparentemente utópica ao resgatar soluções sociológicas apresentadas pelos pioneiros da sociologia.

Essa ordem que outrora esteve presente no imaginário positivista seria resgatada a partir de um posicionamento de responsabilização do ofensor em relação à vítima, restituindolhe a condição na medida do possível, mais próxima a uma situação de comunidade e integração social, de relação quebrada à relação restituída. 
Outra perspectiva que se adota para perquirir uma teoria ou entender o que é a visão da justiça restaurativa é entendê-la em um processo educativo no qual os indivíduos aprendem a se relacionar mesmo em uma sociedade cheia de conflitos como a atual.

Nessa perspectiva apresenta-se o cenário do documentário francês denominado "ser e ter" em que estudantes são educados pelo professor Georges Lopez na zona rural por meio de mediação de seus conflitos, com os quais aprendem algo mais importante que matemática, física, química, ou seja, relacionar-se de forma harmônica e por meio do diálogo resolver seus problemas de convivência na comunidade.

A perspectiva educativa parece ser apropriada para esclarecer questões primeiras da aplicação da justiça restaurativa na medida em que as partes envolvidas no conflito podem crescer e aprender a solucionar elas mesmas seus embates de interesses que ocorrem normalmente em uma sociedade.

No entanto, a justiça restaurativa tem outro inimigo voraz, a realidade social que circunda a criança e o adolescente e a desigualdade dessa realidade dentro de uma sociedade capitalista de divisão de classes e de inexistência da solidariedade orgânica tão almejada por Durkheim.

Nesta sociedade os indivíduos são ou consumidores ou produtores e devem aceitar as regras do jogo que parece ser democrático, mas talvez não seja. Qual a participação desse indivíduo na reformulação do sistema penal? Quem dita as regras do jogo econômico e jurídico na sociedade capitalista? A classe dominante, da qual esses menores reiteradamente marginalizados pela história não fazem parte.

Portanto, o problema que se coloca ainda para reflexão é se há algum futuro ou solução para uma sociedade que, como Chomsky aponta, deixa seus "surplus" para a marginalização, quer eliminar seu excedente não aproveitável.

A modificação tão somente do sistema penal não surtiria efeito se não há amparo fora do sistema penal para que esses indivíduos/crianças e adolescentes possam participar da sociedade sem o estigma da marginalização, sem o estigma da delinquência, sem o estigma de não pertencer ao grupo dominante e, portanto, aceitar as regras do jogo como já postas.

Desse modo, o viés durkheimiano seria bem aplicável, na medida em que há um peso maior da sociedade sobre o indivíduo, esmagando, na maioria das vezes, qualquer tentativa em abandonar essa realidade marginalizante e discriminatória. $\mathrm{O}$ indivíduo faria parte de um jogo, uma encenação na qual ele seria um mero fantoche, um ser passivo diante da força que domina o coletivo, que domina a sociedade. A mera introjeção de valores e de responsabilização diante das injustiças sociais pouco afetaria o indivíduo ofensor. 
Por outro lado, a justiça restaurativa pode trazer a reflexão uma reformulação dessa sociedade que se baseia na punição para a solução de conflitos e ressignificar nossa visão de mundo e visão do outro. Fato é que, conforme apontam vários doutrinadores, a justiça restaurativa é mais uma prática ou um conjunto de práticas em busca de uma teoria.

\section{Referências Bibliográficas}

ACHUTTI, Daniel. Justiça Restaurativa no Brasil. Possibilidades a partir da experiência belga. Revista Civitas, Porto Alegre, v.13, n.1, jan-abr/2013.

\section{CUSTÓDIO, André Viana. A exploração do trabalho infantil doméstico no Brasil}

Contemporâneo: limites e perspectivas para sua erradicação. Florianópolis: UFSC, 2006.

GOMES, Leonardo de Castro. Da situação irregular à proteção integral (Do Código Mello Mattos ao ECA). Revista da EMERJ, v. 10, Edição Especial, 2007.

MARTINS, Carlos Benedito. O que é Sociologia. São Paulo: Editora Brasiliense, 1994.

MINISTÉRIO DOS DIREITOS HUMANOS. SINASE. Levantamento anual SINASE 2016. Brasília, 2018. Disponível em < http://www.sdh.gov.br/assustos/criancas-eadolescentes/programas/sistema-nacional-de-medidas-socioeducativas/sistema-nacional-deatendimento-socioeducativo-sinase-1> acesso em maio de 2018.

PEREIRA, Tânia da Silva. Direito da Criança e do Adolescente: uma proposta interdisciplinar. Rio de Janeiro: Renovar, 1996.

RIZZINI, Irene; PILOTTI, Francisco. A arte de governar crianças: a história das políticas sociais, da legislação e da assistência à infância no Brasil. 2a ${ }^{\text {a }}$ ed. São Paulo: Cortez, 2009.

SANDOZ, Gilles \& PHILIBERT, Nicolas. (2002) Ser e Ter. França. Maïa Films.

SICA, Leonardo. Justiça Restaurativa e Mediação Penal. O Novo modelo de justiça criminal e de gestão do crime. Rio de Janeiro: Editora Lumen Juris, 2007. 
SIQUEIRA, Liborni. Sociologia do Direito do Menor. RJ: Âmbito Cultural, 1979.

TEIXEIRA, Salvio de Figueiredo. Infância e Adolescência: uma visão histórica de sua proteção social e jurídica no Brasil. São Paulo: Revista dos Tribunais, 1992.

ZEHR, Howard. Trocando as lentes: um novo foco sobre o crime e a justiça restaurativa. São Paulo: Palas Athena, 2008. 
E ¿ ste livro reúne artigos científicos apresentados e debatidos nos Grupos de Trabalho: "PROCESSO, ADMINISTRAÇÃO, ACESSO E JURISDIÇÃO DA JUSTIÇA" e "FORMAS CONSENSUAIS DE SOLUÇÃO DE CONFLITOS" no decorrer do VIII Encontro Internacional do CONPEDI (Conselho Nacional de Pesquisa e Pós-Graduação em Direito - Brasil), realizado entre os dias 06 e 08 de setembro de 2018 na cidade de Zaragoza - Espanha. 